SZEGEDI TUDOMÁNYEGYETEM

BÖLCSÉSZETTUDOMÁNYI KAR

NEVELÉSTUDOMÁNYI DOKTORI ISKOLA

INFORMÁCIÓS ÉS KOMMUNIKÁCIÓS TECHNOLÓGIÁK AZ OKTATÁSBAN

DOKTORI PROGRAM

MAJOR LENKE

\title{
EGY KÖRNYEZETI NEVELÉSI PROGRAM BEILLESZTÉSÉNEK KÍSÉRLETE A SZERBIAI ALSÓ TAGOZATOS OKTATÁSBA, TANÍTÓKÉPZŐS HALLGATÓK BEVONÁSÁVAL
}

PhD-ÉRTEKEZÉS

TÉMAVEZETÖ:

DR. PAPP KATALIN, CÍMZETES EGYETEMI TANÁR A NEVELÉSTUDOMÁNY KANDIDÁTUSA

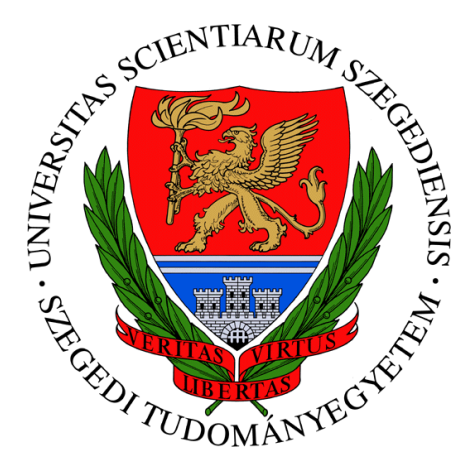

SZEGED 


\section{TARTALOMJEGYZÉK}

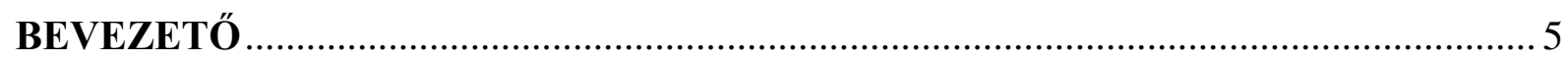

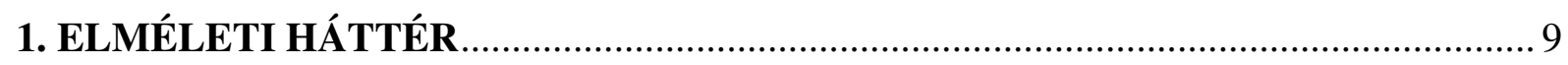

1.1. A fenntarthatóság pedagógiájának kialakulása ................................................... 9

1.1.1. A környezetvédelem, a környezeti nevelés és a fenntartható fejlödés fogalma ........... 9

1.1.2. Az ember és környezete kapcsolatának fejlődése ................................................... 11

1.1.3. Ökológiai elméletek az ember és környezete kapcsolatáról...................................... 12

1.1.4. A fenntartható fejlődés célrendszere .................................................................... 13

1.1.5. A fenntarthatóság pedagógiája nemzetközi téren................................................... 16

1.1.6. Fenntartható Fejlődési Program 2015-2030 ......................................................... 18

1.2. A környezeti nevelés pedagógiai szempontjai ........................................................ 19

1.2.1. A környezeti nevelés „,taníthatósága” ..................................................................... 19

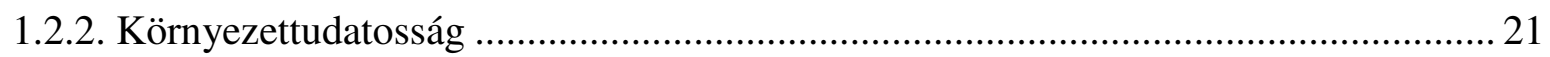

1.2.3. Az attitüdök szerepe a környezeti nevelés szempontjából ........................................ 22

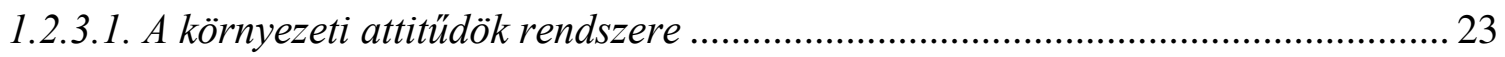

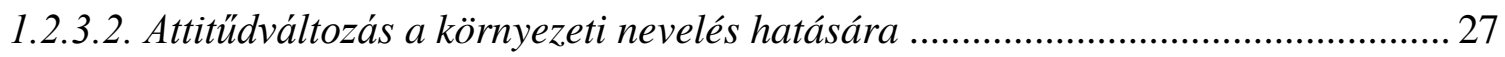

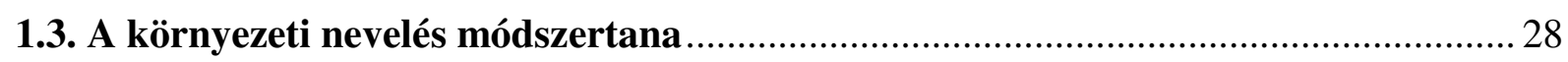

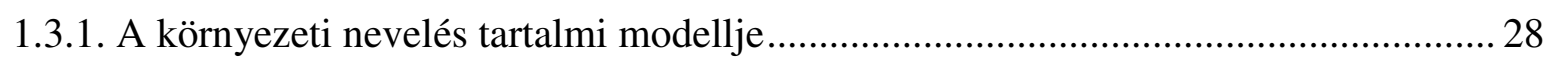

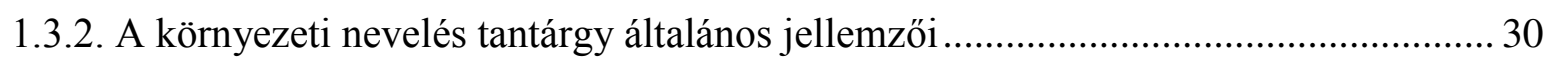

1.3.3. A környezeti nevelés helye a tudományok és tantárgyak rendszerében .................... 31

1.3.4. A környezeti nevelés célja és feladatai ...................................................................... 31

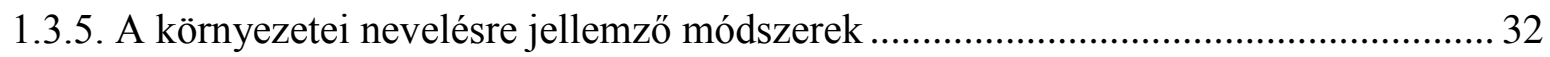

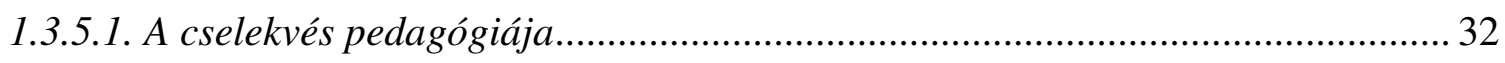

1.3.5.2. Projektmódszer a környezeti nevelésben ....................................................... 33

1.3.5.3. A természetes környezetben való tanulás és az élmény szerepe a tanulási

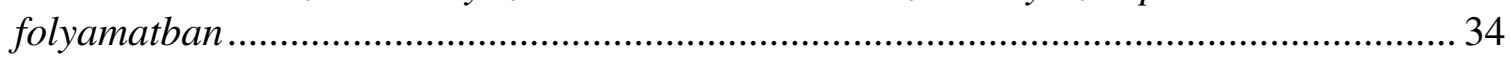

1.3.5.4. A környezeti nevelési programok jelentösége ..................................................... 35

1.3.5.5. A nevelési gyakorlat megújulása a környezeti nevelés által ............................... 36

1.3.6. A környezeti nevelés általános tantervi céljai .......................................................... 37

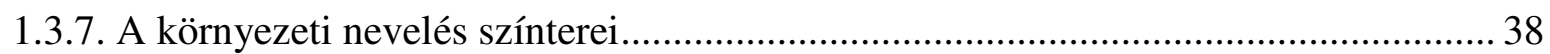

1.3.8. A környezeti nevelés helye az alsó tagozatos tantárgyak rendszerében ................... 40

1.3.9. Fenntartható fejlődés és környezeti nevelés a felsőoktatásban ................................. 40

1.3.9.1. Fenntarthatóságra nevelés az európai zöld egyetemeken ................................. 41 
2.1. A környezeti nevelés és a fenntartható fejlődés céljainak és feladatainak helye a szerbiai alapfokú oktatási rendszerben

2.1.1. Környezeti neveléssel kapcsolatban megfogalmazott célok és feladatok a

Környezetünk és a Természet és társadalom tantárgyak tantervében

2.1.2. A környezeti nevelési tartalmak beillesztésének lehetőségei a Környezetünk, illetve

a Természet és társadalom tantárgyak tanmenetébe 47

2.2. A fenntarthatóság fogalmának megjelenése a szerbiai felsőoktatásban 57

2.2.1. Fenntarthatóságra nevelés az Újvidéki Egyetem Magyar Tannyelvű Tanítóképző Karán

3. AZ EMPIRIKUS VIZSGÁLATOK ALAPJÁT KÉPEZŐ KÖRNYEZETI NEVELÉSI

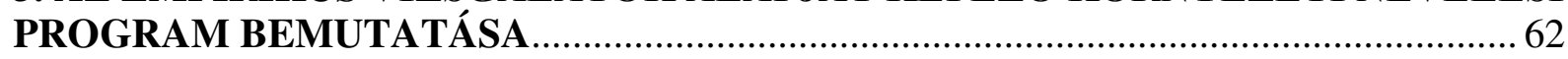

3.1. A tanítóképzős hallgatók részére kidolgozott tantárgy bemutatása 62

3.2. Az alsó tagozatos hallgatók részére kidolgozott, intenzív környezeti nevelési program bemutatása 64

3.2.1. A víz témakörében kidolgozott programelemek 65

3.2.2. A hulladék témakörében kidolgozott programelemek 69

3.2.3. Az energia témakörében kidolgozott programelemek .72

3.3. A program gyakorló pedagógusok általi elemzése .75

4. A TANÍTÓKÉPZŐS HALLGATÓK KÖRÉBEN ELVÉGZETT EMPIRIKUS VIZSGÁLAT 79

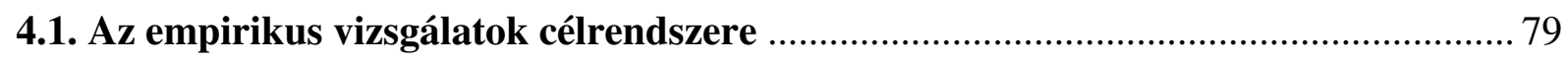

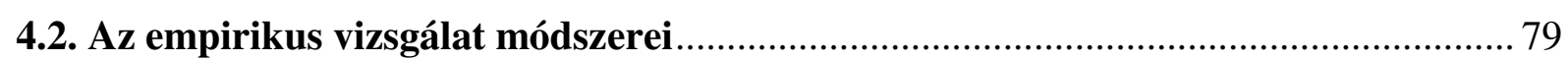

4.3. A tanítóképzős hallgatók körében elvégzett empirikus vizsgálat hipotézisei ............ 81

4.4. Az empirikus vizsgálatban részt vevő tanítóképzős hallgatók ................................... 81

4.4.1. A kísérletben részt vevő minta háttéradatai .............................................................. 82

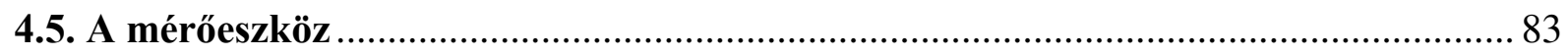

4.6. A tanítóképzős hallgatók körében elvégzett empirikus vizsgálat eredményei........... 87

4.6.1. A tanítóképzős hallgatók környezeti attitüdjének alakulása a kísérlet során ............. 87

4.6.1.1. Az ENV skálával mért attitüdértékek alakulása .............................................. 87

4.6.1.2. A RevNEP skálával mért attitüdértékek alakulása ........................................... 91

4.6.1.3. A CHEAKS skálával mért attitüdértékek alakulása .......................................... 94

4.6.1.4. Az attitüdértékek alakulása a teljes attitüdmérö skála átlagát tekintve .............. 96

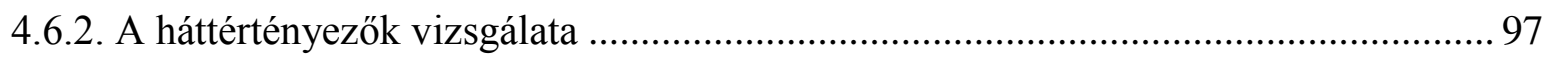

4.6.2.1. A kisérleti csoport háttértényezöinek és környezeti attitüdjének összefüggései .. 97

4.6.2.2. A kontrollcsoport háttértényezöinek és környezeti attitüdjének összefüggései ... 98

4.6.3. A környezeti attitüd longitudinális vizsgálata a Magyar Tannyelvü Tanítóképző Kar hallgatóinak körében 101 
4.6.4. A tanítóképzős hallgatók körében elvégzett empirikus vizsgálat eredményeinek összefoglalása

5. AZ ALSÓ TAGOZATOS TANULÓK KÖRÉBEN ELVÉGZETT EMPIRIKUS VIZSGÁLAT 103

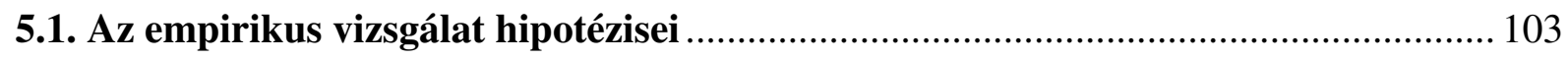

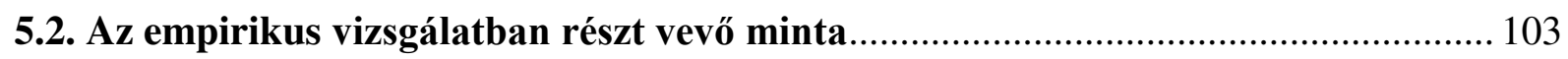

5.2.1. Az empirikus vizsgálatban részt vevő minta háttéradatai ..................................... 104

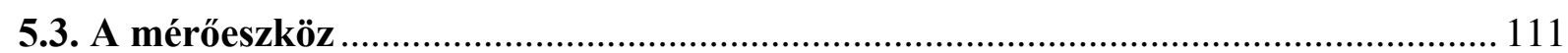

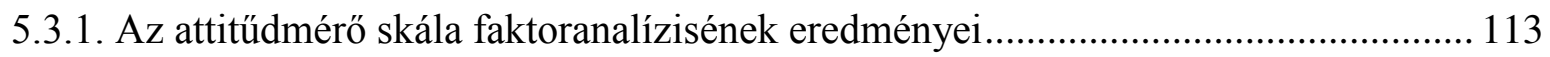

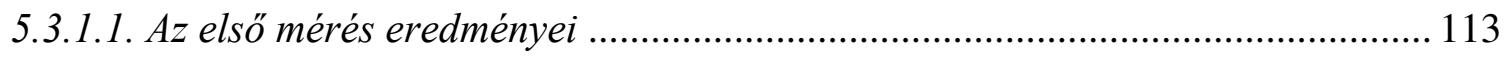

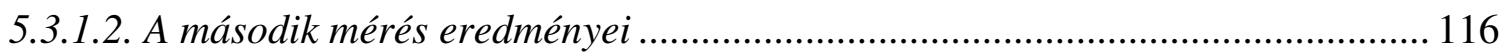

5.4. Az alsó tagozatos tanulók körében elvégzett empirikus vizsgálat eredményei........ 118

5.4.1. Az alsó tagozatos tanulók attitüdértékének alakulása az első mérés alkalmával ..... 118

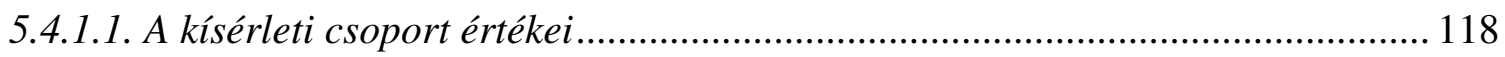

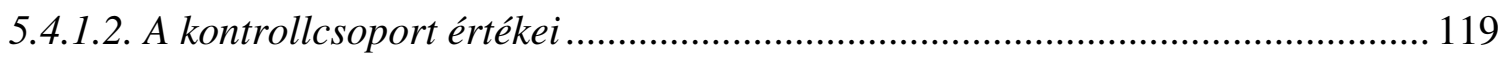

5.4.2. Az alsó tagozatos tanulók attitűdértékének alakulása a második mérés alkalmával 123

5.4.2.1. A kísérleti csoport eredményei ....................................................................... 123

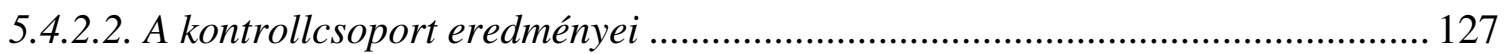

5.4.2.3. A kísérleti és a kontrollcsoportban mért értékek összehasonlitása ................... 131

5.4.2.4. Az alsó tagozatos tanulók háttértényezőinek és környezeti attitüdjének

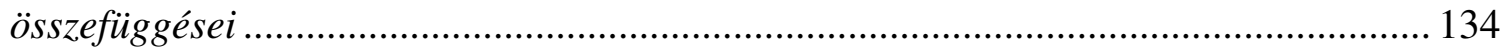

5.4.3. A környezetet veszélyeztető tényezők megítélése az első mérés során .................... 138

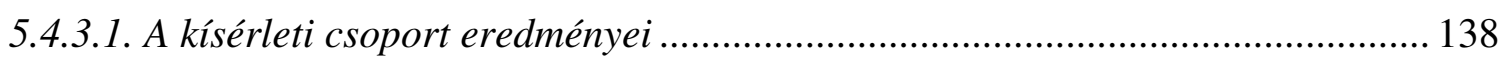

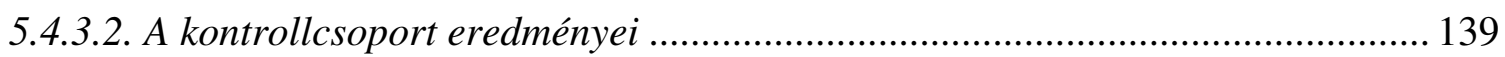

5.4.4. A környezetet veszélyeztető tényezők megítélése a második mérés során............... 140

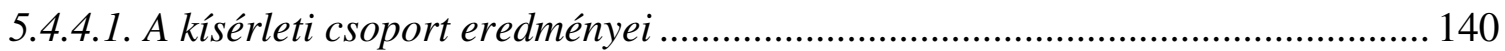

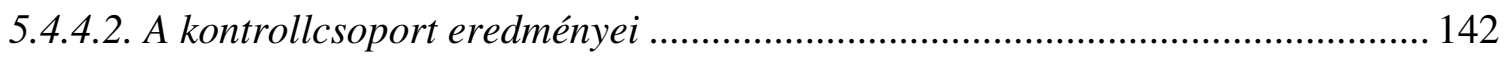

5.4.5. A környezetszennyezés okainak megítélése az első mérés során ............................ 144

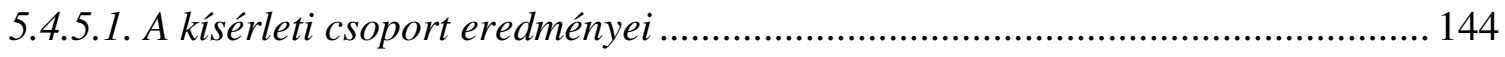

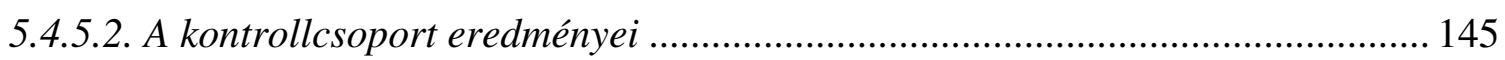

5.4.6. A környezetszennyezés okainak megítélése a második mérés során ....................... 145

5.4.6.1. A kísérleti csoport eredményei ........................................................................ 145

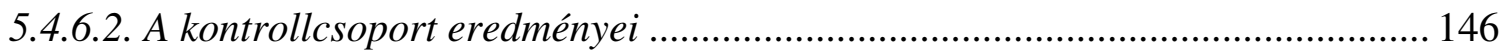

5.4.7. A saját lehetőségek észlelése a környezetvédelem terén, az első mérés során ......... 148

5.4.7.1. Az emlitett lehetöségek számának alakulása .................................................. 150

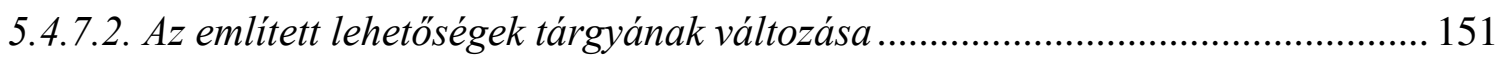

5.4.8. Az alsó tagozatos tanulók körében elvégzett empirikus vizsgálat eredményeinek összefoglalója 


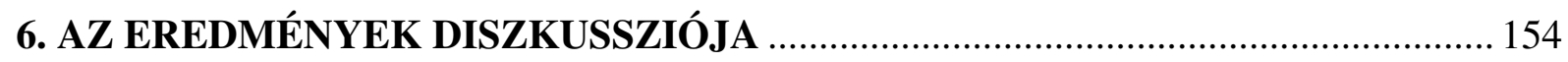

6.1. A hipotézisek és a kapott eredmények összevetése ............................................. 154

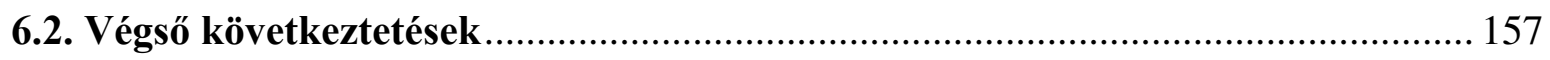

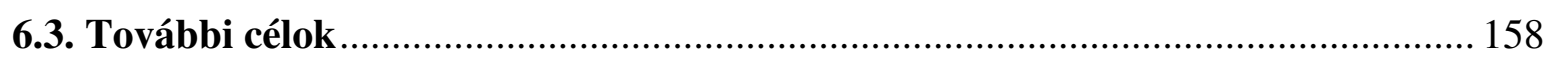

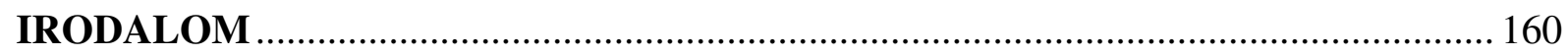

A DISSZERTÁCIÓ TÉMAKÖRÉHEZ KAPCSOLÓDÓ PUBLIKÁCIÓK ………….... 175

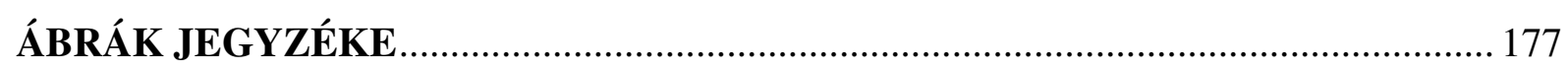

TÁBLÁZATOK JEGYZÉKE ...................................................................................... 179

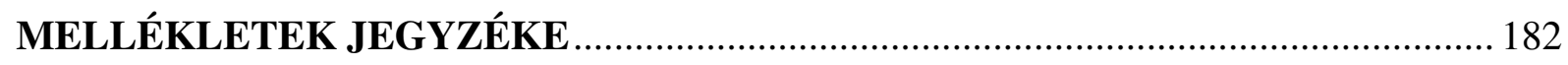

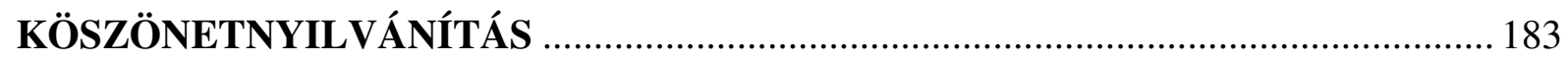

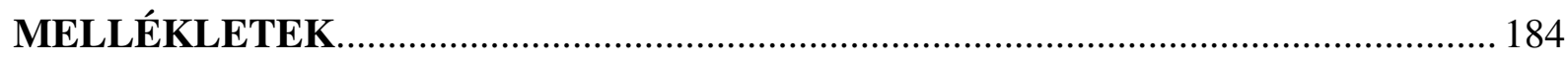




\section{BEVEZETŐ}

A hetvenes évek elején az előre tekintő tudományos szakértők és közéleti szereplők komolyan mérlegelték, hogy a Föld milyen környezeti terheléseket bír el és a természeti erőforrások készletei mennyi ideig elégítik ki a növekvő igényeket (Láng, 2008). Arra a következtetésre jutottak, hogy ha a népesség, az iparosítás, a környezetszennyezés, az élelmiszer-termelés jelenlegi növekedése és a természeti erőforrások kizsákmányolása nem csökken, a Föld eltartóképessége a következő évszázadban eléri az abszolút határát (Szász, 2010).

A fenntartható fejlődés koncepciójának értelmezésében és népszerüsítésében fontos momentum volt, írja Damjanovich (2003), hogy a nyolcvanas évek közepén a nemzetközi szervezetek kellő időben felismerték, hogy a környezetvédelem egyre inkább globális jelleget kap, környezeti kérdések tekintetében hosszú időhorizontban szükséges gondolkodni és cselekedni. A környezettudatosság fejlesztése, azaz a környezeti nevelés a legtöbb országban jelentős szerepet kapott az elmúlt három évtized során, mivel nyilvánvalóvá vált, hogy környezetünk állapotának fenntartása, megóvása csak jelentős társadalmi nézőpontváltozás esetén biztosítható (Havas és Varga, 2006). Ennek alapfeltétele a környezettudatosság, a környezettudatos magatartás fejlesztése, az értékrend, az attitűd és az érzelmi viszonyulások, valamint a gondolkodás formálása és a környezetről-társadalomról kialakítható tudás bővítése (Mikházi, 2006; Thiengkamol, 2011; Hofman, 2015).

A fenntarthatóság pedagógiájának célja az olyan állampolgárok nevelése, akik megfelelő magatartásformákkal, szokásokkal, attitűdökkel, értékrenddel, kompetenciákkal rendelkeznek ahhoz, hogy lehetővé tegyék a földi ökológiai, társadalmi rendszerek fenntarthatóságát (Havas, 2001).

A környezeti nevelésnek elsősorban nem több környezeti ismeret átadására, hanem sokkal inkább a széles körü környezettudatos attitüdök kialakítására kell törekednie. A környezettudatos életvitelt tanúsító személyek ismerik a fontosabb környezeti fogalmakat, az aktuális környezetvédelmi problémákat és tennivalókat, az adott probléma megoldásához használható cselekvési stratégiákat, hisznek tevékenységük jelentőségében, gyakorlottak az önálló cselekvésben. A környezet kognitív ismerete szükséges, de nem elégséges feltétele a környezetért felelős magatartásnak. A környezetvédelmi problémák felismerése, az ezzel kapcsolatos elemző és értékelő képességek, a megfelelő cselekvéssel párosuló attitüdök és értékek is feltételei az egyéni, felelős cselekvésnek (Nagy, 2008).

Sok esetben éppen azért jelent problémát a fenntarthatóságra nevelés kérdéskörének beépítése az oktatás rendszerébe, mert nemcsak egyszerü tudásátadásra, hanem sokkal komplexebb fejlesztésre, az attitüdök és az érzelmi beállítódás változtatására van szükség (Shepard and Furnari, 2013).

A környezeti nevelés, természeténél fogva, eleve megkérdőjelezi a hagyományos oktatási formákat, módszereket (Hart, 2010). Már kialakulásától kezdve markánsan képviselt egy tanulásfelfogást, amely a maga nemében, az uralkodó nézetekkel szemben, korszerünek, elöremutatónak volt mondható. A környezeti nevelés „ars poeticájához” tartozott mindig, hogy a gyermeknek önállóan kell felfedeznie az összefüggéseket, hogy aktív elsajátításra van szükség, cselekvéseken keresztül, motivált módon kell eljutni elsősorban a mindenféle tartalmak esetében müködő, vagyis általános képességekhez (Nahalka, 2002). Műveltség 
helyett egyre több figyelmet kapnak a kompetenciák, azaz nem annyira az elsajátított tudás, mint inkább az aktív cselekvőképesség kerül előtérbe (Kiss, 2006).

A környezeti nevelés eszméi összekapcsolódnak a 20. század utolsó éveiben megjelenő és uralkodóvá váló nézetekkel, az egész életen át tartó tanulás és a kompetenciaalapú gondolkodás értékével, szemléletmódjával. Az egyéni kompetenciák és komplex cselekvőképesség kialakítása a mai pedagógiai fejlesztések legalapvetőbb célja (Könczey, 2009).

A tanítóképző intézményeknek nagyon nagy szerepe van az élethosszig tartó tanulás feltételeinek biztosításában és a társadalom környezettudatosságának erősítésében (KelleyLaine, 1998). Önmagában a megfelelő környezettudatos magatartással bíró pedagógusok képzése is alapvető fontosságú. A tanítók ugyanakkor a jövő generációk neveléséért felelnek majd, akiknek átadhatják megszerzett ismereteiket, és kialakíthatják saját meggyőződésük mintájára a környezettudatos magatartás alapvető elemeit. Emellett a tanítóképző intézmények jellegüknél fogva összekapcsolják az oktatás különböző területein müködő szakembereket az iskoláskor előtti nevelés szintjétől az alapfokú oktatáson keresztül a felsőoktatásig, sőt, a felnőttoktatásig, megteremtve ezzel az élethosszig tartó tanulás feltételeit.

A kutatás időszerüsége abból a problémából adódik, hogy a szerbiai oktatási rendszer nem kínál megfelelő lehetőségeket a környezeti nevelés oktatásba történő beillesztésére a tantervi szabályozás során. A hiányosságok pótlására viszont egyre sürgetőbb szükség mutatkozik a fenntarthatóság pedagógiájának mai álláspontja szerint.

Vizsgálatom középpontjában egy határon túli magyar tannyelvü felsőoktatási intézmény tevékenysége áll, amely most teszi meg első lépéseit a zöld egyetemmé válás folyamatában. Az Újvidéki Egyetem Szabadkán müködő Magyar Tannyelvű Tanítóképző Kara az egyedüli egyetemi kar Szerbiában, ahol teljes egészében magyar tannyelvü képzés folyik. A kar hallgatói Vajdaság egész területéről érkeznek ide abból a célból, hogy az európai standardoknak megfelelően élhessenek kisebbségi jogaikkal a tudomány, oktatás és kultúra területén.

Kutatásaim során egy olyan, az intézményen belül müködő, komplex tevékenységrendszer alapjainak a megteremtése volt a célom, amely lehetővé teszi az alsó tagozatos tanulók, a tanítóképzős hallgatók és a már gyakorló tanítók környezettudatos magatartásának kialakítását, környezeti attitüdjének fejlesztését.

A disszertáció öt fö részből áll. Az elméleti háttér taglalása során elöször a környezetvédelem, a környezeti nevelés és a fenntartható fejlődés fogalmainak meghatározásakor felmerülő nehézségeket igyekszem tisztázni. A továbbiakban bemutatom a fenntartható fejlődés elméletére vonatkozó legfontosabb elemeket, mint a fenntarthatóság célrendszerének kialakulását, a fenntartható pedagógia mibenlétét, illetve a 2015-2030 közötti időszakra kitüzött nemzetközi Fenntartható Fejlődési Célokat. A következő témakör az elméleti háttéren belül a környezeti nevelés kérdésköre, ahol azokat az elméleti és módszertani elemeket foglalom össze a környezeti neveléssel kapcsolatban, amelyek a későbbiekben hozzájárultak az empirikus kutatás alapját képező program kidolgozásához. Bemutatásra kerülnek továbbá azok a lehetőségek, amelyek a szerbiai oktatási rendszeren belül teret engednek a környezeti nevelés megvalósítására az alsó tagozatos tantárgyak esetében, illetve a felsőoktatáson belül. 
A disszertáció második részében azokat a lehetőségeket foglalom össze, amelyek keretet adnak egy komplex környezeti nevelési program létrehozására, amely egyaránt segíti a tanítóképzős hallgatók és az alsó tagozatos tanulók környezeti attitüdjének fejlesztését. A szerbiai oktatási rendszer nyújtotta kereteken belül olyan program kidolgozására van szükség, amely beépíthető a jelenlegi alsó tagozatos tantárgyak rendszerébe, ugyanakkor lehetőséget ad a tanítóképzős hallgatók és a gyakorló pedagógusok módszertani ismereteinek fejlesztésére a környezeti nevelés terén. Elsősorban az alsó tagozatos Környezetünk, illetve a Természet és társadalom tantárgyak operatív tervét elemeztem, amelyen belül megjelöltem azokat a lehetőségeket, ahol beépíthetővé válnak a környezeti nevelés oktatási és nevelési céljai.

A dolgozat következő egységében kerül bemutatásra az empirikus kutatások alapját képező környezeti nevelési program. Először az Újvidéki Egyetem Magyar Tannyelvü Tanítóképző Kara tantervének részét képező tantárgy bemutatására került sor, amelyet azért terveztünk meg és dolgoztunk ki, hogy szervezett keretek között tudjuk megvalósítani a tanítóképzős hallgatók környezeti nevelését. A tantárgy a Környezeti nevelési program szervezése, megvalósítása elnevezést viseli. A tantárgy keretein belül került sor annak az intenzív, élményt nyújtó környezeti nevelési programnak a kidolgozására, amely az empirikus vizsgálatok alapját képezi. A program erősségeiről, gyengeségeiről, lehetőségeiröl és veszélyeiről többéves tapasztalattal rendelkező tanítók alkottak véleményt. Az általuk készített SWOT analízis bemutatására is ebben a szakaszban kerül sor.

A dolgozat következő tartalmi elemét a tanítóképzős hallgatók körében elvégzett empirikus vizsgálat eredményeinek bemutatása képezi. A vizsgált hallgatók a már említett tantárgyon belül részt vettek a környezeti nevelési program kidolgozásában. A tantárgy és a program jellegéből fakadóan mindössze 14 hallgató vett részt ebben a kutatásban. Ugyanakkor a vizsgálatot a Kar többi hallgatójára is kiterjesztettuik egy longitudinális felmérés során. A vizsgálat célja kettős. Egyrészt a kísérleti programban részt vevő tanulók eredményeinek összehasonlíthatóságát teszi lehetővé a programban nem szereplő tanulók környezeti attitüdjének értékével. Ezzel vizsgálhatóvá válik a kísérleti programnak a tanítóképzős hallgatókra gyakorolt hatása. Másrészt a Magyar Tannyelvü Tanítóképző Karon müködő Fenntarthatóság munkacsoport további tevékenységeinek fontos iránymutatói lehetnek a disszertációban bemutatott kutatássorozat eredményei, amelyek kiegészítik a munkacsoport által végzett egyéb vizsgálatok eredményeit. A tanterv hatékonyságvizsgálata érdekében elvégzett kutatás nem képezi a disszertáció szerves részét, de eredményei képet adnak az intézmény tantervének hatékonyságáról a környezeti nevelés célkitüzéseinek megvalósítása terén. A két kutatás eredményeinek összevetése hozzájárul a Kar környezettudatosság és fenntartható fejlődés terén végzett fejlesztő munkájának tervezéséhez.

A disszertáció ötödik szakaszában kerülnek bemutatásra az alsó tagozatos tanulók körében elvégzett központi kutatás eredményei. A kutatás kérdőíves felmérésre épül, célja pedig a tanítóképzős hallgatók által kidolgozott és végrehajtott környezeti nevelési program hatékonyságának vizsgálata az alsó tagozatos tanulók körében. A kontrollcsoportos pedagógiai kísérlet eredményeinek függvényében tervezzük a továbbiakban változtatni és fejleszteni a kísérleti program tartalmát. Távlati céljaink között szerepel, hogy egyre több iskolát, ezáltal gyerekeket és pedagógusokat vonjunk be a programba. Ezzel szeretnénk elősegíteni, hogy az egyelőre kísérleti szakaszban lévő program egy intézmények közötti együttműködésre épülő, az oktatási rendszer különböző szakaszain átívelő, intenzív, a 
nemzetközi fenntartható fejlödési célok által kitüzött követelményrendszernek is eleget tevő környezeti nevelési programmá nője ki magát.

Szeretnénk elérni, hogy a tanítóképzés által érintett különböző oktatási színtereken hatékonyan, tervszerủen felépített tevékenységek és foglalkozások a tantárgyközi kérdéskörök, közös értékek felé forduljanak. Több kompetencia összekapcsolása által az alsó tagozatos gyerekek nevelésén keresztül a tanítóképzős hallgatók és a már gyakorló pedagógusok támogathatják egymás fejlődését. Az Újvidéki Egyetem Magyar Tannyelvü Tanítóképző Kara bekapcsolódhat a környezeti nevelés fejlesztésébe, sőt annak központja lehet a régión belül, ezáltal biztosítva a helyi és a nemzeti kulturális örökség és a fenntarthatóság eszméjének átadását a jövő generációi felé. 


\section{ELMÉLETI HÁTTÉR}

\subsection{A fenntarthatóság pedagógiájának kialakulása}

\subsubsection{A környezetvédelem, a környezeti nevelés és a fenntartható fejlődés fogalma}

A környezeti nevelés, a környezetvédelem és a fenntartható fejlödés fogalma nem azonos, de kialakulásuk története és céljaik óhatatlanul összefonódnak, egymásba ágyazódnak. A környezeti nevelés is a környezet értékeinek megóvását célozza, de a környezetvédelem és a környezeti nevelés nem azonos fogalmak. A környezeti nevelés fogalmának és céljainak kialakulását megelőzte a globális környezeti problémákra való ráismerés, valamint a környezetvédelem kialakulása és fejlődése.

A környezetvédelem első formális szervezete az 1968-ban megalakult Római Klub volt, amelyben 25 ország 70 tudósa mérte fel Földünk globális problémáit (Rosta, 2008). A radikálisan gondolkodó értelmiségi elitből álló szervezet a hetvenes évek elején jelentést készített arról, hogy mi várható a 21. században, ha minden úgy folytatódik tovább, ahogy a 20. század hatvanas éveiben megindult a népesség növekedése, a környezet szennyeződése és az erőforrások hasznosítása (Szász, 2010).

Meadows és társai első tanulmányukban, az 1972-ben kiadott The Limits to Growth (A növekedés határai) címü munkájukban foglalkoztak először az emberiség jövőképével és mutattak rá a gazdasági növekedés és a környezetben kialakult következmények kapcsolatára. A jelentés világméretü vitát váltott ki. Ettől a pillanattól kezdve beszélhetünk a környezetvédelemről mint országhatárokat átlépő, globális társadalmi mozgalomról (Láng, 1980).

A környezet megóvását szorgalmazó szakemberek az 1972-ben megtartott Stockholmi Konferencián fektették le a modern környezetvédelem alapjait, fogalmazták meg legfontosabb alapelveit. Itt már megjelent a nevelés szükségességének hangsúlyozása is (Havas, 2001).

A környezetvédelem a környezetet több egységre tagolva tárgyalja. Az egyik lehetséges felosztás szerint ezek az egységek a levegő, talaj, víz, élővilág, valamint az épített környezet (Kerényi, 2003). Amikor környezetvédelemről beszélünk, akkor ezen egységek védelmét, a jelenlegi állapot fenntarthatóságát célozzuk meg (Horváth, 2008). Környezetvédelem alatt tehát „olyan céltudatos, szervezett, intézményesített emberi (társadalmi) tevékenységet értünk, amelynek célja az ember ipari, mezögazdasági, bányászati tevékenységéböl származó káros következmények kiküszöbölése és megelözése az élövilág és az ember károsodás nélküli fennmaradásának érdekében" (Láng, 2002).

Mivel a környezet védelme alapvetően a természeti környezet megóvására vonatkozik, így a környezeti nevelés kifejezést sokszor tévesen a környezetvédelmi nevelés szinonimájaként használják, elsősorban ökológiai-természetvédelmi nevelést értenek alatta (Havas, 1997a; Varga, Czippán és Benedict, 2011). A fogalmak közötti különbség abban van, hogy a környezetvédelmi nevelés általában a természeti környezet védelmét és fenntarthatóságát célozza. A környezeti nevelés ezzel szemben a természet értékei mellett számol az emberi tényezők hatásával, figyelembe veszi az ember által létrehozott környezetet is. Ennek értelmében a környezeti nevelés magában foglalja a természetvédelmi nevelés célkitüzéseit is (Palmer és Neal, 1998). 
A rövidebb forma - környezeti nevelés - azt is érzékelteti, hogy nem csupán a környezet megvédésére irányul a nevelés, hanem a környezettel való együttélésre, a környezeti kultúrára. Ez magába foglalja a környezetvédelmet, de annál összetettebb, bonyolultabb rendszer, amely az életmód, viselkedés, gondolkodásmód átalakítására törekszik (Victor, 1998). A környezeti nevelés tehát egyfajta környezeti kultúrára nevelés, amely kultúra magába foglalja a környezetre vonatkozó ismeretektől a környezetbarát életmódig tartó teljes skálát (Varga, Czippán és Benedict, 2011).

1975-ben jelent meg az ENSZ első olyan dokumentuma, amely a környezeti neveléssel foglalkozik. Ez volt a Belgrádi Charta, amely a következő célkitüzéseket fogalmazta meg a környezeti neveléssel kapcsolatban: „,... a világ népei számára tudatosítani és ismertetni kell azt, hogy a környezet és a hozzá kapcsolódó problémák megoldása és az újabbak megelözése egyénileg és közösségekben megfelelö tudást, felkészültséget, készségeket, attitüdöket, inditékokat és együttmüködési szándékokat igényel, amelyek biztosítása a környezeti nevelés feladata” (UNESCO, 1976 idézi: Havas, 1995).

A Tbilisziben 1977-ben tartott környezeti nevelési konferencia zárójelentésében találkozunk először a környezeti nevelés fogalmának hivatalos meghatározásával (Kalindi, 2014): „A környezeti nevelés egy folyamat, amelyben olyan világnemzedék nevelkedik fel, amely ismeri legtágabb környezetét is, törödik azzal, valamint annak problémáival. Ismeretekkel, készségekkel, attitüdökkel, motivációval és elkötelezettséggel rendelkezik, hogy egyénileg és közösségben dolgozzon a jelenlegi problémák megoldásain és az újabbak megelözésén” (UNESCO, 1978 idézi: Nemzeti Környezeti Nevelési Stratégia, 2010).

A környezeti nevelés kifejezésben azért szerepel a nevelés szó, mert itt nemcsak az ismeretek átadásáról, az oktatásról van szó, hanem a teljes személyiség fejlesztéséröl, vagyis nevelésröl (Koruoglu, Ugulu, Yorek, 2015). A pontos megfogalmazás tehát környezeti oktatás és nevelés lenne, de egyezményesen a nevelés kifejezést használjuk, amibe automatikusan beleértjük az oktatási tartalmakat is. Más szóval a környezeti nevelés legfontosabb feladata a környezettudatos magatartás, viselkedés, szemléletmód kialakítása, mely ösztönzi az embert természeti, társadalmi, kulturális környezetének megóvására (Victor, 1998).

1987-ben jelent meg a Bruntland-jelentés, ami a fenntartható fejlődésben látta a környezetvédelmi problémák megoldását. A norvég miniszterelnök asszony, Gro Harlem Brundtland által vezetett bizottság kidolgozta a fenntartható fejlődés koncepcióját, mely szerint úgy kell kielégíteni a jelen generációk (materiális) igényeit, hogy ezzel ne veszélyeztessük a következő generációk életlehetőségeit (Náray-Szabó, 1999).

A fenntarthatóság fogalma máig nem egyértelmü, a mai napig nagyon sok meghatározása létezik (Scott, 2015). Jelentését azért nehéz megragadni, mert a kifejezést a különböző tudományok más és más értelmezés szerint használják (Bolis, Morioka és Sznelwar, 2014). A Brudtland Bizottság Közös jövőnk címü jelentése alapján a fenntartható fejlődés fogalma alatt a társadalom egyes elemeinek olyan fejlődési folyamatát értjük, amely „kielégiti a jelen igényeit anélkül, hogy csökkentené a jövő generációk képességét, hogy kielégítsék a saját igényeiket" (WCED, 1987).

A fenntarthatóság pedagógiája és a környezeti nevelés kapcsolata történeti eredetü. Világszerte a környezeti nevelés gyakorlata és fogalma alakult ki korábban, és csak fokozatosan válik a fenntarthatóság pedagógiai rendszerének részévé (Németh, 2008). A két fogalom összefonódása azt a felfogást közvetíti, hogy a természeti környezet megóvása 
lehetetlen a társadalom fenntarthatóságának elérése nélkül (Gulyás és Varga, 2009). A környezeti nevelés és a fenntarthatóság pedagógiája közötti különbség abban érhető tetten, hogy mire irányul a fö vizsgálódási területük. A két fogalom ugyanakkor nem választható szét, hiszen a fenntarthatóság pedagógiája nem más, mint a környezeti nevelés kibővült tartalmi és fogalmi rendszerére épülő, a környezeti nevelést magában foglaló pedagógiai gyakorlat. Mindazok az alapvető szempontok és értékek, amelyek a környezeti nevelést meghatározzák, érvényesek a fenntarthatóság pedagógiájára is. A fenntarthatóság pedagógiája a környezeti nevelés kibővült tartalmára épül. Ez pedig elősegíti azoknak a nevelési törekvéseknek a rendszerbe való szerveződését, amelyek a globális fejlődésre, a béke megteremtésére, a környezeti erőforrásokkal való gazdálkodásra irányulnak és együttesen alkotják a fenntarthatóság pedagógiájának tartalmát (Vöcsei et al., 2008).

A helyes értékrend kialakítása a környezeti nevelés kiemelt feladata. Megalapozza viszonyulásainkat, cselekedeteinket. Rávilágít környezetünk összetettségére és összefüggéseire, a legkisebb elem fontosságára (Ádám, Kuti és Kuti, 2007).

Az oktatásnak segíteni kell a tanulókat abban, hogy jobban megértsék a világot, amelyben élnek, hogy felismerjék az emberiség jövőjét fenyegető problémákat: a szegénység, a pazarló fogyasztás, a természetes és az épített környezet leromlása, a népességnövekedés, a nemek közötti egyenlőtlenség, az egészségügy, a háborúk és az emberi jogok megsértésének az összetettségét és egymásba kapcsolódó jellegét. A környezeti nevelésnek ez az új és kibővített felfogása hangsúlyozza egy holisztikus, interdiszciplináris megközelítés szükségességét a fenntartható jövő felépítéséhez szükséges tudás és készségek fejlesztése terén, és nagy hangsúlyt fektet az értékbeli, magatartásbeli és életstílusbeli változtatásra (Cseri, 2003; Esler et al., 2016).

\subsubsection{Az ember és környezete kapcsolatának fejlődése}

A civilizáció során az embernek a természethez való kapcsolata több változáson ment keresztuil. Ez a viszony három szakaszra bontható (Kohák, 1997 idézi: Lányi, 2007).

Az első szakasz volt a kultúra hajnalán a vadászó-gyüjtögető életmóddal együtt járó természetközeliség megtapasztalása, ami a természettől való félelemmel jár együtt. Ez a természetfelfogás nem harmóniára törekedett a természettel, csak arra, hogy a természet megadja azt, ami az emberek számára szükséges. Környezetének ismeretére a puszta túlélés miatt volt szüksége az embernek (Bas, Teksoz és Ertepinar, 2011).

A mezőgazdaság megjelenésével eltűnt ez a fajta felfogás, és kezdetét vette a második szakasz. A föld a gazda tulajdona lett, ahol az ő törvényei és akarata érvényesült. Minél nagyobb lett az ember szükséglete, minél bonyolultabb, hatásosabb módszerekkel tudta igényeit kielégíteni, annál nagyobb szeletet hasított ki a természetből. A gazdálkodó társadalmak természetfelfogásában a természet épp ezért kimeríthetetlennek tűnik. A természetnek alárendelt emberből a természettel egyenrangú partner lesz (Major, 2012).

A harmadik szint az ipari, fogyasztói társadalmak természetfelfogása. A partnerségből hamarosan fölöttiség lett, az ember már természet fölöttinek érzékeli magát, a természetre csak kimeríthetetlen nyersanyagforrásként tekint (Huang és Chang, 2003). Az ember igénye, hogy újabb földterületeket hódítson meg és használjon ki, a természeti erőforrások drasztikus csökkenését, a szennyező anyagok olyan mértékü felhalmozódását eredményezte, ami 
bármikor ökológiai katasztrófához vezethet (Niklanović és Miljanović, 2008). A fejlett civilizációkban a természet, az élőlények már nem partnerek, hanem a gazdasági haszonszerzés tényezői (Fien, 1999 idézi: Havas, 1998). Mindhárom természetfelfogás a természetet korlátlannak fogja fel (Molnár, 2009).

A negyedik szint lehet a napjaink civilizációjára jellemző felfogás, mely az információs társadalom kialakulásához vezetett el. Ennek a felfogásnak az értelmében az elsődleges tőke maga az információ és az elméleti tudás lett, az új természetfelfogást pedig a fenntartható fejlődésre való törekvés jellemzi (Major, 2012a).

Az információs társadalom az emberi együttélés új módja. Az információ és az azzal kapcsolatos jelenségek - tudás, kommunikáció, adatok, informálás, gondolkodás, adatfeldolgozás - a korábbinál fontosabb, központi szerepbe kerülnek, meghatározzák az emberi kapcsolatokat, a társadalmi átörökítést, az oktatást, a kultúrát (Pintér, 2007). Az információs és kommunikációs technológiák robbanásszerü fejlődése, a globalizáció egyre gyorsabb ütemü kiterjedése együtt jár a sebesség, az információmennyiség, a fogyasztás növekedésével, melyek egyre mélyülő globális, ökológiai és társadalmi problémákat vetnek fel (Lányi, 2007).

Akkor válhatunk fenntartható információs társadalommá, ha biztosítani tudjuk, hogy nem használunk el több erőforrást annál, mint amennyit a környezet és a jövő generációk sérelme nélkül tehetünk, ezen belül a gazdaságnak pedig a maximális környezeti hatékonysággal kell biztosítania, hogy a határokon belül a lehető legtöbbet és legjobbat nyújtsa a társadalom számára (Gyulai, 2013).

\subsection{3. Ökológiai elméletek az ember és környezete kapcsolatáról}

A fenntartható fejlődés és környezeti nevelés alakulását nagyban befolyásolták az ember és környezete viszonyával kapcsolatban kialakult ideológiák, nézetek.

A humanista, vagy antropocentrikus felfogás abból indul ki, hogy a természet óvása által az ember önmagát védi meg. A környezetnek itt nincs semmiféle belső értéke. Az ember kiemelése a természet leértékelődését vonta maga után. A korszak vezető elve az ember természet feletti uralmának érvényesítése (Balog, 2005).

A mélyökológusok igyekeznek a természet szabályait és ritmusát szem előtt tartva, nem azzal szembehelyezve vizsgálni az emberi életmódot. Ugyanakkor nem hagyatkoznak pusztán a tudományos ökológiai ismeretekre, hanem értékelik az érzelmeken és megérzéseken alapuló tudást is. A környezeti neveléssel foglalkozó pedagógusok többsége is követi ezt a szemléletmódot (Füzné Kószó, 2002).

A Gaia-elmélet azt vallja, hogy a Földet úgy kell tekinteni, mint egy nagy organizmust, amelynek müködése hasonlít az élő szervezethez. Minden alkotóeleme és rendszere kiveszi a részét a bolygó szabályozásából és egyensúlyban tartásából, fenntartva ezzel az élet jelenlegi folyamatait. Ennek a bonyolult szabályozórendszernek a működése biztosítja a bioszféra egyensúlyi állapotát. A Földet érő tartós és drasztikus hatások (stresszhelyzetek) felboríthatják az önszabályozó folyamatokat, az egyensúlyi állapot oly módon változhat meg, hogy maradandó károsodás jöhet létre bolygónkon (Lovelock, 1989 idézi: Füzné Kószó, 2002). 
A fenntartható fejlödés elméletének hívei kidolgoztak egy olyan gazdaságfejődési modellt, amely megőrzi a természeti erőforrásokat a következő generációk számára is, anyagés energiatakarékos termeléssel, a megújítható energiaforrások hasznosításával, a fogyasztás ésszerü módosításával. Ebben a folyamatban a világ nemzetei olyan fejlődés szereplőiként jelennének meg, melynek eredményeként az egyre növekvő létszámú emberiség olyan módon használná a természeti erőforrásokat, hogy az fenntartható lenne a jövő nemzedékei számára is (Pearce, Markandya és Barbie, 1989 idézi: Füzné Kószó, 2002).

\subsubsection{A fenntartható fejlődés célrendszere}

A fenntartható fejlődés célja, hogy a népesség számára úgy biztosítsa az alapvető emberi szükségletek kielégítését, hogy a fejlődő országokban nem korlátozza a gazdasági fejlődést, mert annak hiányában nem lehet az emberi szükségleteket kielégíteni, de sürgeti a környezetkímélő technikák alkalmazását. A fejlett országokban viszont a luxus fogyasztások korlátozását szorgalmazza. Ebben a formában az egyre növekvő létszámú emberiség olyan módon használná a természeti erőforrásokat, hogy az fenntartható lenne a jövő nemzedék számára is (Pearce, Markandya, és Barbier, 1989).

Abban a tekintetben, hogy az emberek milyen környezetet kívánnak maguknak, közgazdaságilag két álláspont létezik:

1.) A „,gyenge fenntarthatóság” álláspontja a természet helyettesíthetőségéből indul ki. Ha az élet természeti alapjai károsodnának, akkor a fenntarthatóságot az anyagi javak fokozott termelésével érik majd el. A gazdasági erőforrásoknak ez a szemlélete szük látókörü és tarthatatlan.

2.) Az „erős fenntarthatóság” álláspontja szerint a természeti javakat csak korlátozott mértékben lehet gazdasági tőkével helyettesíteni. E felfogás képviselői a jövő generációi számára biztosítandó „,konstans természeti tőkéről” beszélnek. Itt is az érték megőrzése a cél, és a teljes természeti tőke megőrzését tartják fontosnak (Németh, 2008 idézi: Major, 2012a).

A fenntartható fejlődés meghatározásakor három alrendszer kerül egymással szerves kapcsolatba: a környezeti, a társadalmi és a gazdasági rendszer (1. ábra). A rendszerek közötti sürü kölcsönhatásokat az emberek folyamatosan észlelik, értelmezik, és ezért az a nézet vált elfogadottá, hogy a fenntarthatóságot több nézőpontból kell szemlélni (Musters, Graaf és Keurs, 1998; Havas, 2001; López-Ridaura, Masera és Astier, 2002; Lehtonen, 2004; Abolaji, Oke és Adebanjo, 2011).

Ez a modell a mennyiségi növekedés és a minőségi fejlődés elemeit egyaránt magába foglalja, de ezek aránya szükségszerüen eltérő a konkrét országok esetében. A fejlődő országoknál a mennyiségi jellegű növekedés a jellegzetes, de előtérbe kerülnek a minőségi fejlődés iránti igények is. A fejlett országok esetében általában nem a további növekedés az elsődleges cél, hanem a termelés és a fogyasztás minőségi jellegü változtatása. A környezetkímélés és az erőforrás-takarékosság természetesen mindkét esetben elsőrendü igény (Láng, 2008). 


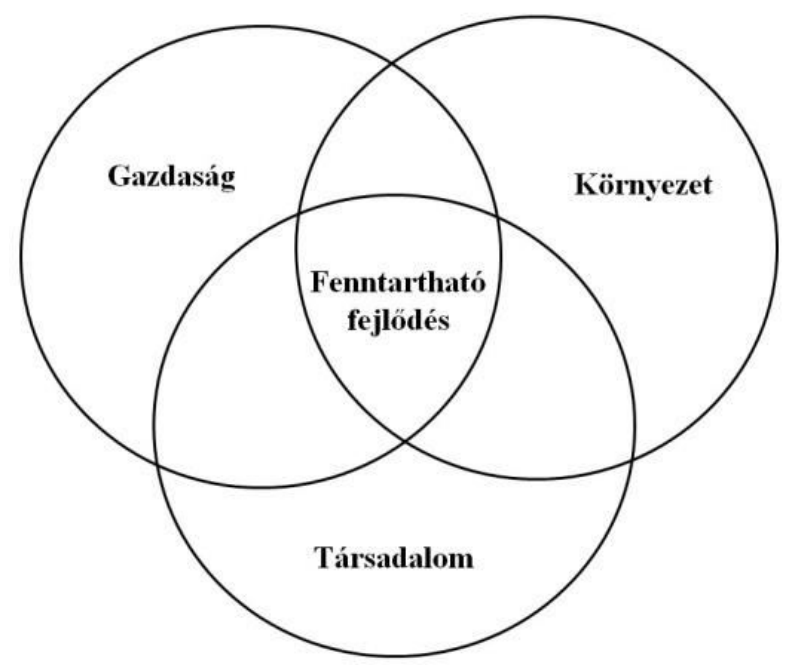

1. ábra: A fenntartható fejlődés három alrendszere (Havas, 2001 alapján)

Az ipari társadalom jellemzője, hogy a három nagy és összetett tényező, a gazdaság, a környezet és a társadalom összhangját a gazdaság hivatott megteremteni (2. ábra).

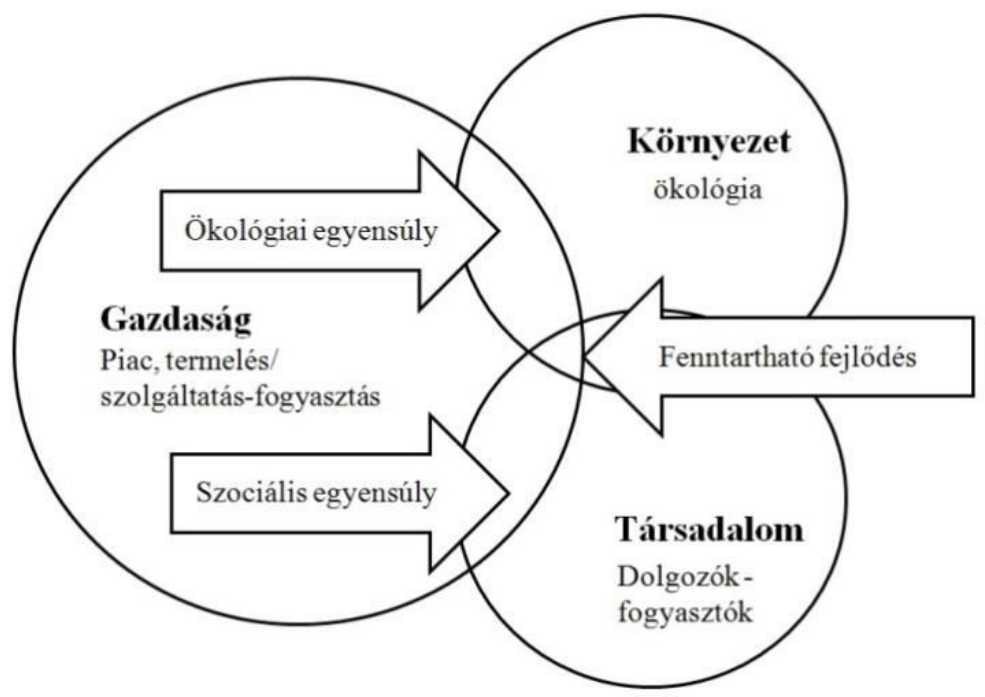

2. ábra: A fenntartható fejlödés gazdasághangsúlyos modellje (Turchany et al., 2004 alapján)

A fenntarthatóság problémáinak köztudatba kerülését követően azonban a gazdaság, a társadalom és a környezet viszonyában a hangsúly a környezetre tevődik át, amivel végeredményben a környezetnek jut a meghatározó szerep (3. ábra). 


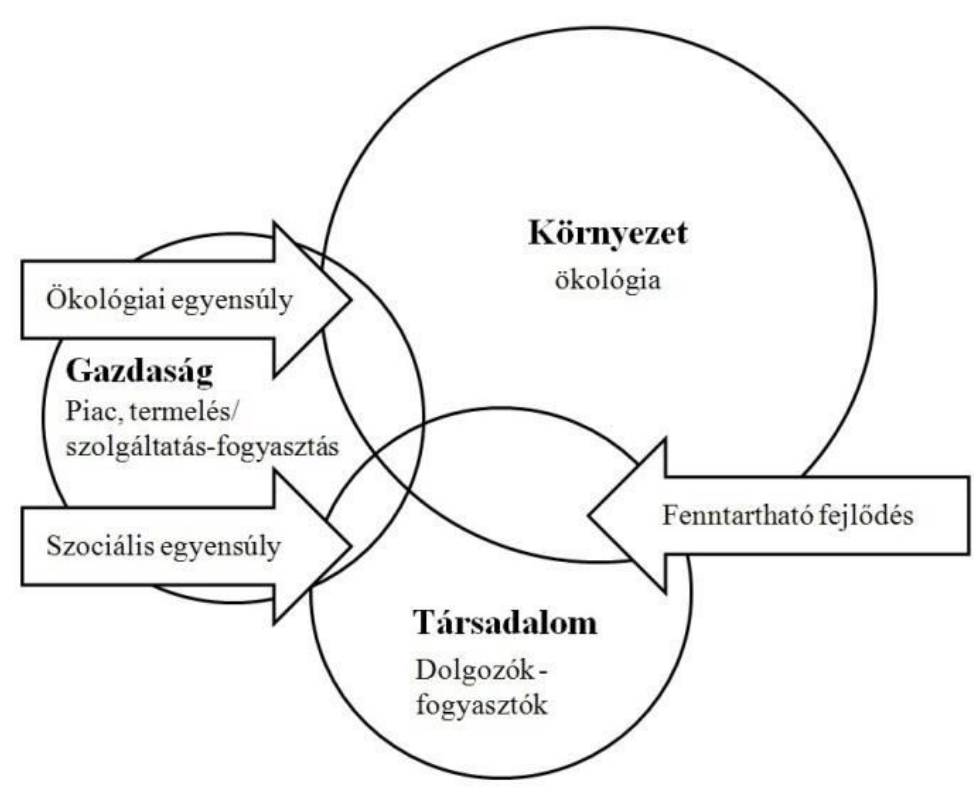

3. ábra: A fenntartható fejlödés környezethangsúlyos modellje (Turchany et al., 2004 alapján)

A fenntartható fejlődés a tágan értelmezett életminőség javulását szolgálja, ezért a szociális jólét elérését, megtartását elősegítő gazdasági fejlödéssel együtt kell érvényesülnie a szociális igazságosságnak és az esélyegyenlőségnek, valamint a természeti erőforrásokkal való fenntartható gazdálkodásnak. Ez utóbbi azt jelenti, hogy a természeti környezet eltartóképességével összhangban lehet csak a társadalom reális szükségleteinek a kielégítéséről gondoskodni, a környezet eltartóképessége egyben az igények kielégítésének korlátja is. Egyetlen társadalom sem szigetelheti el magát a nagyobb természeti, társadalmi környezettől (UNESCO, 1992 idézi: Mayer, 2014).

A johannesburgi világcsúcson kettős fordulat következik be, amennyiben nemcsak az eddig még mindössze háttérként kezelt társadalom lép előtérbe mint a legfőbb koordináló tényező, hanem kirajzolódik az ember központi, azaz meghatározó szerepe is. Ezzel egy negyedik önálló faktor is helyet kap az alapfogalmak itt vázolt rendszerében (4. ábra) (Turchany, et al., 2004) 


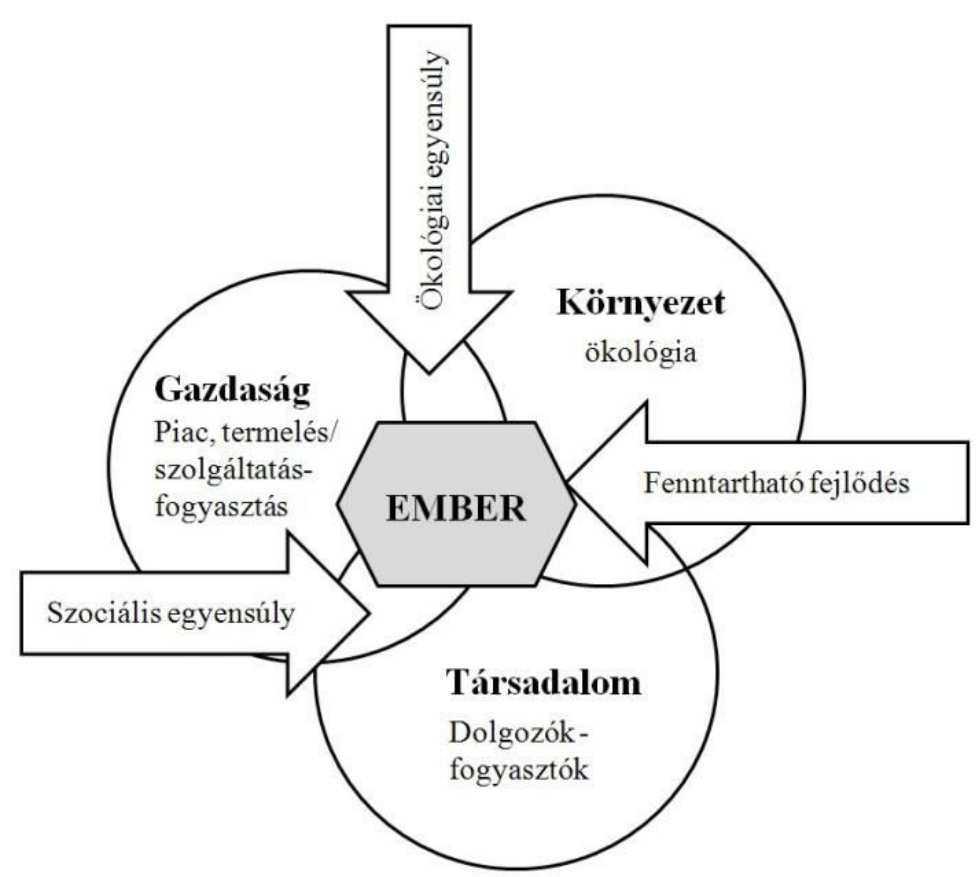

4. ábra: A fenntartható fejlödés emberközpontú modellje (Turchany et al., 2004 alapján)

\subsubsection{A fenntarthatóság pedagógiája nemzetközi téren}

A fenntarthatóság pedagógiája kifejezés magában foglalja mindazokat a pedagógiai törekvéseket, amelyek célja olyan emberek nevelése, akik képesek fenntartható társadalmat kialakítani és müködtetni. A fenntarthatóságra törekvés hosszú távú célja, hogy az emberiség rendelkezésére álló erőforrásokból biztosíthatóvá váljon az emberi társadalom hosszú távú müködése (Varga, 2003; Song, Zhou és Zhang, 2011). A fenntarthatóságra nevelés tehát nem csak arról szól, hogyan védhetnénk meg a környezetet, hanem arról is, hogyan védhetnénk meg az emberiséget saját pusztító tevékenységétöl. A környezet tönkretételével az emberi civilizáció akár el is tünhet a Föld színéről. A természet vagy a környezet fenntarthatósága tehát közvetve az emberiség, a társadalom fenntartásáról is szól. Az emberiség számára nagy kihívás, hogy képes-e életvitelét oly módon átalakítani, hogy hosszú távon ne veszélyeztesse saját fennmaradását (Jakab és Varga, 2007).

A fenntarthatóság pedagógiájának másik fontos feladata az ember szerepének hangsúlyozása a környezetvédelem területén. Ennek értelmében nem csak saját fajunkról, hanem a körülöttünk élö, ezen a téren önmagukban tehetetlen élőlények fenntartásáról is gondoskodnunk kell. Az ember az, aki szennyezi a környezetet és mértéktelenül használja az erőforrásait. Ezzel nem csak saját jövőjét teszi kockára, hanem a mellette létező, kölcsönhatásban lévő többi élőlényét is. Ezzel a felelősséggel is szembe kell néznünk, amikor a fenntarthatóság fogalmáról beszélünk (Major, 2012).

A fenntarthatóság pedagógiájának célja egy egész életen át tartó tanulási folyamat, amely olyan informált és tevékeny állampolgárokat nevel, akik kreatív, problémamegoldó gondolkodásmóddal rendelkeznek, eligazodnak a természet- és környezettudomány, a társadalom, a jog és a gazdaság terén, és felelős elkötelezettséget vállalnak egyéni vagy közös intézkedésekben. Ezek az intézkedések biztosítják az egészséges környezetet és a hatékony 
gazdaságot a jövő számára (Ideland és Malmberg, 2015; Zsóka et. al., 2013; Wheeler és Bijur, 2001).

Az ENSZ 1992-ben Rio de Janeiróban megtartott Környezet és Fejlödés címü konferenciáján született meg az Agenda 21 nevü program. A dokumentum a fenntartható fejlödés minden fontos területére kitér, különös tekintettel a környezetvédelem kérdéseire, és áttekinti a nemzetközi együttmüködést, a szegénység elleni küzdelmet, az ember egészségét és a népesség alakulását. A program hangsúlyozza a gyerekek elismert és fontos szerepét a fenntartható környezet fejlesztésében (Tilbury és Wortman, 2004). Mivel a környezettel szembeni pozitív hozzáállás gyermekkorban alakítható ki, nagyon fontos szerepe lehet a jövőre nézve a gyerekek és a fiatalok ilyen irányú nevelésének (Kopnina, 2011). Éppen ezért a környezeti nevelés céljainak, feladatainak rendszerszintü, szervezett megvalósítását leghatékonyabban az általános iskolai gyakorlatba lehet beépíteni (Niklanović és Miljanović, 2008).

A fenntartható fejlödést szolgáló tanulásra és oktatásra úgy tekinthetünk, mint egy folyamatra, melynek során tanulóink megtanulnak olyan személyes döntéseket hozni, úgy bekapcsolódni a társadalmi döntéshozatali folyamatokba, hogy döntéseik elösegítsék a jelen és a jövő generációinak jólétét, miközben nem veszélyeztetik a földi ökoszisztémák müködöképességét (Havas, 1997b).

A fenntarthatóságra nevelés lényegében azt jelenti, hogy az oktatás kapcsolatokat hozzon létre a környezeti, a társadalmi és a gazdasági rendszer között abból a célból, hogy megértessük e kapcsolatok müködési szabályait (Németh, 2008). Ez integrált rendszerközelítést, tantárgy- és tudományközi megközelítést igényel, ahol a vizsgálat tárgya (a környezet) integrált rendszerként, azaz egyidejüleg egységes egészként és részekböl állóként jelenik meg (Simon, 2009; Hofman, 2015). A fenntarthatóság pedagógiájának alapját a természetes összefüggések (általános sémák) képezik, és a kulturális kötöttségek (speciális sémák) csak az előbbiekbe ágyazódva fejtik ki hatásukat (Füzné Kószó, 2002; Fountain, Koppen és Leemans, 2011). A rendszerek közötti sürü kölcsönhatásokat az emberek folyamatosan észlelik, értelmezik, és ezért az a nézet válik elfogadottá, hogy a fenntarthatóságot több nézőpontból kell szemlélni (Havas, 2001).

Sajnos ma még mindig erőteljesen érvényesül az a szemlélet, hogy a fenntarthatóságnak és a környezeti nevelésnek elsősorban a környezet és a természet védelmével kell foglalkoznia, és eközben a fenntarthatóság problémaköre - ha közvetlenül nem kapcsolható valamiféle környezeti témához - háttérbe szorul (Vöcsei, Varga, Horváth és Carvalho, 2008).

Az ENSZ a 2005-2014-es időszakot a Tanulás a fenntarthatóságért évtizedévé nyilvánította (Wals, 2013 idézi: Bentham, Sinnes és Gjøtterud, 2015; Kalindi, 2014). A nemzetközi közösség egy teljes évtizedet szánt annak a célnak az elérésére, hogy az oktatás minden szintjét és formáját áthassák a fenntarthatóság, a környezet- és egészségvédelem alapértékei (Havas és Varga, 2005). Ezzel a törekvéssel igyekeztek hozzájárulni a magatartásformák olyan változásához, amelyek a fenntarthatóbb jövőhöz vezetnek a környezet egészsége, a gazdasági életképesség és a jelen és jövő nemzedékek igazságosabb társadalma tekintetében (UNESCO, 2005). 


\subsubsection{Fenntartható Fejlődési Program 2015-2030}

A 2015 utáni időszakra vonatkozó fenntartható fejlődési program tervezése 2015 szeptemberében, az ENSZ konferenciájának keretében zárult. A háromnapos Fenntartható Fejlődési Csúcstalálkozón az ENSZ 193 tagállama egyhangúlag fogadta el azt a történelmi, új globális fejlődési programot, amely 2030-ig a szegénység felszámolását és a fenntartható jövő felépítését tüzi ki célul. Ezek a célok minden ország számára feladatokat jelentenek fenntartható fejlődésük megvalósítása érdekében. A nemzeti programok és a nemzetközi együttmüködés új korszakát bevezető új agenda valamennyi országot olyan tevékenységekre kötelez, amelyek nemcsak a szegénység alapvetö okaival foglalkoznak, hanem a gazdasági növekedés és jólét fokozásával, továbbá az emberek egészségügyi, oktatási és szociális szükségleteivel, miközben a környezetvédelemre is koncentrálnak (Faragó, 2015).

Az új fenntartható fejlödési program: The 2030 Agenda for Sustainable Development (United Nations, 2015) középpontjában 17 globális, Fenntartható Fejlődési Cél található (Chin és Jacobsson, 2016). A 4. cél (5. ábra) vonatkozik az oktatás minőségének javítására a fenntartható fejlődés elérése érdekében.

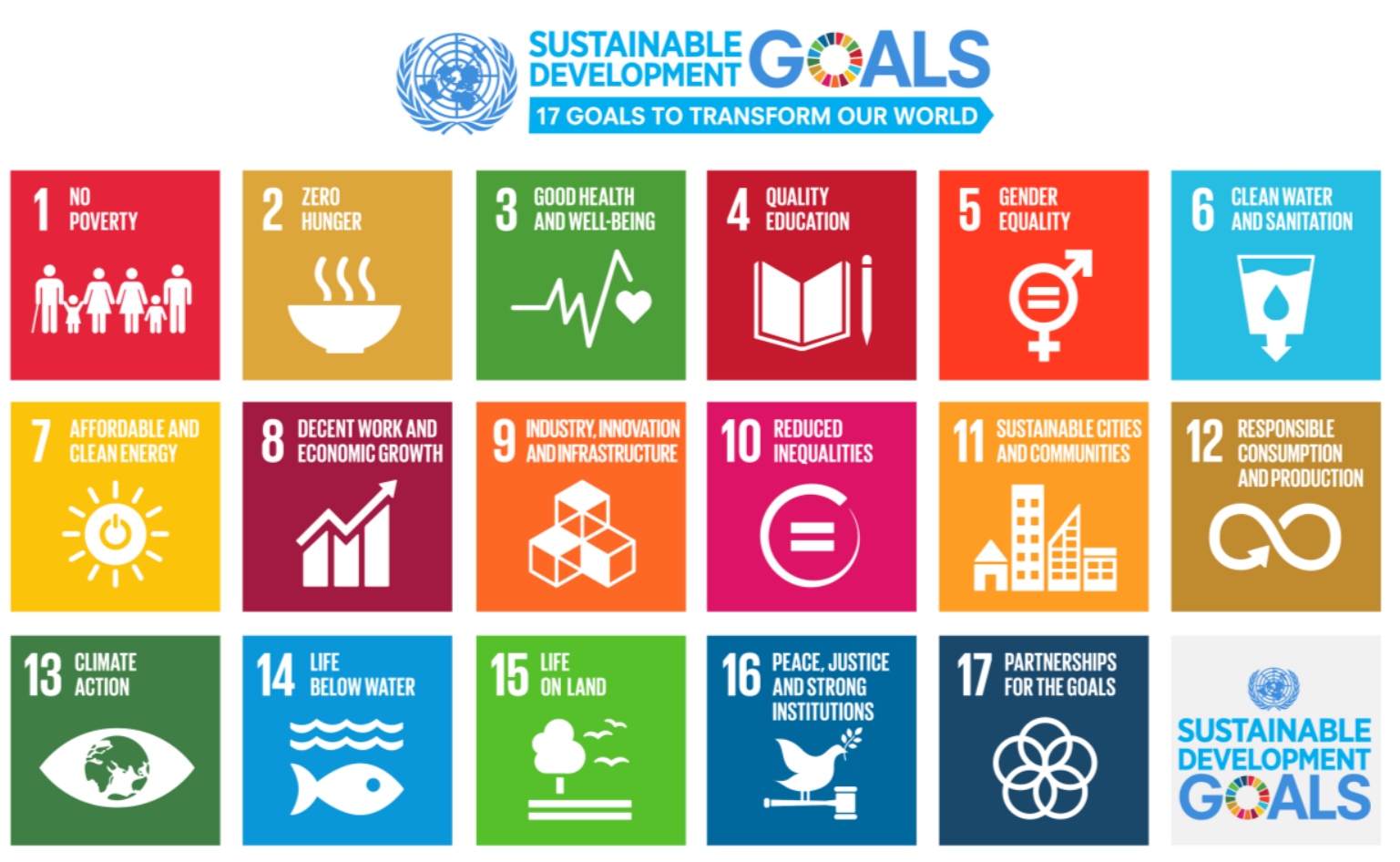

5. ábra: Fenntartható fejlödési célok 2030-ig (Forrás:

Division for Sustanaible Developement, 2015)

Faragó (2015), valamint az UNIS (2015) témával kapcsolatos oldala a következőképpen foglalta össze az oktatással kapcsolatos föcélok, és a hozzájuk kapcsolódó alcélok lényegét:

4. cél: biztosítani az átfogó és igazságos minőségi oktatást és elömozdítani az egész életen át tartó tanulási lehetőségeket mindenki számára. Ezen belül a következő alcélok kerültek megfogalmazásra az oktatással kapcsolatban: 
- minden fiatalnak adasson meg a megfelelö minőségü alap- és középfokú oktatásban való részvétel és annak elvégzése;

- az idősebb korúak körében csökkenteni kell az írástudatlanságot;

- minden tanuló sajátítsa el a fenntartható fejlödéssel kapcsolatos ismereteket;

- a fejlődő országokat támogatni kell az oktatás ezen céljainak elérése érdekében.

A múlt évben, 2016. május 30-a és június 5-e között került megrendezésre az Európai Fenntarthatósági Hét (European Sustainable Development Week), melynek célja egy olyan közös platform kialakítása Európa-szerte, ahol civil szerveztek, önkormányzatok, kulturális intézmények, kutatóintézetek és egészen kis közösségek is megmutathatják, hogyan járulnak hozzá a fenntartható fejlődés eléréséhez. Az események aktualitását a 2015 szeptemberében elfogadott Fenntartható Fejlődési Célok adták. A kezdeményezéseknek kapcsolódniuk kellett az ENSZ által megfogalmazott 17 fő célkitüzés valamelyikéhez, ezzel is hozzájárulva a célok minél szélesebb publicitásához. 2016-ban mintegy 4212 rendezvényt tartottak meg a fenntarthatóság jegyében Európa 38 országában (ESDW, 2016).

\subsection{A környezeti nevelés pedagógiai szempontjai}

\subsubsection{A környezeti nevelés „taníthatósága”}

A környezeti nevelés által megkívánt tanulásfelfogás alapja az az elgondolás, hogy a világot a tapasztalatainkból kiindulva, mindig az egyszerübbtől a bonyolultabb felé, a konkréttól az absztrakt felé, az egyes felől az általános felé haladva ismerjük meg. A jól ismert induktív-empirikus megismerés-felfogás ez, amely évszázadokon keresztül uralkodott a filozófiában, a pszichológiában és a pedagógiában is. Napjainkban a pedagógiában egyre fontosabb szerephez jut az az elképzelés, amely szerint a tudás az emberben nem kívülröl befelé irányuló közvetítési folyamatban jön létre, hanem alapvetően belső építkezés, konstrukció eredménye.

A konstruktív filozófia a pedagógiai gondolkodás holisztikus gondolatrendszere (Nahalka, 2002b; Feketéné, 2002). A konstruktivizmus szerint az emberi tudás konstrukció eredménye, vagyis a megismerő ember felépít magában egy világot, amely tapasztalatainak szervezője, befogadója, értelmezője lesz, amely lehetővé teszi, hogy bizonyos elörejelzésekkel éljen a valóságban található dolgok jövőbeli állapotával kapcsolatban. A tanulás tehát nem más, mint állandó konstrukció, a belső világ folyamatos építése. Ennek a belső világnak, világmodellnek nagyon fontos funkciója a megismerő embert érő információk feldolgozása, értelmezése, rendszerbe való beépítése. Ez pedig nem más, mint tanulás. A tudással kapcsolatos legfontosabb kérdés, hogy adaptív-e az ismeret, lehetővé teszi-e a megismerő egyed alkalmazkodását a környezetéhez, vagy sem (Nahalka, 1997a).

A gyermek csak azt képes felfedezni, ami meglévő tudásának keretei közt elhelyezhető, értelmezhető a számára. Ha ez a helyzet, akkor természetesen az a legjobb, ha a felfedezés folyamatában önálló. A környezeti nevelés is csak személyre koncentráló, differenciáló pedagógiát valósíthat meg, különben elveszítjük azokat a kis, egyéni világokat, a tanulók fejében létező megannyi egyedi értelmezést, amely csak gazdagíthatja munkánkat és a tanulók tevékenységrendszerét is (Nahalka, 2002a). 
Arra a kérdésre, hogy tanítható-e a környezetvédelem, ma a pedagógia két különböző paradigmájához kötődő táborai egymásnak ellentmondó válaszokat adnának. Az egyik tábor a környezeti nevelést is elsősorban ismeretek átadásának tartja, azt tekinti alapvetőnek, hogy a jövendő generációk tagjai alapos, korszerü tudást szerezzenek. Ennek a tudásnak a birtokában lehet csak elképzelni bármifajta környezeti cselekvést, ezt a tudást át kell adni, közvetíteni kell. Védeni, szeretni csak azt lehet, amit ismerünk. Környezetünk ismerete nemcsak tananyag, hanem a szemléletformálás nagyon fontos eszköze is. Az e táborhoz tartozók a természettudományok képviseletét tartják fontosnak a környezeti nevelésben (Nahalka, 1997).

A másik nézet képviselői is fontosnak tartják a természettudományi, környezettudományi alapokat (Morrone, Mancl és Carr, 2001), de nem ezt tekintik döntőnek. A környezeti ismeretek önmagukban nem elegendőek (Mikházi, 2006). A környezettudatos nevelés nem fogható fel ismeretszerzésként, hiszen a környezeti nevelés a mindennapi életvitel, magatartás, szemléletmód megváltoztatására is irányul (Alp, Ertepinar és Tekkaya, 2006). Ök elsősorban a környezeti attitüdöket akarják megváltoztatni, olyan környezettudatos magatartást kívánnak kialakítani, amely globálisan megváltoztatja az embernek a bioszférában elfoglalt pozícióját. Az iskolai nevelésben nem annyira a kemény tananyagok és azok átszármaztatása fontosak számukra, inkább az attitüdök, az érzések, a környezeti problémákhoz való viszonyulás, a cselekedni akarás (Nahalka, 1997).

A kétféle elképzelés a környezeti neveléssel kapcsolatban a pedagógiának két olyan paradigmatikus jelentőséggel bíró koncepciójához kötődik, amelyek nem békíthetők ki egymással, ugyanakkor nem is dönthető el, hogy melyik az igaz (Nahalka, 1997). A környezeti nevelés-oktatás ugyanis sokkal több egyszerü tudásátadásnál a környezetről, hiszen ma már a fenntartható fejlödés gondolatkörének átadása, megismertetése is a nevelőmunka feladata, csakúgy, mint az emberi hozzáállás és az értékek, a viselkedési és fogyasztási minták megváltoztatása, az emberek személyes felelösségérzetének kialakítása és az aktív részvétel elősegítése. A fenntartható fejlődésre nevelés magában foglalja a kritikai képességek, valamint a problémafelismerés, rendszerezés és megoldás képességének fejlesztését is (Kelley-Laine, 1998; Ádám, Kuti és Kuti, 2007).

A konstruktív pedagógia lehet az az elméletrendszer, paradigma, amely képes lesz alternatív választ adni a két tábor által felvetett kérdésekre. A konstruktív elmélet legfontosabb mondanivalója, hogy a tanuló ember a tudást nemcsak egyszerüen befogadja, hanem létrehozza, megkonstruálja, meglévő és kognitív rendszerekbe rendezett ismeretei segítségével értelmezi is az új információt (Inhelder és Piaget, 1984). Ez a konstrukció a már korábban birtokolt ismeretek, kognitív struktúrák bázisán, alapvetően egy értelmezési folyamatban zajlik. A folyamat eredménye egy olyan tudásrendszer, amely a tanulót adaptívabbá teszi, alkalmasabbá arra, hogy környezetével számára alkalmas módon lépjen kölcsönhatásba (Nahalka, 1997). 


\subsubsection{Környezettudatosság}

A környezeti nevelés - elsősorban a kisiskolások nevelésére vonatkoztatva - nem más, mint egy tapasztalatokat és ismereteket gyüjtő, a gyermek környezet iránti pozitív hozzáállást kialakító, pozitív szokásokon keresztül környezetorientált magatartást alakító, tudatformáló tevékenység. A környezeti nevelés több mint a környezet megismerése!

A környezeti nevelés a környezettudatos, környezetre figyelő magatartás megalapozását tartalmazza. Kialakíthatóak azok a szokások, magatartásformák, amelyek a környezettel való harmonikus együttélést biztosítják későbbi életvitelükben. A környezeti nevelésben megjelennek a különböző nevelési területek, integrálódnak és sajátos kölcsönhatásban felerősítik egymást (Ádám, Kuti és Kuti, 2007).

A környezeti nevelés az emberre, az ember magatartására, annak szabályozására irányul. Igyekszik az egész személyiségre hatni, a tudatra ismeretekkel, az érzelmekre élményekkel, az akaratra célszerü tevékenységekkel. A környezeti nevelés átfogja a személyiség kognitív és nem-kognitív tartományait, átalakíthatja az érzelmi viszonyulásokat, értékrendet, megismerési, cselekvési és döntési képességeket fejleszt, az embert képessé teszi együttmüködésre, életvitelének tudatos hangolására, beleértve az önkorlátozást is. Felismerteti az élet különleges és ismételhetetlen jelentőségét, a személyes felelősséget a természet és a környezet fenntartása és védelme szempontjából (Vásárhelyi, 2010 idézi: Major, 2012).

A környezettudatos életvitelt tanúsító személyek ismerik a fontosabb környezeti fogalmakat, az aktuális környezetvédelmi problémákat és tennivalókat, ismerik az adott probléma megoldásához használható cselekvési stratégiákat, hisznek a tevékenységük jelentőségében, elkötelezettek a cselekvésben és gyakorlatuk van az önálló cselekvésben (Gulyás és Havas, 1998).

A környezet kognitív ismerete a környezetért felelős magatartás szükséges, de nem elégséges feltétele. A környezetvédelmi problémák ismerete, az ezzel kapcsolatos attitüdök és értékek is szükségesek az egyéni, felelös cselekvéshez (Péntekné, 1999).

$\mathrm{Az}$ ember és környezete kölcsönhatásának megértésében, alakításában három szemléleti alapelv érvényesül (Rókusfalvy, 2002):

1. A komplex rendszerre irányultság elve: az emberi életet, az emberi tevékenységet nem rendezetlen halmaznak tekintjük, hanem a környezet és az ember külön-külön is jól értelmezhető rendszere kölcsönhatásai megnyilvánulásainak. Valójában három alrendszer, a környezet, a tevékenység és a személyiség rendszerének kölcsönhatásáról van szó.

2. A tevékenység-központúság elve: arra világít rá, hogy a környezet és az ember kölcsönhatása a tevékenységen (a megismerésen és a cselekvésen) keresztül valósul meg. Csak egy cselekvésközpontú emberismeret, pszichológia lehet az alapja a nevelésnek, így a környezeti nevelésnek is.

3. A személyiségelv: a cselekvések, a tevékenység szabályozását, s ezen keresztül a környezet, a körülmények - s végső soron az emberi sors - bizonyos mértékü alakítását is az ember egésze végzi, valósítja meg. 


\subsubsection{Az attitüdök szerepe a környezeti nevelés szempontjából}

Az irányultságot tekintjük az emberi személyiség legdinamikusabb összetevőjének. Az irányultságot, beállítódást leíró szociálpszichológiai elméleti fogalom az attitüd (Molnár, 2009). Az attitüdök pszichés képződmények, a lelki élet rugói, az indítékokat kötik össze a cselekvés céljával, értékrendjével (Havas, 1993 idézi: Major, 2014).

Az ,attitűd” fogalmára máig nincs egyaránt elfogadott definíció. A legáltalánosabb megfogalmazás szerint az attitüd értékelő viszonyulás valamihez (az attitüd tárgyához) (Mezö, 2008). Atkinson (2003) az attitüdöket olyan személyiségjellemzőkként írja le, amelyek meghatározzák, hogy a bennünket körülvevő világ különféle dolgaira kedvezően, elutasítóan, ellenségesen reagálunk-e. Az attitüdök mindig konkrétan egyetlen személyre, dologra, eseményre irányulnak.

Attitüdnek nevezünk bármely kognitív reprezentációt, amely összegzi egy attitűdtárggyal - önmagunkkal, másokkal, tárgyakkal, cselekedetekkel, eseményekkel vagy ötletekkel - kapcsolatos értékeléseinket (Ostrom, 1969 idézi: Molnár, 2009). Ezek az értékelések lehetnek: kedvezőek, semlegesek vagy kedvezőtlenek. Így az attitüdök lehetnek pozitívak, negatívak vagy semlegesek irányukban is. Az attitüdök különböznek intenzitásukban is, attól függően, hogy az egyén értékelése erős vagy gyenge a kommunikációs folyamatban (annak kódolása, dekódolása során) (Molnár, 2009).

A környezeti nevelés alapvetően nem ismeretek átadása, hanem beállítódások, attitüdök, érzelmi viszonyulások alakítása (Lehoczky, 1998; Bradley, Waliczek és Zajicek, 1999 idézi Gokhan, 2010). A környezeti attitüd azt jelöli, ahogy az ember az öt körülvevő környezethez viszonyul (Smit, 2009). Ez lehet pozitív vagy éppen negatív irányultságú. Az előbbi törődést, felelősségvállalást, odafigyelést jelent a környezetre, a negatív környezeti hatások minimalizálására törekszik. A negatív attitüd pedig egyfajta nemtörödömséget, az értékmegőrző cselekedetek hiányát jelenti (Havas és Varga, 1998).

Az attitüd áthatja a tevékenységeket, tartalmakat, környezeti nevelési célelemként is megjelennek. Részei a (környezetbarát) cselekvések és szokások, az érzelmek és az ismeret. A környezettel pozitív érzelmi kapcsolatot kell kialakítani. A pozitív érzelmi kapcsolat nem azonos a szeretettel, más viszonyulásokat is tartalmaz. Az élölények szeretete helyett alkalmazhatjuk az elfogadást, a tiszteletet, bizalmat, együttérzést stb. Így valódibb lehet a viszonykialakítás.

Az attitüdök vagy viszonyulások a szükségleteken alapuló motiváció erejével alapozzák meg a cselekvést, a tevékenységet. A személyiség viszonyulhat valahogyan önmagához, társaihoz, alapvető értékekhez, a környezethez. Ezt a környezethez füződö viszonyulást kell a pedagógusnak az iskolában formálni a környezeti nevelés számos színterén, szocializációs csatornáján keresztül. Mivel a beállítódásnál, viszonyulásnál megjelennek az érzelmi összetevők, a természet megismertetése és megszerettetése útján tudjuk megalapozni a védelmét is (Lükö, 1996; Yang, 2015). 


\subsubsection{A környezeti attitüdök rendszere}

A környezettudatos magatartás, a környezettel és a környezet problémáival kapcsolatos ismeretek, a környezet megóvását célzó attitüdök, készségek és a környezet megóvása érdekében történő cselekvésre való hajlam képezik a környezeti nevelés legfontosabb tényezőit (Lichtveld, 2010).

A környezeti attitüdöt egydimenziós modellként leírók gyakran azonosítják a fogalmat a környezettel való törődés definíciójával (Dunlap és Jones, 2002 idézi Medvés, 2012). A környezettel való törődés annak a mértékét jelöli, hogy az egyén mennyire van tudatában a környezetet érintő problémáknak, és mennyire támogatja ezek megoldását (Medvés, 2012). A környezeti problémák felismerése, okainak megértése még nem elegendő. A problémák megoldásához annak érdekében tenni akaró, elkötelezett, környezettudatos állampolgárokra van szükség (Lasso de la Vega, 2006; Akengin és Aydemir, 2012). A környezeti nevelés alapvető célkitűzése, hogy a társadalom és a természet fenntarthatósága céljából kialakítsa az emberek környezettudatos magatartását. Ez a korábbiaktól eltérő viszonyulásokat, irányultságot igényel. Más és új értékrend elfogadását, olyan cselekvési és döntési képességeket, amely az emberek életvitelének tudatos megváltoztatását eredményezi (Molnár, 2009).

A környezettudatosságot olyan magatartásformaként lehet definiálni, amely az egyén vagy a szervezet felelős és aktív szerepvállalásán alapul a környezeti problémák megoldásával kapcsolatosan. Lényegében a cselekvések minőségi jelzője, jellemzője. A környezet tágabb értelmezése szerint a természeti környezeten túl, ide értve a társadalmi viszonyokat és a gazdasági érdekeket is, a környezettudatosság a fenntarthatóság megvalósítását megalapozó magatartásforma (Berényi, 2009). Az egyik legkomplexebb, a felelős környezeti magatartást leíró modell Hines, Hungerford és Tomera (1986) felelős környezeti magatartási modellje (6. ábra).

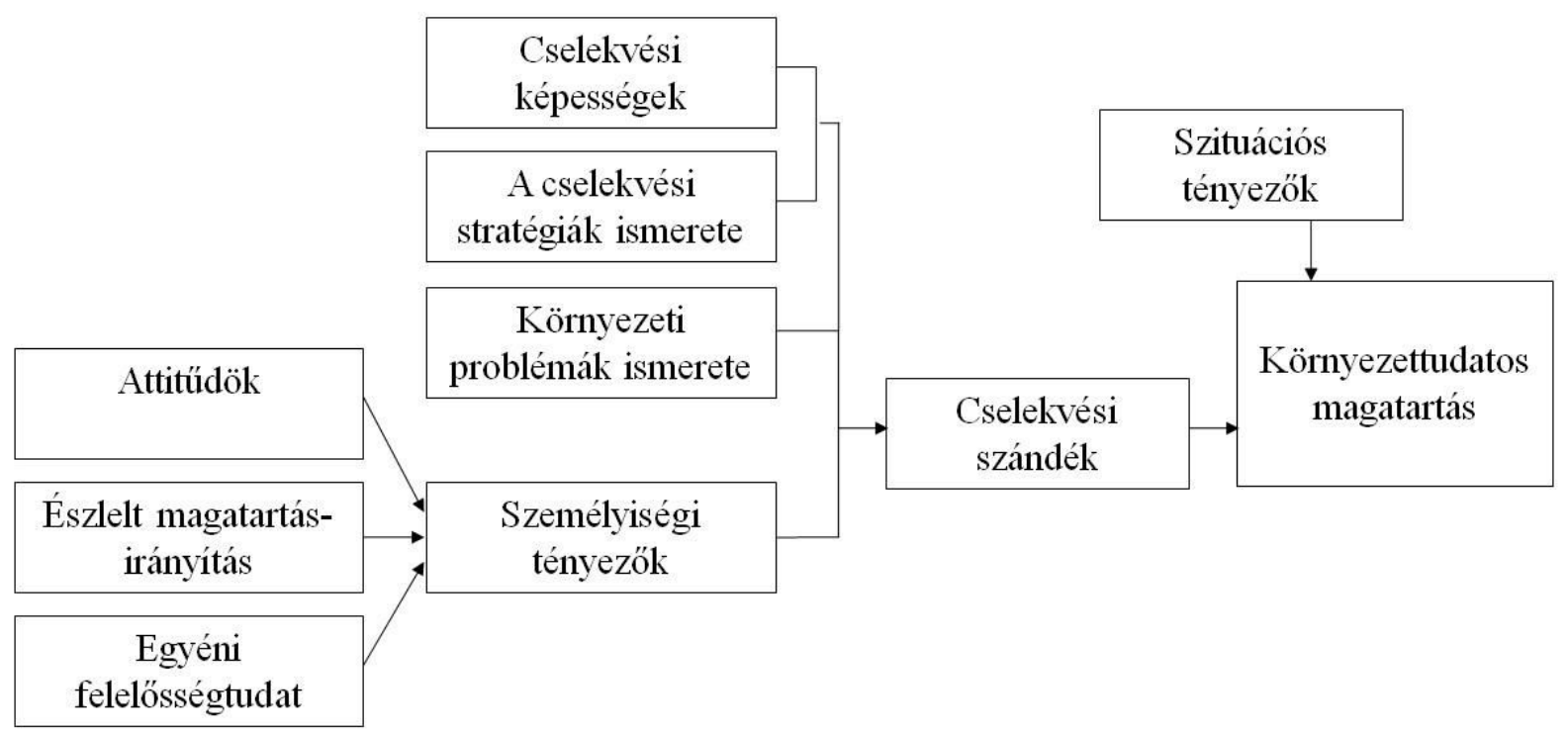

6. ábra: A felelös környezeti magatartás modellje (Hines, Hungerfold és Tomera, 1986 alapján) 
A modell kifejezi a különböző hiedelmek és az azok hatására kialakuló tényezők (attitűd, norma, észlelt magatartásirányítás) közötti meglehetősen komplex összefüggésrendszert, amely együttesen befolyásolja azután az egyén cselekvési szándékát, s végül a megvalósuló magatartást. A személyiségi szempontokat a modell szerint az attitődök, az észlelt magatartásirányítás, és az egyéni felelősségtudat határozzák meg. Az erősebb egyéni felelősségtudat a nagyobb elkötelezettség irányába hat. A cselekvési stratégiák ismerete azt jelenti, hogy az egyén tisztában van azokkal a lehetséges cselekvési alternatívákkal, amik közül választva tudja, hogy mit kell tennie ahhoz, hogy csökkentse saját tevékenységének a környezetre gyakorolt káros hatását. Cselekvési képességei ugyanakkor alapfeltételei is annak, hogy erősítheti, vagy gyengítheti szándékát e stratégiák megvalósításában (Takáts, 2010). A modell figyelembe veszi a szituációs tényezőket is, amelyek az egyén magatartását a környezettudatos cselekvési szándék megléte mellett a konkrét cselekvési helyzetben befolyásolhatják (Nemcsicsné, 2005). A cselekvési szándék ennek alapján nem vezet automatikusan a környezettudatos magatartás megvalósulásához, mert ún. szituációs tényezők befolyásolják a konkrét helyzetben létrejövő cselekvést. Ilyen szituációs lehetnek gazdasági korlátok, társadalmi nyomás, régi szokások, a magatartással járó áldozat mértéke, stb. (Takáts, 2010).

Bogner és Wiseman (1999) a környezeti attitüdöt már kétdimenziós struktúraként írják le. A két magasabbrendü faktor a megörzés és a használat dimenziójaként definiálható (7. ábra). A megőrzés dimenziója az ökológiai viselkedés leírására és a környezeti értékek megóvására utal, a használat dimenziója pedig a környezeti erőforrások kihasználását foglalja magába (Medvés, 2012).

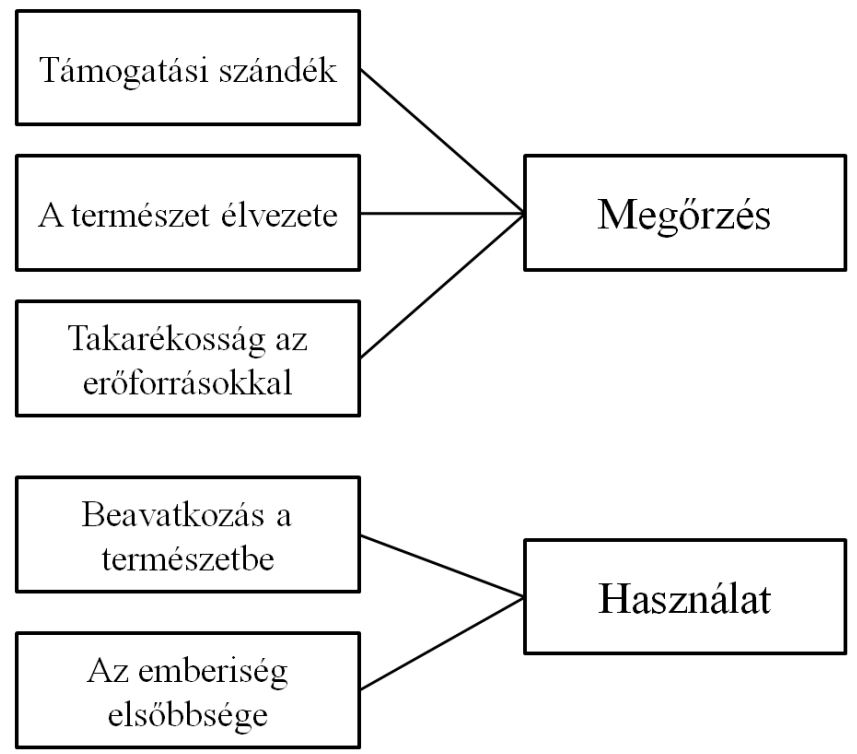

7. ábra: A környezet iránti attitüdök elsőrendü faktorainak és két magasabb rendü faktorának strukturális felépitése (Bogner és Wiseman, 1999 alapján)

Johnson és Manoli (2009) szerint a megőrzés és használat faktor a környezeti attitüdrendszer két nem feltétlenül összefüggő dimenziója. A két faktor alapján kialakítható az ökológiai értékek modellje, amelynek alapján négy, egymással nem közvetlenül korreláló kategóriába sorolhatjuk az egyéneket környezettudatos magatartásuk szerint (8. ábra). Az 
erős pozitív érzelmekkel rendelkező emberek (például a környezetvédők) várhatóan magas értéket érnek el a megőrzés faktoron belül, és alacsony értéket a használat faktor esetében. Ezzel ellentétben a megőrzés skálán tapasztalt alacsony, és a használat skálán tapasztalt magas pontszám olyanoktól származik, akik teljesen közömbös magatartást tanúsítanak a környezet problémáival kapcsolatban, miközben a természeti forrásokat kiapadhatatlannak ítélik és mérték nélkül használják is. Abban az esetben, ha valaki mindkét faktoron belül magas pontszámot ér el, akkor valószínűleg erős környezetvédelmi szándékot mutat ugyan, de emellett úgy véli, hogy a természeti erőforrások elsődleges szerepe az emberi szükségletek biztosítása. Amennyiben mindkét skálán alacsony pontszámmal rendelkezik valaki, az azt jelzi, hogy teljesen közömbös a környezet megóvása és a természeti erőforrások felhasználása iránt (Johnson és Manoli, 2009).

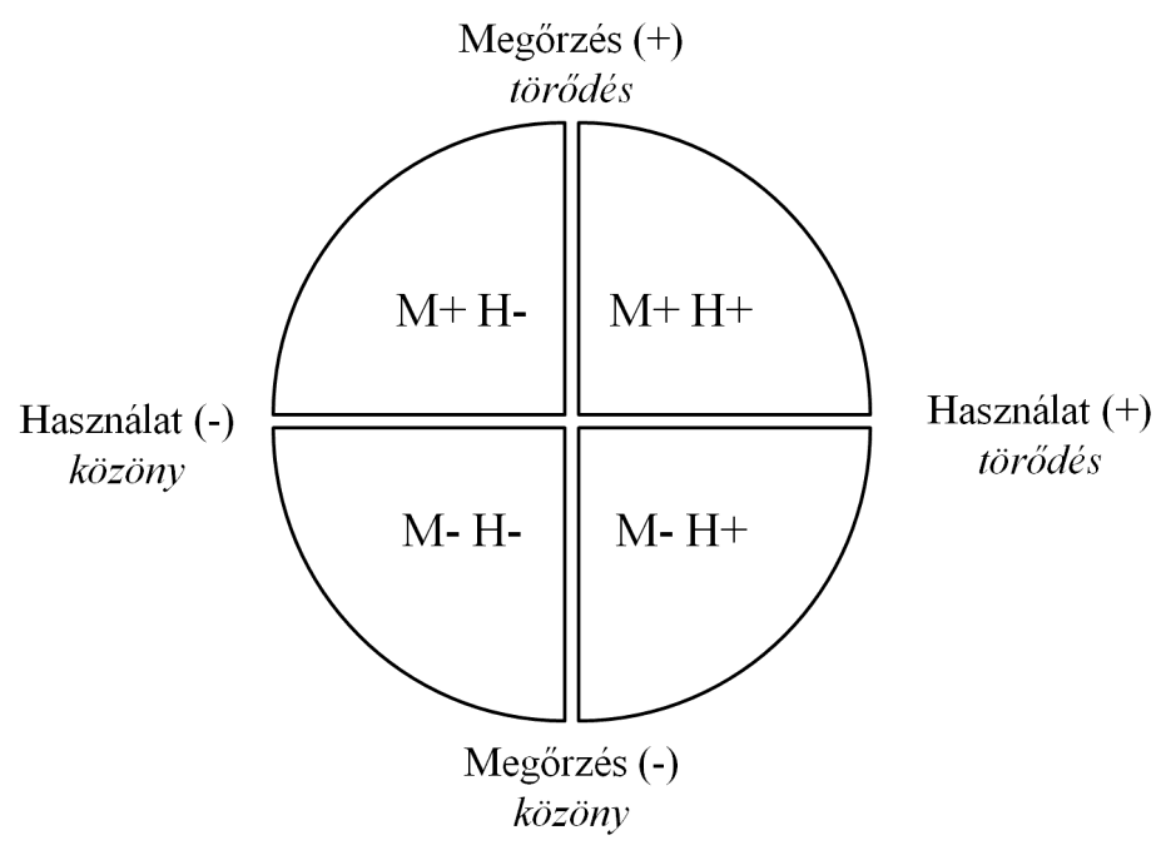

8. ábra: Ökológiai értékek modellje (Johnson és Manoli, 2009 alapján)

Más elméletek a környezetre vonatkozó attitüdöket három komponens mentén, a tárgyukkal kapcsolatos ismeretek, érzelmi viszonyulások és viselkedések alapján építik fel, megkülönböztetve a kognitív (ismereti), affektív (érzelmi) és konatív (viselkedési) összetevőket (9. ábra) (Marlowe and Woodrow, 1996; Kaiser, Wölfing and Fuhrer, 1999; Flamm, 2009; Pruneau et al., 2006; Okur-Berberoglu, 2015). Ezek az összetevők kísérleti helyzetben függő változóknak felelnek meg (Alp, Ertepinar és Tekkaya, 2006).

Az attitüd kialakulásakor a kialakult attitűd szorosan hozzákapcsolódik az egyén tárggyal kapcsolatos (addigi, meglévő) tudásához, ismereteihez (Molnár, 2009). A kognitív információ az attitüd tárgyával kapcsolatos tények és hiedelmek rendszere, mindaz, amit egy attitüdtárggyal kapcsolatban tudunk vagy tudni vélünk (Mezö, 2008). 


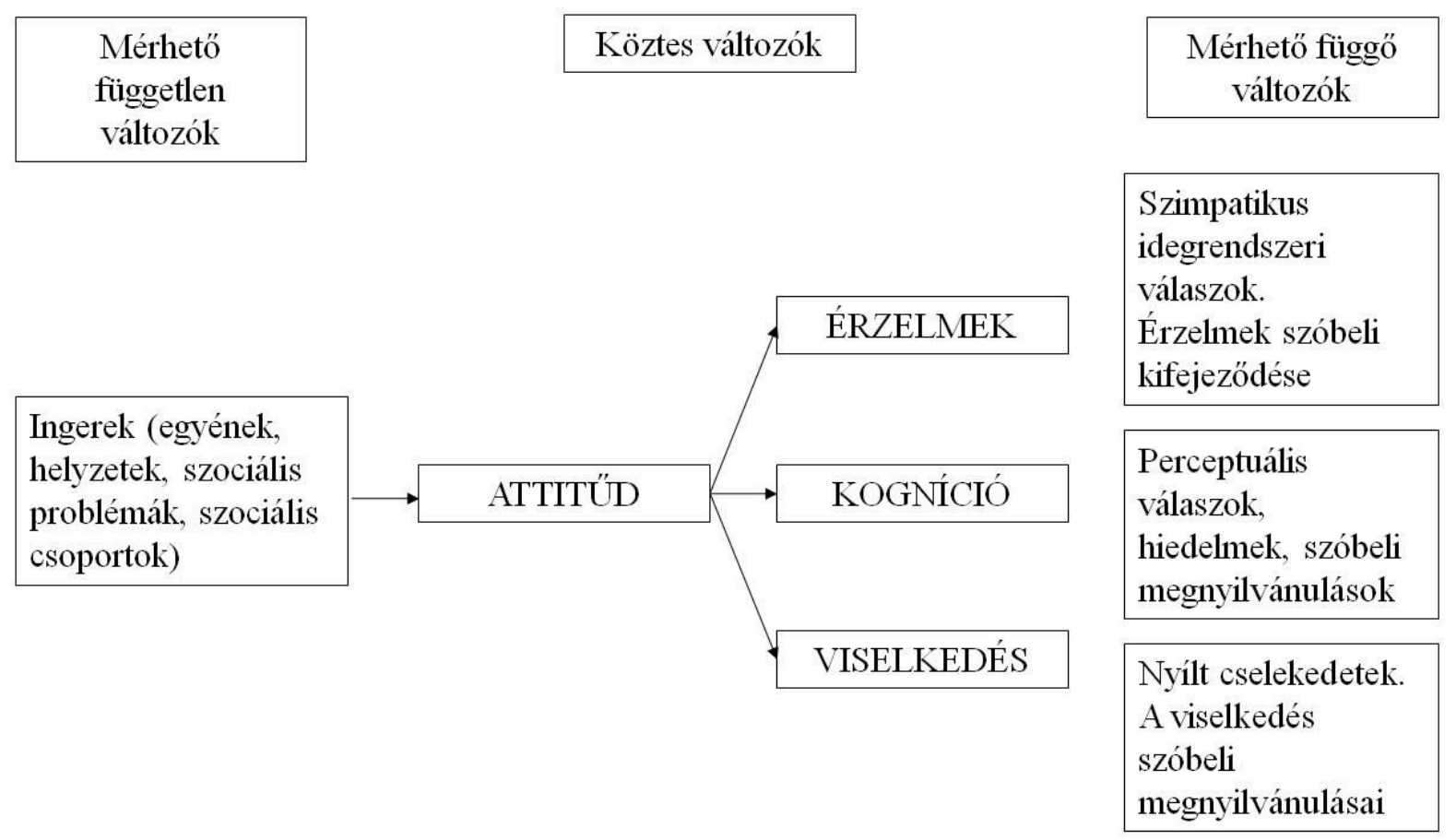

9. ábra: Az attitüd kognitív, affektív és viselkedésbeli összetevői (Rosenberg és Hovland, 1960 alapján idézi: Fletcher, Haynes és Miller, 2005)

Az attitüdök kognitív összetevője arra vonatkozik, hogy az egyén hogyan ítéli meg az attitüdtárgyat, milyen ismeretei vannak róla (Smith és Mackie, 2004). A kognitív komponensre irányul az attitűd megváltoztatásának egyik stratégiája, az úgynevezett nézetorientált megközelítés (Bandura, 1979). Ennek lényege, hogy az attitüdtárgyról szóló új vagy ismételt információk adásával változtatható meg egy attitüd.

Az attitüd affektív összetevője a személynek az attitűdtárgyra irányuló kedvező vagy kedvezőtlen érzéseivel foglalkozik. A konatív komponens a személy attitüdtárgyra vonatkozó viselkedési tendenciáival kapcsolatos, az attitüdtárggyal kapcsolatos múlt-, jelen- és jövőbeli viselkedési szándékok, megnyilvánulások alkotják (Smith és Mackie, 2004).

Az ismeret-attitüd-viselkedés modell szerint a környezeti ismeret elsajátítása pozitív környezeti attitüdöt, a pozitív környezeti attitüd környezettudatos viselkedést eredményez. Bár még az ok-okozati kapcsolatok nem tisztázottak. „Vajon a több tudás okozza a pozitívabb attitüdöt, vagy a pozitívabb attitűd motiválja több ismeret megszerzésére az egyént?” teszi fel a kérdést Zimmermann (1996) (idézi Varga, 2004). Kopnina (2011) holland gyerekek körében végezett vizsgálatának eredményeként azt állapította meg a kérdéssel kapcsolatban, hogy hiába nőnek fel a gyerekek Nyugat-Európa egyik legsürübben lakott országában, ahol a mezőgazdasági fejlesztések hatására az erdők 90\%-a kiveszett a középkorban, és a gyerekek még nem is láttak erdőt, a környezettel szembeni attitüdjük mégsem negatív. A holland gyerekek nem közvetlen tapasztalatok alapján szerzik meg a környezetvédelemmel kapcsolatos alapvető tudást, hanem a nevelés által. A gyerekek hozzáállását, attitüdjeit a természettel szemben nagymértékben befolyásolja az, hogy milyen társadalomban nőnek fel, milyen a szüleik hozzáállása, milyen mintákat/példákat látnak maguk körül (Kopnina, 2011).

A környezeti nevelési program hatásait vizsgáló empirikus kutatás során mindhárom modell alapján kidolgozott mérőeszköz közül alkalmaztam egyet-egyet a tanítóképzős 
hallgatók körében. A tesztek közül a Környezet Percepciós Teszt-Environmental Perception Test (Bogner és Wiseman, 1999 idézi Gulyás, 2004), a Módosított Új Ökológiai Paradigma Skála - Revised New Ecological Paradigm Scale (Dunlap et al., 2000 idézi Gulyás, 2004), valamint a Gyermek környezeti attitüd és tudásskála - Children's Environmental Attitude and Knowledge Scale (Leeming, Dwyer és Bracken, 1995 idézi Varga, 2004) került alkalmazásra. Mivel a CHEAKS és az ENV skála föként a viselkedés vizsgálatát teszik lehetővé, a RevNEP skála pedig az általános beállítódást vizsgálja, így általuk a minta széleskörü felmérése vált lehetővé.

\subsubsection{Attitüdváltozás a környezeti nevelés hatására}

A cselekedetek irányítása attitűdök révén történik (Allport, 1979 idézi: Mezö, 2008). Ebböl arra következtethetünk, hogy ha az emberek tetteit az attitüdök vezérlik, akkor az emberek attitüdjeinek megismerése, ismerete lehetővé teszi a viselkedésük megjóslását. Ez épp azt eredményezi, hogy az attitüdök megváltoztatása lehetővé teszi a viselkedés módosulását is. Az attitüdváltoztatás viselkedésorientált megközelítése keretében a célszemélyt olyan viselkedésre késztetik, ami attitüdjeivel szemben áll (McGuire, 1979). Mivel a viselkedés ellentmond a meglévő attitűdöknek egy ellentétes motivációs állapot jön létre, ami az attitűdváltozás irányába hat (Mezö, 2008).

Az attitüdváltoztatás érzelemorientált megközelítése során az attitüdtárggyal kapcsolatos emocionális változásokat legtöbbször klasszikus kondicionálással valósítják meg. Például: „az attitüd és a viselkedés megfordításához vezet, ha a nagymértékben pozitív valenciájú tárgyak az ellenkondicionálás taszító formáiban káros tapasztalatokkal asszociálódnak, vagy pedig ha a lehangoló szubjektív ingereket az érzéketlenités müveleteiben pozitív módon megerösitö eseményekkel párositjuk” - állítja Bandura (1979). Nem beszélhetünk egyértelmű megfelelésről az attitüd és a viselkedés fogalmát elemezve (Alp, Ertepinar and Tekkaya, 2006; Johnson és Manoli, 2011), azonban megállapíthatjuk, hogy a viselkedés és az attitüdök közötti kapcsolat meghatározó, két fontos ok miatt. Egyrészt bizonyos körülmények között a cselekedeteink megváltoztathatják az attitüdjeinket. Molnár (2009) példája szerint „...ha elkülönitve gyüjtünk hulladékot, az segíthet a környezet- és természetvédelemmel kapcsolatos attitüdjeink megváltozásában, különösen akkor, ha ezt nem egyedül, hanem társakkal, kortársakkal, vagy számunkra más fontos személyekkel együtt végezzük." Másrészt az attitüdök és a viselkedés jósolható kapcsolatban állnak egymással, az attitűdök befolyásolják a cselekvést. Így sem a kutatásban, sem a nevelésben nem az attitüd mint következmény vizsgálata és formálása a cél, hanem az attitüd közvetlen meghatározóinak feltárása (Heyl, Moyano Díaz y and Cifuentes, 2013; Molnár, 2009).

A környezeti nevelés során magas szintű készségek - kritikai gondolkodás, kreatív gondolkodás, integrálókészség és problémamegoldás - fejlesztése valósulhat meg, mivel valós problémákat vet fel, amelyeket tanulmányozni vagy szimulálni lehet. A környezeti nevelést úgy is értelmezhetjük, mint a viselkedés megváltozásával összefüggő készségek és értékek fejlesztését, amelyek szerves részét alkotják az ökológiai műveltségnek (Füzné Kószó, 2002).

A környezet minőségének megtartása és javítása érdekében különösen fontos olyan tanulási mechanizmusok fejlesztése, amelyek segítenek a diákoknak megérteni a természeti 
környezet és az emberi - gazdasági, társadalmi és politikai - tevékenységek közötti összefüggéseket, s azt, hogy a problémákat hogyan lehet megoldani. Ebben az értelemben a környezeti nevelés kapcsolatrendszert biztosít a magas szintü gondolkodási és tanulási készségek fejlesztéséhez (Fountain, Koppen és Leemans, 2011).

\subsection{A környezeti nevelés módszertana}

\subsubsection{A környezeti nevelés tartalmi modellje}

A környezeti nevelés összetett szakterület, tartalmának leírására több meghatározás is létezik. Az ún. „TÉT”-koncepció alapján a környezeti nevelés három fö komponensét és azok összefüggéseit írhatjuk le. E három fő tényező határozza meg a környezettel és természettel kapcsolatos elképzeléseket, ezáltal a környezeti nevelés/fenntarthatóságra nevelés értelmezését, felfogását. A modell három pólusa a következő tartalmakból tevődik össze (10. ábra):

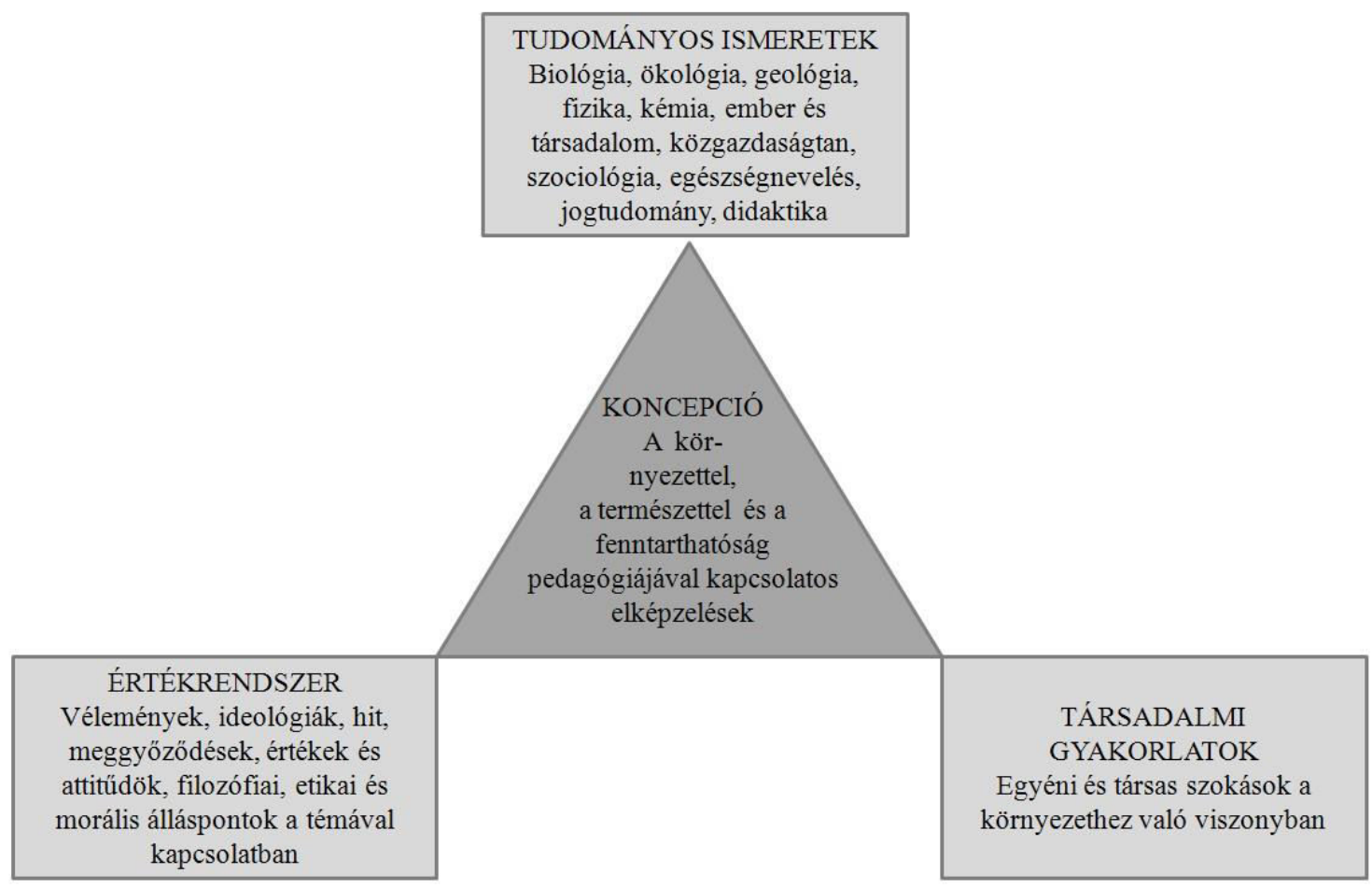

10. ábra: A ,,TÉT”-koncepció (Schróth, 2015 alapján)

$T$ - tudományos ismeretek: a különböző tantárgyakból származó tudományos háttértudás;

É-értékrendszer: az egyének döntéseit alapvetően meghatározó tényezők;

$T$ - társadalmi gyakorlatok: egyéni és társas szokások, amelyek összefüggésbe hozhatók a környezethez és természethez való viszonnyal, valamint befolyásolják azokat, illetve idetartoznak azok a gyakorlatok is, amelyek a használat/megőrzés kettősségére irányulnak (Vöcsei et al., 2008). 
A környezeti nevelés tartalmát a környezetről, környezetben, környezetért (Palmer és Neal, 1998) vezérfonalak mentén felállított hármas tagolás fejezi ki legátfogóbban (11. ábra):

A környezetröl szóló nevelés az értékekről és a környezeti problémákról szóló ismeretek átadását és azok megértését jelenti.

A környezetben, illetve a környezet által folytatott nevelés során a környezet a tanulás eszköze. A hangsúly a kutatáson, a tudakozódáson van. Ez olyan lehetőség, ami a vizsgálódási és a kommunikációs készségeket fejleszti.

A környezetért való nevelés a környezettel szembeni gondoskodó magatartás és az egyéni felelősség érzésének kialakítását szolgálja. Ez kapcsolódik a hozzáállás, az emberi felfogás és viselkedés fejlesztéséhez.

A környezetért, a környezetben történö nevelés során kialakult készségek alkalmazásával különböző célok (pl. akciók, kampányok stb.) megvalósítására lesznek képesek a tanulók. A környezetben (környezet által), a környezetről folyó nevelés eredménye az önálló élményszerzés lehetősége. A környezetről, a környezetért megvalósuló nevelés következtében aggodalom alakul ki a tanulókban az egyes környezetet károsító tényezőkkel kapcsolatban (Schróth, 2004).

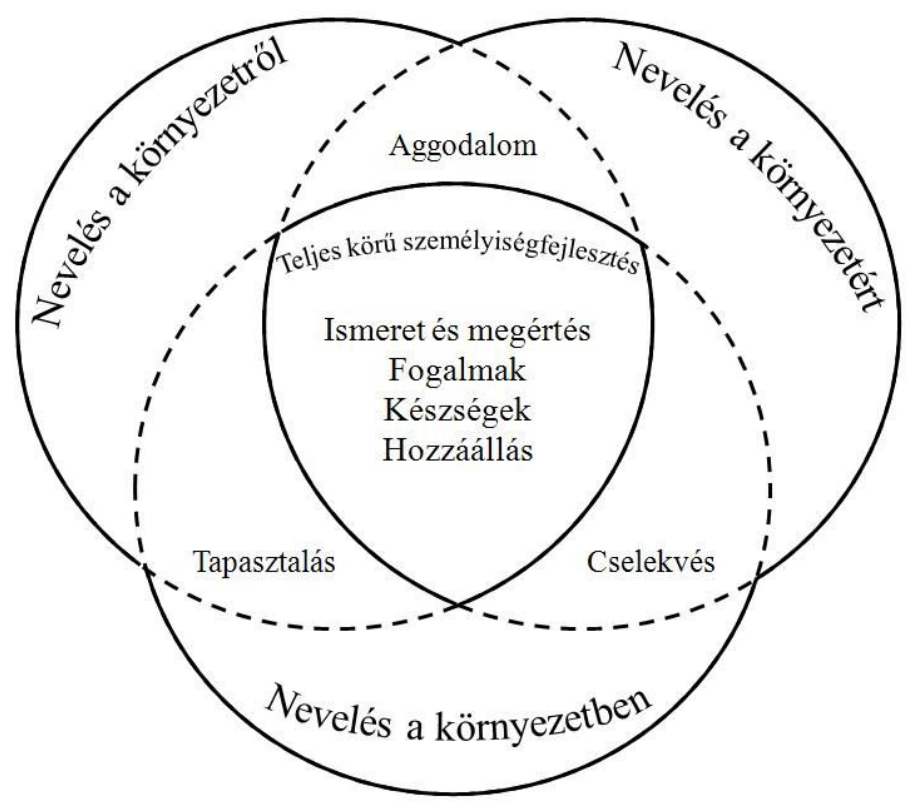

11. ábra: A környezeti nevelés tartalmi modellje (Palmer és Neal, 1998 alapján)

Ez a modell jól szemlélteti azt, hogy a környezeti nevelés a személyiség egészére próbál hatni: az ismeretek révén a tudatra, az élmények révén az érzelmekre, a célratörő tevékenységekkel az akaratra (Kuknyó, 2006). 


\subsubsection{A környezeti nevelés tantárgy általános jellemzői}

A környezeti nevelés összetett módszertani alapokon nyugszik. Más tantárgyak módszertanával ellentétben elsősorban élethosszig tartó. Azok a benyomások, élmények, amelyek meghatározzák az embereknek a környezethez füződő viszonyát, már kora gyermekkorban kialakulnak, és a környezeti nevelés nem fejeződik be az iskoláskor végén sem (Tung, Huang és Kawata, 2002). A felnőttek ilyen irányú nevelése ugyanolyan fontos, mint a gyerekeké, mivel a napjainkban jelentkező környezeti problémák nagy része új keletü, amelyekkel a felnőttek is csak ma találkoznak.

A környezeti nevelés megvalósulhat intézményes formában, szervezett keretek között, oktatási rendszerben, de ugyanúgy jelen van intézményen kívüli formában is. A család és a barátok befolyása is jelentős lehet, és ugyanígy az ismeretterjesztő irodalmak, illetve a tömegkommunikációs eszközök is különösen fontos hatással bírnak a környezeti nevelés terén. A televízió és az internet elsődleges információforrások a mai gyerekek számára. A rendelkezésre álló információk ellenére azonban a gyerekeknek a mindennapi életben tanúsított környezettudatos viselkedése nem kielégítő (Kara, Aydos és Aydın, 2015). Ezért fontos az intézményes és intézményen kívüli oktatási színtéren zajló környezeti nevelés összehangolása (Tung, Huang és Kawata, 2002).

Környezetünkben minden összefügg, nem léteznek egymástól elkülöníthető folyamatok. Minden változás kihatással van a rendszer többi elemére. Ezek a változások pedig sokszor kiszámíthatatlanok, ezért felelösséggel tartozunk tetteinkért, és azokért a következményekért, amiket a környezetünkben okozunk. Így a környezeti nevelés csak rendszerszemléletet tanúsító módszerként képes müködni. A környezeti nevelés interdiszciplináris, tartalma nem korlátozódik egyetlen tudományterületre, illetve tantárgyra. Minden tudományágból fel kell használnia a rendszerébe beilleszthető elemeket, és minden tantárgy oktatása közben tudni kell alkalmazni ezeket, az oktatás minden szintjén, az iskoláskor elötti neveléstől az egyetemi képzésig (Aydos és Yă̆cl, 2015; Dyment és Hill, 2015). A környezeti nevelés emellett transzdiszciplináris jellegü terület is. Nem csak a többi tudományterület fogalmait és eszközrendszerét használja fel céljainak megvalósításához, de egyesíti és új megvilágításba helyezi a különböző tudományágakat, és a fenntarthatóság érdekében magasabb szintre emeli őket (Esler et al., 2016).

A környezeti problémák - például a fajpusztulás, ózonlyuk, üvegházhatás - nagyobb része globális jellegü, vagyis az egész Földet érinti. Így a környezeti nevelésnek is globális szemlélet alapján kell működnie. Viszont minden régiónak, országnak, városnak megvannak a saját lokális környezetvédelmi problémái is. A helyi problémák azok, amelyekkel „személyesen”, testközelböl is kapcsolatba kerülünk. A környezeti nevelés lokális jellegü alkalmazása mellett ezeknek a helyi gondoknak a megismerésével személyes kötődést alakíthatunk ki a gyerekben a környezetuik iránt. Másrészt mindenkiben ki kell alakítani egyfajta átfogó felelősségérzetet a Földért, közös élőhelyünkért is. Szükséges, hogy tudatában legyünk, mennyire fontos számunkra a környezetünk egésze és helyi része egyaránt. Mindehhez holisztikus látásmód szükséges, amely ráirányítja a figyelmet arra, hogy nincs a környezetben elhanyagolható, lényegtelen, felesleges elem, tényező, hanem minden hálószerűen összekapcsolódik (Ádám, Kuti és Kuti, 2007). 
Jellemző környezeti nevelési probléma, hogy mindig abból kell kiindulni, azokkal a tényezőkkel kell foglalkozni, amik a jelen pillanatban lejátszódnak körülöttünk. Így a környezeti nevelés aktuális jellegü. Ugyanakkor bizonyos, hogy beavatkozásaink eredményei előbb-utóbb ránk is visszahatnak. A környezeti nevelés egyúttal tehát jövőbe tekintő tevékenység is.

Mivel a környezeti problémák nem állnak meg az emberi társadalom szabta határok előtt, ezért megoldásuk legtöbb esetben nemzetközi összefogást igényel. A környezeti nevelésnek elsősorban tehát együttmüködésre kell ösztönöznie. Mindenkinek ki kell vennie a részét a megoldások keresésében, és csapatmunkával, másokkal együttmüködve kell megoldani a problémákat (Victor, 1998 idézi Major és Czékus, 2011).

\subsubsection{A környezeti nevelés helye a tudományok és tantárgyak rendszerében}

Az iskolában tanítandó tantárgyak, valamint azok módszertana különálló tartalommal bír, és egy meghatározott rendszerbe sorolhatók. A környezeti nevelés azonban kivételt képez. Több tudományterület tartalmából meríti ugyanis azt a tudáskészletet, amelynek átadására vállalkozik. Nem önálló tantárgyként, hanem a többi tantárgyba integrálva jelenik meg, összekapcsolva, harmonizálva a különböző tantárgyak ismeretkészletét (Major és Horák, 2015).

A környezeti nevelés tantárgyközi és tudományközi fogalom is egyben, amelynek több kapcsolódási pontja van a többi tantárggyal és tudományterülettel. Módszertana a pedagógiai tudományok rendszerében a szakmódszertanok között helyezkedik el mint a pedagógia egyik résztudománya. Fontosabb kapcsolódási területei a következők (Major és Czékus, 2011):

Pedagógiai tudományágak: a környezeti nevelés megjelenik a pedagógiának az iskolán belül és az iskolán kívül alkalmazott területeiben, mint például a neveléselméletben, az oktatáselméletben (didaktika), a tantárgypedagógiában (szakmódszertanok), zoopedagógiában, múzeumpedagógiában stb.

A tantárgyak, valamint az azok alapját képezö tudományok: a környezeti nevelés iskolai gyakorlatában ötvöződik a környezettudományi és a társadalomtudományi ismeretek köre. Megjelenik az összes tantárgy tartalmán belül, valamint ötvözi a természet és társadalom alapját képező tudományterületeket (pl. biológia, földrajz, történelem, fizika, kémia, szociológia, filozófia stb.).

A környezetvédelem tudományterületei: a környezetvédelmi és a természetvédelmi tartalmakkal foglalkozó tananyagrészek kiemelkedő lehetőséget nyújtanak a környezetvédelmi nevelésre. A környezetvédelmen, illetve a természetvédelmen belül a környezeti nevelésnek ki kell terjednie az állatvilág, a növényvilág védelmére, a víz-, föld-, település- és tájvédelemre.

\subsubsection{A környezeti nevelés célja és feladatai}

A környezeti nevelés célja nem egyszerüen a tanulást szolgáló információk átadása, közvetítése, hanem olyan felelős és törődő állampolgárok nevelése, akik intellektuálisan és pszichológiailag felkészültek arra, hogy szembesüljenek a környezeti kérdésekkel, és megoldják azokat. A környezeti nevelés lényege, hogy a társadalom tagjaiban kialakítson és 
tudatosítson egy olyan viselkedésmintát, attitüdöt a természettel kapcsolatban, amely nem a kihasználáson, hanem a harmonikus együttélésen alapul (Weiland és Morrison, 2013; Aydos és $Y a \breve{g} c l, 2015)$. A környezeti nevelés a manapság elterjedt rövid távú érdekeket szem elött tartó profit- és növekedésközpontú gondolkodás helyett a hosszú távra tekintő fenntarthatóság érték- és nézetrendszerének meggyökeresedését tűzi ki célul. Mindehhez elengedhetetlen a tantárgyak és tudományágak közötti összefüggések bemutatása (Vöcsei et al., 2008).

A környezeti nevelés célrendszere felöleli a problémákra való nyitottságot, a megfelelő ismereteket és készségeket, a helyes hozzáállást (attitüdöt) és az aktív részvételt, a kreatív, szabad, kritikus gondolkodási folyamatok elősegítését egyéni szinten (Hofman, 2015), a társadalmak szintjén pedig az egész termelési és fogyasztási rendszer fenntarthatóvá tételét (Vásárhelyi, 2010).

Tágabb értelemben véve a környezetvédelmi nevelés célja a bioszféra megőrzése, fenntartása. A környezeti nevelés fontos feladata, hogy erősítse a gyerekekben a veleszületett spontán érdeklődést és kíváncsiságot, melyet a világ jelenségei iránt tanúsít. Tartsa fenn azt az érzést, hogy részeként is egyek vagyunk a világgal. Segítse az egyént a szépség és a harmónia keresésében. Ugyanis a szépség is érték, és az esztétika által felkeltett öröm is kiválthat aggódást, a megőrzés iránti vágyat (Orgoványi, 1999; Yang, 2015).

\subsubsection{A környezetei nevelésre jellemző módszerek}

Havas (1997) megállapítása alapján a környezeti nevelés olyan összetett rendszer, amely segít kialakítani a környezettudatos magatartást, amelynek keretében az emberek, a családok jobban odafigyelnek az apró, mindennapos környezeti szokásaikra, például az energiával, anyagokkal való gazdálkodásra, az ivóvíz és a hulladék kérdésére, az élő természettel való kapcsolatra és hasonlókra. Ez az állandó odafigyelés, tudatosság elsősorban attitűdökön és érzelmi viszonyulásokon alapul. Ennek az összetett rendszernek a kialakítása újfajta pedagógiai módszerekkel valósítható meg.

A környezeti nevelés módszerei alapvetően élményközpontú, tevékeny módszerek, amelyek lehetővé teszik, hogy a tanulók aktívan részt vehessenek a tanítás-tanulás folyamatában (Kostova és Atasoy, 2008). A módszerek alkalmazása azonban csak szemléletváltással valósítható meg, ami azt jelenti, hogy az ismeretközpontú oktatást fel kell váltania a cselekvésközpontú oktatásnak, vagyis a mindennapi gyakorlatban is jól alkalmazható tudás megszerzésére irányuló gyakorlatnak (Láng 2002; Koutsoukos, Fragoulis és Valkanos, 2015).

\subsubsection{A cselekvés pedagógiája}

A cselekvési képesség fogalma elterjedt a környezeti nevelés szakirodalmában (Jensen és Schank, 1994 idézi: Varga, 2004). A cselekvéspedagógia képviselői nem a tanulást tekintik a pedagógiai munka végcéljának, hanem az értelmes társadalmi cselekvést (Varga, 2004). A cselekvésre nevelés csak akkor vezet eredményre a cselekvési képesség fogalmának hívei szerint, ha a tanulók maguk is minél több valódi cselekvési lehetőséghez juthatnak, ha az iskolai tevékenységben szerepelnek valódi cselekvési lehetőségek, és ezek által, ezekhez kapcsolódva folyik a nevelés, oktatás. A környezeti nevelés célja a környezet megóvásáért 
cselekedni képes emberek kinevelése, vagyis környezeti kérdésekkel kapcsolatban cselekvési képességgel kell rendelkezniük a tanulóknak (Jensen és Schank, 1994, idézi: Varga, 2004; Álvarez és Vega, 2010; Koutsoukos, Fragoulis és Valkanos, 2015).

A jelenlegi nevelési módszerek között azonban alig akad olyan, mely valódi cselekvésekhez kötődne. A cselekvésre nevelés pedig csak akkor vezet eredményre, ha a tanulók maguk is minél több valódi cselekvési lehetőséghez juthatnak, vagyis ha az iskolai tevékenységben szerepelnek valódi cselekvési lehetőségek, vagy a tanulók iskolán kívüli cselekvései képezik az iskolai munka tárgyát, és ezek által, ezekhez kapcsolódva folyik a nevelés, oktatás (Varga, 2003).

\subsubsection{Projektmódszer a környezeti nevelésben}

A projektmódszer nem új keletű pedagógiai fogalom, a Dewey-féle reformpedagógia egyik hozományaként került be a pedagógia eszköztárába (Barabás és Görbe, 2015).

A projekt olyan szervezési eljárás, amely az oktatás menetét gyakorlati problémák megoldása köré csoportosítja (Major és Czékus, 2011). A pedagógiai projekt lényege, hogy az egyes komplex témákat önálló tanulói tevékenységek, sok különböző részlet egységben látása és egységben kezelése során dolgozzák fel (Nádasi, 2010).

A projektmódszer legfontosabb feladata a problémaközpontú gondolkodás fejlesztése, lehetőség teremtése az önálló gyakorlati tevékenységek során szerzett tapasztalatszerzésre, az élmények szellemi és érzelmi hatásának megvalósulására. A módszer elősegíti az önálló gondolkodás és problémamegoldás képességének fejlesztése mellett a tolerancia, az együttmüködés és a kognitív képességek fejlödését is (Kacsúr, 1995; Szállassy, 2008). A módszer alkalmazása során a tanító csak a folyamat megfigyelője, kísérője. Nem irányítja a diákokat, de aktívan követi őket, információkkal látja el, kritikus kérdéseket tesz fel, magyaráz a tanulóknak (Lükö, 2003).

A pedagógiai projektnek egy nyitott végü, autentikus fö kérdésre kell keresnie a választ. Ez szerencsés esetben olyan problémára vagy helyzetre irányítja a figyelmet, amely a tanulók szemszögéből is értelmes és releváns (Hunya, 2009). A környezeti nevelés során a projekt fö kérdése egy valóságos környezeti probléma, ehhez kapcsolódnak a tanulók meglévő ismeretei, tudásanyagai (Mérő, 2007). A módszer első lépése a témaválasztást követően a cél megfogalmazása, majd a projekt lebontása kezelhető egységekre. A következő lépés a projektterv elkészítése, majd ezt követi a megtervezett tevékenységsorozat megvalósítása. A projekt záró tevékenységei közé az eredmények bemutatása, dokumentálása és értékelése tartozik (Hunya, 2010). 
A természetet legeredményesebben a természetben lehet megismerni (Czekuš, 2002; Hadzigeorgiou és Skoumios, 2013). Az érintetlen természettel való találkozás kora gyermekkorban kulcsfontosságú jelentőséggel bír a környezeti értékek megóvására való hajlam kialakítása érdekében (Kahtz, 1995; Kopnina, 2011; King és Ginns, 2015). Az ember és környezete kapcsolatának megértése, az élő és élettelen természet elemei közötti összefüggések, ok-okozati viszonyok megértése közvetlen megfigyelés vagy tapasztalat útján lehetséges (Palmberg és Kuru, 2000). Kizárólag a tantermi nevelésre alapozva nehezen építhető ki a személyes felelősség érzete a környezet iránt (Jovanović, Živković és Anđelković, 2010; Akengin és Aydemir, 2012; Erdogan, 2015). Arra kell törekedni, hogy a gyerekek ösztönös belső késztetését követve támogassuk a természeti környezethez való szoros kapcsolat kialakulását (Sobel, 1999 idézi: Füzné Kószó, 2002).

A szabadban végzett feladatok hatásos kiegészítői lehetnek a tankönyveknek, mivel érdeklődést felkeltő, konkrét tapasztalatot kínálnak, továbbá fejlesztik a környezeti problémák megoldásához szükséges készségeket és stratégiákat (Pedretti, 2012; Erdogan, 2015). Ha a tanulók saját maguk vizsgálnak meg például helyi problémákat, akkor az ebből származó meggyőződésük pozitív lesz (Brossard, Lewenstein és Bonney, 2005). A természetben történő megfigyelések során szinte észrevétlenül sajátítják el a tanulók az ismereteket, fejlődik környezettudatos magatartásuk (Kövecsesné Gösi, 2009). A természetközelben megvalósuló tanulás vezethet csak el oda, hogy a gyerekek közel kerüljenek a természethez, élményeket, tapasztalatokat szerezzenek vele kapcsolatban, pozitív viszony, kapcsolat alakuljon ki az ember és a természet között (Bonnett és Williams, 1998; Hadzigeorgiou és Skoumios, 2013; King és Ginns, 2015).

A környezeti nevelés interaktív, folyamatos összefogással müködő tevékenységrendszer. Nem lehet elsajátítani „elmondás” által, csak átéléssel. A környezeti nevelés nem csak a pedagógiai folyamat által, hanem az egész életvitel révén valósulhat meg (Ádám, Kuti és Kuti, 1997). Mindezt osztálytermi környezetben nehéz megvalósítani (Dopico és Garcia-Vazquez, 2011), függetlenül attól, milyen magas a környezettel kapcsolatos oktatás színvonala. A természettel való közvetlen érintkezést nem lehet mással helyettesíteni (Kobierska, Tarabuła-Fiertak és Grodzińska-Jurczak, 2007). Lehetőséget kell adni a gyerekeknek, hogy sok időt töltsenek a természetben olyan felnőttek mellett, akik felelős magatartást tanúsítanak a környezetük iránt.

A gyermek először érezze jól magát a természetben, szeresse azt, s csak ezután foglalkozzon a természet problémáival, hiszen a megfelelő érzelmi motiváltság után reagál csak érdeklődéssel a környezeti problémákra (Füzné Kószó, 2002). A szeretet nélküli tudás nem tartós. De ha először a szeretet alakul ki, a tudás biztosan követni fogja (Sobel, 1999 idézi: Füzné Kószó, 2002). 


\subsubsection{A környezeti nevelési programok jelentösége}

Ahhoz, hogy a környezeti nevelés alapvető céljait elérjük, azaz környezettudatosan élő, a fenntarthatóságot szolgáló megoldásokat kereső, állandó fejlődésre képes tanulókat neveljünk, szükség van pozitív élményt nyújtó, szabad aktivitásra épülö, önálló problémamegoldásra ösztönző környezetnevelési programokra (Nagy C., 2008; Carleton-Hug és Hug, 2010; Grodzińska-Jurczak, Bartosiewicz, Twardowska és Ballantyne, 2004; Monroe, 2010).

Az intenzív környezeti nevelési programok az eddig kialakult nevelési gyakorlattal párhuzamosan történő megvalósításuk során alkalmat teremthetnek a környezeti nevelés sajátos módszertani elemeinek megvalósítására, és a hagyományos oktatási rendszerbe történő beillesztésükre (Carleton-Hug és Hug, 2010). A környezetnevelési programok ugyanúgy alkalmat teremthetnek az interdiszciplinaritás megvalósítására az oktatásban, mint a hagyományosan szervezett környezeti nevelési rendszer, azzal, hogy a programok keretében intenzívebb, maradandóbb élményekkel, komplexebb tudásanyaggal gazdagodhatnak a tanulók (Koutsoukos, Fragoulis és Valkanos, 2015; Esler et al., 2016).

Gokhan (2010) szerint a tanulók környezettudatosságának és a környezeti attitüdjének fejlesztése sokkal hatékonyabb az intenzív programok által, mint a hagyományos oktatási módszerek alkalmazásával. Manapság egyre több oktatási intézmény ismeri fel a környezeti nevelési programok jelentőségét, és alakítják ki saját környezeti nevelési stratégiáikat (Chapman, 2014). Az oktatási folyamatba beépített környezeti nevelési program várhatóan lehetőségeket nyújt a diákok számára, hogy gyakorolják a felelős állampolgár készségeit is (Füzné Kószó, 2002). Ezzel az iskolai tanulási színtér kitágul, gazdagodik, az iskola betagolódik az öt körülvevő társadalomba, és a partnerségek, együttmüködések képviselik a felelősség megosztását (Nagy C., 2008).

A megfelelően szervezett programok kedvező irányban befolyásolhatják a gyerekek környezettel szembeni hozzáállását, környezettudatos magatartását (Dimopoulos, Paraskevopoulos és Pantis, 2008; Smith-Sebasto és Cavern, 2006; Ballantyne, Fien és Packer, 2000). A programok megvalósításához azonban mindenekelőtt megfelelő hozzáállással és tudással rendelkező pedagógusokra van szükség, akik képesek értékelni munkájuk hatékonyságát és hajlandóak alkalmazkodni a megváltozott tanítási környezethez (Moseley, Reinke és Bookout, 2002). A tanároknak fel kell ismerniük azt a tényt, hogy a pedagógus mesterség ma már egyet jelent egy egész életen át tartó tanulási és fejlődési folyamattal, nem csak a környezeti nevelés, de minden tantárgy és tudományterület esetében (Gatzke, Gayle és Akerson, 2015). 


\subsubsection{A nevelési gyakorlat megújulása a környezeti nevelés által}

A nevelés általános feladata az összegyüjtött ismeretek, tapasztalatok és a létrejött értékek átadása a következő nemzedékeknek (Kuknyó, 2006). Azonban ma még annak az elvnek az alapján fogalmazódnak meg a nevelési célok, hogy a jelen határozza meg a jövőt. Pedig a mai, globalizálódó világban nem a mára érvényes ismeretek készítik fel a tanulókat a jövő kihívásaira, hanem a majdani jövőt kell elörelátni, és arra kell őket a jelenben felkészíteni. A jövő legnagyobb kihívásai pedig a környezeti problémák lesznek (Schróth, 2004).

A környezeti nevelés tényekkel, célokkal, gondokkal, lehetséges megoldásokkal, modellekkel, értékekkel foglalkozik. A tények megismeréséhez tapasztalatra, megfigyelésre van szükség. A modellezéshez meg kell érteni a környezet müködésének rendszerét (Meadows, 1989; Campbell et al., 2010). A célok és értékek meghatározásában nagy szerepet játszik az etika. A környezet esztétikájának meglátásához szépérzékre és művészi érzékre van szükség. Fontos az elkötelezettség, a személyes felelősségérzet kialakítása a környezet iránt. Ezek az elemek eddig is a nevelés részei voltak, de csak külön-külön, az egyes tantárgyakon belül (Schróth, 2004). A környezeti nevelés integrálja ezeket az elemeket. Ezzel nem helyettesíti vagy teszi feleslegessé a többi tantárgyat, csak egységbe szervezi őket, új ismeretkörökkel bővítve, a megismerés és a gondolkodás új módjaival gyarapítva újítja meg a pedagógia eszköztárát, a didaktikai módszereket és rendszereket (Kostova és Atasoy, 2008).

Ma már semmilyen oktatás nem nélkülözheti a technika vívmányait, eszközeit. A technika a környezeti nevelés során nem kerül szembe a környezettudatos magatartással, hanem egyfajta kölcsönös együttmüködés jön létre a technika és a természeti környezet között (Lükö, 2003). Az információs és kommunikációs technológiák oktatásban való integrálása hozzájárulhat a fenntartható fejlődés elősegítéséhez, hiszen szolgáltatásokhoz, információhoz való hozzáférést biztosítanak. Az integrált szemlélet kialakulásának legalkalmasabb helyszíne a virtuális tér, hiszen a világháló használata bevezeti a diákokat a globális összefüggések felismerésébe és az információk használatába (Besenyei, 2013).

A társadalom változásai, valamint a környezeti nevelés sajátos igényei magukkal hozták a tanári szerep változását is (Schróth, 2004 idézi: Bagány et al., 2014). Korábban a tanár egyértelmủen a tudás egyedüli közvetítője volt. Mára viszont a tanári szerepkör több elemmel gazdagodott, egyrészt a környezeti nevelés jellegéből adódóan, másrészt az információs társadalom által az oktatási rendszerben bekövetkező változások hatására (Varga, 1998). A tanár ma már nem a tudás egyedüli forrása és közvetítője, hanem a tanulási folyamat része, annak háttérirányítója (Gokhan, 2010). A tanulókkal együttmüködve, gondolataik, véleményük figyelembevételével építi fel az oktatás folyamatát. Fontos, hogy segítsék a tanulókat az önálló felfedezésben, élményszerzésben (Néder, Saly és Szentpétery, 2013).

A tanárok pedagógiai kultúrájának egy könnyen megfogható pontja az alkalmazott oktatási módszerek köre. Minél változatosabb egy tanár módszertani repertoárja, minél nagyobb szerepet kapnak benne a csoportos tevékenységek, a kooperatív, projektszerü vagy problémaalapú tanítási módszerek, annál inkább fejleszti a diákok együttműködő és szervezési, feladatmegosztó és szerepelfogadó készségeit, az elsajátított tudás hatékony használatát, amelyek elengedhetetlen kulcsfontosságú kompetenciák a 21. század teammunkára alapozó munkaerőpiacán. Mindezen módszerek használatát kiegészítve különböző 
információs és kommunikációs technológiákkal még hatékonyabb eredményeket érhetünk el, miközben az eszközök egyszerü használatának készségein és képességein kívül fejlesztjük a virtuális világban való eligazodási képességüket, továbbá a feladatok, problémák megoldásához szükséges információ gyors és hatékony megtalálási képességét, azok kritikus kezelését.

A jövő tanulási környezetét nem lehet elképzelni IKT-eszközök és az információs és kommunikációs technológia használatát lehetővé tévő készségek, képességek és kompetenciák hatékony használata nélkül (Molnár, 2011). A tanároknak képesnek kell lenniük az informatikai eszközök oktatási szempontból történő értékelésére, azok tanulókra gyakorolt egészségügyi, lelki, társadalmi, kulturális hatásának megítélésére. Ismerniük kell az IKT-eszközök használatával együtt járó módszereket, interaktív megoldásokat (Kárpáti, 2004).

\subsubsection{A környezeti nevelés általános tantervi céljai}

A környezeti nevelés tulajdonságaival összhangban képessé válhatunk a tanulók következő kompetenciáinak fejlesztésére (Vásárhelyi, 2010 idézi: Major és Horák, 2014):

Rendszerszemléletre nevelés: a tanulókat képessé kell tenni arra, hogy a tanórán szerzett ismereteket össze tudják kapcsolni az élet valós dolgaival, hogy önmaguk lássák meg a problémákat, azok összefüggéseit, és önmaguk keressék az arra adható válaszokat. Ennek során el kell jutni odáig, hogy a tanulók képesek legyenek megérteni a fejlődés és környezet kérdéseinek összefüggő rendszerét.

Alternatív, problémamegoldó gondolkodás elsajátítása: nem elegendő az egyes problémák, de még a problémák összefüggéseinek felfedeztetése sem, ha nem alakul ki az a képesség, hogy a problémákra válaszokat is keressenek a tanulók (Koruoglu, Ugulu, Yorek, 2015). Fontos, hogy az egyes kérdések megválaszolására több alternatíva felállítását igényeljék, s az alternatívák értékelése, ellenőrzése után képesek legyenek a helyes, megfelelő válasz kiválasztására.

Globális összefüggések megértése: a létező környezeti problémák mögött gazdasági, társadalmi problémák állnak, amelyek globális problémákká szövődnek össze. Nagyon fontos, hogy ne csak egyenként lássák ezeket a gondokat a tanulók, hanem azok gazdasági, társadalmi okait is megértsék. Legyenek képesek ezeket az okokat azonosítani saját környezetükben, életükben, és tanuljanak meg ezeket szem előtt tartva cselekedni.

A biológiai sokféleség jelentöségének megértése: az ember a természet része, csak akkor van esélye a boldogulásra, ha együttmüködik környezetével, és nem uralkodni akar felette, ami a természet törvényeinek megértését, az élet minden formájának elismerését feltételezi. Meg kell értetni, hogy biológiai sokféleség nélkül nincs emberi létezés sem. 


\subsubsection{A környezeti nevelés színterei}

A környezeti nevelés interdiszciplináris jellegű (Pace, 2003), tartalma beépülhet az általános iskolai tantárgyak tartalmába, akár az állampolgári ismeretek, a természettudományokkal foglalkozó tantárgyak tantervébe, iskolán kívüli foglalkozások témájába egyaránt. A környezeti nevelés így nem valósítható meg kizárólag tanórai keretek között. Sok olyan eleme van, amely a tanterem vagy az iskola falain is túlnyúlik. A környezeti nevelés során a tanítás-tanulás folyamata a kompetenciafejlesztés, a módszertani kultúra teljes készletének alkalmazásával történik (Fernengel, 2002).

A környezeti nevelés több ponton kapcsolódik a reál, a humán, a technikai múveltséghez, a testkultúrához, de tárgya mégsem azonos azokéval. A környezeti nevelés ugyanis az ember és környezete kapcsolatáról szól, tárgyát tehát ennek a kapcsolatnak az összefüggései jelentik (Lehoczky, 1999).

Az iskolákban a környezeti nevelés így megvalósulhat tantárgyi és tantárgyközi keretek között egyaránt. Megjelenhet a tanórákon, tantárgyakban, különböző iskolán belüli vagy iskolán kívüli helyszíneken. Mivel a kisiskoláskorú gyerekek jellemző sajátossága az érzelmek dominanciája, ezért igyekezni kell minél több olyan helyzetet teremteni, amelyben megszerettethetjük velük a természetet. Hiszen amit szeretünk, azt védjük is (Yang, 2015). Ezért fontos, hogy ne csak a természetismereti foglalkozások biztosítsák a környezeti nevelés megvalósítását, hanem annak szelleme, tevékenységei és eszközei komplex módon jelenjenek meg az összes tantárgyon belül (Major és Czékus, 2011).

A tanórákon a környezeti nevelés integrált módon történik. Tartalma átfogja az alsó tagozatos tárgyak teljes körét, valamennyi tantárgy ismeretanyagába beépítve elemeit. Tanórákon történik azon ismeretek megalapozása, azon szemlélet formálása, amelynek segítségével lehetőség van a természethez füződő helyes értékrend, viszony kialakítására. Az első és második osztályban inkább a természettel szembeni érzelmi beállítódás alakítása, a környezettel való ismerkedés, és a környezetbarát szokások formálása a fö cél, később fokozatosan alakul ki a tudatosság és elkötelezettség szintje (Dámné, 2001; Berty, Juhász és Soltész, 2004 idézi: Major, 2014; Setyowati és Widiati, 2014). A környezeti nevelés tantervbe illesztésének egyik megvalósítási módja a beleoldás, tematikus tanítás, amikor a környezeti nevelési fogalmakat, feladatokat és példákat a már meglévő tantervi célkitüzésekbe építik be (Berty, Juhász és Soltész, 2004 idézi: Major, 2014). Ezt a módszert alkalmazhatjuk egyetlen téma tanításánál, vagy úgy is, hogy az egész tantervet áthatja a környezeti nevelés szemlélete. A megszokott tananyag kiegészítését és kibővítését adják a környezeti nevelési témák (Setyowati és Widiati, 2014).

A környezeti nevelés szempontjából kiemelt jelentősége van a tanórán kívüli iskolai tevékenységeknek. A tanórán kívüli nevelésnek arra kell összpontosítania, ami a tanórákon nem történhet meg, így például a globális ismeretekre, a globális szemlélet formálására. A szabadabb keretek nagyobb teret engednek a többirányú pedagógiai módszerek alkalmazásának (Kacsúr, 1995; Berty, Juhász és Soltész, 2004 idézi: Major, 2014).

A nem hagyományos foglalkozások, illetve a tanórán kívüli környezeti nevelési programok megvalósíthatóak különböző szakkörök keretein belül, a környezetvédelem jeles napjainak megünneplésével, iskolai zöld médiumok által, tanulmányi versenyek, tematikus hetek, zöld napok, környezetszépítő akciók alkalmával (Lehoczky, 1999; Schróth, 2004; Nádai, 2005). 
Az iskolán kívüli környezeti nevelésre rövidebb és hosszabb időkeret áll a tanár rendelkezésére. A heti órarendbe jól beilleszthetők például a múzeumi és állatkerti órák, a rövidebb tájséták, terepgyakorlatok vagy közmüvelődési intézmények meglátogatása (Balogh, 2002).

A környezeti nevelésnek egyik hatékony eszköze lehet a zoopedagógia, azaz az állatkerti nevelés, amely az állatok és az életközösségek közvetlen tanulmányozhatóságára épít (Füzné Kószó és Négyökrü, 2015). Az állatkertekben megvalósított foglalkozások nem csupán az állatok és növények gyüjteményekben való bemutatására szorítkoznak, hanem a látványosság mellett számos más feladatot is ellátnak (Pintér, 2003). Ilyen tevékenységek például a nevelés, szemléletformálás, ismeretterjesztés, a kutatás, a fajok védelme, megőrzése, az állatkertben élő állatok eredeti élőhelyének védelme. Az állatkertek, mint a természettel való találkozás színhelyei, a környezeti nevelés ideális területei. Az állatokkal való személyes találkozás felelősségérzetre nevel. Az állatkertben szerzett élmények hatására a gyerekek könnyen elkötelezettekké válhatnak a környezetvédelem iránt (Major és Czékus, 2011).

A múzeumok nyújtotta lehetőségek szintén sokféleképpen beépíthetők a környezeti nevelésbe. A múzeumi kiállítások anyaga nagyszerüen tükrözi a környezeti nevelés tartalmának sokszínűségét (Mácsai, 2010; Burány, 2014). A korszerü gyüjtemények bemutatják az ember és környezete viszonyának változásait, a természetes környezet változásait, az épített környezet tárgyait, és így kirajzolódik a társadalmi gondolkodás módosulása. A tárlatok felidézik a múltat, mutatják a jelent, utalnak a jövőre, éppen ezért a környezeti nevelés kitünő színhelyei lehetnek (Foghtüy és Harangi, 1993). A korszerü múzeumok a figyelmet a természet értékeire, és azok megóvására irányítják. Új ismereteket közvetítenek, adatokat mutatnak be. Sok múzeumban lehetőség van arra, hogy a látogatók kézbe vegyék, közelről is megszemlélhessék a kiállított darabokat. Ez, különösen a gyerekek számára, nagyszerü élményszerzési lehetőség (Horányi és Magyar, 2011; Schróth, 2015).

Az éves iskolai programba kell beépíteni az erdei iskola, a többnapos terepgyakorlat és esetleg a környezeti neveléshez kapcsolható tanulmányi kirándulás szervezését. Fontos szerepe van az iskola életében a környezeti témákkal foglalkozó nyári táboroknak is (Schróth, 2004).

Az erdei iskolákban folyó munka a környezeti nevelés egyik legkiemelkedöbb terepe (Kövecsesné Gösi, 2009). Az ilyen iskolák nem feltétlenül erdőkben létesülnek, sokkal inkább vízpartokon vagy a települések közelében elhelyezkedő zöldövezetben (Budayné és Ungvári, 2005). Ha a környezeti nevelés vonatkozásában szeretnénk megfogalmazni, hogy lényegében mi is az erdei iskola, akkor azt mondhatnánk, hogy a természetben létrehozott környezeti nevelési színtér. Kiemelkedő nevelési feladata a környezettel harmonikus, egészséges életvezetési képességek fejlesztése és a közösségi tevékenységekhez kötődő szocializáció (Kurucz, 2012). Az erdei iskolában lehetőség van a természet közvetlen megismerésére, a környezettel kapcsolatos élményszerzésre, az aktív, cselekvő tanulásra.

A környezeti nevelést már a családban el kell kezdeni. Az elsődleges szocializációs folyamatok során a szülők magatartási mintáját vésik be a gyerekek. Ezek a minták a környezeti értékek, az anyaghoz, a növényekhez, az állatokhoz füződő kapcsolatok, a fogyasztás és a termelés attitüdjei, az élethez és az élőlényekhez kötődő viszonyulások (Havas, 1998). Valójában a családon belül számos környezetvédelmi tevékenységet valósítanak meg tervezés nélkül is. A gyerekek részvétele a takarításban, a kertgondozásban, a 
családi programok, kirándulások a természetben mind-mind szerves részét képezik a környezeti nevelésnek (Major és Czékus, 2011). Ugyanakkor a gyerekek hazaviszik az elsajátított szemléletet és számon kérik szüleiken, környezetükön is. Jó, ha a család befogadja ezt a szemléletet és viselkedésében is megnyilvánul (Berty, Juhász és Soltész, 2004 idézi: Major, 2014).

\subsubsection{A környezeti nevelés helye az alsó tagozatos tantárgyak rendszerében}

Az iskolák legtöbbször környezeti nevelési céljaikat a természettudományi tantárgyakon belül igyekeznek megvalósítani (Gokhan, 2010). A környezeti folyamatok megértése valóban lehetetlen bizonyos szintü természettudományos alaptudás nélkül. Ugyanakkor a környezeti problémák alapjukat tekintve nem természettudományi jellegüek, mert mögöttük valamilyen emberi cselekvés, érdekek és ellentétek húzódnak meg. Éppen ezért a humán tudományterületek és tartalmak nagyon fontos elemei a környezeti problémák kezelésének. A szemlélet és az értékrend sokkal inkább ezen csatornák által, mintsem az ismeretterjesztés által fordíthatók helyes irányba (Major és Horák, 2015).

A környezeti nevelés átfogja az alsó tagozatos tantárgyak körét, valamennyi tantárgy ismeretanyagába beépítve a környezettudatos magatartás alapelveit. Az első és második osztályban inkább az érzelmi beállítódás alakítása a természettel, a környezettel való ismerkedés és a környezetbarát szokások formálása a fő cél, később fokozatosan alakul ki a tudatosság és elkötelezettség szintje (Major és Czékus, 2011).

A környezeti nevelés tantervbe illesztésének egyik megvalósítási módja az ún. „beleoldás”. Beleoldásnak, vagy tematikus tanításnak nevezzük azt a módszert, amikor a környezeti nevelési fogalmakat, feladatokat és példákat a már meglévő tantervi célkitüzésekbe építik bele. Ezt a módszert alkalmazhatjuk egyetlen téma tanításánál, vagy úgy is, hogy az egész tantervet áthatja a környezeti nevelés szemlélete (Berty, Juhász és Soltész, 2004). A beleoldás módszerének előnye, hogy könnyü megvalósítani. Itt nyílik a leginkább lehetőség arra, hogy a szokásos napi tevékenységen belül helyet találjanak a környezeti nevelésnek (Berty, Juhász és Soltész, 2004 idézi: Major, 2014).

Sajnos a környezeti nevelésre vonatkozó tantervi szabályozásokat ma még mindig inkább egyfajta ajánlásnak, nem pedig kötelező érvényü tevékenységnek tekintik a tanítók. Ennek okai a nem megfelelő felkészítésben, a tananyagok hiányában, a megfelelő gondolkodásmód kialakításában, a tanárképzés hiányosságaiban keresendők (Mutisya és Barker, 2011; Pedretti, 2012; Weiland és Morrison, 2013).

\subsubsection{Fenntartható fejlődés és környezeti nevelés a felsőoktatásban}

A fenntarthatóságra nevelés megvalósításában fontos szerep jut a felsőoktatásnak és az élethosszig tartó tanulásnak. Az elmúlt években egyre több egyetem ismerte fel a felsőoktatás szerepét a fenntartható fejlődésben, hiszen a jövő vezetőinek, döntéshozóinak, vállalkozóinak, kutatóinak, nem utolsósorban pedig fogyasztóinak a neveléséért felelősek. Éppen ezért egyre több egyetem igyekszik átalakítani oktatáspolitikáját a fenntarthatóság céljainak elérése érdekében (Vicente-Molina, Fernández-Sáinz és Izagirre-Olaizola, 2013; Jowett et. al., 2014). Sajnos azonban még nem minden tudományterület találta meg a helyét a fenntarthatóságért 
vívott harcban, még a fenntartható egyetemeken belül sem. Sokszor találkozunk azzal a téves elképzeléssel, hogy a környezettudatosságot a természettudományokon belül kell fejleszteni. A környezeti problémák azonban alapjukat tekintve társadalomtudományi jellegüek, mert mögöttük valamilyen emberi cselekvés, érdekek és ellentétek húzódnak meg. Éppen ezért a társadalomtudományok és kulturális tartalmak nagyon fontos szerepet játszanak a fenntarthatóság szemléletének kialakításában (Vicente-Molina, Fernández-Sáinz and IzagirreOlaizola, 2013).

\subsubsection{Fenntarthatóságra nevelés az európai zöld egyetemeken}

Európában sok ország felismerte már a felsőoktatás kiemelt szerepét a fenntarthatóság terén, és igyekeznek beépíteni oktatáspolitikájukba a „zöld egyetem” legfontosabb eszméit. Írországban a Cork University Hospital (CUH) a Green-Campus Programme-hoz (GCP) csatlakozott. Ennek eredményeként három éven belül jelentősen csökkent az intézmény hulladéktermelése és energiafelhasználása (Ryan-Fogarty et al., 2016).

A Szegedi Tudományegyetem világviszonylatban is kiemelt helyen szerepel a zöld egyetemek listáján. Az Universitas Indonesia (UI) által először 2010-ben meghirdetett versengésben (Lauder et. al, 2015), a több mint 400 egyetem között pillanatnyilag a 107. helyen áll az intézmény (UI Green Metric, 2016). Az egyetem Szenátusa 2008-ban fogadta el a Szegedi Tudományegyetem Fenntartható Fejlődési Stratégiáját, majd 2010-ben és 2011-ben ezen stratégia aktualizálását (University of Szeged, 2016).

Litvániában, a The Institute of Environmental Engineering at Kaunas University of Technology MSc és PhD képzésén, egy előfelmérés (pilot research) során bevezetésre került a "QUESTE-SI evaluation and accreditation process", amely szavatolja a fenntarthatóság elveinek beépítését az adott oktatási tartalmakba. A 2 éves MSc Environmental Engineering képzési program célja, hogy az ipar fejlődése miatt jelentkező jelenlegi és hosszútávú környezetvédelmi problémákat minél környezetbarátabb módon oldják meg, szavatolva a fenntarthatóság kérdését ezen a területen. A PhD-képzésen pedig a kísérlet célja, hogy a képzési rendszerben már 1994 óta fellelhető, fenntarthatósággal kapcsolatos elemek sokkal határozottabban beépüljenek a 2012-es Environmental Engineering and Landscape Management programba. A pilot kutatás eredménye az volt, hogy a fenntarthatósággal kapcsolatos müszaki és tudományos ismeretek eredményesen beépültek a tananyagba. Sikerült a problémákat interdiszciplináris módon megközelíteni, amelynek hatására a hallgatók megismerték a fenntarthatóságra vonatkozó nemzetközi szabványokat, és fejlődtek a kockázatkezeléssel és a válságkommunikációval összefüggő képességeik, amelyek hosszú távon lehetővé teszik az iparban dolgozó szakemberekkel való zavartalan együttmüködést (Staniškis and Katiliūtè, 2016).

A Litvániai Állami Egyetem (Vytautas Magnus University, Lithuania) akár kontrollintézményként is szolgálhatna a fenti vizsgálathoz, ugyanis itt a fenntarthatóság eszméjének beépülése az oktatási rendszerbe még gyerekcipőben jár, és nagyon sokat kell fejlődnie. Dagiliūtè' and Liobikiene (2015) egy 2011-2012 között, 492 hallgatóval elvégzett vizsgálat eredményeként megállapították, hogy a fenntarthatóságot sokkal mélyebben bele kell építeni az egyetemi oktatásba, annak folyamatosan és mélyrehatóbban át kell járnia a tananyagot, nem szabad, hogy fragmentált és felszínes legyen. 
Fernandez-Manzanal és társai (2015) a spanyolországi Zaragozai Egyetem (University of Zaragoza) 70 diplomását kérdezték meg a környezetvédelemmel és a fenntarthatósággal kapcsolatos tudásuk, ismereteik, aktivitásaik kapcsán. Megállapították, hogy nagyobb együttmüködésre lenne szükség a cégek és az egyetemek között az oktatási rendszer és a tananyag tartalmának kiépítése során. Sokkal több gyakorlati oktatásra is szükség lenne, ugyanis a megkérdezettek csak kis százaléka vélte úgy, hogy az egyetemi oktatás jól felkészítette őket a környezeti problémák kezelésére, vagyis a fenntartható fejlődés eszméjének gyakorlatba történő beültetésére.

A fenntarthatóságra neveléshez elkötelezett, megfelelően felkészített tanárokra van szükség az oktatási rendszer minden szintjén, az óvodától az egyetemi képzésig. Az angliai Plymouth Egyetemen (University of Plymouth) megvizsgálták, hogy milyen az előadók ismerete és hozzáállása a fenntartható fejlődéssel kapcsolatban, és mi a véleményük az egyetemi tananyagba való beépíthetőségéről. A kutatás eredményei arra mutattak rá, hogy bár a fenntartható fejlődéssel kapcsolatos fogalmak megértése és az attitüdök igen magas szinten állnak a tanárok esetében, mégis csak valamivel több mint 50\%-uk építette be mindezt központi elemként a tantárgyába (Cotton et al., 2007).

A felsorolt példák ellenére a fenntartható fejlődés pedagógiájának beillesztése az egyetemek tantervi rendszerébe még nem bevett gyakorlat. A „zöld egyetemek” elsősorban gazdaságpolitikai szempontok kidolgozásával (például takarékos energia- és vízhasználat, vagy szelektív hulladékgyüjtés), valamint a belső és külső terek rendezésével járulnak hozzá a fenntarthatósághoz. Az intézmények a fenntarthatóságra nevelés pedagógiai céljait legfeljebb egy-egy speciális kurzus alkalmával igyekeznek megvalósítani. Az egyetem teljes oktatási rendszerének megreformálása, a tantervek komplex fejlesztése, az interdiszciplináris szemlélet kialakítása az egyes tantárgyi célok összekapcsolása érdekében legfeljebb csak tervek formájában létezik (Cebrián, Grace and Humphris, 2015). 


\section{KUTATÁSI ELŐZMÉNYEK}

Az empirikus kutatások alapját képező környezeti nevelési program kidolgozását a szerbiai oktatási rendszer feltérképezése előzte meg. Igyekeztem feltárni azokat a lehetőségeket, amelyek a környezeti nevelés megvalósítását teszik lehetővé az oktatás azon színterein - alsó tagozatos oktatás és egyetemi oktatás -, amelyre a program vonatkozik.

Megvizsgáltam az alsó tagozatos globális és operatív tantervet, az általános tantervi ajánlásokat, és kikerestem a környezeti nevelésre és a fenntartható fejlődésre vonatkozó oktatási és nevelési célokat, feladatokat. Ugyanezt a vizsgálatot elvégeztem a szerbiai egyetemek körében is a fenntarthatóság fogalmának megjelenése szempontjából, különös tekintettel az Újvidéki Egyetem Magyar Tannyelvü Tanítóképző Karának tantervére, amely keretet adott a kísérleti környezeti nevelési programnak.

\subsection{A környezeti nevelés és a fenntartható fejlődés céljainak és feladatainak helye a szerbiai alapfokú oktatási rendszerben}

A környezeti nevelés alapjai a XX. század elején már megtalálhatóak Szerbiában. 1914-ben a Szerb Királyságban a diákok olyan fogadalmat tettek, amelynek ma is alapvető ökológiai üzenete van: „Esküszöm, hogy nem pusztítom a fákat és virágokat [...] soha nem dobálom el a papírt, sem más szemetet az utcán; mindig udvarias leszek; védeni fogom a madarakat, megvédem más tulajdonát..." (Stojanović et al., 1997).

Az oktatás hatékonyabbá tétele és a helyes környezeti viszonyulás kialakítása a nemzetközi szerződések létrejöttének idejétől számítható (Niklanović, 2008). Jugoszlávia az ENSZ egyik alapító tagjaként aktív résztvevője volt a nemzetközi testületek környezetvédelemre és környezeti nevelésre vonatkozó munkájában (Czékus, 2003). Annak ellenére azonban, hogy szerepet vállalt a környezetvédelmi kérdések értelmezésében, Szerbia a gyakorlatban kifejezetten elmaradt az elméleti megállapítások megvalósításában (Klemenović, 2003). Az első normatív, törvényi rendelkezések a környezet védelméröl a hetvenes évek közepén jelentek meg, de mindmáig nem sikerült megfelelő módon teljesíteni a benne foglalt követelményeket.

1973-tól több kezdeményezés is történt az ember és környezete között fennálló viszony megvitatására tudományos szinten, kongresszusi keretek között. Ilyen volt a Jugoszláv Ökológusok Első Kongresszusa, az Ember és a bioszféra (eredeti címén: Prvi kongres ekologa Jugoslavije: čovek i sredina) témájában megtartott tanácskozás. A találkozó eredménye a környezeti nevelésre nézve komplex és általános jelentőségű volt. Megszületett az Állásfoglalás az emberi környezet védelméről címü dokumentum, amelyben követelték a „környezeti oktatás” (ekološko obrazovanje) bevezetését az egyetemeken és az iskolákban (Čolić, 1973). Még ugyanebben az évben a Szerb Tudományos és Müvészeti Akadémia (Srpska akademija nauka i umetnosti - SANU) tudományos ülésén hangsúlyozták, hogy szükséges a társadalmi tudatosság megerősítése a környezetvédelmi problémák tekintetében az óvodáskortól egészen az egyetemig. A következő években még számos konferenciát szerveztek a témában, így az ökológiai nevelés és oktatás első fejlődési periódusának végére kialakultak a környezeti nevelés alapjai Szerbiában. Már ekkor fontosnak tartották, hogy a környezeti oktatás átfogó, tantárgyakon átívelő és folyamatos legyen, beleértve a tanórai és 
tanórán kívüli tevékenységeket is. Sajnos annak ellenére, hogy a környezeti nevelés és oktatás jelentőségét kiemelten kezelték, nem tudott önálló oktatási területként beépülni a hagyományos pedagógiai rendszer gyakorlatába (Klemenović, 2003).

A kilencvenes évektöl napjainkig terjedő időszakban a környezeti nevelés és oktatás kérdése újra előtérbe került. A társadalom és a felnövekvő nemzedékek környezettudatossá formálása az egész világon jelentős kérdéssé vált. A megvalósítás lehetőségét elsősorban az oktatásban látták, és vezérgondolatként hozzácsatolták a fenntarthatóság fogalmát. Ennek hatására a kétezres évek elején Szerbiában újabb oktatási reform indult. Az ökológiai és környezetvédelmi oktatás bekerült a kötelező oktatás alapvető céljai közé. Az alapfokú oktatás tantervének általános céljai közül kettő vonatkozik a környezeti nevelés és oktatás területére:

1. ismeretszerzés a természeti erőforrásokról, azok korlátozottságáról és fenntartható használatáról;

2. ismeretszerzés a környezet védelmének szükségességéröl, a környezet egyensúlyának helyreállitásáról és fejlesztéséröl.

A tanulás ebben az elképzelésben a diák és környezete közötti interakciók folyamata, melyben a tanuló felfedezi a környezet rombolásának következményeit, és megérti, felfogja súlyukat (Niklanović, 2008).

Annak ellenére, hogy a tanmenet 2010 óta tartalmazza a fenntarthatóságra vonatkozó célokat, a környezeti nevelés és a környezettudatosság megszilárdítása érdekében bevezetett újítások - tantervi innováció, kísérleti programok, a pedagógusok ökológiai képzése - nem bizonyultak elegendőnek ahhoz, hogy a környezeti nevelés céljai az oktatási gyakorlatban is megvalósuljanak (Stanišić és Maksić, 2014). A szervezési, programbeli és módszertani természetü problémákon túl a környezetvédelem területén dolgozó oktatók képzettségbeli hiányosságai is hozzájárulnak a kedvezőtlen helyzet kialakulásához (Klemenović, 2003).

A Hivatalos Közlönyben 2004. augusztus 12-én megjelent tanmenet a fenntarthatóság fogalma helyett még az ökológiai tudat kialakítása, a környezethez való felelösségteljes viszony kialakítása megfogalmazást tartalmazza. A 2010. március 15-én megjelent tanmenetben viszont a Környezetünk tantárgy céljainak és feladatainak felsorolásában megjelenik a fenntartható fejlődés fogalma is: „a környezettudatosság kialakítása a személyes részvétel és hozzájárulás szükségességéről és lehetőségeiröl a környezetvédelemben és a fenntartható fejlödésben" (Prosvetni glasnik, 2010).

Európa néhány országában, például Belgiumban, Finnországban vagy Spanyolországban a környezeti nevelés önálló, kötelező tantárgyként jelenik meg az alsó tagozatos tantervekben. Szerbiában azonban, a legtöbb államhoz hasonlóan, a környezeti nevelés a kötelező és választható tantárgyak tartalmába integráltan van jelen (Stanišić és Slavica, 2014). Az új alsós tankönyvekben a környezetvédelemmel kapcsolatos témák megjelennek ugyan, de messzemenően nem kapnak elegendő hangsúlyt. A gyermekek környezeti attitűdjeink alakulása így jórészt a tanító hozzáállásától, találékonyságától és talpraesettségétöl függ (Czekuš és Horak, 2015).

A 2012 óta érvényben lévő első osztályos tanmenetben további kiegészítések találhatóak a környezeti nevelésre vonatkozóan, amelyek a tanítási egységek bővülésében vagy módosulásában nyilvánulnak meg. Ezek többnyire aktivitásokat szorgalmaznak, témájuk pedig a növények és állatok jobb megismerésére, az emberi tevékenységek következményeire, 
a takarékosságra, illetve a környezetszennyezésre vonatkoznak. Hasonló változásokat találunk a felsőbb évfolyamok tanmeneteiben is, ami valamivel részletesebb a gyerekek korának megfelelően mélyülö anyagrészek formájában (Stanišić és Slavica, 2014).

A szerbiai alsó tagozatokra vonatkozó tanterv 12 pontban összefoglalt általános céljai és feladatai között a következő tétel szerepel a környezettudatosságra nevelésre vonatkozóan: „,Tudatosítani környezetünk és a természet megóvásának fontosságát”.

A környezeti nevelés és a fenntarthatóság elvének szélesebb körü kibontakoztatására, és az ezzel kapcsolatos tanórai és tanórán kívüli tevékenységek megvalósítására alsó tagozaton a kötelező Környezetünk (1. és 2. osztály), valamint a Természet és társadalom (3. és 4. osztály) tantárgyak mellett az Ifjú természetvédők és a Kéz a tésztában - a világ felfedezése elnevezésü választható tantárgyak adnak lehetőséget (Czékus, Major és Horák, 2013). A kötelező tantárgyak programjának célkitüzései között helyet kapott a környezettudatosság fejlesztése is. Azokat az alsó tagozatos kötelező és választható tantárgyakat, amelyeknek a programjába a hivatalos tanterv szerint beépíthetőek a környezeti nevelési tartalmak, az 1. táblázat szemlélteti (Republika Srbija - Zavod za unapredjivanje obrazovanja i vaspitanja: Nastavni planovi i programi za osnovne i srednje škole, 2016).

\section{1. táblázat}

A környezeti nevelési tartalmak megjelenése a szerbiai alsó tagozatos tantárgyak tantervében

\begin{tabular}{|c|c|c|c|c|c|}
\hline Jelleg & Tantárgy & $\begin{array}{l}\text { 1. osztály } \\
\text { heti / évi } \\
\text { óraszám }\end{array}$ & $\begin{array}{l}\text { 2. osztály } \\
\text { heti / évi } \\
\text { óraszám }\end{array}$ & $\begin{array}{l}\text { 3. osztály } \\
\text { heti / évi } \\
\text { óraszám }\end{array}$ & $\begin{array}{l}\text { 4. osztály } \\
\text { heti / évi } \\
\text { óraszám }\end{array}$ \\
\hline \multirow[t]{2}{*}{ kötelező } & $\begin{array}{l}\text { Környezetünk } \\
\text { (Svet oko nas) }\end{array}$ & $2 / 72$ & $2 / 72$ & - & - \\
\hline & $\begin{array}{l}\text { Természet és társadalom } \\
\text { (Priroda is društvo) }\end{array}$ & - & - & $2 / 72$ & $2 / 72$ \\
\hline \multirow[t]{2}{*}{ választható } & $\begin{array}{l}\text { Kéz a tésztában - a világ felfedezése } \\
\text { (Ruka u testu-Otkrivanje sveta) }\end{array}$ & $1 / 36$ & $1 / 36$ & $1 / 36$ & $1 / 36$ \\
\hline & 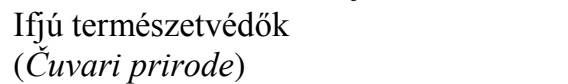 & $1 / 36$ & $1 / 36$ & $1 / 36$ & $1 / 36$ \\
\hline
\end{tabular}

2.1.1. Környezeti neveléssel kapcsolatban megfogalmazott célok és feladatok a Környezetünk és a Természet és társadalom tantárgyak tantervében

A környezeti nevelés alapvető pillérei a szerbiai alsó tagozatos tanterven belül a környezeti, természeti és társadalmi tartalmakat feldolgozó tantárgyak. Ezek a tárgyak útmutatást adnak a környezeti gondok felismeréséhez és megoldásához. Általuk szerzi a tanuló a természetre vonatkozó ismeretek, összefüggések, kölcsönhatások sokaságát.

Az első osztályos Környezetünk tantárgy globális tantervében meghatározott környezeti nevelési célok és feladatok (Kobrehel et al., 2012):

Célok: a tanulók ismerjék meg önmagukat, környezetüket és tegyék magukévá a környezettudatos életmód elveit.

Feladatok:

- alapvető természetismereti fogalmak kialakítása;

- az alapvető tudományos megismerési módszerek elsajátítása;

- az érdeklődés felkeltése a természeti jelenségekkel kapcsolatban; 
- egyszerübb összefüggések levonása;

- felelősségteljes viselkedés kialakítása másokkal és környezetünkkel szemben.

A második osztályos Környezetünk tantárgy globális tantervében meghatározott környezeti nevelési célok és feladatok (Vásárhelyi et al., 2012):

- a tanulók tudásának bővítése a természeti és társadalmi jelenségekről;

- az élő és élettelen természet közötti kölcsönhatásra való rámutatás;

- az ok-okozati összefüggések megértése (értsék meg az ember tevékenysége és a természetben végbemenő változások közötti kapcsolatot);

- természetvédelemre való nevelés;

- az önálló tanulási tevékenységek serkentése: megfigyelés, kísérletezés, tapasztalatszerzés.

A harmadik osztályos Természet és társadalom tantárgy globális tantervében meghatározott környezeti nevelési célok és feladatok (Borsos et al., 2012):

- mélyítse el a tanulók szerzett tapasztalatait, bővítse tudásukat vidékünk természeti adottságairól és társadalmáról;

- az élő és az élettelen természet kölcsönhatásának ismertetése;

- ismertesse a tanulókkal az ember és az emberi munka szerepét a természeti feltételek megváltoztatásában, a természet gazdagságának felhasználásában a jobb életfeltételek biztosítása érdekében, valamint az ökológiai egyensúly megőrzésében;

- ismertesse a tanulókkal az élőhelyek és életközösségek jellegzetességeit, a bennük uralkodó kölcsönhatásokat, valamint alkalmazkodásukat, táplálékláncukat és világítson rá az ember rájuk gyakorolt hatására;

- a természet iránti csodálat fejlesztése, a környezetvédelem fontosságának belátása;

- a lakosság tagjainak viszonya a természethez és a többi emberhez.

A negyedik osztályos Természet és társadalom tantárgy globális tantervében meghatározott környezeti nevelési célok és feladatok (Poljaković et al., 2012):

- önismeret, a természeti és társadalmi környezet megismerése és a környezetben való felelősségteljes élethez szükséges képességek fejlesztése;

- a természeti és társadalmi környezettel kapcsolatos alapfogalmak kialakítása és a fogalmak összekapcsolása;

- fejleszteni a környezet létesítményeinek, jelenségeinek és folyamatainak alapvető jellegzetességeire irányuló megfigyelés és a közöttük fennálló összefüggések felismerésének képességét;

- az érdeklődés és a környezetre irányuló aktív megismerés képességének fejlesztése;

- alkalmassá tenni a tanulókat az önálló tanulásra és az információk önálló megszerzésére;

- a tapasztalati és tudományos ismeretek integrálása a természet és társadalom fogalomkörébe;

- a civilizációs értékek befogadása és racionális használatuk, ezek továbbfejlesztésének lehetőségei;

- ökológiai öntudat fejlesztése. 
Az alsó tagozatos Ifjú természetvédők választható tantárgy globális tantervében meghatározott környezeti nevelési célok és feladatok (Czékus, Major és Horák, 2013):

Célok: a gyermekek öntudatának fejlesztése a környezetvédelemben való személyes részvétel szükségességéröl és lehetőségeiről, valamint az elkövetkező generációk számára a környezeti élettérrel kapcsolatos jogok, etikai elvek elfogadása, azok alkalmazása.

\section{Feladatok:}

- a környezet fogalmának és alapelemeinek ismertetése;

- az alapvető környezeti jelenségek és változások felismerése és leírása;

- a környezetet veszélyeztető jelenségek felismerése és leírása;

- felelösségteljes viszonyulás fejlesztése önmagunk és a környezet iránt;

- a természeti kincsek ésszerü felhasználási szokásainak fejlesztése;

- az érdeklődés, kreativitás és kutatási képességek fejlesztése;

- a logikus és kritikus vélemény alapelemeinek fejlesztése.

Az alsó tagozatos Kéz a tésztában - a világ felfedezése választható tantárgy globális tantervében meghatározott környezeti nevelési célok és feladatok (Czékus, Major és Horák, 2013):

Célok: a tantárgy bevezetésének alapvető elképzelése a gyermekek érdeklődésének felkeltése, ápolása, ösztönzése és fejlesztése, valamint válaszok keresése a MI, HOGYAN és MIÉRT kérdésekre. A tantárgy a Környezetünk tárgy céljaira és feladataira támaszkodik, amivel lehetővé válik a természeti jelenségek átfogóbb megértése, a környezet aktív kutatásának fejlesztése.

\section{Feladatok:}

- a természettudományok alapfogalmainak fejlesztése (bővítése) és azok összekötése;

- az érdeklődés és a kutatás képességének fejlesztése;

- a logikus és kritikus gondolkodás alapvető elemeinek fejlesztése;

- a szóbeli és írásbeli kifejezésmódra való ösztönzés, a kísérletekről folytatott beszélgetések és leírások segítségével.

2.1.2. A környezeti nevelési tartalmak beillesztésének lehetöségei a Környezetünk, illetve a Természet és társadalom tantárgyak tanmenetébe

Kutatásom során igyekeztem feltárni a környezettudatosság fejlesztésére vonatkozó tantervi célokat és feladatokat. Megállapítottam, hogy a tantervi ajánlások szükszavúak, és bár a környezeti nevelési tartalmak és feljesztési feladatok megjelennek a globális és az operatív tantervekben, a végső óratervekben és föleg a megvalósuló tanórákon már ritkán köszönnek vissza. Ebböl a problémából kiindulva részletes elemzést végeztem, amelynek során megvizsgáltam minden egyes tanítási egységet az alsó tagozatos Környezetünk, illetve a Természet és társadalom tantárgyakon belül (Major, 2011). Igyekeztem meghatározni, hogy a 2.1.2-es fejezetben felsorolt oktatási célokat és feladatokat melyik tanítási órán, milyen tartalmakhoz kapcsolódóan lehetne megvalósíta a környezettudatosság fejlesztése érdekében, a szerbiai tanterv elö́rásaihoz igazodva.

Nagy és Nagy 2014-ben összeállította a fenntarthatóság pedagógiájának alapvető ismeretelemeit feldolgozó témakörök listáját, amely a következő elemeket tartalmazza: 
energia; ipar; biotechnológia; közlekedés; város; népesedés; mezögazdaság; földhasználat; vidékfejlesztés, településfejlesztés; élelmiszerek; fogyasztás; turizmus, szolgáltatás; víz; levegö; klímaváltozás; talaj; ásványok; természetes eröforrások; fajok; biodiverzitás és élőhely-megörzés; erdők; hulladékgazdálkodás; fejlödés és környezet; egészség; génmódositás; életmód; szegénység; közösség és kultúra; egyenlöség és jogok; kormányzás (Nagy és Nagy, 2014). Ezen témakörök figyelembevételével minden, a tantervben szereplő fö témakör megnevezése mellett igyekeztem feltüntetni, hogy az adott témakörön belül melyek azok az alapvető ismeretelemek, amelyek a fenntarthatóság pedagógiáját is jellemzik.

Az elemzés eredményeit bemutató táblázatokban (2-5. táblázat) az első oszlop tartalmazza az egyes tantárgyak tantervben meghatározott témaköreit és tanítási egységeit, a második oszlop pedig az egységen belül megvalósítható környezeti nevelési célokra és tartalmakra vonatkozó ajánlásokat. Az elemzés eredményei alapján készült el a kísérleti környezeti nevelési program tanítási órákon megvalósított részének tanterve. Az eredmények emellett segítséget nyújthatnak az alsó tagozaton tanító pedagógusok számára a környezeti nevelés tantárgyi keretek között történő megvalósítása során.

\section{2. táblázat}

A környezeti nevelési tartalmak beillesztésének lehetöségei az első osztályos Környezetünk tantárgy tanmenetébe

\begin{tabular}{|c|c|}
\hline $\begin{array}{c}\text { A TANTERVBEN MEGHATÁROZOTT } \\
\text { TANÍTÁSI EGYSÉGEK }\end{array}$ & $\begin{array}{l}\text { AJÁNLÁSOK A KÖRNYEZETI NEVELÉSI } \\
\text { CÉLOK ÉS TARTALMAK BEÉPÍTÉSÉRE }\end{array}$ \\
\hline I. téma: ÉN ÉS MÁSOK & $\begin{array}{c}\text { A fenntarthatóság pedagógiájának ismeretelemei: } \\
\text { VÁROS, ÉLETMÓD, KÖZÖSSÉG ÉS KULTÚRA, } \\
\text { EGYENLÖSÉG ÉS JOGOK }\end{array}$ \\
\hline 1. A természet és társadalom része vagyok & $\begin{array}{l}\text { A környezeti tudatosság kialakítása, önmagára } \\
\text { fogékony, a társadalomra nyitott személyiség nevelése, } \\
\text { a környezettel kapcsolatos érdeklödés fokozása, } \\
\text { ökológiai tudat kialakítása. }\end{array}$ \\
\hline $\begin{array}{l}\text { 2. Szükségleteim kielégítése és mások szükségleteinek } \\
\text { tiszteletben tartása }\end{array}$ & $\begin{array}{l}\text { Önmagunk és a másik ember elfogadása, tiszteletben } \\
\text { tartása. Tolerancia, tisztelet fogalmának megértése. } \\
\text { Annak megértetése, hogy minden élölénynek } \\
\text { (emberek, állatok, növények) vannak igényei és } \\
\text { egyforma joga, hogy azt kielégítse. Ezért nem } \\
\text { korlátozhatjuk és veszélyeztethetjük a többi élölényt és } \\
\text { környezetünket szükségleteink kielégítése közben. }\end{array}$ \\
\hline $\begin{array}{l}\text { 3. Milyen környezetben élek? Otthonunk, utcánk, } \\
\text { iskolánk, településünk }\end{array}$ & $\begin{array}{l}\text { A tanulók lakóhelyének, iskolájának, településének } \\
\text { környezeti értékeivel való megismertetése, } \\
\text { megszerettetése. } \\
\text { A környezettel kapcsolatos érdeklődés felkeltése. } \\
\text { A természeti és társadalmi környezetbe való } \\
\text { beilleszkedés. }\end{array}$ \\
\hline $\begin{array}{l}\text { 4. Az emberek csoportja lakóhelyemen, és az én } \\
\text { helyem ezekben a csoportokban: család, rokonok, } \\
\text { szomszédok, kortársaim, lakótársaim... }\end{array}$ & $\begin{array}{l}\text { A társadalom részeként közösségi } \\
\text { szerepeink vannak. Együttélési } \\
\text { felelösségvállalás, munkamegosztás, } \\
\text { szerepek. }\end{array}$ \\
\hline 5. Ünnepek és szokások & $\begin{array}{l}\text { Hagyományápolás. Más kultúrák hagyományainak, } \\
\text { szokásainak elfogadása, tiszteletben tartása. }\end{array}$ \\
\hline $\begin{array}{l}\text { 6. A gyerekek jogai (a különbözőségek elfogadása, } \\
\text { mások jogai) }\end{array}$ & $\begin{array}{l}\text { A Föld mindannyiunké, minden élölénynek (ember, } \\
\text { állat, növény) egyformán joga van itt élni. Tiszteletben } \\
\text { kell tartani mások életterét. Felelősséggel tartozunk a } \\
\text { többi élőlény iránt. }\end{array}$ \\
\hline II. téma: ÉLÖ ÉS ÉLETTELEN TERMÉSZET & $\begin{array}{c}\text { A fenntarthatóság pedagógiájának ismeretelemei: } \\
\text { FEJLŐDÉS ÉS KÖRNYEZET }\end{array}$ \\
\hline $\begin{array}{l}\text { 1. Mi alkotja a természetet? - az élö és élettelen } \\
\text { természet megkülönböztetése }\end{array}$ & $\begin{array}{l}\mathrm{Az} \text { ember az élö természet része. Felelösséggel } \\
\text { tartozik iránta. Szerezzenek tapasztalatot, gyüjtsenek }\end{array}$ \\
\hline
\end{tabular}




\begin{tabular}{|c|c|}
\hline & élményeket a közvetlen élő és élettelen termész \\
\hline \multicolumn{2}{|c|}{ III. téma: Elö természet } \\
\hline 1. A különböző élethelyek növényei és állatai & \multirow{3}{*}{$\begin{array}{l}\text { A gyerekek érdeklödésének felkeltése } \\
\text { környezetünkben élö növények és állatok iránt, a } \\
\text { meglévő tapasztalatokra alapozva. Az élőlények } \\
\text { egymás közötti és környezetükkel való kapcsolatainak } \\
\text { megfigyelése. A cél a természet iránti tisztelet és } \\
\text { szeretet, a természetért való aggódás érzetének } \\
\text { felkeltése, a természeti értékek megőrzése. }\end{array}$} \\
\hline $\begin{array}{l}\text { 2. Környezetünk jellegzetes növényei (kinézetük, } \\
\text { élethelyük, jelentőségük, ápolásuk) }\end{array}$ & \\
\hline $\begin{array}{l}\text { 3. Környezetünk jellegzetes állatai (kinézetük, } \\
\text { élethelyük, életmódjuk, hogyan gondoskodunk róluk?) }\end{array}$ & \\
\hline $\begin{array}{l}\text { 4. A megfigyelt tulajdonságok alapján miben } \\
\text { különböznek és miben hasonlók az élölények? }\end{array}$ & \multirow{3}{*}{$\begin{array}{l}\text { A megfigyelés módszerének alapjai: a környezetben } \\
\text { előforduló élőlények érzékelhető tulajdonságainak } \\
\text { megfigyelése, megnevezése. Hasonlóságok és } \\
\text { különbségek felfedezése. } \\
\text { Biodiverzitás. A földi élővilág, növények és állatok } \\
\text { sokféleségének, változékonyságának bemutatása. Az } \\
\text { ember és környezete közötti kapcsolatrendszer } \\
\text { bemutatása. }\end{array}$} \\
\hline $\begin{array}{l}\text { 5. A külső jellegek alapján miben hasonlítanak és } \\
\text { miben különböznek a növények egymástól? }\end{array}$ & \\
\hline $\begin{array}{l}\text { 6. A külső jellegek alapján miben hasonlítanak és } \\
\text { miben különböznek az állatok egymástól? }\end{array}$ & \\
\hline IV. téma: ÉLETTELEN TERMÉSZET & $\begin{array}{c}\text { A fenntarthatóság pedagógiájának ismeretelemei: } \\
\text { MEZÖGAZDASÁG, VÍZ, LEVEGÖ, } \\
\text { KLIMMAVÁLTOZÁS, TALAJ, ERÖFORRÁSOK }\end{array}$ \\
\hline 1. A víz tulaj & \multirow{3}{*}{$\begin{array}{l}\text { A víz érzékelhető tulajdonságainak megfigyelése. A } \\
\text { víz szennyezésének veszélyei. Vízfogyasztás. A } \\
\text { vízhiány kialakulásának okai és következményei. A } \\
\text { vizek védelme. Mit tehetünk egyéni szinten a } \\
\text { vízkészlet megóvása érdekében? }\end{array}$} \\
\hline $\begin{array}{l}\text { 2. A víz megjelenési formái: források, folyók, patakok, } \\
\text { lápok (barák), mocsarak, tavak... }\end{array}$ & \\
\hline 3. A víz mint oldószer & \\
\hline $\begin{array}{l}\text { 4. A levegő tulajdonságai: szaga, átlátszósága, } \\
\text { szennyezettsége }\end{array}$ & \multirow{2}{*}{$\begin{array}{l}\text { A levegő érzékelhető tulajdonságainak megfigyelése. } \\
\text { A levegő tisztaságának fontossága. A levegőt } \\
\text { szennyező tevékenységek megismertetése. A levegő } \\
\text { tisztaságának védelme. A levegő védelme egyéni } \\
\text { szinten. }\end{array}$} \\
\hline 5. A levegő áramlása & \\
\hline $\begin{array}{l}\text { donságai: színe, porhanyóssága, } \\
\text { Ima }\end{array}$ & $\begin{array}{l}\text { A talaj érzékelhető tulajdonságainak megfigyelése. A } \\
\text { termőterület fontossága. Az emberi tevékenységek } \\
\text { hatása a termőterületekre. A termőföld szennyezése. A } \\
\text { szennyezés okai és következményei. Mit tehetünk } \\
\text { egyénileg a talaj védelmében? A hulladékkezelés } \\
\text { problémája. }\end{array}$ \\
\hline 7. Környezetünk domborzata & $\begin{array}{l}\text { Természeti értékek. A táj tulajdonságainak hatása az } \\
\text { emberek életére: az emberi létesítmények a földfelszín } \\
\text { viszonylatában. Az élőlények előfordulása és a } \\
\text { földfelszín kapcsolata. }\end{array}$ \\
\hline 8. Anyagok, azok tulajdonságai, viselkedésük a vízben & \multirow{3}{*}{$\begin{array}{l}\text { Az anyagok tulajdonságainak megfigyelése, } \\
\text { megnevezése. A kibocsájtott szennyező anyagok } \\
\text { lehetséges hatásai. } \\
\text { Az éghajlat változásának következményei (a légkör } \\
\text { felmelegedése, olvadó jégtáblák). }\end{array}$} \\
\hline $\begin{array}{l}\text { 9. Az anyagok viselkedése különböző mechanikai és } \\
\text { hőhatásra, változások melegítés és hütés hatására }\end{array}$ & \\
\hline $\begin{array}{l}\text { 10. A víz halmazállapot-változása melegítéskor és } \\
\text { hütéskor }\end{array}$ & \\
\hline 11. A nap fénye, melege és az élőlények & \multirow{3}{*}{$\begin{array}{l}\text { Az időjárás szerepe az élőlények életében. Az időjárás, } \\
\text { éghajlat változásának okai és következményei. Mit } \\
\text { tehetünk a kedvezőtlen folyamatok megállítása } \\
\text { érdekében? } \\
\text { Az időjárás változásának megfigyelése, elemeinek } \\
\text { lejegyzése. Az időjárás megfigyelése az évszakok } \\
\text { függvényében. }\end{array}$} \\
\hline $\begin{array}{l}\text { 12. Fény és árnyék: az árnyék alakja és nagysága, } \\
\text { nappal és éjszaka }\end{array}$ & \\
\hline $\begin{array}{l}\text { 13. A természeti jelenségek hatása az élőlényekre: a } \\
\text { nappalok és éjszakák váltakozása, az évszakok } \\
\text { váltakozása, időjárási feltételek és azok hatása a } \\
\text { növényekre, állatokra és az emberekre }\end{array}$ & \\
\hline $\begin{array}{l}\text { 14. A víz, a levegö és a talaj jelentősége az élővilág } \\
\text { számára és az emberi tevékenységekben }\end{array}$ & $\begin{array}{l}\text { A víz, levegő és talaj szerepe, jelentősége az élőlények } \\
\text { szempontjából. Megóvásuk fontossága. Szennyezésük } \\
\text { okai, következményei, védelmük. }\end{array}$ \\
\hline 15. Növénytermesztés különböző feltételek között & $\begin{array}{l}\text { A mezőgazdasági tevékenység környezeti hatásainak } \\
\text { megismertetése. Az ember és környezetének } \\
\text { egymástól függő viszonya. }\end{array}$ \\
\hline
\end{tabular}


V. téma: TÁJÉKOZÓDÁS TÉRBEN ÉS IDŐBEN

1. Mozgás - helyzetváltozás térben és időben, térbeli (előre-hátra, fel-le, jobbra-balra) és időbeli (előbbmost-később) változások

2. Körülöttünk mindenütt mozgás

3. A tárgyak mozgatása és megállítása: tolni, húzni, megemelni

4. Mozgás a különböző környezetben és különböző felületen: sebesség, a mozgás iránya

5. A tárgyak alakja és azok mozgása közti összefüggés

- csúszás és gördülés

6. Tájékozódás a térben a jellegzetes épületek segítségével

7. Tájékozódás az időben

8. Követem, mérem és feljegyzem a távolságot és az időt

VI. téma: ÉLETMÓD

1. Lakáskultúra: lakás, táplálkozás, öltözködés, egészséges élettér

2. Az anyagok tulajdonsága határozza meg azok felhasználhatóságát és életmódunk javítását
A fenntarthatóság pedagógiájának ismeretelemei: FEJLÖDÉS ÉS KÖRNYEZET, KÖZÖSSÉG ÉS KULTÚRA

Mérések, tájékozódás időben és térben. Időbeni és térbeli összefüggések megértése.

Naptár, ünnepek. (Környezetvédelem jeles napjainak megemlítése.)

A környezet változásai az idő függvényében (évszakok). Az évszaknak megfelelő természetvédelmi tevékenységek. Alkalmazkodás a természethez, annak változásaihoz.
A fenntarthatóság pedagógiájának ismeretelemei: KÖZLEKEDÉS, FOGYASZTÁS, EGÉSZSÉG, ÉLETMÓD

A különböző népek eltérő életkörülményeinek megismerése.

Életterünk, életminőségünk, egészségünk minőségének megörzése, javítása. Környezetbarát anyagok, termékek felhasználása, megvásárlása.

A felesleges vásárlás, túlzott fogyasztás mértékének csökkentése.

Fenntartható fogyasztás.

3. A különböző információforrások hasznosítása $\quad$ Közvetlen környezetünk megismerése, összefüggések felismerése, alkalmazása.

4. Az életre, egészségre és környezetre nézve veszélyes helyzetek - megelőzés és helyes viselkedés 5. Közlekedés és helyes viselkedés
Háztartási berendezések, eszközök helyes használata, környezetünk és saját épségünk megóvása érdekében.

A közlekedés légszennyező hatása.

\section{3. táblázat}

A környezeti nevelési tartalmak beillesztésének lehetöségei a második osztályos Környezetünk tantárgy tanmenetébe

\begin{tabular}{|c|c|}
\hline $\begin{array}{r}\text { A TANTERV } \\
\text { TANí }\end{array}$ & $\begin{array}{l}\text { AJÁNLÁSOK A KÖRNYEZETI NEVELÉSI } \\
\text { CÉLOK ÉS TARTALMAK BEÉPÍTÉSÉRE }\end{array}$ \\
\hline ZET & $\begin{array}{l}\text { A fenntarthatóság pedagógiájának ismeretelemei: } \\
\text { FAJOK, BIODIVERZITÁS ÉS ELLÖHELY-MEGÖRZÉS }\end{array}$ \\
\hline 1. $\mathrm{Az}$ & \\
\hline $\begin{array}{l}\text { 2. Milye } \\
\text { Légzés, }\end{array}$ & \multirow{4}{*}{$\begin{array}{lll}\text { Ismerjék meg az élölények } & \text { kapcsolatát, } \\
\text { egymásrautaltságát a környezetükkel. } & \\
\text { Az élőlények alapvető szervezeti-működési } \\
\text { jellemzöinek } & \text { megismerése, } & \text { ok-okozati } \\
\text { összefüggéseinek vizsgálata. } & \\
\text { Az élővilág sokféleségének megismerése. }\end{array}$} \\
\hline 3. Az élöl & \\
\hline 4. A & \\
\hline 5. Az & \\
\hline 6. An & \multirow{2}{*}{$\begin{array}{l}\text { A környezetünkben élő növények és állatok védelme } \\
\text { alapvető fontosságú, mert az ember fennmaradása } \\
\text { tölük függ. Az élölények nem élhetnek egymással való } \\
\text { kölcsönhhatás nélkül. }\end{array}$} \\
\hline $\begin{array}{l}\text { 7. Az embe } \\
\text { megörzéséb }\end{array}$ & \\
\hline II. téma: ÉLETTELE & $\begin{array}{l}\text { A fenntarthatóság pedagógiájának ismeretelemei: VÍZ, } \\
\text { LEVEGÖ, TALAJ, TERMÉSZETES ERÖFORRÁSOK }\end{array}$ \\
\hline $\begin{array}{l}\text { 1. Hol fordul elö víz? A víz elö } \\
\text { tulajdonságai }\end{array}$ & \multirow{2}{*}{$\begin{array}{l}\text { Vízzel kapcsolatos globális problémák } \\
\text { megismertetése. A vízkészlet szennyezésének, } \\
\text { kimerülésének okai. Vízvédelem. }\end{array}$} \\
\hline $\begin{array}{l}\text { 2. A víz alakváltoz } \\
\text { folyik-e? }\end{array}$ & \\
\hline
\end{tabular}




\begin{tabular}{|c|c|}
\hline $\begin{array}{l}\text { 3. A bennünket körülvevö levegö - a levegö } \\
\text { életfeltételei } \\
\text { 4. Hogyan ismerhetjük fel a levegőt (saját és a tárgyak } \\
\text { mozgása)? }\end{array}$ & $\begin{array}{l}\text { A levegö szennyezésének okai, következményei. } \\
\text { Levegövédelem. }\end{array}$ \\
\hline $\begin{array}{l}\text { 5. A Nap - fény- és höforrás, életfeltétel } \\
\text { 6. Hőmérséklet-változás, a víz párolgása, fagyása, a } \\
\text { felhők képződése, köd, csapadékok, szél... }\end{array}$ & $\begin{array}{l}\text { Függünk a természettől, annak változásaitól, ezér } \\
\text { figyelnünk kell, hogy az általunk előidézett változások } \\
\text { kedvezőek legyenek, ne károsítsák a természetet. }\end{array}$ \\
\hline 7. Szivárvány & $\begin{array}{l}\text { A természet csodálatos jelenségeket produkál. } \\
\text { Ügyeljünk, hogy az ember által elöidézett változások } \\
\text { ne veszélyeztessék őket. }\end{array}$ \\
\hline $\begin{array}{l}\text { 8. A talaj - a növények növekedésének és fejlődésének } \\
\text { feltétele }\end{array}$ & $\begin{array}{l}\text { Talajszennyezés okai, következményei. Talajvédelem. } \\
\text { Hulladékkezelés. }\end{array}$ \\
\hline $\begin{array}{c}\text { III. téma: AZ ÉLÖ ÉS ÉLETTELEN TERMÉSZET } \\
\text { KAPCSOLATA }\end{array}$ & $\begin{array}{c}\text { A fenntarthatóság pedagógiájának ismeretelemei: } \\
\text { FEJLÖDÉS ESS KÖRNYEZET }\end{array}$ \\
\hline $\begin{array}{l}\text { 1. A természetben végbem } \\
\text { tevékenysége az egyes évs } \\
\text { 2. Az élölények teste-alakj } \\
\text { 3. Ami nélkül az élőlényel } \\
\text { és élettelen természet szét }\end{array}$ & $\begin{array}{l}\text { Felkelteni a tanulókban a környezetük élő és élettelen } \\
\text { világa iránti érdeklödést. A természet, környezet } \\
\text { változásának törvényszerüségei. } \\
\text { Az élőlények környezetükhöz való } \\
\text { alkalmazkodóképessége. } \\
\text { Függünk környezetünktöl, és a környezet is változik } \\
\text { tevékenységeink hatására. Ügyelnünk kell, hogy a } \\
\text { változások pozitívak legyenek. }\end{array}$ \\
\hline IV. téma: $H O L E ́ L$ & $\begin{array}{c}\text { A fenntarthatóság pedagógiájának ismeretelemei: } \\
\text { VÁROS, ÉLETMÓD, KÖZZOSSÉG ÉS KULTÚRA, } \\
\text { EGYENLÖSÉG ÉS JOGOK }\end{array}$ \\
\hline $\begin{array}{l}\text { 1. Települések (a települések fogalma, fajtái régen és } \\
\text { ma) } \\
\text { 2. Lakóhelyünk és környékünk domborzata és vizei }\end{array}$ & $\begin{array}{l}\text { A tanulók lakóhelye, települése környezeti értékeinek } \\
\text { megismertetésére, megszerettetése. Erösíteni a } \\
\text { lakóhelyhez való kötődést. } \\
\text { Alakuljon ki bennük az igény az élő és élettelen } \\
\text { környezet megóvására, védelmére. }\end{array}$ \\
\hline $\begin{array}{l}\text { 3. Településen él } \\
\text { csoportban betöl } \\
\text { 4. Hogyan viselk } \\
\text { kötelezettségek, }\end{array}$ & $\begin{array}{l}\text { Család, családtagok, generációk, életkorok és } \\
\text { változások. Együttélési szabályok. Kommunikációs } \\
\text { készség fejlesztése, mások meghallgatása, saját közlés } \\
\text { késleltetése. } \\
\text { A hagyománytisztelet fontossága. }\end{array}$ \\
\hline $\begin{array}{l}\text { 5. Tájé } \\
\text { jellegz }\end{array}$ & 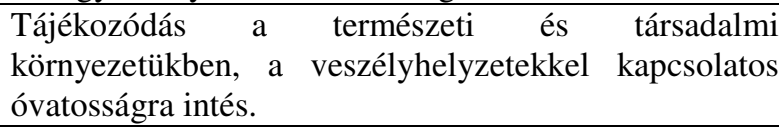 \\
\hline $\begin{array}{l}\text { 6. Hogyan közlekedünk a településen? A közlekedés } \\
\text { és kommunikáció formái, közlekedési eszközök, a } \\
\text { biztonságos közlekedés, kulturált viselkedés a } \\
\text { közlekedésben }\end{array}$ & $\begin{array}{l}\text { Szokásos közlekedési útvonalak és eszközök, } \\
\text { közlekedési szabályok. Szabályok szükségességének } \\
\text { és betartásának felismerése néhány viselkedési, } \\
\text { együttélési és közlekedési szabály alapján. }\end{array}$ \\
\hline V. téma: AZ EMBERI TEVÉKE & $\begin{array}{c}\text { A fenntarthatóság pedagógiájának ismeretelemei: } \\
\text { FEJLÖDÉS ESS KÖRNYEZET }\end{array}$ \\
\hline $\begin{array}{l}\text { 1. Az ember alk } \\
\text { szükségletei, az }\end{array}$ & $\begin{array}{l}\text { A környezet és az ember kapcsolata. A környezet } \\
\text { hatésa az ember életfeltételeire. Az emberi } \\
\text { tevékenység környezetalakító hatásai. }\end{array}$ \\
\hline $\begin{array}{l}\text { 2. Egyaz } \\
\text { anyagok } \\
\text { 3. Külön }\end{array}$ & \multirow{4}{*}{$\begin{array}{l}\text { Természetes és mesterséges anyagok. Hatásuk a } \\
\text { környezetre. A környezetet szennyezö anyagok } \\
\text { megismerése. } \\
\text { A környezetben elöforduló anyagok, tárgyak } \\
\text { érzékelhető tulajdonságainak megfigyelése. } \\
\text { Az emberi tevékenységek hatása a természetben } \\
\text { előforduló tárgyakra. Az emberi tevékenységek } \\
\text { környezetkárosító hatása. } \\
\text { A felelősség felismerése az anyagok felhasználásával, } \\
\text { illetve az újrahasznosítás fontosságával kapcsolatban. }\end{array}$} \\
\hline $\begin{array}{l}\text { 4. Az anyagok tulajdonságai (keménység, } \\
\text { rugalmasság...) és jelentőségük az emberi } \\
\text { tevékenységben }\end{array}$ & \\
\hline $\begin{array}{l}\text { 5. Az anyagok viselkedése mechanikai hatások } \\
\text { (hőmérséklet-változás, tágulás és összehúzódás, } \\
\text { olvadás, dermedés, égés...) }\end{array}$ & \\
\hline vezetése & \\
\hline
\end{tabular}




\begin{tabular}{|c|c|}
\hline $\begin{array}{l}\text { töltésủ test tulajdonságai } \\
\text { 8. Az anyagok elektromos vezetése (áramkö }\end{array}$ & \\
\hline VI. téma: MOZGÁS TÉRBEN ÉS IDÖBEN & $\begin{array}{c}\text { A fenntarthatóság pedagógiájának ismeretelemei: } \\
\text { FEJLÖDÉS ÉS KÖRNYEZET, KÖZÖSSÉG ÉS } \\
\text { KULTÚRA }\end{array}$ \\
\hline 1. Egy nap, a nap szakaszai (a Nap állásától függően) & \multirow{4}{*}{$\begin{array}{l}\text { A környezet változásainak hatásai mindennapi } \\
\text { tevékenységeinkre, életmódunkra. }\end{array}$} \\
\hline 2. Mozgás térben és időben & \\
\hline 3. Mi mindentől függ a tárgyak mozgási sebessége? & \\
\hline $\begin{array}{l}\text { 4. Az élőlények mozgásának sebessége hogyan függ az } \\
\text { alakjuktól, és attól, milyen környezetben élnek? }\end{array}$ & \\
\hline 5. Az idő mérése (az óra fogalma és leolvasása) & \multirow{4}{*}{$\begin{array}{l}\text { A tanuló idö-fogalmának fejlesztése saját életének és } \\
\text { közvetlen környezetének tapasztalatai alapján. } \\
\text { Saját és környezetük jövőképe. }\end{array}$} \\
\hline 6. Az idő meghatározói: nap, hét, hónap, év & \\
\hline 7. Az év szakaszai - évszakok & \\
\hline 8. Tájékozódás időlétra segítségével & \\
\hline
\end{tabular}

\section{4. táblázat}

A környezeti nevelési tartalmak beillesztésének lehetőségei a harmadik osztályos Természet és társadalom tantárgy tanmenetébe

\begin{tabular}{|c|c|}
\hline $\begin{array}{c}\text { A TANTERVBEN MEGHATÁROZOTT } \\
\text { TANÍTÁSI EGYSÉGEK }\end{array}$ & $\begin{array}{l}\text { AJÁNLÁSOK A KÖRNYEZETI NEVELÉSI } \\
\text { CÉLOK ÉS TARTALMAK BEÉPÍTÉSÉRE }\end{array}$ \\
\hline I. téma: SZÜLŐFÖLDEM & $\begin{array}{c}\text { A fenntarthatóság pedagógiájának ismeretelemei: } \\
\text { MEZÖGAZDASÁG, FÖLDHASZNÁLAT, VÍZ, } \\
\text { ERDÖK, BIODIVERZITÁS ÉS ÉLÖHELY- } \\
\text { MEGÖRZÉS }\end{array}$ \\
\hline $\begin{array}{l}\text { 1. Vidékünk domborzati formái: síkság, } \\
\text { völgykatlanok, hegyek }\end{array}$ & A környezet tulajdonságainak hatása életmódunkra. \\
\hline $\begin{array}{l}\text { 2. A víz előfordulási formái (folyó, mellékfolyók, } \\
\text { mocsár, tó...) }\end{array}$ & \multirow{2}{*}{$\begin{array}{l}\text { Az életközösségek típusainak, tulajdonságainak } \\
\text { megismerése. } \\
\text { Az egyes életközösségek tulajdonságainak felismerése, } \\
\text { összehasonlítása. }\end{array}$} \\
\hline $\begin{array}{l}\text { 3. Életközösségek (a talaj összetétele, nedvessége, a } \\
\text { fény és a hő hatása, növény- és állatvilág, tápláléklánc) }\end{array}$ & \\
\hline 4. Szárazföldi életközösségek (erdők és füves vidékek) & \multirow{7}{*}{$\begin{array}{l}\text { Az egyes életközösségre jellemző élőlények } \\
\text { megismerése, megfigyelése. } \\
\text { A természetben való viselkedés szabályainak } \\
\text { megismerése. } \\
\text { A természet önálló megfigyelése. } \\
\text { A természet szeretete, védelme, környezeti károk } \\
\text { megelőzése. }\end{array}$} \\
\hline $\begin{array}{l}\text { 5. Megművelt területek életközössége: megmüvelt } \\
\text { talaj }\end{array}$ & \\
\hline $\begin{array}{l}\text { 6. A szárazföldi életközösségek jellegzetes növényei és } \\
\text { állatai }\end{array}$ & \\
\hline $\begin{array}{l}\text { 7. A domborzat jelentősége és védelme (talaj és } \\
\text { szárazföldi életközösségek) }\end{array}$ & \\
\hline $\begin{array}{l}\text { 8. Vízi életközösségek (lápok/barák, mocsarak, tavak, } \\
\text { folyók...) }\end{array}$ & \\
\hline 9. A vízi életközösségek jellegzetes növényei és állatai & \\
\hline $\begin{array}{l}\text { 10. A vizek és vízi életközösségek jelentősége és } \\
\text { védelme }\end{array}$ & \\
\hline II. téma: ÉLETTELEN TERMÉSZET & $\begin{array}{c}\text { A fenntarthatóság pedagógiájának ismeretelemei: VÍZ, } \\
\text { LEVEGÖ, TERMÉSZETES ERÖFORRÁSOK }\end{array}$ \\
\hline $\begin{array}{l}\text { 1. A víz és egyéb folyadékok közti hasonlóság és } \\
\text { különbség }\end{array}$ & \multirow{8}{*}{$\begin{array}{l}\text { Az ember által létrehozott környezet jellemzö anyagai, } \\
\text { jelenségei, illetve azok változásai, valamint az } \\
\text { emberek és környezetük kapcsolata. } \\
\text { Az egyes anyagoknak a természetre gyakorolt káros } \\
\text { hatásai. } \\
\text { A globális felmelegedés és következményei, a sarki } \\
\text { jég olvadása. }\end{array}$} \\
\hline $\begin{array}{l}\text { 2. A tárgyak (anyagok) viselkedése a vízben és } \\
\text { különböző folyadékokban }\end{array}$ & \\
\hline $\begin{array}{l}\text { 3. A folyadékok melegítése és hütése miatt jelentkező } \\
\text { változások }\end{array}$ & \\
\hline 4. A folyadékok általános tulajdonságai & \\
\hline $\begin{array}{l}\text { 5. A levegö nyomást gyakorol és mozog. Alak- és } \\
\text { térfogatváltozása }\end{array}$ & \\
\hline $\begin{array}{l}\text { 6. A levegő melegítése és hütése miatt jelentkező } \\
\text { változások }\end{array}$ & \\
\hline $\begin{array}{l}\text { 7. Szilárd, cseppfolyós és gáznemű - különbségek és } \\
\text { hasonlóságok }\end{array}$ & \\
\hline 8. Az anyagok és tárgyak változása & \\
\hline
\end{tabular}




\begin{tabular}{|c|c|}
\hline $\begin{array}{c}\text { III. téma: AZ ÉLÖ ÉS ÉLETTELEN TERMÉSZET } \\
\text { KÖZÖTTI KAPCSOLAT }\end{array}$ & $\begin{array}{c}\text { A fenntarthatóság pedagógiájának ismeretelemei: VÍZ, } \\
\text { LEVEGÖ, KLIIMAVÁLTOZÁS, BIODIVERZITÁS- } \\
\text { ELOÖHELY MEGÖRZÉS, FEJLÖDÉS ÉS } \\
\text { KÖRNYEZET }\end{array}$ \\
\hline $\begin{array}{l}\text { 1. A talaj tulajdonságai és jelentősége az élővilág } \\
\text { számára }\end{array}$ & $\begin{array}{l}\text { Talajszennyezés, talajvédelem, tennivalók egyéni } \\
\text { szinten. Hulladékkezelés. }\end{array}$ \\
\hline $\begin{array}{l}\text { 2. A víz és a levegő tulajdonságai, amelyek az élővilág } \\
\text { számára fontosak }\end{array}$ & $\begin{array}{l}\text { Vízhiány, levegőszennyezés, víz- és levegővédelem, } \\
\text { tennivalók egyéni szinten. }\end{array}$ \\
\hline 3. A víz körforgása & \multirow[b]{2}{*}{$\begin{array}{l}\text { Az időjárás elemeinek megfigyelése, az adatok } \\
\text { rögzítése, évszakok jellemzése, időjárás-jelentések } \\
\text { értelmezése, jelentősége életünkben. } \\
\text { Alkalmazkodási példák a természetben. }\end{array}$} \\
\hline $\begin{array}{l}\text { 4. Időjárási viszonyok, jelentőségük környékünk } \\
\text { élővilágára }\end{array}$ & \\
\hline 5. Különböző hangok mint a mozgás következményei & $\begin{array}{l}\text { A természet jelenségeinek, szépségeinek, csodáinak } \\
\text { megfigyelése, megbecsülése. }\end{array}$ \\
\hline $\begin{array}{l}\text { 6. Az életközösségek kapcsolata és az ember szerepe a } \\
\text { természetes egyensúly megőrzésében }\end{array}$ & $\begin{array}{l}\text { Az élőlények egymásra hatása, szerepük egymás } \\
\text { életében. Környezetünk megóvásának fontossága. }\end{array}$ \\
\hline IV. téma: MOZGÁS TÉRBEN ÉS IDŐBEN & $\begin{array}{c}\text { A fenntarthatóság pedagógiájának ismeretelemei: } \\
\text { VÁROS, VIDEKKFEJLESZTÉS, } \\
\text { TELEPÜLÉSFEJLESZTÉS, FEJLÖDÉS ÉS } \\
\text { KÖRNYEZET }\end{array}$ \\
\hline $\begin{array}{l}\text { 1. Különböző mozgásformák, azok jellemzöi, a } \\
\text { mozgások okozói, periodikus ismétlődésük }\end{array}$ & \multirow{4}{*}{$\begin{array}{l}\text { A Nap mozgásának hatása a Földön lejátszódó } \\
\text { folyamatokra, az élőlények szokásaira, napirendjére. } \\
\text { A természet jelenségeinek megfigyelése. }\end{array}$} \\
\hline 2. A mozgás hangot eredményez & \\
\hline $\begin{array}{l}\text { 3. Mikor és hogyan esnek, csúsznak és gördülnek a } \\
\text { tárgyak? }\end{array}$ & \\
\hline $\begin{array}{l}\text { 4. Tájékozódás a Nap segítségével és a fö égtájak } \\
\text { meghatározása }\end{array}$ & \\
\hline 5. Tájékozódás a település térképe segítségével & \multirow{3}{*}{$\begin{array}{l}\text { A környezet változásának pozitív vagy negatív hatásai } \\
\text { a településre. A település változása az elmúlt } \\
\text { időszakokhoz képest. }\end{array}$} \\
\hline 6. Tájékozódás Szerbia térképén & \\
\hline $\begin{array}{l}\text { 7. Fontosabb idöszakok (dátum, év, évtized, évszázad, } \\
\text { közel- és régmúlt) }\end{array}$ & \\
\hline V. téma: ÖRÖKSÉG̈̈NK & $\begin{array}{c}\text { A fenntarthatóság pedagógiájának ismeretelemei: } \\
\text { KÖZÖSSÉG ÉS KULTÚRA }\end{array}$ \\
\hline $\begin{array}{l}\text { 1. Hogyan tárjuk fel a múltat (a közel- és régmúlt } \\
\text { tanúi)? }\end{array}$ & \multirow[t]{3}{*}{$\begin{array}{l}\text { Az ember alkotta értékek megörzésének fontossága. } \\
\text { Hagyománytisztelet. }\end{array}$} \\
\hline $\begin{array}{l}\text { 2. A múlt nyomai: tárgyi, írásos, szóbeli emlékek és } \\
\text { szokások }\end{array}$ & \\
\hline 3. Óvjuk és ápoljuk a múlt nyomait & \\
\hline VI. téma: VALAHA ÉS MA & $\begin{array}{c}\text { A fenntarthatóság pedagógiájának ismeretelemei: } \\
\text { KÖZÖSSÉG ÉS KULTÚRA }\end{array}$ \\
\hline $\begin{array}{l}\text { 1. Élet a családban, iskolában, településen, } \\
\text { lakóhelyünkön a közel- és régmúltban }\end{array}$ & \multirow{4}{*}{$\begin{array}{l}\text { Hagyománytisztelet. A szellemi és kulturális értékek } \\
\text { megőrzésének fontossága. } \\
\text { Ismeretek szerezése a helyi hagyományokról, a } \\
\text { lakóhely múltjáról, továbbá a környék, a lakóhely } \\
\text { természeti értékeirool, az azokat fenyegető veszélyekról } \\
\text { és a megóvásukra tett erőfeszítésekről. }\end{array}$} \\
\hline 2. Lakóhelyem kulturális és történelmi múltja & \\
\hline $\begin{array}{l}\text { 3. A népdalok, elbeszélések és mesék alakjai - a múlt } \\
\text { eseményei, az események helye és ideje közötti } \\
\text { összefüggések }\end{array}$ & \\
\hline 4. Vidékünk ismert személyei & \\
\hline VII. téma: AZ ANYAGOK ÉS FELHASZNÁLÁSUK & $\begin{array}{c}\text { A fenntarthatóság pedagógiájának ismeretelemei: } \\
\text { ENERGIA, TERMÉSZETES ERÖFORRÁSOK, } \\
\text { HULLADÉKGAZDÁLKODÁS }\end{array}$ \\
\hline $\begin{array}{l}\text { 1. Az anyagban hö- és mechanikai hatásra történő } \\
\text { speciális változások }\end{array}$ & \multirow{5}{*}{$\begin{array}{l}\text { A környezetben előforduló elemek tulajdonságainak } \\
\text { megfigyelése, vizsgálata. } \\
\text { Veszélyes anyagok, hulladékok (galvánelem). } \\
\text { A természetes eröforrások jelentősége és felelőtlen } \\
\text { fogyasztásuk veszélyei. } \\
\text { Alternatív energiahordozók. }\end{array}$} \\
\hline 2. A víz, vizes oldatok és a levegő elektromos vezetése & \\
\hline 3. A levegő - höszigetelő & \\
\hline 4. Az anyag mágneses tulajdonsága & \\
\hline $\begin{array}{l}\text { 5. Az anyagok tulajdonságai határozzák meg azok } \\
\text { felhasználását }\end{array}$ & \\
\hline
\end{tabular}


VIII. téma: EMBERI TEVÉKENYSÉGEK

1. Vidékünk lakossága (hasonlóságok, különbségek, együttélés)

2. A gyerekek jogai, a csoportok jogai (a jogok ismerete, elfogadása és betartása)

3. Termelő és nem termelö tevékenységek és azok kölcsönhatása

4. Város és falu, azok összefüggése és egymás feltételezése

5. Vidékünk úthálózata (hogyan viselkedjünk az utakon)

6. Az ember és környezete közti hatások, az egészségre és életre gyakorolt hatások
A fenntarthatóság pedagógiájának ismeretelemei: KÖZLEKEDÉS, NÉPESEDÉS, FEJLÖDÉS ÉS KÖRNYEZET, ÉLETMÓD

A különböző népek eltérő életmódja, gazdasági és kulturális körülményei.

Azonos jogok és kötelezettségek a Föld összes lakója számára.

A környezet hatása a gazdálkodásra, életmódra, a közösségi normák alakulására.

Az emberek egymásra utaltsága, munkájuk haszna a közösség számára.

Közlekedéskultúra.

Tájékozódás a környezetünkben.

A közlekedési eszközök környezet- és egészségkárosító hatása. Környezetkímélő közlekedés.

Az ember tevékenységének környezetátalakító hatása. Annak negatív, a környezetet és az ember életkörülményeit, egészségét károsító elemei.

\section{5. táblázat}

A környezeti nevelési tartalmak beillesztésének lehetöségei a negyedik osztályos Természet és társadalom tantárgy tanmenetébe

\begin{tabular}{|c|c|}
\hline $\begin{array}{l}\text { A TANTERVBEN MEGHATÁROZOTT } \\
\text { TANÍTÁSI EGYSÉGEK }\end{array}$ & $\begin{array}{l}\text { AJÁNLÁSOK A KÖRNYEZETI NEVELÉSI } \\
\text { CÉLOK ÉS TARTALMAK BEÉPÍTÉSÉRE }\end{array}$ \\
\hline I. téma: HAZÁM A VILÁG RÉSZE & $\begin{array}{l}\text { A fenntarthatóság pedagógiájának ismeretelemei: } \\
\text { NÉPESEDÉS, FÖLDHASZNÁLAT, ÉLETMÓD, } \\
\text { KÖZÖSSÉG ÉS KULTÚRA, EGYENLÖSÉG ÉS } \\
\text { JOGOK, KORMÁNYZÁS }\end{array}$ \\
\hline $\begin{array}{l}\text { 1. Az államot meghatározó tényezők (terület, lakosság, } \\
\text { jelképek...) }\end{array}$ & $\begin{array}{l}\text { A világban, a társadalomban, közvetlen } \\
\text { környezetünkben betöltött helyünk. }\end{array}$ \\
\hline $\begin{array}{l}\text { 2. Szerbiát meghatározó tényezők (terület, határok, } \\
\text { lakosság, főváros, jelképek) }\end{array}$ & $\begin{array}{l}\text { Országunk jellemzői, jelképei. Közös szellemi } \\
\text { tulajdonunk. }\end{array}$ \\
\hline $\begin{array}{l}\text { 3. A modern szerb állam fejlődése (a 19. és a } 20 . \\
\text { század) }\end{array}$ & $\begin{array}{l}\text { Országunk múltbéli és jelenlegi helyzetének } \\
\text { megfigyelése a környezet szempontjából. }\end{array}$ \\
\hline $\begin{array}{l}\text { 4. Szerbia stratégiai helyzete - fizikai-földrajzi és } \\
\text { közlekedésföldrajzi helyzete (a Balkán-félszigeten, } \\
\text { Európában és a világban) }\end{array}$ & $\begin{array}{l}\text { Országunk elhelyezkedése, a többi ország } \\
\text { tevékenységének (környezetvédelmi tevékenység, } \\
\text { szennyezés) hatása környezetünkre. }\end{array}$ \\
\hline $\begin{array}{l}\text { 5. Szerbia természetföldrajzi jellegzetességei: hazánk } \\
\text { domborzata, vizei és éghajlata }\end{array}$ & \multirow{3}{*}{$\begin{array}{l}\text { Országunk természetföldrajzi értékeinek megismerése, } \\
\text { számba vétele. Megörzésük, védelmük, fenntartásuk } \\
\text { fontossága. } \\
\text { A domborzat, vizeink, az éghajlat környezetalakító } \\
\text { hatása. Hogyan befolyásolják életmódunkat ezek az } \\
\text { adottságok. Megőrzésük fontossága, módszerei. }\end{array}$} \\
\hline $\begin{array}{l}\text { 6. Domborzat (Pannon-medence, folyóvölgyek sík } \\
\text { vidékei, völgykatlanok, hegyvidék, legnagyobb } \\
\text { hegyeink); vizek (leghosszabb folyóink, folyam, } \\
\text { természetes és mesterséges tavak, gyógyvizek); } \\
\text { éghajlat (a mérsékelt éghajlat jellegzetességei) }\end{array}$ & \\
\hline $\begin{array}{l}\text { 7. Károsodott és védett vidékek Szerbiában (nemzeti } \\
\text { parkok, rezervátumok, a természet emlékmúvei) }\end{array}$ & \\
\hline $\begin{array}{l}\text { 8. Szerbia lakossága: a lakosság természetes alakulása } \\
\text { (száma, a település sürűsége, migráció); a lakosság } \\
\text { összetétele }\end{array}$ & \multirow{2}{*}{$\begin{array}{l}\text { A túlnépesedés problémája. Okai, következményei, } \\
\text { megoldásának lehetőségei. Mit tehetünk egyéni } \\
\text { szinten? } \\
\text { Az állampolgárok jogairól. Valamennyien egyforma } \\
\text { jogokkal és kötelezettségekkel bírunk. } \\
\text { A környezeti válság és migráció kapcsolata. }\end{array}$} \\
\hline $\begin{array}{l}\text { 9. Demokratikus viszonyok építése (mely jogok } \\
\text { szabályozzák az állam és a polgárok kölcsönös jogait } \\
\text { és kötelezettségeit) }\end{array}$ & \\
\hline $\begin{array}{l}\text { 10. A nemzeti azonosságtudat megőrzése és a világ } \\
\text { kulturális vérkörébe (,svetska kulturna baština”) való } \\
\text { bekapcsolódás }\end{array}$ & \multirow{2}{*}{$\begin{array}{l}\text { Kulturális örökségünk megőrzésének, védelmének } \\
\text { fontossága. } \\
\text { A szúkebb és tágabb környezetünk részei vagyunk. } \\
\text { Egyformán felelősek vagyunk az ott végbemenő } \\
\text { pozitív és negatív változásokért. } \\
\text { Hogyan hatnak a környezeti gondok a társadalom } \\
\text { müködésére? Milyen megoldások kínálkoznak? }\end{array}$} \\
\hline $\begin{array}{l}\text { 11. Mi egy közös világ gyerekei vagyunk - a } \\
\text { Gyerekjogok Konvenciója (ENSZ, UNICEF, } \\
\text { UNESCO, Európa Tanács, „Európa öröme”) }\end{array}$ & \\
\hline
\end{tabular}


II. téma: SZERBIA NÖVÉNY- ÉS ÁLLATVILÁGA

1. Az élővilág csoportosítása hasonlóságuk és különbségeik alapján

2. Hazánk flórája (jelentősége, tipikus, ritka és veszélyeztetett növények; sokféleség, gazdagság, védelem, revitalizáció)

3. Hazánk faunája (jelentősége, tipikus, ritka és veszélyeztetett állatok, sokféleség, gazdagság, védelem, revitalizáció)

4. Háziállatok és termesztett növények (jelentősége, szükségletek és lehetőségek, az egészséges táplálék előállításának potenciálja)

5. Természeti jelenségek, alkalmazkodás: néhány adaptív változás és viselkedés (születés, virágzás, terméshozás, vedlés, költözés...) megfigyelése, észlelése, követése, feljegyzése

\section{III. téma: AZ EMBER A TERMÉSZET RÉSZE}

1. Az ember a természet része - értelmes és társadalmi lény

\section{Az ember megismeri önmagát - feltárja a nemi} különbségeket

3. Az egészséges életvitel alapjai - hogy tudok hatni életem minőségére? (táplálkozás, higiéné, ruházkodás, lakás, egészségügyi kultúra...)

4. Mások és önmagunk (korosztályunk, idősebbek, betegek, házi kedvencek, kóbor állatok...) iránti felelősség

IV. téma: A TERMÉSZETI JELENSÉGEKET
TANULMÁNYOZZUK

1. Az ok-okozati összefüggések tanulmányozása és észlelése, a paraméterek (méretek) meghatározása, egymás közti viszonyuk, kísérletek

2. Mozgásra vonatkozó szabályok (a mozgás elkezdése, befejezése, változó sebesség...); az eddig szerzett ismeretek rendszerezése és a paraméterek leellenőrzése

3. Mi és hogyan hat arra a távolságra, amit egy test megtesz; különböző tárgyak esése, csúszása, gördülése, mitöl függ az inga lengési ideje?

4. Mitől függ az árnyék nagysága?

5. Hogyan hat a levegőoszlop (a pohárban lévő víz magassága) a hang magasságára?

\section{V. téma: AZ ANYAGOK TULAJDONSÁGAINAK} TANULMÁNYOZÁSA

1. Anyagok és azok tulajdonságai: mechanikai, hö, elektromos, mágneses jellegzetességei, oldhatóság 2. Mely tárgyak (anyagok) válnak legjobban elektromossá, és melyek a legjobb elektromos vezetők? Hogyan határozhatjuk ezt meg?

3. Hogyan növelhető vagy csökkenthető a mágneses hatás?

4. Anyagok és fényáteresztő képességük
A fenntarthatóság pedagógiájának ismeretelemei: FOGYASZTÁS, FAJOK, BIODIVERZITÁS ÉS ÉLÖHELY-MEGÖRZÉS, ÉLETMÓD

Környezetünk növény- és állatvilágának sokszínüsége. Megőrzésük, védelmük fontossága.

A biodiverzitás csökkenésnek problémája, kialakulásának okai, következményei. A lehetséges megoldások. Mit tehetünk egyéni szinten?

A többi élölény hatása a mi életkörülményeinkre, táplálkozásunkra, egyéb szükségleteink kielégítésére.

A környezet változásának hatása a mi életkörülményeinkre, tevékenységeinkre. Alkalmazkodás a környezetünkhöz. Környezetünk megfigyelése.

A fenntarthatóság pedagógiájának ismeretelemei: EGÉSZSÉG, ÉLETMÓD, KÖZÖSSÉG ÉS KULTÚRA

A természet részei vagyunk. Egyformán részesülünk a hatásaiból a többi élőlénnyel. A környezet hat az életkörülményeinkre, és mi is hatással vagyunk a környezetünkre.

A nemek közötti különbségek megismerése. A társadalomban egyforma jogok, kötelezettségek illetik meg mindkét nemet.

Egészséges életmód kialakítása, fenntartása. Az egészségvédelem alapjai. Lakás tisztán tartása, hulladékkezelés stb.

Egymással kölcsönhatásban élünk, hatással a többi élőlény életére. Ezért kötelesek vagyunk törödni azokkal, akikkel megtehetjük.

A fenntarthatóság pedagógiájának ismeretelemei: FEJLÖDÉS ÉS KÖRNYEZET

A világ több szemszögből való megismerése, a kíváncsiság felkeltése a természeti jelenségek megfigyelése iránt.

A természeti jelenségek észlelése, folyamatos megfigyelések, vizsgálatok, kísérletek végzése.

A kölcsönhatás fogalmának értelmezése (minden környezeti probléma kialakulása, megoldása kölcsönhatások sorozatának eredménye).

\section{A fenntarthatóság pedagógiájának ismeretelemei:} TERMÉSZETES ERÖFORRÁSOK

A természeti jelenségek megfigyelése, összefüggések keresése, kísérletezés.

Természetes anyagok és mesterséges anyagok tanulmányozása.

A keverékek szétválasztása: víztisztítás, levegötisztítás.

A vegyszerek (pl. háztartásban használatosak) hatása az emberi szervezetre. 


\begin{tabular}{|c|c|}
\hline $\begin{array}{l}\text { 5. Mely anyagoknak van a legjobb hövezetö } \\
\text { képességük? }\end{array}$ & \multirow{4}{*}{$\begin{array}{l}\text { A környezet anyagai és ezek állapota. } \\
\text { Termőtalaj, vizek és levegö védelme, annak } \\
\text { megismerése, hogy mit tehetnek ezért a gyerekek. }\end{array}$} \\
\hline $\begin{array}{l}\text { 6. Az anyagok oldékonyságának tanulmányozása (a } \\
\text { szilárd, cseppfolyós és gáznemú anyagok } \\
\text { különbözőfokú oldhatósága a vízben) }\end{array}$ & \\
\hline $\begin{array}{l}\text { 7. Keverékek - azonosításuk, jellemzésük, a } \\
\text { környezetünkben előforduló keverékek }\end{array}$ & \\
\hline $\begin{array}{l}\text { 8. A keverékek különbözö módon történő } \\
\text { szétválasztása, amelyeket a keverék alkotói alapján } \\
\text { választunk meg (rostálás, szúrés, párologtatás...) }\end{array}$ & \\
\hline $\begin{array}{c}\text { VI. téma: AZ ANYAGOKON TAPASZTALHATÓ } \\
\text { VÁLTOZÁSOK }\end{array}$ & $\begin{array}{c}\text { A fenntarthatóság pedagógiájának ismeretelemei: } \\
\text { TERMÉSZETES ERÓFORRÁSOK }\end{array}$ \\
\hline $\begin{array}{l}\text { 1. Az anyagokon végbemenő visszafordítható és } \\
\text { visszafordíthatatlan változások }\end{array}$ & \multirow{4}{*}{$\begin{array}{l}\text { A visszafordítható és visszafordíthatatlan változások } \\
\text { hatásai a környezetre. } \\
\text { Korrózióvédelem. } \\
\text { Égés: a tüz szerepe, a tüzek környezetszennyezö } \\
\text { hatása. } \\
\text { Kísérletezés, megfigyelés. Vegyi anyagok, balesetek, } \\
\text { önvédelem lehetöségei. }\end{array}$} \\
\hline $\begin{array}{l}\text { 2. Más, különbözö tulajdonságú anyagok létrejöttét } \\
\text { eredményező változások meghatározása (égés, } \\
\text { rozsdásodás, rothadás...) }\end{array}$ & \\
\hline $\begin{array}{l}\text { 3. Gyúlékony anyagok, ezek jelölése; tüzveszély, } \\
\text { tüzvédelem, túzoltás }\end{array}$ & \\
\hline $\begin{array}{l}\text { 4. Hol tapasztaljuk és alkalmazzuk azt, amit a } \\
\text { különböző mozgásformákról, elektromos } \\
\text { jelenségekről, mágnesességről, fényjelenségekről, az } \\
\text { anyagok tulajdonságairól és változásairól tanultunk? }\end{array}$ & \\
\hline $\begin{array}{c}\text { VII. téma: MUNKA, ENERGIA, TERMELÉS ÉS } \\
\text { FOGYASZTÁS }\end{array}$ & $\begin{array}{c}\text { A fenntarthatóság pedagógiájának ismeretelemei: } \\
\text { MEZÓGAZDASÁG, FÖLDHASZNÁLAT, } \\
\text { FOGYASZTÁS, VIDÉKFEJLESZTÉS, TERMÉSZETES } \\
\text { ERÖFORRÁSOK, EGYENLÖSÉG ÉS JOGOK }\end{array}$ \\
\hline 1. A munka - tudatos emberi tevékenység & \multirow{2}{*}{$\begin{array}{l}\text { Az emberi tevékenységek és a környezet egymásra } \\
\text { gyakorolt pozitív és negatív hatásai. } \\
\text { A táj erőforrásai és az életmód, kultúra kapcsolata. }\end{array}$} \\
\hline $\begin{array}{l}\text { 2. A természeti és társadalmi tényezők ember életére } \\
\text { és munkájára gyakorolt hatása }\end{array}$ & \\
\hline 3. Természeti kincsek és azok kiaknázása & \multirow{7}{*}{$\begin{array}{l}\text { A mezőgazdasági tevékenység környezeti hatásának } \\
\text { megismerése. } \\
\text { A természeti kincsek kiaknázása. } \\
\text { Túlzott kihasználásuk, ami környezeti problémákhoz } \\
\text { vezet. } \\
\text { A különböző nyersanyagforrások (víz, üzemanyag, élö ó } \\
\text { természet produktumai, energia stb.) és a velük való } \\
\text { takarékosság fontossága. } \\
\text { A kiaknázott javak környezetbarát használata. } \\
\text { Megújuló nyersanyagforrások. } \\
\text { A fenntarthatóság fogalma. } \\
\text { Az ember szerepe az ökológiai folyamatokban. }\end{array}$} \\
\hline $\begin{array}{l}\text { 4. Tartalékok: víz, üzemanyagok, kőzetek és ásványok, } \\
\text { termöföld, erdők, növény- és állatvilág }\end{array}$ & \\
\hline $\begin{array}{l}\text { 5. Természetes nyersanyagok - alkalmazásuk: } \\
\text { konyhasó, gipsz, márvány }\end{array}$ & \\
\hline $\begin{array}{l}\text { 6. A természetes nyersanyagok felhasználása - a } \\
\text { fémek, a papír, gumi elóállításának technológiája. A } \\
\text { víz átdolgozása, egészséges táplálék }\end{array}$ & \\
\hline 7. Nap, levegö, víz - megújuló energiaforrások & \\
\hline $\begin{array}{l}\text { 8. Szén, köolaj, földgáz - nem megújuló } \\
\text { energiaforrások, környezetvédelem }\end{array}$ & \\
\hline 9. A kihasználatlan és ökológiai energiaforrások & \\
\hline $\begin{array}{l}\text { 10. Az emberek tevékenysége Szerbia különbözö } \\
\text { vidékein (sík vidéken, völgykatlanokban, } \\
\text { hegyvidéken; falun, városban) }\end{array}$ & \multirow{3}{*}{$\begin{array}{l}\text { A környezeti viszonyok meghatározzák az } \\
\text { életközösségek tevékenységét, a termelés, a } \\
\text { kereskedelem milyenségét egy országon belül. } \\
\text { A mértéktelen fogyasztás problémája, ami társadalmi } \\
\text { egyenlőtlenségekhez vezet. } \\
\text { A szükségletek, igények, vágyak megkülönböztetése. } \\
\text { Vásárlási szokások. A termékek csomagolása és a } \\
\text { környezetszennyezés kapcsolata. } \\
\text { A reklám, és ami mögötte van. } \\
\text { A természet tartalékainak mértékletes kihasználása. A } \\
\text { fenntartható fejlödés fogalma. }\end{array}$} \\
\hline $\begin{array}{l}\text { 11. Termelés és szolgáltatás; piacra bocsátás, } \\
\text { kereskedelem, kínálat-kereslet; kereskedelem és } \\
\text { fogyasztás (marketing) }\end{array}$ & \\
\hline $\begin{array}{l}\text { 12. Munka, termelés, fogyasztás és a fenntartható } \\
\text { fejlődés (felismerni a természeti tartalékok, } \\
\text { alkalmazott technológiák és a fenntartható fejlődés } \\
\text { közti összefüggéseket) }\end{array}$ & \\
\hline VIII. téma: VISSZATEKINTÉS - A MÚLT & $\begin{array}{c}\text { A fenntarthatóság pedagógiájának ismeretelemei: } \\
\text { FEJLÖDÉS ES KÖRNYEZET, ÉLETMÓD, } \\
\text { KÖZÖSSÉG ÉS KULTÚRA }\end{array}$ \\
\hline $\begin{array}{l}\text { 1. A múlt nyomai (magunk és családunk múltja, } \\
\text { településünk, vidékünk múltja) }\end{array}$ & \multirow{2}{*}{$\begin{array}{l}\text { A múlt nyomai: hogyan éltek, mivel foglalkoztak, } \\
\text { milyen életmódot folytattak elödeink. } \\
\text { Hogyan fütöttek, világítottak, hogyan kezelték a }\end{array}$} \\
\hline 2. Időlétra (az évszázadok időben történő & \\
\hline
\end{tabular}




\begin{tabular}{|c|c|}
\hline megl & \multirow{7}{*}{$\begin{array}{l}\text { hulladékot, az ivóvizet. } \\
\text { Étkezési szokásaink kialakulása. Néhány alapvető } \\
\text { élelmiszer elkészítési módja, története. } \\
\text { Családunk történetének, egykori életmódjának } \\
\text { megismerése. } \\
\text { Hogyan hatottak a környezeti változások a } \\
\text { gazdálkodásra, életmódra, a közösségi normák } \\
\text { alakulására? } \\
\text { Az ökológiai válság miatt elpusztult kultúrák. } \\
\text { A környezeti alapproblémák történeti megközelítése. } \\
\text { Múltunk megismerése, a múltban történt események } \\
\text { környezetátalakító hatásai. } \\
\text { A hagyományok eredete, megőrzése. }\end{array}$} \\
\hline $\begin{array}{l}\text { 3. Az } \\
\text { időlé }\end{array}$ & \\
\hline & \\
\hline $\begin{array}{l}\text { 5. Kö } \\
\text { szitua } \\
\text { egykd }\end{array}$ & \\
\hline & \\
\hline an és hazánkban bekövetkezett események & \\
\hline Szerbia uralkodói a $\mathrm{N}$ & \\
\hline
\end{tabular}

\subsection{A fenntarthatóság fogalmának megjelenése a szerbiai felsőoktatásban}

Szerbiában a lakosság kevesebb mint 10\%-a rendelkezik felsőfokú végzettséggel (Vukasović, 2007). Az ország jelenleg több akadály, gazdasági válság, demográfiai kihívások mellett igyekszik felzárkózni a posztmodern, globalizált társadalmakhoz. A gazdasági válságból való kijutás egyetlen módja az lehet, ha Szerbia igyekszik utat találni a tudásáramlás, a megfelelően képzett humánerőforrás irányába, ezáltal kialakítva egy versenyképes, tudás alapú társadalmat (Milutinović és Nikolić, 2014). A folyamat első lépése a Szerb Köztársaság Oktatásfejlesztési Stratégia 2020+ elnevezésü dokumentumának kidolgozása volt. Az oktatás megreformálása érdekében kidolgozott stratégia egyik erőssége, hogy szoros együttmüködést feltételez az oktatás és a társadalom egyéb szegmensei között, valamint hogy a változtatások szükségességét az óvodától kezdve az oktatás minden területére kiterjeszti, hangsúlyozva a felsőoktatás és az élethosszig tartó tanulás jelentőségét (Ivic és Pesikan, 2012).

Szerbiában összesen 8 állami és 9 magánegyetem, valamint 47 államilag finanszírozott és 17 magánfőiskola müködik (European Commission, 2012). Ezen egyetemek közül három városban (Belgrad, Niš, Kragujevac) müködő felsőoktatási intézmény a COPERNICUS program tagja. A programot 1988-ban indította útjára az Európai Rektori Konferencia (CRE). A COoperation Programme in Europe for Research on Nature and Industry through Coordinated University Studies olyan európai egyetemeket tömörít magába, amelyek elkötelezettek a fenntartható fejlődés irányában. A COPERNICUS prioritásai a következők: (1) a fenntarthatóság interdiszciplináris megközelítése és a kapcsolódó témák feldolgozása; (2) az élethosszig tartó tanulás ösztönzése; (3) fenntartható termelési és fogyasztási minták megismertetése; (4) tanártovábbképzés; (5) együttműködések és hálózatépítés; (6) a témák távoktatásban, távegyüttmüködésben megvalósuló megközelítése (Milutinović and Nikolić, 2014).

Jelenleg két, egymással párhuzamos oktatási reform bevezetése folyik a szerbiai oktatási rendszerben, amely a felsőoktatási intézményeknek a fenntarthatóságban játszott szerepét erősítik. Az egyik reformot a bolognai oktatási rendszer kiépítése jelenti a szerbiai felsőoktatásban, a másik fontos reform pedig a Nemzeti Fenntartható Fejlödési Stratégia, valamint a Szerbia 2020 Stratégia kidolgozása, amelyekben fontos szerepet szánnak a felsőoktatásnak (Milutinović és Nikolić, 2014). 
A szerbiai egyetemek oktatási rendszerének elsődleges vizsgálatai a fenntartható fejlődés jelenlétére vonatkozóan azt mutatják, hogy maga a fogalom már megjelent, és néhány kezdeményezés el is indult ebben az irányban. Ugyanakkor a fenntarthatóságra nevelés területén számos bővíteni- és fejlesztenivaló teendő vár még a szerbiai felsőoktatási rendszerre (Pavlović, 2011). A szerbiai Nemzeti Fenntartható Fejlödési Stratégia a következő célokat fogalmazta meg a felsőoktatási rendszerre vonatkozóan: (1) kedvezőbb általános gazdasági feltételek megteremtése, pénzügyi, intézményi és technikai támogatás biztosítása a fenntartható fejlődés oktatásának bevezetését célzó reformok érdekében; (2) a fenntartható fejlődés bevezetésének elősegítése a formális és nem formális oktatásban; (3) a fenntartható fejlődéssel kapcsolatos képzések biztosítása a tanárok számára az oktatás minden szintjén; (4) a fenntartható fejlődésre vonatkozó kutatások támogatása az oktatási rendszeren belül; ( 5) az együttmüködés folyamatos javítása nemzeti, regionális és nemzetközi szinten ezen a területen (Nacionalna strategija održivog razvoja, 2008 / Nemzeti Fenntartható Fejlödési Stratégia, 2008).

A fenntartható fejlődés és környezeti nevelés témakörére az interdiszciplinaritás jellemző, hiszen a környezeti problémák elemzése, a konfliktusok feloldása és az új problémák megelőzése nem tisztán természettudományi jellegü, hanem történelmi, gazdasági, kulturális és több más szempontot is magában foglal. Ezáltal megfelelő tervezés mellett a legtöbb egyetemen oktatott tantárgy tartalmában helyet kaphatna a fenntarthatóság fogalma és a környezettudatosság kialakítása. Ugyanakkor a gyakorlat azt mutatja, hogy a szerbiai felsőoktatási intézményekben nem fordítanak kellő figyelmet a fenntarthatóságra nevelésre. Továbbra is a müszaki főiskolák tananyagában jelenik meg leggyakrabban a fenntartható fejlödés fogalma, és csak csekély mértékü érdeklődés figyelhető meg a téma iránt a humán és társadalmi irányzatok részéről. A probléma forrásaként több okot is felsorol Lončar (2011):

(1) Elsősorban az jelent problémát, hogy a főiskolák és egyetemek önállóan állítják össze a tantervüket, és emiatt nem jelenik meg egy átfogó megközelítés a felsőoktatási rendszeren belül, miközben a fenntarthatóságot éppen ez a globális szemlélet jellemzi. Gyakran előfordul, hogy megfelelően képzett szakemberek híján a rendelkezésre álló oktatók profiljához illeszkedő programok és kurzusok jönnek létre, amelyek nem összeegyeztethetök a többi intézmény programjával.

(2) Szerbiában a fenntartható fejlődés oktatása a bölcsészettudományi és társadalomtudományi karokon túlnyomórészt az ökológia tantárgyhoz kapcsolódik. A humán és társadalomtudományi témákat oktató tanárok nem rendelkeznek megfelelő rálátással és képesítéssel annak érdekében, hogy saját tárgyaikba is beépítsék a fenntarthatóság kérdéskörét, így a természettudományok oktatóira hárítják a feladatot.

(3) A felsőoktatási intézményekben nem megfelelő a fenntartható fejlődéssel kapcsolatos elméleti és gyakorlati ismeretekkel rendelkező oktatók száma. A fenntartható fejlödéssel kapcsolatos tudásukat általában külföldi egyetemi tanulmányaik és kutatásaik során szerzik meg a szakemberek, amely ismereteiket nem minden esetben hozzák haza és kamatoztatják az itthoni intézményekben.

(4) Feltünő az érdektelenség az új tudományterületeken megszerezhető tudás kifejlesztésére és annak alkalmazására a már „saját” tantárggyal rendelkező, régebb óta a felsőoktatásban dolgozó oktatók és kutatók részéröl. Leginkább a feltörekvő fiatal kutatók választják a fenntartható fejlődés témakörét doktori téziseik és további kutatásaik alapjául. Ez 
a tendencia hosszú távon azonban reményt adhat arra, hogy a jövőbeni tantervekbe beépíthetővé válik a téma, mivel megfelelően képzett szakemberek állnak majd rendelkezésre a fenntarthatóságra nevelés érdekében.

(5) A fenntartható fejlődés fogalmának beépítése az oktatás rendszerébe nem csupán részleges, kizárólag a tananyagot érintő fejlesztéseket igényel. Sokkal mélyebb, átfogóbb változásokra lenne szükség. A fenntartható fejlődés oktatása ugyanis magába foglalja a kölcsönös, tapasztalati tanulást, a kreatív módszereket, a tanári szerepek és munkaformák átértékelését, amelyre a merev, „ex cathedra” elven müködő szerbiai egyetemek még nincsenek felkészülve (Lončar, 2011).

Reményre ad azonban okot, hogy az elmúlt néhány évben számos alap, mester, posztgraduális vagy egyéb szakirányú továbbképzést nyújtó, a környezetvédelem témájában müködő egyetemi kar, tanszék, tanulmányi csoport jött létre Szerbiában. Az oktatási programokat vizsgálva észrevehető, hogy a fenntartható fejlődés még mindig a müszaki főiskolák oktatási programjában van leginkább jelen, egyre nagyobb azonban az érdeklődés a társadalmi irányzatok részéről is. (Milutinović és Nikolić, 2014). Lončar (2011) eredményei is arra engednek következtetni, hogy bár a fenntartható fejlődés oktatása egyelöre nincs jelen megfelelő mértékben a szerbiai egyetemek humán és társadalomtudományi karain, a tananyag jellege lehetővé teszi, hogy a fogalom beépíthetővé váljon és megfelelő szinten foglalkozzanak a fenntarthatóságra nevelés kérdéseivel.

Az Újvidéki Egyetem 14 kara mellett müködő ACIMSI (Asocijacija centara za interdisciplinarne i multidisciplinarne studije i istraživanja / Interdiszciplináris és Multidiszciplináris Tanulmányok és Kutatások Szövetsége) tizenegy egyetemi központot tömörít. Ezek közül az egyik a Környezeti és Fenntartható Fejlődési Központ (Centar za održivi razvoj i životnu sredinu), amelynek fö célkitűzése olyan kutatások végzése a felsőoktatáson belül, amelyek hozzájárulnak egy egységes koncepció kialakításához a környezeti neveléssel és a fenntartható fejlődéssel kapcsolatos ismeretek oktatása terén. A központ a következő eredményeket igyekszik elérni tevékenységei nyomán (Centre for Sustainable Development and Environment, University of Novi Sad):

(1) több szakterületen is képzett, professzionális oktatói gárda létrehozása a globális és lokális környezeti problémák megoldása érdekében;

(2) elismert és minőségi oktatási és kutatási programok létrejötte a környezetvédelem területén;

(3) aktív együttműködés kialakulása a Szerb Köztársaság és az Európai Unió között a környezetvédelmi kérdések tekintetében;

(4) fejlett nemzetközi és egyetemek közötti oktatási-kutatási programok kialakulása;

(5) technológiai és tudástranszfer kialakítása a fejlett országok és a Szerb Köztársaság között;

(6) hosszútávú környezetvédelmi fejlesztési stratégia kialakítása az oktatás és a kutatás terén, az Európai Unió általi szabályozással összhangban. 
A környezeti nevelés során a pedagógusok felkészültsége, ismereteik, készségeik, életmódjuk és életvezetésük az, ami a leginkább befolyásolni képes a tanulók attitűdjeit és a fenntartható fejlődés szemléletének és gyakorlatának terjesztését. Különösen a tanárképző intézmények feladata a tanítók ilyen irányú képzése, úgy, hogy a megfelelő tudás kialakítását az előlátott kurzusokon interdiszciplináris megközelítéssel érjék el, ahol minden tantárgy a saját területére értelmezi a fenntarthatóság fogalmát (Vicente-Molina, Fernández-Sáinz és Izagirre-Olaizola, 2013).

Az Újvidéki Egyetem legfiatalabb, 14. egyetemi kara a szabadkai székhelyü Magyar Tannyelvü Tanítóképző Kar. Az intézmény 2006. október 16-án kezdte meg a müködését. Szabadkán a tanítóképzés nagy hagyományokra tekint vissza. 1871-ben alakult meg a tanítónő-képezde, ahol először magyar nyelven, majd a későbbiekben szerb és horvát nyelven folyt az oktatás. Így 2016-ban a szabadkai tanítóképzés a fennállásának 145. évét, a Magyar Tannyelvü Tanítóképző Kar pedig a 10 éves jubileumát ünnepelte.

A Kar jelenleg három akkreditált oktatási programot tud felkínálni, nevezetesen az osztálytanító és az óvópedagógus alapképzést, valamint az erre épülő mesterképzést. A tanulmányok ideje az első kettő esetében négy év, a mesterképzés pedig egy évig tart. Az alapképzésen 240, a mesterképzésen pedig 60 ECTS pontot kell megszerezni.

A Karon oktatott tantárgyakat öt különböző csoportba sorolhatjuk, az adott tárgyat oktató tanszék jellege alapján (2. táblázat). Az öt tantárgycsoport a következő: (1) nyelvi és irodalmi tartalmú tantárgyak; (2) társadalomtudományi tantárgyak; (3) természettudományi tantárgyak; (4) készségtárgyak (mủvészetek és testnevelés); (5) módszertani tantárgyak.

\section{6. táblázat:}

A kötelezö tantárgyak tanévenkénti aránya a 2012/2013-as tanévben

\begin{tabular}{|c|c|c|c|c|c|c|c|c|c|c|}
\hline & \multicolumn{2}{|c|}{ 1. évfolyam } & \multicolumn{2}{|c|}{ 2. évfolyam } & \multicolumn{2}{|c|}{ 3. évfolyam } & \multicolumn{2}{|c|}{ 4. évfolyam } & \multicolumn{2}{|c|}{ összesen } \\
\hline & $\begin{array}{c}\text { tárgyak } \\
\text { száma }\end{array}$ & $\%$ & $\begin{array}{c}\text { tárgyak } \\
\text { száma }\end{array}$ & $\%$ & $\begin{array}{c}\text { tárgyak } \\
\text { száma }\end{array}$ & $\%$ & $\begin{array}{c}\text { tárgyak } \\
\text { száma }\end{array}$ & $\%$ & $\begin{array}{c}\text { tárgyak } \\
\text { száma }\end{array}$ & $\%$ \\
\hline 1. nyelv/irodalom & 3 & 19 & 4 & 27 & $\mathbf{1}$ & 4 & $\mathbf{0}$ & 0 & 8 & 12 \\
\hline 2. társadalomtudományok & 6 & 37 & 4 & 27 & 8 & 35 & $\mathbf{0}$ & 0 & 18 & 27 \\
\hline 3. természettudományok & 4 & 25 & 2 & 13 & 1 & 4 & $\mathbf{0}$ & 0 & 7 & 11 \\
\hline 4. készségtárgyak & 3 & 4 & 5 & 33 & $\mathbf{0}$ & 0 & $\mathbf{0}$ & 0 & 8 & 12 \\
\hline 5. módszertanok & $\mathbf{0}$ & 0 & $\mathbf{0}$ & 0 & 13 & 57 & 12 & 100 & 25 & 38 \\
\hline
\end{tabular}

A Magyar Tannyelvü Tanítóképző Karon 2015-ben kezdődött meg az a felkészülés, melynek a végső célja a fenntartható egyetemek rendszerébe történő bekapcsolódás. Felismerve azt a tényt, hogy tanítóképző intézményként fontos szerepe van a Vajdaságban magyar nyelven tanító, leendő pedagógusok elméleti és praktikus tudásának kialakításában, egy tervezet kidolgozásába kezdtek, melynek alapvető célkitűzése feltárni azokat a lehetőségeket, amelyek megvalósítása által az intézmény hozzájárulhat a környezeti nevelés és a fenntarthatóság pedagógiájának terjesztéséhez a vajdasági pedagógusok körében.

Egy intézmény zöld egyetemmé válásához az intézmény egészének, az intézményvezetésnek, az egyetemen müködő munkaközösségeknek, az oktatóknak és az egyetemen dolgozó technikai munkatársaknak is a közös cél érdekében kell tevékenykedniük. Az intézmény minden területére kihatóan érvényesíteni kell a fenntarthatóság alapértékeit 
(Lozano et. al., 2013). Az Újvidéki Egyetem Magyar Tannyelvü Tanítóképző Kar a zöld egyetemmé válás folyamatát egy munkacsoport létrehozásával kezdte meg, amelynek első feladata a zöld egyetem munkatervének kialakítása volt.

A Fenntarthatóság munkacsoport további feladatai közé tartozik a következő feltételek biztosítása az egyetemen belül, az Oktatáskutató és Fejlesztő Intézet ajánlásai alapján (Könczey, Szabó és Varga, 2014):

(1) az intézmény humánpolitikájának megfelelő tervezése: továbbképzések, átképzések megfelelő szakemberek alkalmazása révén;

(2) programok szervezése komplex tanulásszervezési formában a fenntarthatóság témakörében;

(3) az intézmény müködésének (fütés, vízfelhasználás, villamosenergia használata) hosszútávú megreformálása, az iskola belső terének alakítása; kialakítása;

(4) szerbiai vagy magyarországi központi intézménnyel való együttmüködés

(5) hálózati tanulásban való együttmüködés a fenntarthatóságra nevelés terén;

(6) az intézmény munkájába bekapcsolni a helyi természeti, épített és más értékeket.

$\mathrm{Az}$ előkészületek első, pedagógiai szintjén az intézmény tantervének hatékonyságvizsgálata volt a cél. A kapott eredmények tükrében dolgozhatja ki a Fenntarthatóság munkacsoport a tantervi rendszer megreformálására, a tantárgyak és módszerek hatékonyságának növelésére vonatkozó terveket. A megfelelő tanterv kialakítása elsődleges lépés a fenntartható egyetemhez vezető úton (Cotton et al., 2007). 


\section{AZ EMPIRIKUS VIZSGÁLATOK ALAPJÁT KÉPEZŐ KÖRNYEZETI NEVELÉSI PROGRAM BEMUTATÁSA}

Az értekezésben bemutatott empirikus vizsgálat általános célja egy intenzív, élményt nyújtó környezeti nevelési program kidolgozása alsó tagozatos tanulók számára, tanítóképzős hallgatók bevonásával. A tervezés során fontos szempont volt a programnak a lehető legoptimálisabb idö- és költséghatékonysággal való beilleszthetősége a már meglévő tantervbe - az alsó tagozatos és az egyetemi tantervbe egyaránt -, a környezeti nevelés módszertani elveinek tiszteletben tartása mellett.

A program alkalmazásával igazolni szeretném, hogy megfelelő hozzáállással, a környezeti nevelés elméletének és gyakorlatának ismeretével, korszerü környezeti nevelési eszközökkel és megfelelő szintü tervezéssel megvalósítható olyan hatékony környezeti nevelés, amely elősegíti az alsó tagozatos tanulók és a tanítóképzős hallgatók környezeti attitüdjének, környezetkultúrájának együttes fejlesztését. Szeretném elérni, hogy a lehetőségek szintjén az Újvidéki Egyetem Magyar Tannyelvü Tanítóképző Karán tanuló leendő pedagógusok, valamint a Kar gyakorlóiskoláiban tanuló gyerekek bevonásával egy olyan programot hozzunk létre, amely hozzájárul ahhoz, hogy a környezetet ismerő, szerető, a környezet védelme érdekében tenni akaró és tudó felnőtteket neveljünk.

A vizsgálatsorozat módszertani célkitüzése a fent meghatározott célokhoz kapcsolódóan a következö: olyan intenzív, élményt nyújtó környezeti nevelési program létrehozása, amely egyaránt hozzájárul a program kialakításában résztvevő tanítóképzős hallgatók, valamint a program résztvevőinek, az alsó tagozatos tanulóknak a környezeti neveléséhez, a megfelelö viselkedéskultúra, környezetorientált magatartás, környezetért felelős életvitel kialakításához, biztosítva a fenntarthatóság pedagógiájának és a környezeti nevelésnek a hatékony megvalósulását.

\subsection{A tanítóképzős hallgatók részére kidolgozott tantárgy bemutatása}

A környezeti nevelési program kidolgozására a 2012/2013-as tanév első félévében, a Környezeti nevelési program szervezése, megvalósítása tantárgy keretein belül került sor 14 tanítóképzős hallgató részvételével. A választható tantárgy kidolgozása és tantervbe illesztése a vizsgálat végrehajthatóságának céljából történt, kísérleti jelleggel. A tantárgy távlati céljai között szerepel, hogy a jövőben állandó jellegü tantárgyként folyamatosan segítse a tanítóképzős hallgatók környezeti nevelését, környezettudatos magatartását. A tantárgy azóta bekerült az Újvidéki Egyetem Magyar Tannyelvű Tanítóképző Kar Módszertani Tanszékének tantervébe, így megfelelő szakkáder vezetése mellett meghirdethetővé válhat a jövőben is.

A két féléves választható tantárgy kísérleti jelleggel a tanítóképző alapszakon került meghirdetésre, a 2012/2013-as tanévben:

A tantárgy további adatai:

Meghirdetés idöpontja: VII. és VIII. félév

Tervezett létszám: 15 fö

Heti óraszám: 1 előadás +1 gyakorlat

Az oktatási célja és a kurzus várható eredménye: olyan tanítók képzése, akik ismerik a környezeti nevelés, a fenntarthatóság alapfogalmait, alkalmasak az általános iskola 1-4. 
osztályában intézményen belüli és kívüli színtereken a korszerü környezeti nevelés elméletére épülő differenciált környezeti nevelési programok tervezésére, megvalósítására, értékelésére, a fenntarthatóság kultúrájának és a fenntartható életvitelnek az élményszerü, játékos alapozására és fejlesztésére, képesek a környezeti problémák felismerésére, kritikus elemzésére. A hallgatók ismerjék és alkalmazzák a fenntarthatóság alapelveit és eredménnyel neveljenek a környezettudatos magatartásra.

Az előadások tematikája: a fenntartható fejlődés fogalma, célkitüzése; A fenntartható fejlődés pedagógiája; A környezeti nevelés és a fenntartható fejlődés kapcsolata; A környezeti nevelés fogalma; A környezeti nevelés alapelvei, jellemzői; A környezeti nevelés helye a tudományok és a tantárgyak rendszerében; A környezeti nevelés célrendszere, feladatai az általános iskola 2-4. osztályában; A környezeti nevelés tartalmi modellje; A nevelési gyakorlat megújulása a környezeti nevelés által; A kisiskolások életkori sajátosságai és a környezeti nevelés; A környezeti nevelés módszerei; Oktatás- és információs technológia a környezeti nevelésben és oktatásban; A környezeti nevelés színterei; A környezeti nevelés értékelése; Globális környezetvédelmi problémák.

A gyakorlatok tartalma: környezeti nevelési program tervezése, megvalósítása, értékelése az általános iskola 2-4. osztályában. Különböző környezeti tartalmú tevékenységek szervezése iskolán belüli (tanórákon, előadások, versenyek, kiállítások szervezése) és iskolán kívüli (állatkerti séták, erdei kirándulások, múzeumlátogatások szervezése) színtereken.

A tantárgy első félévében a környezeti nevelési program kidolgozása történt meg. Az elméleti előadások, valamint a program elkészítésének ütemterve, vagyis a tantárgy gyakorlati részének végrehajtása az alábbiakban bemutatott modulokon keresztül valósult meg.

\section{1. modul}

- Elmélet: Bevezető, a kurzus ismertetése, feladatok, követelmények megbeszélése

- Gyakorlat: Csoportok kialakítása, ötletbörze a programmal kapcsolatban, tervek összehangolása, további tevékenységek ütemének megbeszélése

\section{2. modul}

- Elmélet: Globális környezeti problémák - elöadás (1. melléklet)

- Gyakorlat: Projektfeladatok megtervezése (konkrét feladatok kigondolása, a végrehajtás és az ellenőrzés menetének megtervezése, a várható eredmények megfogalmazása)

\section{3. modul}

- Elmélet: Fenntartható fejlődés a természetközeliségtől az információs társadalomig előadás (2. melléklet)

- Gyakorlat: Állatkerti látogatások megtervezése (időpontok, tematika)

\section{4. modul}

- Elmélet: A fenntartható fejlődés fogalma és pedagógiája - előadás (3. melléklet)

- Gyakorlat: Az elkészült óravázlatok elemzése, megbeszélése

\section{5. modul}

- Elmélet: A környezeti nevelés alapjai - előadás (4. melléklet)

- Gyakorlat: A kiállítás témájának, részleteinek megbeszélése 


\section{6. modul}

- Elmélet: A környezeti nevelés pedagógiája - előadás (5. melléklet)

- Gyakorlat: Az előadások témájának megbeszélése, az elöadásokra készült prezentációk elemzése

\section{7. modul}

- Elmélet: A környezeti nevelés a gyakorlatban - elöadás (6. melléklet)

- Gyakorlat: A környezetvédelmi nap részleteinek kidolgozása (szlogen, szórólapok,

8. modul plakátok, programok, egyéb részletek megbeszélése)

- Elmélet: Zoopedagógia a környezeti nevelés szolgálatában - előadás (7. melléklet)

- Gyakorlat: A kimaradt feladatok pótlása, a kész terv összefoglalása

A második félévben került sor magának a kéthetes programnak a megvalósítására, a tanítóképzős hallgatók esetében tömbösített tanórák keretein belül.

\subsection{Az alsó tagozatos hallgatók részére kidolgozott, intenzív környezeti nevelési program bemutatása}

A kéthetes, intenzív környezeti nevelési program 11 alsó tagozatos osztályban zajlott, 14 tanítóképzős hallgató részvételével. Három témakör került feldolgozásra, a tanítóképzősök így három csoportot alkotva teljesítették a megtervezett tevékenységeket:

- a második osztályokban a VíZ,

- a harmadik osztályokban a HULLADÉK,

- a negyedik osztályokban az ENERGIA témakörével foglalkoztak.

A három témakör (víz, hulladék, energia) kiválasztása az alsó tagozatos tanterv jellegéből adódott. Az állatok és a növények témáját széleskörüen tárgyalják az alsó osztályokban, ugyanakkor a víz témáját a vízvédelem szempontjából, a hulladék kérdését, vagy az energiát nem érintik megfelelö mértékben. A vízvédelem témakörén belül ugyanakkor feldolgozásra kerülhetnek olyan további témák is, mint az élettelen természet elemei, az elemek kölcsönhatása, az élöhelyek és a biodiverzitás megörzésének fontossága. A hulladék témakörén belül beszélhetünk a túlfogyasztás kérdéséről, hulladékgazdálkodásról, egészséges életmódról. Az energia témakörén belül a tanulók megismerkedhetnek az energia fogalmával, felhasználásának módjával, a megújuló és nem megújuló energiaforrások közötti különbségekkel, valamint az energiatakarékos életmód alapjaival. Ezen témakörök érintésével a környezeti nevelés alapvető ismerettartalmának széles körét lefedhetjük.

Az egyes modulokat a tanulók életkori sajátosságai alapján osztottuk fel az osztályok között. A másodikosok a víz témakörét kapták, a harmadikosok a hulladék témakörét, a negyedikesek pedig az energiáét, amelynek fogalmát és mibenlétét a legidősebb korosztály már megértheti. Amennyiben pedig a program rendszeresen, évröl-évre megrendezésre kerül, a tanulók mindhárom témakörről tanulhatnak a felsőbb osztályok felé haladva, megismerve ezáltal a környezeti nevelési tartalmak szélesebb körét.

A program megrendezésének két hete során minden tanítási napon igyekeztük megvalósítani a program legalább egy-egy elemét, ezáltal biztosítva a program intenzivitását. Az egyes programelemek a környezeti nevelés módszertani elveinek megfelelően iskolai 
helyszíneken, tanórák, illetve tanórán kívüli tevékenységek keretein belül, valamint iskolán kívüli helyszíneken, állatkerti látogatások során, illetve a Tanítóképző Karon megrendezett, „,Megérkezett a tavasz, vigyázzunk környezetünkre!” elnevezésű rendezvényen valósultak meg.

A tanórákat illetően a Környezetünk (2. osztály), illetve a Természet és társadalom (3. és 4. osztály) órák mellett igyekeztünk beépíteni a környezeti nevelési tartalmakat más jellegü tantárgyak, így a Képzőmüvészet és a Zenei nevelés tantárgyak tartalmába is.

A tanítási órákon kívül az adott témakörhöz kapcsolódó előadások, illetve projektmunkák keretein belül valósult meg a környezeti nevelési program.

Az iskolán kívüli tevékenységek közül a városi séta (hulladékgyüjtési projekt) és az állatkerti látogatás volt az egyik program, amelynek keretein belül igyekeztünk átadni a környezeti nevelési tartalmakat. Másik iskolán kívüli tevékenység az a kiállítás volt, melyet a gyerekeknek a két hét során készített munkáiból rendeztünk a Magyar Tannyelvü Tanítóképző Kar épületében. Ugyancsak a tanítóképzőben került megrendezésre a kéthetes program lezárását képező környezetvédelmi nap, amely a „Megérkezett a tavasz, vigyázzunk környezetünkre!" nevet kapta. A rendezvény során különféle, a környezetvédelem témaköréhez kapcsolódó foglalkozásokkal, vetélkedőkkel, játékokkal várták a tanítóképzősök a programban részt vevő gyerekeket.

A kéthetes, intenzív környezeti nevelési programról az Újvidéken megjelenő, Vajdaság egész területén olvasott diáklap, a Jó Pajtás is tudósított (25. melléklet).

\subsubsection{A víz témakörében kidolgozott programelemek}

A víz témakörében (2. osztályok) a két hét során két Környezetünk, két Képzőmüvészet, és egy Zenei nevelés óra során dolgoztuk fel a kapcsolódó tartalmakat. A tanórán kívüli tevékenységek három előadás, egy az iskolában megrendezett kiállítás, valamint egy kéthetes projekt keretein belül zajlottak. Az iskolán kívüli foglalkozások egy állatkerti látogatás, valamint az Újvidéki Egyetem Magyar Tannyelvü Tanítóképző Karán megrendezett képzőmüvészeti kiállítás, és a „Megérkezett a tavasz, vigyázzunk környezetünkre!" elnevezésű rendezvény során valósultak meg (7. és 8. táblázat).

\begin{tabular}{|c|c|c|c|c|c|}
\hline \multicolumn{6}{|c|}{ 7. táblázat: A „víz” program részletes ütemterve, 1 . hét } \\
\hline \multirow{7}{*}{ 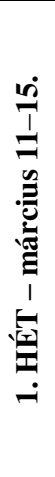 } & HÉTFŐ & KEDD & SZERDA & CSÜTÖRTÖK & PÉNTEK \\
\hline & $\begin{array}{l}\text { ÁLLATKERT, } \\
\text { 2/a, 2/c, } 2 / \mathrm{d} \\
\end{array}$ & & & & \\
\hline & $\begin{array}{c}\text { A projekt } \\
\text { indítása, } 2 / \mathrm{c}, 2 / \mathrm{d}\end{array}$ & \multirow{2}{*}{$\begin{array}{l}\text { Képzőművészet: } \\
\text { Vízvédelem, 2/a }\end{array}$} & $\begin{array}{l}\text { Környezetünk: A víz } \\
\text { tulajdonságai, 2/c }\end{array}$ & $\begin{array}{l}\text { Környezetünk.: A víz } \\
\text { tulajdonságai, 2/a }\end{array}$ & \\
\hline & & & $\begin{array}{l}\text { Környezetünk: A víz } \\
\text { tulajdonságai, 2/d }\end{array}$ & \multirow{2}{*}{$\begin{array}{l}\text { Képzőmüvészet: } \\
\text { Vízvédelem, } 2 / \mathrm{c}\end{array}$} & $\begin{array}{c}\text { Zene: Ess eső, ess, } \\
2 / \mathrm{a}\end{array}$ \\
\hline & $\begin{array}{c}\text { A projekt } \\
\text { indítása, } 2 / \mathrm{a}\end{array}$ & Elöadás: Víz, 2/a & & & \\
\hline & & & & \multirow{2}{*}{$\begin{array}{l}\text { Képzőmüvészet: } \\
\text { Vízvédelem, 2/d }\end{array}$} & $\begin{array}{c}\text { Zene: Ess esö, ess, } \\
2 / \mathrm{c} \\
\end{array}$ \\
\hline & & $\begin{array}{c}\text { Elöadás: Víz, } 2 / \mathrm{c}, \\
\text { 2/d }\end{array}$ & & & $\begin{array}{c}\text { Zene: Ess esö, ess, } \\
2 / \mathrm{d}\end{array}$ \\
\hline
\end{tabular}




\begin{tabular}{|c|c|c|c|c|c|c|c|}
\hline \multicolumn{8}{|c|}{ 8. táblázat: A „víz” program részletes ütemterve, 2. hét } \\
\hline \multirow{5}{*}{ 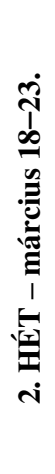 } & HÉTFÖ & KEDD & SZERDA & CSÜTÖR. & & EK & SZOM. \\
\hline & $\begin{array}{l}\text { Előadás: Vizeink } \\
\text { védelme, 2/a }\end{array}$ & $\begin{array}{l}\text { Vinkó Tamás } \\
\text { előadása, } 2 / \mathrm{a}\end{array}$ & $\begin{array}{c}\text { Környezetünk: } \\
\text { Vizek élővilága, } \\
\text { 2/a }\end{array}$ & $\begin{array}{l}\text { Képzőmüv.: } \\
\text { Jégsapkák } \\
\text { olvadása, 2/a }\end{array}$ & \multirow{2}{*}{$\begin{array}{l}\text { Képzőm.: } \\
\text { Jégsapkák } \\
\text { olvadása, } \\
\text { 2/c }\end{array}$} & \multirow{2}{*}{$\begin{array}{l}\text { Képzőm.: } \\
\text { Jégsapkák } \\
\text { olvadása, } \\
\text { 2/d }\end{array}$} & \multirow{4}{*}{ 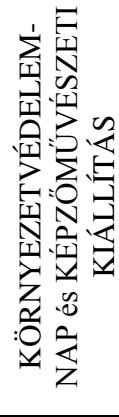 } \\
\hline & & & & $\begin{array}{c}\text { Projekt zárása, } \\
\text { 2/a } \\
\end{array}$ & & & \\
\hline & $\begin{array}{l}\text { Elöadás: Vizeink } \\
\text { védelme, } 2 / \mathrm{c}, 2 / \mathrm{d}\end{array}$ & $\begin{array}{c}\text { Vinkó Tamás } \\
\text { előadása, } 2 / \mathrm{c} \text {, } \\
2 / \mathrm{d}\end{array}$ & $\begin{array}{c}\text { Környezetünk: } \\
\text { Vizek élővilága, } \\
2 / \mathrm{c}\end{array}$ & & \multirow{2}{*}{\multicolumn{2}{|c|}{$\begin{array}{l}\text { KIÁLLÍTÁS } 2 . \\
\text { OSZTÁLYOK: ÓVJUK } \\
\text { VIZEINKET! }\end{array}$}} & \\
\hline & & & $\begin{array}{l}\text { Környezetünk: } \\
\text { Vizek élővilága, } \\
\text { 2/d }\end{array}$ & $\begin{array}{c}\text { Projekt zárása, } \\
\text { 2/c, } 2 / \mathrm{d}\end{array}$ & & & \\
\hline
\end{tabular}

\section{Tanórai tevékenységek a víz témakörében}

A tantárgyakban megvalósított tananyagtartalmak a víz témakörén belül (9. táblázat):

1. tanítási óra: Környezetünk. Tanítási egység: A víz tulajdonságai (8. melléklet)

2. tanítási óra: Környezetünk. Tanítási egység: A vizek élővilága, és a benne élö állatok veszélyeztetettsége (9. melléklet)

3. tanítási óra: Képzömüvészet. Tanítási egység: Vízszennyezés, vízvédelem (plakátkészítés) (10. melléklet)

4. tanítási óra: Képzömüvészet. Tanítási egység: Jégsapkák olvadása (hideg és meleg színek alkalmazása) (11. melléklet)

5. tanítási óra: Zenei nevelés. Tanítási egység: Ess eső, ess (daltanulás) (12. melléklet)

\section{Tanórán kívüli tevékenységek a víz témakörében}

A tanórán kívüli tevékenységek során megvalósított tartalmak a víz témakörén belül:

1. előadás: $A$ víz. Tárgyalt tartalmak:

- a víz világnapja;

- a víz jeletösége;

- a víz elöfordulása a földön;

- ivóvíz;

- vízkészleteink;

- vízszennyezés;

- vízvédelem;

- takarékoskodás a vízzel.

2. előadás: Környezetvédelem, vizeink védelme (filmvetítés, beszélgetés a videókban látottakról). Tárgyalt tartalmak:

- klímaváltozás, globális felmelegedés (videó forrása: http://bit.ly/2s76kZm)

- az emberi tevékenység környezetkárositó hatása (videó forrása: http://bit.ly/2tqT5Gq)

- fogyasztás, hulladék, újrahasznositás, vízszennyezés, víztisztítás, hogyan óvhatod környezetedet? (videó forrása: http://bit.ly/2srlY1g) 
3. előadás: A Palicsi-tó élővilága (vendégelőadó: Vinkó Tamás környezetkutató). Vendégünk a Palicsi-tóról ${ }^{1}$ tartott előadást, a tó környékén élő növényvilágról, állatvilágról valamint a tó szennyezéséről, a szennyezés ártalmairól, és a szennyezés hatásáról az állat és növényvilágra nézve. Az előadás témakörei:

- A Palicsi-tó állat és növényvilága

- Mi szennyezi a Palicsi tavat?

- Mely állatok és növények vannak a legnagyobb veszélyben?

- Melyek a Palicsi-tó legkülönlegesebb állatai és növényei amelyek máshol nem nagy csak ritkán találhatók?

- Hogyan tudnánk megakadályozni a Palicsi-tó további szennyezését?

- Miért kell megóvni a Palicsi tavat?

- Milyen hasznuk származhat a tanulóknak a tó meglétéből?

- Hogyan tudnák a diákok is javítani a Palicsi-tó minőségén (mit tehetnek a tanulók)?

4. kiállítás: Óvjuk vizeinket (a 2. osztályos tanulók alkotásainak kiállítása): a program során készült alkotásokat a tanulók kiállították iskolájukban. A kiállítás formabontó volt, ugyanis egy beszélgetéssel egybekötött bemutató során valósult meg. A tanulók elmondták a többi osztály tagjainak, mi volt a témájuk, és miért a vízzel foglalkoztak. Ezt követően minden tanuló bemutatta a saját alkotását, és beszélt arról is, hogy ő hogyan óvná a vizet a szennyezéstől és a pazarlástól (13. melléklet).

5. projekt: Takarékoskodjunk a vízzel! A projekt lényege, hogy a tanulók két héten keresztuil megfigyelik és feljegyzik, milyen mennyiségü víz veszik kárba a szándékosan, vagy meghibásodás folytán csöpögő csapokból az iskolában (14. melléklet).

\section{Iskolán kívüli tevékenységek a víz témakörében}

Az iskolán kívüli tevékenységek során megvalósított tartalmak a víz témakörén belül:

1. program: Állatkerti látogatás - A kirándulás során a programban résztvevő tanítóképzős hallgatók és alsó tagozatos tanulók meglátogatták a Palicsi Állatkertet.

2. program: Kiállitás - A program során készült összes képzőművészeti alkotás bemutatása a Magyar Tannyelvü Tanítóképző Kar épületében (15. melléklet)

3. program: „Megérkezett a tavasz, vigyázzunk környezetünkre!” - A kéthetes program környezetvédelem-nap keretein belül zárult a Magyar Tannyelvü Tanítóképző Karon. A programban résztvevő tanítóképzős hallgatók vetélkedőkkel, játékokkal, érdekes programokkal várták az intézménybe ellátogató diákokat (16. melléklet).

\footnotetext{
${ }^{1}$ A Palicsi-tó egy természetes tó Szerbiában, amely Szabadkától 8 km-re terül el Palics településen. Palics másik nevezetes, a tanulók által gyakran látogatott kirándulóhelye az állatkert.
} 
9. táblázat: A tantárgyakban megvalósitott módszertani elemek a víz témaköréhez kapcsolódóan

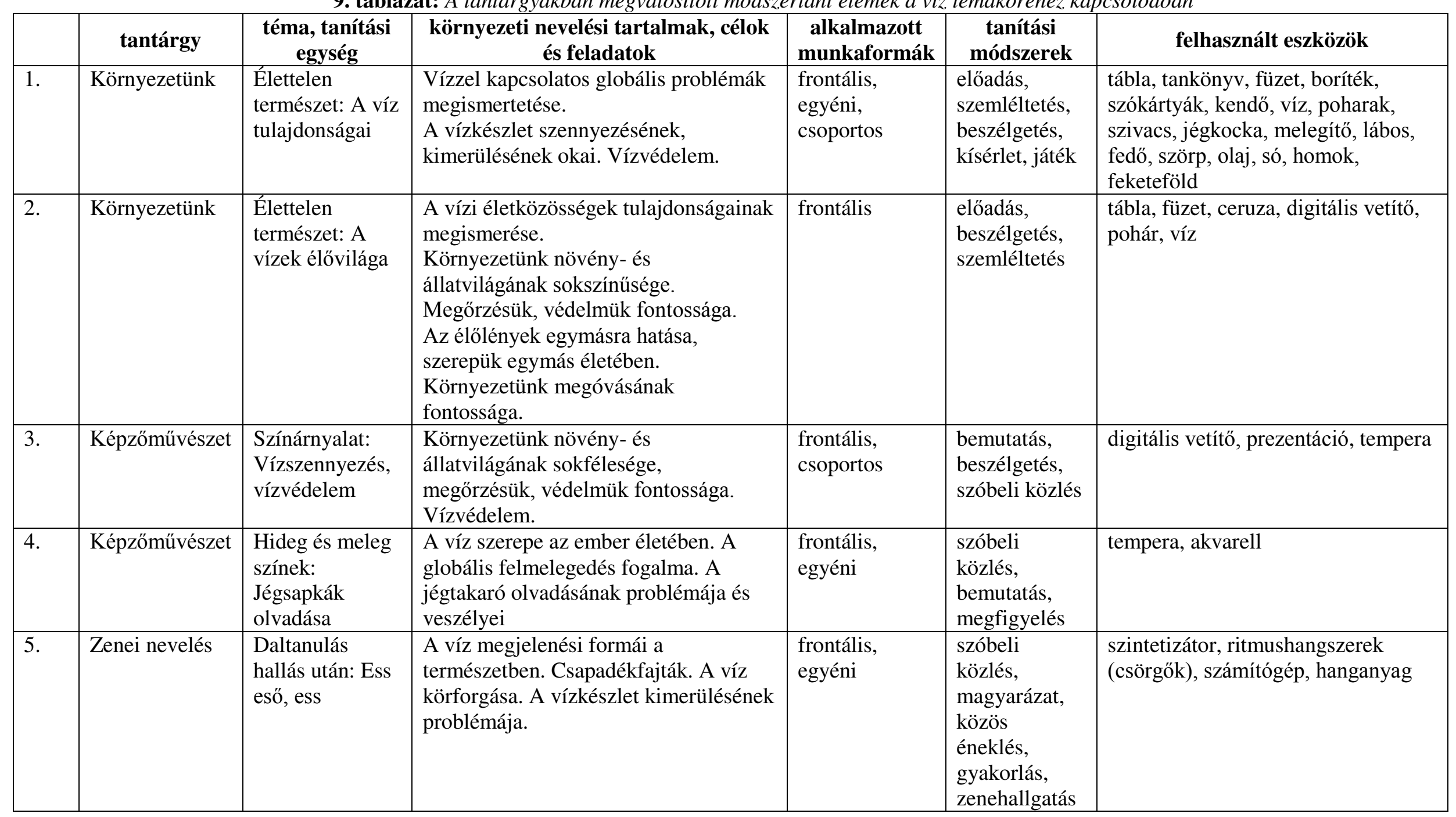




\subsubsection{A hulladék témakörében kidolgozott programelemek}

A hulladék témakörében (3. osztályok) a két hét során két Természet és társadalom, egy Képzőművészet, és egy Zenei nevelés óra során dolgoztuk fel a kapcsolódó tartalmakat. A tanórán kívüli tevékenységek három előadás, valamint egy kéthetes projekt keretein belül zajlottak. Az iskolán kívüli foglalkozások az állatkerti látogatás, egy hulladékgyüjtési akció, valamint a már említett, az MTTK épületében megrendezett környezetvédelem-nap során valósultak meg (10. és 11. táblázat).

\begin{tabular}{|c|c|c|c|c|c|}
\hline \multicolumn{6}{|c|}{ 10. táblázat: $\mathrm{A}$ „,hulladék” program részletes ütemterve, 1 . hét } \\
\hline \multirow{8}{*}{ 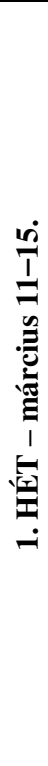 } & HÉTFŐ & KEDD & SZERDA & CSÜTÖRTÖK & PÉNTEK \\
\hline & $\begin{array}{c}\text { Természet és } \\
\text { társadalom: } \\
\text { Környezetvéd., 3/c }\end{array}$ & & \multirow{3}{*}{$\begin{array}{l}\text { ÁLLATKERT, } \\
\text { 3/a, 3/b, 3/c, 3/d }\end{array}$} & $\begin{array}{c}\text { Természet és } \\
\text { társadalom: Anyagok } \\
\text { újrahasznosítása, 3/c }\end{array}$ & \\
\hline & $\begin{array}{c}\text { Természet és } \\
\text { társadalom: } \\
\text { Környezetvéd., 3/d }\end{array}$ & $\begin{array}{l}\text { Előadás: Szelektív } \\
\text { hulladékgyüjt., 2/c, } \\
\text { 3/d }\end{array}$ & & $\begin{array}{c}\text { Természet és } \\
\text { társadalom: Anyagok } \\
\text { újrahasznosítása, 3/d }\end{array}$ & $\begin{array}{c}\text { Előadás: } \\
\text { Érdekességek- } \\
\text { hulladék, 3/c, 3/d }\end{array}$ \\
\hline & $\begin{array}{c}\text { Projekt indítása, } \\
3 / \mathrm{c}, 3 / \mathrm{d}\end{array}$ & & & & \\
\hline & $\begin{array}{c}\text { Természet és } \\
\text { társadalom: } \\
\text { Környezetvéd., 3/b }\end{array}$ & & & & \\
\hline & $\begin{array}{c}\text { Természet és } \\
\text { társadalom: } \\
\text { Környezetvéd., 3/a }\end{array}$ & & & & $\begin{array}{c}\text { Előadás: } \\
\text { Érdekességek- } \\
\text { hulladék, 3/a, 3/b }\end{array}$ \\
\hline & $\begin{array}{c}\text { Projekt indítása, } \\
\text { 3/a, 3/b }\end{array}$ & $\begin{array}{l}\text { Előadás: Szelektív } \\
\text { hulladékgyüjt., 3/a, } \\
3 / \mathrm{b}\end{array}$ & & $\begin{array}{c}\text { Természet és } \\
\text { társadalom: Anyagok } \\
\text { újrahasznosítása, 3/a }\end{array}$ & \\
\hline & & & & $\begin{array}{l}\text { Természet és } \\
\text { társadalom: Anyagok } \\
\text { újrahasznosítása, 3/b }\end{array}$ & \\
\hline
\end{tabular}

\begin{tabular}{|c|c|c|c|c|c|c|}
\hline \multicolumn{7}{|c|}{ 11. táblázat: $\mathrm{A}$ „,hulladék” program részletes ütemterve, 2. hét } \\
\hline \multirow{8}{*}{$\begin{array}{l}\stackrel{1}{0} \\
\stackrel{\infty}{=} \\
\stackrel{0}{ٍ}\end{array}$} & HÉTFÖ & KEDD & SZERDA & CSÜT. & PÉNTEK & SZOMB. \\
\hline & $\begin{array}{c}\text { Előadás: A } \\
\text { hulladék útja, } \\
\text { 3/c, 3/d }\end{array}$ & \multirow{2}{*}{$\begin{array}{l}\text { Hulladékgyűjtési } \\
\text { projekt: } \\
\text { Környékünk } \\
\text { tisztasága 3/c, 3/d }\end{array}$} & & $\begin{array}{l}\text { Projekt zárása, } \\
\text { 3/c, 3/d }\end{array}$ & $\begin{array}{l}\text { Zene: Hulladék- } \\
\text { hangszerek, } 2 / \mathrm{c}\end{array}$ & \multirow{7}{*}{ 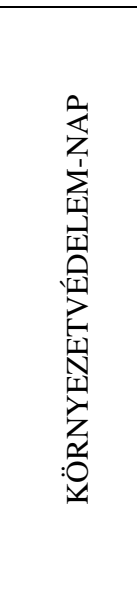 } \\
\hline & & & & $\begin{array}{l}\text { Képzőmüv.: } \\
\text { A hulladék életre }\end{array}$ & $\begin{array}{l}\text { Zene: Hulladék- } \\
\text { hangszerek, 2/d }\end{array}$ & \\
\hline & & & $\begin{array}{c}\text { Képzőmüv.: } \\
\text { A hulladék életre }\end{array}$ & $\begin{array}{c}\mathrm{kel} / \text { hangszerek } \\
2 / \mathrm{d}\end{array}$ & & \\
\hline & & & $\begin{array}{c}\mathrm{kel} / \mathrm{hangszerek} \\
2 / \mathrm{c} \\
\end{array}$ & & & \\
\hline & $\begin{array}{c}\text { Előadás: A } \\
\text { hulladék útja, } \\
3 / \mathrm{a}, 3 / \mathrm{b}\end{array}$ & & & $\begin{array}{c}\text { Projekt zárása, } \\
\text { 3/a, 3/b }\end{array}$ & & \\
\hline & & \multirow{2}{*}{$\begin{array}{c}\text { Hulladékgyüjtési } \\
\text { projekt: } \\
\text { Környékünk } \\
\text { tisztasága 3/a, 3/b }\end{array}$} & \multirow{2}{*}{$\begin{array}{c}\text { Képzőműv.: } \\
\text { A hulladék életre } \\
\text { kel/hangszerek } \\
\text { 2/a }\end{array}$} & \multirow{2}{*}{$\begin{array}{c}\text { Képzőmüv.: } \\
\text { A hulladék életre } \\
\text { kel/hangszerek } \\
\text { 2/b }\end{array}$} & $\begin{array}{l}\text { Zene: Hulladék- } \\
\text { hangszerek, 2/a }\end{array}$ & \\
\hline & & & & & $\begin{array}{l}\text { Zene: Hulladék- } \\
\text { hangszerek, } 2 / b\end{array}$ & \\
\hline
\end{tabular}




\section{Tanórai tevékenységek a hulladék témakörében}

A tantárgyakban megvalósított tananyagtartalmak a hulladék témakörén belül ( 12 . táblázat):

1. tanítási óra: Természet és társadalom. Tanítási egység: Környezetvédelem a mindennapokban (17. melléklet)

2. tanítási óra: Természet és társadalom. Tanítási egység: Az anyagok újrahasznosítása (18. melléklet)

3. tanítási óra: Képzömüvészet. Tanítási egység: A hulladék életre kel (19. melléklet)

4. tanítási óra: Zenei nevelés. Tanítási egység: Hulladékhangszerek (20. melléklet)

\section{Tanórán kívüli tevékenységek a hulladék témakörében}

A tanórán kívüli tevékenységek során megvalósított tartalmak a hulladék témakörén belül:

1. elöadás: Szelektiv hulladékgyüjtés. Tárgyalt tartalmak:

- Melyik szelektív hulladékgyüjtö melyik anyag gyüjtésére alkalmas?

- Mit tekintünk papírhulladéknak?

- Hogyan kell elhelyezni a papírhulladékot a szelektív gyüjtőben?

- Mit nevezünk müanyag hulladéknak?

- Hogyan kell elhelyezni a müanyag hulladékot a szelektív gyüjtőben?

- Mit nevezünk üveghulladéknak?

- Hogyan kell elhelyezni az üveghulladékot a szelektív gyüjtöben?

2. előadás: Interaktív elöadás a hulladékfeldolgozással kapcsolatban: a szabadkai Regionális Hulladéktároló Kft. által készített videó megtekintése (forrás: http://bit.ly/2tbxC24), a hulladéktároló munkájának bemutatása, beszélgetés a hallottakról.

3. előadás: A hulladék útja. Tárgyalt tartalmak:

- Különbségek a szemét és a hulladék között;

- Hulladékfajták;

- A szemét útvonala az otthoni kukából a szeméttelepig;

- A hulladék útvonala az otthoni gyüjtötöl a szelektív hulladékfeldolgozóig;

- Milyen termékek készülhetnek az újrahasznosított hulladékból?

- Korszerü hulladékgazdálkodás.

4. projekt: Hulladékgyüjtési, újrahasznosítási akció. A tanulók müanyagpalackokat, kupakokat, használt elemeket gyüjtöttek a projekt időszaka alatt. Az összegyüjtött hulladékok újrahasznosítása érdekében Képzőmüvészet órán hulladékhagszereket készítettek, amelyeket a Zenei nevelés óra alkalmával meg is szólaltattak. 
12. táblázat: A tantárgyakban megvalósitott módszertani elemek a hulladék témaköréhez kapcsolódóan

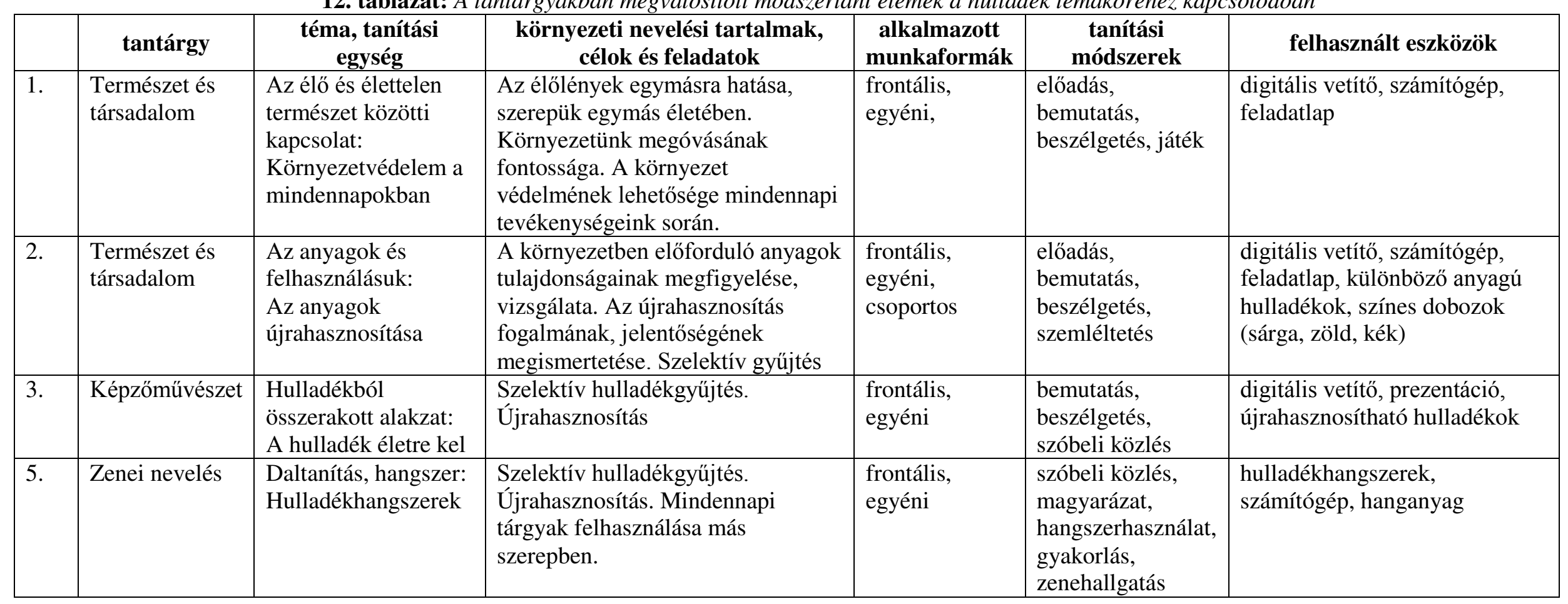




\section{Iskolán kívüli tevékenységek a hulladék témakörében}

Az iskolán kívüli tevékenységek során megvalósított tartalmak a hulladék témakörén belül:

1. program: Állatkerti látogatás - Látogatás a Palicsi Állatkertben.

2. program: Környékünk tisztasága (hulladékgyüjtési akció). A programban résztvevő tanulók a hallgatókkal együtt két iskolai órát felölelő hulladékgyüjtési akciót szerveztek iskolájuk környékének megtisztítása érdekében.

3. program: Megérkezett a tavasz, vigyázzunk környezetünkre! - A kéthetes program környezetvédelem-nap keretein belül zárult a Magyar Tannyelvü Tanítóképző Karon (16. melléklet).

\subsubsection{Az energia témakörében kidolgozott programelemek}

Az energia témakörében (4. osztályok) a két hét folyamán egy Természet és társadalom, és két Képzőmüvészet óra alkalmával dolgoztuk fel a tanórai tartalmakat. A tanórán kívüli tevékenységek három előadás, valamint egy kéthetes projekt során valósultak meg. Az iskolán kívüli foglalkozások egy állatkerti látogatás, valamint az Újvidéki Egyetem Magyar Tannyelvü Tanítóképző Karán megrendezett képzőművészeti kiállítás, és a „Megérkezett a tavasz, vigyázzunk környezetünkre!” elnevezésü rendezvény keretein belül zajlottak (13. és 14. táblázat).

\begin{tabular}{|c|c|c|c|c|c|}
\hline \multicolumn{6}{|c|}{ 13. táblázat: $\mathrm{Az}$ „energia” program részletes ütemterve, 1 . hét } \\
\hline \multirow{8}{*}{ 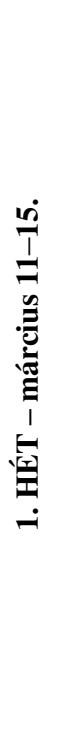 } & HÉTFÖ & KEDD & SZERDA & CSÜTÖRTÖK & PÉNTEK \\
\hline & \multirow{3}{*}{$\begin{array}{l}\text { ÁLLATKERT, 4/a, } \\
\text { 4/b, 4/c, 4/d }\end{array}$} & $\begin{array}{c}\text { Projekt indítása } \\
4 / \mathrm{a}, 4 / \mathrm{b}\end{array}$ & & & \\
\hline & & & & \multirow{2}{*}{$\begin{array}{c}\text { Képzőmủvészet: } \\
\text { Takarékos és pazarló } \\
\text { háztartás - plakát, 4/a, 4/b }\end{array}$} & $\begin{array}{c}\text { Természet és } \\
\text { társadalom: } \\
\text { Energiaforrások, 4/c }\end{array}$ \\
\hline & & & & & $\begin{array}{l}\text { Természet és } \\
\text { társadalom: } \\
\text { Energiaforrások, 4/d } \\
\end{array}$ \\
\hline & & & $\begin{array}{c}\text { Elöadás: Mi az } \\
\text { energia? } \\
\text { 4/a, 4/b } \\
\end{array}$ & & $\begin{array}{l}\text { Természet és } \\
\text { társadalom: } \\
\text { Energiaforrások, 4/a }\end{array}$ \\
\hline & & & & & $\begin{array}{c}\text { Természet és } \\
\text { társadalom: } \\
\text { Energiaforrások, 4/b }\end{array}$ \\
\hline & & $\begin{array}{c}\text { Projekt indítása } \\
4 / \mathrm{c}, 4 / \mathrm{d}\end{array}$ & $\begin{array}{c}\text { Elöadás: Mi az } \\
\text { energia? } \\
\text { 4/c, } 4 / \mathrm{d}\end{array}$ & \multirow{2}{*}{$\begin{array}{c}\text { Képzőművészet: } \\
\text { Takarékos és pazarló } \\
\text { háztartás - plakát, 4/c, 4/d }\end{array}$} & \\
\hline & & & & & \\
\hline
\end{tabular}




\begin{tabular}{|c|c|c|c|c|c|c|}
\hline \multicolumn{7}{|c|}{ 14. táblázat: $\mathrm{Az}$ „energia” program részletes ütemterve, 2 . hét } \\
\hline \multirow{7}{*}{ 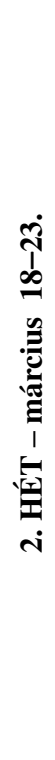 } & HÉTFÖ & KEDD & SZERDA & CSÜTÖRTÖK & PÉNTEK & SZOMB. \\
\hline & & $\begin{array}{l}\text { Képzőmüvészet: } \\
\text { Energiaforrások- } \\
\text { szélkerék, 4/b }\end{array}$ & $\begin{array}{c}\text { Előadás: } \\
\text { Megújuló } \\
\text { energiaforrások } \\
\text { (filmvetítés) 4/a,4/b }\end{array}$ & & \multirow{6}{*}{ 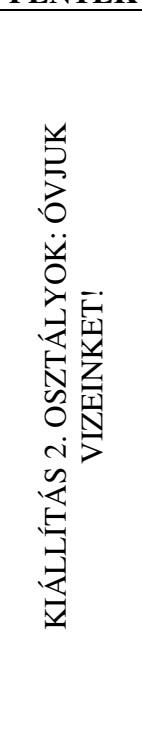 } & \multirow{6}{*}{ 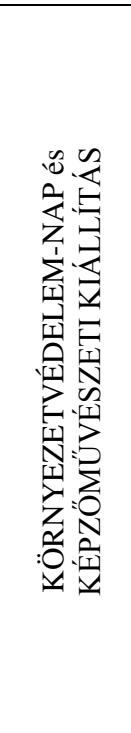 } \\
\hline & $\begin{array}{c}\text { Előadás: } \\
\text { Energiaforrások } \\
\text { 4/a, 4/b } \\
\end{array}$ & & & & & \\
\hline & & $\begin{array}{l}\text { Képzőművészet: } \\
\text { Energiaforrások- } \\
\text { szélkerék, 4/a }\end{array}$ & & $\begin{array}{l}\text { Projekt zárása } \\
\text { 4/a, 4/b }\end{array}$ & & \\
\hline & & $\begin{array}{l}\text { Képzőművészet: } \\
\text { Energiaforrások- } \\
\text { szélkerék, 4/c }\end{array}$ & $\begin{array}{c}\text { Előadás: } \\
\text { Megújuló } \\
\text { energiaforrások } \\
\text { (filmvetítés) } 4 / c, 4 / d\end{array}$ & & & \\
\hline & & \multirow{2}{*}{$\begin{array}{l}\text { Képzőművészet: } \\
\text { Energiaforrások- } \\
\text { szélkerék, 4/d }\end{array}$} & & $\begin{array}{c}\text { Projekt zárása } \\
4 / \mathrm{c}, 4 / \mathrm{d}\end{array}$ & & \\
\hline & $\begin{array}{c}\text { Előadás: } \\
\text { Energiaforrások } \\
4 / \mathrm{c}, 4 / \mathrm{d}\end{array}$ & & & & & \\
\hline
\end{tabular}

\section{Tanórai tevékenységek az energia témakörében}

A tantárgyakban megvalósított tananyagtartalmak az energia témakörén belül ( 15 . táblázat):

1. tanítási óra: Természet és társadalom. Tanítási egység: Energiaforrások (21. melléklet)

2. tanítási óra: Képzőmüvészet. Tanítási egység: Energiatakarékos és energiapazarló háztartás (plakátkészítés) (22. melléklet)

3. tanítási óra: Képzömüvészet. Tanítási egység: Energiaforrások, szélkerék készítése (24. melléklet)

\section{Tanórán kívüli tevékenységek az energia témakörében}

A tanórán kívüli tevékenységek során megvalósított tartalmak az energia témakörén belül:

1. előadás: $M i$ az energia? Tárgyalt tartalmak:

- Körülöttünk mindenhol energia: evés, alvás, légzés, mozgás, hütés, fütés...;

- Minden energiával müködik: az élölények energiaszükséglete;

- Energia földben, vízben, levegöben;

- Mesterséges energia: mi mindenhez használunk elektromos áramot?

2. előadás: Energiaforrások. Tárgyalt tartalmak:

- Az energiaforrások fogalma, típusai;

- Nem megújuló energiaforrások: szén, kőolaj, földgáz;

- Megújuló energiaforrások: nap-, szél-, vízenergia, geotermikus energia, atomenergia. 
15. táblázat: A tantárgyakban megvalósított módszertani elemek az energia témaköréhez kapcsolódóan

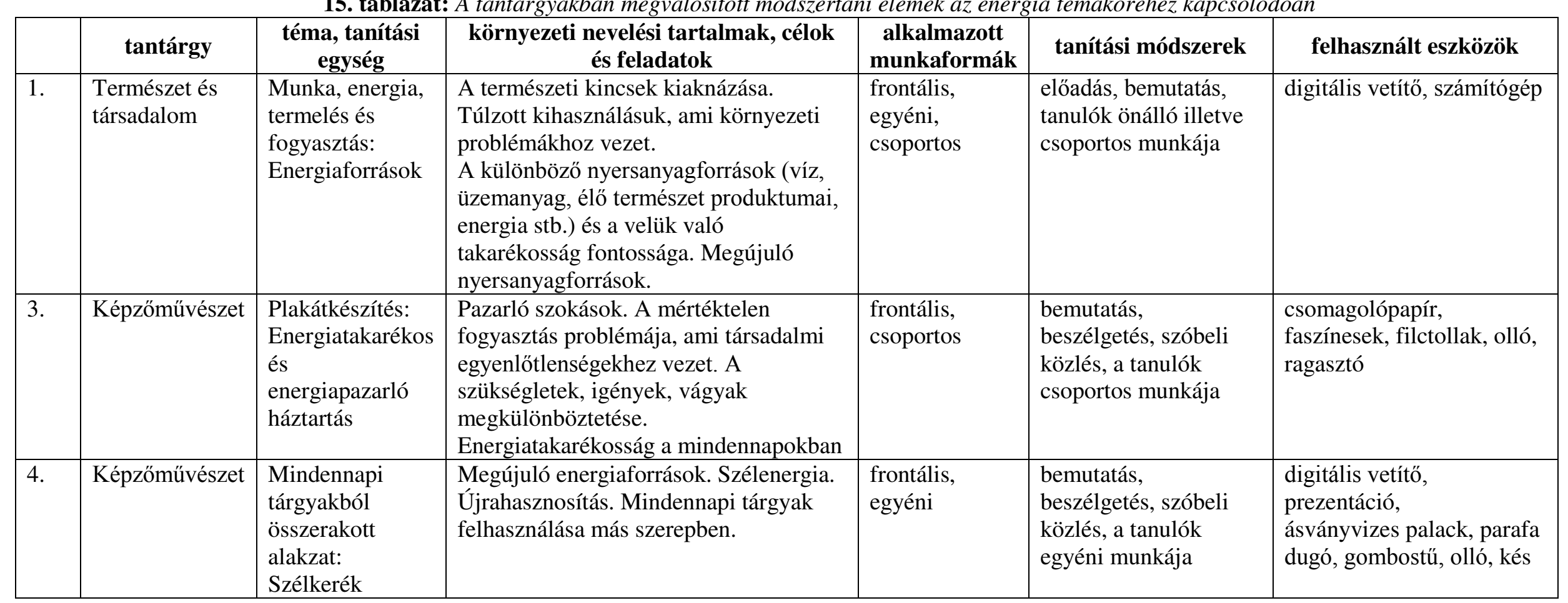


3. előadás: Megújuló energiaforrások (filmvetités). A tanulók részleteket néztek meg az Otthonunk (Home) címü filmből (forrás: http://bit.ly/2sdjNyY). A dokumentumfilm megtekintése után közösen beszélgettek a látottakról.

4. projekt: Oltsd le a lámpát, zárd el a csapot! Projektfeladat: a gyerekeknek meg kellett számolniuk, hogy hány villanykörte, konnektor és vízcsap van az otthonukban (feladatlap: 23. melléklet). Ezt követően egy héten keresztül meg kellett figyelniük, hogy mennyi energiát használnak el családjukban. Amikor fogat mosnak, elzárják-e a csapot, amikor nem tartózkodnak a szobában, lekapcsolják-e a villanyt, ha nem használják a számítógépet, kikapcsolják-e, kihúzzák-e a konnektorból azokat a készülékeket, amelyekre nincs szükségük? A tapasztalatokról a projekt lezárásának alkalmával számoltak be.

\section{Iskolán kívüli tevékenységek az energia témakörében}

Az iskolán kívüli tevékenységek során megvalósított tartalmak az energia témakörén belül:

1. program: Állatkerti látogatás - Látogatás a Palicsi Állatkertben.

2. program: Kiállitás - A projekthét során készült összes képzőmüvészeti alkotás bemutatása a Magyar Tannyelvü Tanítóképző Kar épületében (15. melléklet)

3. program: „Megérkezett a tavasz, vigyázzunk környezetünkre!” - A kéthetes program környezetvédelem-nap keretein belül zárult a Magyar Tannyelvü Tanítóképző Karon (16. melléklet).

\subsection{A program gyakorló pedagógusok általi elemzése}

A program végrehajtását követően egy, a pedagógusok környezeti nevelését célzó továbbképzés alkalmával bemutattuk az egyes programelemeket a gyakorló tanítók számára.

A továbbképzés célja az volt, hogy a képzésen részt vevők ismerjék fel a környezeti nevelés fontosságát, szerezzenek a pedagógiai gyakorlatukban alkalmazható ismereteket a környezeti nevelésben alkalmazható módszerekről, ezek megszervezéséről és lebonyolításáról. A környezeti nevelés módszertani elveit alkalmazva képesek legyenek az alsó tagozatos gyerekek környezettel kapcsolatos szemléletének formálására.

Az Újvidéki Egyetem Magyar Tannyelvű Tanítóképző Kara által szervezett téli egyetem keretein belül két alkalommal is sor került a továbbképzés megrendezésére. Összesen 39 gyakorló pedagógus - osztálytanítók és óvodapedagógusok - vett részt a képzésben. Közöttük olyan pedagógusok is, akiknek az osztályában a kísérleti programot végrehajtottuk, illetve olyan egykori tanítóképzősök, akik részt vettek a kiérleti program kivitelezésében, és azóta saját osztályt kaptak. A kurzuson részt vevő pedagógusokat arra kértük, hogy véleményezzék és elemezzék az alsós tanulók részére kidolgozott intenzív környezeti nevelési programot.

A tanítók SWOT analízis (Hamidi és Delbahari, 2011; Živković et al., 2015) segítségével elemezték a programot. A SWOT analízis szempontjai alapján (Czeglédi, 2011) feltárták a program erősségeit, gyengeségeit, lehetőségeit és veszélyeit:

- erősségek: azok a pozitív tényezők, amelyek jól müködnek a programban, és további fejlesztéssel még jobban működhetnek; 
- gyengeségek: olyan, a programra jellemző tényezők, amelyek nem jól müködnek, de javíthatunk rajtuk;

- lehetőségek: olyan külső tényezők, amelyeket nem tudunk befolyásolni, de kedvezőek, és rájuk építve kihasználhatjuk az erősségeinket;

- veszélyek: olyan külső korlátok, negatív tényezők, amelyeket nem tudunk befolyásolni, csökkentik a program sikerességének esélyeit.

A válaszok alapján elmondható, hogy a pedagógusok alapvetően pozitívan értékelték a programot. Sokan jelezték, hogy saját ötleteikkel kiegészítve maguk is szívesen kiviteleznék a program egyes elemeit osztályukban.

Az elemzés során nagyon sok olyan erösséget felsoroltak, amelyek alátámasztják a program létjogosultságát. A lehetőségek sorában is számos olyan elemet megjelöltek, amelyekkel tovább bővíthető a program tartalma. A gyengeségek és a veszélyek tekintetében is reálisak voltak, és nem említettek olyan kizáró tényezőt, amelyet nem lehet kiküszöbölni, vagy aminek alapján a program kivitelezhetetlen volna. Az említett nehézségek zöme az oktatási rendszer jellegéből adódó probléma, amely bármely egyéb jellegủ kezdeményezés esetében veszélyeztetné az ötlet teljes körü megvalósíthatóságát. A tanítók által elkészített elemzéseket összevontam és a 16. táblázatban foglaltam össze.

$\mathrm{Az}$ analízis elvégzése mellett a pedagógusok nagyon sok új ötletet adtak a program továbbfejlesztésével kapcsolatban, és teljesen új programelemeket is kidolgoztak, amelyekkel a későbbiekben ki lehet majd egészíteni a már feldolgozott tartalmakat. 
16. táblázat: A program hatékonyságának elemzése pedagógusok által, SWOT analízis segítségével

\section{ERÖSSÉGEK}

- több tantárgyon keresztül meg lehet valósítani;

- a program több tantárgy korrelációjára épít;

- hagyományos tanítási keretek között is feldolgozhatóak a témák;

- motiválja a tanulókat: a tanulók élvezik az olyan feladatokat, amelyek a közvetlen környezetükkel kapcsolatosak;

- pozitív hozzáállást alakít ki a tanulókban a környezet iránt;

- közvetlen tapasztalatszerzésre ad lehetőséget;

- ötleteket ad az iskolán kívüli tevékenységek megvalósítására;

- a program nevelési hatása intenzív, ugyanis egy cikluson belül minden nap találkoznak a gyerekek az érintett területtel;

- a program tartalma túlmutat a tankönyvek tartalmán, tovább bővítve a tanulók ismereteit;

- olyan hétköznapi problémákkal találkozhatunk egy-egy modulon belül (hulladékgyüjtés, környezetszennyezés, pazarlás, természetóvás), amelyről folyamatos információáramlásra van szükség a gyerekek felé;

- a gyermekek kiállítása a program során készített és megtanult dolgokból motiváló hatású;

- a program nem csak a tanulóknak, de a tanítóképzős hallgatóknak, sőt a gyakorló pedagógusoknak is lehetőséget ad a tapasztalatszerzésre, tanulásra;

- a program lehetőséget ad iskolán kívüli tevékenységek folytatására

\section{GYENGESÉGEK}

- az iskolákban kevés segédeszköz áll rendelkezésre a programok megvalósításához;

- a program megvalósítása felkészülést és komoly hozzáállást igényel a tanítók részéről;

- újfajta megközelítést igényel a tanítók részéről, hogy több szempontból is feldolgozzon egy-egy tanítási egységet;

- témához kapcsolódó előadások megszervezése többletmunkát igényel a tanítótól;

- nehézkes lehet a tanulók más kötelezettségeivel, foglalkozásaival való időbeli egyeztetés;

- a program kidolgozásába a gyerekek előtudását jobban ismerő, gyakorló pedagógusokat is be kell vonni a tanítóképzős hallgatók mellett;

- a program tartalmát a testnevelés tantárgyra és az osztályfőnöki órákra is szükséges lenne kidolgozni;

- a szervezett állatkerti látogatás egyelőre csak a szabadkai iskolák számára áll rendelkezésre, így a vidéki iskolákban a program nem valósítható meg változatlan formában;

- nem csak az alsó tagozatos tanulóknál, de az általános iskola felsőbb osztályaiban és a középiskolában is biztosítani kell a folyamatos környezeti nevelést, különben elvész a hatása 


\begin{tabular}{|c|c|c|}
\hline & LEHETŐSÉGEK & VESZÉLYEK \\
\hline 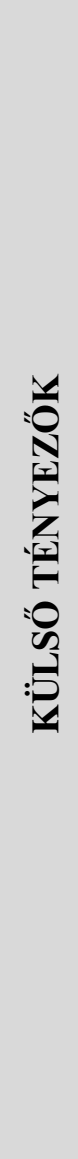 & 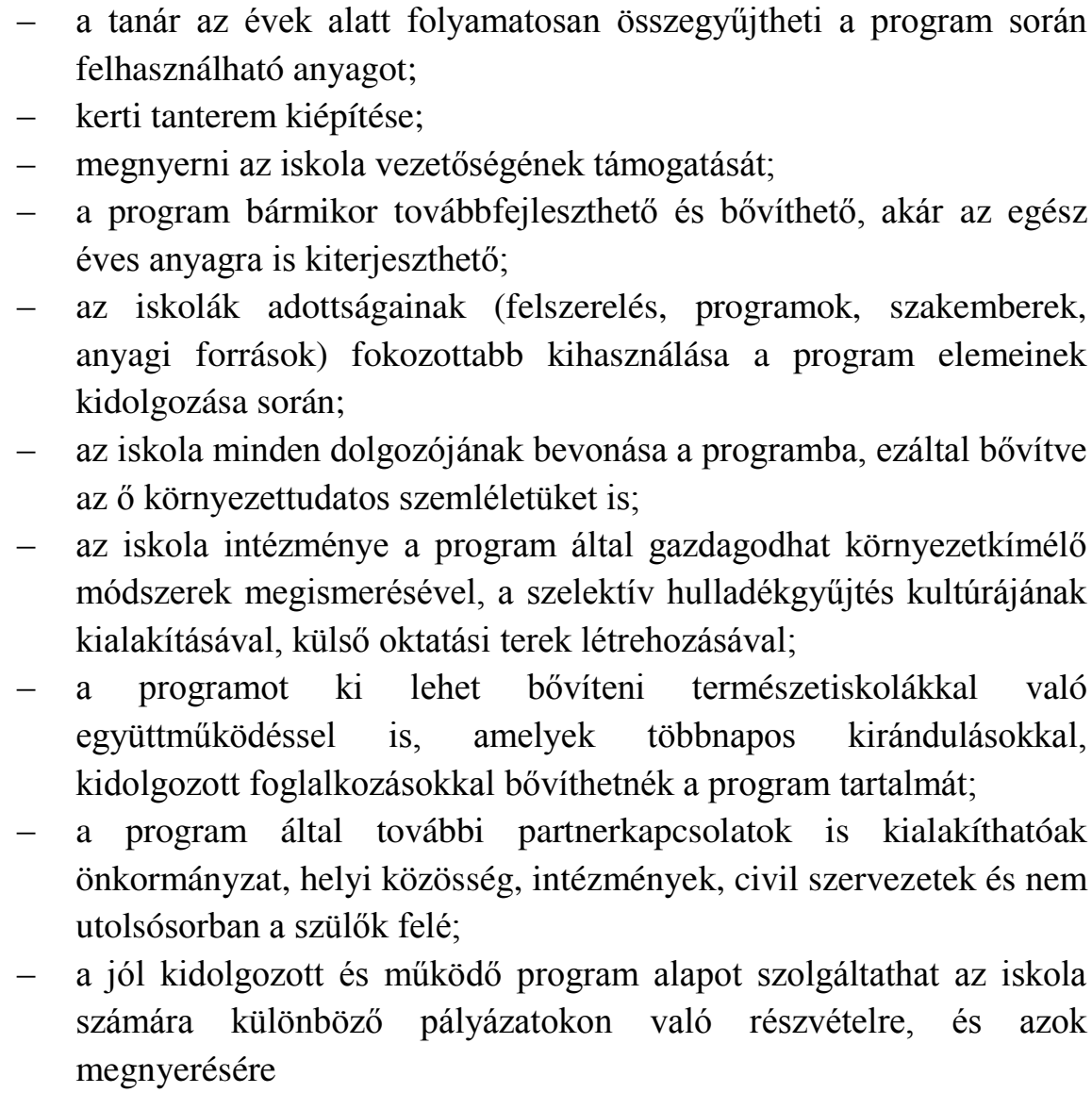 & $\begin{array}{l}\text { - az anyagi források hiánya csökkentheti az esélyeinket a } \\
\text { megvalósításhoz; } \\
\text { - } \\
\text { a gyerekek családi háttere, a szülök hozzáállása, anyagi forrásainak } \\
\text { hiánya is hátráltathatja a program sikerességét; } \\
\text { - } \text { külső segítség nélkül sok pluszteher hárul a tanítókra; } \\
\text { - } \text { pluszteher hárul a tanulókra is; } \\
\text { - } \\
\text { ha a tanulókban el is ültetjük a környezet szeretetét, az utcára kilépve } \\
\text { azt tapasztalják, hogy kevés ember figyel oda erre, és ezért előbb- } \\
\text { utóbb csökken a program hatása; } \\
\text { - } \quad \text { külső motiváció hiányában és a hosszú megtérülési idő miatt könnyen } \\
\text { megtörténhet, hogy a tanítók, tanárok kezdeti lelkesedése lelohad, és } \\
\text { nem lesz hajlandó hosszú távon fenntartani a program müködését }\end{array}$ \\
\hline
\end{tabular}




\section{A TANÍTÓKÉPZŐS HALLGATÓK KÖRÉBEN ELVÉGZETT EMPIRIKUS VIZSGÁLAT}

\subsection{Az empirikus vizsgálatok célrendszere}

A kutatás konkrét célrendszere a következő szempontok alapján összegezhető:

Tudományos célkitüzés: empirikus vizsgálattal hozzájárulni annak bizonyításához, hogy a környezeti nevelésben fontos szerepe van a változatos oktatási színtereken, korszerü módszerek segítségével megvalósított, a tanterv részét képező környezeti nevelési programoknak.

Gyakorlati célkitüzés I.: a szabadkai Magyar Tannyelvü Tanítóképző Kar hallgatóinak segítségével kidolgozni egy olyan környezeti nevelési programot, amely által elősegíthetjük az alsó tagozatos tanulók környezettudatos magatartásának és környezeti attitüdjeinek fejlesztését, egyúttal felkészíthetjük a leendő tanítókat a környezeti nevelési feladatok ellátására, a módszerek tanítási gyakorlatban való kipróbálására.

Gyakorlati célkitüzés II.: feltárni, hogy a kísérleti csoportban részt vevő tanulók csoportjának - akik részt vesznek a környezeti nevelési programban - környezettudatos magatartása, környezeti attitüdjei pozitívabb értéket mutatnak-e a hagyományos oktatásban részt vevő társaikkal szemben. A változatos oktatási színterek, módszerek és tartalmak alkalmazása által valóban elérhetjük-e a környezeti nevelés célját, azt, hogy az így oktatott tanulóknál kimutatható a környezet megóvása érdekében való cselekvés hajlama.

Gyakorlati célkitüzés III.: vizsgálni a program tervezésében és kivitelezésében résztvevő tanítóképzős hallgatók környezettudatos magatartásában és környezeti attitüdjük értékében bekövetkező változásokat.

Gyakorlati célkitüzés IV.: a tanítóképzős hallgatók kontrollcsoportjának a kísérlet alatt, illetve az azt követő további két tanévben való vizsgálata által meghatározni a Vajdaságban magyar nyelven tanuló tanító- és óvóképzős hallgatók környezeti attitüdjét és környezettudatosságának mértékét.

\subsection{Az empirikus vizsgálat módszerei}

A vizsgálat a következő elemekre épül:

I. a környezeti nevelési programban részt vevő hallgatók környezeti attitüdjének értékében bekövetkező változások vizsgálatára kontrollcsoportos pedagógiai kísérlet során;

II. a tanítóképzős hallgatók kontrollcsoportjában mért értékek változásának nyomon követése longitudinális felmérés során, további két tanéven keresztül;

III. a környezeti nevelési programban részt vevő alsó tagozatos tanulók környezeti attitüdjének értékében bekövetkező változások vizsgálatára kontrollcsoportos pedagógiai kísérlet során. 
Először a kiinduló állapotok vizsgálatára került sor, amely az általános iskolás tanulók és leendő tanítók környezettel kapcsolatos ismereteit, környezeti attitüdjeit, a környezethez kapcsolódó viszonyukat, környezettudatos magatartásukat tárja fel. Az első adatfelvételre a tanítójelöltek esetében a program kidolgozása előtt, az alsó tagozatos tanulók esetében pedig a program megkezdése előtt került sor.

A következő lépésben a program hatásainak vizsgálata történt meg. A második adatfelvételre mindkét célcsoport esetében a program zárása után került sor.

Az alsó tagozatos tanulók mérése a programban résztvevő tanítóképzős hallgatók segítségével történt. A hallgatók mérőeszközének is részét képezte az a kérdőív, amelyet a gyerekek esetében használtunk. Így ennek kitöltése által megismerkedhettek a hallgatók a mérőeszközzel. Emellett a tanítóképzősök számára kidolgozott környezeti nevelési tantárgy keretein belül közösen megbeszéltük a kérdőív felépítését, az alskálák szerkezetét, és az egyes itemek jelentését is. Az adatfelvétel során a kérdőív minden, az attitüdök mérésére vonatkozó kérdését egyenként felolvasták a gyerekek számára, és el is magyarázták a kérdések jelentését ott, ahol szükség mutatkozott rá. A gyerekek egyszerre, kérdésről kérdésre haladva töltötték ki a saját kérdőívüket. A háttéradatok felvételét illetően (szülők iskolai végzettsége, család anyagi helyzete, tanulmányi átlag) az osztálytanítók nyújtottak segítséget, és adták át a vonatkozó adatokat a tanítóképzős hallgatók számára, akik rávezették az adatokat a kérdőívekre. Ezzel biztosítva az adatok valódiságát.

A környezeti nevelési programban részt vevő tanítóképzős hallgatók túl kis mintát alkotnak ahhoz, hogy a velük mért eredményekből messzemenő következtetéseket vonhassunk le a tanítóképzős hallgatók környezeti attitüdjére, valamint az egyetem oktatási rendszerének ezen a területen kifejtett hatékonyságára vonatkozóan. Ugyanakkor a kutatás során nem szerettem volna kihagyni a lehetőséget, hogy a program elsődleges célközönsége, az alsó tagozatos gyerekek felmérése mellett megvizsgáljam a program kidolgozásában és végrehajtásában közreműködő tanítóképzős hallgatókat. A hallgatókra vonatkozó vizsgálatot ezért nem zártam le a kontrollcsoportos kísérletet követően, hanem a vizsgálatsorozat harmadik részeként további két tanéven keresztül megfigyeltem az attitüdértékek alakulását a hallgatók körében. A környezeti nevelési program hatékonysága legjobb esetben is csak az adott, a program kidolgozását célzó tantárgyban részt vevő hallgatók környezettudatosságát képes fejleszteni. A program hatása mellett azonban az oktatási rendszer egyéb tényezői is hozzájárulhatnak az értékek alakulásához. Ez a longitudinális vizsgálat pedig segíthet feltárni, hogy a Karon biztosított képzés elősegíti-e a hallgatók környezeti attitüdjének fejlődését.

A kidolgozott környezeti nevelési program hatékonyságát tehát két részből álló vizsgálatsorozat segítségével tártam fel, illetve további két éven keresztül vizsgáltam a tanítóképzős hallgatók környezeti attitüdjét (12. ábra).

\begin{tabular}{|c|c|c|c|c|c|c|c|}
\hline \multicolumn{2}{|c|}{$\begin{array}{l}\text { 2012/2013 } \\
\text { I. félév }\end{array}$} & \multicolumn{4}{|c|}{$\begin{array}{c}2012 / 2013 \\
\text { II. félév }\end{array}$} & \multirow{2}{*}{$\begin{array}{c}\begin{array}{c}\mathbf{2 0 1 3} / \mathbf{2 0 1 4} \\
\text { II. félév }\end{array} \\
2014.05 .01 .- \\
2014.05 .31 . \\
\end{array}$} & \multirow{2}{*}{$\begin{array}{c}\begin{array}{c}\mathbf{2 0 1 4 / 2 0 1 5} \\
\text { II. félév }\end{array} \\
2015.05 .01- \\
2015.05 .31 \\
\end{array}$} \\
\hline 2012.10 .08 & $\begin{array}{l}2012.10 .15 \text { - } \\
2012.12 .10 .\end{array}$ & $\begin{array}{l}2013.03 .04 .- \\
2013.03 .05\end{array}$ & $\begin{array}{l}2013.03 .11 .- \\
2013.03 .23 .\end{array}$ & & $\begin{array}{l}26 .- \\
27 .\end{array}$ & & \\
\hline $\begin{array}{c}\text { 1. mérés: } \\
\text { EGYETEMI } \\
\text { HALLGATÓK } \\
\text { kiinduló } \\
\text { állapotok } \\
\text { felmérése }\end{array}$ & $\begin{array}{c}\text { A } \\
\text { PROGRAM } \\
\text { KIDOL- } \\
\text { GOZÁSA }\end{array}$ & $\begin{array}{l}\text { 1. mérés: } \\
\text { ISKOLÁS } \\
\text { TANULÓK } \\
\text { kiinduló } \\
\text { állapotok } \\
\text { felmérése }\end{array}$ & $\begin{array}{c}\text { A } \\
\text { PROGRAM } \\
\text { VÉGRE- } \\
\text { HAJTÁSA }\end{array}$ & $\begin{array}{c}\text { 2. mérés: } \\
\text { ISKOLÁS } \\
\text { TANULÓK } \\
\text { hatások } \\
\text { vizsgálata }\end{array}$ & $\begin{array}{c}\text { 2. mérés: } \\
\text { EGYETEMI } \\
\text { HALLGATÓK } \\
\text { hatások } \\
\text { vizsgálata }\end{array}$ & $\begin{array}{c}\text { 3. mérés: } \\
\text { EGYETEMI } \\
\text { HALLGATÓK } \\
\text { további } \\
\text { vizsgálata }\end{array}$ & $\begin{array}{c}\text { 4. mérés: } \\
\text { EGYETEMI } \\
\text { HALLGATÓK } \\
\text { további } \\
\text { vizsgálata }\end{array}$ \\
\hline
\end{tabular}

12. ábra: A kérdöives felmérések végrehajtásának ütemezése 


\subsection{A tanítóképzős hallgatók körében elvégzett empirikus vizsgálat hipotézisei}

A hipotézisek megfogalmazása során abból a feltevésből indultam ki, hogy a hallgatók alapvetően pozitív környezetkultúrával rendelkeznek, mivel az egyetemi képzés szerkezete és a rájuk jellemző háttértényezők hatása pozitív befolyással lehet az eredményeik alakulására. Ezt a feltevést az eredmények több tanéven keresztül történő nyomon követése során igazolni lehet. Elsődleges célom a hallgatók longitudinális felmérésével az volt, hogy megvizsgáljam, növekszik-e környezeti attitüdjük mértéke az első, kísérleti évben mért értékekhez képest. Amennyiben beigazolódik az a hipotézis, hogy az értékek növekednek, egy további vizsgálatsorozat segíthet feltárni az egyetem oktatási rendszerének azon elemeit, amelyek hozzájárulnak a tanítóképzős hallgatók környezeti attitüdjének fejlesztéséhez.

Azoknál a hallgatóknál pedig, akik részt vettek a konkrét céllal meghatározott, változatos oktatási színterekre és módszerekre épített környezeti nevelési program kidolgozásában és végrehajtásában, feltételeztem, még pozitívabbá vált a környezethez való hozzáállás mértéke. Ennek megfelelően a következő hipotéziseket fogalmaztam meg:

- H1: A környezeti nevelési program kialakításában részt vevő tanítóképzős hallgatók (kísérleti csoport) környezettudatos magatartásának értéke növekszik a program kidolgozását és megvalósítását követően:

- H1/a: az előzetes felmérés során kapott eredményekhez viszonyítva;

- H1/b: a kontrollcsoportban mért értékekhez viszonyítva;

- H1/c: mind a három skála (ENV, RevNEP, CHEAKS) által mért adatok alapján.

- H2: A kontrollcsoport (Vajdaságban magyar nyelven tanuló tanító- és óvóképzős hallgatók) környezeti attitüdjének értéke alapvetően pozitív, vagyis a semleges érték felett helyezkedik el a három skála (ENV, RevNEP, CHEAKS) által mért adatok alapján.

- H3: A vizsgált tanítóképzős hallgatókra jellemző háttérváltozók befolyásolják környezeti attitüdjük mértékét mind a kísérleti, mind a kontrollcsoportban.

- H4: A tanítóképzős hallgatók környezeti attitüdjének mértéke tovább növekszik a kísérlet évét követő további vizsgált tanévekben is.

\subsection{Az empirikus vizsgálatban részt vevő tanítóképzős hallgatók}

A tanítóképzős hallgatók kísérleti csoportját az Újvidéki Egyetem Magyar Tannyelvü Tanítóképző Karának azon negyedéves, tanítóképzős hallgatói alkotják, akik részt vettek az intenzív környezeti nevelési program kidolgozásában és kivitelezésében.

A kontrollcsoport tagjait a többi, a Karon tanuló óvó- és tanítóképzős évfolyamokról kerültek ki.

Kísérleti csoport $(N=14)$ : a 2012/2013-as tanév negyedik évfolyamos, tanító szakos, a programban részt vevő hallgatók.

Kontrollcsoport $(N=119)$ : a 2012/2013-as tanév 1-3. évfolyamos tanító szakos, és 1-4. évfolyamos óvodapedagógus szakos hallgatói, összesen 119-en a 206, az adott tanévre beiratkozott hallgató közül. 
A további két tanévben (2013/2014 és 2014/2015) elvégzett vizsgálatba ugyancsak a Magyar Tannyelvü Tanítóképző Kar hallgatóit vontuk be, minden évfolyamot érintve. Vajdaságban egyedül ezen az egyetemi karon folyik magyar tannyelvü tanítóképzés. Ez azt jelenti, hogy a Szerbiában magyarul tanuló tanítóképzősök teljes populációjának környezettudatosságára tudunk következtetni a vizsgált minta alapján (Major et. al, 2017). A három vizsgált tanév (2012/2013, 2013/2014 és 2014/2015) során összesen 603 beiratkozott hallgatója volt a Karnak. Közülük összesen 407 hallgató vett részt a felmérésben a három tanév folyamán. A 2012/2013-as tanévben, a környezeti nevelési program hatékonyságát mérő vizsgálat kontrollcsoportjában 119 hallgató vett részt. A 2013/2014-es tanévben elvégzett vizsgálatba 143 tanítóképzős hallgatót vontam be, a 2014/2015-ös tanévben pedig 145 hallgatót vizsgáltam.

\subsubsection{A kísérletben részt vevő minta háttéradatai}

A mintára jellemző egyes szociáldemográfiai tényezők hatással lehetnek az eredményül kapott attitűdértékekre (Saraçli, Yilmaz and Arslan, 2014), ezért megvizsgáltam a hallgatók alább felsorolt háttéradatait, hogy összevethető legyen a felmérés során kapott eredményekkel.

(1) Évfolyam:

- kísérleti csoport $(N=14)$ : a kísérleti csoportba tartozó hallgatók mindannyian negyedik évfolyamra járnak a vizsgálat időpontjában.

- kontrollcsoport $(N=119)$ : a mintában szereplő hallgatók 27\%-a első $(\mathrm{N}=32), 26 \%$-a második ( $\mathrm{N}=31), 25 \%$-a harmadik $(\mathrm{N}=30), 22 \%$-a negyedik $(\mathrm{N}=26)$ évfolyamra jár.

(2) Nem:

- kísérleti csoport $(N=14)$ : a kísérleti csoport munkájában 1 fiú és 13 lány vett részt.

- kontrollcsoport $(N=119)$ : a hallgatók 15\%-a fiú $(\mathrm{N}=18), 85 \%$-a lány $(\mathrm{N}=101)$. A mintában szereplő nemek aránya tükrözi a karra beiratkozott hallgatók nemének arányát.

(3) Kedvenc tantárgy:

- kísérleti csoport $(N=14)$ : a kísérleti csoportot alkotó hallgatók felének, 7 hallgatónak a nyelv és irodalom jellegü tantárgyak a kedvencei. A társadalomtudományi tárgyakat mindössze 1 hallgató kedveli. A természettudományi tárgyak 4 hallgató kedvencei, a készségtárgyakat pedig 2 hallgató jelölte meg kedvenceként.

- kontrollcsoport $(N=119)$ : a kontrollcsoportba tartozó hallgatók 34\%-a $(\mathrm{N}=36)$, a kísérleti csoport hallgatóihoz hasonlóan, a legnagyobb arányban a nyelv és irodalom jellegü tantárgyakat kedvelik. A társadalomtudományi tárgyakat 27\%-uk (N=29), a természettudományi tárgyakat 17\%-uk (N=19), a készségtárgyak (müvészetek és testnevelés) csoportjába tartozó tárgyakat $17 \%$-uk $(\mathrm{N}=19)$, a módszertan tárgyakat pedig 5\%-uk $(\mathrm{N}=5)$ kedveli.

(4) Tanulmányi átlag:

- kísérleti csoport ( $N=14)$ : a kísérleti csoport 8 tagja jeles (8-as), 5 hallgató erős jeles (9-es), 1 hallgató pedig kitűnő (10-es) tanulmányi eredménnyel rendelkezik.

- kontrollcsoport $(N=119)$ : a mintába tartozó hallgatók 11\%-a jó, azaz 7-es átlageredménnyel $(\mathrm{N}=12), 47 \%$-a jeles, 8-as átlageredménnyel $(\mathrm{N}=54), 34 \%$-a erős jeles, 9-es átlageredménnyel $(\mathrm{N}=39), 8 \%$-a kitünő, 10-es átlageredménnyel $(\mathrm{N}=9)$ rendelkezik. 
(5) Lakóhely:

- kísérleti csoport $(N=14)$ : a csoport tagjai közül 9-en falun, 5-en városban élnek.

- kontrollcsoport $(N=119)$ : a kontrollcsoport 59\%-a falun $(\mathrm{N}=70), 41 \%$-a városban ( $\mathrm{N}=49)$ él.

(6) Szülök iskolai végzettsége:

- kísérleti csoport $(N=14)$ : összesen 10 hallgató édesapjának legmagasabb iskolai végzettsége középiskola. Általános iskolát és föiskolát, illetve egyetemet is 2-2-en végeztek. Az édesanyák közül 8 hallgatóé középiskolát, 2 hallgatóé általános iskolát, 4 hallgatóé pedig föiskolát, illetve egyetemet végzett.

- kontrollcsoport $(N=119)$ : az apák 14\%-ban $(\mathrm{N}=16)$ általános iskolát végeztek, 76\%nak ( $\mathrm{N}=89)$ középiskola, 10\%-nak $(\mathrm{N}=12)$ föiskola vagy egyetem a legmagasabb iskolai végzettsége. Az anyák esetében $18 \%(\mathrm{~N}=22)$ az általános iskolát, $64 \%(\mathrm{~N}=76)$ a középiskolát, $18 \%(\mathrm{~N}=21)$ a fóiskolát vagy egyetemet végzettek száma.

(7) Egy háztartásban élök száma:

- kísérleti csoport $(N=14)$ : a kísérleti csoport tagjainak többsége, 6-an négytagú családban élnek. Háromtagú és öttagú családban pedig 4-4 hallgató él.

- kontrollcsoport $(N=119)$ : a kontrollcsoportba tartozó hallgatók többsége, 48\%-uk ( $\mathrm{N}=57)$ négytagú családban él. 29\%-uk háromtagú $(\mathrm{N}=35), 17 \%$-uk $(\mathrm{N}=20)$ öttagú, 4\%-uk $(\mathrm{N}=5)$ kéttagú családban él.

(8) Család anyagi helyzete:

- kísérleti csoport $(N=14)$ : a hallgatók közül 10-en átlagos anyagi körülmények között élnek. Emellett 2 hallgató rossz, 2 hallgató pedig jó anyagi körülményeket vallott magáénak.

- kontrollcsoport $(N=119)$ : a mintában szereplő hallgatók 69\%-a $(\mathrm{N}=81)$ átlagos anyagi körülmények között él. Rossz körülmények között él a hallgatók 16\%-a (N=19), nagyon rossz anyagi helyzetben él további 3\% (N=3). Jó anyagi körülmények között csak a hallgatók 11\%-a $(\mathrm{N}=13)$, nagyon jó körülmények között pedig csak egy hallgató, vagyis $1 \%$ él.

\subsection{A mérőeszköz}

A tanítóképzős hallgatókkal elvégzett vizsgálatban egy 69 kérdést tartalmazó kérdőívet használtunk. Az első 10 kérdés a felmérésben részt vevő személyek háttéradataira vonatkozott. A kérdőív következő szakasza 59 itemet tartalmazó, ötfokú Líkert-skálából felépülő kérdéssor volt (26. melléklet). A kérdések három különböző, magyar nyelvre adaptált attitűdmérő kérdőívből származnak: az ENV, a RevNEP és a CHEAKS kérdőívekből.

(1) Az ENV skálát (Environmental Perception Test) először Bogner és Wiseman (1999) publikálta, magyarra adaptált változata pedig Gulyástól (2004) származik. Az ENV skála két fő faktorból és öt további alskálából tevődik össze, melyekhez 4-4 kérdés tartozik: A használat-faktor alskálái: (1) beavatkozás a természetbe, (2) az emberiség elsőbbsége; A megörzés-faktor alskálái: (3) támogatási szándék, (4) a természet élvezete, (5) takarékosság az erőforrásokkal. A vizsgálat során az ENV skála mind a 20 kérdését felhasználtam. A kérdéseket a 17. táblázat szemlélteti. A táblázatban a félkövéren szedett állítások a fordítottan megfogalmazott itemeket jelölik. 
17. táblázat:

A környezeti attitüdöt mérö tételek besorolása az ENV kérdöiven (Bogner and Wiseman, 1999)

Használat

Beavatkozás a természetbe

(1) Gondozatlannak néz ki, ha fü és gaz nő a járda kövei közt

(2) A gyomokat ki kell irtani, mert akadályozzák a haszon- és dísznövények növekedését

(3) Egy igazi természetjáró gyönyörü és ritka növényeket hoz magával haza kirándulásról

(4) Jobban tetszik egy jól ápolt pázsit, mint egy buja mező, ahol össze-vissza nőnek a virágok

Az emberiség elsöbbsége

(1) Fontos, hogy autópályákat és kerülőutakat építsünk, ezért megéri eltávolítani az erdőket és mezőket

(2) Hogy az embereknek legyen mit enniük, a természetet háttérbe kell szorítani

(3) Mivel a szúnyogok tavakban fejlődnek ki, jobb lenne lecsapolni ezeket

(4) A szabadstrandokat meg kellene tisztítani a hínártól

Támogatási szándék

Megőrzés

(1) Ha több pénzem lenne, valamennyit egy környezetvédelmi szervezetnek adományoznék belöle

(2) A környezet védelme sok pénzbe kerül. Kész vagyok rá, hogy segítsek egy erre a célra szervezett gyüjtésben

(3) Tervezem, hogy csatlakozom/aktívan részt veszek egy környezetvédelmi csoportban

(4) Gyakran próbálok meggyőzni másokat arról, hogy a környezet ügye fontos

A természet élvezete

(1) A természet csendjében jól érzem magam

(2) Nagyon szeretek vidékre utazni - például kirándulni az erdőbe vagy egy rétre

(3) Nagyon szeretem a falevelek finom susogását, ahogy a szél átfúj a fák felett

(4) Szívesen üldögélnék egy tó partján és nézném, ahogy repkednek a szitakötők

Takarékosság az eröforrásokkal

(1) Mindig lekapcsolom a lámpát, amikor már nincs szükségem rá

(2) Amikor csak lehetséges, fürdés helyett zuhanyzom, hogy takarékoskodjak a vízzel

(3) Megbizonyosodom róla, hogy télen nincs túl magasra állítva a fütés a szobámban

(4) Hogy ne szennyezzem a levegőt, inkább gyalog teszek meg rövid távokat, mint autóval

A kapott eredmények az egyes kérdésekre adott válaszok pontszámának átlagából származnak. A Líkert-skála ugyan szigorúan tekintve rangskálának számít, de általánosan elfogadott, hogy a komplex statisztikai eljárások adta lehetőségek kihasználása céljából intervallumskálaként kezelik, ennek megfelelően összeadhatóvá válnak a pontszámok (Varga, 2004). Ennek megfelelően a használat-skálán 8-tól 40 pontot érhettek el a hallgatók. A 24-es érték felett pozitív, alatta negatív környezeti attitüd jellemzi a kitöltőket. A megörzés-skála értékei a 12 és 60 pont között mozognak, 36 pont a semleges érték. A két fötengelyt alkotó alskálákon 5-től 20 pont érhető el, itt a 12,5 pont jelenti a semleges attitüdöt. A teljes ENV skála értéke 20 pont és 100 pont között lehetséges, ehhez mérten 62,5 pont a semleges attitüd. A válaszbeállítódás elkerülésének érdekében 8 tétel fordítottan van megfogalmazva.

(2) A RevNEP skála (Revised New Ecological Paradigm Scale) az eredeti, NEP skála (New Ecological Paradigm Scale) Dunlap és társai (2000) által felújított változata, amelyet szintén Gulyás (2004) adaptált magyar nyelvre. A három kérdőív közül ez a skála (illetve változtatása elött a NEP skála) a nemzetközi szinten leggyakrabban használt eszköz a környezeti attitüd mérésére a fiatalok és a felnőtt populáció körében (Gadenne et al., 2011; Lucy, Hawcroft and Milfont, 2010; Jowett et al., 2014; Kuo and Jackson, 2014; Shepard et al., 2015b). Shepard és társai (2015a) négyéves longitudinális felmérés során bizonyították a skála alkalmasságát a környezeti attitűd mérésére vonatkozóan az egyetemi hallgatók körében.

A RevNEP skála 5 alskálára osztható: (1) A növekedés korlátai; (2) Anti-emberközpontúság; (3) A természet egyensúlyának törékenysége; (4) Az emberi kiváltság elutasítása; (5) Egy ökológiai válság lehetősége. Az alskálák esetében 3 és 15 pont közötti pontszámot érhetnek el 
a kitöltők. A semleges érték, amely felett pozitív attitüdértékről beszélhetünk, a 9-es pontszám. A teljes RevNep skála pontszámai 15 és 75 pont közé esnek, a semleges értéket így a 38-as pontszám jelenti. A válaszbeállítódás elkerülésének érdekében 7 tétel fordítottan van megfogalmazva. A kérdéseket a 18. táblázat mutatja be. A fordítottan megfogalmazott tételek félkövér formázással vannak megjelölve.

\section{8. táblázat:}

A környezeti attitüdöt mérö tételek besorolása a RevNep kérdölven (Dunlap et al., 2000)

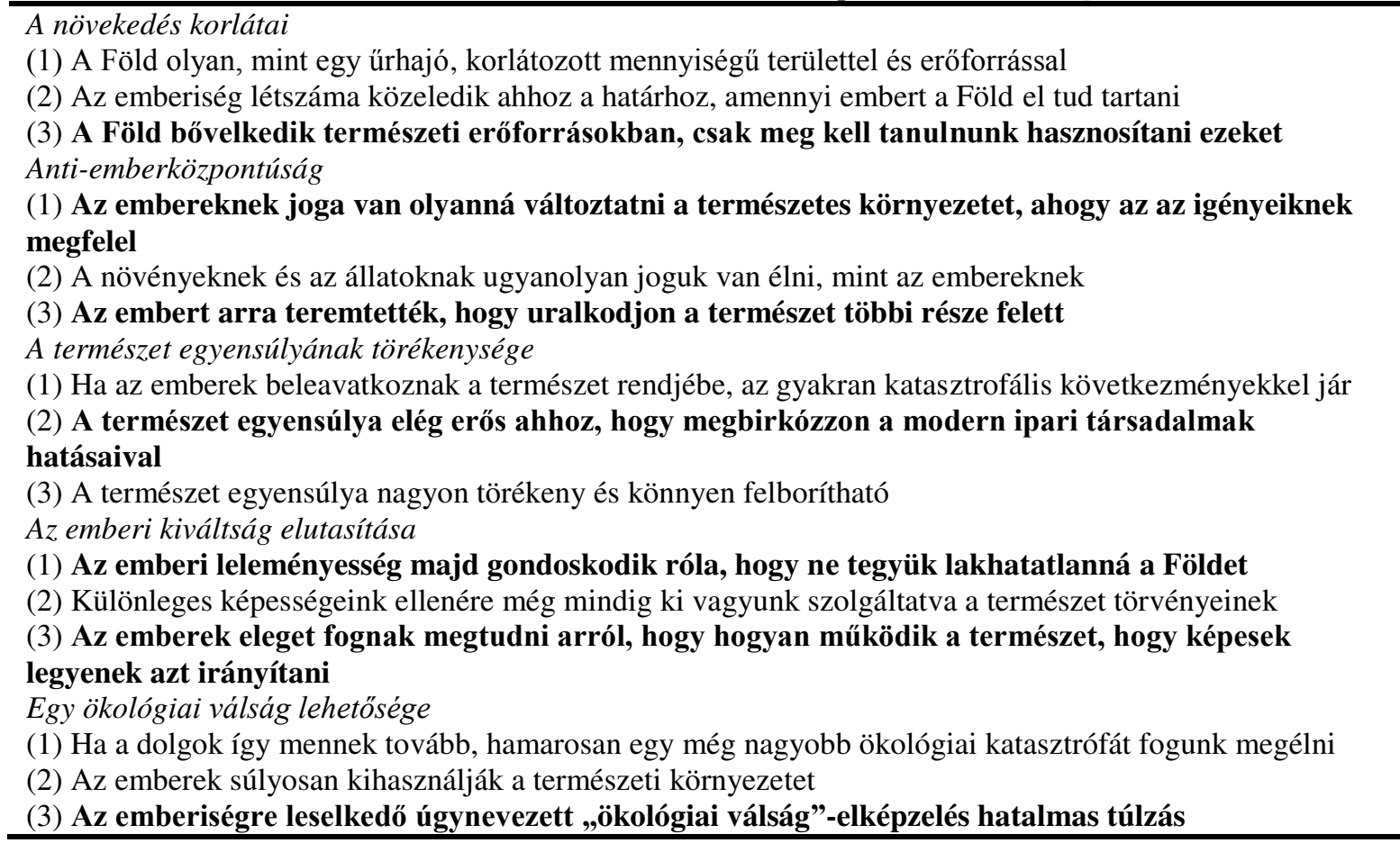

(3) A harmadik felhasznált kérdöív a CHEAKS skála (Children's Environmental Attitude and Knowledge Scale), amelyet eredetileg Leeming, Dwyer and Bracken (1995) szerkesztett és Varga (2004) adaptálta magyar nyelvre. A skála 24 tételből álló, attitüdmérö részét használtuk fel a hallgatókkal elvégzett vizsgálat során. A teszt hat alskálából tevődik össze, melyek a következő témaköröket vizsgálják: általános környezeti kérdések, állatok, növények, víz, energia, hulladék. Minden alskálához 4-4 kérdés tartozik, melyböl kettő a vizsgált személynek a témakörrel kapcsolatos érzelmeit, kettő pedig a viselkedéses viszonyulását méri fel (19. táblázat). A Varga (2004) által adaptált kérdőívben az eredeti „,szennyezés” alskálát felváltja a „növények” alskála. Felmérésünk során ezt a változatot használtuk. A CHEAKS kérdőív eredetileg gyerekek számára készült, de az egyes tételek nem tartalmaznak olyan specifikus, korosztályi jelleget, amely miatt nem lehet 18-22 éves egyetemisták, vagy akár felnőttek körében alkalmazni. 
19. táblázat:

A környezeti attitüdöt mérö tételek besorolása a CHEAKS kérdöiven (Leeming, Dwyer and Bracken, 1995 alapján idézi Varga, 2004)

\begin{tabular}{|c|c|c|}
\hline & Viselkedés & Érzelem \\
\hline \multirow[t]{3}{*}{ Általános } & (1) Figyelem a környezetvédelemmel & (3) Becsülöm azokat, akik pénzt áldoznak a \\
\hline & kapcsolatos híreket. & környezet védelmére. \\
\hline & $\begin{array}{l}\text { (2) Nem szoktam környezetvédelmi } \\
\text { tanácsokat kérni másoktól. }\end{array}$ & $\begin{array}{l}\text { (4) Aggódom, hogy az emberek nem vigyáznak } \\
\text { eléggé a környezetükre. }\end{array}$ \\
\hline \multirow[t]{2}{*}{ Állat } & $\begin{array}{l}\text { (1) Ellenzem az állati szőrből készült ruházat } \\
\text { használatát. }\end{array}$ & $\begin{array}{l}\text { (3) Jónak tartom, ha egy kozmetikai szert } \\
\text { állatokon próbálnak ki. }\end{array}$ \\
\hline & (2) Szoktam télen etetni a madarakat. & $\begin{array}{l}\text { (4) Elszomorít, hogy az építkezések csökkentik } \\
\text { az állatok élőhelyét. }\end{array}$ \\
\hline Növény & $\begin{array}{l}\text { (1) Amikor egy erdőben járok, megfigyelem a } \\
\text { növényeket. } \\
\text { (2) Bárhol kirándulok, gyakran viszek haza } \\
\text { virágot. }\end{array}$ & $\begin{array}{l}\text { (3) Nagyon szeretek erdőben sétálni. } \\
\text { (4) Szerintem gyönyörüek a levelek színei } \\
\text { ősszel. }\end{array}$ \\
\hline \multirow[t]{2}{*}{ Víz } & $\begin{array}{l}\text { (1) Fogmosás közben általában elzárom a } \\
\text { csapot. }\end{array}$ & $\begin{array}{l}\text { (3) Nem aggódom amiatt, hogy elfogy a } \\
\text { tiszta víz. }\end{array}$ \\
\hline & $\begin{array}{l}\text { (2) Ha feleslegesen folyik a víz, elzárom a } \\
\text { vízcsapot. }\end{array}$ & $\begin{array}{l}\text { (4) Idegesít, ha azt látom, hogy az emberek } \\
\text { pazarolják a vizet. }\end{array}$ \\
\hline \multirow[t]{3}{*}{ Hulladék } & (1) Megkértem családtagjaimat, hogy & (3) Örülök, amikor látom, hogy az emberek \\
\hline & $\begin{array}{l}\text { eldobható palackot vásároljanak. } \\
\text { (2) A háziszemét valamely részét elkülönítve }\end{array}$ & $\begin{array}{l}\text { újrahasznosítanak. } \\
\text { (4) Bosszant, hogy az emberek kidobnak }\end{array}$ \\
\hline & gyüjtöm. & újrahasznosítható dolgokat. \\
\hline \multirow[t]{2}{*}{ Energia } & $\begin{array}{l}\text { (1) Nyitva hagyom a hütőszekrény ajtaját, } \\
\text { amíg eldöntöm, mit veszek ki belőle. }\end{array}$ & $\begin{array}{l}\text { (3) Örülök, ha az emberek energiát próbálnak } \\
\text { megtakarítani. }\end{array}$ \\
\hline & $\begin{array}{l}\text { (2) Otthon leoltom a lámpákat, ha kevesebb fény } \\
\text { is elég. }\end{array}$ & $\begin{array}{l}\text { (4) Zavar, hogy mennyi energiát pocsékolnak el } \\
\text { feleslegesen. }\end{array}$ \\
\hline
\end{tabular}

Egyetlen olyan tétel szerepelt a kérdőívben, amelyet át kellett fogalmazni ahhoz, hogy felnőttek számára is értelmezhető legyen, de a kérdés lényegét tekintve a változtatás nem számottevő. Az állatok alskálán az eredeti kérdés így szerepel: „, Megkértem a szüleimet, hogy ne vásároljonak állati szörböl készült ruhákat”. Ezt a kérdést kellett a következő formában átfogalmazni: „Ellenzem az állati szörböl készült ruházatok használatát”.

Alskálánként minimum 4, maximum 20 pontot érhetnek el a kitöltők. Ennek megfelelöen a 12-es pontérték jelöli a semleges környezeti attitüdöt, az e fölötti pontérték pozitív környezeti attitüdöt, a 12 pont alatti érték pedig negatív környezeti attitüdöt jelent. Az érzelem és viselkedés skála egyaránt 12 tételt tartalmaz, így a semleges attitüdöt jelentő érték 36 pont, az e fölötti értékek pozitív, az ez alattiak negatív környezeti attitüdöt jelentenek. Az összes attitüdtétel pontszámának összeadásával kapjuk a teljes attitüdskálát. Itt 24 és 120 pont között van az elérhető lehetséges pontszám, vagyis 72 pont jelenti a semleges környezeti attitüdöt. A válaszbeállítódás elkerülésének érdekében 6 tétel fordítottan van megfogalmazva.

A környezeti attitüd skálát nagymértékben befolyásolja az, hogy a kérdezett mennyire akar megfelelni a társadalmi elvárásoknak. Az életkor előrehaladtával a szociális kívánatosság szintje azonban csökken, így a mintában szereplö 18-22 éves korosztályban már nem annyira számottevő, mint kisgyermekkorban (Gulyás and Varga, 2006). A CHEAKS és az ENV skála a konkrét cselekvésekre kérdez rá, vagyis leginkább a viselkedés vizsgálatát teszik lehetővé. A RevNep skála viszont inkább az általános beállítódást vizsgálja, így nem áll fenn a szociális kívánatosság befolyásoló hatása, amely a másik két skálánál óhatatlanul jelen van (Gulyás, 2004). 
A teljes kérdőív attitüdmérő része a következő itemekből tevődik össze:

(1) az ENV skála 20 itemje;

(2) a RevNep skála 15 itemje;

(3) a CHEAKS skála 24, környezeti attitüdöt mérö itemje.

A kérdöív összesen tehát 59 környezeti attitűdöt vizsgáló, ötfokú Líkert-skálán alapuló kérdésből épül fel. Ennek megfelelően egy kitöltő minimum 59, maximum 295 pontot érhetett el a vizsgálat során. A 118-as pontszám jelenti a semleges értéket, amely felett összességében pozitív, alatta pedig összességében negatív környezeti attitűdröl beszélünk.

A teljes, 59 tételes attitüdskála megbízhatóságát vizsgálva a Cronbach-alfa értéke az első mérés alkalmával 0,71, a második mérés során 0,83. A skála az adatok alapján tehát megfelelően mér mindkét méréskor.

\subsection{A tanítóképzős hallgatók körében elvégzett empirikus vizsgálat eredményei}

\subsubsection{A tanítóképzős hallgatók környezeti attitüdjének alakulása a kísérlet során}

A tanítóképzős hallgatók vizsgálata során az egyik célom az volt, hogy megállapítsam, a kísérletben részt vevő hallgatók környezettudatos magatartásának értéke milyen változást mutat a program kidolgozását és megvalósítását követően. A feltevésem az volt, hogy az értékek növekedést mutatnak egyrészt az előzetes felmérés során kapott eredményekhez viszonyítva, másrészt pedig a kontrollcsoportban mért értékekhez viszonyítva. A növekedés mindhárom alkalmazott kérdőív (ENV, RevNEP, CHEAKS) eredményei alapján igazolható. A környezeti nevelési program kidolgozását megelőzően elvégeztem a hallgatók környezeti attitüdjének felmérését. A kísérleti és a kontrollcsoportban részt vevő hallgatók is kitöltötték a három attitűdmérő skálából összeállított kérdőívet. A környezeti nevelési program végrehajtását követően újra mértem a hallgatók környezeti attitüdjének mértékét mindkét csoportban, mind a három skála segítségével.

\subsubsection{Az ENV skálával mért attitüdértékek alakulása}

Az első mérés során a kísérleti csoportban $(\mathrm{N}=14)$ részt vevő hallgatók az ENV skála megőrzésre vonatkozó alskáláin pozitív értéket értek el, a használat skálát tekintve azonban a teljes használat skálán és a két alskálán (beavatkozás a természetbe és az emberiség elsőbbsége) is negatív, a semleges érték alatt elhelyezkedő attitüdértéket produkáltak (20. táblázat). A második mérés során az ENV skála minden alskáláján pozitív értéket értek el a hallgatók (20. táblázat). 
20. táblázat: Az ENV skálával mért értékek a kísérleti csoportban

\begin{tabular}{|c|c|c|c|c|c|c|c|}
\hline \multirow[t]{2}{*}{ alskálák } & \multicolumn{2}{|c|}{ első mérés } & \multicolumn{2}{|c|}{ második mérés } & \multicolumn{2}{|c|}{$\begin{array}{c}\text { változás } \\
\text { (páros t-próba) }\end{array}$} & \multirow{2}{*}{$\begin{array}{c}\text { semleges } \\
\text { érték }\end{array}$} \\
\hline & átlag & szórás & átlag & szórás & $\mathrm{t}$ & $p$ & \\
\hline Használat-faktor & 21,4 & 3,4 & 29,5 & 5,9 & $-3,6$ & 0,003 & 24 \\
\hline 1. Beavatkozás a természetbe & 11,8 & 1,8 & 13,8 & 3,8 & $-1,7$ & 0,1 & 12,5 \\
\hline 2. Az emberiség elsőbbsége & 9,6 & 2,3 & 15,7 & 2,7 & $-5,2$ & 0,001 & 12,5 \\
\hline Megőrzés-faktor & 47,6 & 5,7 & 48,3 & 6,3 & $-0,4$ & 0,7 & 36 \\
\hline 3. Támogatási szándék & 14,3 & 2,6 & 13,6 & 1,9 & 0,9 & 0,4 & 12,5 \\
\hline 4. A természet élvezete & 17 & 2,9 & 18,1 & 2,6 & $-1,1$ & 0,3 & 12,5 \\
\hline $\begin{array}{l}\text { 5. Takarékosság az } \\
\text { erőforrásokkal }\end{array}$ & 16,3 & 2,5 & 16,6 & 2,7 & $-0,3$ & 0,7 & 12,5 \\
\hline Teljes ENV skála & 69 & 6,9 & 77,9 & 10,7 & $-2,5$ & 0,02 & 62,5 \\
\hline
\end{tabular}

A két mérés között egyedül a támogatási szándékot mérő alskálán elért értékek csökkentek, de ez a csökkenés statisztikailag nem tekinthető szignifikánsnak. Az összes többi skálán az attitüdértékek növekedése figyelhető meg, de szignifikáns növekedésről a páros tpróba eredményei alapján csak a használat faktor esetében $(\mathrm{t}=-3,6 \mathrm{p}=0,003)$, az emberiség elsöbbsége alskála esetében ( $\mathrm{t}=-5,2 \mathrm{p}=0,001)$ és a teljes $E N V$ skála értékei esetében $(\mathrm{t}=-2,5$ $\mathrm{p}=0,02)$ beszélhetünk (13. ábra).

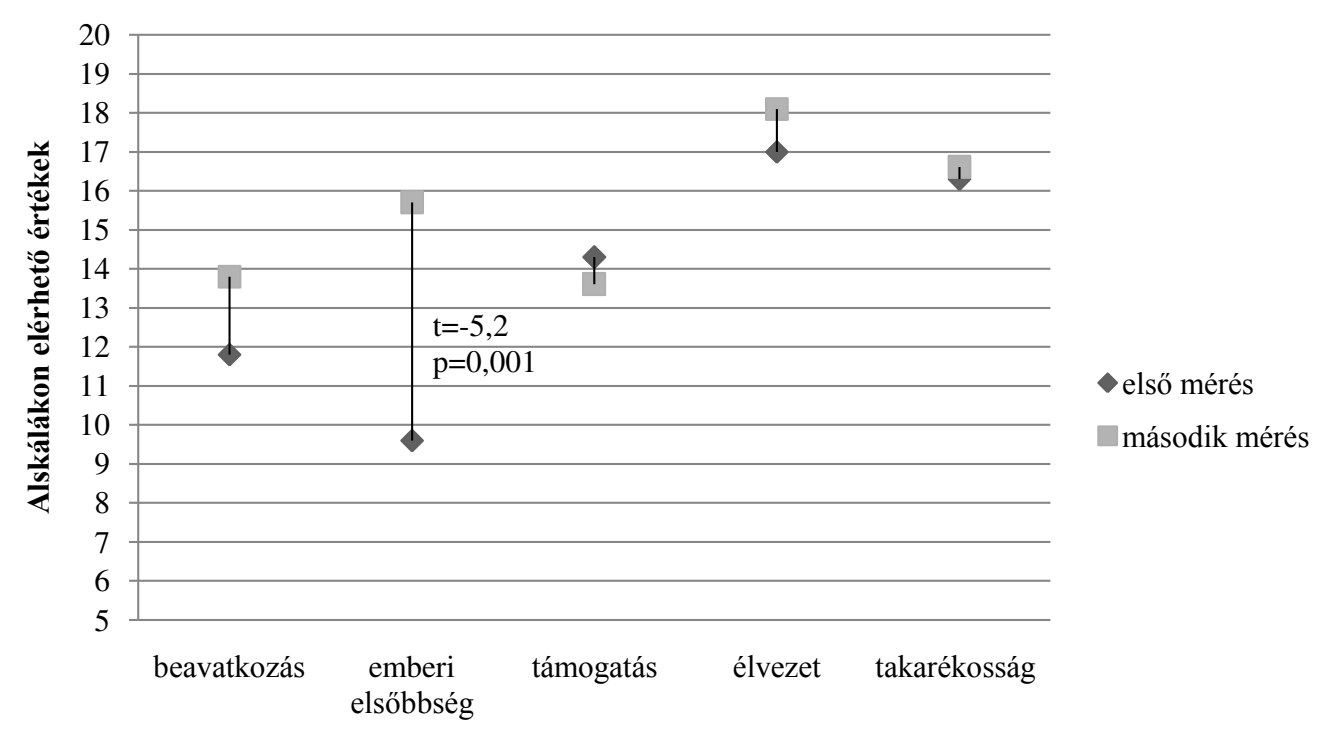

Alskálák

13. ábra: Az ENV skálával mért értékek alakulása a két mérés között a kísérleti csoportban

Az eredmények alapján a $H 1 / a$ hipotézisben foglalt állítást, hogy a kísérleti csoport eredményei növekednek a programban való részvételt követően, csak ennek a három skálának az eredményei igazolták, a többi ENV alskála eredményei nem. A $H 1 / c$ hipotézis is megdőlt már itt, az első skála eredményeinek elemzése során, mivel volt olyan ENV alskála, ahol nem növekedtek az attitüdértékek, tehát ezek után nem beszélhetünk egyöntetü növekedésről mindhárom (ENV, RevNEP, CHEAKS) skálán. Az eredmény abból a szempontból viszont 
biztató, hogy az első mérés során három negatív értékeket jelző skálából kettőnél is jelentős növekedés tapasztalható az attitüdértékek tekintetében.

A kontrollcsoportban ( $\mathrm{N}=119)$ az ENV skála segítségével elvégzett első mérés során a beavatkozás a természetbe és az emberiség elsőbbsége alskálákon mutatható ki negatív eredmény. Megvizsgáltam, hogy melyek azok az itemek az egyes alskálákon belül, ahol a vizsgált hallgatók alacsony értékeket produkáltak. Kiderült, hogy két olyan item van, amelynél a válaszok az itemenkénti semleges, 3-as érték alá esnek. Az „Egy igazi természetjáró gyönyörü és ritka növényeket hoz magával haza a kirándulásról” kérdésnél mindössze 1,57-es volt az adott válaszok átlagértéke. A kérdés fordított irányban lett feltéve, és az eredmények értékelését megelőzően visszafordítottam a pontszámokat. Vagyis a kapott értékek nem a fordított itemnek tulajdoníthatóak, hanem a hallgatók valóban úgy vélik, hogy a ritka növényeket össze lehet gyüjteni. A „,Jobban tetszik egy jól ápolt pázsit, mint egy mezö, ahol össze-vissza nönek a virágok" tartalmú item esetében 2,64 átlagpontot mértem. A hallgatók ennek alapján az ember által rendezett környezetet szebbnek ítélik meg, mint a természet rendjét.

Az emberiség elsőbbsége alskála esetében két olyan kérdés is volt, ahol a hallgatók negatív attitüdértéket produkáltak. A „Fontos, hogy autópályákat és kerülőutakat épitsünk, ezért megéri eltávolitani az erdőket és mezőket” item esetében mindössze 1,5 átlagpontot értek el a hallgatók a 3-as, semleges értékhez képest. Vagyis valóban fontosabbnak tartják az autóutak építését, mint a környezet megőrzését. A „,Mivel a szúnyogok tavakban fejlödnek ki, jobb lenne lecsapolni ezeket” tartalmú itemnél 2,07 átlagpontot mértem. Ezek szerint a szúnyogok jelenlétét olyan szinten ártalmasnak találják a hallgatók, hogy szerintük megéri emiatt lecsapolni az élőhelyüket jelentő tavakat.

Az alskála további két itemje esetében semleges attitüdértéket mértem a kísérleti csoportban. Mind a „Hogy az embereknek legyen mit enniük, a természetet háttérbe kell szorítani, hogy például gabonát termeszthessünk”, mind pedig „A strandokat meg kellene tisztítani a hínártól" item esetében 3-as átlagértéket értek el a hallgatók.

A beavatkozás a természetbe és az emberiség elsőbbsége alskálánál a kontrollcsoport is negatív értékeket produkált az első mérésnél. Ez a csoport azonban más itemek esetében bizonyult gyengébbnek, mint a kísérleti csoport. A kontrollcsoportban a beavatkozás alskálánál a „,Gondozatlannak néz ki, ha fü és gaz nö a járda kövei közt” (átlagérték: 2,34) és „A gyomokat ki kell irtani, mert akadályozzák a hasznos növények és a dísznövények növekedését" (átlagérték: 2,46) itemek voltak azok, ahol a hallgatók nem érték el a semleges, 3-as értéket. Az elsöbbség alskálánál pedig a kísérleti csoport véleményéhez hasonlóan az autópályákkal kapcsolatos kérdésben (átlagérték: 2,42), valamint a „Hogy az embereknek legyen mit enniük, a természetet háttérbe kell szorítani, hogy például gabonát termeszthessünk" itemek esetében mértem a hallgatóknál negatív irányú hozzáállást. A beavatkozás alskálánál a második mérésnél is negatív eredményt kaptunk a kontrollcsoportban. Itt a „Gondozatlannak néz ki, ha fü és gaz nö a járda kövei közt” item esetében volt negatív a hallgatók attitüdje (átlagérték: 2,83).

A többi alskála esetében növekedés tapasztalható mindkét csoport esetében, amely növekedés a támogatási szándék alskála kivételével szignifikánsnak tekinthető a páros t-próba eredményei alapján (21. táblázat). A H2-es hipotézis tehát nem bizonyítható minden ENV alskálára vonatkozóan. 
21. táblázat: $A z$ ENV skálával mért értékek a kontrollcsoportban

\begin{tabular}{|c|c|c|c|c|c|c|c|}
\hline \multirow[t]{2}{*}{ alskálák } & \multicolumn{2}{|c|}{ első mérés } & \multicolumn{2}{|c|}{ második mérés } & \multicolumn{2}{|c|}{$\begin{array}{c}\text { változás } \\
\text { (páros t-próba) }\end{array}$} & \multirow{2}{*}{$\begin{array}{l}\text { semleges } \\
\text { érték }\end{array}$} \\
\hline & átlag & szórás & átlag & szórás & $\mathrm{t}$ & $p$ & \\
\hline Használat-faktor & 24,4 & 3,6 & 25,4 & 4,3 & $-1,8$ & 0,06 & 24 \\
\hline 1. Beavatkozás a természetbe & 12,3 & 2,6 & 12,2 & 3,2 & 0,2 & 0,8 & 12,5 \\
\hline 2. Az emberiség elsőbbsége & 12,1 & 2,2 & 13,2 & 2,8 & $-3,3$ & 0,001 & 12,5 \\
\hline Megőrzés-faktor & 44,9 & 5,8 & 46,9 & 7,9 & $-2,7$ & 0,008 & 36 \\
\hline 3. Támogatási szándék & 14,4 & 2,9 & 14,6 & 3,4 & $-0,6$ & 0,5 & 12,5 \\
\hline 4. A természet élvezete & 15,8 & 2,6 & 16,5 & 3 & $-2,6$ & 0,008 & 12,5 \\
\hline $\begin{array}{l}\text { 5. Takarékosság az } \\
\text { erőforrásokkal }\end{array}$ & 14,7 & 2,8 & 15,7 & 3,2 & $-2,7$ & 0,008 & 12,5 \\
\hline Teljes ENV skála & 69,4 & 6,9 & 72,3 & 9,6 & $-3,1$ & 0,002 & 62,5 \\
\hline
\end{tabular}

A két csoportnak a második mérés során elért értékei alapján elmondható, hogy a használat faktor, az emberiség elsöbbsége alskála, valamint a teljes ENV skála esetében szignifikánsan jobb eredményt értek el a programban részt vevő hallgatók, mint a kontrollcsoport tagjai (14. ábra). A többi alskálánál azonban nem mutatható ki jelentős változás (22. táblázat).

22. táblázat: A kísérleti és a kontrollcsoport ENV skálával mért értékeinek összehasonlítása

\begin{tabular}{|c|c|c|c|c|c|c|c|}
\hline \multirow[t]{2}{*}{ alskálák } & \multicolumn{2}{|c|}{ kísérleti csoport } & \multicolumn{2}{|c|}{ kontrollcsoport } & \multicolumn{2}{|c|}{$\begin{array}{c}\text { változás } \\
\text { (kétmintás t-próba) }\end{array}$} & \multirow{2}{*}{$\begin{array}{c}\text { semleges } \\
\text { érték }\end{array}$} \\
\hline & átlag & szórás & átlag & szórás & $\mathrm{t}$ & $p$ & \\
\hline Használat-faktor & 29,5 & 5,9 & 25,4 & 4,3 & $-2,5$ & 0,02 & 24 \\
\hline 1. Beavatkozás a természetbe & 13,8 & 3,8 & 12,2 & 3,2 & $-1,7$ & 0,08 & 12,5 \\
\hline 2. Az emberiség elsőbbsége & 15,7 & 2,7 & 13,2 & 2,8 & $-3,1$ & 0,002 & 12,5 \\
\hline Megőrzés-faktor & 48,3 & 6,3 & 46,9 & 7,9 & $-0,6$ & 0,5 & 36 \\
\hline 3. Támogatási szándék & 13,6 & 1,9 & 14,6 & 3,4 & 1,6 & 0,1 & 12,5 \\
\hline 4. A természet élvezete & 18,1 & 2,6 & 16,5 & 3 & $-1,8$ & 0,06 & 12,5 \\
\hline $\begin{array}{l}\text { 5. Takarékosság az } \\
\text { erőforrásokkal }\end{array}$ & 16,6 & 2,7 & 15,7 & 3,2 & $-0,9$ & 0,3 & 12,5 \\
\hline Teljes ENV skála & 77,9 & 10,7 & 72,3 & 9,6 & $-2,02$ & 0,04 & 62,5 \\
\hline
\end{tabular}

Az ENV skála értékei alapján nem tudtam teljes mértékben alátámasztani a $H 1 / b$ hipotézisben foglaltakat, amely szerint a környezeti nevelési programban részt vevő tanulók környezettudatos magatartásának értéke magasabb lesz a második mérés során a kontrollcsoportban mért eredményekhez viszonyítva. 


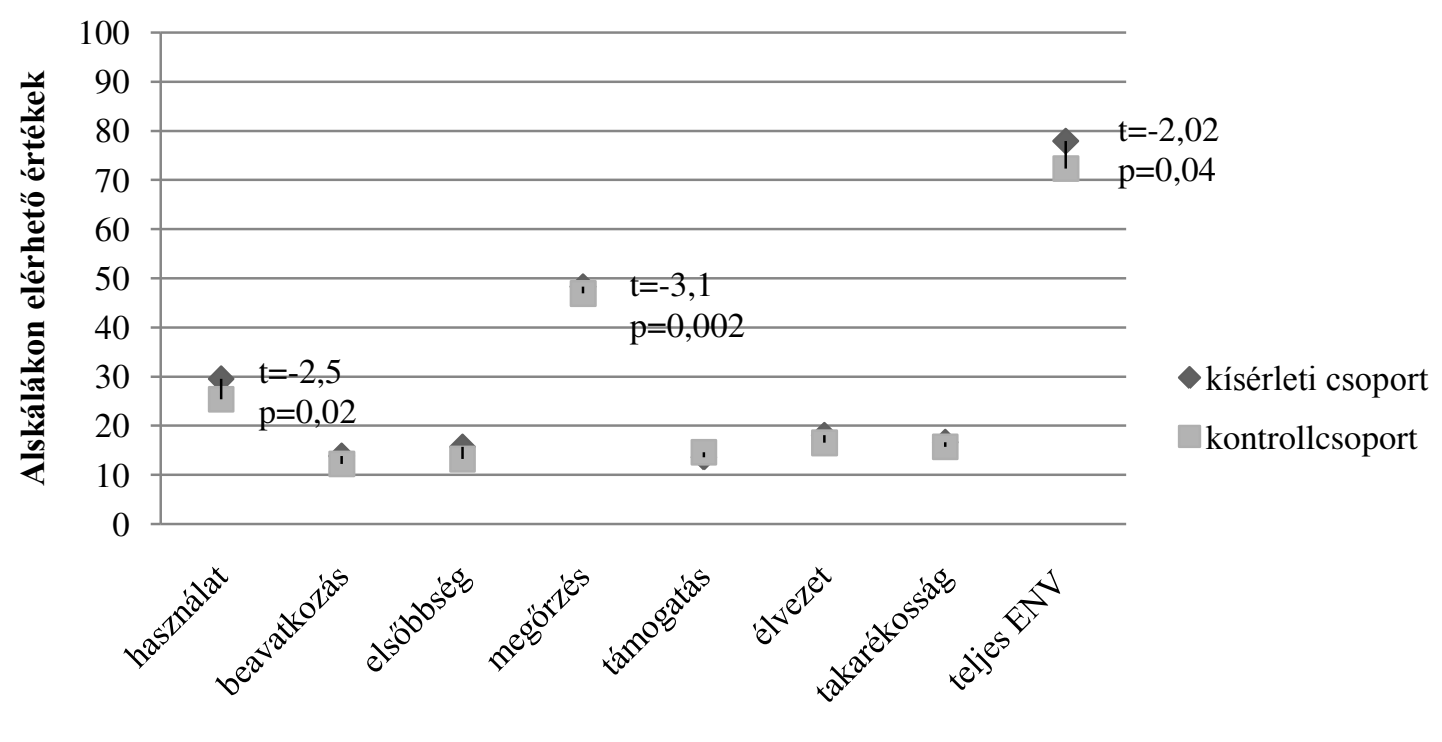

Alskálák

14. ábra: Az ENV skálával mért értékek alakulása a második mérés során a két csoport tekintetében

\subsubsection{A RevNEP skálával mért attitüdértékek alakulása}

A kísérleti csoport $(\mathrm{N}=14)$ a RevNEP skála anti-emberközpontúság alskálája kivételével minden más alskálán és a teljes skála átlagát tekintve is pozitív attitüdértéket ért el már az első mérés alkalmával is. Az anti-emberközpontúság alskála esetében azonban a három itemből kettőben is negatív attitüdöt mértem a kísérleti csoport hallgatóinak körében. $\mathrm{Az}$ „Embereknek joga van olyanná változtatni a természetet, ahogy az nekik a legjobban megfelel” tartalmú itemnél 2,36 átlagpontot, „Az embert arra teremtették, hogy uralkodjon a természet többi része felett” itemnél pedig 1,79 átlagpontot értek el a hallgatók a 3-as, semleges értékhez képest (23. táblázat).

23. táblázat: A RevNEP skálával mért értékek a kísérleti csoportban

\begin{tabular}{lcccccccc}
\hline \multicolumn{1}{c}{ alskálák } & \multicolumn{2}{c}{ első mérés } & \multicolumn{2}{c}{ második mérés } & \multicolumn{2}{c}{ változás } \\
& átlag & szórós & átlag & szórás & t & $p$ & $\begin{array}{c}\text { semleges } \\
\text { érték }\end{array}$ \\
\hline A növekedés korlátai & 11,9 & 1,9 & 9,9 & 1,5 & 2,5 & 0,02 \\
Anti-emberközpontúság & 8,6 & 1,8 & 14 & 1,1 & $-9,1$ & 0,001 & \\
A természet egyensúlyának törékenysége & 10,5 & 2,1 & 11,9 & 1,1 & $-1,8$ & 0,08 & $\mathbf{9}$ \\
Az emberi kiváltság elutasítása & 9,9 & 1,5 & 10,7 & 1,9 & $-1,1$ & 0,2 & \\
Egy ökológiai válság lehetösége & 11,5 & 1,8 & 12,3 & 1,9 & $-1,1$ & 0,3 & \\
\hline Teljes RevNEP skála & 52,5 & 4,5 & 58,8 & 5,9 & $-2,7$ & 0,01 & $\mathbf{3 8}$ \\
\hline
\end{tabular}

A második mérés során a növekedés korlátai alskála esetében szignifikáns csökkenés tapasztalható. Ezzel a RevNEP skála esetében is el kell vetni a $H 1 / c$ hipotézist. Ugyanakkor a többi alskála esetében növekedtek az értékek, amelyek viszont a $H 1 / a$ hipotézisben foglaltakat alátámasztják. Ez a növekedés éppen az első méréskor negatív értékü anti-emberközpontúság skálánál volt a legjelentősebb mértékü, itt 8,6 helyett már 14-es átlagpontot értek el a hallgatók az adott skálán maximálisan elérhető 15 pontból $(\mathrm{t}=-9,1 \mathrm{p}=0,001)$. Emellett a növekedés korlátai $(\mathrm{t}=2,5 \mathrm{p}=0,02)$ és a teljes $\operatorname{RevNEP}(-2,7 \mathrm{p}=0,01)$ skálákon megfigyelt 
növekedés tekinthető szignifikánsnak a program végrehajtását követően, a páros t-próba értékei alapján (15. ábra).

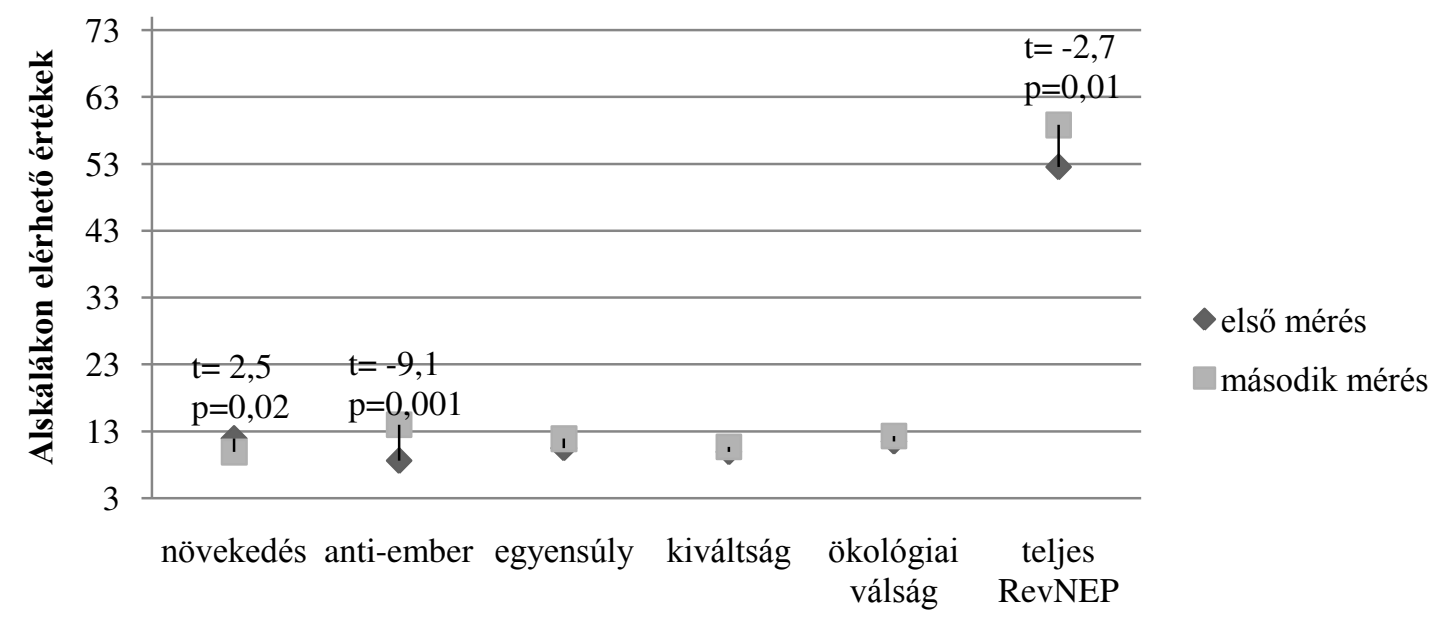

Alskálák

15. ábra: A RevNEP skálával mért értékek alakulása a két mérés között a kísérleti csoportban

A kontrollcsoportban $(\mathrm{N}=119)$ a környezeti nevelési program végrehajtását követő második mérés során egyetlen, az egy ökológiai válság lehetösége alskálán figyelhető meg csökkenés az attitüdértékeket tekintve (24. táblázat). A negatív irányú változás jelentős mértékü ( $\mathrm{t}=-3,2 \mathrm{p}=0,002)$, az első méréskor tapasztalt 9,9-es átlagpontról 8,8-ra csökkent az érték. Ez már negatív attitüdöt jelent, mivel nem éri el a 9-es, semleges értéket, és így ennél a skálánál nem nyert bizonyítást a $H 2$ hipotézis. A többi alskála esetében, a természet egyensúlyának törékenysége skálát kivéve, ahol a változás statisztikai szempontból nem tekinthető jelentősnek, szignifikánsan növekedtek a mért értékek. A kontrollcsoportban tehát a növekedés korlátai, az anti-emberközpontúság, az egy ökológiai válság lehetösége és a teljes RevNep skálákon egyaránt megfigyelhető egy jelentős mértékü növekedés az attitüdértékek tekintetében a második mérés során. Ez a változás nem magyarázható a programban történö részvétellel, tehát más tényezők is befolyásolják a tanítóképzős hallgatók attitüdértékeinek alakulását, ami a $H 3$ hipotézist látszik alátámasztani.

24. táblázat: A RevNEP skálával mért értékek a kontrollcsoportban

\begin{tabular}{|c|c|c|c|c|c|c|c|}
\hline \multirow[t]{2}{*}{ alskálák } & \multicolumn{2}{|c|}{ első mérés } & \multicolumn{2}{|c|}{ második mérés } & \multicolumn{2}{|c|}{$\begin{array}{c}\text { változás } \\
\text { (páros t-próba) }\end{array}$} & \multirow{2}{*}{$\begin{array}{c}\text { semleges } \\
\text { érték }\end{array}$} \\
\hline & átlag & szórás & átlag & szórás & $\mathrm{t}$ & $p$ & \\
\hline A növekedés korlátai & 9,8 & 2,7 & 10,4 & 2,1 & $-2,3$ & 0,02 & \\
\hline Anti-emberközpontúság & 9,9 & 2,3 & 10,8 & 2,6 & $-2,8$ & 0,005 & \\
\hline A természet egyensúlyának törékenysége & 9,5 & 2,5 & 9,6 & 2,8 & $-0,6$ & 0,5 & 9 \\
\hline Az emberi kiváltság elutasítása & 8,8 & 2,1 & 9,7 & 2,1 & $-3,2$ & 0,002 & \\
\hline Egy ökológiai válság lehetősége & 11,5 & 2,7 & 12,2 & 2,4 & $-2,3$ & 0,01 & \\
\hline Teljes RevNEP skála & 49,5 & 5,4 & 52,9 & 6,8 & $-4,8$ & 0,001 & 38 \\
\hline
\end{tabular}


A két csoport eredményeinek összehasonlítása során (16. ábra) megfigyelhető, hogy a növekedés korlátai és az egy ökológiai válság lehetősége alskálák kivételével a többi skálán szignifikánsan magasabb átlagértéket értek el a kísérleti csoportban részt vevő hallgatók a kontrollcsoporthoz képest a második mérés során. Az adatokat a 25. táblázat foglalja össze.

25. táblázat: A kísérleti és a kontrollcsoport RevNEP skálával mért értékeinek összehasonlítása

\begin{tabular}{|c|c|c|c|c|c|c|c|}
\hline \multirow{2}{*}{ alskálák } & \multicolumn{2}{|c|}{ kísérleti csoport } & \multicolumn{2}{|c|}{ kontrollcsoport } & \multicolumn{2}{|c|}{$\begin{array}{c}\text { változás } \\
\text { (kétmintás } t \text {-próba) }\end{array}$} & \multirow{2}{*}{$\begin{array}{l}\text { semleges } \\
\text { érték }\end{array}$} \\
\hline & átlag & szórás & átlag & szórás & $\mathrm{t}$ & $p$ & \\
\hline A növekedés korlátai & 9,9 & 1,5 & 10,4 & 2,1 & 0,9 & 0,3 & \\
\hline Anti-emberközpontúság & 14 & 1,1 & 10,8 & 2,6 & $-8,1$ & 0,001 & \\
\hline $\begin{array}{l}\text { A természet egyensúlyának } \\
\text { törékenysége }\end{array}$ & 11,9 & 1,1 & 9,6 & 2,8 & $-2,8$ & 0,005 & 9 \\
\hline Az emberi kiváltság elutasítása & 10,7 & 1,9 & 9,7 & 2,1 & $-1,6$ & 0,09 & \\
\hline $\begin{array}{l}\text { Egy ökológiai válság } \\
\text { lehetősége }\end{array}$ & 12,3 & 1,9 & 12,2 & 2,4 & $-0,1$ & 0,8 & \\
\hline Teljes RevNEP skála & 58,8 & 5,9 & 52,9 & 6,8 & $-3,1$ & 0,002 & 38 \\
\hline
\end{tabular}

Az eredmények alapján kijelenthető, hogy a RevNEP skála segítségével mért értékek többnyire a program hatékonyságát igazolják a tanítóképzős hallgatók szempontjából, igazolva ezzel a $H 1 / b$ hipotézisben foglaltakat.

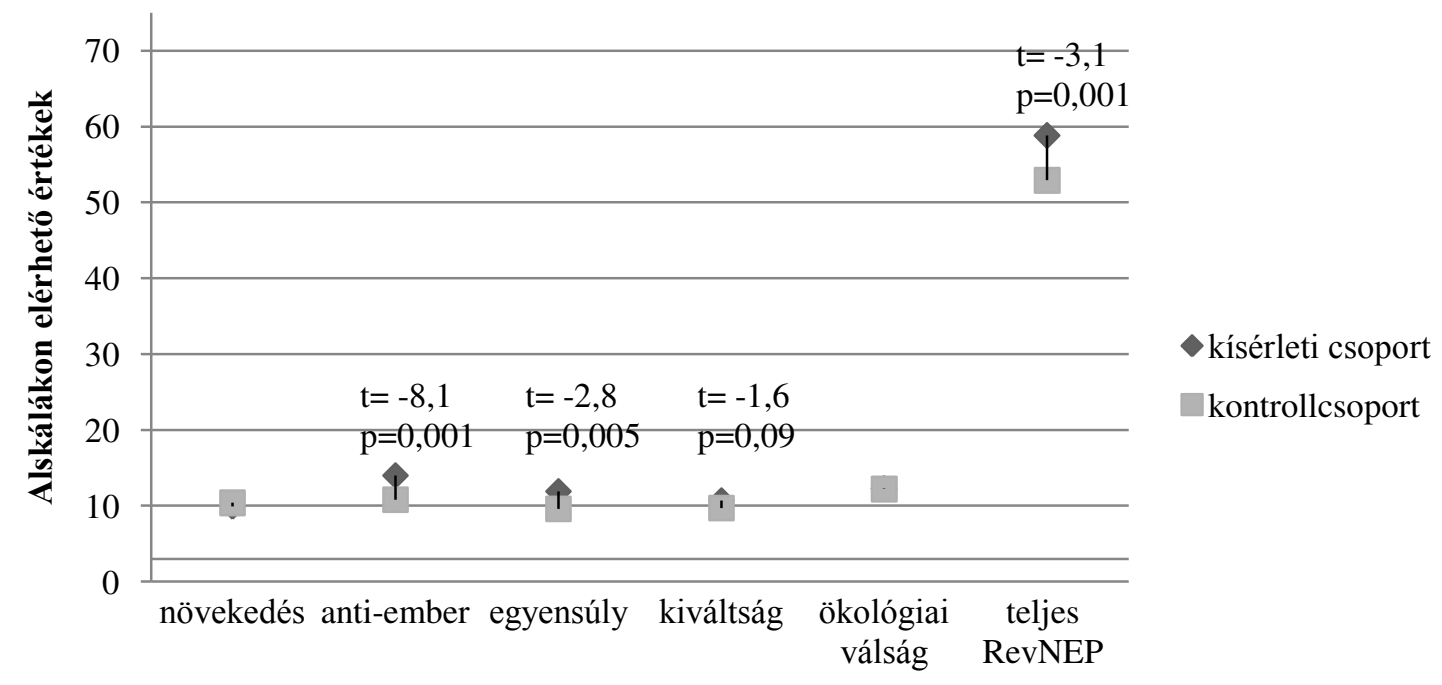

Alskálák

16. ábra: A RevNEP skálával mért értékek alakulása a második mérés során a két csoport tekintetében 


\subsubsection{A CHEAKS skálával mért attitüdértékek alakulása}

A kísérleti csoport ( $\mathrm{N}=14)$ a CHEAKS skála alapján már az első mérés során is pozitív értékeket ért el minden alskálán és a teljes CHEAKS skála átlagát tekintve is (26. táblázat).

26. táblázat: A CHEAKS skálával mért értékek a kísérleti csoportban

\begin{tabular}{|c|c|c|c|c|c|c|c|}
\hline \multirow[t]{2}{*}{ alskálák } & \multicolumn{2}{|c|}{ első mérés } & \multicolumn{2}{|c|}{ második mérés } & \multicolumn{2}{|c|}{$\begin{array}{c}\text { változás } \\
\text { (páros t-próba) }\end{array}$} & \multirow{2}{*}{$\begin{array}{c}\text { semleges } \\
\text { érték }\end{array}$} \\
\hline & átlag & szórás & átlag & szórás & $\mathrm{t}$ & $p$ & \\
\hline általános környezeti kérdések alskála & 15,4 & 1,3 & 15,8 & 2,9 & $-0,5$ & 0,6 & \multirow{6}{*}{12} \\
\hline növények alskála & 14,5 & 3,5 & 16,5 & 2,6 & $-1,5$ & 0,1 & \\
\hline állatok alskála & 14,2 & 3,1 & 16,9 & 1,9 & $-3,8$ & 0,002 & \\
\hline víz alskála & 15,3 & 3,4 & 17,6 & 2,8 & $-3,1$ & 0,007 & \\
\hline hulladék alskála & 14 & 2,9 & 16,6 & 2,1 & $-3,1$ & 0,008 & \\
\hline energia alskála & 14,1 & 2,5 & 18,4 & 2,2 & $-6,1$ & 0,001 & \\
\hline érzelem faktor & 46,4 & 6,1 & 51,8 & 5,8 & $-3,9$ & 0,002 & \multirow{2}{*}{36} \\
\hline viselkedés faktor & 41,2 & 6,7 & 50,1 & 5,9 & $-5,4$ & 0,001 & \\
\hline Teljes CHEAKS skála & 87,6 & 10,9 & 102 & 11,1 & $-6,1$ & 0,001 & 72 \\
\hline
\end{tabular}

A második mérésre minden érték növekedett (17. ábra), és az általános kérdések, illetve a növények alskála kivételével ez a növekedés statisztikailag is relevánsnak tekinthető, igazolva ezzel a $H 1 / a$ hipotézisben foglalt állítást.

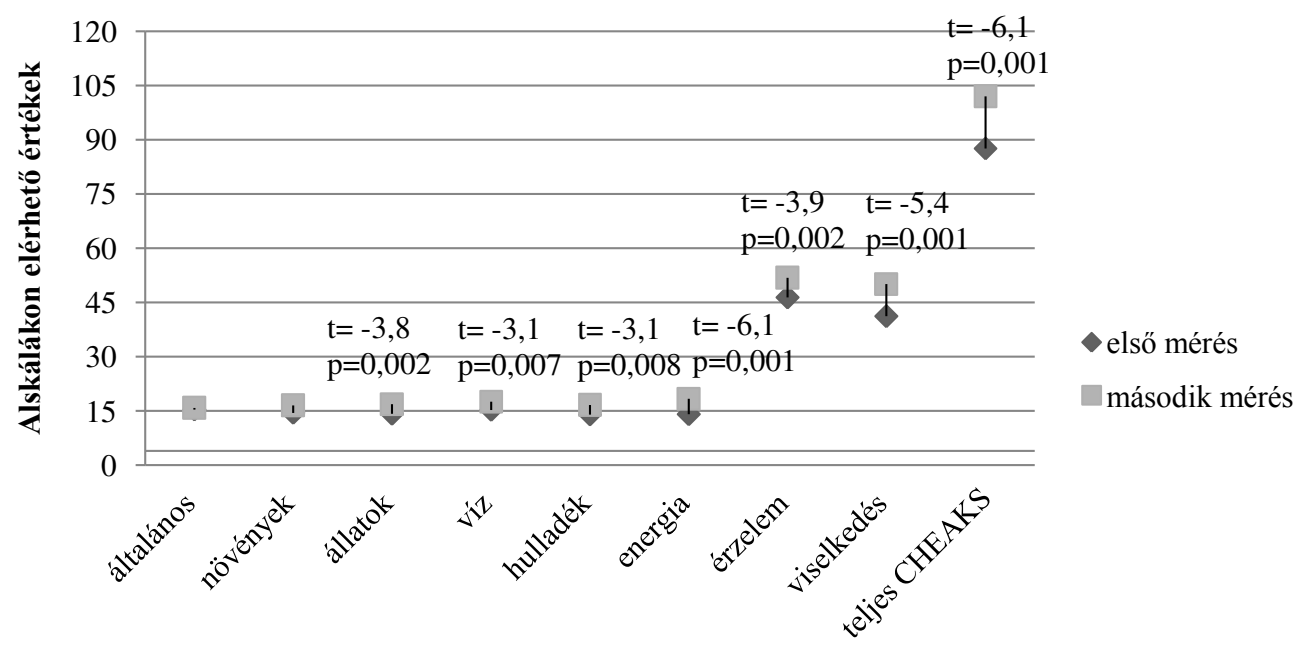

Alskálák

17. ábra: A CHEAKS skálával mért értékek alakulása a két mérés között a kísérleti csoportban

A kontrollcsoport $(\mathrm{N}=119)$ a növények alskála kivételével pozitív attitüdértékekkel rendelkezik a többi alskála által vizsgált témákat illetően. A növények alskálánál két olyan item is volt, ahol negatív értéket értek el a hallgatók. Az „Amikor egy erdőben járok, figyelem az ott élö növényeket” itemnél 2,92 átlagpontot, a „Bárhol kirándulok, gyakran viszek haza virágot” itemnél pedig 2,39 átlagpontot értek el a hallgatók. A másik két, növények 
alskálához tartozó itemnél is csak alig haladja meg a 3-as, semleges attitüdértéket a hallgatók válasza (27. táblázat).

27. táblázat: A CHEAKS skálával mért értékek a kontrollcsoportban

\begin{tabular}{|c|c|c|c|c|c|c|c|}
\hline \multirow{2}{*}{ alskálák } & \multicolumn{2}{|c|}{ első mérés } & \multicolumn{2}{|c|}{ második mérés } & \multicolumn{2}{|c|}{$\begin{array}{c}\text { változás } \\
\text { (páros t-próba) }\end{array}$} & \multirow{2}{*}{$\begin{array}{l}\text { semleges } \\
\text { érték }\end{array}$} \\
\hline & átlag & szórás & átlag & szórás & $\mathrm{t}$ & $p$ & \\
\hline általános környezeti kérdések alskála & 15,3 & 2,4 & 15,2 & 2,5 & 0,5 & 0,5 & \multirow{6}{*}{12} \\
\hline növények alskála & 11,5 & 5,2 & 13,6 & 5,3 & $-3,8$ & 0,001 & \\
\hline állatok alskála & 15,3 & 2,2 & 15,2 & 2,7 & 0,3 & 0,7 & \\
\hline víz alskála & 16,9 & 2,4 & 16,7 & 2,7 & 0,5 & 0,6 & \\
\hline hulladék alskála & 12,7 & 2,4 & 14,7 & 3,1 & $-5,9$ & 0,001 & \\
\hline energia alskála & 13,5 & 3,5 & 14,3 & 3,2 & $-2,1$ & 0,03 & \\
\hline érzelem faktor & 43,2 & 8,2 & 46,2 & 8,7 & $-3,1$ & 0,002 & \multirow{2}{*}{36} \\
\hline viselkedés faktor & 42,2 & 8,2 & 43,6 & 5,4 & $-2,5$ & 0,01 & \\
\hline Teljes CHEAKS skála & 85,5 & 12,4 & 89,9 & 12,8 & $-3,3$ & 0,001 & 72 \\
\hline
\end{tabular}

Mivel van negatív attitüdértéket jelző alskála is, így a H2-es hipotézis nem tekinthető bizonyítottnak. Három skála esetében (általános kérdések, állatok, víz) a második méréskor értékcsökkenés figyelhető meg, de egyik se tekinthető statisztikailag jelentős változásnak. Ugyanakkor az összes többi alskálán és a teljes skálán megfigyelhető növekedés már szignifikánsnak mondható a páros t-próba eredményei alapján.

A két csoport értékeit összehasonlítva (18. ábra) megállapítható, hogy a kísérleti csoport által elért átlagértékek minden esetben magasabbak a második mérés során, mint a kontrollcsoportban mért eredmények (28. táblázat). A pozitív irányú változás az általános kérdéseket vizsgáló alskála és a víz alskála kivételével minden egyéb skálán szignifikáns a kétmintás t-próba alapján. Az eredmények alátámasztják a $H 1 / b$ hipotézisben foglalt állítást.

28. táblázat: A kísérleti és a kontrollcsoport CHEAKS skálával mért értékeinek összehasonlítása

\begin{tabular}{|c|c|c|c|c|c|c|c|}
\hline \multirow{2}{*}{ alskálák } & \multicolumn{2}{|c|}{ kísérleti csoport } & \multicolumn{2}{|c|}{ kontrollcsoport } & \multicolumn{2}{|c|}{$\begin{array}{c}\text { változás } \\
\text { (kétmintás t-próba) }\end{array}$} & \multirow{2}{*}{$\begin{array}{c}\text { semleges } \\
\text { érték }\end{array}$} \\
\hline & átlag & szórás & átlag & szórás & $\mathrm{t}$ & $p$ & \\
\hline általános környezeti kérdések alskála & 15,8 & 2,9 & 15,2 & 2,5 & $-0,8$ & 0,3 & \multirow{6}{*}{12} \\
\hline növények alskála & 16,5 & 2,6 & 13,6 & 5,3 & $-3,2$ & 0,003 & \\
\hline állatok alskála & 16,9 & 1,9 & 15,2 & 2,7 & $-2,9$ & 0,008 & \\
\hline víz alskála & 17,6 & 2,8 & 16,7 & 2,7 & $-1,1$ & 0,2 & \\
\hline hulladék alskála & 16,6 & 2,1 & 14,7 & 3,1 & $-2,2$ & 0,02 & \\
\hline energia alskála & 18,4 & 2,2 & 14,3 & 3,2 & $-6,2$ & 0,001 & \\
\hline érzelem faktor & 51,8 & 5,8 & 46,2 & 8,7 & $-3,2$ & 0,004 & \multirow{2}{*}{36} \\
\hline viselkedés faktor & 50,1 & 5,9 & 43,6 & 5,4 & $-4,1$ & 0,001 & \\
\hline Teljes CHEAKS skála & 102 & 11,1 & 89,9 & 12,8 & $-3,3$ & 0,001 & 72 \\
\hline
\end{tabular}




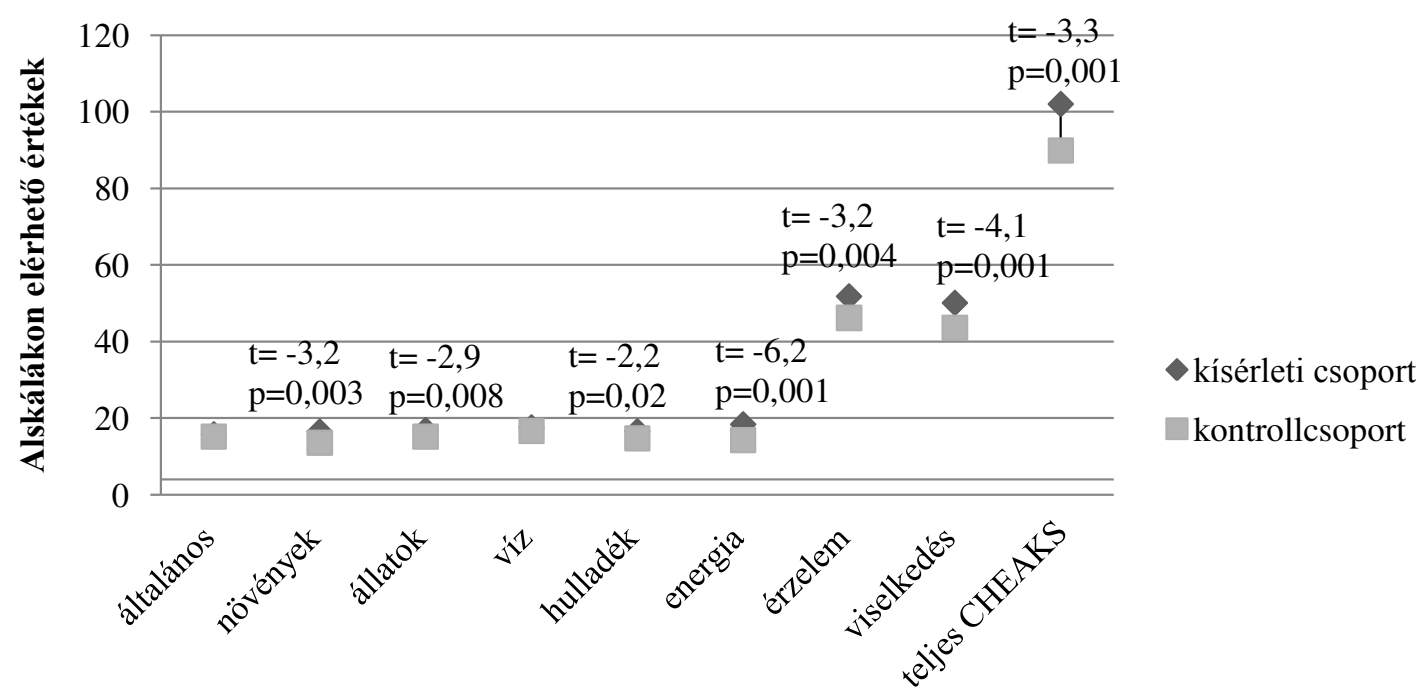

Alskálák

18. ábra: A CHEAKS skálával mért értékek alakulása a második mérés során a két csoport tekintetében

\subsubsection{Az attitüdértékek alakulása a teljes attitüdmérő skála átlagát tekintve}

Az összes, 59 attitüdmérő kérdésre adott válaszok átlagértékét tekintve az első mérésnél a kísérleti csoport $(\mathrm{N}=14)$ eleve pozitív értéket ért el, 209,2 átlagpontot. A programot követően elvégzett második mérés során az attitűdértékek növekedése volt tapasztalható, ekkor már 238,8 átlagpontot értek el a hallgatók. A növekedés szignifikánsnak tekinthető a páros t-próba értékei alapján ( $\mathrm{t}=-5,2 \mathrm{p}=0,001)$. Ez az eredmény a $H 1 / a$ hipotézist igazolja.

A kontrollcsoport $(\mathrm{N}=119)$ első méréskor megállapított attitüdértéke szintén pozitív, ők összesen 204,4 pontot értek el, és ebben a csoportban is jelentős $(t=-5,4$ p=0,001) értéknövekedés tapasztalható a második mérés során, ahol már 215,2 pontot mérhettünk (29. táblázat). Mindez a H2-es hipotézisben foglaltakat erösíti.

29. táblázat: Az attitüdértékek alakulása a teljes skála átlagát tekintve

\begin{tabular}{cccccccc}
\hline \multirow{3}{*}{ csoport } & \multicolumn{3}{c}{ első mérés } & \multicolumn{3}{c}{ második mérés } & \multicolumn{3}{c}{ változás } \\
& átlag & szórór & átlag & szórás & $\mathrm{t}$ & $p$ & semleges érték \\
\hline kísérleti & 209,2 & 17,1 & 238,8 & 21,5 & $-5,2$ & 0,001 & \multirow{2}{*}{$\mathbf{1 1 8}$} \\
kontroll & 204,4 & 18,7 & 215,2 & 22 & $-5,4$ & 0,001 & \\
\hline
\end{tabular}

A két csoport eredményei között a második mérés során tapasztalt eltérések jelentősnek mondhatóak a kísérleti csoport javára a kétmintás t-próba értékei alapján $(\mathrm{t}=-3,7$ $\mathrm{p}=0,001)$. A kísérleti csoport által elért magasabb attitüdértékek tehát a program hatékonyságára engednek utalni a $H 1$ hipotézisben megfogalmazott állítás szerint. 


\subsubsection{A háttértényezők vizsgálata}

\subsubsection{A kísérleti csoport háttértényezöinek és környezeti attitüdjének összefüggései}

Az egyes háttérváltozókkal kapcsolatos eredményeket és az első mérés során az egyes alskálákon, valamint a teljes skálán elért attitüdértékeket a Pearson-féle korrelációs vizsgálat (Bonett és Wright, 2000; Hauke és Kossowski, 2011) segítségével vetettem össze.

A kísérleti csoport esetében az évfolyam változóval nem végeztem el a vizsgálatot, mivel a csoport tagjai mindannyian a negyedik évfolyamról kerültek ki. Ugyanígy a nemek szerinti összefüggéseket sem vizsgáltam, mivel a kísérleti csoportban mindössze egy fiú van. A szülök iskolai végzettsége, valamint a család anyagi helyzete tekintetében nem volt kimutatható az összefüggés egyik alskála eredményeivel sem.

A többi összefüggést tekintve az ENV skála esetében a tanulmányi átlag bír erős befolyásoló hatással a beavatkozás a természetbe $(\mathrm{r}=0,56 \mathrm{p}=0,03)$, valamint a használat alskálán $(\mathrm{r}=0,58 \mathrm{p}=0,02)$ elért eredményekre. Mindkét esetben pozitív korreláció figyelhető meg az értékek között (30. táblázat).

30. táblázat: A kisérleti csoport háttérváltozóinak összefüggése az ENV skálán elért attitüdértékekkel

\begin{tabular}{|c|c|c|c|c|c|c|}
\hline alskálák & $\begin{array}{l}\text { kedvenc } \\
\text { tantárgy }\end{array}$ & $\begin{array}{c}\text { tanulmányi } \\
\text { átlag }\end{array}$ & lakóhely & $\begin{array}{c}\text { szülők } \\
\text { iskolai } \\
\text { végzettsége }\end{array}$ & $\begin{array}{c}\text { egy } \\
\text { háztartásban } \\
\text { élők száma }\end{array}$ & $\begin{array}{c}\text { család } \\
\text { anyagi } \\
\text { helyzete }\end{array}$ \\
\hline $\begin{array}{l}\text { Beavatkozás a } \\
\text { természetbe }\end{array}$ & n.s. ${ }^{2}$ & $\begin{array}{l}\mathrm{r}=0,56 \\
\mathrm{p}=0,03\end{array}$ & n.s. & n.s. & n.s. & n.s. \\
\hline Az emberiség elsőbbsége & n.s. & n.s. & n.s. & n.s. & n.s. & n.s. \\
\hline Támogatási szándék & n.s. & n.s. & n.s. & n.s. & n.s. & n.s. \\
\hline A természet élvezete & n.s. & n.s. & n.s. & n.s. & n.s. & n.s. \\
\hline $\begin{array}{l}\text { Takarékosság az } \\
\text { erőforrásokkal }\end{array}$ & n.s. & n.s. & n.s. & n.s. & n.s. & n.s. \\
\hline Használat & n.s. & $\begin{array}{l}r=0,58 \\
p=0,02\end{array}$ & n.s. & n.s. & n.s. & n.s. \\
\hline Megőrzés & n.s. & n.s. & n.s. & n.s. & n.s. & n.s. \\
\hline Teljes skála & n.s. & n.s. & n.s. & n.s. & n.s. & n.s. \\
\hline
\end{tabular}

A RevNEP skálánál az egy háztartásban élők száma a természet egyensúlyának törékenysége alskálán elért eredményekkel $(\mathrm{r}=-0,55 \mathrm{p}=0,04)$, a kedvenc tantárgy az emberi kiváltság elutasítása alskálán elért eredményekkel $(\mathrm{r}=-0,53 \mathrm{p}=0,04)$ áll negatív korrelációban. A lakóhely változó a teljes RevNEP skálán elért eredményeket ( $\mathrm{r}=0,71 \mathrm{p}=0,004)$ befolyásolja erőteljesen (31. táblázat).

\footnotetext{
${ }^{2}$ n.s. = nem szignifikáns
} 
31. táblázat: A kísérleti csoport háttérváltozóinak összefüggése a RevNEP skálán elért attitüdértékekkel

\begin{tabular}{|c|c|c|c|c|c|c|}
\hline alskálák & $\begin{array}{l}\text { kedvenc } \\
\text { tantárgy }\end{array}$ & $\begin{array}{c}\text { tanulmányi } \\
\text { átlag }\end{array}$ & lakóhely & $\begin{array}{c}\text { szülők } \\
\text { iskolai } \\
\text { végzettsége }\end{array}$ & $\begin{array}{c}\text { egy } \\
\text { háztartásban } \\
\text { élők száma } \\
\end{array}$ & $\begin{array}{c}\text { család } \\
\text { anyagi } \\
\text { helyzete }\end{array}$ \\
\hline A növekedés korlátai & n.s. & n.s. & n.s. & n.s. & n.s. & n.s. \\
\hline Anti-emberközpontúság & n.s. & n.s. & n.s. & n.s. & n.s. & n.s. \\
\hline $\begin{array}{l}\text { A természet } \\
\text { egyensúlyának } \\
\text { törékenysége }\end{array}$ & n.s. & n.s. & n.s. & n.s. & $\begin{array}{l}r=-0,55 \\
p=0,04\end{array}$ & n.s. \\
\hline $\begin{array}{l}\text { Az emberi kiváltság } \\
\text { elutasítása }\end{array}$ & $\begin{array}{l}r=-0,53 \\
p=0,04\end{array}$ & n.s. & n.s. & n.s. & n.s. & n.s. \\
\hline $\begin{array}{l}\text { Egy ökológiai válság } \\
\text { lehetősége }\end{array}$ & n.s. & n.s. & n.s. & n.s. & n.s. & n.s. \\
\hline Teljes skála & n.s. & n.s. & $\begin{array}{c}r=0,71 \\
p=0,004\end{array}$ & n.s. & n.s. & n.s. \\
\hline
\end{tabular}

A CHEAKS skálánál az egy háztartásban élők száma negatív korrelációt mutat a hulladék $(\mathrm{r}=-0,56 \mathrm{p}=0,03)$ és az érzelem $(\mathrm{r}=-0,57 \mathrm{p}=0,03)$ alskálákon elért eredményekkel. A kedvenc tantárgy változó az állatok alskálán $(\mathrm{r}=0,56 \mathrm{p}=0,03)$ elért értékeket befolyásolja erősen (32. táblázat).

32. táblázat: A kísérleti csoport háttérváltozóinak összefüggése a CHEAKS skálán elért attitüdértékekkel

\begin{tabular}{lcccccc}
\hline \multicolumn{1}{c}{ alskálák } & $\begin{array}{c}\text { kedvenc } \\
\text { tantárgy }\end{array}$ & $\begin{array}{c}\text { tanulmányi } \\
\text { átlag }\end{array}$ & lakóhely & $\begin{array}{c}\text { szülők } \\
\text { iskolai } \\
\text { végzettsége }\end{array}$ & $\begin{array}{c}\text { egy } \\
\text { háztartásban } \\
\text { élök száma }\end{array}$ & $\begin{array}{c}\text { család } \\
\text { anyagi } \\
\text { helyzete }\end{array}$ \\
\hline Általános & n.s. & n.s. & n.s. & n.s. & n.s. & n.s. \\
Állat & r=0,56 p=0,03 & n.s. & n.s. & n.s. & n.s. & n.s. \\
Növény & n.s. & n.s. & n.s. & n.s. & n.s. & n.s. \\
Víz & n.s. & n.s. & n.s. & n.s. & n.s. & n.s. \\
Hulladék & n.s. & n.s. & n.s. & n.s. & r=-0,56 p=0,03 & n.s. \\
Energia & n.s. & n.s. & n.s. & n.s. & n.s. & n.s. \\
Viselkedés & n.s. & n.s. & n.s. & n.s. & n.s. & n.s. \\
Érzelem & n.s. & n.s. & n.s. & n.s. & r=-0,57 p=0,03 & n.s. \\
Teljes skála & n.s. & n.s. & n.s. & n.s. & n.s. & n.s. \\
\hline
\end{tabular}

\subsubsection{A kontrollcsoport háttértényezöinek és környezeti attitüdjének összefüggései}

A kontrollcsoport esetében a kedvenc tantárgy és a lakóhely változók nem állnak kölcsönhatásban egyik skála egyetlen alskálájával sem. A többi háttérváltozó viszont befolyásolja egyik vagy másik skála értékének alakulását.

Az évfolyam változó mindhárom skálánál mutatott korrelációt néhány alskálával, vagy akár a teljes skála értékeivel. Az ENV skála esetében (33. táblázat) gyenge összefüggés figyelhető meg az évfolyam és a természetbe történő beavatkozás $(r=0,28 \mathrm{p}=0,002)$ alskála értékeivel, a támogatási szándék alskálával $(\mathrm{r}=0,26 \mathrm{p}=0,004)$, a természet élvezete alskálával $(\mathrm{r}=0,3 \mathrm{p}=0,001)$, a teljes megőrzés skálával $(\mathrm{r}=0,31 \mathrm{p}=0,001)$, valamint a teljes ENV skála $(\mathrm{r}=0,32 \mathrm{p}=0,001)$ értékeivel is. 
33. táblázat: A kontrollcsoport háttérváltozóinak összefüggése az ENV skálán elért attitüdértékekkel

\begin{tabular}{|c|c|c|c|c|c|c|c|}
\hline alskálák & évfolyam & nem & $\begin{array}{c}\text { tanul- } \\
\text { mányi } \\
\text { átlag }\end{array}$ & $\begin{array}{c}\text { apa } \\
\text { isk. } \\
\text { végz. }\end{array}$ & $\begin{array}{l}\text { anya } \\
\text { isk. } \\
\text { végz. }\end{array}$ & $\begin{array}{l}\text { egy házt. } \\
\text { élők } \\
\text { száma }\end{array}$ & $\begin{array}{c}\text { család anyagi } \\
\text { helyzete }\end{array}$ \\
\hline Beavatkozás a természetbe & $\mathrm{r}=0,28 \mathrm{p}=0,002$ & n.s. & $\begin{array}{l}\mathrm{r}=-0,18 \\
\mathrm{p}=0,04\end{array}$ & n.s. & n.s. & n.s. & n.s. \\
\hline Az emberiség elsőbbsége & n.s. & n.s. & n.s. & n.s. & n.s. & n.s. & $\begin{array}{l}r=-0,25 \\
p=0,005\end{array}$ \\
\hline Támogatási szándék & $\mathrm{r}=0,26 \mathrm{p}=0,004$ & n.s. & n.s. & n.s. & n.s. & n.s. & n.s. \\
\hline A természet élvezete & $\mathrm{r}=0,3 \mathrm{p}=0,001$ & n.s. & n.s. & n.s. & n.s. & n.s. & $\mathrm{r}=0,23 \mathrm{p}=0,01$ \\
\hline $\begin{array}{l}\text { Takarékosság az } \\
\text { erőforrásokkal }\end{array}$ & n.s. & n.s. & n.s. & n.s. & n.s. & n.s. & n.s. \\
\hline Használat & n.s. & n.s. & n.s. & n.s. & n.s. & n.s. & n.s. \\
\hline Megőrzés & $\mathrm{r}=0,31 \mathrm{p}=0,001$ & n.s. & n.s. & n.s. & n.s. & n.s. & $\mathrm{r}=0,22 \mathrm{p}=0,01$ \\
\hline Teljes ENV skála & $\mathrm{r}=0,32 \mathrm{p}=0,001$ & n.s. & n.s. & n.s. & n.s. & n.s. & n.s. \\
\hline
\end{tabular}

A RevNEP skála esetében (34. táblázat) az anti-emberközpontúság alskála negatív irányú, gyenge korrelációt mutat $(\mathrm{r}=-0,18 \mathrm{p}=0,04)$, az emberi kiváltság elutasítása alskála $(\mathrm{r}=0,37 \mathrm{p}=0,001)$ és a teljes RevNEP skála $(\mathrm{r}=0,21 \mathrm{p}=0,01)$ esetében pozitív, gyenge korreláció figyelhető meg az évfolyam változóval.

34. táblázat: A kontrollcsoport háttérváltozóinak összefüggése a RevNEP skálán elért attitüdértékekkel

\begin{tabular}{|c|c|c|c|c|c|c|c|}
\hline alskálák & évfolyam & nem & $\begin{array}{l}\text { tanul- } \\
\text { mányi } \\
\text { átlag }\end{array}$ & $\begin{array}{c}\text { apa } \\
\text { isk. } \\
\text { végz. }\end{array}$ & $\begin{array}{c}\text { anya } \\
\text { isk. } \\
\text { végz. }\end{array}$ & $\begin{array}{c}\text { egy } \\
\text { házt. } \\
\text { élők } \\
\text { száma } \\
\end{array}$ & $\begin{array}{c}\text { család } \\
\text { anyagi } \\
\text { helyzete }\end{array}$ \\
\hline A növekedés korlátai & n.s. & n.s. & $\begin{array}{c}\mathrm{r}=0,2 \\
\mathrm{p}=1,13\end{array}$ & n.s. & n.s. & n.s. & n.s. \\
\hline Anti-emberközpontúság & $\mathrm{r}=-0,18 \mathrm{p}=0,04$ & n.s. & n.s. & n.s. & n.s. & $\begin{array}{l}r=-0,18 \\
p=0,04\end{array}$ & n.s. \\
\hline $\begin{array}{l}\text { A természet egyensúlyának } \\
\text { törékenysége }\end{array}$ & n.s. & n.s. & n.s. & $\begin{array}{l}\mathrm{r}=0,19 \\
\mathrm{p}=0,03\end{array}$ & n.s. & $\begin{array}{l}r=0,19 \\
p=0,03\end{array}$ & n.s. \\
\hline $\begin{array}{l}\text { Az emberi kiváltság } \\
\text { elutasítása }\end{array}$ & $\mathrm{r}=0,37 \mathrm{p}=0,001$ & n.s. & n.s. & n.s. & n.s. & n.s. & n.s. \\
\hline $\begin{array}{l}\text { Egy ökológiai válság } \\
\text { lehetősége }\end{array}$ & n.s. & n.s. & $\begin{array}{c}r=0,31 \\
p=0,001\end{array}$ & n.s. & n.s. & $\begin{array}{l}r=-0,2 \\
p=0,02\end{array}$ & $\begin{array}{l}r=-0,29 \\
p=0,001\end{array}$ \\
\hline Teljes Rev NEP skála & $\mathrm{r}=0,21 \mathrm{p}=0,01$ & n.s. & $\begin{array}{c}r=0,33 \\
p=0,001\end{array}$ & n.s. & n.s. & n.s. & n.s. \\
\hline
\end{tabular}

A CHEAKS skálánál (35. táblázat) egyedül az állatokra vonatkozó alskála eredményeit nem befolyásolja, hogy a vizsgált hallgatók melyik évfolyamra járnak. Az általános környezeti kérdések alskála $(\mathrm{r}=0,32 \mathrm{p}=0,001)$, a növények alskála $(\mathrm{r}=0,45 \mathrm{p}=0,001)$, a víz alskála $(\mathrm{r}=0,28 \mathrm{p}=0,002)$, a hulladék alskála $(\mathrm{r}=0,33 \mathrm{p}=0,001)$, az energia alskála $(\mathrm{r}=0,54$ $\mathrm{p}=0,001)$, a viselkedés $(\mathrm{r}=0,53 \mathrm{p}=0,001)$ és érzelem $(\mathrm{r}=0,47 \mathrm{p}=0,001)$ alskálák és a teljes CHEAKS skála $(\mathrm{r}=0,54 \mathrm{p}=0,001)$ esetében egyaránt kimutatható a közepes, illetve erőteljes összefüggés. 
35. táblázat: A kontrollcsoport háttérváltozóinak összefüggése a CHEAKS skálán elért attitüdértékekkel

\begin{tabular}{|c|c|c|c|c|c|c|c|}
\hline alskálák & évfolyam & nem & $\begin{array}{c}\text { tanul- } \\
\text { mányi } \\
\text { átlag }\end{array}$ & $\begin{array}{c}\text { apa } \\
\text { isk. } \\
\text { végz. }\end{array}$ & $\begin{array}{c}\text { anya } \\
\text { isk. } \\
\text { végz. }\end{array}$ & $\begin{array}{c}\text { egy } \\
\text { házt. } \\
\text { élők } \\
\text { száma }\end{array}$ & $\begin{array}{c}\text { család } \\
\text { anyagi } \\
\text { helyzete }\end{array}$ \\
\hline Általános & $\mathrm{r}=0,32 \mathrm{p}=0,001$ & $\begin{array}{l}\mathrm{r}=0,21 \\
\mathrm{p}=0,02\end{array}$ & n.s. & n.s. & $\begin{array}{c}\mathrm{r}=0,2 \\
\mathrm{p}=0,02\end{array}$ & n.s. & $\begin{array}{c}\mathrm{r}=0,2 \\
\mathrm{p}=0,03\end{array}$ \\
\hline Állat & n.s. & n.s. & n.s. & n.s. & n.s. & n.s. & n.s. \\
\hline Növény & $\mathrm{r}=0,45 \mathrm{p}=0,001$ & n.s. & n.s. & n.s. & n.s. & n.s. & n.s. \\
\hline Víz & $\mathrm{r}=0,28 \mathrm{p}=0,002$ & $\begin{array}{c}\mathrm{r}=0,37 \\
\mathrm{p}=0,001\end{array}$ & $\begin{array}{l}\mathrm{r}=0,23 \\
\mathrm{p}=0,01\end{array}$ & $\begin{array}{c}r=-0,18 \\
p=0,04\end{array}$ & n.s. & n.s. & n.s. \\
\hline Hulladék & $\mathrm{r}=0,33 \mathrm{p}=0,001$ & n.s. & n.s. & n.s. & n.s. & n.s. & n.s. \\
\hline Energia & $\mathrm{r}=0,54 \mathrm{p}=0,001$ & n.s. & n.s. & n.s. & n.s. & n.s. & n.s. \\
\hline Viselkedés & $\mathrm{r}=0,53 \mathrm{p}=0,001$ & n.s. & n.s. & n.s. & n.s. & n.s. & n.s. \\
\hline Érzelem & $\mathrm{r}=0,47 \mathrm{p}=0,001$ & n.s. & n.s. & n.s. & n.s. & n.s. & n.s. \\
\hline Teljes CHEAKS skála & $\mathrm{r}=0,54 \mathrm{p}=0,001$ & n.s. & n.s. & n.s. & n.s. & n.s. & n.s. \\
\hline
\end{tabular}

A nem változó nincs hatással az ENV és a RevNEP skálák eredményeire, viszont gyenge összefüggés mutatható ki a CHEAKS skála általános környezeti kérdéseket vizsgáló alskálája $(\mathrm{r}=0,21 \mathrm{p}=0,02)$ és közepes erösségü összefüggés a víz alskála $(\mathrm{r}=0,37 \mathrm{p}=0,001)$ eredményeivel.

A hallgatók tanulmányi átlaga negatív irányú, gyenge korrelációs összefüggést mutat az ENV skála esetében a beavatkozás a természetbe alskálán $(\mathrm{r}=-0,18 \mathrm{p}=0,04)$ elért eredményeikkel. A RevNEP skálánál a növekedés korlátai ( $\mathrm{r}=0,2 \mathrm{p}=1,13)$, az egy ökológiai válság lehetösége $(\mathrm{r}=0,31 \mathrm{p}=0,001)$ és a teljes RevNEP skála $(\mathrm{r}=0,33 \mathrm{p}=0,001)$ esetében mutatható ki összefüggés a háttérváltozóval. A CHEAKS skála esetében a víz alskálán $(\mathrm{r}=0,23 \mathrm{p}=0,01)$ kapott eredményeket befolyásolja kis mértékben a hallgatók tanulmányi átlaga.

A szülők iskolai végzettségét tekintve az apa végzettsége a RevNEP skálánál a természet egyensúlyának törékenysége alskálán $(\mathrm{r}=0,19 \mathrm{p}=0,03)$ elért eredményekkel pozitív irányban, a CHEAKS skála esetében pedig a víz alskálával ( $\mathrm{r}=-0,18 \mathrm{p}=0,04)$ negatív irányban korrelál gyenge intenzitással. Az anya iskolai végzettsége a CHEAKS általános környezeti kérdéseket vizsgáló alskálájának $(\mathrm{r}=0,2 \mathrm{p}=0,02)$ eredményeivel jár együtt.

$\mathrm{Az}$ a tény, hogy hány családtaggal élnek együtt egy háztartásban a hallgatók, egyedül a RevNEP skála három alskálájának eredményeivel mutatott összefüggést. Az antiemberközpontúság $(\mathrm{r}=-0,18 \mathrm{p}=0,04)$, a természet egyensúlyának törékenysége $(\mathrm{r}=0,19$ $\mathrm{p}=0,03)$ és az egy ökológiai válság lehetösége $(\mathrm{r}=-0,2 \mathrm{p}=0,02)$ alskálák esetében volt szignifikáns, bár gyenge kapcsolatra utaló a korrelációs együttható értéke.

A család anyagi helyzete mindhárom skála eredményeire hatással volt bizonyos mértékben. Az ENV skálánál az emberiség elsőbbsége $(\mathrm{r}=-0,25 \mathrm{p}=0,005)$ esetében negatív irányú összefüggés, a temészet élvezete $(\mathrm{r}=0,23 \mathrm{p}=0,01)$ alskálák, valamint a teljes megőrzés skála $(\mathrm{r}=0,22 \mathrm{p}=0,01)$ esetében pozitív irányú, gyenge intenzitású összefüggés mutatható ki a kapott attitűdértékekkel. A RevNEP skálánál az egy ökológiai válság lehetősége alskála ( $\mathrm{r}=-$ 0,29 p=0,001) eredményeivel mutat negatív irányú, gyenge korrelációt a változó. A CHEAKS skálánál az általános környezeti kérdéseket vizsgáló alskálánál $(\mathrm{r}=0,2 \mathrm{p}=0,03)$ figyelhető meg szignifikáns, de gyenge összefüggés. A kontrollcsoportra jellemző háttérváltozók, és az általuk az egyes skálákon elért attitüdértékek közötti összefüggést a 35. táblázat foglalja össze. 
A H3 hipotézis a fent megfogalmazott eredmények alapján bizonyítást nyert. Nem minden háttérváltozó befolyásolja ugyan a hallgatóknak az összes alskálán elért eredményét, de egyes tényezők hatással vannak a környezeti attitüd mértékére mind a kísérleti, mind pedig a kontrollcsoportban.

4.6.3. A környezeti attitüd longitudinális vizsgálata a Magyar Tannyelvü Tanítóképző Kar hallgatóinak körében

Az első vizsgált tanévben (2012/2013) mért attitüdértékeket az eredeti kísérletben részt vevő kontrollcsoport második mérésénél kapott értékei jelentik. Ennek alapján a hallgatóknak a skálán elért átlagos pontszáma 215,2. Ez fölötte van a semleges 118-as értéknek, így elmondható, hogy a tanítóképzősök pozitív környezeti attitüddel rendelkeznek az első vizsgált tanévben.

A 2013/2014-es tanévben csökkent a hallgatók által elért pontszám, ekkor átlagosan 194,6 pontot értek el. Ez a szám még mindig a pozitív tartományba esik, ugyanakkor az előző tanévhez viszonyított csökkenés szignifikánsnak tekinthető a kétmintás t-próba alapján $(\mathrm{t}=9,5$ $\mathrm{p}=0,001$ ).

A 2014/2015-ös tanévben a hallgatók 207,9 átlagpontot értek el az attitüdmérő skálán. A pontszám alatta marad az első évben mért pontszámnak, de még pozitív attitüdöt jelöl (36. táblázat). A második tanévhez viszonyítva statisztikailag is jelentős növekedés figyelhető meg a kapott eredmények között $(\mathrm{t}=-7,9 \mathrm{p}=0,001)$. Ugyanakkor a harmadik tanévben kapott eredmények szignifikánsan alacsonyabbak, mint az első tanévben mértek $(\mathrm{t}=2,9 \mathrm{p}=0,004)$.

36. táblázat: A tanitóképzös hallgatók környezeti attitüdjének változása a három vizsgált tanévben

\begin{tabular}{ccc} 
attitüdjének változása a három vizsgált tanévben \\
\hline \multirow{2}{*}{ tanév } & környezeti attitüd értéke \\
& átlag & szórás \\
\hline $2012 / 2013$ & 215,2 & 22 \\
$2013 / 2014$ & 194,6 & 8,95 \\
$2014 / 2015$ & 207,9 & 17,5 \\
\hline
\end{tabular}

A fent leírt különbségeket az egyutas ANOVA vizsgálat (Ostertagová és Ostertag, 2013; Sow, 2014) is alátámasztotta, amely szerint különbségek vannak az egyes tanévekben kapott attitüdértékek között. Nem folyamatos, de jelentős csökkenés figyelhető meg a három vizsgált tanév során $(\mathrm{F}=49,1 \mathrm{p}=0,001)$.

A kapott eredmények rácáfolnak a H4-es hipotézisre, amely szerint a tanítóképzős hallgatók környezeti attitüdjének mértéke folyamatosan növekedne a három tanév során. Ezzel ellentétben az értékek csökkenése figyelhető meg. 
4.6.4. A tanítóképzős hallgatók körében elvégzett empirikus vizsgálat eredményeinek összefoglalása

A H1 hipotézis feltevései alapján a környezeti nevelési program kialakításában részt vevő tanítóképzős hallgatók attitüd értéke növekszik a programot követően. Az előzetes felmérés során kapott értékekhez viszonyítva az ENV skála öt alskálája közül három esetében bizonyítást nyert a H1/a hipotézisben megfogalmazott állítás. Ugyanígy a RevNEP skála esetében is több alskálán növekedtek az értékek a két mérés között. A CHEAKS skálán két alskála kivételével minden egyéb alskála alátámasztotta a H1/a hipotézist, és magasabb eredményeket hozott a második méréskor, mint az első mérés során. A teljes attitüdmérős skála eredményeinek átlagát tekintve ugyancsak bizonyítást nyert az állítás, hogy a hallgatók attitűdértékei emelkedtek az előzetes felmérés során kapott eredményekhez viszonyítva.

A két csoport értékeinek összehasonlítása során a teljes ENV skála átlagértéke alapján jobb eredményt értek el a programban részt vevő hallgatók, mint a kontrollcsoport tagjai. Ezzel a H1/b hipotézis nyert bizonyítást. Az ENV skála egyes alskáláin azonban nem minden esetben mutatható ki ez az eltérés a kísérleti csoport javára. A RevNEP skálán viszont a legtöbb alskála értéke alátámasztotta a H1/b hipotézisben foglaltakat. A CHEAKS skálán már minden alskála esetében magasabbak a kísérleti csoport által elért értékek, mint a kontrollcsoport értékei. Ezáltal további igazolást nyert a program hatékonysága a tanítóképzős hallgatókra vonatkozóan.

A H1/c hipotézist el kellett vetni, ugyanis nem minden egyes alkalmazott skála összes alskálája esetében bizonyította a program hatékonyságát. Több alskála azonban pozitív irányú változásra engedett következtetni, az általuk összefoglalt témaköröknél tehát bizonyíthatóan eredményes volt a program a tanítóképzős hallgatók körében.

A H2-es hipotézisben feltételeztem, hogy a Vajdaságban magyar nyelven tanuló tanító- és óvóképzős hallgatók, vagyis a kísérleti és a kontrollcsoport tagja eleve pozitív környezeti attitüddel rendelkeznek, a program hatásaitól függetlenül. Ezt az első, alapállapotokat vizsgáló mérés eredményeivel igyekeztem alátámasztani. A hipotézis azonban megdőlt, mivel mind a kísérleti, mind pedig a kontrollcsoportban voltak olyan alskálák a három attitűdmérő skálán belül, ahol negatív értéket mértem a hallgatóknál. Ugyanakkor az első mérés során három negatív értékeket jelző skálából kettőnél is jelentős növekedés tapasztalható az attitüdértékek tekintetében a kísérleti csoportban. Ezek az értékek alátámasztják a program pozitív hatásait.

A tanítóképzős hallgatók vizsgálata során felállított hármas számú (H3) hipotézis a felmérés eredményei alapján bizonyítást nyert. Nem minden háttérváltozó esetében mutatható ki összefüggés, de egyes tényezők hatással vannak a környezeti attitűd mértékére mindkét csoportban.

A negyedik számú hipotézis (H4) az Újvidéki Egyetem Magyar Tannyelvű Tanítóképző Karán elvégzett longitudinális felmérés eredményeit feltételezi. A hipotézisben foglaltak alapján a hallgatók környezeti attitüdjének értékére pozitív hatással van a Kar oktatási rendszere, a program hatásaitól függetlenül is. Ezt az állítást nem sikerült bizonyítani. A kapott eredmények alapján indokolt lehet az oktatási rendszer ebben a kérdéskörben kifejtett hatékonyságának és a hallgatók környezettudatos magatartását befolyásoló egyéb tényezőknek a vizsgálata és a fenntarthatóságra nevelés lehetőségeinek további kutatása. 


\section{AZ ALSÓ TAGOZATOS TANULÓK KÖRÉBEN ELVÉGZETT EMPIRIKUS VIZSGÁLAT}

\subsection{Az empirikus vizsgálat hipotézisei}

Az alsó tagozatos tanulók mintájára vonatkozó hipotézisek megfogalmazása során abból a feltevésből indultam ki, hogy a gyerekek alapvetően pozitív környezetkultúrával rendelkeznek, környezeti attitüdjük értéke pedig az intenzív környezeti nevelési programban való részvételt követően tovább növekszik. Ennek megfelelően a következő hipotéziseket fogalmaztam meg:

- H1: Az alsó tagozatos gyerekek környezeti attitüdje pozitív átlagértéket mutat már a program megkezdése előtt elvégzett előzetes felmérés során:

- H1/a: a kísérleti csoportban;

- H1/b: a kontrollcsoportban.

- H2: Az élményt nyújtó, intenzív környezeti nevelési programban részt vevő alsó tagozatos diákok környezeti attitüdje, környezettudatos magatartásának értéke pozitívabb a programban való részvételt követően, mint elötte:

- H2/a: az előzetes felmérés során kapott eredményekhez viszonyítva;

- H2/b: a kontrollcsoportban mért értékekhez viszonyítva.

- H3: A környezeti nevelési programban részt vevő alsó tagozatos diákok környezeti attitüdjének értéke magasabb értéket mutat a programban feldolgozott témakörök (víz, hulladék, energia) esetében a második mérés során.

- H3/a: az előzetes felmérés során kapott eredményekhez viszonyítva;

- H3/b: a kontrollcsoportban mért értékekhez viszonyítva.

- H4: A vizsgált alsó tagozatos tanulókra jellemző háttérváltozók befolyásolják környezeti attitüdjük mértékét mind a kísérleti, mind a kontrollcsoportban.

- H5: A környezeti nevelési programban való részvételt követően az alsó tagozatos tanulók reálisabban szemlélik a környezetszennyezés kialakulásáért valóban felelős okokat és tényezőket:

- H5/a: az előzetes felmérés során kapott eredményekhez viszonyítva;

- H5/b: a kontrollcsoportban mért értékekhez viszonyítva.

- H6: A környezeti nevelési programban való részvételt követően az alsó tagozatos tanulók több saját cselekvési/viselkedési lehetőséget ismernek fel a környezet megóvása érdekében:

- H6/a: az előzetes felmérés során kapott eredményekhez viszonyítva;

- H6/b: a kontrollcsoportban mért értékekhez viszonyítva.

\subsection{Az empirikus vizsgálatban részt vevő minta}

Vizsgálatom során a Szabadkán magyar osztályban tanuló alsó tagozatos gyerekek közül választottam ki a kutatásban szereplő mintát. Az alsó tagozatos tanulók kísérleti csoportjának tagjai az Újvidéki Egyetem Magyar Tannyelvü Tanítóképző Karának szabadkai gyakorlóiskoláiból kerültek ki, a kontrollcsoport tagjai pedig két másik szabadkai általános 
iskola alsó tagozatos tanulói voltak. Második, harmadik és negyedik osztályos tanulók vettek részt a vizsgálatban, mind a kísérleti, mind pedig a kontrollcsoportban. Az adatfelvételre a 2012/2013-as tanévben került sor, így a mintában szereplő negyedik osztályos tanulók a 2009/2010-es tanévben, a harmadik osztályosok a 2010/2011-es tanévben, a második osztályosok pedig a 2011/2012-es tanévben iratkoztak be első osztályba.

A vajdasági Magyar Nemzeti Tanács közoktatási bizottságának adatai szerint (Tápai, 2012) a következőképpen alakult az első osztályba iratkozó tanulók száma Szabadkán a 2009/2010-es és a 2011/2012-es tanévek között: a 2009/2010-es tanévben összesen 1542 elsős iratkozott be szabadkai általános iskolába, közülük 469-en magyar tannyelvü osztályba. A 2010/2011-es tanévben 1383 elsős volt, közülük 416 magyar ajkú. A 2011/2012-es tanévben az 1311 elsős közül 369 iratkozott magyar osztályba (37. táblázat).

37. táblázat: Első osztályba iratkozó tanulók száma

\begin{tabular}{|c|c|c|}
\hline tanév & $\begin{array}{c}\text { elsősök száma } \\
\text { Szabadkán }\end{array}$ & $\begin{array}{c}\text { magyar elsősök } \\
\text { száma } \\
\end{array}$ \\
\hline $2009 / 2010$ & 1542 & 469 \\
\hline $2010 / 2011$ & 1383 & 416 \\
\hline $2011 / 2012$ & 1311 & 369 \\
\hline összesen & 4236 & 1254 \\
\hline
\end{tabular}

A vizsgálatba összesen 334 tanulót vontam be, vagyis a teljes populáció (Szabadkán magyar osztályban tanuló gyerekek) megközelítőleg 27\%-át. A kísérleti és a kontrollcsoport összetétele a következő:

I. Kísérleti csoport $(N=216)$ :

- Széchenyi István Általános Iskola, Szabadka (N=83): 2/a, 3/a, 3/b, 4/a és 4/b osztály;

- Majsai Úti Általános Iskola, Szabadka (N=133): 2/c, 2/d, 3/c, 3/d, 4/c és 4/d osztály.

II. Kontrollcsoport $(N=118)$ :

- Jovan Jovanović Zmaj Általános Iskola, Szabadka (N=49): 2., 3. és 4. osztály.

- Jovan Mikić Általános Iskola, Szabadka (N=69): 2., 3. és 4. osztály.

5.2.1. Az empirikus vizsgálatban részt vevő minta háttéradatai

Az alsó tagozatos tanulók esetében a nem, életkor, osztály, szülők iskolai végzettsége, szülőkkel/családtagokkal való együttélés, egy háztartásban élők száma, anyagi helyzet, kedvenc tantárgy, valamint a tanulmányi átlag háttérváltozókat vizsgáltam meg, hogy összevethessem a felmérés során kapott attitűdértékekkel. Az eredmények a következők:

(1) Nem:

- kísérleti csoport ( $N=216)$ : 52\% fiú ( $\mathrm{N}=113), 48 \%(\mathrm{~N}=103)$ lány (19. ábra).

- kontrollcsoport $(N=118)$ : 48\% fiú $(\mathrm{N}=57), 52 \%$ lány $(\mathrm{N}=61)$ (19. ábra). 


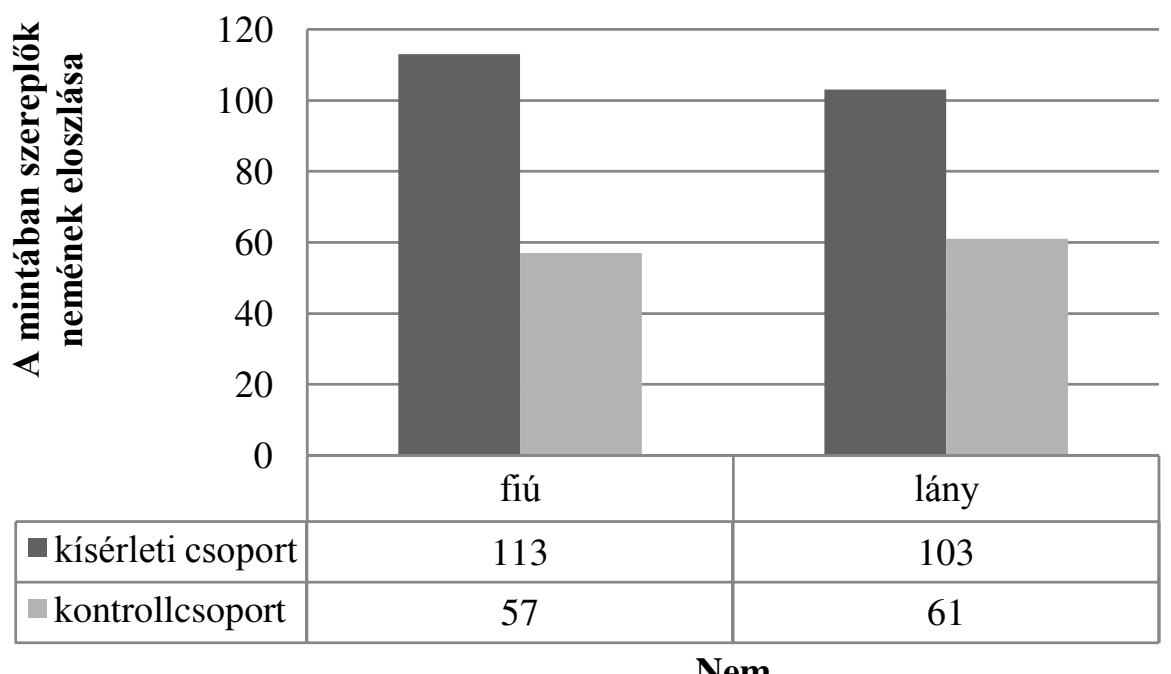

19. ábra: A nemek eloszlása az alsó tagozatos tanulók mintájában

\section{(2) Életkor:}

- kísérleti csoport $(N=216)$ : a kísérleti csoportba tartozó tanulók közül a kilencévesek vannak többségben, ők a minta 34\%-át ( $\mathrm{N}=74)$ alkotják. A nyolcévesek 29\%-ban $(\mathrm{N}=63)$, a tízévesek 27\%-ban $(\mathrm{N}=58)$ vannak jelen a mintában. A 11 évesek a minta 9\%-át $(\mathrm{N}=19)$ alkotják, míg a 12 évesek közül 1\% (N=2) szerepel a mintában (20. ábra).

- kontrollcsoport $(N=118)$ : a kontrollcsoportban szintén a kilencévesek vannak többségben, 47\%-ban ( $\mathrm{N}=56)$. A nyolcévesek 20\%-ban ( $\mathrm{N}=23)$, a tízévesek 23\%-ban ( $\mathrm{N}=27)$, a 11 évesek 9\%-ban $(\mathrm{N}=11)$ vannak jelen a mintában. A kontrollcsoportban egy hétéves tanuló is szerepel (1\%) (20. ábra).

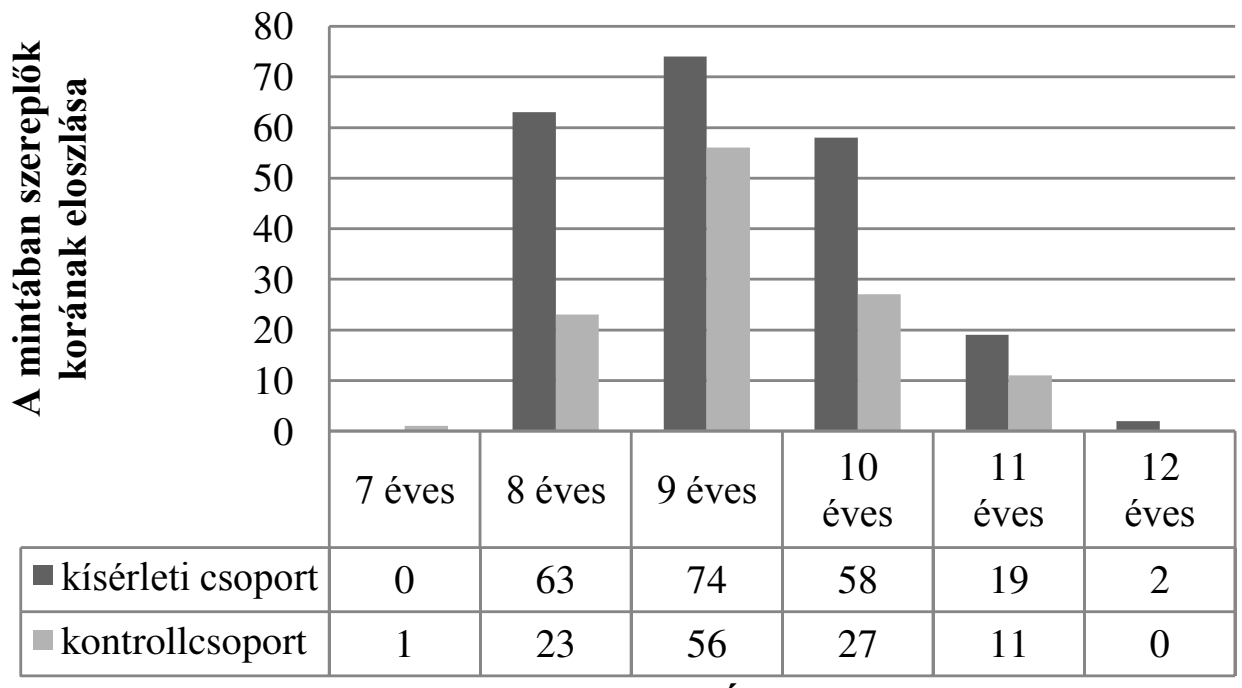

Életkor

20. ábra: Az életkor megoszlása az alsó tagozatos tanulók mintájában 
(3) Osztály:

- kísérleti csoport $(N=216)$ : a kísérleti csoportba tartozó tanulók 36\%-a $(\mathrm{N}=77)$ második osztályos, azaz a víz témakörét feldolgozó program-modulban vettek részt. 33\%-uk $(\mathrm{N}=71)$ a hulladék témakörét feldolgozó 3. osztályba jár, 31\%-uk $(\mathrm{N}=68)$ pedig az energia témakörét feldolgozó negyedik osztályba (21. ábra).

- kontrollcsoport $(N=118)$ : a kontrollcsoportban részt vevő tanulók 45\%-a $(\mathrm{N}=53)$ harmadik osztályos. Második osztályba a csoport $28 \%$-a $(\mathrm{N}=33)$, negyedik osztályba pedig 27\%-a (N=32) jár (21. ábra).

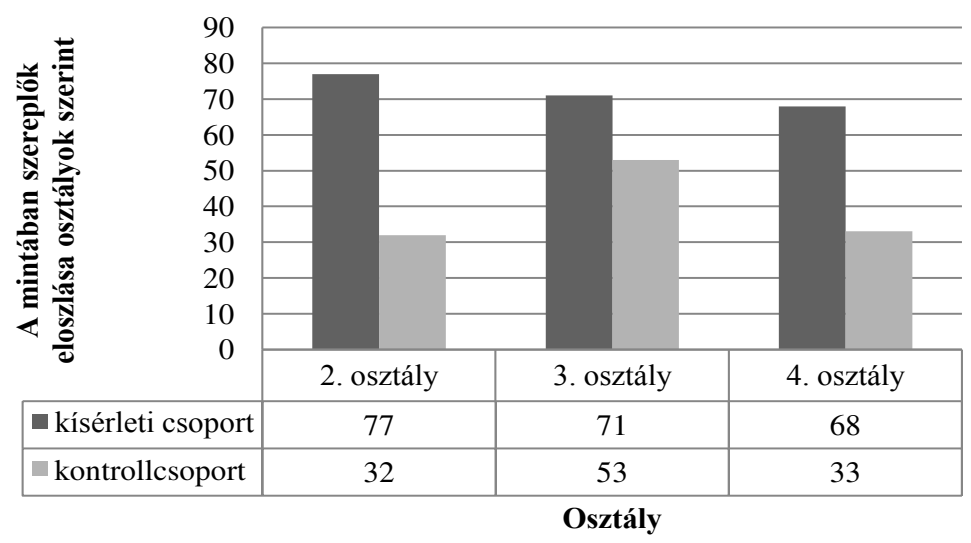

21. ábra: Az alsó tagozatos tanulók mintájának osztályok szerinti megoszlása

(4) Az apa iskolai végzettsége:

- kísérleti csoport $(N=216)$ : a tanulók 27\%-a $(\mathrm{N}=58)$ vallotta, hogy édesapja legmagasabb iskolai végzettsége a középiskola. Általános iskolát 16\%-uk $(\mathrm{N}=35)$, egyetemet vagy föiskolát 14\%-uk ( $\mathrm{N}=30)$ végzett. Az édesapák mindössze 4\%-a $(\mathrm{N}=8)$ nem fejezte be az általános iskolát. A csoportba tartozó tanulók 39\%-a (N=85) nem válaszolt a kérdésre (22. ábra).

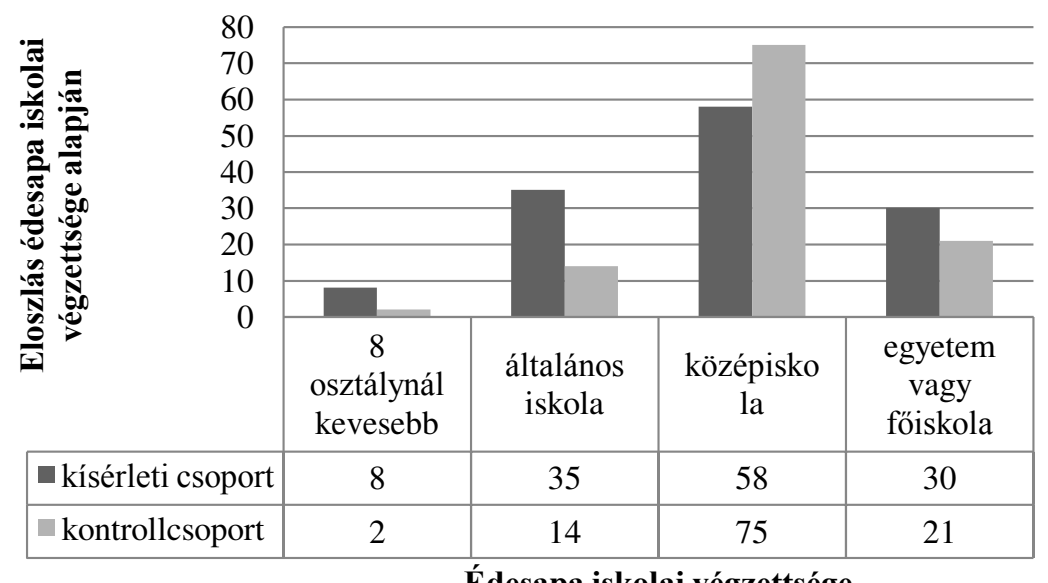

22. ábra: Az alsó tagozatos tanulók édesapjának legmagasabb iskolai végzettsége 
- kontrollcsoport $(N=118)$ : a kontrollcsoportba tartozó tanulók többségének, 64\%-nak $(\mathrm{N}=75)$ édesapja középiskolát végzett. 18\%-uk $(\mathrm{N}=21)$ egyetemet vagy fóiskolát, $12 \%$-uk $(\mathrm{N}=14)$ általános iskolát végzett. Az édesapák mindössze 2\%-a $(\mathrm{N}=2)$ nem fejezte be az általános iskolát. A csoportba tartozó tanulók 5\%-a $(\mathrm{N}=6)$ nem válaszolt a kérdésre (22. ábra).

\section{(5) Az anya iskolai végzettsége:}

- kísérleti csoport $(N=216)$ : a választ adó tanulók többségének, 31\%-nak $(\mathrm{N}=66)$ édesanyja középiskolát végzett, 15\%-uk $(\mathrm{N}=33)$ egyetemet vagy föiskolát, 10\%-uk $(\mathrm{N}=21)$ általános iskolát fejezett be. $2 \%$-uk $(\mathrm{N}=4)$ nem fejezte be az általános iskolát. A csoportba tartozó tanulók 42\%-a ( $\mathrm{N}=92)$ nem válaszolt a kérdésre (23. ábra).

- kontrollcsoport $(N=118):$ a kontrollcsoportba tartozó tanulók édesanyjának legmagasabb iskolai végzettsége a legmagasabb arányban, 60\%-ban $(\mathrm{N}=71)$ középiskola. 24\%-uk $(\mathrm{N}=28)$ egyetemet vagy föiskolát végzett, 14\%-uk $(\mathrm{N}=17)$ legmagasabb iskolai végzettsége általános iskola. Mindössze $1 \%(\mathrm{~N}=1)$ nem végezte el az általános iskolát. A csoportba tartozó tanulók 1\%-a (N=1) nem válaszolt a kérdésre (23. ábra).

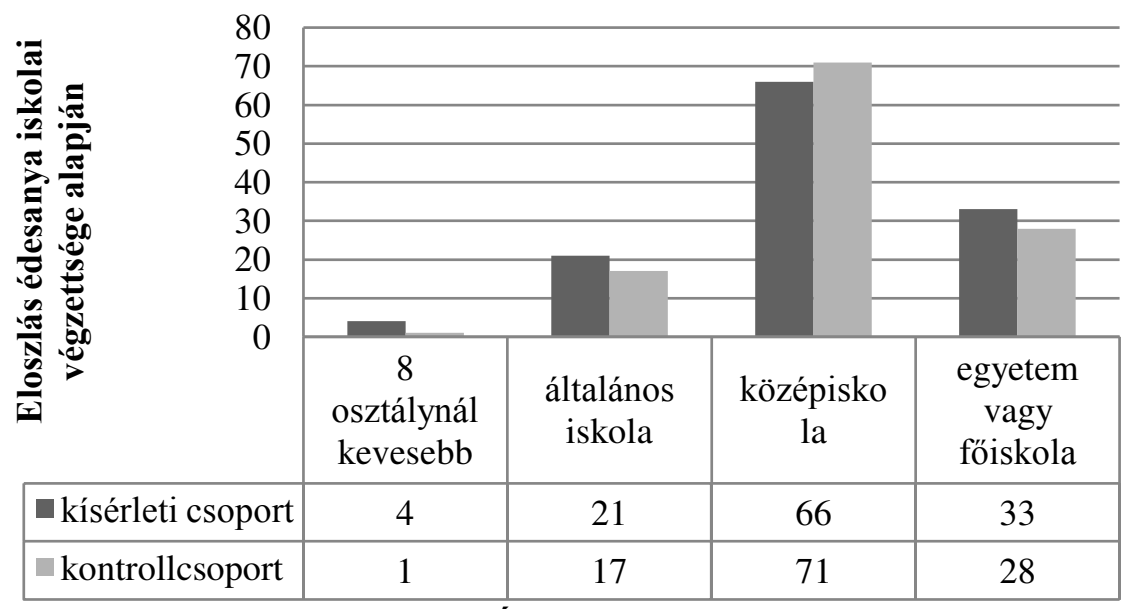

Édesanya iskolai végzettsége

23. ábra: Az alsó tagozatos tanulók édesanyjának legmagasabb iskolai végzettsége

\section{(6) Egy háztartásban élö családtagok}

- kísérleti csoport $(N=216)$ : a kísérleti csoportba tartozó tanulók 74\%-a $(\mathrm{N}=160)$ él egy háztartásban az édesanyjával, 63\%-uk ( $\mathrm{N}=136)$ édesapjával. 81\%-nak ( $\mathrm{N}=121)$ van testvére. Közülük a legtöbb tanulónak, 72\%-nak ( $\mathrm{N}=87)$ egy testvére van, 17\%-nak $(\mathrm{N}=21)$ kettő, 4\%-nak $(\mathrm{N}=5)$ három. Négy vagy annál több testvére a tanulók 7\%-ának $(\mathrm{N}=8)$ van. A tanulók 14\%-a ( $\mathrm{N}=31)$ él együtt egyik (vagy mindkét) nagyszülöjével. A tanulók további 5\%a $(\mathrm{N}=10)$ egyéb családtaggal is együtt él, egy háztartásban.

A tanulók többsége, 32\%-uk ( $\mathrm{N}=68)$ négytagú családban él. További 15\%-uk $(\mathrm{N}=33)$ háromtagú, 12\% ( $\mathrm{N}=26)$ öttagú család tagja. 4\% ( $=8)$ azok aránya, akik kéttagú családban élnek. Hattagú vagy annál nagyobb családban a tanulók 12\%-a (N=27) él. A csoportba tartozó tanulók 25\%-a $(\mathrm{N}=54)$ nem válaszolt a kérdésre (24. ábra). 
- kontrollcsoport $(N=118)$ : a kontrollcsoportba tartozó tanulók 100\%-a $(\mathrm{N}=118)$ él egy háztartásban az édesanyjával, 85\%-uk $(\mathrm{N}=100)$ együtt él az édesapjával. 75\%-nak $(\mathrm{N}=88)$ van testvére. Közülük a legtöbb tanulónak, 58\%-nak $(\mathrm{N}=68)$ egy testvére van, 13\%-nak $(\mathrm{N}=15)$ kettő, 4\%-nak $(\mathrm{N}=4)$ három, $1 \%$-nak $(\mathrm{N}=1)$ pedig négy testvére van. A tanulók 24\%-a $(\mathrm{N}=28)$ él együtt egyik (vagy mindkét) nagyszülőjével. A tanulók további 10\%-a $(\mathrm{N}=12)$ egyéb családtaggal is együtt él, egy háztartásban.

A tanulók többsége, 41\%-uk (N=49) négytagú családban él. További 21\%-uk (N=25) háromtagú, 19\% ( $\mathrm{N}=22)$ öttagú család tagja. 1\% ( $\mathrm{N}=1)$ azok aránya, akik kéttagú családban élnek. Hattagú vagy annál nagyobb családban a tanulók 18\%-a (N=21) él (24. ábra).

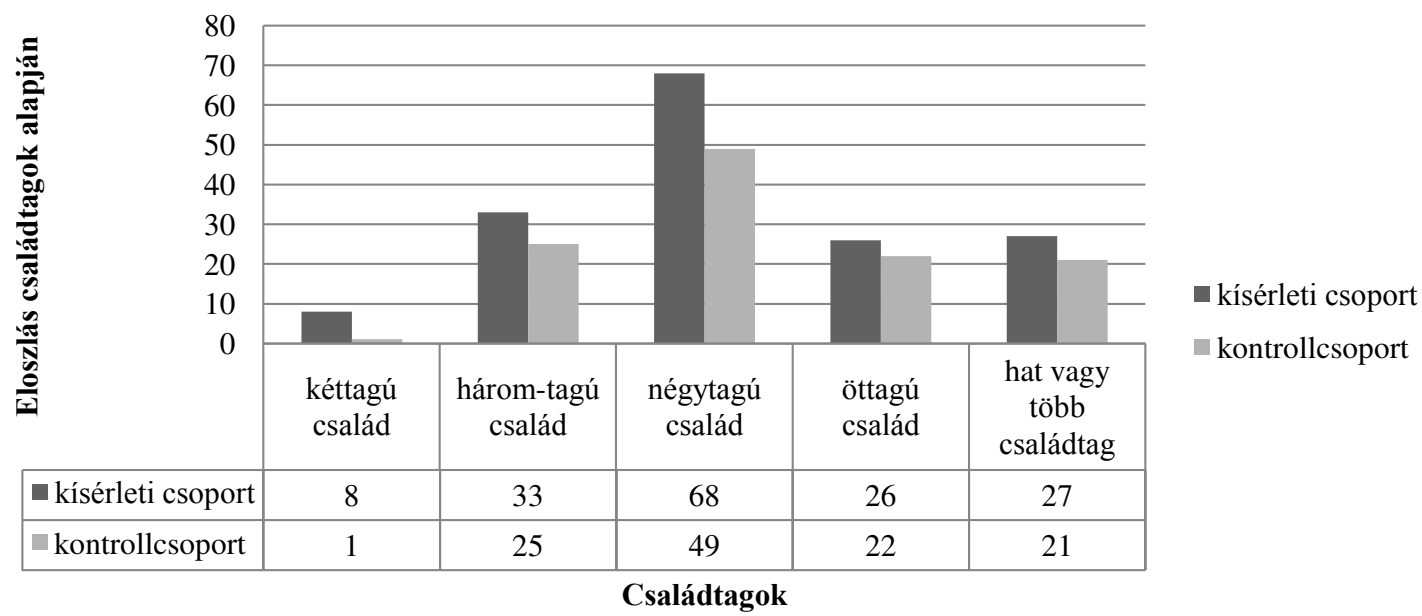

24. ábra: Az alsó tagozatos tanulók családtagjainak száma

(7) A család anyagi helyzete:

- kísérleti csoport $(N=216)$ : a kísérleti csoportba tartozó tanulók 29\%-a ( $\mathrm{N}=62)$ jó anyagi körülmények között él, 23\%-uk ( $\mathrm{N}=49)$ átlagos, 17\%-uk ( $=36)$ nagyon jó anyagi körülményeket vallott magáénak. 6\%-uk $(\mathrm{N}=13)$ vallotta, hogy rosszak az anyagi körülményeik, és mindössze $1 \%(\mathrm{~N}=1)$ szerint nagyon rossz anyagi körülmények között élnek. A csoportba tartozó tanulók 25\%-a (N=55) nem tudott válaszolni a kérdésre (25. ábra).

- kontrollcsoport $(N=118)$ : a kontrollcsoportba tartozók 40\%-a $(\mathrm{N}=47)$ átlagos anyagi körülmények között él, 31\%-uk (N=37) jó, 25\%-uk (N=30) nagyon jó anyagi körülményeket vallott magáénak. 2\%-uk ( $\mathrm{N}=2)$ állította, hogy rosszak, és ugyancsak 2\% ( $\mathrm{N}=2)$ szerint nagyon rosszak a családjuk anyagi körülményei (25. ábra). 


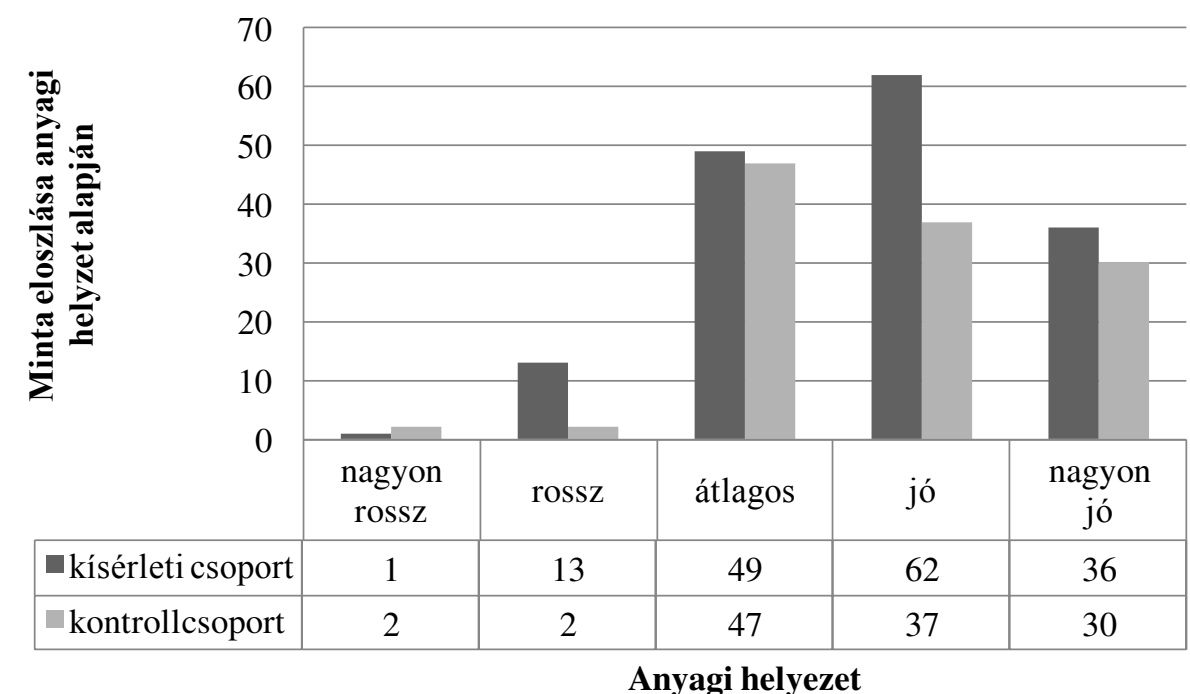

25. ábra: Az alsó tagozatos tanulók családjának anyagi helyzete

\section{(8) Kedvenc tantárgy:}

- kísérleti csoport $(N=216)$ : a kísérleti csoportba tartozó tanulók többségének, 36\%nak $(\mathrm{N}=77)$ a testnevelés a kedvenc tantárgya. A tanulók 13-13\%-a ( $\mathrm{N}=28$, illetve $\mathrm{N}=29)$ egyforma arányban kedveli a matematikát és a képzőmüvészetet. 3\%-uk $(\mathrm{N}=7)$ a Környezetünk (Természet és társadalom) tantárgyat kedveli leginkább, további 3\%-uk (N=6) pedig a magyar nyelvet. Az angol nyelvet a tanulók 2\%-a (N=3) jelölte meg kedvenceként. A hittan és a polgári ismeretek tantárgyat mindössze 1-1\% (N=1) kedveli. A csoportba tartozó tanulók 29\%-a (N=64) nem válaszolt a kérdésre (26. ábra).

- kontrollcsoport $(N=118)$ : a kontrollcsoportba tartozó tanulók többségének, 37\%-nak $(\mathrm{N}=44)$ a testnevelés a kedvenc tantárgya. A tanulók 27\%-a ( $=32)$ a matematikát kedveli leginkább, $18 \%$-uk $(\mathrm{N}=21)$ a képzőmüvészetet, 4\%-uk $(\mathrm{N}=5)$ a magyar nyelvet. A tanulók további 2\%-a ( $=2)$ kedveli elsősorban a Környezetünk (Természet és társadalom) tantárgyat, 3\%-uk (N=4) pedig a szerb nyelvet. 2-2\% (N=3) a zenei nevelést, illetve az angol nyelvet jelölte meg kedvenc tantárgyaként. A csoportba tartozó tanulók 3\%-a $(\mathrm{N}=4)$ nem válaszolt a kérdésre (26. ábra). 


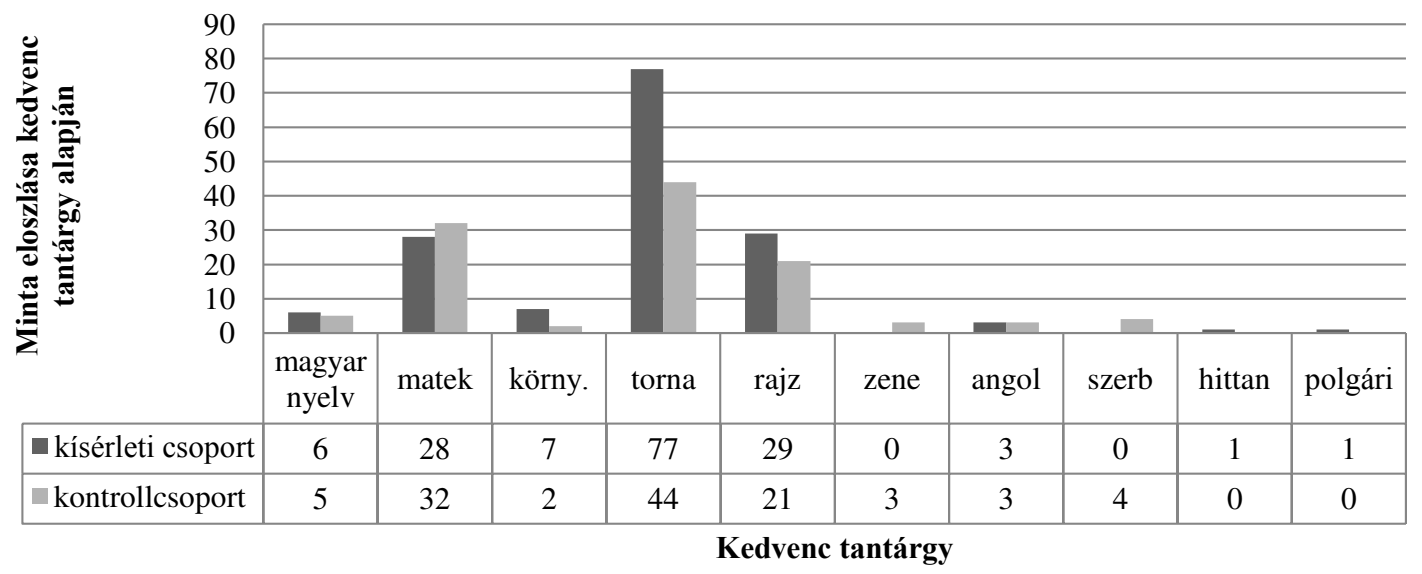

26. ábra: Az alsó tagozatos tanulók kedvenc tantárgya

(9) Tanulmányi átlag:

- kisérleti csoport $(N=216)$ : a kísérleti csoport tagjainak többsége, 41\%-uk $(\mathrm{N}=89)$ kitünő átlageredménnyel rendelkezik. 24\% ( $\mathrm{N}=52)$ a jeles tanulók aránya, 6\% ( $\mathrm{N}=31)$ pedig jó átlageredményt ért el. A csoportba tartozó tanulók 32\%-a (N=69) nem válaszolt a kérdésre (27. ábra).

- kontrollcsoport $(N=118)$ : a mintába tartozó tanulók 76\%-a $(\mathrm{N}=90)$ kitünő, 16\%-a $(\mathrm{N}=19)$ jeles, 5\%-a $(\mathrm{N}=6)$ pedig jó átlageredménnyel rendelkezik. A csoportba tartozó tanulók 3\%-a (N=3) nem válaszolt a kérdésre (27. ábra).

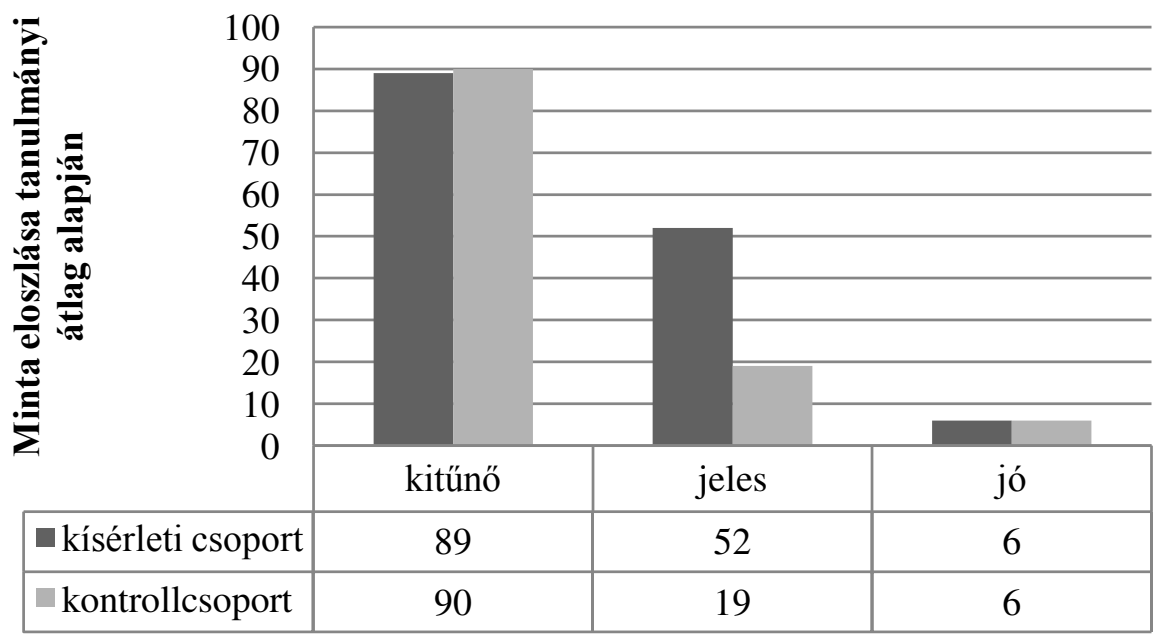

Tanulmányi átlag

27. ábra: Az alsó tagozatos tanulók tanulmányi átlaga 


\subsection{A mérőeszköz}

A vizsgálatban a környezeti attitüd mérésének alapját mindkét mérés alkalmával a CHEAKS skála attitüdmérő része szolgáltatta (27. melléklet). A kérdőívnek az alsó tagozatos tanulók körében végzett vizsgálatok alkalmával használt részei a következők:

I. Háttéradatok (kor, szülők iskolai végzettsége, tanulmányi eredmény, szociális háttér);

II. Negyvennyolc tételes, ötfokú Líkert-skála, amely három további szakaszra tagolódik:

a) Attitüdmérö skála: 24 item a diákok környezeti attitüdjét méri az általános környezeti kérdések, állatok, növények, víz, energia és hulladék témakörökkel kapcsolatban. Négyből két kérdés a tanulónak a témakörrel kapcsolatos érzelmeit, kettő pedig a viselkedéses viszonyulását vizsgálja. A gyerekek kérdőívében néhány tételt kisebb mértékben átfogalmaztam a tanítóképzősöknél alkalmazott kérdöívhez képest (38. táblázat). A táblázatban a fordítottan megfogalmazott tételeket a félkövér itemek jelölik.

38. táblázat:

A tételek besorolása a gyerekek környezeti attitüdjének mérésekor alkalmazott CHEAKS kérdöiven

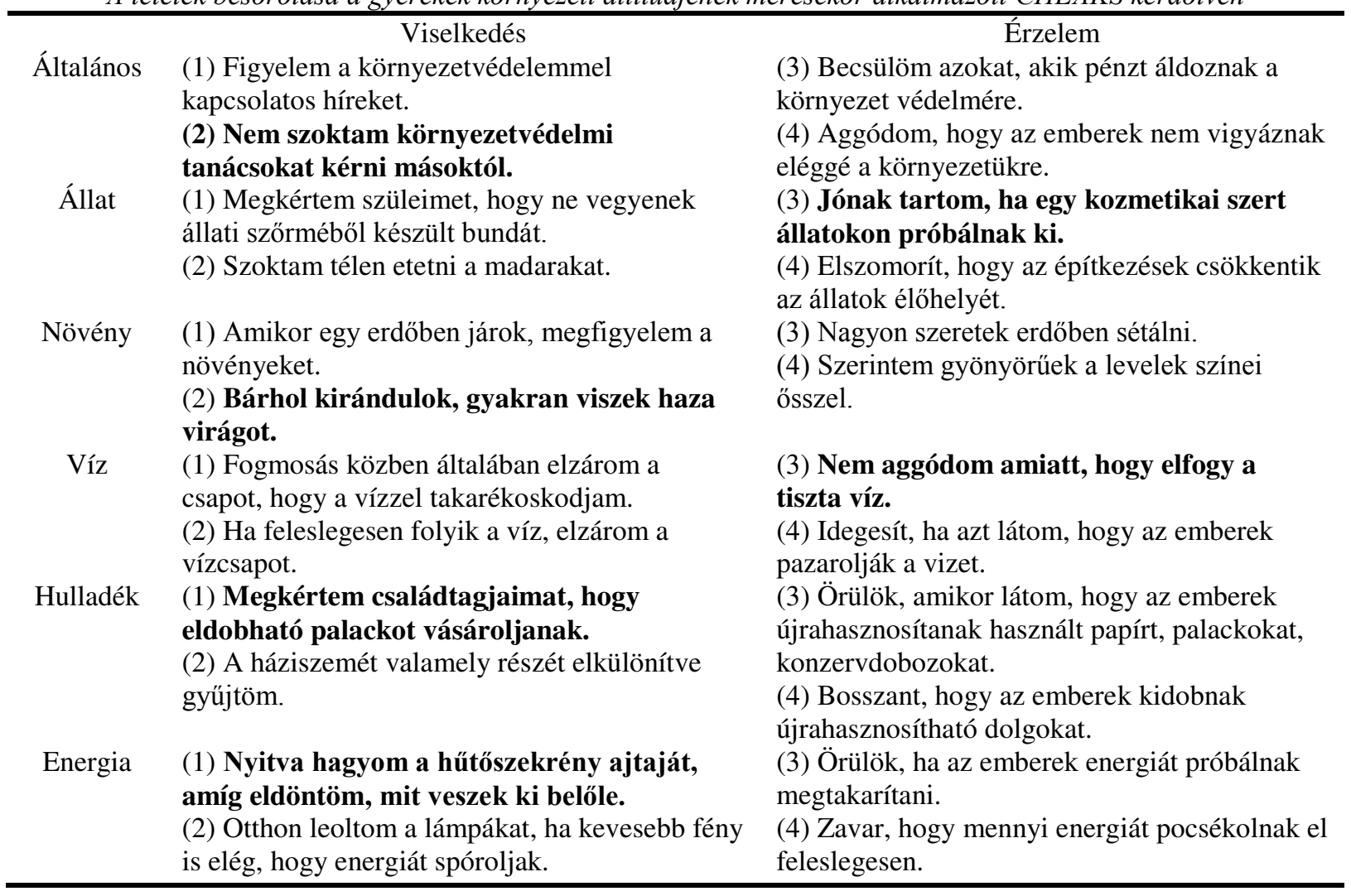

A 24 tételes attitüdmérő skála megbízhatóságának vizsgálatakor a Cronbach-alfa értéke az első méréskor 0,73 , a második méréskor pedig 0,84 volt. A skála ennek alapján megbízhatóan mér.

Ahogy a tanítóképzős hallgatók esetében alkalmazott kérdőívnél, itt is az általános, állat, növény, víz, hulladék és energia témaköröket feldolgozó alskálák esetében minimum 4, maximum 20 pontot érhetnek el a kitöltők, ahol a 12-es pontérték jelöli a semleges környezeti attitüdöt. Az érzelem és viselkedés skála 12-12 tételt tartalmaz, ennek alapján a semleges 
attitüdöt jelentő érték a 36 pont. A teljes attitüdskála értéke 24 és 120 pont között mozog, így a 72 pont jelentheti a semleges környezeti attitüdöt.

b) Környezetet veszélyeztető tényezők: 15 item méri a gyerekeknek a környezetet veszélyeztető tényezőkkel kapcsolatos véleményét. A tételek a következők:

1. A természetvédelem veszélyezteti a környezetet.

2. A mezőgazdaság veszélyezteti a környezetet.

3. A vízerőmüvek építése veszélyezteti a környezetet.

4. A bányászat veszélyes a környezetre.

5. A környezetet veszélyezteti a vizek szennyezése.

6. A közlekedés veszélyezteti a környezetet.

7. A túlnépesedés veszélyezteti a környezetet.

8. A talaj pusztulása (talajerózió) veszélyezteti a környezetet.

9. Az atomerőművek építése veszélyezteti a környezetet.

10. Az ipar veszélyezteti a környezetet.

11. A savas esők veszélyeztetik a környezetet.

12. Az utcai szemetelés veszélyezteti a környezetet.

13. A dohányzás veszélyes a környezetre.

14. Az erdők kivágása veszélyezteti a környezetet.

15. A levegőszennyezés veszélyezteti a környezetet.

c) A környezetszennyezés okai: a témával kapcsolatban 5 item vizsgálja a gyerekek véleményét. A vonatkozó tételek a következők:

1. A környezetszennyezés egyik oka, hogy az emberek magas életszínvonalon élnek, túl sokat fogyasztanak.

2. Azért van környezetszennyezés, mert vannak emberek, akik szándékosan szennyezik a környezetet.

3. Azért van környezetszennyezés, mert csak a gazdag országokban tudnak figyelni a környezetvédelemre.

4. A környezetszennyezés egyik oka, hogy az emberek csak a saját érdekeikre figyelnek, nem törődnek a többi élölény sorsával.

5. Az emberek sokszor nem is tudják, mikor ártanak a környezetnek, ezért van környezetszennyezés.

III. Nyilt végü kérdés: a saját lehetőségek vizsgálata a környezetszennyezés csökkentésére vonatkozóan.

Az első mérés során a teljes Líkert-skála, azaz a 44 itemet tartalmazó skála megbízhatóságának értéke a következő: Cronbach-alfa=0,76. A második mérésnél a Cronbach-alfa értéke 0,84 , a skála tehát megbízhatóbban mér a második alkalommal. 


\subsubsection{Az attitüdmérő skála faktoranalízisének eredményei}

\subsubsection{Az első mérés eredményei}

A 24 tételes attitüdskála tételeinek faktoranalízise során kiderült, hogy az első mérés alkalmával az állítások hét faktorba rendeződtek (39. táblázat).

Az analízis eredményeként kapott Kaiser-Meyer-Olkin mutató értéke 0,83 ( $\mathrm{p}=0,001$ ), ami elfogadhatóan magas értéket jelent, vagyis hangsúlyos a változók jelenléte a faktorok között. Minden vizsgált kérdés faktorsúlya 0,3 feletti, a megmagyarázott variancia 54,07\%.

39. táblázat: A létrejött faktorok és az egyes kérdésekhez tartozó faktorsúlyok értéke az első mérés során

\begin{tabular}{|c|c|c|c|c|c|c|c|}
\hline & 1 & 2 & 3 & 4 & 5 & 6 & 7 \\
\hline $\begin{array}{l}\text { Amikor egy erdőben járok, figyelem az ott élö } \\
\text { növényeket. }\end{array}$ & ,743 & & & & & & \\
\hline Szerintem gyönyörüek a falevelek színei ősszel. & ,684 & & & & & & \\
\hline Nagyon szeretek erdőben sétálni. & ,647 & & & & & & \\
\hline $\begin{array}{l}\text { Becsülöm azokat, akik saját pénzüket áldozzák a } \\
\text { környezet védelmére. }\end{array}$ & ,645 & & & & & & \\
\hline $\begin{array}{l}\text { Feldob, ha azt látom, hogy az emberek energiát } \\
\text { próbálnak megtakarítani. }\end{array}$ & ,598 & & & & & & \\
\hline A háziszemét valamely részét elkülönítve gyüjtöm. & & ,643 & & & & & \\
\hline $\begin{array}{l}\text { Megkértem családtagjaimat, hogy italokat csak } \\
\text { eldobható palackban vásároljanak. }\end{array}$ & &,- 556 & & & & & \\
\hline Figyelem a környezetvédelemmel kapcsolatos híreket. & & ,504 & & & & & \\
\hline Szoktam télen etetni a madarakat. & & ,496 & & & & & \\
\hline $\begin{array}{l}\text { Aggódom amiatt, hogy az emberek nem vigyáznak } \\
\text { eléggé a környezetükre. }\end{array}$ & & &, 593 & & & & \\
\hline $\begin{array}{l}\text { Idegesít, ha azt látom, hogy az emberek pazarolják a } \\
\text { vizet. }\end{array}$ & & &, 581 & & & & \\
\hline $\begin{array}{l}\text { Fogmosás közben általában elzárom a csapot, hogy a } \\
\text { vízzel takarékoskodjam. }\end{array}$ & & &, 562 & & & & \\
\hline $\begin{array}{l}\text { Zavar, hogy mennyi energiát pocsékolnak el } \\
\text { feleslegesen. }\end{array}$ & & &, 527 & & & & \\
\hline $\begin{array}{l}\text { Nem szoktam környezetvédelmi tanácsokat kérni } \\
\text { másoktól. }\end{array}$ & & &, 506 & & & & \\
\hline Ha feleslegesen folyik a víz, elzárom a vízcsapot. & & & & ,654 & & & \\
\hline $\begin{array}{l}\text { Örülök, amikor azt látom, hogy az emberek } \\
\text { újrahasznosítanak. }\end{array}$ & & & &, 541 & & & \\
\hline $\begin{array}{l}\text { Otthon leoltom a lámpákat, ha kevesebb fény is elég, } \\
\text { hogy energiát spóroljak. }\end{array}$ & & & &, 529 & & & \\
\hline $\begin{array}{l}\text { Jónak tartom, hogy ha egy kozmetikai készítményt élő } \\
\text { állatokon próbálnak ki, mielőtt emberek használnák. }\end{array}$ & & & & & ,773 & & \\
\hline Bárhol kirándulok, gyakran viszek haza virágot. & & & & & ,553 & & \\
\hline $\begin{array}{l}\text { Nyitva hagyom a hütőszekrény ajtaját, amíg eldöntöm, } \\
\text { mit veszek ki belőle. }\end{array}$ & & & & & ,476 & & \\
\hline Ellenzem az állati szőrből készült bunda használatát. & & & & & & ,733 & \\
\hline $\begin{array}{l}\text { Elszomorít, hogy a sok építkezés az állatokat } \\
\text { megfosztja természetes lakóhelyüktől. }\end{array}$ & & & & & &, 572 & \\
\hline $\begin{array}{l}\text { Bosszant, hogy az emberek kidobnak a szemétbe } \\
\text { dolgokat, amiket újra lehetne hasznosítani. }\end{array}$ & & & & & & ,461 & \\
\hline Nem aggódom amiatt, hogy elfogy a tiszta víz. & & & & & & & ,782 \\
\hline
\end{tabular}


A 24 kérdés között egyetlen olyan item van, amely nem illeszkedett megfelelően a kérdőívbe: „Nem aggódom amiatt, hogy elfogy a tiszta víz”. Ez a víz témakörével foglalkozó, viselkedést vizsgáló tétel fordítottan lett megfogalmazva, ráadásul a gyerekek számára közvetlenül nem érzékelhető, elvont problémát fogalmaz meg. Valószínűleg emiatt volt nehezen értelmezhető a válaszadók számára.

A létrejött új faktorok nem adják ki pontosan a kérdőív vonatkozó alskáláit, ugyanakkor a kapott kérdéscsoportok elemei között összefüggések figyelhetők meg.

Az 1. faktor a következő kérdéseket foglalja magába:

1. Amikor egy erdöben járok, megfigyelem a növényeket. $\left(V^{3}\right)$

2. Szerintem gyönyörüek a levelek színei összel. $\left(\dot{E}^{4}\right)$

3. Nagyon szeretek erdöben sétálni. (É)

4. Becsülöm azokat, akik saját pénzüket áldozzák a környezet védelmére. (É)

5. Feldob, ha az emberek energiát próbálnak megtakarítani. (É)

Az első három kérdés az eredeti, növények alskálához tartozik. A negyedik, növényekre vonatkozó kérdés egy fordított tétel volt, mely így hangzik: Bárhol kirándulok, gyakran viszek haza virágot. Ez a kérdés a faktor által vizsgált tulajdonságokat ellentétesen vizsgálja, ezzel magyarázható, hogy kimaradt ebből a kérdéscsoportból.

Az öt kérdés közül a 2-5. kérdések az érzelem alskálához tartoznak, egyedül az első kérdés része az eredeti viselkedés alskálának. Ugyanakkor az első item a növények témája kapcsán illeszkedik a faktorba. Ennek alapján elmondhatjuk, hogy az 1. faktor a CHEAKS skála alapján összetartozó kérdéseket tartalmaz, így a kapott eredmények is megfelelően értékelhetőek.

A 2. faktor kérdései:

1. A háziszemét valamely részét elkülönitve gyüjtöm. (V)

2. Megkértem családtagjaimat, hogy eldobható palackot vásároljanak. (V)

3. Figyelem a környezetvédelemmel kapcsolatos híreket. (V)

4. Szoktam télen etetni a madarakat. (V)

Az ebbe a faktorba sorolható négy kérdés közül az első kettő a hulladék alskála részét képezi, a harmadik kérdés az általános környezetvédelmi témákkal, a negyedik pedig az állatokkal kapcsolatos alskálából került ki. A kérdések eredetileg 3 különböző alskálához tartoznak, ugyanakkor mind a négy kérdés viselkedést jelöl a CHEAKS skálán.

A 3. faktorhoz tartozó kérdések a következők:

1. Aggódom, hogy az emberek nem vigyáznak eléggé a környezetükre. (É)

2. Idegesít, ha azt látom, hogy az emberek pazarolják a vizet. (É)

3. Fogmosás közben általában elzárom a csapot. (V)

4. Zavar, hogy mennyi energiát pocsékolnak el feleslegesen. (É)

5. Nem szoktam környezetvédelmi tanácsokat kérni másoktól. (V)

Ez a faktor tartalmazza a legtöbb kérdést. Az itemek összesen három alskála részét képezik, az általános kérdések, a víz és az energia témaköréből is kerültek kérdések ebbe a faktorba. Az ötödik item kivételével minden kérdés a felesleges pazarlással foglalkozó témakört öleli fel.

\footnotetext{
${ }^{3} \mathrm{~V}=$ viselkedés

${ }^{4}$ É = érzelem
} 
A 4. faktorba a következö tételek sorolhatók:

1. Ha feleslegesen folyik a víz, elzárom a vízcsapot. (V)

2. Örülök, amikor látom, hogy az emberek újrahasznosítanak. (É)

3. Otthon leoltom a lámpákat, ha kevesebb fény is elég. (V)

A negyedik faktorba tartozó három item három különböző alskála részét képezi. Eredetileg a víz, a hulladék és az energia témakörét vizsgálják. Ugyanakkor tartalmilag mindhárom item az egyes energiaforrásokkal kapcsolatos takarékosság és újrahasznosítás témaköréhez kapcsolódnak, ezzel magyarázható, hogy ugyanabba a faktorba kerültek.

Az 5. faktorba tartozó itemek:

1. Jónak tartom, hogy ha egy kozmetikai készítményt élö állatokon próbálnak ki, mielött emberek használnák. (É)

2. Bárhol kirándulok, gyakran viszek haza virágot. (V)

3. Nyitva hagyom a hütöszekrény ajtaját, amíg eldöntöm, mit veszek ki belöle. (V)

Az ötödik faktorba tartozó kérdések tartalmilag ugyan nem kapcsolódnak egymáshoz, mivel mindhárom item más-más alskála részét képezi. Ugyanakkor mindhárom item fordított kérdésként lett feltéve, ezzel magyarázható, hogy egy faktorba kerültek.

A 6. faktorba tartozó kérdések:

1. Ellenzem az állati szörböl készült bunda használatát. (V)

2. Elszomorit, hogy az épitkezések csökkentik az állatok élöhelyét. (É)

3. Bosszant, hogy az emberek kidobnak újrahasznosítható dolgokat. (É)

A három kérdésből az első kettő az állatokkal kapcsolatos alskálából került ki. A harmadik item pedig az energiával kapcsolatos alskála részét képezi. Az első két kérdés tehát a tartalmát tekintve kapcsolódik egymáshoz, a második és a harmadik item pedig az érzelem alskálához tartozik.

Az utolsó, 7. faktor egyetlen kérdést tartalmaz: Nem szoktam környezetvédelmi tanácsokat kérni másoktól. (V)

A faktorelemzés eredményei alapján a kérdés nem illeszkedik a kérdőívhez. Valószínűleg a megfogalmazása miatt nehezen volt értelmezhető a gyerekek számára. 


\subsubsection{A második mérés eredményei}

A második mérés során alkalmazott kérdőív itemjei faktort alkotnak (40. táblázat). Az analízis eredményeként kapott Kaiser-Meyer-Olkin mutató értéke 0,9 ( $\mathrm{p}=0,001)$. Minden vizsgált kérdés faktorsúlya 0,3 feletti, a megmagyarázott variancia 56,03\%.

\section{0. táblázat:}

A létrejött faktorok és az egyes kérdésekhez tartozó faktorsúlyok értéke a második mérés során

\begin{tabular}{|c|c|c|c|c|c|}
\hline & 1 & 2 & 3 & 4 & 5 \\
\hline Amikor egy erdőben járok, figyelem az ott élő növényeket. & ,785 & & & & \\
\hline Zavar, hogy mennyi energiát pocsékolnak el feleslegesen. & ,764 & & & & \\
\hline $\begin{array}{l}\text { Elszomorít, hogy a sok építkezés az állatokat megfosztja természetes } \\
\text { lakóhelyüktől. }\end{array}$ & ,744 & & & & \\
\hline $\begin{array}{l}\text { Aggódom amiatt, hogy az emberek nem vigyáznak eléggé a } \\
\text { környezetükre. }\end{array}$ & ,711 & & & & \\
\hline Idegesít, ha azt látom, hogy az emberek pazarolják a vizet. & 675 & & & & \\
\hline Feldob, ha azt látom, hogy az emberek energiát próbálnak megtakarítani. & ,658 & & & & \\
\hline $\begin{array}{l}\text { Örülök, amikor azt látom, hogy az emberek újrahasznosítják a használt } \\
\text { papírt, üvegeket, konzervdobozokat. }\end{array}$ & 610 & & & & \\
\hline Ha feleslegesen folyik a víz, elzárom a vízcsapot. & ,588 & & & & \\
\hline $\begin{array}{l}\text { Fogmosás közben általában elzárom a csapot, hogy a vízzel } \\
\text { takarékoskodjjam. }\end{array}$ & ,580 & & & & \\
\hline $\begin{array}{l}\text { Bosszant, hogy az emberek kidobnak a szemétbe dolgokat, amiket újra } \\
\text { lehetne hasznosítani. }\end{array}$ & ,568 & & & & \\
\hline $\begin{array}{l}\text { Nyitva hagyom a hủtőszekrény ajtaját, amíg eldöntöm, mit veszek ki } \\
\text { belőle. }\end{array}$ & ,305 & & & & \\
\hline Szerintem gyönyörüek a falevelek színei összel. & & ,746 & & & \\
\hline $\begin{array}{l}\text { A háziszemét valamely részét elkülönítve gyüjtöm (pl.: elemeket, a } \\
\text { szerves hulladékot, komposztot) }\end{array}$ & & ,710 & & & \\
\hline Szoktam télen etetni a madarakat. & & 657 & & & \\
\hline $\begin{array}{l}\text { Megkértem családtagjaimat, hogy italokat csak eldobható palackban } \\
\text { vásároljanak. }\end{array}$ & &,- 656 & & & \\
\hline Figyelem a környezetvédelemmel kapcsolatos híreket. & & 584 & & & \\
\hline Bárhol kirándulok, gyakran viszek haza virágot. & & ,581 & & & \\
\hline Ellenzem az állati szőrből készült bunda használatát. & & 528 & & & \\
\hline Nem aggódom amiatt, hogy elfogy a tiszta víz. & & & ,793 & & \\
\hline Becsülöm azokat, akik saját pénzüket áldozzák a környezet védelmére. & & & ,708 & & \\
\hline Nagyon szeretek erdőben sétálni. & & & ,701 & & \\
\hline $\begin{array}{l}\text { Otthon leoltom a lámpákat, ha kevesebb fény is elég, hogy energiát } \\
\text { spóroljak. }\end{array}$ & & & & ,636 & \\
\hline $\begin{array}{l}\text { Jónak tartom, hogy ha egy kozmetikai készítményt élő állatokon } \\
\text { próbálnak ki, mielőtt emberek használnák. }\end{array}$ & & & &, 570 & \\
\hline Nem szoktam környezetvédelmi tanácsokat kérni másoktól. & & & & & \\
\hline
\end{tabular}

A második mérés során létrejövő öt faktor ugyancsak nem adja ki pontosan a kérdöív vonatkozó alskáláit, de a kapott kérdéscsoportok elemei között a tartalmukat tekintve megfigyelhetőek bizonyos szintü összefüggések.

Az 1. faktor tizenegy itemet foglal magába:

1. Amikor egy erdöben járok, megfigyelem a növényeket. (V)

2. Zavar, hogy mennyi energiát pocsékolnak el feleslegesen. (É)

3. Elszomorit, hogy az építkezések csökkentik az állatok élöhelyét. (É)

4. Aggódom, hogy az emberek nem vigyáznak eléggé a környezetükre. (É)

5. Idegesít, ha azt látom, hogy az emberek pazarolják a vizet. (É) 
6. Feldob, ha az emberek energiát próbálnak megtakarítani. (É)

7. Örülök, amikor látom, hogy az emberek újrahasznosítanak. (É)

8. Ha feleslegesen folyik a víz, elzárom a vízcsapot. (V)

9. Fogmosás közben általában elzárom a csapot. (V)

10. Bosszant, hogy az emberek kidobnak újrahasznositható dolgokat. (É)

11. Nyitva hagyom a hütőszekrény ajtaját, amíg eldöntöm, mit veszek ki belöle. (V)

A faktorba tartozó itemek többsége az érzelem alskála részét képezi. A négy viselkedést vizsgáló kérdésből kettő a víztakarékosságra, egy pedig az energiatakarékosságra vonatkozik. A növények alskálára vonatkozó első item ebből a szempontból nem illeszkedik a többi, a faktort alkotó kérdés közé.

A 2. faktor kérdései:

1. Szerintem gyönyörüek a levelek szinei összel. (É)

2. A háziszemét valamely részét elkülönitve gyüjtöm. (V)

3. Szoktam télen etetni a madarakat. (V)

4. Megkértem családtagjaimat, hogy eldobható palackot vásároljanak. (V)

5. Figyelem a környezetvédelemmel kapcsolatos híreket. (V)

6. Bárhol kirándulok, gyakran viszek haza virágot. (V)

7. Ellenzem az állati szörböl készült bunda használatát. (V)

A második faktor 2-5. itemje az első méréskor kapott második faktor itemjeivel egyezik meg.

A 3. faktorhoz tartozó kérdések a következők:

1. Nem aggódom amiatt, hogy elfogy a tiszta víz. (É)

2. Becsülöm azokat, akik saját pénzüket áldozzák a környezet védelmére. (É)

3. Nagyon szeretek erdőben sétálni. (É)

Mindhárom, a faktorba tartozó item az érzelmi attitüdöket vizsgáló skála része. A faktor első kérdése az első felmérés során még nem illeszkedett megfelelően a skála többi részéhez, de a második mérésnél másik két itemhez hasonló faktorsúllyal bír. A faktor második itemje ugyancsak az általános környezeti kérdések alskála részét képezi.

A 4. faktorba a következő két tétel sorolható:

1. Otthon leoltom a lámpákat, ha kevesebb fény is elég. (V)

2. Jónak tartom, hogy ha egy kozmetikai készítményt élö állatokon próbálnak ki, mielött emberek használnák. (É)

A két item sem tartalmilag, sem pedig az érzelem/viselkedés alskála tekintetében nem tartozik egymáshoz. A létrejött faktor nem felel meg az eredeti kérdőívben kialakított alskáláknak.

Az ötödik faktor egyetlen itemből áll. A „,Nem szoktam környezetvédelmi tanácsokat kérni másoktól" item az, amelyik nem illeszkedik megfelelően a kérdöív többi itemjéhez. A kérdés az általános környezeti kérdéseket tartalmazó alskála egyik fordított itemje. Valószínűleg a megfogalmazása miatt volt nehezebben értelmezhető a gyerekek számára.

Tekintettel arra, hogy a CHEAKS kérdöív nemzetközileg bemért, magyar nyelvre hivatalosan is adaptált kérdöív, és a szabadkai tanulók körében elvégzett faktoranalízis egyetlen item esetében jelzett csak illeszkedési problémát, így a felmérés során kapott adatokat továbbra is az eredeti szerkezet alapján elemeztem az adatok további összehasonlíthatósága érdekében. 


\subsection{Az alsó tagozatos tanulók körében elvégzett empirikus vizsgálat eredményei}

Az alsó tagozatos tanulók vizsgálata során az egyik célom az volt, hogy megállapítsam, a kísérletben részt vevő gyerekek környezettudatos magatartásának értéke pozitív-e már a kísérlet megkezdésekor. A feltevésem az volt, hogy az eredmények eleve pozitív átlagértéket mutatnak majd a kísérleti és a kontrollcsoportban egyaránt. A további feltevéseim alapján az intenzív környezeti nevelési programban való részvétel a tanulók környezeti attitüdjének pozitív irányú változását idézi majd elö, különös tekintettel a programban feldolgozott témakörök esetében.

A feltevések alátámasztása érdekében a környezeti nevelési program kidolgozását megelözően elvégeztem a tanulók környezeti attitüdjének felmérését a CHEAKS skála segítségével. A kísérleti és a kontrollcsoportban részt vevő diákok is kitöltötték a kérdőívet. A környezeti nevelési program végrehajtását követően újra mértem a tanulók környezeti attitűdjének mértékét mindkét csoportban.

\subsubsection{Az alsó tagozatos tanulók attitüdértékének alakulása az első mérés alkalmával}

\subsubsection{A kísérleti csoport értékei}

A kísérleti csoport tagjai az első mérés során minden alskála és az alskálákhoz tartozó összes tétel esetében pozitív attitüdértéket értek el (36. táblázat). A hat, környezeti kérdéseket feldolgozó alskála esetében a 12 pont jelenti a semleges értéket, amely felett már pozitív környezeti attitüdről beszélhetünk a kérdéses témakör tekintetében. A táblázatban megjelölt százalékértékek esetében az adott item, illetve alskálák esetében a maximálisan elérhető pontszámot tekintettem 100\%-nak, és ehhez képest tüntettem fel a kapott átlagpontok százalékban kifejezett értékét.

A növények alskálán érték el a legmagasabb, 17,81 pontot $(86,3 \%)$ a tanulók. Ugyanúgy 17 pont, vagyis $80 \%$ feletti értéket kaptam az energia (17,25 pont, 82,8\%) és a víz alskálák (17,17 pont, 82,3\%) esetében is. Az általános környezeti kérdések alskálán szintén a 12-es semleges pontszámnál sokkal magasabb, 16,27-es értéket (76,6\%) mértem. A hulladék alskála hasonló, 16,05-ös értéket (75,3\%) mutatott. A hat, környezeti témákat feldolgozó alskálából az állatokkal kapcsolatos skálán érték el a legalacsonyabb, de még így is pozitív környezeti attitüdre utaló, 15,68-as értéket (73\%) a tanulók.

Az alskálákon belül 8 olyan item van, ahol 4,5-ös átlagérték feletti (90\%-hoz közeli) eredményeket mértem. A legtöbb, összesen 3 ilyen item a növények alskálán belül található. Itt a fordítottan megfogalmazott 2-es tételt kivéve mindhárom item 4,5 fölötti értéket kapott. A víz alskála esetében az első két item kapott magas pontszámot (4,63 pont, 90,6\% és 4,69 pont, 92,1\%), mindkettő a viselkedés faktorhoz tartozik a víz alskálán belül. A víz témakörével kapcsolatban fordítottan megfogalmazott tételnél szintén alacsonyabb átlagot (3,48 pont, 61,9\%) kaptak a tanulók, mint a másik három item esetében. Az általános környezeti kérdések, a hulladék és az energia témakörét összefoglaló alskálák egy-egy 4,5 átlagpontnál magasabb itemet tartalmaznak, amelyek közül mindhárom item az érzelem faktor részét képezi. 
A legalacsonyabb, a semlegesnél csak alig nagyobb átlagértéket $(3,10$ pont, 52,4\%) mutató item az általános környezeti kérdések alskála 2. kérdése: „Nem szoktam környezetvédelmi tanácsokat kérni másoktól”. A tétel fordítottan lett megfogalmazva. Több alskála fordított tételei is hasonlóan alacsony, 3-as átlag (50\%) körüli értéket kaptak. Kivételt képez az állatok alskálán belül a 3. item: Jó, ha egy kozmetikai készítményt elöször állatokon próbálnának $\mathrm{ki}$ (4,40 pont, 85,1\%). A tanulóknak az állatokkal végzett kísérletekkel kapcsolatos ismeretei nyilvánvalóan hiányosak, azért ítélhették meg vártnál pozitívabban a kérdést. Ugyanúgy magasabb értéket kaptunk az energia alskála fordított, 1. számú itemjénél is: Nyitva hagyom a hütöszekrény ajtaját, amíg eldöntöm, mit veszek ki belöle (4,15 pont, 78,7\%). Ezzel a témakörrel kapcsolatban is szükség lehet felvilágosítani a tanulókat a hütőszekrény müködésével, energiahasználatával kapcsolatban ahhoz, hogy pozitívabban megítélhessék, mi a megfelelő viselkedési forma ebben az esetben.

A viselkedés és az érzelem faktorok 12-12 itemből tevődnek össze. A kísérleti csoportba tartozó tanulók 52,84 átlagpontot $(85,1 \%)$ értek el az érzelem faktor esetében, és 47,41 átlagpontot $(73,8 \%)$ a viselkedés faktornál. Ez azt jelenti, hogy mindkét faktor esetében jóval a semlegesnek ítélt 36-os érték (50\%) felett helyezkedik el a tanulók környezeti attitüdjének értéke. Az érzelem faktor ugyanakkor magasabb értéket mutat, mint a viselkedés faktor. Ennek alapján szükség van arra, hogy minél több, a környezet megóvását célzó viselkedési lehetőséget ismertessünk meg az alsó tagozatos tanulókkal. Ezt a feltevést erősíti meg az is, hogy egyetlen alskála esetében figyelhető meg fordított tendencia a viselkedés és az érzelem faktor értékei alapján. A víz alskála esetében ugyanis a viselkedésre utaló két kérdés esetében magasabb átlagértékeket figyelhettem meg, mint az érzelemre vonatkozó két kérdésnél. A víztakarékosság kérdésköre sokkal gyakrabban megjelenik az alsó tagozatosok nevelése során, mint a hulladék vagy az energia témaköre. Nem csak az iskolai, de a családi nevelés során is gyakrabban elhangzik a figyelmeztetés, hogy a gyerekek ne folyassák feleslegesen a vizet. Az, hogy fogmosás közben, vagy ha feleslegesen folyik, el kell zárni a csapot, egyértelmü viselkedési formák a gyerekek számára, amelyet a mindennapokban alkalmazni tudnak. Erre utal az itt kapott magas attitüdérték is. Szükség van tehát arra, hogy a többi témakör esetében is hasonló, könnyen alkalmazható és kimenetelét tekintve könnyen értelmezhető viselkedési lehetőségekkel ismertessük meg az alsó tagozatos tanulókat.

A teljes attitűdskála tekintetében 100,25 átlagpontot (79,4\%) ért el a kísérleti csoport, a lehetséges 120 pontból (100\%). Ez az érték magasan a 72-es, semleges attitüdöt jelentő érték $(50 \%)$ fölött van, tehát összességében is pozitívnak tekinthető a tanulók környezeti attitüdje az első mérés alkalmával a kísérleti csoportban.

Ezzel a H1/a hipotézisben megfogalmazott állítás igazolást nyert, a kísérleti csoportba tartozó tanulók környezeti attitüdje valóban pozitív átlagértéket mutat már a program megkezdése előtt elvégzett előzetes felmérés során is.

\subsubsection{A kontrollcsoport értékei}

A kontrollcsoportban ugyancsak minden alskála esetében pozitív attitüdértéket mértem a tanulóknál (41. táblázat). A 24 item közül egyetlen kérdés esetében tapasztaltam negatív értéket, a többi itemnél a kísérleti csoporthoz hasonlóan pozitív értékeket produkáltak a tanulók. A negatív item a hulladék alskála 1. kérdése: „Megkértem családtagjaimat, hogy 
csak eldobható palackot vásároljanak”. Ez a tétel a hulladék alskála fordítottan megfogalmazott kérdése, ahol összesen 2,9 átlagpontot $(47,4 \%)$ értek el a tanulók. A kísérleti csoport tagjai is alacsony eredményt produkáltak az item esetében a többi eredményhez képest, esetükben 3,25 átlagpontot $(65,1 \%)$ mértem. A kétmintás t-próba eredményei arra utalnak, hogy a két csoport eredményei közötti különbség szignifikáns. A kísérleti csoportba tartozó tanulók véleménye a kérdésről pozitív környezeti attitűdre utal, a kontrollcsoportba tartozó tanulóké pedig negatívra. Az értékek közötti különbség statisztikai szempontból relevánsnak tekinthető $(\mathrm{t}=2,02 \mathrm{p}=0,04)$.

A kontrollcsoportban a legmagasabb átlagértéket, 17,46 pontot $(84,2 \%)$ a víz alskálán mértem. Ugyancsak 17 átlagpont feletti érték (17,17 pont, 82,3\%) figyelhető meg a növények alskála esetében is ebben a csoportban. Az energia és az általános környezeti kérdések alskálán is 16 átlagpontnál (80\%) magasabb eredményt értek el a tanulók. Az energia alskálán 16,96 átlagpontot $(81,2)$, az általános alskálán pedig 16,28 pontot $(76,7 \%)$.

Az állatok alskálán, a kísérleti csoportban mért eredményekhez hasonlóan, 15,45 átlagpont (71,5\%) mérhető ebben a csoportban. A legalacsonyabb értéket, 15,37 pontot $(71,1 \%)$ pedig a hulladék alskálán érték el a kontrollcsoport tagjai.

A kontrollcsoportban ugyanúgy, mint a kísérleti csoport esetében, a 24 itemböl 8-nál figyelhető meg 4,5-ös átlagértéknél magasabb, 90\% körüli pontszám. Az általános, a növények és a víz alskálák esetében 2-2 itemnél, a hulladék és az energia alskálák esetében pedig 1-1 itemnél mértem 4,5 átlagpontnál magasabb értéket. A víz alskála kivételével minden esetben az érzelem faktorhoz tartozó itemeknél fordul elő ez a magas érték. A víz alskála két magasan értékelt kérdése azonban a viselkedés faktorhoz tartozik. Ugyanez volt megfigyelhető a kísérleti csoport esetében is ennél a két itemnél. A kontrollcsoport értékei csak megerősítik azt a megállapítást, hogy szükség van a víz témájával kapcsolatban gyakran felmerülő viselkedésmintákhoz hasonló lehetőségek bemutatására a többi témakör esetében is.

A kísérleti és a kontrollcsoportban az első vizsgálat alkalmával mért értékek között túlnyomó részben nincs számottevő eltérés (28. és 29. ábra).

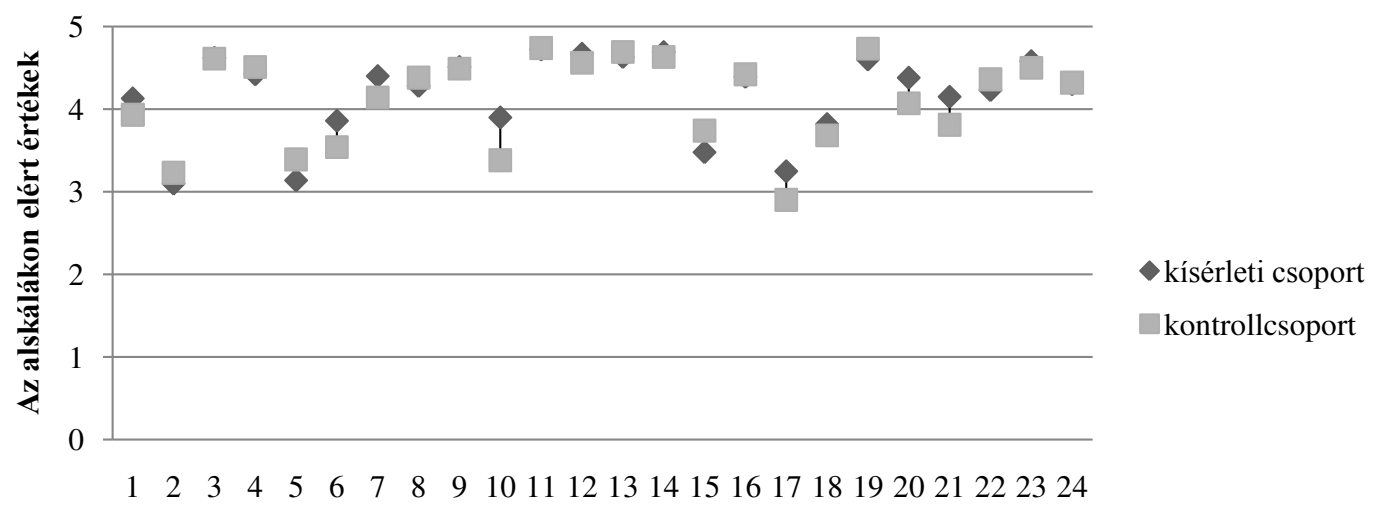

Itemek száma

28. ábra: A kísérleti és a kontrollcsoport környezeti attitüdje az első mérés során az egyes itemek tekintetében 
41. táblázat: Az attitüdértékek alakulása az első mérés során az alsó tagozatos tanulók körében

\begin{tabular}{|c|c|c|c|c|c|c|c|c|c|}
\hline \multirow{2}{*}{\multicolumn{2}{|c|}{ kérdések/alskálák }} & \multicolumn{3}{|c|}{ kísérleti csoport $(\mathrm{N}=216)$} & \multicolumn{3}{|c|}{ kontrollcsoport $(\mathrm{N}=118)$} & \multicolumn{2}{|c|}{ t-próba } \\
\hline & & átlag & szórás & $\%^{5}$ & átlag & szórás & $\%$ & $\mathrm{t}$ & $p$ \\
\hline \multicolumn{2}{|c|}{ ÁLTALÁNOS KÖRNYEZETI KÉRDÉSEK ALSKÁLA } & 16,27 & 2,81 & 76,6 & 16,28 & 3,02 & 76,7 & $-0,03$ & 0,97 \\
\hline viselkedés & 1. Figyelem a környezetvédelemmel kapcsolatos híreket. & 4,13 & 1,32 & 78,3 & 3,93 & 1,37 & 73,3 & 1,31 & 0,18 \\
\hline viselkedés & 2. Nem szoktam környezetvédelmi tanácsokat kérni másoktól. & 3,10 & 1,64 & 52,4 & 3,23 & 1,59 & 55,7 & $-0,71$ & 0,48 \\
\hline érzelem & 3. Becsülöm azokat, akik saját pénzüket áldozzák a környezet védelmére. & 4,62 & 0,91 & 90,4 & 4,61 & 0,83 & 90,2 & 0,05 & 0,95 \\
\hline érzelem & 4. Aggódom amiatt, hogy az emberek nem vigyáznak eléggé a környezetükre. & 4,42 & 1,19 & 85,5 & 4,51 & 0,96 & 87,7 & $-0,68$ & 0,49 \\
\hline \multicolumn{2}{|c|}{ ÁLLATOK ALSKÂLA } & 15,68 & 3,21 & 73 & 15,45 & 3,39 & 71,5 & 0,62 & 0,53 \\
\hline viselkedés & 1. Megkértem a szüleimet, hogy ne vegyenek állati szőrből készült bundát. & 3,14 & 1,89 & 53,6 & 3,39 & 1,78 & 59,7 & $-1,17$ & 0,23 \\
\hline viselkedés & 2. Szoktam télen etetni a madarakat & 3,86 & 1,58 & 71,4 & 3,54 & 1,64 & 63,5 & 1,71 & 0,08 \\
\hline érzelem & 3. Jó, ha egy kozmetikai készítményt először élő állatokon próbálnak ki. & 4,40 & 1,2 & 85,1 & 4,14 & 1,28 & 78,4 & 1,89 & 0,05 \\
\hline érzelem & 4. Elszomorít, hogy a sok építkezés az állatokat megfosztja lakóhelyüktöl. & 4,28 & 1,36 & 82,1 & 4,38 & 1,21 & 84,5 & $-0,65$ & 0,51 \\
\hline \multicolumn{2}{|c|}{ NÖVÉNYEK ALSKÁLA } & 17,81 & 2,73 & 86,3 & 17,17 & 2,53 & 82,3 & 2,09 & 0,03 \\
\hline viselkedés & 1. Amikor egy erdőben járok, figyelem az ott élő növényeket. & 4,51 & 1,08 & 87,8 & 4,49 & 1,04 & 87,3 & 0,18 & 0,85 \\
\hline viselkedés & 2. Bárhol kirándulok, gyakran viszek haza virágot. & 3,90 & 1,58 & 72,6 & 3,38 & 1,56 & 59,5 & 2,89 & 0,004 \\
\hline érzelem & 3. Nagyon szeretek erdőben sétálni. & 4,72 & 0,75 & 93,1 & 4,74 & 0,67 & 93,4 & $-0,18$ & 0,85 \\
\hline érzelem & 4. Szerintem gyönyörüek a falevelek színei összel. & 4,67 & 0,99 & 91,8 & 4,56 & 1,02 & 88,9 & 0,97 & 0,32 \\
\hline \multicolumn{2}{|c|}{ VÍZ ALSKÁLA } & 17,17 & 2,91 & 82,3 & 17,46 & 2,54 & 84,2 & $-0,9$ & 0,36 \\
\hline viselkedés & 1. Fogmosás közben általában elzárom a csapot, hogy a vízzel takarékoskodjam. & 4,63 & 0,92 & 90,6 & 4,69 & 0,91 & 92,2 & $-0,58$ & 0,56 \\
\hline viselkedés & 2. Ha feleslegesen folyik a víz, elzárom a vízcsapot. & 4,69 & 0,92 & 92,1 & 4,63 & 0,9 & 90,7 & 0,55 & 0,57 \\
\hline érzelem & 3. Nem aggódom amiatt, hogy elfogy a tiszta víz. & 3,48 & 1,77 & 61,9 & 3,74 & 1,65 & 68,4 & $-1,33$ & 0,18 \\
\hline érzelem & 4. Idegesít, ha azt látom, hogy az emberek pazarolják a vizet. & 4,39 & 1,15 & 84,7 & 4,42 & 1,14 & 85,4 & $-0,2$ & 0,84 \\
\hline \multicolumn{2}{|c|}{ HULLADÉK ALSKÁLA } & 16,05 & 2,54 & 75,3 & 15,37 & 2,58 & 71,1 & 2,33 & 0,02 \\
\hline viselkedés & 1. Megkértem családtagjaimat, hogy csak eldobható palackot vásároljanak. & 3,25 & 1,58 & 65,1 & 2,90 & 1,44 & 47,4 & 2,02 & 0,04 \\
\hline viselkedés & 2. A háziszemét valamely részét elkülönítve gyüjtöm. & 3,82 & 1,49 & 70,6 & 3,68 & 1,51 & 66,9 & 0,85 & 0,39 \\
\hline érzelem & 3. Örülök, amikor azt látom, hogy az emberek újrahasznosítanak. & 4,60 & 0,93 & 90 & 4,73 & 0,8 & 93,2 & $-1,3$ & 0,19 \\
\hline érzelem & 4. Bosszant, hogy az emberek kidobnak újrahasznosítható dolgokat. & 4,38 & 1,22 & 84,6 & 4,07 & 1,38 & 76,7 & 2,07 & 0,03 \\
\hline \multicolumn{2}{|c|}{ ENERGIA ALSKÁLA } & 17,25 & 2,95 & 82,8 & 16,96 & 3,25 & 81,2 & 0,82 & 0,41 \\
\hline viselkedés & 1. Nyitva hagyom a hütőszekrény ajtaját, amíg eldöntöm, mit veszek ki belöle. & 4,15 & 1,37 & 78,7 & 3,81 & 1,58 & 70,1 & 1,97 & 0,04 \\
\hline viselkedés & 2. Otthon leoltom a lámpákat, ha kevesebb fény is elég, hogy energiát spóroljak. & 4,23 & 1,29 & 80,8 & 4,36 & 1,11 & 83,9 & $-0,88$ & 0,37 \\
\hline érzelem & 3. Feldob, ha azt látom, hogy az emberek energiát próbálnak megtakarítani. & 4,58 & 0,85 & 89,5 & 4,50 & 0,94 & 87,6 & 0,73 & 0,46 \\
\hline érzelem & 4. Zavar, hogy mennyi energiát pocsékolnak el feleslegesen. & 4,30 & 1,15 & 82,4 & 4,32 & 1,13 & 83,1 & $-0,19$ & 0,84 \\
\hline \multicolumn{2}{|c|}{ TELJES ÉRZELEM FAKTOR } & 52,84 & 6,89 & 85,1 & 52,67 & 6,3 & 84,8 & 0,22 & 0,82 \\
\hline \multicolumn{2}{|c|}{ TELJES VISELKEDÉS FAKTOR } & 47,41 & 5,98 & 73,8 & 46,01 & 7,09 & 70,9 & 1,8 & 0,07 \\
\hline \multicolumn{2}{|c|}{ TELJES ATTITÜDSKÁLA } & 100,25 & 11,32 & 79,4 & 98,59 & 11,96 & 77,8 & 1,24 & 0,21 \\
\hline
\end{tabular}

${ }^{5}$ Az adott skálán maximálisan elérhető pontszámhoz viszonyított érték. 
A két csoport t-próbával való összehasonlítása során összesen két alskála (27. ábra), és ezen belül 4 kérdés esetében figyelhető meg szignifikáns különbség. A növények és a hulladék alskálák esetében is a kísérleti csoport az, amelyben jelentősen magasabbak az attitüdértékek a kontrollcsoportban mért értékekhez képest. A növények alskálán a kísérleti csoportban 17,81 pontot $(86,3 \%)$, a kontrollcsoportban 17,17 pontot $(82,3 \%)$ mértem $(\mathrm{t}=2,09$ p=0,03). Az alskálán belül a második, „Bárhol kirándulok, gyakran viszek haza virágot” megfogalmazású item esetében figyelhető meg jelentős eltérés $(\mathrm{t}=2,89 \mathrm{p}=0,004)$ a kísérleti csoport javára. Ez az item fordított tétel, tehát elképzelhető, hogy nem a kérdés tartalma, hanem a helyes értelmezése végett alakult ki különbség az értékek között. A hulladék alskálán a kísérleti csoport 16,05 pontot $(75,3 \%)$, a kontrollcsoport pedig 15,37 pontot $(71,1 \%)$ ért el $(\mathrm{t}=2,33 \mathrm{p}=0,02)$. Ezen az alskálán belül két item esetében is eltérés mutatkozik a csoportok értékei között. Az 1. kérdésnél: „,Megkértem családtagjaimat, hogy italokat csak eldobható palackban vásároljanak" a kísérleti csoport 3,25 pontot $(65,1 \%)$, a kontrollcsoport pedig 2,9 pontot $(47,4 \%)$ ért el. Ez utóbbi egyetlen olyan érték a két csoport eredményei között, amely negatív attitűdre utal. Az item egyébként ugyanúgy fordítottan megfogalmazott tétel, mint az előzőleg kiemelt, a növények alskálához tartozó kérdés, amely esetében eltérés mutatkozott a két csoport eredményei között.

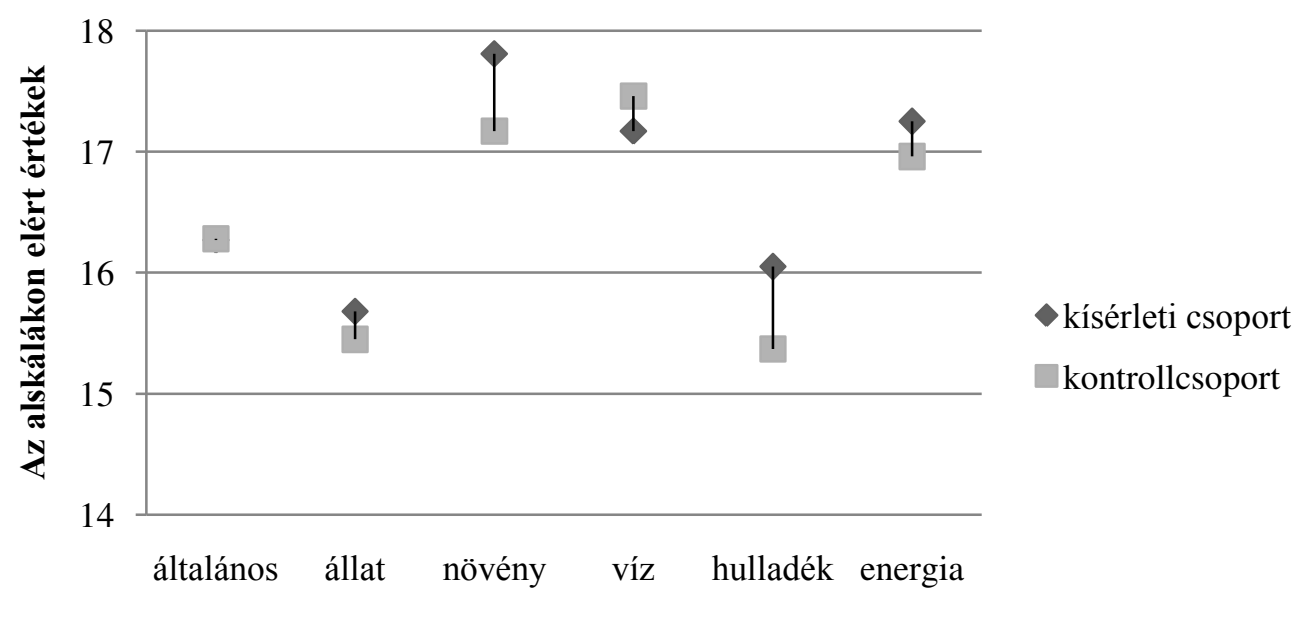

Alskálák

29. ábra: A kísérleti és a kontrollcsoport környezeti attitüdje az elsö mérés során az alskálák tekintetében

A hulladék alskálán belül még egy olyan item van, ahol szignifikáns eltérés mutatkozik a két csoport eredményei között. A skálán belüli negyedik, „Bosszant, hogy az emberek kidobnak újrahasznosítható dolgokat" kérdésnél is a kísérleti csoport ért el magasabb eredményt, 4,38 pontot (84,6\%). A kísérleti csoportban ennél az itemnél 4,07 pontot $(76,7 \%)$ mértem. A kétmintás t-próba alapján az eredmények közötti különbség számottevő $(\mathrm{t}=2,07 \mathrm{p}=0,03)$. Ez a kérdés nem fordított tétel, vagyis az egyetlen ilyen a négy, a két csoport véleményében különbséget jelentő kérdés közül. Az energia alskálán szerepelő fordított első tételnél (,Nyitva hagyom a hütöszekrény ajtaját, amíg eldöntöm, mit veszek ki belöle”) ugyanis szintén különbség ( $\mathrm{t}=1,97$ p=0,004) alakult ki a két csoport attitüdje között. Vagyis az újrahasznosítással kapcsolatos magasabb attitüd a kísérleti csoport részéről valós 
eltérésre utal, itt nem áll fenn a lehetőség, hogy a fordítottan megfogalmazott tétel értelmezése miatt jött létre különbség a két csoport eredményei között. A különbségeken túl azonban a kontrollcsoport értékei pozitív attitüdre utalnak. Mindez alátámasztja a H1/b hipotézisben megfogalmazott állítást.

Az érzelem és a viselkedés faktoron belül a pontszámok alakulása nagyon hasonló képet mutat a kísérleti és a kontrollcsoportban. Az utóbbi csoportban szintén az érzelem faktorban mértem magasabb értéket, 52,67 átlagpontot (84,8\%), a viselkedés faktorban pedig 46,01 pontot $(70,9 \%)$. Mindkét csoport esetében tehát pozitív attitüdről beszélhetünk ezeken a faktorokon belül.

A teljes attitüdskálán 98,59 pontot $(77,8 \%)$ értek el a kontrollcsoport tagjai. Ez az érték bőven a pozitív tartományba esik, hasonlóan a kísérleti csoportban mért adatokhoz.

A H1 hipotézis tehát mindkét csoport esetében igazolást nyert, és elmondható, hogy a vizsgálatban részt vevő alsó tagozatos tanulók környezeti attitűdje pozitív átlagértéket mutat a program megkezdése előtt elvégzett előzetes felmérés során.

5.4.2. Az alsó tagozatos tanulók attitűdértékének alakulása a második mérés alkalmával

A második mérésre a kísérleti és a kontrollcsoport esetében is a kéthetes, intenzív környezeti nevelési program befejezését követően került sor. A vizsgálat során ugyanazt a kérdőívet alkalmaztam mindkét csoport esetében, mint az előzetes felmérés során.

\subsubsection{A kísérleti csoport eredményei}

A második méréskor a kísérleti csoportban az elvárt eredményekkel ellenkezőleg, nem növekedés, hanem csökkenés tapasztalható az attitüdértékekben, az alskálák és az egyes itemek többségében egyaránt (30. ábra).

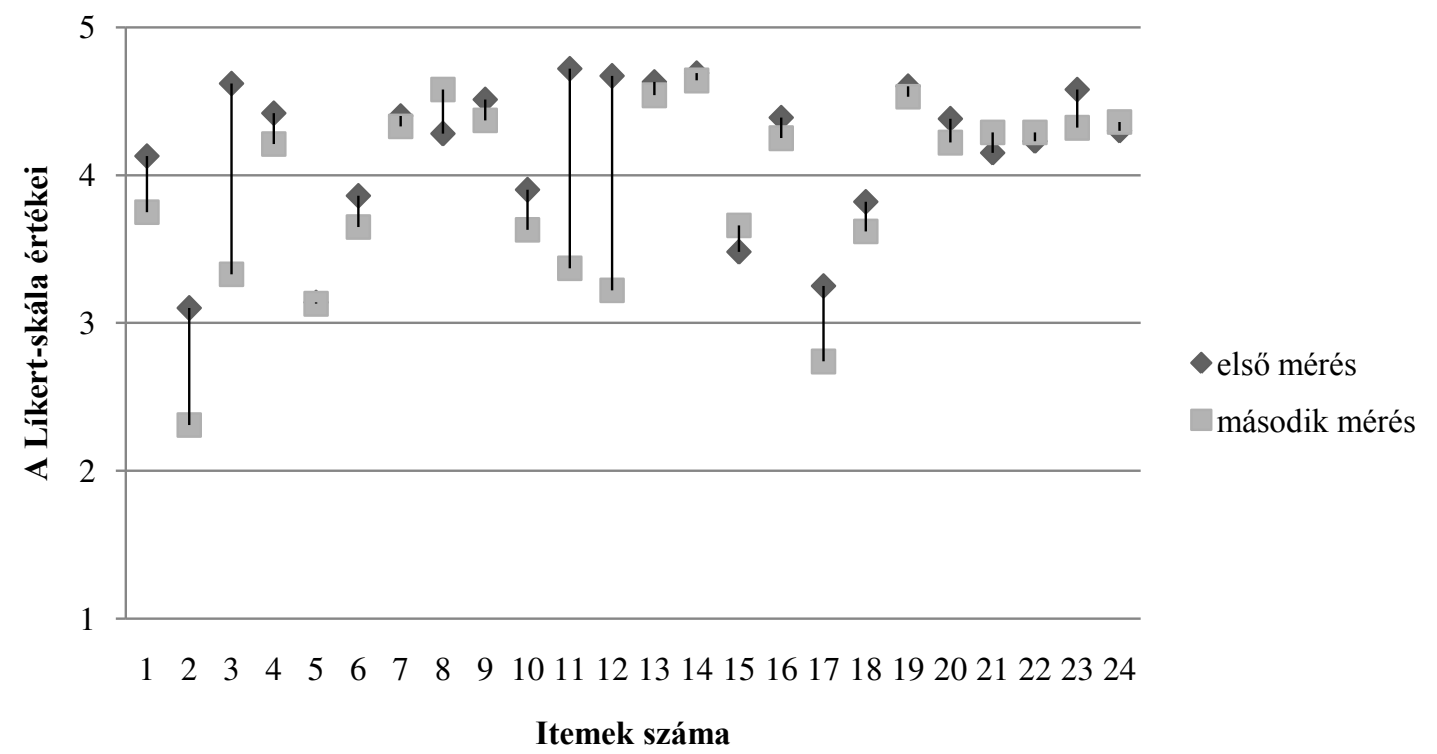

30. ábra: A kísérleti csoport környezeti attitüdjének változása az első és a második mérés során az egyes itemek tekintetében 
Az egyes alskálák, az érzelem és a viselkedés faktor, valamint a teljes attitüdskála esetében a környezeti attitűd mértéke továbbra is a pozitív tartományban helyezkedik el (42. táblázat), viszont két item esetében a negatív tartományba kerültek az értékek. Az általános környezeti kérdések alskálához tartozó második, ,,Nem szoktam környezetvédelmi tanácsokat kérni másoktól” megfogalmazású kérdés esetében az első méréskor tapasztalt 3,10-es átlagponthoz képest $(52,4 \%)$ a második méréskor 2,31 átlagpontra $(32,6 \%)$ csökkent az érték.

$\mathrm{A}$ változás szignifikánsnak tekinthető a páros t-próba alapján $(\mathrm{t}=4,83 \mathrm{p}=0,001)$. A másik kérdéses item a hulladék alskála első itemje, és a következőképpen hangzik: „Megkértem családtagjaimat, hogy csak eldobható palackot vásároljanak”. Itt az első méréskor kapott 3,25-ös pontszámhoz $(65,1 \%)$ képest 2,74 pontra $(43,4 \%)$ csökkent a második alkalommal mért érték. A csökkenés ebben az esetben is jelentősnek mondható a tpróba értékei alapján $(\mathrm{t}=3,22 \mathrm{p}=0,001)$. Mindkét kérdéses item fordított tételt jelöl, így a negatív eredmények kialakulásához az a lehetőség is hozzájárulhat, hogy továbbra is nehézséget okozott a gyerekek számára a kérdések megfelelő értelmezése.

Az általános környezeti kérdések alskálán belül a négy itemből háromban is, és a teljes skálán is szignifikáns csökkenés tapasztalható. A második, fordított itemmel kapcsolatos értékeket az előzőekben már értelmeztem. Az első, „,Figyelem a környezetvédelemmel kapcsolatos híreket” item esetében az első mérésnél 4,13-as pontszámot kaptunk (78,3\%), ami a második mérésnél már 3,75 pont volt $(68,7 \%)$. A változás statisztikailag is alátámasztható $(\mathrm{t}=2,62 \mathrm{p}=0,009)$. A skálán belül a harmadik item a következő: „Becsülöm azokat, akik saját pénzüket áldozzák a környezet védelmére”. Itt az első mérésnél még 4,62 átlagpontot, azaz 90,4\%-ot értek el a tanulók. A második mérésnél viszont szignifikáns csökkenés $(\mathrm{t}=9,2 \mathrm{p}=0,001)$ tapasztalható, mindössze 3,33 átlagpontot $(58,3 \%)$ mértem.

A kísérleti csoportban a teljes általános környezeti kérdések alskálán elért érték az első mérés során 16,27 átlagpont volt (76,6\%), a második mérésnél viszont 13,82 pont (56\%). A csökkenés ebben az esetben is jelentősnek tekinthető $(\mathrm{t}=7,89 \mathrm{p}=0,001)$. Az általános kérdések skálán belül egyedül az érzelem faktorhoz tartozó, negyedik item esetében nem bizonyult statisztikailag relevánsnak a két mérés során kapott értékek közötti különbség. Az „Aggódom amiatt, hogy az emberek nem vigyáznak eléggé a környezetükre" megfogalmazású itemnél az első méréskor 4,42 pontot $(85,5 \%)$, a második méréskor 4,21 pontot $(80,1 \%)$ értek el a tanulók.

A növények alskálánál szintén a teljes skála, azon belül pedig két további item esetében is szignifikáns értékcsökkenés volt tapasztalható. Mindkét kérdéses item az érzelem faktorhoz tartozik. A skálán belüli harmadik kérdésnél, amely a következőképpen hangzik: „Nagyon szeretek erdőben sétálni”, az első méréskor 4,72 pontot (93,1\%), a második méréskor már csak 3,37 pontot $(59,3 \%)$ értek el a tanulók. A páros t-próba értéke: $\mathrm{t}=10,1$ p=0,001. A skálán belül a negyedik, „Szerintem gyönyörüek a falevelek színei összel” megfogalmazású itemnél ugyancsak szignifikáns értékcsökkenés van jelen ( $\mathrm{t}=10,56 \mathrm{p}=0,001)$. A teljes növények témakörét feldolgozó alskálán az első méréskor 17,81 pontot (86,3\%) értek el a tanulók, a második mérésnél már csak 14,6 pontot $(66,1 \%)$. A csökkenés mértéke szignifikáns ( $\mathrm{t}=8,51 \mathrm{p}=0,001)$. 
42. táblázat: Az attitüdértékek alakulása az első és a második mérés során a kísérleti csoportban

\begin{tabular}{|c|c|c|c|c|c|c|c|c|c|}
\hline \multirow{2}{*}{\multicolumn{2}{|c|}{ kérdések/alskálák }} & \multicolumn{3}{|c|}{ első mérés $(\mathrm{N}=216)$} & \multicolumn{3}{|c|}{ második mértés (N=216) } & \multicolumn{2}{|c|}{ t-próba } \\
\hline & & átlag & szórás & $\%$ & átlag & szórás & $\%$ & $\mathrm{t}$ & $p$ \\
\hline \multicolumn{2}{|c|}{ ÁLTALÁNOS KÖRNYEZETI KÉRDÉSEK ALSKÁLA } & 16,27 & 2,81 & 76,6 & 13,82 & 3,27 & 56,0 & 7,89 & 0,001 \\
\hline viselkedés & 1. Figyelem a környezetvédelemmel kapcsolatos híreket. & 4,13 & 1,32 & 78,3 & 3,75 & 1,57 & 68,7 & 2,62 & 0,009 \\
\hline viselkedés & 2. Nem szoktam környezetvédelmi tanácsokat kérni másoktól. & 3,10 & 1,64 & 52,4 & 2,31 & 1,69 & 32,6 & 4,83 & 0,001 \\
\hline érzelem & 3. Becsülöm azokat, akik saját pénzüket áldozzák a környezet védelmére. & 4,62 & 0,91 & 90,4 & 3,33 & 1,68 & 58,3 & 9,20 & 0,001 \\
\hline érzelem & 4. Aggódom amiatt, hogy az emberek nem vigyáznak eléggé a környezetükre. & 4,42 & 1,19 & 85,5 & 4,21 & 1,31 & 80,1 & 1,54 & 0,12 \\
\hline \multicolumn{2}{|c|}{ ÁLLATOK ALSKÁLA } & 15,68 & 3,21 & 73 & 15,91 & 3,76 & 68,7 & $-0,08$ & 0,41 \\
\hline viselkedés & 1. Megkértem a szüleimet, hogy ne vegyenek állati szőrből készült bundát. & 3,14 & 1,89 & 53,6 & 3,13 & 1,76 & 53,2 & 0,08 & 0,93 \\
\hline viselkedés & 2. Szoktam télen etetni a madarakat & 3,86 & 1,58 & 71,4 & 3,65 & 1,68 & 66,3 & 1,22 & 0,22 \\
\hline érzelem & 3. Jó, ha egy kozmetikai készítményt először élő állatokon próbálnak ki. & 4,40 & 1,2 & 85,1 & 4,33 & 1,2 & 83,3 & 0,54 & 0,58 \\
\hline érzelem & 4. Elszomorít, hogy a sok építkezés az állatokat megfosztja lakóhelyüktől. & 4,28 & 1,36 & 82,1 & 4,58 & 0,98 & 89,5 & $-2,80$ & 0,005 \\
\hline \multicolumn{2}{|c|}{ NÖVÉNYEK ALSKÁLA } & 17,81 & 2,73 & 86,3 & 14,60 & 4,01 & 66,1 & 8,51 & 0,001 \\
\hline viselkedés & 1. Amikor egy erdőben járok, figyelem az ott élő növényeket. & 4,51 & 1,08 & 87,8 & 4,37 & 1,15 & 84,2 & 1,05 & 0,29 \\
\hline viselkedés & 2. Bárhol kirándulok, gyakran viszek haza virágot. & 3,90 & 1,58 & 72,6 & 3,63 & 1,51 & 65,7 & 1,49 & 0,13 \\
\hline érzelem & 3. Nagyon szeretek erdőben sétálni. & 4,72 & 0,75 & 93,1 & 3,37 & 1,71 & 59,3 & 10,1 & 0,001 \\
\hline érzelem & 4. Szerintem gyönyörüek a falevelek színei ősszel. & 4,67 & 0,99 & 91,8 & 3,22 & 1,62 & 55,4 & 10,56 & 0,001 \\
\hline \multicolumn{2}{|c|}{ VÍZ ALSKÁLA } & 17,17 & 2,91 & 82,3 & 17,13 & 3,55 & 81,9 & 0,04 & 0,96 \\
\hline viselkedés & 1. Fogmosás közben általában elzárom a csapot, hogy a vízzel takarékoskodjam. & 4,63 & 0,92 & 90,6 & 4,54 & 1,07 & 88,6 & 0,65 & 0,51 \\
\hline viselkedés & 2. Ha feleslegesen folyik a víz, elzárom a vízcsapot. & 4,69 & 0,92 & 92,1 & 4,64 & 0,96 & 91,0 & 0,25 & 0,80 \\
\hline érzelem & 3. Nem aggódom amiatt, hogy elfogy a tiszta víz. & 3,48 & 1,77 & 61,9 & 3,66 & 1,75 & 66,5 & $-0,78$ & 0,43 \\
\hline érzelem & 4. Idegesít, ha azt látom, hogy az emberek pazarolják a vizet. & 4,39 & 1,15 & 84,7 & 4,25 & 1,34 & 81,4 & 0,85 & 0,39 \\
\hline \multicolumn{2}{|c|}{ HULLADÉK ALSKÁLA } & 16,05 & 2,54 & 75,3 & 15,14 & 2,61 & 69,4 & 3,06 & 0,002 \\
\hline viselkedés & 1. Megkértem családtagjaimat, hogy csak eldobható palackot vásároljanak. & 3,25 & 1,58 & 65,1 & 2,74 & 1,62 & 43,4 & 3,22 & 0,001 \\
\hline viselkedés & 2. A háziszemét valamely részét elkülönítve gyüjtöm. & 3,82 & 1,49 & 70,6 & 3,62 & 1,55 & 65,6 & 1,24 & 0,21 \\
\hline érzelem & 3. Örülök, amikor azt látom, hogy az emberek újrahasznosítanak. & 4,60 & 0,93 & 90 & 4,53 & 1,06 & 88,4 & 0,58 & 0,56 \\
\hline érzelem & 4. Bosszant, hogy az emberek kidobnak újrahasznosítható dolgokat. & 4,38 & 1,22 & 84,6 & 4,22 & 1,31 & 80,5 & 1,23 & 0,23 \\
\hline \multicolumn{2}{|c|}{ ENERGIA ALSKÁLA } & 17,25 & 2,95 & 82,8 & 17,31 & 3,84 & 82,8 & $-0,19$ & 0,84 \\
\hline viselkedés & 1. Nyitva hagyom a hütőszekrény ajtaját, amíg eldöntöm, mit veszek ki belőle. & 4,15 & 1,37 & 78,7 & 4,29 & 1,31 & 82,2 & $-1,00$ & 0,32 \\
\hline viselkedés & 2. Otthon leoltom a lámpákat, ha kevesebb fény is elég, hogy energiát spóroljak. & 4,23 & 1,29 & 80,8 & 4,29 & 1,25 & 82,2 & $-0,57$ & 0,56 \\
\hline érzelem & 3. Feldob, ha azt látom, hogy az emberek energiát próbálnak megtakarítani. & 4,58 & 0,85 & 89,5 & 4,32 & 1,19 & 82,9 & 2,35 & 0,02 \\
\hline érzelem & 4. Zavar, hogy mennyi energiát pocsékolnak el feleslegesen. & 4,30 & 1,15 & 82,4 & 4,36 & 1,17 & 83,9 & $-0,72$ & 0,47 \\
\hline \multicolumn{2}{|c|}{ TELJES ÉRZELEM FAKTOR } & 52,84 & 6,89 & 85,1 & 48,49 & 9,49 & 75,8 & 4,91 & 0,001 \\
\hline \multicolumn{2}{|c|}{ TELJES VISELKEDÉS FAKTOR } & 47,41 & 5,98 & 73,8 & 45,45 & 8,08 & 64,1 & 2,65 & 0,009 \\
\hline \multicolumn{2}{|c|}{ TELJES ATTITÜDSKÁLA } & 100,25 & 11,32 & 79,4 & 93,94 & 16,26 & 67,1 & 4,25 & 0,001 \\
\hline
\end{tabular}


A hulladék alskálánál ugyancsak releváns értékcsökkenésről $(\mathrm{t}=3,06 \mathrm{p}=0,002)$ beszélhetünk a teljes skála tekintetében. Az első mérésnél 16,05 pontot (75,3\%), a másodiknál 15,14 pontot $(69,4 \%)$ mértem. A skálán belül az első item értékei ugyancsak jelentős csökkenést mutatnak. A „Megkértem családtagjaimat, hogy csak eldobható palackot vásároljanak" megfogalmazású itemmel kapcsolatos megállapításokat a fentiekben már elemeztem.

Az energia alskálán önmagában nem tapasztalható értékcsökkenés, de a skálán belül a harmadik item pontszámai a második mérés alkalmával jelentősen alacsonyabbak voltak. Az érzelem faktorba tartozó kérdés a következöképpen hangzik: „Feldob, ha azt látom, hogy az emberek energiát próbálnak megtakarítani”. Az első mérés alkalmával 4,58 pontot $(89,5 \%)$ mértem, a második méréskor 4,32 pontot $(82,9 \%)$. A t-próba alapján a csökkenés mértéke szignifikánsnak mondható: $\mathrm{t}=2,35 \mathrm{p}=0,02$.

Az állatok alskálán önmagában szintén nem tapasztalható értékváltozás. Ugyanakkor ezen az egy skálán belül található az egyetlen olyan item, amelynél szignifikáns növekedést mértem a második alkalommal. Az állatok alskála negyedik, érzelem faktorhoz tartozó itemje a következőképpen hangzik: „Elszomorít, hogy a sok építkezés megfosztja az állatokat lakóhelyüktöl”. Itt az első mérésnél 4,28 pontot (82,1\%) értek el a tanulók, a második mérésnél már 4,58 pontot $(89,5 \%)$. A t-próba értéke: $\mathrm{t}=-2,8 \mathrm{p}=0,005$.

Az alskálák közül egyedül a víz alskála az, amely esetében sem a skála értéke, sem pedig a hozzá tartozó itemek esetében nem tapasztalható változás (31. ábra).

Az érzelmek és a viselkedés faktor, valamint a teljes skála értékeit tekintve azonban a legtöbb alskálához hasonlóan megfigyelhető az értékek szignifikáns csökkenése. Az érzelmek faktor esetében az első mérésnél 52,84 pontot (85,1\%), a második mérésnél 48,49 pontot $(75,8 \%)$ kaptam. Az eltérés mértéke a következő: $t=4,91 \mathrm{p}=0,001$. A viselkedés faktornál az első mérésnél kapott pontszám 47,41 (73,8\%), a második mérésnél már csak 45,45 (64,1\%). A t-próba értéke ebben az esetben: $\mathrm{t}=2,65 \mathrm{p}=0,009$. A teljes skálára vonatkozóan az első mérés alkalmával 100,25 pontot $(79,4 \%)$ mértem, a második mérés alkalmával pedig 93,94 pontot $(67,1 \%)$. A változás mértéke: $t=4,25 \mathrm{p}=0,001$.

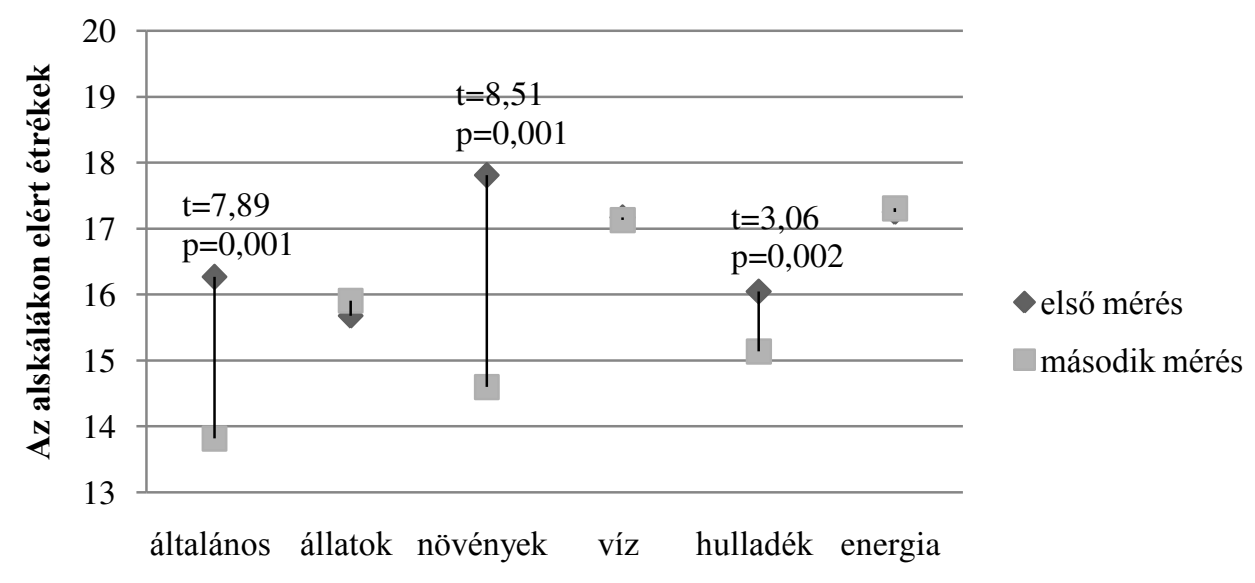

Alskálák

31. ábra: A kisérleti csoport környezeti attitüdje az első és a második mérés során az alskálák tekintetében 
A kísérleti csoportban elvégzett, második mérés alkalmával kapott eredmények alapján a H2/a hipotézisben foglalt állítást el kell vetnem. Nem sikerült egyértelmüen bizonyítani, hogy az élményt nyújtó, intenzív környezeti nevelési programban részt vevő alsó tagozatos diákok környezeti attitüdje, környezettudatos magatartásának értéke pozitívabb a programban való részvételt követően, mint előtte, az előzetes felmérés során kapott eredményekhez viszonyítva.

\subsubsection{A kontrollcsoport eredményei}

A kontrollcsoportban a kísérleti csoport példájához hasonlóan csökkentek az attitűdértékek a legtöbb alskálán, azon belül az egyes itemek esetében is. Három item kivételével azonban ebben a csoportban is a pozitív tartományban helyezkedik el az attitüdök értéke az alskálák, az érzelem és viselkedés faktorok, valamint a teljes skála esetében is (43. táblázat).

Az általános környezeti kérdések, az állatok és a hulladék alskálán egy-egy item negatív környezeti attitüdöt jelöl a kontrollcsoportban. Az általános és a hulladék alskála negatív itemjei megegyeznek azokkal, amelyeknél a kísérleti csoportban is negatív értékeket mértem. Az általános skála második itemje esetében (,Nem szoktam környezetvédelmi tanácsokat kérni másoktól”) az első méréskor 3,23 pontot (55,7\%), a második méréskor 2,69 pontot $(42,4 \%)$ értek el a tanulók. A csökkenés szignifikánsnak tekinthető a páros t-próba eredményei alapján: t=2,29 p=0,02. A hulladék skála első itemje (,,Megkértem családtagjaimat, hogy csak eldobható palackban vásároljanak”) már az első méréskor is negatív attitüdöt jelzett a kontrollcsoportban (2,90 pont, 47,4\%). A második méréskor csekély mértékben tovább csökkentek az értékek, itt 2,89 (47,2\%) pontot értek el a tanulók. Ez a csökkenés nem tekinthető statisztikailag relevánsnak $(\mathrm{t}=-0,04 \mathrm{p}=0,96)$, de ettől függetlenül az érték továbbra is negatív attitűdöt jelez az adott témában. A harmadik olyan item, ahol a második mérés során negatív attitüdöt jelez a kontrollcsoportban, az állatok alskála első itemje: „Megkértem a szüleimet, hogy ne vegyenek állati szörböl készült bundát”. Itt az első méréskor 3,39 átlagpontot $(59,7 \%)$ mértem, ami még a pozitív tartományban helyezkedik el. A második méréskor statisztikailag nem jelentős mértékű csökkenés következett be, amelynek eredményeként az érték (2,96 pont, 48,9\%) már negatív környezeti attitüdöt jelöl (32. ábra).

A kontrollcsoportban az általános környezeti kérdések alskálán belül nem csak a fent jelzett item, de az összes ide tartozó tétel és a teljes skála esetében is szignifikáns csökkenés tapasztalható. A kísérleti csoportban is az általános kérdések volt az az alskála, amelyen belül a legtöbb item értéke szignifikáns attitüdcsökkenést jelzett. Az első itemnél: „,Figyelem a környezetvédelemmel kapcsolatos híreket" az első mérés során 3,93 pontot (73,3\%) mértem, a második méréskor már csak 3,45 pontot $(61,2 \%)$. A különbség jelentős a t-próba szerint: $\mathrm{t}=2,41 \mathrm{p}=0,01$. 


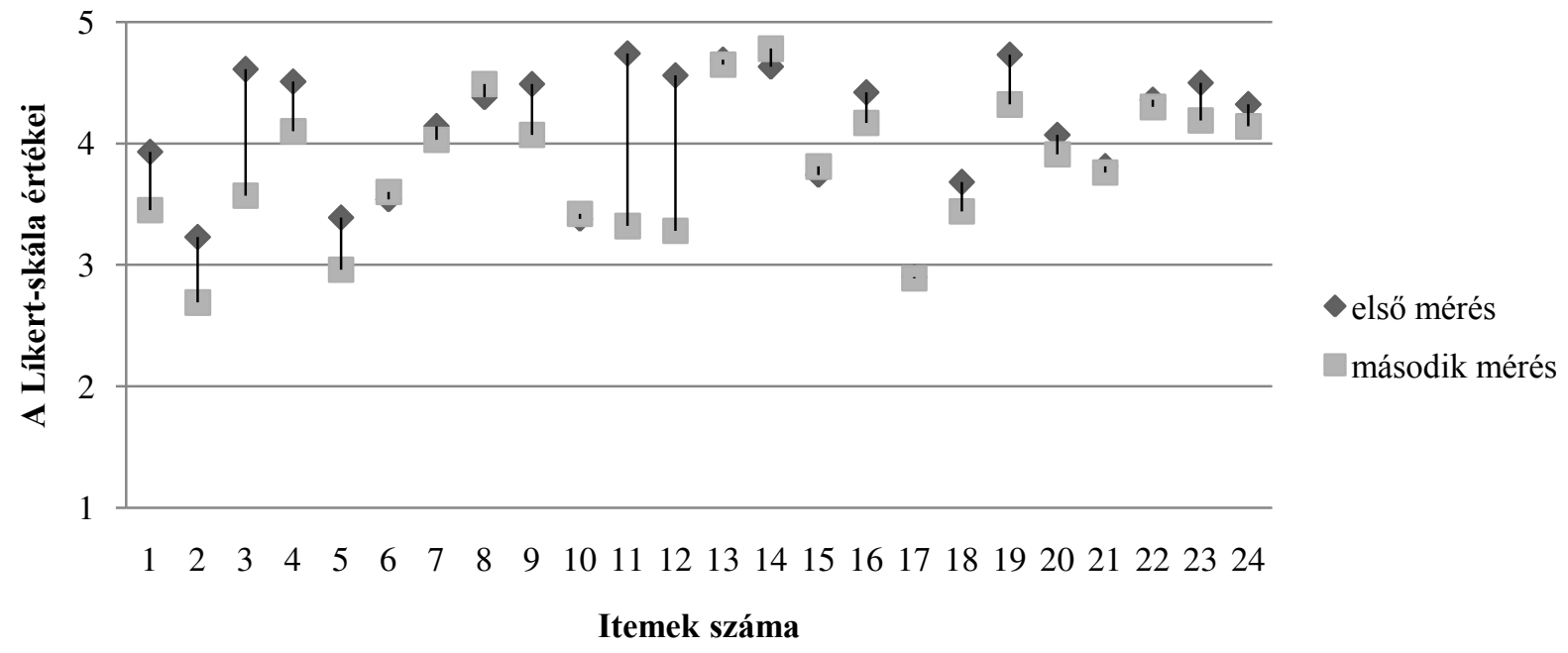

32. ábra: A kontrollcsoport környezeti attitüdjének változása az elsö és a második mérés során az egyes itemek tekintetében

A harmadik item (,Becsülöm azokat, akik saját pénzüket áldozzák a környezet védelmére”) esetében az első méréskor 4,61 pontot (90,2\%) értek el a tanulók, a második méréskor mindössze 3,57 pontot $(64,2 \%)$. A csökkenés releváns mértékü: $\mathrm{t}=6,16 \mathrm{p}=0,001$. A negyedik itemnél (,Aggódom amiatt, hogy az emberek nem vigyáznak eléggé a környezetükre”) az első méréskor 4,51 pont (87,7\%), a második méréskor 4,1 pont (77,5\%) volt a tanulók által elért érték. A csökkenés itt is szignifikáns: $t=2,32 \mathrm{p}=0,02$. A teljes alskála tekintetében elért csökkenés mértéke a t-próba alapján: $\mathrm{t}=5,38 \mathrm{p}=0,001$. Itt az első mérés értéke még 16,28 átlagpont (76,7\%) volt, a második méréskor már mindössze csak 14,03 átlagpont (56\%).

A növények alskálán a kísérleti csoport példájához hasonlóan ugyancsak a teljes skála tekintetében, valamint további három item esetében is jelentős mértékü csökkenés figyelhető meg a két mérés során kapott értékek között a kontrollcsoportban. Az alskálán belül az első itemnél (,Amikor egy erdőben járok, figyelem az ott élö növényeket”) 4,49 pontot (87,3\%) mértem az első felmérés alkalmával, és 4,07 pontot $(76,8 \%)$ a második mérés során. A csökkenés mértéke szignifikáns $(\mathrm{t}=2,34 \mathrm{p}=0,02)$. A skála második, a viselkedés faktorba tartozó itemjénél (,,Bárhol kirándulok, gyakran viszek haza virágot”) csekély mértékü értéknövekedés figyelhető meg, de ez a változás statisztikailag nem tekinthető relevánsnak $(\mathrm{t}=-0,24 \mathrm{p}=0,81)$. Az első méréskor ennél a kérdésnél 3,38 pontot (59,5\%), a második méréskor 3,42 pontot (60,5\%) értek el a tanulók. A harmadik item (,Nagyon szeretek erdőben sétálni”) esetében az első méréskor kapott érték 4,74 pont $(93,4 \%)$ volt, a második méréskor csak 3,32 pont (58\%). Ez a változás már szignifikánsnak számít ( $\mathrm{t}=8,76 \mathrm{p}=0,001)$. A skála negyedik kérdése a következöképpen hangzik: „Szerintem gyönyörüek a falevelek szinei összel”. Itt az első méréskor kapott 4,56 pont (88,9\%) 3,28 pontra $(56,8 \%)$ csökkent a második mérés során $(\mathrm{t}=7,06 \mathrm{p}=0,001)$. 
43. táblázat: Az attitüdértékek alakulása az első és a második mérés során a kontrollcsoportban

\begin{tabular}{|c|c|c|c|c|c|c|c|c|c|}
\hline \multirow{2}{*}{\multicolumn{2}{|c|}{ kérdések/alskálák }} & \multicolumn{3}{|c|}{ első mérés $(\mathrm{N}=118)$} & \multicolumn{3}{|c|}{ második mérés $(\mathrm{N}=118)$} & \multicolumn{2}{|c|}{ t-próba } \\
\hline & & átlag & szórás & $\%$ & átlag & szórás & $\%$ & $\mathrm{t}$ & $p$ \\
\hline \multicolumn{2}{|c|}{ ÁLTALÁNOS KÖRNYEZETI KÉRDÉSEK ALSKÁLA } & 16,28 & 3,02 & 76,7 & 14,03 & 3,01 & 56,0 & 5,38 & 0,001 \\
\hline viselkedés & 1. Figyelem a környezetvédelemmel kapcsolatos híreket. & 3,93 & 1,37 & 73,3 & 3,45 & 1,55 & 61,2 & 2,41 & 0,01 \\
\hline viselkedés & 2. Nem szoktam környezetvédelmi tanácsokat kérni másoktól. & 3,23 & 1,59 & 55,7 & 2,69 & 1,73 & 42,4 & 2,29 & 0,02 \\
\hline érzelem & 3. Becsülöm azokat, akik saját pénzüket áldozzák a környezet védelmére. & 4,61 & 0,83 & 90,2 & 3,57 & 1,53 & 64,2 & 6,16 & 0,001 \\
\hline érzelem & 4. Aggódom amiatt, hogy az emberek nem vigyáznak eléggé a környezetükre. & 4,51 & 0,96 & 87,7 & 4,1 & 1,3 & 77,5 & 2,32 & 0,02 \\
\hline \multicolumn{2}{|c|}{ ÁLLATOK ALSKÂLA } & 15,45 & 3,39 & 71,5 & 15,31 & 3,54 & 63,4 & 0,67 & 0,49 \\
\hline viselkedés & 1. Megkértem a szüleimet, hogy ne vegyenek állati szőrből készült bundát. & 3,39 & 1,78 & 59,7 & 2,96 & 1,87 & 48,9 & 1,84 & 0,07 \\
\hline viselkedés & 2. Szoktam télen etetni a madarakat & 3,54 & 1,64 & 63,5 & 3,6 & 1,66 & 64,9 & $-0,25$ & 0,81 \\
\hline érzelem & 3. Jó, ha egy kozmetikai készítményt elöször élő állatokon próbálnak ki. & 4,14 & 1,28 & 78,4 & 4,03 & 1,47 & 75,7 & 0,62 & 0,53 \\
\hline érzelem & 4. Elszomorít, hogy a sok építkezés az állatokat megfosztja lakóhelyüktől. & 4,38 & 1,21 & 84,5 & 4,49 & 1,08 & 87,2 & $-0,12$ & 0,91 \\
\hline \multicolumn{2}{|c|}{ NÖVÉNYEK ALSKÁLA } & 17,17 & 2,53 & 82,3 & 14,09 & 3,78 & 63,1 & 6,81 & 0,001 \\
\hline viselkedés & 1. Amikor egy erdőben járok, figyelem az ott élő növényeket. & 4,49 & 1,04 & 87,3 & 4,07 & 1,38 & 76,8 & 2,34 & 0,02 \\
\hline viselkedés & 2. Bárhol kirándulok, gyakran viszek haza virágot. & 3,38 & 1,56 & 59,5 & 3,42 & 1,62 & 60,5 & $-0,24$ & 0,81 \\
\hline érzelem & 3. Nagyon szeretek erdőben sétálni. & 4,74 & 0,67 & 93,4 & 3,32 & 1,68 & 58,0 & 8,76 & 0,001 \\
\hline érzelem & 4. Szerintem gyönyörủek a falevelek színei ősszel. & 4,56 & 1,02 & 88,9 & 3,28 & 1,52 & 56,8 & 7,06 & 0,001 \\
\hline \multicolumn{2}{|c|}{ VÍZ ALSKÁLA } & 17,46 & 2,54 & 84,2 & 17,40 & 2,90 & 83,7 & $-0,13$ & 0,89 \\
\hline viselkedés & 1. Fogmosás közben általában elzárom a csapot, hogy a vízzel takarékoskodjam. & 4,69 & 0,91 & 92,2 & 4,65 & 0,97 & 91,3 & 0,07 & 0,94 \\
\hline viselkedés & 2. Ha feleslegesen folyik a víz, elzárom a vízcsapot. & 4,63 & 0,9 & 90,7 & 4,78 & 0,68 & 94,5 & $-1,54$ & 0,12 \\
\hline érzelem & 3. Nem aggódom amiatt, hogy elfogy a tiszta víz. & 3,74 & 1,65 & 68,4 & 3,81 & 1,68 & 70,2 & $-0,37$ & 0,71 \\
\hline érzelem & 4. Idegesít, ha azt látom, hogy az emberek pazarolják a vizet. & 4,42 & 1,14 & 85,4 & 4,17 & 1,31 & 79,1 & 1,21 & 0,23 \\
\hline \multicolumn{2}{|c|}{ HULLADÉK ALSKÁLA } & 15,37 & 2,58 & 71,1 & 14,56 & 2,91 & 65,9 & 1,66 & 0,09 \\
\hline viselkedés & 1. Megkértem családtagjaimat, hogy csak eldobható palackot vásároljanak. & 2,90 & 1,44 & 47,4 & 2,89 & 1,57 & 47,2 & $-0,04$ & 0,96 \\
\hline viselkedés & 2. A háziszemét valamely részét elkülönítve gyüjtöm. & 3,68 & 1,51 & 66,9 & 3,44 & 1,55 & 61,0 & 0,57 & 0,56 \\
\hline érzelem & 3. Örülök, amikor azt látom, hogy az emberek újrahasznosítanak. & 4,73 & 0,8 & 93,2 & 4,32 & 1,23 & 83,0 & 2,97 & 0,004 \\
\hline érzelem & 4. Bosszant, hogy az emberek kidobnak újrahasznosítható dolgokat. & 4,07 & 1,38 & 76,7 & 3,91 & 1,48 & 72,7 & 0,60 & 0,55 \\
\hline \multicolumn{2}{|c|}{ ENERGIA ALSKÁLA } & 16,96 & 3,25 & 81,2 & 16,39 & 3,75 & 77,5 & 0,85 & 0,39 \\
\hline viselkedés & 1. Nyitva hagyom a hütőszekrény ajtaját, amíg eldöntöm, mit veszek ki belöle. & 3,81 & 1,58 & 70,1 & 3,76 & 1,64 & 69,0 & $-0,08$ & 0,93 \\
\hline viselkedés & 2. Otthon leoltom a lámpákat, ha kevesebb fény is elég, hogy energiát spóroljak. & 4,36 & 1,11 & 83,9 & 4,3 & 1,33 & 82,5 & 0,05 & 0,96 \\
\hline érzelem & 3. Feldob, ha azt látom, hogy az emberek energiát próbálnak megtakarítani. & 4,50 & 0,94 & 87,6 & 4,19 & 1,31 & 79,8 & 1,78 & 0,07 \\
\hline érzelem & 4. Zavar, hogy mennyi energiát pocsékolnak el feleslegesen. & 4,32 & 1,13 & 83,1 & 4,14 & 1,3 & 78,4 & 0,85 & 0,39 \\
\hline \multicolumn{2}{|c|}{ TELJES ÉRZELEM FAKTOR } & 52,67 & 6,3 & 84,8 & 47,31 & 8,93 & 73,6 & 5,13 & 0,001 \\
\hline \multicolumn{2}{|c|}{ TELJES VISELKEDÉS FAKTOR } & 46,01 & 7,09 & 70,9 & 44,48 & 7,75 & 60,6 & 1,22 & 0,22 \\
\hline \multicolumn{2}{|c|}{ TELJES ATTITÜDSKÁLA } & 98,59 & 11,96 & 77,8 & 91,79 & 14,66 & 63,3 & 3,55 & 0,001 \\
\hline
\end{tabular}


A hulladék és az energia alskálák esetében a teljes alskála tekintetében nem történt jelentős változás az első és a második mérés során. Ugyanakkor mindkét alskálán belül van egy-egy olyan item (mindkettő az érzelem faktorhoz tartozó item), ahol értékcsökkenés tapasztalható. A hulladék alskála harmadik itemje esetében (,,Örülök, amikor azt látom, hogy az emberek újrahasznosítanak”) az első méréskor kapott érték 4,73 pont (93,2\%) volt, a második méréskor 4,32 pont (83\%). A változás szignifikáns ( $\mathrm{t}=2,97 \mathrm{p}=0,004)$. Az energia alskála harmadik itemje a következő: „Feldob, ha azt látom, hogy az emberek energiát próbálnak megtakarítani”. Ennél a kérdésnél az első méréskor kapott 4,50-es pontszám (87,6\%) 4,19 pontra $(79,8 \%)$ csökkent a második mérés során. A csökkenés statisztikai szempontból is jelentős a t-próba értékei alapján: $t=1,78 \mathrm{p}=0,07$. Az ennél az itemnél tapasztalt változások a kísérleti csoportban is hasonlóak voltak.

Az állatok és a növények alskálák esetében sem a teljes skála, sem pedig az egyes itemek szempontjából nem történt jelentős változás a két mérés értékei között a kontrollcsoportban (33. ábra). Ugyanígy nem változott számottevően a viselkedés faktor értéke sem ebben a csoportban.

Az érzelem faktor esetében szignifikáns csökkenés $(\mathrm{t}=5,13 \mathrm{p}=0,001)$ figyelhető meg. Az első méréskor 52,67 pontot $(84,8 \%)$ értek el a tanulók, a második méréskor 47,31 pontot $(73,6 \%)$. A teljes attitüdskála értékei is jelentősen csökkentek $(t=3,55 \mathrm{p}=0,001)$ a kontrollcsoportban is az első mérés értékeihez képest, amikor 98,59 pontot $(77,8 \%)$ értek el a tanulók, a második mérés során már csak 91,79 pontot $(63,3 \%)$ produkáltak.

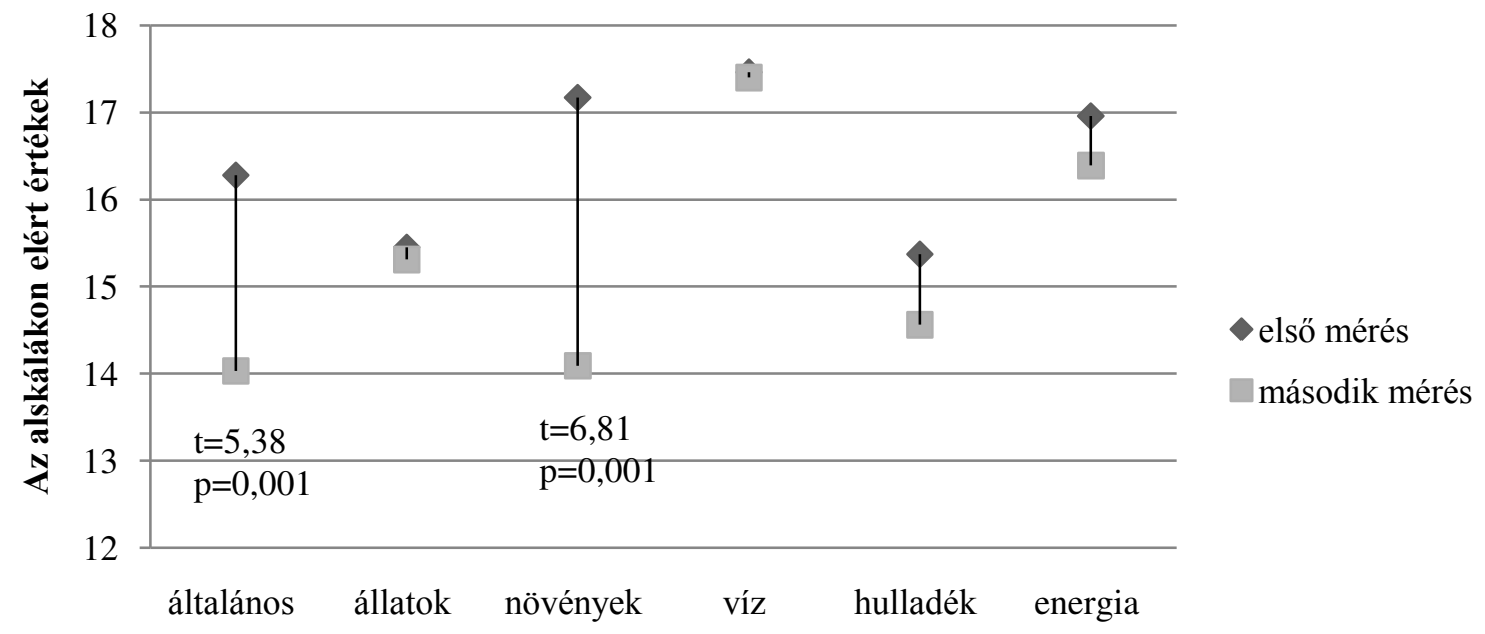

Alskálák

33. ábra: A kontrollcsoport környezeti attitüdjének változása az első és a második mérés során az alskálák tekintetében

Az előzőekben megállapítottam, hogy a H2/a hipotézist a kísérleti csoportban, az első és második alkalommal kapott eredmények alapján el kell vetni. Ugyanakkor a kontrollcsoportban kapott eredmények, amelyek hasonló mértékü csökkenést jeleznek az attitüdértékek tekintetében az első és a második mérés között, arra utalnak, hogy nem a program negatív hatása idézi elő ezt a változást. 
A környezeti attitüd skála értékeit nagymértékben befolyásolja az, hogy a kitöltő mennyire akar a szociális elvárásoknak megfelelni. A ténylegesnél pozitívabb környezeti attitüdöt produkál a környezeti attitüd skálán az, aki nagymértékben meg akar felelni a szociális elvárásoknak (Bogner és Wiseman, 2002). Ez félrevezető eredményeket adhat az ilyen jellegü felmérések során. Ennek köszönhetö, hogy a kisgyerekek körében elvégzett vizsgálatoknál a környezeti attitüdskálán mért első eredmények gyakran magasabbak lehetnek, mint a nem sokkal később elvégzett második mérés során kapott eredmények. Ez a tendencia fennáll hatéves kortól egészen a serdülőkorig (Eysenck és Eysenck 1969 idézi: Varga, 2004). A szociális kívánatosság skálán az életkor elörehaladtával egyre alacsonyabb pontszámokat érnek el a kitöltők (Varga, 2004). Erre a megállapításra utal, hogy a tanítóképzős hallgatók körében az ugyanezzel a kérdőívvel elvégzett attitüdvizsgálat során nem tapasztaltam ilyen jellegü attitüdcsökkenést.

A magyar gyerekek, sőt még a serdülök is nemzetközi összehasonlításban magas pontszámot érnek el a szociális kívánatosság skálán (Kálmánchey és Kozéki 1998 idézi: Varga, 2004; Kasik és társai, 2016). Juhász és társai 2015-ben a vajdasági magyar tanulók esetében is azonosították a jelenséget, és megállapították, hogy a szociális megfelelés iránti vágy számottevő az alsó tagozatos tanulók körében. Ennek alapján azt a következtetést vontam le, hogy sokkal inkább a szociális elvárásoknak való megfelelés iránti vágy felelős a második mérés során a csökkenő attitüdértékekért, nem pedig a program esetleges negatív hatásai.

\subsubsection{A kísérleti és a kontrollcsoportban mért értékek összehasonlitása}

A második mérést követően a két csoport értékeinek összehasonlítása során mindössze két item és egy alskála esetében figyelhető meg szignifikáns eltérés a kísérleti és a kontrollcsoport környezeti attitüdjét illetően (44. táblázat).

Az általános környezeti kérdések alskálán belül a második item (,Nem szoktam környezetvédelmi tanácsokat kérni másoktól”) esetében különbözik jelentősen a két csoport értéke a kétmintás t-próba értékei alapján: $\mathrm{t}=-1,99 \mathrm{p}=0,004$. A második mérést követően a kontrollcsoportban lényegesen magasabb eredményt értek el a tanulók, mint a kísérleti csoportban (26. ábra). Ez az item az első és a második mérés során is kérdéses eredményeket hozott a nehezen értelmezhető megfogalmazása miatt. A második mérés során elvégzett faktoranalízis eredményei szintén azt jelezték, hogy ez az item nem illeszkedik megfelelö mértékben a kérdőív többi részéhez. A jövőben a CHEAKS kérdöívvel végzett vizsgálatok során érdemes lehet átfogalmazni a kérdést. 
44. táblázat: Az attitüdértékek alakulása a második mérés során az alsó tagozatos tanulók körében

\begin{tabular}{|c|c|c|c|c|c|c|c|c|c|}
\hline \multirow{2}{*}{\multicolumn{2}{|c|}{ kérdések/alskálák }} & \multicolumn{3}{|c|}{ kísérleti csoport $(\mathrm{N}=216)$} & \multicolumn{3}{|c|}{ kontrollcsoport $(\mathrm{N}=118)$} & \multicolumn{2}{|c|}{ t-próba } \\
\hline & & átlag & szórás & $\%$ & átlag & szórás & $\%$ & $\mathrm{t}$ & $p$ \\
\hline \multicolumn{2}{|c|}{ ÁLTALÁNOS KÖRNYEZETI KÉRDÉSEK ALSKÁLA } & 13,82 & 3,27 & 56,0 & 14,03 & 3,01 & 56,0 & $-0,55$ & 0,58 \\
\hline viselkedés & 5. Figyelem a környezetvédelemmel kapcsolatos híreket. & 3,75 & 1,57 & 68,7 & 3,45 & 1,55 & 61,2 & 1,61 & 0,11 \\
\hline viselkedés & 6. Nem szoktam környezetvédelmi tanácsokat kérni másoktól. & 2,31 & 1,69 & 32,6 & 2,69 & 1,73 & 42,4 & $-1,99$ & 0,04 \\
\hline érzelem & 7. Becsülöm azokat, akik saját pénzüket áldozzák a környezet védelmére. & 3,33 & 1,68 & 58,3 & 3,57 & 1,53 & 64,2 & $-1,24$ & 0,21 \\
\hline érzelem & 8. Aggódom amiatt, hogy az emberek nem vigyáznak eléggé a környezetükre. & 4,21 & 1,31 & 80,1 & 4,1 & 1,3 & 77,5 & 0,67 & 0,5 \\
\hline \multicolumn{2}{|c|}{ ÁLLATOK ALSKÁLA } & 15,91 & 3,76 & 68,7 & 15,31 & 3,54 & 63,4 & 1,36 & 0,17 \\
\hline viselkedés & 5. Megkértem a szüleimet, hogy ne vegyenek állati szőrből készült bundát. & 3,13 & 1,76 & 53,2 & 2,96 & 1,87 & 48,9 & 0,83 & 0,41 \\
\hline viselkedés & 6. Szoktam télen etetni a madarakat & 3,65 & 1,68 & 66,3 & 3,6 & 1,66 & 64,9 & 0,28 & 0,78 \\
\hline érzelem & 7. Jó, ha egy kozmetikai készítményt elöször élő állatokon próbálnak ki. & 4,33 & 1,2 & 83,3 & 4,03 & 1,47 & 75,7 & 1,86 & 0,06 \\
\hline érzelem & 8. Elszomorít, hogy a sok építkezés az állatokat megfosztja lakóhelyüktől. & 4,58 & 0,98 & 89,5 & 4,49 & 1,08 & 87,2 & 0,76 & 0,44 \\
\hline \multicolumn{2}{|c|}{ NÖVÉNYEK ALSKÁLA } & 14,60 & 4,01 & 66,1 & 14,09 & 3,78 & 63,1 & 1,09 & 0,27 \\
\hline viselkedés & 5. Amikor egy erdőben járok, figyelem az ott élő növényeket. & 4,37 & 1,15 & 84,2 & 4,07 & 1,38 & 76,8 & 1,89 & 0,06 \\
\hline viselkedés & 6. Bárhol kirándulok, gyakran viszek haza virágot. & 3,63 & 1,51 & 65,7 & 3,42 & 1,62 & 60,5 & 1,11 & 0,26 \\
\hline érzelem & 7. Nagyon szeretek erdőben sétálni. & 3,37 & 1,71 & 59,3 & 3,32 & 1,68 & 58,0 & 0,25 & 0,79 \\
\hline érzelem & 8. Szerintem gyönyörüek a falevelek színei ősszel. & 3,22 & 1,62 & 55,4 & 3,28 & 1,52 & 56,8 & $-0,31$ & 0,75 \\
\hline \multicolumn{2}{|c|}{ VÍZ ALSKÁLA } & 17,13 & 3,55 & 81,9 & 17,40 & 2,90 & 83,7 & $-0,67$ & 0,5 \\
\hline viselkedés & 5. Fogmosás közben általában elzárom a csapot, hogy a vízzel takarékoskodjam. & 4,54 & 1,07 & 88,6 & 4,65 & 0,97 & 91,3 & $-0,86$ & 0,38 \\
\hline viselkedés & 6. Ha feleslegesen folyik a víz, elzárom a vízcsapot. & 4,64 & 0,96 & 91,0 & 4,78 & 0,68 & 94,5 & $-1,46$ & 0,14 \\
\hline érzelem & 7. Nem aggódom amiatt, hogy elfogy a tiszta víz. & 3,66 & 1,75 & 66,5 & 3,81 & 1,68 & 70,2 & $-0,71$ & 0,48 \\
\hline érzelem & 8. Idegesít, ha azt látom, hogy az emberek pazarolják a vizet. & 4,25 & 1,34 & 81,4 & 4,17 & 1,31 & 79,1 & 0,56 & 0,57 \\
\hline \multicolumn{2}{|c|}{ HULLADÉK ALSKÁLA } & 15,14 & 2,61 & 69,4 & 14,56 & 2,91 & 65,9 & 1,81 & 0,07 \\
\hline viselkedés & 5. Megkértem családtagjaimat, hogy csak eldobható palackot vásároljanak. & 2,74 & 1,62 & 43,4 & 2,89 & 1,57 & 47,2 & $-0,81$ & 0,41 \\
\hline viselkedés & 6. A háziszemét valamely részét elkülönítve gyüjtöm. & 3,62 & 1,55 & 65,6 & 3,44 & 1,55 & 61,0 & 0,98 & 0,32 \\
\hline érzelem & 7. Örülök, amikor azt látom, hogy az emberek újrahasznosítanak. & 4,53 & 1,06 & 88,4 & 4,32 & 1,23 & 83,0 & 1,53 & 0,12 \\
\hline érzelem & 8. Bosszant, hogy az emberek kidobnak újrahasznosítható dolgokat. & 4,22 & 1,31 & 80,5 & 3,91 & 1,48 & 72,7 & 1,84 & 0,06 \\
\hline \multicolumn{2}{|c|}{ ENERGIA ALSKÁLA } & 17,31 & 3,84 & 82,8 & 16,39 & 3,75 & 77,5 & 2,03 & 0,04 \\
\hline viselkedés & 5. Nyitva hagyom a hütőszekrény ajtaját, amíg eldöntöm, mit veszek ki belöle. & 4,29 & 1,31 & 82,2 & 3,76 & 1,64 & 69,0 & 2,88 & 0,004 \\
\hline viselkedés & 6. Otthon leoltom a lámpákat, ha kevesebb fény is elég, hogy energiát spóroljak. & 4,29 & 1,25 & 82,2 & 4,3 & 1,33 & 82,5 & 0,08 & 0,92 \\
\hline érzelem & 7. Feldob, ha azt látom, hogy az emberek energiát próbálnak megtakarítani. & 4,32 & 1,19 & 82,9 & 4,19 & 1,31 & 79,8 & 0,85 & 0,39 \\
\hline érzelem & 8. Zavar, hogy mennyi energiát pocsékolnak el feleslegesen. & 4,36 & 1,17 & 83,9 & 4,14 & 1,3 & 78,4 & 1,52 & 0,12 \\
\hline \multicolumn{2}{|c|}{ TELJES ÉRZELEM FAKTOR } & 48,49 & 9,49 & 75,8 & 47,31 & 8,93 & 73,6 & 1,06 & 0,28 \\
\hline \multicolumn{2}{|c|}{ TELJES VISELKEDÉS FAKTOR } & 45,45 & 8,08 & 64,1 & 44,48 & 7,75 & 60,6 & 1,01 & 0,31 \\
\hline \multicolumn{2}{|c|}{ TELJES ATTITÜDSKÁLA } & 93,94 & 16,26 & 67,1 & 91,79 & 14,66 & 63,3 & 1,14 & 0,25 \\
\hline
\end{tabular}


Az energia alskálán belül az első item esetében különbözik jelentősen a két csoport környezeti attitüdje $(\mathrm{t}=2,88 \mathrm{p}=0,004)$. A ,Nyitva hagyom a hütöszekrény ajtaját, amíg eldöntöm, mit veszek ki belöle” megfogalmazású item esetében a kísérleti csoportban mért értékek sokkal magasabbak a kontrollcsoportban mért értékeknél (34. ábra). Az item megfogalmazása az előző kérdéses tételhez hasonlóan nem túl szerencsés, ez lehet az oka a csoportok közötti különbségnek. A kérdöív faktoranalízise során ez az item esett a legalacsonyabb súllyal az első faktorba. Ez az eredmény is azt jelzi, hogy a kérdés átfogalmazásra szorul a kérdőív további alkalmazása során.

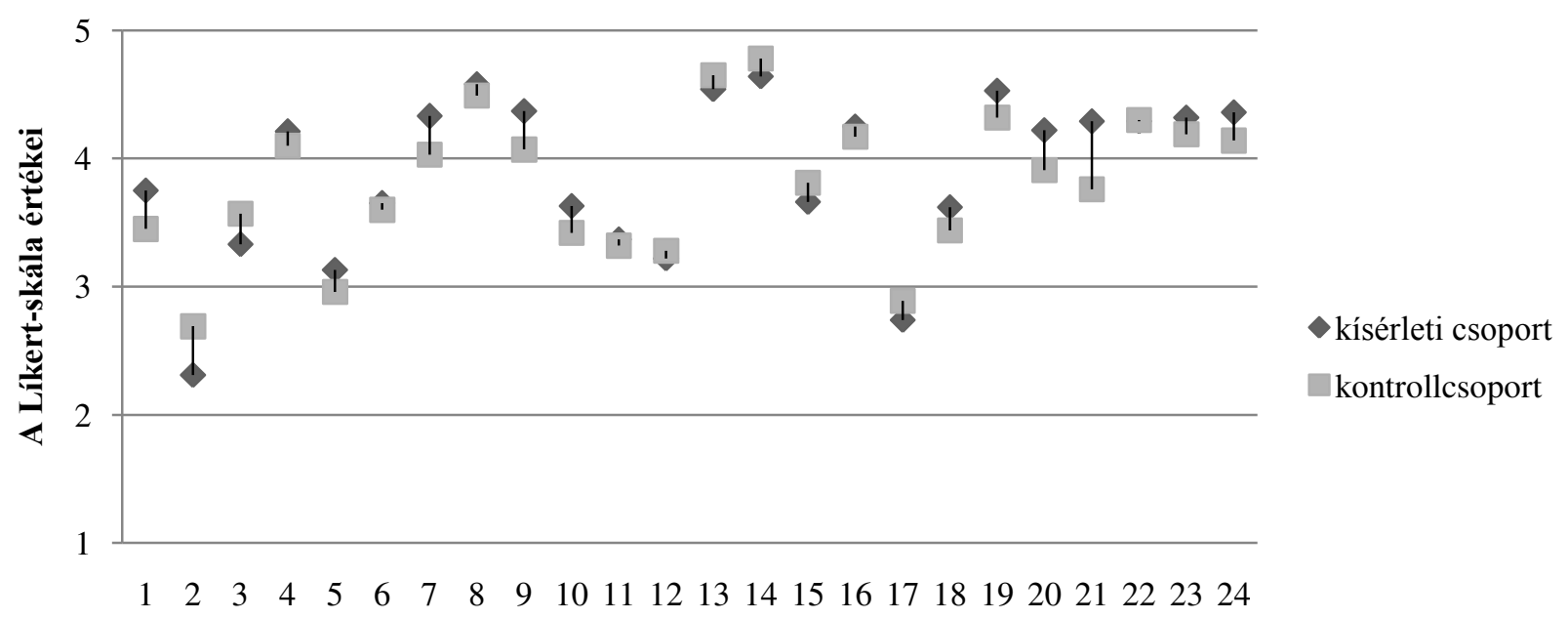

Itemek száma

34. ábra: A kísérleti és a kontrollcsoport környezeti attitüdjének változása a második mérés során az egyes itemek tekintetében

Az összes alskála eredményeit figyelembe véve egyedül az energia alskála esetében mondhatjuk el, hogy a két csoport környezeti attitüdje szignifikánsan eltérö $(\mathrm{t}=2,03 \mathrm{p}=0,04)$. A kísérleti csoport értékei jelentős mértékben meghaladják a kontrollcsoportban mért értékeket (35. ábra). Ez az eredmény a program hatékonyságára utal a kérdéses témakör tekintetében.

A többi alskála, az érzelem és a viselkedés faktorok, valamint a teljes skála esetében azonban el kell vetni a $\mathrm{H} 2 / \mathrm{b}$ hipotézisben foglaltakat. A környezeti nevelési programban részt vevő alsó tagozatos diákok környezeti attitüdje, környezettudatos magatartásának értéke az energia témakörét kivéve nem mutat eltérést a kontrollcsoportban részt vevő tanulókéhoz képest. 


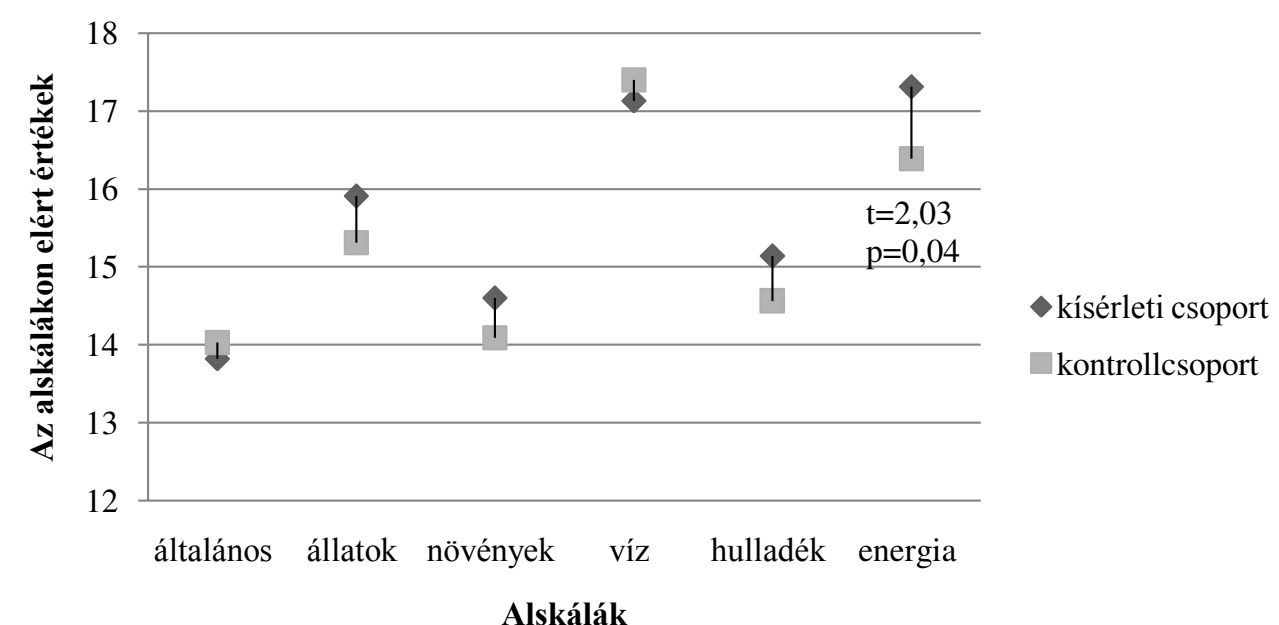

35. ábra: A kísérleti és a kontrollcsoport környezeti attitüdjének változása a második mérés során az alskálák tekintetében

A program hatékonyságát az alsó tagozatos tanulók esetében nem tudtam egyértelmủen bizonyítani, sem a kísérleti csoport első és második alkalommal mért értekeinek összehasonlítása, sem pedig a kísérleti és a kontrollcsoport által elért értékek összehasonlítása által.

A H3-as hipotézisben azt állítottam, hogy a környezeti nevelési programban részt vevő alsó tagozatos diákok környezeti attitüdjének értéke magasabb értéket mutat a programban feldolgozott témakörök esetében. A hipotézist nem sikerült alátámasztani a két mérés közötti értékek összehasonlítása által a kísérleti csoportban (H3/a hipotézis). A két csoport értékeinek összehasonlítás sem hozott egyértelmü bizonyítást mindhárom modul (víz, hulladék, energia) hatékonyságát illetően. Az energia témakörének esetében azonban bizonyítást nyert a H3/b állítás, a kísérleti csoportban ugyanis magasabb attitüdértéket értek el a tanulók ezen a témakörön belül, mint a kontrollcsoportban.

\subsubsection{Az alsó tagozatos tanulók háttértényezőinek és környezeti attitüdjének összefüggései}

A kísérleti csoport eredményei

A H4 jelzésü hipotézisben megfogalmazott feltételezésem alapján a vizsgált alsó tagozatos tanulókra jellemző háttérváltozók befolyásolják környezeti attitüdjük mértékét. Az egyes háttérváltozókkal kapcsolatos eredményeket és az első mérés során az egyes alskálákon, valamint a teljes skálán elért attitüdértékeket a Pearson-féle korrelációs vizsgálat, segítségével hasonlítottam össze. Az attitüdértékek és a háttérváltozók mindkét csoportban csak gyenge kapcsolatot mutatnak. A testvérek száma, a nagyszülőkkel való együttélés, a család anyagi helyzete, valamint a tanulmányi átlag változók sem a kísérleti, sem pedig a kontrollcsoport eredményeivel nem állnak összefüggésben.

A kísérleti csoportban a környezeti attitüdöt befolyásoló háttérváltozókat és a közöttük lévő viszony mértékét a 45. táblázatban ábrázoltam. 
45. táblázat: Az alsó tagozatos tanulók háttérváltozóinak összefüggése az attitüdértékekkel a kisérleti csoportban

\begin{tabular}{|c|c|c|c|c|c|c|c|c|}
\hline alskálák változók & nem & életkor & osztály & $\begin{array}{l}\text { apa iskolai } \\
\text { végzettsége }\end{array}$ & $\begin{array}{l}\text { anya iskolai } \\
\text { végzettsége }\end{array}$ & $\begin{array}{l}\text { egyéb család- } \\
\text { taggal való } \\
\text { együttélés }\end{array}$ & $\begin{array}{l}\text { kedvenc } \\
\text { tantárgy }\end{array}$ & $\begin{array}{l}\text { tanulmányi } \\
\text { átlag }\end{array}$ \\
\hline \multirow{6}{*}{$\begin{array}{l}\text { általános alskála } \\
\text { állat alskála } \\
\text { növény alskála } \\
\text { víz alskála } \\
\text { hulladék alskála } \\
\text { energia alskála }\end{array}$} & n.s. ${ }^{6}$ & \multirow{6}{*}{$\begin{array}{c}\text { n.s. } \\
\mathrm{r}=0,2 \mathrm{p}=0,005 \\
\text { n.s. } \\
\text { n.s. } \\
\text { n.s. } \\
\mathrm{r}=0,1 \mathrm{p}=0,03\end{array}$} & \multirow{6}{*}{$\begin{array}{c}\text { n.s. } \\
\mathrm{r}=0,2 \mathrm{p}=0,001 \\
\text { n.s. } \\
\text { n.s. } \\
\text { n.s. } \\
\text { n.s. }\end{array}$} & n.s. & n.s. & $\mathrm{r}=-0,2 \mathrm{p}=0,01$ & $\mathrm{r}=-0,2 \mathrm{p}=0,03$ & n.s. \\
\hline & n.s. & & & n.s. & n.s. & n.s. & n.s. & n.s. \\
\hline & $\mathrm{r}=0,2 \mathrm{p}=0,004$ & & & n.s. & n.s. & $\mathrm{r}=-0,2 \mathrm{p}=0,01$ & n.s. & n.s. \\
\hline & n.s. & & & n.s. & n.s. & $\mathrm{r}=-0,2 \mathrm{p}=0,01$ & n.s. & n.s. \\
\hline & n.s. & & & n.s. & n.s. & n.s. & n.s. & n.s. \\
\hline & n.s. & & & $\mathrm{r}=0,2 \mathrm{p}=0,02$ & $\mathrm{r}=0,2 \mathrm{p}=0,03$ & n.s. & n.s. & n.s. \\
\hline \multirow{2}{*}{$\begin{array}{l}\text { viselkedés faktor } \\
\text { érzelem faktor }\end{array}$} & n.s. & \multirow{3}{*}{$\begin{array}{c}\text { n.s. } \\
\mathrm{r}=0,1 \mathrm{p}=0,02 \\
\mathrm{r}=0,1 \mathrm{p}=0,02\end{array}$} & \multirow{2}{*}{$\begin{array}{c}\mathrm{r}=0,1 \mathrm{p}=0,02 \\
\text { n.s. }\end{array}$} & \multirow{2}{*}{$\begin{array}{c}\text { n.s. } \\
\mathrm{r}=0,2 \mathrm{p}=0,02\end{array}$} & n.s. & n.s. & n.s. & n.s. \\
\hline & n.s. & & & & n.s. & $\mathrm{r}=-0,3 \mathrm{p}=0,001$ & n.s. & n.s. \\
\hline teljes skála & n.s. & & $\mathrm{r}=0,1 \mathrm{p}=0,02$ & $\mathrm{r}=0,2 \mathrm{p}=0,03$ & n.s. & $\mathrm{r}=-0,2 \mathrm{p}=0,01$ & n.s. & n.s. \\
\hline
\end{tabular}

46. táblázat: Az alsó tagozatos tanulók háttérváltozóinak összefüggése az attitüdértékekkel a kontrollcsoportban

\begin{tabular}{|c|c|c|c|c|c|c|c|c|}
\hline alskálák változók & nem & életkor & osztály & $\begin{array}{l}\text { apa iskolai } \\
\text { végzettsége }\end{array}$ & $\begin{array}{c}\text { anya iskolai } \\
\text { végzettsége }\end{array}$ & $\begin{array}{l}\text { egyéb család- } \\
\text { taggal való } \\
\text { együittélés }\end{array}$ & $\begin{array}{l}\text { kedvenc } \\
\text { tantárgy }\end{array}$ & $\begin{array}{l}\text { tanulmányi } \\
\text { átlag }\end{array}$ \\
\hline általános alskála & n.s. & n.s. & n.s. & n.s. & n.s. & n.s. & n.s. & n.s. \\
\hline állat alskála & n.s. & n.s. & n.s. & n.s. & n.s. & n.s. & n.s. & $\mathrm{r}=0,2 \mathrm{p}=0,03$ \\
\hline növény alskála & $\mathrm{r}=0,3 \mathrm{p}=0,001$ & n.s. & n.s. & n.s. & n.s. & n.s. & n.s. & $\mathrm{r}=0,2 \mathrm{p}=0,01$ \\
\hline víz alskála & n.s. & n.s. & $\mathrm{r}=0,2 \mathrm{p}=0,04$ & n.s. & n.s. & n.s. & n.s. & n.s. \\
\hline hulladék alskála & n.s. & n.s. & n.s. & n.s. & n.s. & n.s. & n.s. & n.s. \\
\hline energia alskála & n.s. & n.s. & n.s. & $\mathrm{r}=0,2 \mathrm{p}=0,02$ & $\mathrm{r}=0,2 \mathrm{p}=0,006$ & n.s. & n.s. & $\mathrm{r}=0,3 \mathrm{p}=0,005$ \\
\hline viselkedés faktor & n.s. & n.s. & n.s. & n.s. & $\mathrm{r}=0,2 \mathrm{p}=0,02$ & n.s. & n.s. & $\mathrm{r}=0,3 \mathrm{p}=0,004$ \\
\hline érzelem faktor & n.s. & n.s. & n.s. & n.s. & n.s. & n.s. & n.s. & $\mathrm{r}=0,2 \mathrm{p}=0,03$ \\
\hline teljes skála & n.s. & n.s. & n.s. & n.s. & $\mathrm{r}=0,2 \mathrm{p}=0,03$ & n.s. & n.s. & $\mathrm{r}=0,3 \mathrm{p}=0,004$ \\
\hline
\end{tabular}

\footnotetext{
${ }^{6}$ n.s. = nem szignifikáns
} 
A legtöbb összefüggést az egyes alskálákon kapott attitüdértékekkel az egyéb (nem szülő, testvér vagy nagyszülő) családtaggal való együttélés mutatja. Minden alskála esetében negatív korreláció figyelhető meg a kapott értékek és a változó között. Az érintett alskálák az általános környezeti kérdések $(\mathrm{r}=-0,2 \mathrm{p}=0,01)$, a növények $(\mathrm{r}=-0,2 \mathrm{p}=0,01)$, valamint a víz ( $\mathrm{r}=-$ $0,2 \mathrm{p}=0,01)$ témakörét fedik le, illetve az érzelem faktor $(\mathrm{r}=-0,3 \mathrm{p}=0,001)$ és a teljes skála $(\mathrm{r}=-$ $0,2 \mathrm{p}=0,01)$ is negatív korrelációt mutat az egyéb családtaggal való együttélés változóval.

Az életkor változó az állatok ( $\mathrm{r}=0,2 \mathrm{p}=0,005)$ és az energia alskálával $(\mathrm{r}=0,1 \mathrm{p}=0,03)$, az érzelem faktorral $(\mathrm{r}=0,1 \mathrm{p}=0,02)$ és a teljes skálával $(\mathrm{r}=0,1 \mathrm{p}=0,02)$ mutat gyenge összefüggést. Az osztály háttérváltozó gyenge korrelációt mutat az állatok alskálával ( $\mathrm{r}=0,2$ $\mathrm{p}=0,001)$, valamint a viselkedés faktorral $(\mathrm{r}=0,1 \mathrm{p}=0,02)$ és a teljes skálával $(\mathrm{r}=0,1 \mathrm{p}=0,02)$. $\mathrm{Az}$ apa iskolai végzettsége változó gyenge kapcsolatot mutat az energia alskála $(\mathrm{r}=0,2$ $\mathrm{p}=0,02)$, az érzelem faktor $(\mathrm{r}=0,2 \mathrm{p}=0,02)$, valamint a teljes skála $(\mathrm{r}=0,2 \mathrm{p}=0,03)$ értékeivel. $\mathrm{Az}$ anya iskolai végzettsége ugyancsak az energia alskála $(\mathrm{r}=0,2 \mathrm{p}=0,03)$ értékeivel mutat összefüggést. További összefüggés figyelhető még meg a nemi változónak a növények alskála értékeivel, valamint a kedvenc tantárgynak az általános környezeti kérdések alskála értékeivel. A tanulmányi átlag változó a kísérleti csoportban nem befolyásolja az attitüdértékek alakulását.

A fenti értékek alapján a legtöbb háttérváltozóval a teljes attitüdskála esetében mutatható ki kapcsolat.

A nem változó tekintetében különbség mutatkozik a fiúk és a lányok attitűdértékét illetően a növények alskálán belül. A fiúk 17,3 átlagpontot, a lányok 18,3 átlagpontot értek el ezen az alskálán az első mérés alkalmával. A különbség szignifikáns $(\mathrm{t}=-2,9 \mathrm{p}=0,004)$. A nemi változó esetében nem mutatható ki további különbség a kísérleti csoporton belül.

Az életkor és az osztály változók több alskála esetében eltérést mutatnak az első méréskor a kísérleti csoport tagjai között, az egyutas ANOVA vizsgálat értékei alapján. Az apa iskolai végzettsége három alskála esetében jelez eltérést a változó alapján kialakuló csoportok értékei között. A növények, az energia, valamint a teljes attitüdskálán figyelhetö meg eltérés az első mérés során. A második méréskor a változó alapján nem mértem eltérést. A kapott eredményeket a 47. táblázat foglalja össze.

47. táblázat:

A háttérváltozók általi eltérések a kísérleti csoportban

\begin{tabular}{lcccccc}
\hline \multirow{2}{*}{ alskálák } & változók & \multicolumn{2}{c}{ életkor } & \multicolumn{2}{c}{ osztály } & \multicolumn{2}{c}{ apa iskolai végz. } \\
& $\mathrm{F}$ & $p$ & $\mathrm{~F}$ & $p$ & $\mathrm{~F}$ & $p$ \\
\hline I. általános alskála & 4,3 & 0,002 & 8,3 & 0,001 & - & - \\
I. állatok alskála & 5,3 & 0,001 & 12,5 & 0,001 & - & - \\
I. növények alskála & 2,9 & 0,02 & 6,5 & 0,002 & 2,9 & 0,03 \\
I. víz alskála & - & - & 5,5 & 0,005 & - & - \\
I. hulladék alskála & - & - & - & - & - & - \\
I. energia alskála & 3,9 & 0,004 & 8,3 & 0,001 & 3,4 & 0,02 \\
I. teljes érzelem faktor & 6,5 & 0,001 & 11,9 & 0,001 & - & - \\
I. teljes viselkedés faktor & 4,1 & 0,003 & 12,5 & 0,001 & - & - \\
I. teljes attitüdskála & 6,9 & 0,001 & 16,3 & 0,001 & 2,8 & 0,04 \\
\hline
\end{tabular}


A kontrollcsoport eredményei

A kontrollcsoportban az életkor, az egyéb családtaggal való együttélés, valamint a kedvenc tantárgy háttérváltozók egyik alskálával sem mutatnak összefüggést (46. táblázat).

A legtöbb összefüggés a kontrollcsoport attitüdértékeivel a tanulmányi átlag változóval kapcsolatban mutatható ki. Az állatok $(\mathrm{r}=0,2 \mathrm{p}=0,03)$, a növények $(\mathrm{r}=0,2 \mathrm{p}=0,01)$ és az energia $(\mathrm{r}=0,3 \mathrm{p}=0,005)$ alskála, valamint az érzelem $(\mathrm{r}=0,3 \mathrm{p}=0,004)$ és a viselkedés $(\mathrm{r}=0,2 \mathrm{p}=0,03)$ faktor, és a teljes skála $(\mathrm{r}=0,3 \mathrm{p}=0,004)$ is gyenge korrelációt mutat a tanulók tanulmányi eredményével.

$\mathrm{Az}$ anya iskolai végzettsége gyenge kapcsolatot jelöl az energia alskála $(\mathrm{r}=0,2$ $\mathrm{p}=0,006)$ értékeivel, a viselkedés faktorral $(\mathrm{r}=0,2 \mathrm{p}=0,02)$ és a teljes skálával $(\mathrm{r}=0,2 \mathrm{p}=0,03)$. Az apa iskolai végzettsége csak az energia alskálával korrelál gyenge mértékben. A kísérleti csoportban ezen alskálákkal való összefüggéseknek pontosan a fordítottja volt megfigyelhető, ott az apa iskolai végzettsége korrelált több skála értékével.

A nem és az osztály háttérváltozók egy-egy skála értékeivel mutatnak gyenge kapcsolatot. A nem változó a növények alskálán elért attitüdértékekkel korrelál ( $\mathrm{r}=0,3$ $\mathrm{p}=0,001)$, az osztály változó pedig a víz skála értékeivel ( $\mathrm{r}=0,2 \mathrm{p}=0,04)$.

A nemi változó alapján elvégzett kétmintás t-próba szignifikáns különbséget jelez a fiúk és a lányok értékei között a kontrollcsoportban. Az első mérés során a kísérleti csoporthoz hasonlóan a növények alskála az, ahol különbség ( $\mathrm{t}=-3,4 \mathrm{p}=0,001)$ jelentkezik. A fiúk 16,4 pontot, a lányok 17,9 pontot értek el ezen az alskálán. A második mérés során a növények alskálánál továbbra is különbséget tapasztaltam $(\mathrm{t}=-2,9 \mathrm{p}=0,004)$. A fiúk 13,03 pontot, a lányok 15,1 pontot értek el az alskálán. A második méréskor az energia alskálán is különbséget jeleztek az eredmények ( $\mathrm{t}=-2,1 \mathrm{p}=0,03)$ a nemek tekintetében. A fiúk 15,6 pontot, a lányok 17,1 pontot értek el ezen a skálán.

$\mathrm{Az}$ életkor változó egyedül a második mérés során, a viselkedés alskálán jelzett különbséget $(\mathrm{F}=2,8 \mathrm{p}=0,03)$ az eredmények között.

Az osztály változónál az állat $(\mathrm{F}=3,8 \mathrm{p}=0,02)$ alskála esetében figyelhető meg különbség az első méréskor. A második méréskor ismét az állat alskálánál ( $\mathrm{F}=4,3 \mathrm{p}=0,01)$, valamint a hulladék $(\mathrm{F}=3,2 \mathrm{p}=0,04)$ és a viselkedés $(\mathrm{F}=6,8 \mathrm{p}=0,002)$ alskáláknál jelentkezik különbség.

Az apa iskolai végzettsége alapján kialakuló csoportok eredményei között az energia $(\mathrm{F}=3,3 \mathrm{p}=0,02)$ és a viselkedés $(\mathrm{F}=3,2 \mathrm{p}=0,02)$ alskálákon mutatkozik eltérés az első méréskor.

A kísérleti és a kontrollcsoportban kapott eredmények több változó esetében is bizonyítják a H4 hipotézis feltevését, amely szerint az alsó tagozatos tanulókra jellemző háttérváltozók befolyásolják környezeti attitüdjük mértékét. 


\subsubsection{A környezetet veszélyeztető tényezők megítélése az első mérés során}

A kérdöívben szereplö, környezeti attitüdöt vizsgáló 24 itemet követő 15 elem a környezetet veszélyeztető tényezők felmérésére szolgál. Tizenöt olyan helyzet, illetve jelenség került felsorolásra, amelyek kisebb-nagyobb mértékben befolyással vannak természeti környezetünk állapotára. A kérdések segítségével azt vizsgáltam, mennyire szemlélik reálisan a tanulók ezeknek a tényezőknek a veszélyességét a környezetre nézve, a programot megelőzően, illetve azt követően.

\subsubsection{A kísérleti csoport eredményei}

A kísérleti csoport tagjai az első mérés alkalmával az utcai szemetelést (90,5\%) jelölték meg a legszigorúbban a környezetet veszélyeztető tényezők közül. Közvetlenül ezután a vízszennyezést (89,8\%), az erdőirtást (89,6\%), majd az ipart $(88,8 \%)$, a dohányzást $(88,6 \%)$ és a légszennyezést $(88,2 \%)$ tartják veszélyes tényezőnek, nagyjából azonos mértékben. A felsorolt tényezők közül azonban az utcai szemetelés vagy a dohányzás nem jelent olyan mértékü veszélyt a természet állapotára nézve, mint például az erdőirtás vagy akár a légszennyezés. Ugyanakkor ezek azok a tényezők, amelyek hatását a gyerekek közvetlenül is tapasztalják, ennek tulajdonítható, hogy ilyen mértékü szigorúsággal ítélték meg őket. A reális szemlélet megalapozása és a környezettudatosság megfelelő szintjének kialakítása érdekében szükség van arra, hogy a tanulókat megismertessük az emberi tevékenységeknek a környezetre gyakorolt káros hatásaival. Emellett természetesen a szemeteléssel vagy a dohányzással kapcsolatos negatív hozzáállást továbbra is támogatni kell a tanulók nevelése során.

A fent említett tényezők mellett a kísérleti csoport tagjai szigorúan ítéltek még a talajerózió $(85,9 \%)$, a közlekedés $(80,2 \%)$, a savas eső $(77,5 \%)$, az atomerőművek $(75,5 \%)$, illetve a bányászat (71,3\%) kérdésével kapcsolatban. Ezeknél a tényezőknél 70\% feletti volt a veszélyeztető hatás megítélése.

A vízerömüvek $(55,7 \%)$, illetve a túlnépesedés $(41,1 \%)$ kérdése kevésbé tünik kockázatosnak a környezetszennyezés szempontjából a tanulók véleménye szerint.

A mezőgazdaságot mindössze 32,9\%-ban tartják veszélyesnek, a természetvédelmet pedig a legkevésbé veszélyes tényezőként $(13,4 \%)$ ítélték meg a tanulók (48. táblázat). 
48. táblázat: A környezetet veszélyeztetö tényezők megitélése az első mérés során az alsó tagozatos tanulók körében

\begin{tabular}{llccccccc}
\hline \multirow{2}{*}{ veszélyeztető tényezők } & \multicolumn{2}{c}{ kísérleti csoport $(\mathrm{N}=216)$} & \multicolumn{3}{c}{ kontrollcsoport $(\mathrm{N}=118)$} & \multicolumn{3}{c}{$t$-próba } \\
& átlag & szórás & $\%^{7}$ & átlag & szórás & $\%$ & t & $p$ \\
\hline 1. természetvédelem & 1,54 & 1,2 & 13,4 & 1,70 & 1,3 & 17,6 & $-1,1$ & 0,2 \\
2. mezőgazdaság & 2,32 & 1,6 & 32,9 & 2,49 & 1,5 & 37,3 & $-9,5$ & 0,3 \\
3. vízerőmüvek & 3,23 & 1,6 & 55,7 & 3,35 & 1,4 & 58,7 & $-6,8$ & 0,5 \\
4. bányászat & 3,85 & 1,3 & 71,3 & 3,35 & 1,4 & 58,7 & 3,2 & 0,02 \\
5. vízszennyezés & 4,59 & 0,9 & 89,8 & 4,55 & 0,9 & 88,7 & 0,4 & 0,7 \\
6. közlekedés & 4,21 & 1,3 & 80,2 & 4,27 & 1,3 & 81,7 & $-0,4$ & 0,6 \\
7. túlnépesedés & 2,64 & 1,6 & 41,1 & 3,32 & 1,5 & 58,05 & $-3,7$ & 0,001 \\
8. talajerózió & 4,44 & 1,1 & 85,9 & 4,43 & 1,1 & 85,8 & 0,1 & 0,9 \\
9. atomerömüvek & 4,02 & 1,5 & 75,5 & 4,21 & 1,3 & 80,1 & $-1,1$ & 0,2 \\
10. ipar & 4,56 & 0,9 & 88,8 & 4,42 & 1,1 & 85,6 & 1,1 & 0,2 \\
11. savas eső & 4,10 & 1,4 & 77,5 & 4,01 & 1,3 & 75,2 & 0,6 & 0,5 \\
12. utcai szemetelés & 4,62 & 0,9 & 90,5 & 4,69 & 0,9 & 92,4 & $-0,7$ & 0,4 \\
13. dohányzás & 4,55 & 1,2 & 88,6 & 4,71 & 0,8 & 92,8 & $-1,3$ & 0,1 \\
14. erdőirtás & 4,58 & 1,0 & 89,6 & 4,61 & 0,9 & 90,2 & $-0,2$ & 0,8 \\
15. légszennyezés & 4,53 & 1,0 & 88,2 & 4,54 & 1,0 & 88,5 & $-0,1$ & 0,9 \\
\hline
\end{tabular}

\subsubsection{A kontrollcsoport eredményei}

A kontrollcsoportban a kísérleti csoport véleményéhez hasonlóan az utcai szemetelést (92,8\%) tartották a legveszélyesebb környezetkárosító tényezőnek. Rögtön ezután következett a savas eső $(92,4 \%)$, majd a dohányzás $(90,2 \%)$, mint legveszélyesebb tényezők.

A kontrollcsoportban $80 \%$ feletti eredménnyel ítélték még veszélyesnek a bányászat $(88,8 \%)$, az erdőirtás $(88,5 \%)$, a túlnépesedés $(85,8 \%)$, az atomerőmủvek $(85,6 \%)$, a vízszennyezés $(81,8 \%)$ és a talajerózió $(80,1 \%)$ tényezőket.

A légszennyezést 76,6\%-ban, az ipart 75,2\%-ban, a vízerőmüvek építésének káros hatását pedig 68,7\%-ban tartották veszélyesnek a kontrollcsoport tagjai.

A mezőgazdaság (37,3\%) és a természetvédelem (17,5\%) károsító hatását a kísérleti csoport véleményéhez hasonlóan a legkevésbé szigorúan ítélték meg a tanulók ebben a csoportban is.

A két csoport véleménye között mindössze két tényező esetében figyelhető meg eltérés (36. ábra). A bányászat esetében a kontrollcsoport szigorúbban ítélt a kísérleti csoporthoz képest, a t-próba eredményei alapján $(\mathrm{t}=3,2 \mathrm{p}=0,02)$. A kísérleti csoportban 71,3\%-ban találták veszélyesnek a kérdéses tényezőt, a kontrollcsoportban már 88,8\%-ban. A túlnépesedés tekintetében még hangsúlyosabb eltérés tapasztalható $(\mathrm{t}=-3,7 \mathrm{p}=0,001)$. Itt a kísérleti csoport csak 41,1\%-ban ítélte veszélyesnek a túlnépesedés kérdését, a kontrollcsoport viszont egészen magas mértékben, 85,8\%-ban. A kontrollcsoport véleménye ebben az esetben sokkal reálisabb, mint a kísérleti csoport véleménye.

\footnotetext{
${ }^{7}$ Az adott skálán maximálisan elérhető pontszámhoz viszonyított érték.
} 


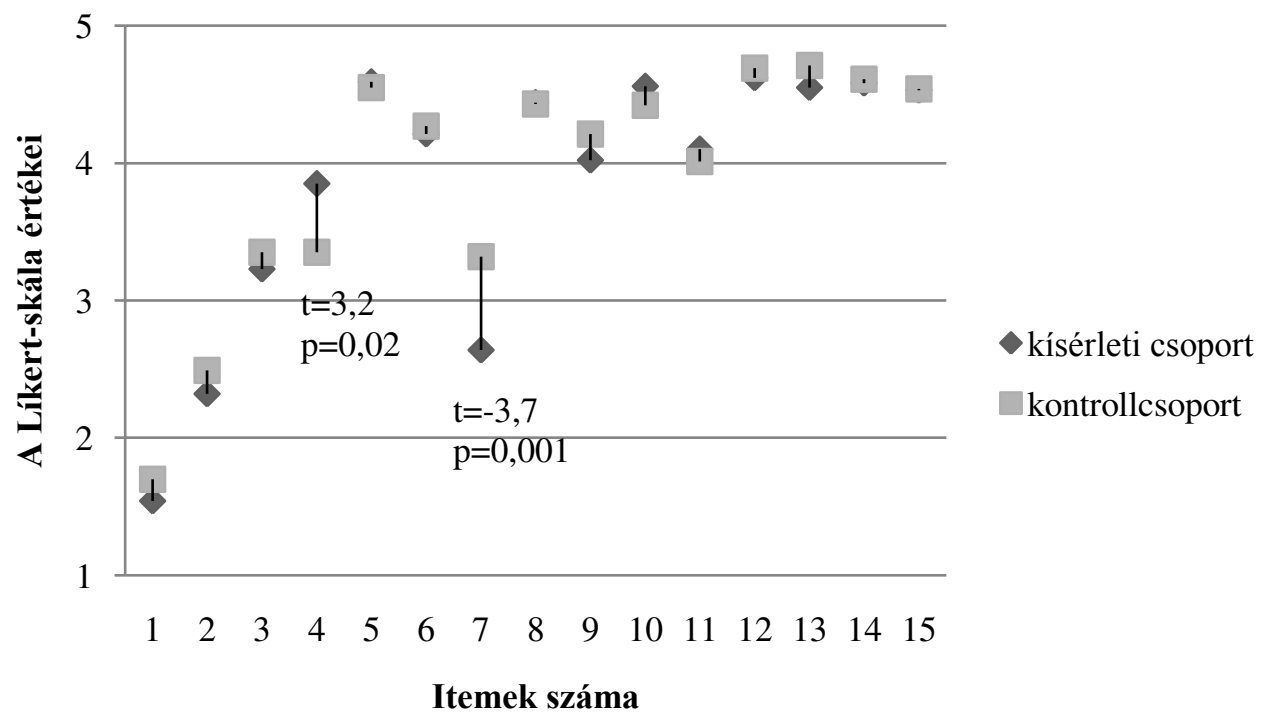

36. ábra: A kísérleti és a kontrollcsoport véleménye a környezetet veszélyeztetö tényezőket illetően az elsö mérés során

5.4.4. A környezetet veszélyeztető tényezők megítélése a második mérés során

\subsubsection{A kísérleti csoport eredményei}

A második mérés alkalmával négy veszélyeztető tényező esetében is jelentősen változott a kísérleti csoportba tartozó tanulók véleménye (49. táblázat). A túlnépesedés szigorúbb megítélés alá esett a második mérés alkalmával. Itt az első méréskor kapott 41,1\% a második mérésnél 51,2\%-ra növekedett. A változás szignifikánsnak tekinthetö: $t=-2,5 \mathrm{p}=0,01$.

A másik tényező, ahol a megítélés mértéke szignifikánsan növekedett ( $\mathrm{t}=-2,5 \mathrm{p}=0,01)$, a légszennyezés kérdése. Az először 88,2\%-ban veszélyesnek tartott tényező megítéltségének értéke a második mérésnél már $94,4 \%$ volt.

A kísérleti csoport véleménye az ipar és a természetvédelem kapcsán csökkenő értéket mutat a két mérés között. Az iparral kapcsolatban enyhült a tanulók véleménye, az első méréskor kapott 88,8\%-ról a második mérésre 82,1\%-ra csökkent. A változás jelentősnek mondható a t-próba alapján: $\mathrm{t}=2,1 \mathrm{p}=0,03$. A természetvédelemmel kapcsolatban már eleve úgy vélekedtek a tanulók, hogy nincs veszélyes hatása a környezet állapotára (13,4\%). A második méréskor már csak 8,21\%-ban tartották veszélyesnek ezt a tényezőt. A két érték közötti eltérés jelentősnek mondható: $\mathrm{t}=2,1 \mathrm{p}=0,03$ (37. ábra). 
49. táblázat: A környezetet veszélyeztető tényezők megitélése az elsö és a második mérés során a kísérleti csoportban

\begin{tabular}{llccccccc}
\hline \multirow{2}{*}{ veszélyeztető tényezők } & \multicolumn{3}{c}{ első mérés $(\mathrm{N}=216)$} & \multicolumn{3}{c}{ második mérés $(\mathrm{N}=216)$} & \multicolumn{2}{c}{$t$-próba } \\
& átlag & szórás & $\%$ & átlag & szórás & $\%$ & t & $p$ \\
\hline 1. természetvédelem & 1,54 & 1,2 & 13,4 & 1,33 & 0,9 & 8,21 & 2,1 & 0,03 \\
2. mezőgazdaság & 2,32 & 1,6 & 32,9 & 2,07 & 1,4 & 26,8 & 1,7 & 0,07 \\
3. vízerőmüvek & 3,23 & 1,6 & 55,7 & 3,17 & 1,6 & 54,3 & 0,3 & 0,7 \\
4. bányászat & 3,85 & 1,3 & 71,3 & 3,76 & 1,3 & 68,9 & 0,6 & 0,5 \\
5. vízszennyezés & 4,59 & 0,9 & 89,8 & 4,47 & 1,1 & 86,6 & 1,1 & 0,2 \\
6. közlekedés & 4,21 & 1,3 & 80,2 & 4,27 & 1,2 & 81,7 & $-0,7$ & 0,4 \\
7. túlnépesedés & 2,64 & 1,6 & 41,1 & 3,05 & 1,6 & 51,2 & $-2,5$ & 0,01 \\
8. talajerózión & 4,44 & 1,1 & 85,9 & 4,54 & 0,9 & 88,6 & $-0,9$ & 0,3 \\
9. atomerömüvek & 4,02 & 1,5 & 75,5 & 4,05 & 1,3 & 76,2 & $-0,3$ & 0,7 \\
10. ipar & 4,56 & 0,9 & 88,8 & 4,28 & 1,4 & 82,1 & 2,1 & 0,03 \\
11. savas eső & 4,10 & 1,4 & 77,5 & 4,18 & 1,3 & 79,5 & $-0,4$ & 0,6 \\
12. utcai szemetelés & 4,62 & 0,9 & 90,5 & 4,64 & 0,9 & 91,05 & $-0,2$ & 0,8 \\
13. dohányzás & 4,55 & 1,2 & 88,6 & 4,64 & 0,9 & 90,9 & $-0,7$ & 0,4 \\
14. erdőirtás & 4,58 & 1,0 & 89,6 & 4,55 & 0,9 & 88,8 & 0,2 & 0,8 \\
15. légszennyezés & 4,53 & 1,0 & 88,2 & 4,77 & 0,7 & 94,4 & $-2,5$ & 0,01 \\
\hline
\end{tabular}

A kapott eredmények tükrében megállapítható, hogy a H5/a számú hipotézisben megfogalmazott állítás, amely szerint a környezeti nevelési programban való részvételt követően az alsó tagozatos tanulók reálisabban szemlélik a környezetszennyezés kialakulásáért felelős tényezőket az előzetes felmérés során kapott eredményekhez viszonyítva, a fent említett négy változó esetében bizonyítást nyert. A többi veszélyeztető tényező szemléletére nem volt jelentős hatással a környezeti nevelési program tartalma.

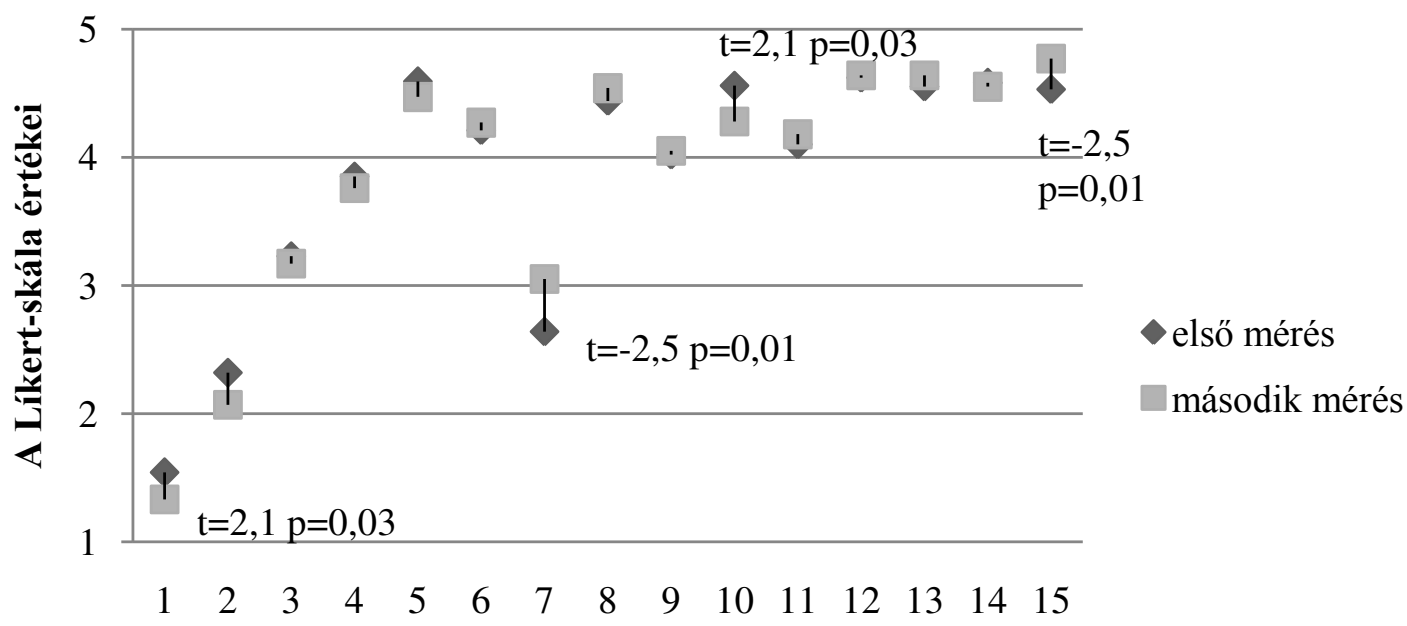

\section{Itemek száma}

37. ábra: A kísérleti csoport véleményének alakulása a környezetet veszélyeztetö tényezőket illetően a két mérés között 


\subsubsection{A kontrollcsoport eredményei}

A kontrollcsoportba tartozó tanulók véleménye egyik veszélyeztető tényezővel kapcsolatban sem változott jelentős mértékben a két vizsgálat között (50. táblázat).

50. táblázat: A környezetet veszélyeztető tényezők megitélése az elsö és a második mérés során a kontrollcsoportban

\begin{tabular}{llccccccc}
\hline \multirow{2}{*}{ veszélyeztető tényezök } & \multicolumn{3}{c}{ elsö mérés $(\mathrm{N}=118)$} & \multicolumn{3}{c}{ második mérés $(\mathrm{N}=118)$} & \multicolumn{2}{c}{ t-próba } \\
& átlag & szórás & $\%$ & átlag & szórás & $\%$ & $\mathrm{t}$ & $p$ \\
\hline 1. $\quad$ természetvédelem & 1,70 & 1,3 & 17,5 & 1,63 & 1,3 & 15,8 & 0,2 & 0,7 \\
2. mezögazdaság & 2,49 & 1,5 & 37,3 & 2,42 & 1,6 & 35,5 & 0,2 & 0,7 \\
3. vízerömüvek & 3,35 & 1,4 & 68,7 & 3,57 & 1,5 & 64,2 & $-1,3$ & 0,2 \\
4. bányászat & 3,35 & 1,4 & 88,8 & 3,57 & 1,5 & 64,2 & $-1,6$ & 0,1 \\
5. vízszzennyezés & 4,55 & 0,9 & 81,8 & 4,33 & 1,2 & 83,3 & 1,5 & 0,1 \\
6. közlekedés & 4,27 & 1,3 & 58,05 & 4,37 & 1,2 & 84,3 & $-0,8$ & 0,3 \\
7. túlnépesedés & 3,32 & 1,5 & 85,8 & 3,41 & 1,5 & 60,3 & $-0,3$ & 0,7 \\
8. talajerózió & 4,43 & 1,1 & 80,1 & 4,46 & 0,9 & 86,5 & $-0,5$ & 0,6 \\
9. atomerömüvek & 4,21 & 1,3 & 85,6 & 4,47 & 1,0 & 86,7 & $-1,6$ & 0,09 \\
10. ipar & 4,42 & 1,1 & 75,2 & 4,28 & 1,5 & 81,9 & 0,8 & 0,4 \\
11. savas eső & 4,01 & 1,3 & 92,4 & 4,31 & 1,1 & 82,8 & $-1,6$ & 0,1 \\
12. utcai szemetelés & 4,69 & 0,9 & 92,8 & 4,79 & 0,8 & 94,7 & $-1,0$ & 0,3 \\
13. dohányzás & 4,71 & 0,8 & 90,2 & 4,60 & 1,05 & 89,9 & 0,9 & 0,3 \\
14. erdőirtás & 4,61 & 0,9 & 88,5 & 4,51 & 1,1 & 87,8 & 0,7 & 0,4 \\
15. légszennyezés & 4,54 & 1,0 & 76,6 & 4,70 & 0,9 & 92,4 & $-1,1$ & 0,2 \\
\hline
\end{tabular}

A második mérést követően a két csoport eredményeit összehasonlítva öt olyan tényezőt emelhetünk ki, amelynél a kísérleti csoport véleménye szignifikánsan eltér a kontrollcsoport véleményétől (51. táblázat). A természetvédelem $(\mathrm{t}=-2,1 \mathrm{p}=0,003)$ és a mezőgazdaság $(\mathrm{t}=-1,9 \mathrm{p}=0,05)$ tekintetében a kísérleti csoport jelentősen szigorúbb hozzáállást tanúsított, mint a kontrollcsoport. A természetvédelmet illetően a kísérleti csoport 17,6\%-ra, a kontrollcsoport csak 15,8\%-ra becsüli a tényező környezetre gyakorolt veszélyességét. Mindez a programban részt vevő gyerekek ismereteinek gyarapodására utal. Ugyanis a szándékosan a természet védelmére irányuló tevékenységek is mesterséges beavatkozásnak számítanak az ember részéről a természet egyensúlyába. Ezek a tevékenységek pedig nem minden esetben jelentenek pozitív hatást a természetre. A programban részt vevő gyerekek találkoztak ennek a jelenségnek a magyarázatával, ezért vélekedhetnek szigorúbban a tényező veszélyességéről a kontrollcsoportban részt vevő tanulóknál.

A mezőgazdaság esetében is ugyanez a magyarázat fedi azt, hogy a kísérleti csoportban 37,3\%-ra, a kontrollcsoportban pedig 35,5\%-ra becsülték a tényező veszélyességét a természetre nézve. A mezőgazdaság is egy olyan mesterséges folyamat az ember részéröl, amely a környezet egyensúlyi állapotának felborítását okozhatja. A kísérleti csoportba tartozó tanulók a program során megismerkedhettek ezzel a ténnyel. 
51. táblázat: A környezetet veszélyeztetö tényezök megitélése a második mérés során a kísérleti és a kontrollcsoportban

\begin{tabular}{lcccccccc}
\hline \multirow{2}{*}{ veszélyeztető tényezők } & \multicolumn{2}{c}{ kísérleti csoport $(\mathrm{N}=216)$} & \multicolumn{3}{c}{ kontrollcsoport $(\mathrm{N}=118)$} & \multicolumn{2}{c}{$t$-próba } \\
& átlag & szórás & $\%$ & átlag & szórás & $\%$ & t & $p$ \\
\hline 1. természetvédelem & 1,70 & 1,3 & 17,6 & 1,63 & 1,3 & 15,8 & $-2,1$ & 0,03 \\
2. mezőgazdaság & 2,49 & 1,5 & 37,3 & 2,42 & 1,6 & 35,5 & $-1,9$ & 0,05 \\
3. vízerőmüvek & 3,35 & 1,4 & 58,7 & 3,57 & 1,5 & 64,2 & $-2,1$ & 0,03 \\
4. bányászat & 3,35 & 1,4 & 58,7 & 3,57 & 1,5 & 64,2 & 1,1 & 0,2 \\
5. vízszennyezés & 4,55 & 0,9 & 88,7 & 4,33 & 1,2 & 83,3 & 1 & 0,3 \\
6. közlekedés & 4,27 & 1,3 & 81,7 & 4,37 & 1,2 & 84,3 & $-0,7$ & 0,4 \\
7. túlnépesedés & 3,32 & 1,5 & 58,05 & 3,41 & 1,5 & 60,3 & $-1,9$ & 0,05 \\
8. talajerózión & 4,43 & 1,1 & 85,8 & 4,46 & 0,9 & 86,5 & 0,7 & 0,4 \\
9. atomerömüvek & 4,21 & 1,3 & 80,1 & 4,47 & 1,0 & 86,7 & $-0,2$ & 0,002 \\
10. ipar & 4,42 & 1,1 & 85,6 & 4,28 & 1,5 & 81,9 & 0,01 & 0,9 \\
11. savas eső & 4,01 & 1,3 & 75,2 & 4,31 & 1,1 & 82,8 & $-0,9$ & 0,3 \\
12. utcai szemetelés & 4,69 & 0,9 & 92,4 & 4,79 & 0,8 & 94,7 & $-1,4$ & 0,1 \\
13. dohányzás & 4,71 & 0,8 & 92,8 & 4,60 & 1,05 & 89,9 & 0,3 & 0,7 \\
14. erdőirtás & 4,61 & 0,9 & 90,2 & 4,51 & 1,1 & 87,8 & 0,3 & 0,7 \\
15. légszennyezés & 4,54 & 1,0 & 88,5 & 4,70 & 0,9 & 92,4 & 0,8 & 0,4 \\
\hline
\end{tabular}

A vízerőművek $(\mathrm{t}=-2,1 \mathrm{p}=0,03)$, a túlnépesedés $(\mathrm{t}=-1,9 \mathrm{p}=0,05)$, valamint az atomerömüvek $(\mathrm{t}=-0,2 \mathrm{p}=0,002)$ témakörét illetően a kísérleti csoport tagjai kevésbé szigorúan ítéltek, mint a kontrollcsoportban részt vevők (38. ábra). Ezeknél a tényezőknél ugyancsak a kísérleti csoportba tartozó tanulók ítéltek reálisabban a második mérés során.

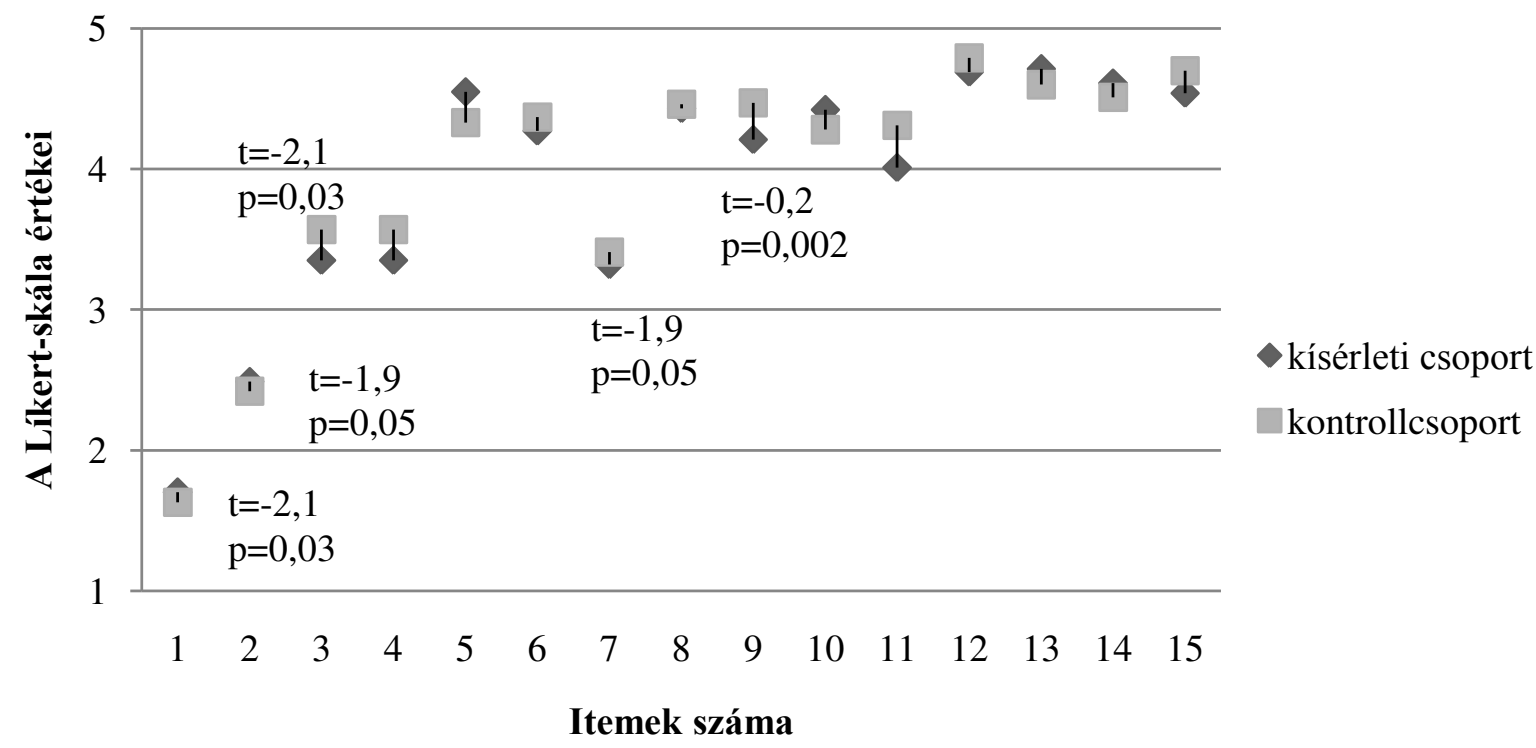

38. ábra: A kísérleti és a kontrollcsoport véleményének összehasonlitása a környezetet veszélyeztetö tényezöket illetöen a második mérést követöen

Az eredmények alapján a $\mathrm{H} 5 / \mathrm{b}$ hipotézisben foglalt állítás a fent említett öt veszélyeztető tényező esetében bizonyítást nyert. A környezeti nevelési programban való részvételt követően az alsó tagozatos tanulók reálisabban szemlélték a környezetet veszélyeztető tényezőket, mint a kontrollcsoport tagjai. 
5.4.5. A környezetszennyezés okainak megítélése az első mérés során

A felmérés során alkalmazott Líkert-skála utolsó öt itemje a környezetszennyezés okaira vonatkozik. A kérdőíven az egyes azt jelenti, hogy az adott okot egyáltalán nem, az ötös pedig azt, hogy az adott okot teljes mértékben a környezetszennyezés okaként ítélik meg a vizsgálatban részt vevő tanulók.

\subsubsection{A kísérleti csoport eredményei}

Az első mérés során a kísérleti csoportban első helyen az emberek önző viselkedését (84,5\%) jelölték meg a környezetszennyezés legfőbb okaként (52. táblázat). Második helyen, 79,9\%-al a magas életszínvonal szerepel. A szándékos szennyezés mint ok is magas, 66,5 százalékkal szerepel a listán. A pénzhiányt már csak 36,6\%-ban tartják kiváltó okként, a legalacsonyabb mértékben pedig a tudatlanságot (20,4\%) emelték ki a kísérleti csoport tagjai.

52. táblázat: A környezetszennyezés okainak megitélése az első mérés során

\begin{tabular}{llcccccccc}
\hline \multirow{2}{*}{ a környezetszennyezés okai } & \multicolumn{2}{c}{ ḱ́sérleti csoport $(\mathrm{N}=216)$} & \multicolumn{3}{c}{ kontrollcsoport $(\mathrm{N}=118)$} & \multicolumn{3}{c}{$t$-próba } \\
& & átlag & szórás & $\%$ & átlag & szórás & $\%$ & t & $p$ \\
\hline 1. magas életszínvonal & 4,20 & 1,1 & 79,9 & 4,04 & 1,2 & 76,1 & 1,2 & 0,2 \\
2. & szándékos szennyezés & 3,66 & 1,5 & 66,5 & 4,08 & 1,3 & 77,1 & $-2,6$ & 0,009 \\
3. pénzhiány & 2,46 & 1,6 & 36,6 & 2,66 & 1,5 & 41,5 & $-1,1$ & 0,2 \\
4. önzés & 4,38 & 1,3 & 84,5 & 4,39 & 1,1 & 84,7 & $-0,1$ & 0,9 \\
5. & 1,81 & 1,3 & 20,4 & 1,77 & 1,2 & 19,3 & 0,3 & 0,7 \\
\hline
\end{tabular}

A különböző okok megítélésének mértékében szerepet játszott néhány háttérváltozó értéke is. Az első méréskor az első és második ok (magas életszínvonal és szándékos szennyezés) esetében a Pearson-féle korrelációs vizsgálat nem mutatott összefüggést egyik háttérváltozóval sem. A harmadik ok, a pénzhiány megítélése viszont már csekély mértékben összefüggésben áll az életkor $(r=0,2 \mathrm{p}=0,001)$ és az osztály $(\mathrm{r}=0,2 \mathrm{p}=0,002)$ változókkal. $\mathrm{Az}$ önzésnek mint oknak a megítélésére hatással volt az osztály $(\mathrm{r}=0,2 \mathrm{p}=0,01)$ és a testvérek $(\mathrm{r}=-$ $0,4 \mathrm{p}=0,03)$ változó alakulása. Ez utóbbi összefüggés közepesen erős, emellett pedig negatív korrelációt mutat a változók kapcsolatában. A tudatlanság megítélésének kérdése a nem (r=$0,2 \mathrm{p}=0,01)$ és a tanulmányi átlag $(\mathrm{r}=-0,2 \mathrm{p}=0,04)$ változókkal mutat gyenge korrelációt.

A háttérváltozók alapján létrehozott csoportok véleményében is mutatkozik eltérés néhány ok megítélése esetében.

A nemek véleményét illetően a fiúk sokkal indokoltabbnak látják a tudatlanság kérdését a környezet szennyezése tekintetében, mint a lányok $(\mathrm{t}=2,6 \mathrm{p}=0,009)$.

A különböző osztályok véleménye is eltérést mutat a túlzott fogyasztás ( $\mathrm{F}=6,2 \mathrm{p}=0,002)$, a pénzhiány $(\mathrm{F}=6,6 \mathrm{p}=0,002)$ és az önzés $(\mathrm{F}=3,3 \mathrm{p}=0,03)$ tekintetében. Ugyanezeknek az okoknak a megítélése az életkorok tekintetében is eltérést mutat. A túlzott fogyasztás $(\mathrm{F}=3,0$ $\mathrm{p}=0,01)$, a pénzhiány $(\mathrm{F}=4,8 \mathrm{p}=0,001)$ és az önzés $(\mathrm{F}=2,4 \mathrm{p}=0,04)$ kérdését is máshogy ítélik meg a fiatalabb és az idősebb tanulók az egyutas ANOVA vizsgálat értékei alapján. 


\subsubsection{A kontrollcsoport eredményei}

A kontrollcsoportban szintén az önzést (84,7\%) jelölték meg a tanulók a környezetszennyezés legjellemzőbb okaként. Második helyen itt a szándékos szennyezés szerepel (77,1\%), a harmadik helyen pedig a magas életszínvonal (76,1\%). A negyedik és az ötödik hely tekintetében megegyezik a kísérleti és a kontrollcsoportba tartozó tanulók véleménye. A kontrollcsoport véleménye szerint a pénzhiány 41,5\%-ban, a tudatlanság pedig 19,3\%-ban okolható a környezetszennyezés kialakulásáért.

A két csoport véleménye között csak a szándékos szennyezés esetében figyelhető meg szignifikáns különbség ( $\mathrm{t}=-2,6 \mathrm{p}=0,009)$. A kontrollcsoport tagjai jelentősen nagyobb mértékben okolják ezt a tényezőt, mint a kísérleti csoport tagjai (39. ábra).

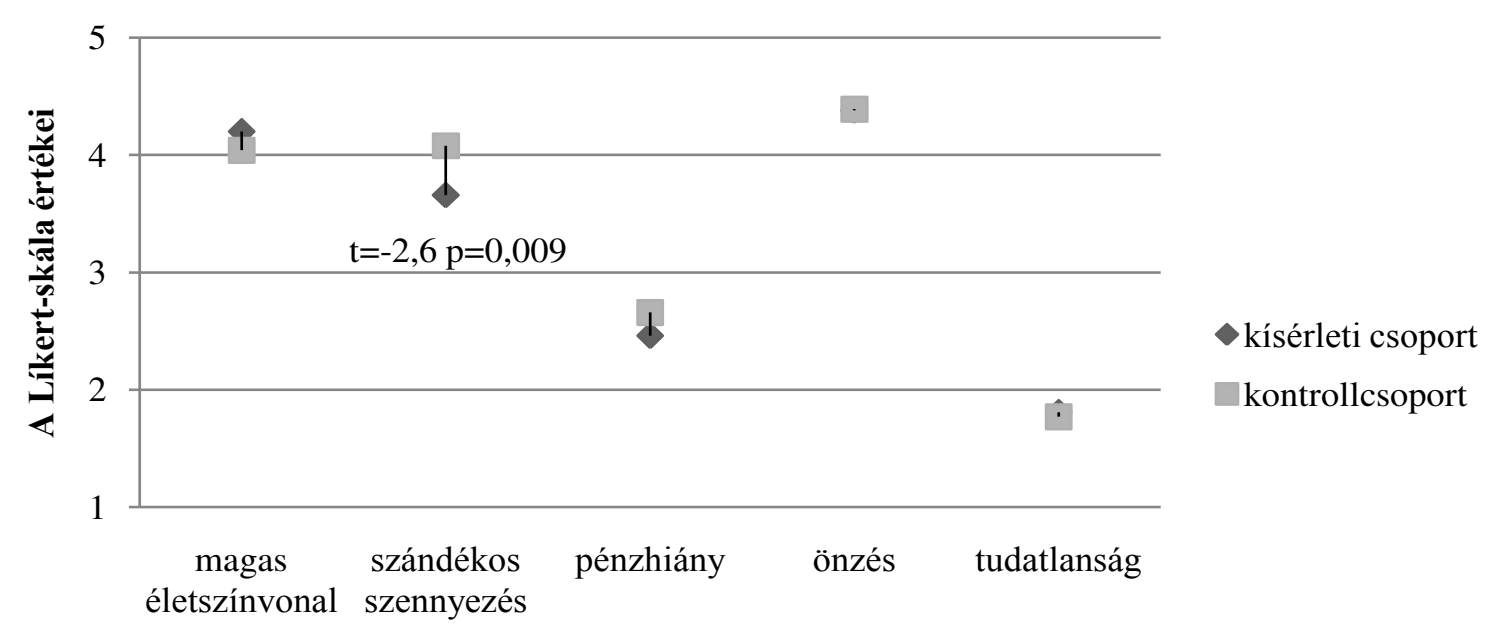

A környezetszennyezés okai

39. ábra: A kísérleti és a kontrollcsoport véleménye a környezetszennyezés okait illetöen az elsö mérés során

5.4.6. A környezetszennyezés okainak megítélése a második mérés során

5.4.6.1. A kísérleti csoport eredményei

A második mérés során négy tényező tekintetében növekedtek az értékek, ami azt jelenti, hogy a tanulók nagyobb mértékben teszik felelőssé ezeknek az okoknak a környezetszennyezés kialakulásában játszott szerepét. Egyedül a magas életszínvonal megítélése csökkent a két mérés között (53. táblázat). Ezek az értékek tovább erősítik a H5/a hipotézisben tett állítást, a környezeti nevelési programban való részvételt követően az alsó tagozatos tanulók valóban reálisabban szemlélik a környezetszennyezés kialakulásáért valóban felelős okokat az előzetes felmérés során kapott eredményekhez viszonyítva. 
53. táblázat: A környezetszennyezés okainak megítélése a kísérleti csoportban a két mérés között

\begin{tabular}{|c|c|c|c|c|c|c|c|c|}
\hline \multirow{2}{*}{ a környezetszennyezés okai } & \multicolumn{3}{|c|}{ első mérés (N=216) } & \multicolumn{3}{|c|}{ második mérés $(\mathrm{N}=216)$} & \multicolumn{2}{|c|}{ t-próba } \\
\hline & átlag & szórás & $\%$ & átlag & szórás & $\%$ & $\mathrm{t}$ & $p$ \\
\hline 1. magas életszínvonal & 4,20 & 1,1 & 79,9 & 4,05 & 1,3 & 76,3 & 1,0 & 0,3 \\
\hline 2. szándékos szennyezés & 3,66 & 1,5 & 66,5 & 4,46 & 1,0 & 86,4 & $-6,1$ & 0,001 \\
\hline 3. pénzhiány & 2,46 & 1,6 & 36,6 & 2,62 & 1,6 & 40,4 & $-1,0$ & 0,3 \\
\hline 4. önzés & 4,38 & 1,3 & 84,5 & 4,55 & 0,9 & 88,8 & $-1,3$ & 0,1 \\
\hline 5. tudatlanság & 1,81 & 1,3 & 20,4 & 4,25 & 1,1 & 81,3 & $-21,3$ & 0,001 \\
\hline
\end{tabular}

A kísérleti csoportban a két mérés között két ok megítélése tekintetében statisztikai szempontból is jelentősen változtak az értékek (40. ábra).

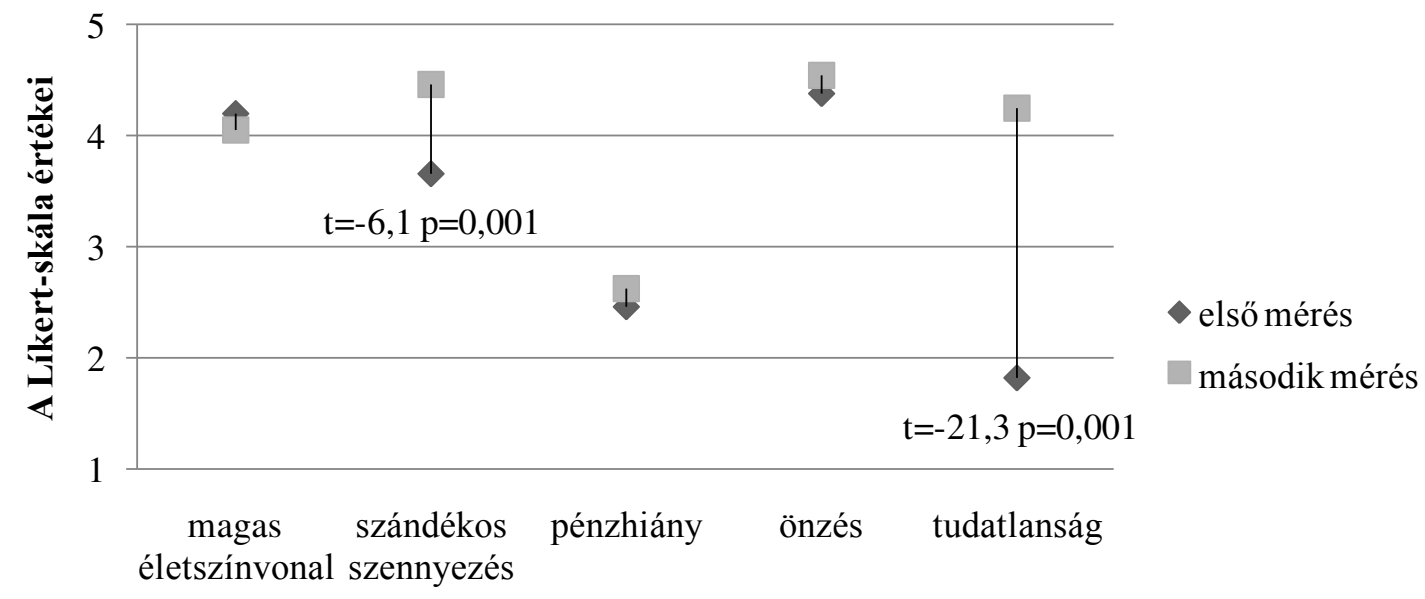

A környezetszennyezés okai

40. ábra: A kisérleti csoport véleményének alakulása a környezetszennyezés okait illetően a két mérés között

A szándékos szennyezés esetében az első méréskor még 66,5\%-ban okolták ezt a tényezőt, a második mérés során már sokkal nagyobb mértékben, 86,4\%-ban. A két érték közötti különbség számottevő a t-próba értékei alapján: $\mathrm{t}=-6,1 \mathrm{p}=0,001$. Az emberi tudatlanságot, mint a környezetszennyezés legföbb okát, az első méréskor mindössze 20,4\%ban jelölték a tanulók. A második mérés során nagymértékű változás ( $\mathrm{t}=-21,3 \mathrm{p}=0,001)$ következett be az értékekben, 81,3\%-ra növekedett a tényező hibáztatása.

\subsubsection{A kontrollcsoport eredményei}

A kontrollcsoportban is történt változás a két mérés között a környezetszennyezés kialakulásáért felelős okok megítélésében. A szándékos szennyezés esetében jelentősen növekedtek az értékek ( $\mathrm{t}=-2,4 \mathrm{p}=0,01)$, az első méréskor tapasztalt 77,1\%-ról 86\%-ra. A pénzhiány esetében viszont jelentős értékcsökkenés figyelhető meg, 41,5\%-ról 32,8\%-ra. A többi ok esetében az értékek változása a két mérés között nem számottevő (54. táblázat). 
54. táblázat: A környezetszennyezés okainak megítélése a kontrollcsoportban a két mérés között

\begin{tabular}{|c|c|c|c|c|c|c|c|c|}
\hline \multirow{2}{*}{ a környezetszennyezés okai } & \multicolumn{3}{|c|}{ első mérés (N=118) } & \multicolumn{3}{|c|}{ második mérés $(\mathrm{N}=118)$} & \multicolumn{2}{|c|}{ t-próba } \\
\hline & átlag & szórás & $\%$ & átlag & szórás & $\%$ & $\mathrm{t}$ & $p$ \\
\hline 1. magas életszínvonal & 4,04 & 1,2 & 76,1 & 3,95 & 1,3 & 73,8 & 0,4 & 0,6 \\
\hline 2. szándékos szennyezés & 4,08 & 1,3 & 77,1 & 4,44 & 1,1 & 86,0 & $-2,4$ & 0,01 \\
\hline 3. pénzhiány & 2,66 & 1,5 & 41,5 & 2,31 & 1,6 & 32,8 & 1,9 & 0,05 \\
\hline 4. önzés & 4,39 & 1,1 & 84,7 & 4,38 & 1,2 & 84,4 & $-2,3$ & 0,8 \\
\hline 5. tudatlanság & 1,77 & 1,2 & 19,3 & 1,86 & 1,3 & 21,6 & $-0,5$ & 0,5 \\
\hline
\end{tabular}

A kísérleti és a kontrollcsoport második méréskor kapott eredményeit összehasonlítva megállapítható, hogy a tudatlanság okát kivéve nincs szignifikáns eltérés a két csoport véleményét illetően (55. táblázat). A tudatlanság oka esetében azonban jelentős véleménykülönbség figyelhető meg a kísérleti csoport javára, a t-próba eredményei alapján: $\mathrm{t}=16,2 \mathrm{p}=0,001$ (41. ábra).

55. táblázat: A környezetszennyezés okainak megítélése a második mérés során, a kísérleti és a kontrollcsoportban

\begin{tabular}{llcccccccc}
\hline \multirow{2}{*}{ a környezetszennyezés okai } & \multicolumn{3}{c}{ kísérleti csoport $(\mathrm{N}=216)$} & \multicolumn{2}{c}{ kontrollcsoport $(\mathrm{N}=118)$} & \multicolumn{3}{c}{$t$-próba } \\
& & átlag & szórás & $\%$ & átlag & szórás & $\%$ & t & $p$ \\
\hline 1. & magas életszínvonal & 4,05 & 1,3 & 76,3 & 3,95 & 1,3 & 73,8 & 0,6 & 0,5 \\
2. & szándékos szennyezés & 4,46 & 1,0 & 86,4 & 4,44 & 1,1 & 86,0 & 0,1 & 0,9 \\
3. pénzhiány & 2,62 & 1,6 & 40,4 & 2,31 & 1,6 & 32,8 & 1,6 & 0,1 \\
4. önzés & 4,55 & 0,9 & 88,8 & 4,38 & 1,2 & 84,4 & 1,4 & 0,1 \\
5. & tudatlanság & 4,25 & 1,1 & 81,3 & 1,86 & 1,3 & 21,6 & 16,2 & 0,001 \\
\hline
\end{tabular}

A kapott eredmények az ötödik (tudatlanság) ok esetében alátámasztják a H5/b hipotézisben foglaltakat, vagyis a környezeti nevelési programban való részvételt követően az alsó tagozatos tanulók reálisabban szemlélik a környezetszennyezés kialakulásáért valóban felelős okokat a kontrollcsoportban mért értékekhez viszonyítva.

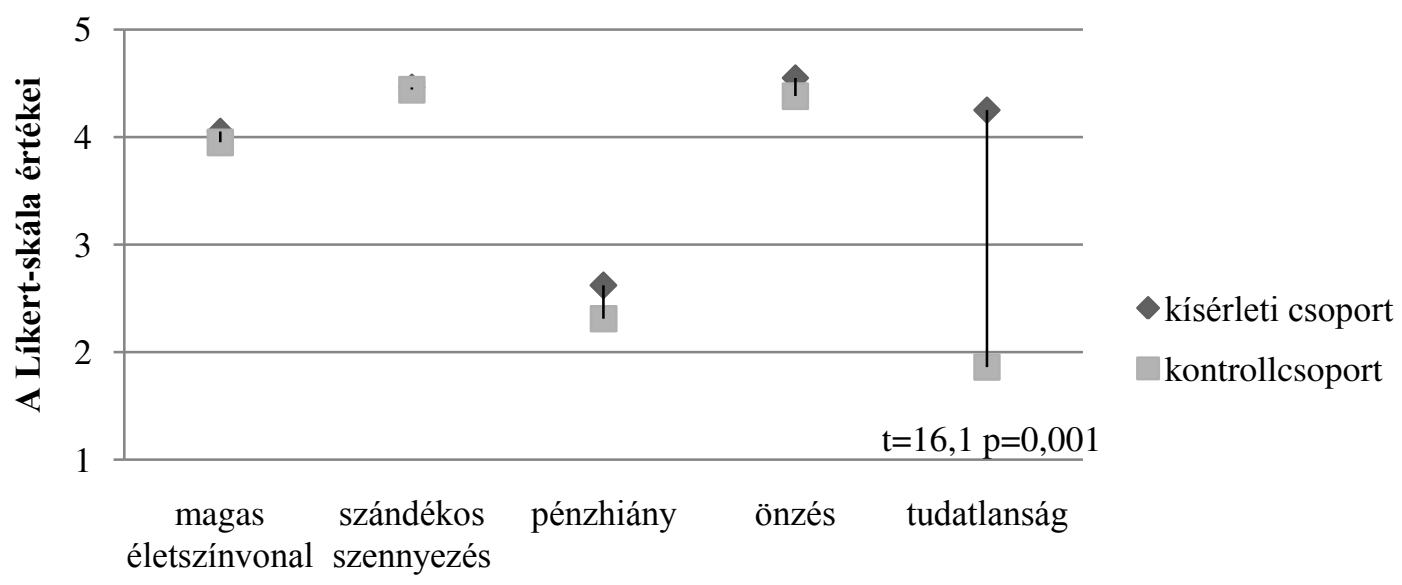

A környezetszennyezés okai

41. ábra: A két csoport véleményének alakulása a környezetszennyezés okait illetően a második mérést követöen 
5.4.7. A saját lehetőségek észlelése a környezetvédelem terén, az első mérés során

A kísérleti csoport tagjai közül az első mérés során 165 tanuló (76,4\%) mondta azt, hogy van lehetösége a környezetszennyezés csökkentésére. Közülük 4-en öt konkrét lehetőséget is felsoroltak, 7 tanuló négy lehetőséget említett, 16 tanuló három lehetőséget sorolt fel, 58 tanuló két lehetőséget, 85 tanuló pedig egy-egy konkrét lehetőséget jelölt meg (53. táblázat).

A kontrollcsoportban 80 tanuló (a csoportba tartozók 67,8\%-a) úgy látja, hogy van saját lehetősége a környezet védelmére. Közülük a tanulók 2\%-a öt saját lehetöséget is felsorolt, 4\% négy lehetőséget, $10 \%$ három lehetőséget, 34\% két lehetőséget, $50 \%$ pedig legalább egy konkrét lehetőséget említett. További 38 tanuló 32,2\% állította azt, hogy nem tud mit tenni a környezetszennyezés csökkentése érdekében (56. táblázat).

56. táblázat: A saját lehetöségek észlelése a kísérleti és a kontrollcsoportban az elsö mérés során

\begin{tabular}{ccccc}
\hline \multirow{2}{*}{ saját lehetőségek } & \multicolumn{2}{c}{ kísérleti csoport $(\mathrm{N}=216)$} & \multicolumn{2}{c}{ kontrollcsoport $(\mathrm{N}=118)$} \\
\cline { 2 - 5 } & $\mathrm{N}$ & $\%$ & $\mathrm{~N}$ & $\%$ \\
\hline van lehetőségem & $\mathbf{1 6 5}$ & $\mathbf{7 6 , 4}$ & $\mathbf{8 0}$ & $\mathbf{6 7 , 8}$ \\
\hline lehetőség1 & 85 & 50 & 65 & 50 \\
lehetőség2 & 58 & 34 & 45 & 34 \\
lehetőség3 & 16 & 10 & 18 & 14 \\
lehetőség4 & 7 & 4 & 2 & 1 \\
lehetőség5 & 4 & 2 & 1 & 1 \\
\hline nincs lehetőségem & $\mathbf{5 1}$ & $\mathbf{2 3 , 6 \%}$ & $\mathbf{3 8}$ & $\mathbf{3 2 , 2}$ \\
\hline
\end{tabular}

A kísérleti és a kontrollcsoport az első mérés alkalmával egyforma arányban vélekedett a lehetőségek meglétéről a kétmintás t-próba alapján $(\mathrm{t}=1,6 \mathrm{p}=0,1)$. Egyforma arányban vallották, hogy személyesen is tudnak tenni valamit a környezet védelme érdekében.

A tanulók által említett konkrét lehetőségeket tíz kategóriába soroltam (57. táblázat). A kísérleti csoportban az első mérés során a nem szemetelek lehetőségét (26\%) említették a legtöbben. Második helyen az otthoni szelektiv hulladékgyüjtés (17\%) lehetősége szerepel. A hulladékgyüjtési akcióban való részvétel (11\%), a növényvédelem (10\%) és a viztakarékosság (9\%) lehetősége nagyjából egyforma arányban jelenik meg. Az újrahasznosítás (6\%), példamutatás (5\%), energiatakarékosság (4\%), valamint a tömegközlekedés gyakori alkalmazásának lehetősége (4\%) a lista második felén szerepel.

57. táblázat: Az emlitett lehetöségek a kísérleti és a kontrollcsoportban az első mérés során

\begin{tabular}{lcccc}
\hline \multirow{2}{*}{ konkrét lehetöségek } & kísérleti csoport $(\mathrm{N}=216)$ & \multicolumn{2}{c}{ kontrollcsoport (N=118) } \\
\cline { 2 - 5 } & $\mathrm{N}$ & $\%$ & $\mathrm{~N}$ & $\%$ \\
\hline nem szemetelek & 67 & 26 & 62 & 30 \\
otthoni szelektív hulladékgyüjtés & 43 & 17 & 25 & 12 \\
hulladékgyüjtési akció & 29 & 11 & 10 & 5 \\
növényvédelem & 25 & 10 & 12 & 6 \\
víztakarékosság & 24 & 9 & 36 & 17 \\
újrahasznosítás & 14 & 6 & 4 & 2 \\
példamutatás, figyelemfelkeltés & 14 & 5 & 15 & 7 \\
energiatakarékosság & 9 & 4 & 14 & 7 \\
gyaloglás, tömegközlekedés & 9 & 4 & 7 & 3 \\
egyéb & 21 & 8 & 23 & 11 \\
\hline
\end{tabular}


A kontrollcsoportban ugyanúgy a nem szemetelek lehetőség szerepelt az első helyen, mint a kísérleti csoportban. A tanulók 30\%-a választotta ezt a lehetőséget. Második helyen azonban a víztakarékosság áll ebben a csoportban, 36\%-ban, ellentétben a kísérleti csoporttal, ahol sokkal kevesebben jelölték meg ezt a lehetőséget.

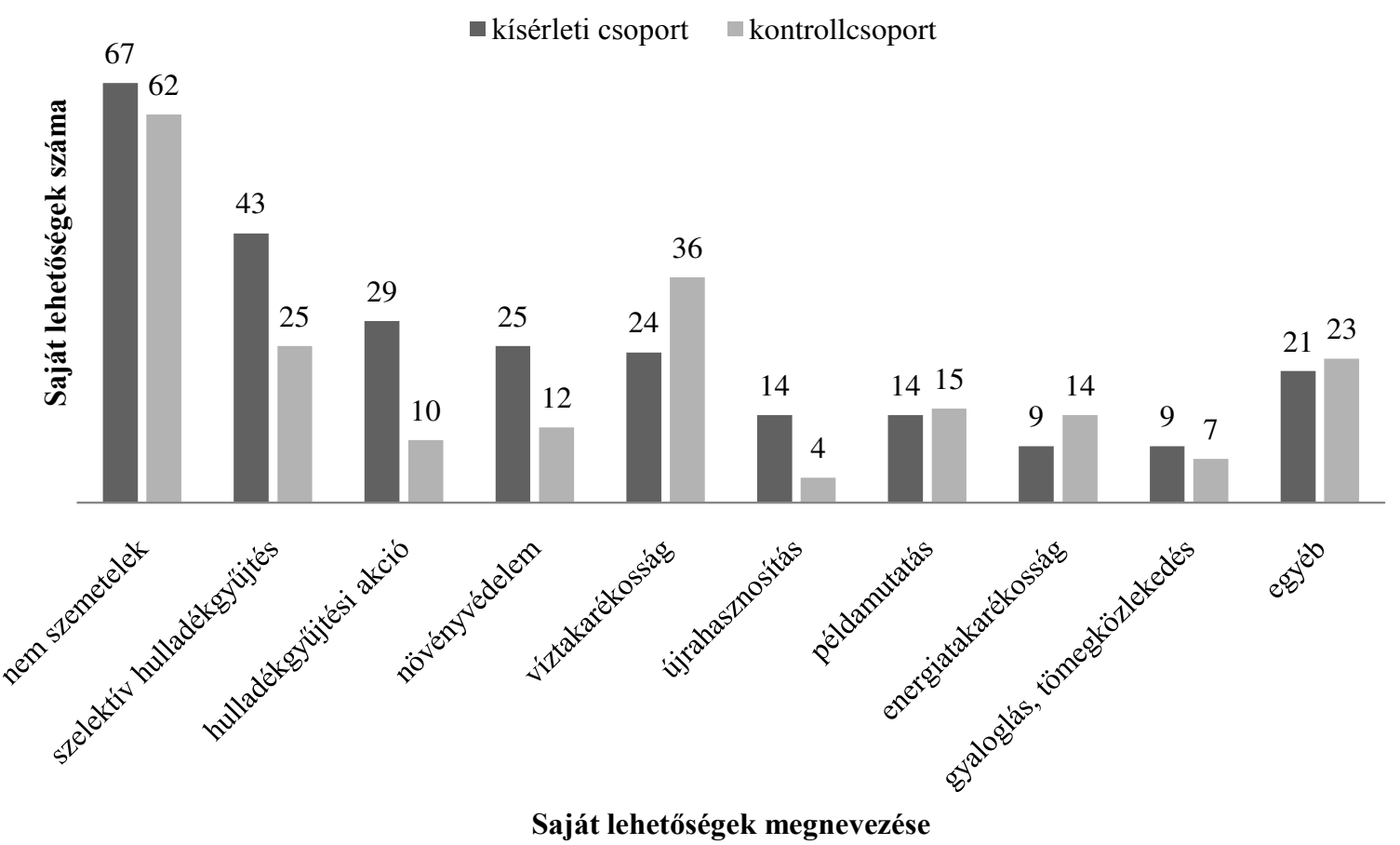

42. ábra: A tanulók saját lehetőségei a környezet megóvása érdekében a kísérleti és a kontrollcsoportban, az elsö mérés alkalmával

A szelektiv hulladékgyüjtés kérdésében ismét közelít egymáshoz a két csoport véleménye, a kontrollcsoportban a tanulók 12\%-a említette ezt a tevékenységet. A példamutatás, energia- és víztakarékosság, valamint a növények védelme nagyjából egyforma arányban fordult elő a kontrollcsoport válaszaiban. A gyaloglás, tömegközlekedés lehetősége a kísérleti csoporthoz hasonlóan itt sem volt túl népszerü, a tanulóknak csak 3\%-a említette (42. ábra).

A kísérleti csoportban 51 tanuló $(23,6 \%)$ válaszolta az első mérés alkalmával, hogy nincs saját lehetösége a környezetszennyezés csökkentésére. Közülük 13 tanuló indokolta meg a válaszát. A kapott indoklásokat hat csoportba soroltam (58. táblázat). Az egyedül kevés vagyok hozzá kifogást jelölték a legtöbben, a tanulók 46\%-a. A túl fiatal vagyok hozzá indokot a tanulók 23\%-a hozta fel. A gyerekek további 15,4\%-át nem érdekli a környezet megóvása. További 7-7\%-uk pedig a pénzhiányt, illetve az ebben az állapotában már úgyis menthetetlen környezetet hozta fel indokként. 
58. táblázat: Indoklás, miért nincs lehetősége a környezet védelmére a kísérleti és a kontrollcsoport tagjainak az elsö mérés során

\begin{tabular}{lcccc}
\hline \multirow{2}{*}{\multicolumn{1}{c}{ indoklás }} & \multicolumn{2}{c}{ kísérleti csoport (N=216) } & \multicolumn{2}{c}{ kontrollcsoport (N=118) } \\
\cline { 2 - 5 } & $\mathrm{N}$ & $\%$ & $\mathrm{~N}$ & $\%$ \\
\hline egyedül kevés vagyok hozzá & 6 & 46,2 & 5 & 33,3 \\
túl fiatal vagyok hozzá & 3 & 23,1 & 4 & 26,7 \\
nem érdekel & 2 & 15,4 & 5 & 33,3 \\
nincs pénzem & 1 & 7,7 & - & - \\
már úgyis hiába, túlzottan szennyezett a & & & - & - \\
környezet & 1 & 7,7 & 1 & 6,7 \\
nem ismerem a lehetőségeimet & - & - & 1 & \\
\hline
\end{tabular}

A kontrollcsoportban csak négy kifogást hoztak fel arra vonatkozóan, hogy miért nem tudnak részt venni a környezet megóvásában. Az egyedül kevés vagyok hozzá, a nem érdekel indokot egyaránt $33 \%$ említette. A túl fiatal vagyok kifogást a tanulók 26,7\%-a hozta fel. Legkevesebben $(6,7 \%)$ azok a tanulók voltak, akik hiányos ismereteikre hivatkoztak a környezetvédelem lehetőségeinek terén.

\subsubsection{Az említett lehetöségek számának alakulása}

A második mérés alkalmával a kísérleti csoport kevesebb tagja (4\%-al kevesebb) említett meg saját lehetőséget a környezetvédelmet illetően, mint az első méréskor (59. táblázat). Ezzel a H6/a hipotézisben foglalt állítást el kell vetnem, ugyanis a környezeti nevelési programban való részvételt követően a tanulók nem ismertek fel több saját cselekvési/viselkedési lehetőséget a környezet megóvása érdekében, az előzetes felmérés során kapott eredményekhez viszonyítva.

59. táblázat: A saját lehetöségek észlelése a kísérleti csoportban a két mérést követöen

\begin{tabular}{ccccc}
\hline \multicolumn{3}{c}{ a két mérést követöen } \\
\hline \multirow{2}{*}{ saját lehetőségek } & \multicolumn{2}{c}{ első mérés $(\mathrm{N}=216)$} & \multicolumn{2}{c}{ második mérés $(\mathrm{N}=216)$} \\
\cline { 2 - 5 } & $\mathrm{N}$ & $\%$ & $\mathrm{~N}$ & $\%$ \\
\hline van lehetőségem & $\mathbf{1 6 5}$ & $\mathbf{7 6 , 4}$ & $\mathbf{1 5 5}$ & $\mathbf{7 1 , 8}$ \\
\hline lehetőség1 & 85 & 50 & 109 & 52 \\
lehetőség2 & 58 & 34 & 59 & 28 \\
lehetőség3 & 16 & 10 & 24 & 12 \\
lehetőség4 & 7 & 4 & 11 & 5 \\
lehetőség5 & 4 & 2 & 5 & 3 \\
\hline nincs lehetöségem & $\mathbf{5 1}$ & $\mathbf{2 3 , 6 \%}$ & $\mathbf{4 9}$ & $\mathbf{2 2 , 7}$ \\
\hline
\end{tabular}

A kontrollcsoportban a második mérés alkalmával a tanulók ugyanúgy 67,9\%-a válaszolt igennel arra a kérdésre, hogy lát-e saját lehetőséget a környezet megörzésére, mint az első mérés során. Ebben a csoportban tehát szintén nem változott számottevően a tanulók véleménye a kérdésröl.

A kísérleti és a kontrollcsoport eredményeinek összehasonlítása során (60. táblázat) nem észleltem jelentős különbséget $(\mathrm{t}=1,4 \mathrm{p}=0,1)$ a kísérleti csoport véleményében a kontrollcsoportéhoz képest, a programban való részvételt követően. Így a H6/b hipotézist is el kell vetnem, amely szerint a környezeti nevelési programban való részvételt követően az alsó tagozatos tanulók több saját cselekvési/viselkedési lehetőséget ismernek fel a környezet megóvása érdekében, mint a kontrollcsoport tagjai. 
60. táblázat: A saját lehetöségek észlelése a kísérleti és a kontrollcsoportban a második méréskor

\begin{tabular}{ccccc}
\hline \multirow{2}{*}{ saját lehetőségek } & \multicolumn{2}{c}{ kísérleti csoport $(\mathrm{N}=216)$} & \multicolumn{2}{c}{ kontrollcsoport $(\mathrm{N}=118)$} \\
\cline { 2 - 5 } & $\mathrm{N}$ & $\%$ & $\mathrm{~N}$ & $\%$ \\
\hline van lehetóségem & $\mathbf{1 5 5}$ & $\mathbf{7 1 , 8}$ & $\mathbf{7 4}$ & $\mathbf{6 7 , 9}$ \\
\hline lehetőség1 & 109 & 52 & 56 & 54 \\
lehetőség2 & 59 & 28 & 31 & 30 \\
lehetőség3 & 24 & 12 & 11 & 11 \\
lehetőség4 & 11 & 5 & 4 & 4 \\
lehetőség5 & 5 & 3 & 1 & 1 \\
\hline nincs lehetőségem & $\mathbf{4 9}$ & $\mathbf{2 2 , 7}$ & $\mathbf{3 5}$ & $\mathbf{3 2 , 1}$ \\
\hline
\end{tabular}

\subsubsection{Az említett lehetőségek tárgyának változása}

A második mérés során a kísérleti csoport tanulói a tíz lehetőség közül ugyanúgy a nem szemetelek lehetőségét említették legtöbben (30\%), mint az első méréskor (61. táblázat).

61. táblázat: Az emlitett lehetőségek a kísérleti csoportban a második méréskor

\begin{tabular}{lcccc}
\hline \multirow{2}{*}{ konkrét lehetőségek } & \multicolumn{2}{c}{ első mérés } & \multicolumn{2}{c}{ második mérés } \\
\cline { 2 - 5 } & $\mathrm{N}$ & $\%$ & $\mathrm{~N}$ & $\%$ \\
\hline nem szemetelek & 67 & 26 & 62 & 30 \\
otthoni szelektív hulladékgyüjtés & 43 & 17 & 25 & 12 \\
hulladékgyüjtési akció & 29 & 11 & 10 & 5 \\
növényvédelem & 25 & 10 & 12 & 6 \\
víztakarékosság & 24 & 9 & 36 & 18 \\
újrahasznosítás & 14 & 6 & 4 & 2 \\
példamutatás, fígyelemfelkeltés & 14 & 5 & 15 & 7 \\
energiatakarékosság & 9 & 4 & 10 & 5 \\
gyaloglás, tömegközlekedés & 9 & 4 & 7 & 4 \\
egyéb & 21 & 8 & 23 & 11 \\
\hline
\end{tabular}

A víztakarékosság kérdése 18\%-kal a második helyre került. Az első mérésnél csak az ötödik helyen említették a tanulók. A szelektív hulladékgyüjtés továbbra is népszerü lehetőség, a tanulók 12\%-a említette. A többi lehetőséget vagy ugyanolyan számban, vagy kevesebb arányban említették meg a tanulók az első mérés eredményeihez viszonyítva. Az eltérés csak a víztakarékosság lehetőségének esetében tekinthető jelentősnek (43. ábra).

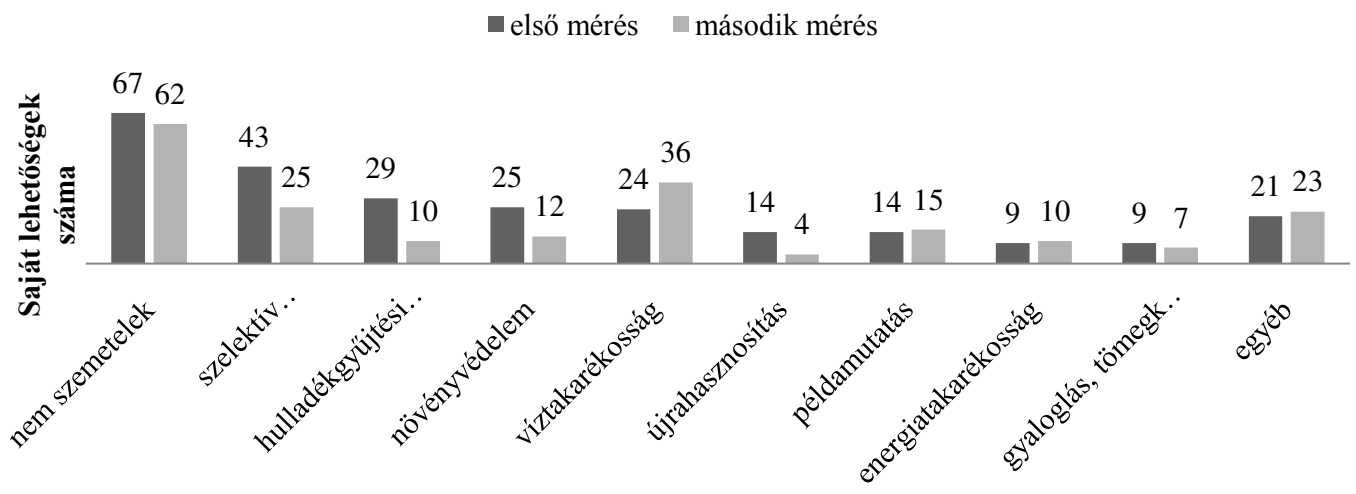

Saját lehetőségek megnevezése

43. ábra: A saját lehetöségek emlitésének változása a kísérleti csoportban a két mérés között 
Annak indoklásául, hogy miért nem tehetnek semmit a környezet megóvása érdekében, a második méréskor a kísérleti csoport tagjai sokkal magasabb arányban hozták fel (51,7\%), hogy túl fiatalok hozzá. Továbbra is sokan állítják, hogy egyedül nem tudnak bármit is tenni (41,4\%). A nem ismerem a lehetöségeimet okot mindössze ketten (6,9\%) hozták fel azok közül, akik indokolták a véleményüket, több lehetőséget nem említettek a második méréskor (62. táblázat).

62. táblázat: Indoklás, miért nincs lehetösége a környezet védelmére a kísérleti csoport tagjainak a második mérés során

\begin{tabular}{lcccc}
\hline \multirow{2}{*}{\multicolumn{1}{c}{ indoklás }} & kísérleti csoport $(\mathrm{N}=216)$ & \multicolumn{2}{c}{ második mérés } \\
\cline { 2 - 5 } & $\mathrm{N}$ & $\%$ & $\mathrm{~N}$ & $\%$ \\
\hline túl fiatal vagyok hozzá & 6 & 46,2 & 15 & 51,7 \\
egyedül kevés vagyok hozzá & 3 & 23,1 & 12 & 41,4 \\
nincs pénzem & 2 & 15,4 & - & - \\
nem érdekel & 1 & 7,7 & 2 & 6,9 \\
nem ismerem a lehetőségeimet & 1 & 7,7 & - & - \\
már úgyis hiába, túl szennyezett a környezet & - & - & - & - \\
\hline
\end{tabular}

5.4.8. Az alsó tagozatos tanulók körében elvégzett empirikus vizsgálat eredményeinek összefoglalója

Az alsó tagozatos tanulókkal végzett vizsgálat során az első hipotézist $(\mathrm{H} 1)$, amely szerint a környezeti attitűdjük pozitív átlagértéket mutat már a program megkezdése elött elvégzett, előzetes felmérés során sikerült igazolnom. A kísérleti csoportban minden alskála és item esetében pozitív eredményt kaptam, ami igazolja a H1/a hipotézist. A kontrollcsoportban egyetlen olyan item volt, amely negatív környezeti attitüdre utalt, de az alskálák és a teljes skála átlagértéke pozitív attitüdöt jelölt ebben a csoportban is. Így a H1/b hipotézist is bizonyítottnak tekintettem.

A H2/a hipotézisben foglaltakat nem sikerült bizonyítanom. Az élményt nyújtó, intenzív környezeti nevelési programban részt vevő alsó tagozatos diákok környezeti attitüdje, környezettudatos magatartásának értéke nem növekvő, hanem ellenkezőleg, csökkenő értéket mutatott az előzetes felmérés során kapott eredményekhez viszonyítva, az alskálák és az egyes itemek többségében egyaránt. Ugyanakkor a H2/b hipotézis sem nyert bizonyítást. A kísérleti csoportban is ugyanolyan mértékü csökkenés volt tapasztalható az attitüdértékek tekintetében, mint a kontrollcsoportban. A kísérleti csoport eredményei tehát nem mutattak eltérést a kontrollcsoportéhoz képest. Ezek az eredmények nem támasztják alá a program eredményességét, de ugyanakkor bizonyítják azt, hogy nem a program hatásai idézik elő a negatív irányú változást az attitűdértékek tekintetében. A vizsgálatban részt vevő tanulók életkori sajátosságaiból adódóan a szociális elvárásoknak való megfelelés igénye az a tényező, amely irányban képes befolyásolni az attitűdértékek alakulását. Mindezt a kontrollcsoportban tapasztalt értékcsökkenés is alátámasztja. A két csoport véleményében ugyanis nem mutatkozik szignifikáns eltérés a második mérés során. Így a program pozitív hatása nem bizonyítható, de az igen, hogy nincs negatív hatással a tanulók környezettel szembeni attitüdjére.

A H3-as hipotézisben azt fogalmaztam meg, hogy a környezeti nevelési programban részt vevő alsó tagozatos diákok környezeti attitüdjének értéke magasabb értéket mutat a 
programban feldolgozott témakörök (víz, hulladék, energia) esetében a második mérés során. Az előzetes felmérés során kapott eredményekhez viszonyítva (H3/a hipotézis) nem nyert bizonyítást az állítás. A víz és az energia alskálák esetében nem következett be számottevő változás, a hulladék alskála összes itmejének átlagát tekintve viszont csökkenés következett be a két mérés között. A kontrollcsoportban mért értékekhez viszonyítva (H3/b hipotézis) az energia alskála esetében bizonyítást nyert a feltevés, a két csoport környezeti attitüdje szignifikánsan eltérő értéket mutatott a két mérés között. Így a kísérleti program energia témakörét feldolgozó modulja sikeresnek tekinthető a két csoport összehasonlítása alapján. A víz és a hulladék alskála esetében nem nyert bizonyítást a H3/b hipotézis feltevése.

A H4-es számú hipotézisben a környezeti attitüd változása és a tanulókra jellemző háttérváltozók kapcsolatára vonatkozó feltevés került megfogalmazásra. Több háttérváltozó esetében is bizonyítást nyert, hogy az alsó tagozatos tanulókra jellemző háttérváltozók befolyásolják környezeti attitüdjük mértékét mind a kísérleti, mind a kontrollcsoportban. A kísérleti csoportban a nem hagyományos családmodell, az életkor és az osztály változók, valamint az anya iskolai végzettsége kölcsönös viszonyt mutat a tanulók környezeti attitüdjének mértékével. Az attitüdmérés során felemerülő egyes témakörökhöz való viszonyulás is eltérő a nemek és az életkor tekintetében. A kontrollcsoportban többek között a tanulmányi átlag, szülők iskolai végzettsége, a nem és az életkor változók esetében fedezhettem fel kölcsönös viszonyt az attitüdértékek alakulásával. A kísérleti és a kontrollcsoportban kapott eredmények bizonyos mértékben alátámasztják a H4-es jelzésű hipotézisben foglalt állítást. A vizsgált háttérváltozók döntő többsége összefüggést mutat a környezeti attitüd mértékével, a kísérleti és a kontrollcsoportban egyaránt. A korreláció azonban minden változó esetében gyenge összefüggést jelöl az attitűdértékekkel. Ennek ellenére a jelzett kapcsolatok nem hagyhatók figyelmen kívül az attitűdértékek alakulásának vizsgálata során, különösen, hogy több háttérváltozó által kialakított csoporton belül is eltérés mutatkozik az attitüdértékek tekintetében, mindkét csoportban.

A H5 hipotézis állítása szerint a környezeti nevelési programban való részvételt követően az alsó tagozatos tanulók reálisabban szemlélik a környezetszennyezés kialakulásáért valóban felelős okokat és tényezőket. Az előzetes felmérés során kapott eredményekhez viszonyítva (H5/a hipotézis) a kísérleti csoport tagjai négy tényező (természetvédelem, túlnépesedés, ipar, légszennyezés) esetében reálisabb szemlélettel bírnak a második mérést követően. A többi tizenegy tényező esetében azonban nem változott lényegesen a véleményük. Az öt környezetszennyezésért felelös ok esetében négynél szigorúbban ítélték meg az adott tényező hatását, alátámasztva ezzel a H5/a hipotézisben foglaltakat. Az első mérés alkalmával két tényező esetében volt megfigyelhető különbség a két csoport véleménye között. A második méréskor azonban már öt tényező esetében ítéltek szigorúbban a kísérleti csoport tagja a kontrollcsoporthoz képest. Ez alátámasztja a H5/b hipotézisben foglaltakat.

A H6-os hipotézis feltételezése alapján a környezeti nevelési programban való részvételt követően az alsó tagozatos tanulók több saját cselekvési/viselkedési lehetőséget ismernek fel a környezet megóvása érdekében. Az előzetes felmérés során kapott eredményekhez viszonyítva (H6/a) és a kontrollcsoportban mért értékekhez képest (H6/b) sem tapasztaltam szignifikáns eltérést, így a H6-os hipotézist el kellett vetnem. 


\section{AZ EREDMÉNYEK DISZKUSSZIÓJA}

\subsection{A hipotézisek és a kapott eredmények összevetése}

A két vizsgálat során, a tanítóképzős hallgatók és az alsó tagozatos tanulók eredményeivel kapcsolatban megfogalmazott hipotéziseket és a felmérés során kapott eredményeket a 63. táblázatban foglaltam össze.

63. táblázat: A vizsgálatsorozat hipotézisei és eredményei

\begin{tabular}{|c|c|c|}
\hline Vizsgálat & Hipotézisek & Eredmények \\
\hline \multirow{7}{*}{$\begin{array}{l}\text { tanítóképzős } \\
\text { hallgatók }\end{array}$} & $\begin{array}{l}\text { H1: A környezeti nevelési program } \\
\text { kialakításában részt vevő tanítóképzős } \\
\text { hallgatók környezettudatos magatartásának } \\
\text { értéke növekszik a programot követően. }\end{array}$ & $\begin{array}{l}\text { A környezeti nevelési program kialakításában } \\
\text { részt vevő tanítóképzős hallgatók értéke } \\
\text { növekszik a programot követően. }\end{array}$ \\
\hline & $\begin{array}{l}\text { H1/a: Az elözetes felmérés során kapott } \\
\text { eredményekhez viszonyítva. }\end{array}$ & $\begin{array}{l}\text { Az ENV skála öt alskálája közül három } \\
\text { esetében; a RevNEP skála két alskálája és a } \\
\text { teljes skála átlagát tekintve, valamint a } \\
\text { CHEAKS skálán két alskála kivételével minden } \\
\text { egyéb alskála esetében bizonyítható. }\end{array}$ \\
\hline & $\begin{array}{l}\text { H1/b: A kontrollcsoportban mért } \\
\text { értékekhez viszonyítva. }\end{array}$ & $\begin{array}{l}\text { Az ENV skála néhány alskálája, a RevNEP } \\
\text { skála legtöbb alskálája és a CHEAKS skála } \\
\text { minden alskálájának értéke igazolja a program } \\
\text { hatékonyságát a tanítóképzős hallgatókra } \\
\text { vonatkozóan. }\end{array}$ \\
\hline & $\begin{array}{l}\text { H1/c: Mind a három skála (ENV, RevNEP, } \\
\text { CHEAKS) által mért adatok alapján. }\end{array}$ & $\begin{array}{l}\text { A H2/c hipotézist el kellett vetni, ugyanis nem } \\
\text { minden egyes alkalmazott skála összes alskálája } \\
\text { esetében bizonyítható a program hatékonysága. }\end{array}$ \\
\hline & $\begin{array}{l}\text { H2: A Vajdaságban magyar nyelven tanuló } \\
\text { tanító- és óvóképzős hallgatók környezeti } \\
\text { attitüdjének értéke alapvetően pozitív, a } \\
\text { három skála adatai alapján. }\end{array}$ & $\begin{array}{l}\text { Mind a kísérleti, mind pedig a } \\
\text { kontrollcsoportban voltak negatív értéket jelző } \\
\text { alskálák az első mérés alkalmával. }\end{array}$ \\
\hline & $\begin{array}{l}\text { H3: A háttérváltozók befolyásolják a } \\
\text { környezeti attitűd mértékét. }\end{array}$ & $\begin{array}{l}\text { Nem minden háttérváltozó esetében mutatható } \\
\text { ki összefüggés, de egyes tényezők hatással } \\
\text { vannak a környezeti attitüd mértékére mindkét } \\
\text { csoportban. }\end{array}$ \\
\hline & $\begin{array}{l}\text { H4: A tanítóképzös hallgatók környezeti } \\
\text { attitüdjének mértéke tovább növekszik a } \\
\text { kísérlet évét követő további vizsgált } \\
\text { tanévekben is. }\end{array}$ & $\begin{array}{l}\text { A Magyar Tannyelvü Tanítóképző Kar oktatási } \\
\text { rendszere a program hatásaitól függetlenül nem } \\
\text { befolyásolja pozitív irányban a környezeti } \\
\text { attitüd mértékét. }\end{array}$ \\
\hline \multirow{5}{*}{$\begin{array}{l}\text { alsó tagozatos } \\
\text { tanulók }\end{array}$} & $\begin{array}{l}\mathrm{H} 1: \text { Az alsó tagozatos gyerekek környezeti } \\
\text { attitüdje alapvetően pozitív. }\end{array}$ & $\begin{array}{l}\text { Az alsó tagozatos tanulók környezeti attitüdje } \\
\text { pozitív átlagértéket mutat már a program } \\
\text { megkezdése előtt elvégzett előzetes felmérés } \\
\text { során. }\end{array}$ \\
\hline & H1/a: A kísérleti csoportban. & $\begin{array}{l}\text { A kísérleti csoportban minden alskála és item } \\
\text { esetében pozitív eredményt kaptam. }\end{array}$ \\
\hline & H1/b: A kontrollcsoportban. & $\begin{array}{l}\text { A kontrollcsoportban egyetlen olyan item volt, } \\
\text { amely negatív környezeti attitüdre utalt, de az } \\
\text { alskálák és a teljes skála átlagértéke pozitív } \\
\text { attitüdöt jelölt. }\end{array}$ \\
\hline & $\begin{array}{l}\text { H2: A programban részt vevő diákok } \\
\text { környezettudatos magatartásának értéke } \\
\text { pozitívabb a program után. }\end{array}$ & A hipotézist nem sikerült bizonyítani. \\
\hline & $\begin{array}{l}\text { H2/a: Az előzetes felmérés során kapott } \\
\text { eredményekhez viszonyítva. }\end{array}$ & $\begin{array}{l}\text { A programban részt vevő alsó tagozatos diákok } \\
\text { környezeti attitüdjének értéke nem növekvő, } \\
\text { hanem csökkenő értéket mutatott az előzetes }\end{array}$ \\
\hline
\end{tabular}




\begin{tabular}{|c|c|}
\hline & $\begin{array}{l}\text { felmérés során kapott } \\
\text { viszonyítva. }\end{array}$ \\
\hline $\begin{array}{l}\mathrm{H} 2 / \mathrm{b}: \text { A kontrollcsoportban mért } \\
\text { értékekhez viszonyítva. }\end{array}$ & $\begin{array}{l}\text { A kísérleti csoport eredményei nem mutattak } \\
\text { eltérést a kontrollcsoportéhoz képest. }\end{array}$ \\
\hline $\begin{array}{l}\text { H3: A programban részt vevő diákok } \\
\text { környezeti attitüdjének értéke magasabb a } \\
\text { programban feldolgozott témakörök (víz, } \\
\text { hulladék, energia) esetében. }\end{array}$ & $\begin{array}{l}\text { A hipotézist csak az energia modul esetében } \\
\text { sikerült bizonyítani, és csak a kontrollcsoportban } \\
\text { mért értékekhez képest. }\end{array}$ \\
\hline $\begin{array}{l}\text { H3/a: Az előzetes felmérés során kapott } \\
\text { eredményekhez viszonyítva. }\end{array}$ & $\begin{array}{l}\text { A víz és az energia alskálák esetében nem } \\
\text { következett be számottevő változás, a hulladék } \\
\text { alskála összes itmejének átlagát tekintve viszont } \\
\text { csökkenés következett be a két mérés között. }\end{array}$ \\
\hline $\begin{array}{l}\text { H3/b: A kontrollcsoportban mért } \\
\text { értékekhez viszonyítva. }\end{array}$ & 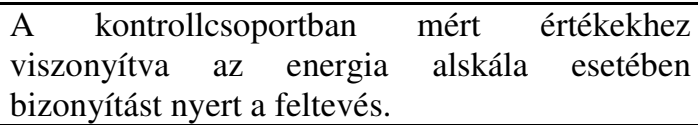 \\
\hline $\begin{array}{l}\text { H4: A tanulókra jellemző háttérváltozók } \\
\text { befolyásolják környezeti attitüdjük } \\
\text { mértékét mindkét csoportban. }\end{array}$ & $\begin{array}{l}\text { Több háttérváltozó esetében is bizonyítást nyert, } \\
\text { hogy az alsó tagozatos tanulókra jellemző } \\
\text { háttérváltozók befolyásolják környezeti } \\
\text { attitüdjük mértékét mind a kísérleti, mind a } \\
\text { kontrollcsoportban. }\end{array}$ \\
\hline $\begin{array}{l}\text { H5: A programban való részvételt } \\
\text { követően a tanulók reálisabban szemlélik a } \\
\text { környezetszennyezés kialakulásáért felelős } \\
\text { okokat és tényezőket. }\end{array}$ & $\begin{array}{l}\text { A tizenöt tényezőböl négynél, az öt ok közül } \\
\text { pedig szintén négynél sikerült bizonyítani a } \\
\text { feltevést. }\end{array}$ \\
\hline $\begin{array}{l}\text { H5/a: Az előzetes felmérés során kapott } \\
\text { eredményekhez viszonyítva. }\end{array}$ & $\begin{array}{l}\text { A természetvédelem, túlnépesedés, ipar és } \\
\text { légszennyezés esetében reálisabb szemlélettel } \\
\text { bírnak a tanulók a második mérést követően. Az } \\
\text { öt környezetszennyezésért felelős ok esetében } \\
\text { négynél szigorúbban ítélték meg az adott } \\
\text { tényezö hatását. }\end{array}$ \\
\hline $\begin{array}{l}\text { H5/b: A kontrollcsoportban mért } \\
\text { értékekhez viszonyítva. }\end{array}$ & $\begin{array}{l}\text { Az elsö méréskor két tényezö esetében volt } \\
\text { megfigyelhető különbség, a második méréskor } \\
\text { már öt tényező esetében ítéltek szigorúbban a } \\
\text { kísérleti csoport tagjai. }\end{array}$ \\
\hline $\begin{array}{l}\text { H6: A programban való részvételt } \\
\text { követően a tanulók több saját cselekvési } \\
\text { lehetőséget ismernek fel a környezet } \\
\text { megóvása érdekében. }\end{array}$ & A feltevést nem sikerült bizonyítani. \\
\hline $\begin{array}{l}\text { H6/a: Az előzetes felmérés során kapott } \\
\text { eredményekhez viszonyítva. }\end{array}$ & $\begin{array}{l}\begin{array}{l}\text { Nincs számottevő különbség a két mérés } \\
\text { eredményei között. }\end{array} \\
\end{array}$ \\
\hline $\begin{array}{l}\text { H6/b: A kontrollcsoportban mért } \\
\text { értékekhez viszonyítva. }\end{array}$ & $\begin{array}{l}\text { Nincs számottevő különbség a két csoport } \\
\text { eredményei között. }\end{array}$ \\
\hline
\end{tabular}

A tanítóképzős hallgatók háttérváltozóinak vizsgálata során találtunk összefüggést egyes tényezők és a környezeti attitüd alakulása között, a kísérleti és a kontrollcsoportban is. Ez az eredmény azt jelenti, hogy a tanítóképzős hallgatók környezettudatos magatartásának fejlesztése során figyelembe kell venni a hallgatók szociokulturális hátterét, tanulmányi eredményeit, valamint az oktatási rendszer eredményességét is a környezettudatosság fejlesztése során. További kutatások során fel kell tárni ezen tényezők környezeti nevelés során kiaknázható lehetőségeit.

A kísérletben részt vevő hallgatók környezeti attitüdjének értéke nem mutatott pozitív értéket minden alskála esetében az első, kezdeti állapotokat vizsgáló felmérés során. A második méréskor viszont több esetben is pozitív attitüdértéket értek el a hallgatók olyan skálákon, amelyek az első méréskor még negatív attitűdértéket jeleztek. A program hatékonyságát nem sikerült az összes alkalmazott attitüdmérő skála összes témaköre esetében 
bizonyítani, de voltak olyan alskálák, amelyek esetében növekedést tapasztaltunk a két mérés között. A kísérleti és a kontrollcsoport eredményeinek összehasonlítása során sem sikerült minden skála esetében szignifikáns eltéréssel alátámasztani a programban részt vevő hallgatók értékeinek növekedését. Ugyanakkor a CHEAKS alskála értékei minden esetben magasabbak voltak a kísérleti csoportban. A program egyes elemei tehát megfelelő mértékben befolyásolták a kísérletben részt vevő hallgatók környezeti attitüdjének mértékét.

A vizsgálatban szereplő alsó tagozatos tanulók esetében bebizonyosodott, hogy alapvetően pozitív környezeti attitüddel rendelkeznek. Ugyanakkor a környezeti attitüd vizsgálatára vonatkozó 24 item eredményeinek elemzése során sem a kísérleti csoport első és második alkalommal mért értekeinek összehasonlítása, sem pedig a kísérleti és a kontrollcsoport által elért értékek összehasonlítása nem mutatott attitüdnövekedést. Ehelyett az értékek csökkenése volt tapasztalható mindkét csoportban. Ezáltal nem tudtam egyértelműen bizonyítani a program hatékonyságát, ugyanakkor bizonyítást nyert, hogy nem a program negatív hatásai idézték elő a változást. Így a kísérleti program továbbfejlesztett változatát a jövőben is igyekszünk majd alkalmazni az alsó tagozatos tanulók körében. Az attitűdmérés folyamatában és eszközeiben felmerült hiányosságokat igyekeznünk kell kiküszöbölni a további kutatások során.

A kísérleti programban feldolgozott modulok közül egyedül az energia témaköre esetében tapasztaltam szignifikáns eltérést a kísérleti és a kontrollcsoport eredményeit illetően. Így csak a negyedik osztályokban végrehajtott program eredményességét sikerült bizonyítani ebben a formában. Ez az eredmény is alátámasztja azt a feltevést, hogy az életkor előrehaladtával csökken a szociális megfelelésnek való kényszer, és a tanulók egyre reálisabb válaszokat adnak az attitüdmérö kérdőív kérdéseire.

A tanulók sokkal reálisabban szemlélik a környezetre veszélyes tényezőket és a környezetszennyezés kialakulásáért felelős okokat a kísérleti programban való részvételt követően. Ez az eredmény a program sikerességét támasztja alá.

A környezet megóvása érdekében fennálló saját lehetőségek észlelése esetében azonban nem tapasztaltam fejlődést a tanulóknál az előzetes felméréshez képest. Ebből a szempontból mindenképpen fejlesztésre szorul a program. 


\subsection{Végső következtetések}

Értekezésemben a környezeti attitüd alakulását vizsgáltam két különböző korcsoportban, tanítóképzős hallgatók és alsó tagozatos tanulók körében. A két csoport vizsgálatának alapját ugyanaz a kísérleti program képezte, amelyben a hallgatók a program tervezőjeként és megvalósítójaként, a gyerekek pedig résztvevőként szerepeltek. A program elsődleges célja a két csoport környezeti attitűdjének együttes fejlesztése volt. A tanítóképzős hallgatók esetében a környezeti neveléssel kapcsolatos módszertani ismereteik bővítésére is lehetőséget adott a program, a gyerekek számára pedig aktív, élményszerü cselekvési lehetőségeket és változatos oktatási színtereket biztosított. A program eredményei és az általa nyújtott lehetőségek a gyakorló tanítók számára is ötleteket, lehetőségeket nyújthatnak környezeti neveléssel kapcsolatos tevékenységeik bővítésére.

A tanítóképzős hallgatókkal elvégzett empirikus vizsgálat eredményei egyértelmüen bizonyítják a program sikerességét. A kísérleti program megvalósításának keretet adó tantárgy elérte célját a hallgatók körében, így a továbbiakban is részét képezi majd a Magyar Tannyelvü Tanítóképző Kar tantervének. Ez azért is fontos, mert a tantervnek a környezettudatosságra gyakorolt hatékonyságvizsgálata során nem tudtuk bizonyítani, hogy önmagában is fejlesztő hatású lenne ezen a téren. Szükség van tehát a célzott környezeti nevelési programok bevezetésére és a tantárgyi célok és feladatok ilyen irányú bővítésére a Kar tantervében.

$\mathrm{Az}$ alsó tagozatos tanulók esetében a program sikerességét nem minden vizsgált szempont esetében sikerült bizonyítani. A kapott értékek második felmérés során való csökkenése arra utal, hogy a felmérésben részt vevő minta esetében jelen vannak a CHEAKS kérdőív hatékonyságát torzító tényezők. Ezért nem vetjük el egyértelműen a kutatás alapját képező környezeti nevelési program hatékonyságát. A vizsgálat egyes eredményei rávilágítottak a program néhány pozitív hatására is. Ez, illetve a program véleményezésére felkért pedagógusok pozitív értékelése arra utal, hogy érdemes a program egyes elemeinek fejlesztését és átdolgozását követően továbbra is bevonni az alsó tagozatos tanulókat az intenzív, élményt nyújtó környezeti nevelési programba. A program tantervbe való beillesztése és megvalósítása a kísérlet tapasztalatai alapján nem ütközik kiküszöbölhetetlen nehézségekbe, ugyanakkor hozzájárul a magyar tannyelven tanuló vajdasági tanítóképzős hallgatók és a szabadkai alsó tagozatos tanulók környezeti attitüdjének együttes fejlesztéséhez, a fenntartható fejlődés pedagógiai céljainak megfelelően. 


\subsection{További célok}

A disszertáció fő célkitüzése, a környezeti nevelési program kidolgozása és megvalósítása a szerbiai tanterv adta keretek között sikeresen megvalósult. A programot a kapott adatok alapján a jövőben mindenképpen tovább kell fejleszteni az empirikus kutatás során kapott adatok alapján. Az eredmények rámutattak arra, hogy az Újvidéki Egyetem Magyar Tannyelvű Karán mindenképpen folytatni kell azokat a megkezdett, többrétü törekvéseket, amelyek a környezeti nevelés és a fenntartható fejlődés pedagógiai céljainak megvalósítására vonatkoznak.

A Karon müködő Fenntarthatóság munkacsoportnak sikerült feltérképeznie az intézmény oktatási programjának hatékonyságát a környezeti attitüd fejlesztése tekintetében. Az eredmények arra utalnak, hogy az intézmény oktatási rendszere már jelenlegi formájában is képes pozitívan befolyásolni a hallgatók környezeti attitüdjének értékét a BA képzés időszakában. A továbbiakban azonban szükség lesz a tanterv és az alkalmazott módszerek hatékonyságának növelésére. Több kompetencia összekapcsolását és a transzdiszciplináris tanulás megvalósítását kell szorgalmazni a Karon. Szükség lesz a fenntarthatóság elveinek tervszerű beépítésére a többi tantárgy rendszerébe is, és a tanórán kívüli foglalkozásokat is ennek megfelelően alakítani.

A szabadkai Magyar Tannyelvű Tanítóképző Karon máris elindultak olyan kezdeményezések, amelyek az oktatás minőségének javítását célozzák a fenntarthatóságra nevelés szempontjából. A Fenntarthatóság munkacsoport megalakulásával párhuzamosan a 2015/2016-os tanév első félévében megkezdte müködését a Fenntarthatóság mühely, amely az egyetemen müködő tíz tehetséggondozó mühely egyike. A mühely általános célja a tanítóképzős hallgatók fenntarthatósággal kapcsolatos ismereteinek és környezettudatos magatartásának fejlesztése a társadalomtudományi és módszertani tartalmak összekapcsolása, saját tapasztalatokra épülő kutatás, valamint a kisiskolások számára szervezett fejlesztő munka által, a fenntartható fejlődés elveinek közvetítésével. A mühely munkájának keretein belül az intézmény 2016-ban első alkalommal csatlakozott az Európai Fenntarthatósági Hét (European Sustainable Development Week) elnevezésű eseményhez egy, a fenntartható fejlődés elveit népszerüsítő programsorozat megrendezésével, a minőségi oktatás (4. fenntartható fejlődési cél) jegyében.

Társas kapcsolatai szintjén mindenképpen szükség van arra, hogy az intézmény oktatói ne magányos tanárokként, hanem egy célirányos csapat tagjaként müködjönek együtt egymással, és az iskoláskor előtti intézményekben, illetve az általános iskolákban tanító pedagógusokkal egyaránt. A 2015/2016-os tanév második félévében 17 olyan továbbképzést sikerült akkreditáltatni a Karon, amelyek ennek a célnak az elérését segíthetik. Az egyik képzés a környezeti nevelés elméletének és gyakorlatának oktatásáról szól gyakorló pedagógusok részére. A kurzus célja elérni azt, hogy az ezen a képzésen résztvevő pedagógusok ismerjék fel a környezeti nevelés fontosságát, szerezzenek a pedagógiai gyakorlatukban alkalmazható ismereteket a környezeti nevelésben alkalmazható módszerekről, ezek megszervezéséről és lebonyolításáról. A környezeti nevelés módszertani elveit alkalmazva képesek legyenek az alsó tagozatos gyerekek környezettel kapcsolatos szemléletének formálására. 
Az intézmény távlati céljai között szerepel egy intenzív, fenntarthatóságra nevelő program kidolgozása az egyetemen belül, amely a természeti és a társadalmi környezetben megvalósuló, közvetlen tapasztalatszerzésre irányuló tevékenységekre épül. A hagyományos és online környezetben megvalósított, a fenntarthatóság témájához kapcsolódó előadások és módszertani gyakorlatok célcsoportját a tanítóképzős hallgatók és a gyakorló pedagógusok együttesen képeznék. A törekvések végső célja egy hatékony, a fenntarthatóság elveinek megfelelően müködő oktatási intézmény kialakítása, amely a társadalmi kihívásokra reagáló, innovatív módszerekkel, online alapú eszközök használata által hozzájárul a tanítóképzős hallgatók környezettudatosságának és tehetségének fejlesztéséhez, ezzel felkészítve a leendő tanítókat a környezeti nevelési feladatok ellátására, a módszerek gyakorlatban való alkalmazására és a jövő generációinak a globális kihívásokra történő felkészítésére. 


\section{IRODALOM}

Abolaji, M. A., Oke, O. A., Adebanjo, A. (2011): An Investigation of Environmental Education Knowledge for Sustainable Development in High School Sectors in UK. Journal of Life Sciences, 5 (8), 670-675.

Ádám Ferencné, Kuti Istvánné, Kuti István (2007): Környezeti nevelés a XXI. század óvodájában. Körlánc, Kecskemét.

Akengin, H., Aydemir, G. (2012): Effects of Using Case-Study Method in Social Studies on Students' Attitudes Towards Environment. International Electronic Journal of Environmental Education, 2 (2), 119-127.

Allport, G. W. (1979): Az attitüdök. In: Halász László, Hunyadi György, Marton L. Magda (szerk.) (1979): Az attitüd pszichológiai kutatásának kérdései. Akadémiai Kiadó, Budapest.

Alp, E., Ertepinar, H., Tekkaya, C. (2006): A Statistical Analysis of Children's Environmental Knowledge and Attitudes in Turkey. International Research in Geographical and Environmental Education, 15 (3), 210-223.

Álvarez, S. P., Vega, M. P. (2010): Developing sustainable environmental behavior in secondary education students (12-16) Analysis of a didactic strategy. Procedia - Social and Behavioral Sciences, 2 (2), 3568-3574.

Atkinson, R. L. (2003): Pszichológia. Osiris, Budapest.

Aydos, E. H., Yağc1, E. (2015): Examination of the teacher candidates' environmental attitudes via NEP scale in terms of different variables. Journal of Education in Science, Environment and Health (JESEH), 1 (1), 20-27.

Bagány Ágnes, Major Lenke, Námesztovszki Zsolt, Szálas Tímea, Takács Márta, Vinkó Attila (2014): A nevelési gyakorlat többszempontú megújításának igénye a digitális társadalomban: IKT-és web 2.0-ás eszközök használata a vajdasági tanárok körében. IKT az oktatásban konferencia. Újvidéki Egyetem Magyar Tannyelvü Tanítóképző Kar, Szabadka.

Ballantyne, R., Fien, J., Packer, J. (2001). Program effectiveness in facilitating intergenerational influence in environmental education: Lessons from the field. Journal of Environmental Education, 32 (4), 8-15.

Balog Adalbert (2005): A 20. század ökológiai irányzatai. Korunk, (4), 50-54.

Balogh Károly Csaba (2002): Viselkedjünk erdőn-mezőn (is). Szaktudás Kiadó Ház Rt., Budapest.

Bandura, A. (1979): Milyen következményekkel járnak a viselkedési és affektív változások az attitüdökre nézve? In: Halász László, Hunyadi György, Marton L. Magda (szerk.) (1979): Az attitüd pszichológiai kutatásának kérdései. Akadémiai Kiadó, Budapest.

Barabási Tünde, Görbe Ágnes Renáta (2015): A projektmódszer óvodai alkalmazásának háttértényezői. PedActa, 5 (2), 35-50.

Bas, M., Teksoz, G. T., Ertepinar, H. (2011): Emphasizing local features for effective environmental education: Environmental attitudes of elementary school students living in ancient Halicarnassus (Turkey). Science Education International, 22 (2), 119-132. 
Bentham, H., Sinnes, A., Gjøtterud, S. (2015): A Teacher Education for Sustainable Development System: An Institutional Responsibility. International Journal of Higher Education, 4 (4), 158-177.

Berényi László (2009): Környezettudatosság vagy környezet-tudatalattiság? Magyar minőség, 18 (12), 8-18.

Berty László, Juhász Ilona, Soltész Ágnes (2004): Környezeti nevelési program. Dunakeszi: Körösi Csoma Sándor Általános Iskola.

Besenyei Mónika (2013): A felsőoktatás fenntarthatósági szempontú vizsgálata. Polgári Szemle, (9), 3-6.

Bogner, F. X., Wiseman, M. (1999): Toward measuring adolescent environmental perception. European Psychologist, 4 (3), 139-151.

Bogner, F. X., Wiseman, M. (2002). Environmental Perception: Factor Profiles of Extreme Groups, In European Psychologist, 7 (3), 225-237.

Bolis, I., Morioka, S. N., Sznelwar, L. I. (2014): When sustainable development risks losing its meaning. Delimiting the concept with a comprehensive literature review and a conceptual model. Journal of Cleaner Production, (83), 7-20.

Bonett, D. G., Wright, T. A. (2000): Sample size requirements for estimating pearson, kendall and spearman correlations. Psychometrika, 65 (1), 23-28.

Bonnett, M., Williams, J. (1998): Environmental Education and Primary Children's Attitudes towards Nature and the Environment. Cambridge Journal of Education, 28 (2), 159-174.

Borsos Éva, Kovács Elvira, Svanner Ildikó, Szirák Kinga, Túrús Biacsi Renáta (2012): Globális tanári munkaterv a Természet és társadalom tantárgy tanításához 3. osztályban. Széchenyi István Általános Iskola, Szabadka.

Bradley, J. C., Waliczek, T. M., Zajicek, J. M. (1999): Relationship between environmental knowledge and environmental attitude of high school students. Journal of Environmental Education, 30 (3), 17-21.

Brossard, D., Lewenstein, B., Bonney, R. (2005): Scientific knowledge and attitude change: The impact of a citizen science project. International Journal of Science Education, 27 (9), 1099-1121.

Budayné Kálóczi Ildikó, Ungvári Jánosné (2005): Erdei iskola a debreceni Erdöspusztán. Juventus 96, Debrecen.

Burány Katalin (2014): Múzeumpedagógia. Híd, 46 (9-10), 60-69.

Campbell, T., Medina-Jerez, W., Erdogan, I., Zhang, D. (2010): Exploring science teachers' attitudes and knowledge about environmental education in three international teaching communities. International Journal of Environmental \& Science Education, 5 (1), 3-29.

Carleton-Hug, A., Hug, W. (2010): Challenges and Opportunities for Evaluating Environmental Education Programs. Evaluation and Program Planning, 33 (2), 159-164.

Cebián, G., Grace, M., Humphris, D. (2015): Academic staff engagement in education for sustainable development. Journal of Cleaner Production, (106), 79-86.

Centre for Sustainable Development and Environment, University of Novi Sad: http://bit.ly/29ThZr6

Chapman, P. (2014): Environmental Education and Sustainability. Independent School Magazine. Megtekintés: 2016.03.11. Forrás: http://bit.ly/1QMkurg 
Chin, A., Jacobsson, T. (2016): TheGoals.org: mobile global education on the Sustainable Development Goals. Journal of Cleaner Production, (123), 227-229.

Čolić, D. (szerk.) (1973): Saopštenja podneta naučnom skupu "Čovek i životna sredina". Srpska akademija nauka i umetnosti, Beograd.

Cotton, D. R. E., Warren M. F., Maiboroda O., Bailey I. (2007): Sustainable development, higher education and pedagogy: a study of lecturers' beliefs and attitudes. Environmental Education Research, 13 (5), 579-597.

Czeglédi László (2011): Minőségmenedzsment. Eszterházy Károly Főiskola, Eger.

Czekuš Geza (2002): Vaspitanje za zaštitu i unapređenje životne sredine u različitim prilikama. Norma, 8 (3), 37-44.

Czékus Géza (2003): Az iskola szerepe a fenntartható fejlödésben - helyzetelelmzés és lehetőségek. In: Molnár Imre (szerk.): A fenntartható fejlödés időszerü kérdései a Vajdaságban. Atlantis, Újvidék.

Czekuš Geza, Horak Rita (2015): Udžbenici Sveta oko nas i Prirode i društva u službi integrisane nastave. Povezivanje nastavnih predmeta i stručno usavršavanje učitelja. 9. Nemzetközi Tudományos Konferencia. Újvidéki Egyetem Magyar Tannyelvü Tanítóképző Kar, Szabadka.

Czékus Géza, Major Lenke, Horák Rita (2013): A környezetünk és a környezetismeret módszertana. Újvidéki Egyetem Magyar Tannyelvü Tanítóképző Kar, Szabadka.

Cseri Anita (szerk.) (2003): Oktatás a fenntartható fejlödés szolgálatában. Környezeti Nevelési és Kommunikációs Programiroda és Magyar UNESCO Bizottság, Budapest.

Dagiliūtè, R., Liobikienè, G. (2015): University contributions to environmental sustainability: challenges and opportunities from the Lithuanian case. Journal of Cleaner Production (108), 891-899.

Damjanovich I. (2003). Környezetbiztonság. In: A környezeti kockázatok egységes értelmezése. Megtekintés: 2016.06.10. Forrás: http://bit.ly/2kHBN2W

Dámné Erdei Gabriella (2001): Módszertani útmutató a környezetismeret-természetismeret tanításához. Kölcsey Ferenc Református Tanítóképző Főiskola, Debrecen.

Dimopoulos, D., Paraskevopoulos, S., Pantis, J. (2008): The cognitive and attitudinal effects of a conservation educational module on elementary school students. Journal of Environmental Education, 39 (3), 47-61.

Division for Sustainable Development (2015): Sustainable Development Goals. Megtekintés: 2016.03.12. Forrás: http://bit.ly/1 IqICxS

Dopico, E., Garcia-Vazquez, E. (2011): Leaving the Classroom: A Didactic Framework for Education in Environmental Sciences. Cultural Studies of Science Education, 6 (2), 311-326.

Dunap, R. E., Jones R.E. (2002): Environmental concern: Conceptual and measurement issues. In. Dunlap R.E., Michelson W. (Eds.): Handbook of environmental sociology. Greenwood Press, Westport, CT, 482-524.

Dunlap, R. E., Van Liere, K. D., Mertig, A. G., Jones, R. E. (2000): Measuring endorsement of the new ecological paradigm: a revised NEP scale. Journal of Social Issues, 56 (3), $425-442$. 
Dyment, J., Hill, A. (2015): You mean I have to teach sustainability too? Initial teacher education students' perspectives on the sustainability cross-curriculum priority. Australian Journal of Teacher Education, 40 (3), 20-35.

Egyesült Nemzetek Információs Szolgálat - UNIS (2015): Fenntartható Fejlődési Célok. Megtekintés: 2016.03.12. Forrás: http://bit.ly/1V102Vy

Erdogan, M. (2015): The Effect of Summer Environmental Education Program (SEEP) on Elementary School Students' Environmental Literacy. International Journal of Environmental \& Science Education, 10 (2), 165-181.

Esler, K. J., Downsborough, L., Roux, D. J., Blignaut, J., Milton, S., Maitre le D., Wit de M. P. (2016): Interdisciplinary and multi-institutional higher learning: reflecting on a South African case study investigating complex and dynamic environmental challenges. Current Opinion in Environmental Sustainability, 19 (April), 103-110.

European Commission (2012): Higher Education in Serbia. Education, Audiovisual and Culture Executive Agency (EACEA) Unit P10 - Tempus and Bilateral Cooperation with Industrialised Countries. http://bit.ly/1TKArjm

European Sustainable Development Week (ESDW), 2016. Megtekintés: 2016.03.12. Forrás: http://www.esdw.eu/

Eysenck, H. J., Eysenck S. B. G. (1969): Personality Structure and Measurment. Routledge \& Kegan Paul, London, 310-312.

Faragó Tibor (2015): A fenntartható fejlődés új ENSZ-programja. Magyar ENSZ Társaság. Megtekintés: 2016.03.12. Forrás: http://bit.ly/228m8L5

Feketéné Szakos Éva (2002): A felnöttek tanulása és oktatása - új felfogásban. Akadémiai Kiadó.

Fernandez-Manzanal, R., Serra, L. M., Morales, M. J., Carrasquer, J., Rodríguez-Barreiro, L. M., Valle del, J., Murillo, M. B. (2015): Environmental behaviours in initial professional development and their relationship with university education. Journal of Cleaner Production (108), 830-840.

Fernengel András (2002): Iskolai tanórán kívüli környezeti nevelés. In: Nemzeti Környezeti Nevelési Stratégia, MKNE, Budapest.

Fien, J. (1999): Neveléssel és tanulással a fenntartható fogyasztásért. In: Havas Péter (szerk.) (1991): A környezeti nevelés Európában. Körlánc Egyesület, Budapest. 242.

Flamm, B. J. (2009): The impacts of environmental knowledge and attitudes on vehicle ownership and use. Transportation Research, 14 (4), 272-279.

Fletcher, T., Haynes, J., Miller, J. (2005): Effects of Grouping by Perceived Ability on the Attitudes of Year 10 Students towards Physical Education. Australian Association for Research in Education (AARE) International Conference, Sydney.

Foghtüy Krisztina, Harangi Anna (1993): Múzeumpedagógia: útmutató pedagógusok számára. Korona, Budapest.

Fountain, K., Koppen, K., Leemans, R. (2011): The Value of Conceptual Models in Coping with Complexity and Interdisciplinarity in Environmental Sciences Education. BioScience, 61 (10), 802-814.

Füzné Kószó Mária (2002): A környezeti nevelés koncepciói. Iskolakultúra, 12 (1), 40-50. 
Füzné Kószó Mária, Négyökrü Mária (2015): Állatkertek, vadasparkok mint környezetitermészeti nevelési színterek. EDU: szakképzés és környezetpedagógia elektronikus szakfolyóirat, (6), 82-92.

Gadenne, D., Sharma, B., Kerr, D., Smith, T. (2011): The influence of consumers' environmental beliefs and attitudes on energy saving behaviours. Energy Policy, (39), 7684-7694.

Gatzke, J. M., Buck, G. A., Akerson, V. L. (2015): More than Just Playing Outside: A SelfStudy on Finding My Identity as an Environmental Educator in Science Education. International Journal of Environmental \& Science Education, 10 (3), 319-335.

Gokhan, B. (2010): The Effects of Multiple Intelligences Instructional Strategy on the Environmental Awareness Knowledge and Environmental Attitude Levels of Elementary Students in Science Course. International Electronic Journal of Environmental Education 1 (1), 53-80.

Grodzińska-Jurczak, M., Bartosiewicz, A., Twardowska, A., Ballantyne, R. (2004): Evaluating the impact of a school waste education programme upon students, parents' and teachers' environmental knowledge, attitudes and behaviour. International Research in Geographical and Environmental Education 12 (2), 2-15.

Gulyás Magda (2004): A környezeti nevelés és a személyiségtényezők hatása a környezeti attitüdre. Szakdolgozat. ELTE BTK, Budapest.

Gulyás Magda, Varga Attila (2009): A környezeti attitüdtöl a minöségi kritériumokig. Oktatáskutató és Fejlesztő Intézet. Megtekintés: 2016.02.10. Forrás: http://bit.ly/1UALXh7

Gulyás Pálné, Havas Péter (1998): Értékek és alapelvek a környezeti nevelésben. Cédrus, 1 (1). Megtekintés: 2016.03.09. Forrás: http://bit.ly/21kU29P

Gyulai Iván (2013): Fenntartható fejlődés és fenntartható növekedés. Statisztikai szemle, 91 (8-9), 797-822.

Hadzigeorgiou, Y., Skoumios, M. (2013): The development of environmental awareness through school science: Problems and possibilities. International Journal of Environmental \& Science Education, 8 (3), 404-426.

Hamidi, K., Delbahari, V. (2011): Formulating a Strategy for a University Using SWOT Technique: A Case Study. Australian Journal of Basic and Applied Sciences, 5 (12), 64-276.

Hart, P. (2010): No Longer a "Little Added Frill": The Transformative Potential of Environmental Education for Educational Change. Teacher Education Quarterly, 37 (4), $155-177$.

Hauke, J., Kossowski, T. (2011): Comparison of Values of Pearson's and Spearman's Correlation Coefficients on the Same Sets of Data. Quaestiones Geographicae, 30 (2), 87-93.

Havas Péter (1993): A környezeti nevelés pszichológiai és pedagógiai alapjai. In: Kisiskolások környezeti nevelése. Alapítvány a Magyarországi Környezeti Nevelésért, Budapest.

Havas Péter (1995): A biológia tanítása és a környezeti nevelés. Módszertani lapok. Biológia, $2(4), 5-11$. 
Havas Péter (1997): Hogyan tanítsunk "környezeti nevelést"? - Hozzászólás Nahalka István: Tanítható-e a környezetvédelem? címü tanulmányához. Új pedagógiai szemle, 47 (9), 85-91.

Havas Péter (1997a): A környezeti szocializáció alternatívái. Cédrus, 1 (1). Megtekintés: 2016.03.09. Forrás: http://bit.ly/2sJqVGW

Havas Péter (1997b): A természet és a társadalom fenntarthatóságának kihívása a neveléstudományokra-gondolatok a környezeti nevelés identitásáról. In Ilosvay György, Szentjóbi Szabó Tibor (szerk.) (1997): Természetvédelem és környezetvédelem a nevelésben. Természet- és Környezetvédö Tanárok Egyesülete, Budapest. 47-59.

Havas Péter (1998): A környezeti neveléstõl a fenntarthatóság pedagógiájáig. Cédrus, 1(1). Megtekintés: 2016.03.09. Forrás: http://bit.ly/1TKBUaq

Havas Péter (2001): A fenntarthatóság pedagógiai elemei. Új pedagógiai szemle, 51 (9), 3-15. Havas Péter, Varga Attila (1998): Általános és középiskolás diákok környezettel kapcsolatos attitüdjei és ismeretei. Összehasonlító vizsgálat a „Természettudományokkal Európán Keresztüll” program hatékonyságáról. Megtekintés: 2016.03.09. Forrás: http://bit.ly/1XcMR2a

Havas Péter, Varga Attila (2005): A fenntartható fejlődés iskoláinak kialakítása. Új Pedagógiai Szemle, 55 (12), 45-64.

Havas Péter, Varga Attila (2006): A környezeti neveléstől a fenntarthatóság pedagógiai gyakorlata felé. In: Varga Attila (szerk.): Tanulás a fenntarthatóságért, OKI, Budapest. 49-72.

Heyl, M., Moyano Díaz y, E., Cifuentes, L. (2013): Environmental attitudes and behaviors of college students: a case study conducted at a Chilean university. Revista Latinoamericana de Psicoiogia, 45 (3), 489-502.

Hines, J. M., Hungerfold, H. R., Tomera, A. N. (1986): Analysis and synthesis of research on responsible pro-environmental behavior: a meta-analysis. The Journal of Environmental Education, 18 (2), 1-8.

Hofman, M. (2015): What is an Education for Sustainable Development Supposed to Achieve - A Question of What, How and Why. Journal of Education for Sustainable Development, 9 (2), 213-228.

Horányi Ildikó, Magyar László András (szerk.) (2011): Életmódszertár. Múzeumpedagógia programok. Semmelweis Orvostörténeti Múzeum, Könyvtár és Levéltár, Budapest.

Horváth Imréné Baráti Ilona (2008): A környezetvédelem fogalma, környezetvédelmi ismeretek jelentösége a gyakorlatban. Nemzeti Szakképzési és Felnőttképzési Intézet. Megtekintés: 2016.02.10. Forrás: http://bit.ly/1K19bnO

Huang G. H., Chang N. B. (2003): Perspectives of Environmental Informatics and Systems Analysis. Journal of Environmental Informatics, 1 (1), 1-6.

Hunya Márta (2009): Projektmódszer a 21. században I. Új pedagógiai szemle, 59 (11), 75-96.

Hunya Márta (2010): Projektmódszer a 21. században II. Új pedagógiai szemle, 60 (1-2), $148-161$. 
Ideland, M., Malmberg, C. (2015): Governing 'eco-certified children' through pastoral power: critical perspectives on education for sustainable development. Environmental Education Research, 21 (2), 173-182.

Inhelder, B., Piaget, J. (1984): A gyermek logikájától az ifjú logikájáig. Akadémiai Kiadó, Budapest.

Ivic, I., Pesikan, A. (2012): Education system reforms in an unstable political situation: The case of Serbia in the first decade of the 21st century. CEPS Journal, 2 (2), 31-53.

Jakab György, Varga Attila (2007). A fenntarthatóság pedagógiája. L'Harmattan, Budapest.

Jensen, B. B., Shnack, K. (szerk.) (1994): Action and Action Competence as Key Concepts in Critical Pedagogy. Educational Theory and Curriculum, Copenhagen.

Johnson, B., Manoli, C. (2009): The Impact of Methodological Practices in Research and Evaluation in Environmental Learning. In: Zandvliet, D. B. (Eds.): Diversity in Environmental Education Research. Sense Publishers, The Netherlands.

Johnson, B., Manoli, C. (2011). The ENV Scale in the US: A Measure of Children's Environmental Attitudes Based on the Theory of Ecological Attitude. Journal of Environmental Education, 42 (2), 84-97.

Jovanović, S., Živković, Lj., Anđelković, S., (2010): Sadržaji o zaštiti životne sredine u udžbenicima geografije za osnovnu i srednju školu. Glasnik Srpskog geografskog društva, 90 (1), 347-375.

Jowett, T., Harraway, J., Lovelock, B., Skeaff, S., Slooten, L., Strack, M., Shephard, K. (2014): Multinomial-Regression Modeling of the Environmental Attitudes of Higher Education Students Based on the Revised New Ecological Paradigm Scale. The Journal of Environmental Education, 45 (1), 1-15.

Juhász Dávid, Major Lenke, Mujagić Daniel (2015): A cheaks kérdőív hatékonyságának vizsgálata alsó tagozatos tanulók környezeti attitüdjének mérésénél. 14. Vajdasági Magyar Tudományos Diákköri Konferencia, Szabadka.

Kacsúr István (1995): Az ökológi-környezetvédelem tanításának, tanulásának módszerei. Veszprémi Egyetem, Veszprém.

Kahtz, A. W. (1995): Impact of environmental education classes at Missouri Botanical Garden on attitude and knowledge change of elementary school children. HortTechnology, 5 (4), 338-340.

Kaiser, F. G., Wölfing, S., Fuhrer, U. (1999): Environmental attitude and ecological behaviour. Journal of Environmental Psychology, 19 (1), 1-19.

Kalindi, B. (2014): Learning engagement and environmental education for sustainability. Primary \& Middle Years Educator, 12 (2), 14-23.

Kálmánchey, M., Kozéki, B. (1998): Az Eysenck-féle személyiség-kérdőív gyermek változatának hazai adaptációja (HJEPQ). In: Mérei F., Szakács F. (szerk.): Pszichodiagnosztikai Vademecum. I-II. rész. Tankönyvkiadó, Budapest, 282-301.

Kara, G. E., Aydos, E. H., Aydın, Ö. (2015): Changing Preschool Children's Attitudes into Behavior towards Selected Environmental Issues: An Action Research Study. International Journal of Education in Mathematics, Science and Technology, 3 (1), 46-63.

Kárpáti Andrea (2004): Tanári szerepek az informatizált iskolában. Iskolakultúra, 14 (9), 3-14. 
Kasik László, Guti Kornél, Tóth Edit, Fejes József Balász (2016): Az elkerülés mint folyamat - az elkerülés kérdőív bemérése 15 és 18 évesek körében. Magyar Pedagógia 116 (2), 219-253.

Kelley-Laine, K. (1998): Oktatás és fenntarthatóság. Cédrus, 1(1). Megtekintés: 2016.03.09. Forrás: http://bit.ly/1R70YI1

Kerényi Attila (2003): Környezettan - Természet és társadalom - globális szempontból. Mezőgazda, Budapest.

King, D., Ginns, I. (2015): Implementing a context-based environmental science unit in the middle years: Teaching and learning at the creek. Teaching Science, 61 (3), 26-36.

Kiss Gábor (2006): A hatékony környezeti nevelés lehetőségei - Kompetenciafejlesztés és környezeti nevelés. XII. Nemzetközi Környezetvédelmi és Vidékfejlesztési Diákkonferencia, Mezőtúr.

Klemenović, J. (2003): Razvoj ideja ekološkog vaspitanja i obrazovanja. Pedagoška stvarnost, 49 (5-6), 408-425.

Kobierska, H., Tarabuła-Fiertak, M., Grodzińska-Jurczak, M. (2007): Attitudes to environmental education in Poland. Journal of Biological Education, 42 (2), 12-18.

Kobrehel Lenke, Lilić Elvira, Krivek Emma, Jeszenszky Gábor, Francišković Eva (2012): Globális tanári munkaterv a Környezetünk tantárgy tanításához 1. osztályban. Széchenyi István Általános Iskola, Szabadka.

Kohák Erazim (1997): Az ökológiai tapasztalat változásai. In: Lányi András (2000): Természet és Szabadság. Humánökológiai Olvasókönyv. Osiris Kiadó, Budapest, $152-168$.

Könczey Réka, Szabó Mária, Varga Attila (szerk.) (2014): Út az Ökoiskola felé. Módszertani segédanyag és útmutató leendő ökoiskoláknak. Oktatáskutató és Fejlesztő Intézet, Budapest.

Kopnina, H. (2011): Kids and cars: Environmental attitudes in children. Transport Policy, 18 (4), 573-578.

Koruoglu, N., Ugulu, I., Yorek, N. (2015): Investigation of High School Students'Environmental Attitudes in Terms of Some Demographic Variables. Psychology 6 (13), 1608-1623.

Kostova, Z., Atasoy, E. (2008): Methods of Successful Learning in Environmental Education. Journal of Theory and Practice in Education, 4 (1), 49-78.

Koutsoukos, M., Fragoulis, I., Valkanos, E. (2015): Connection of Environmental Education with Application of Experiential Teaching Methods: A Case Study from Greece. International Education Studies, 8 (4), 23-28.

Könczey Réka (2009): Az európai környezeti nevelési törekvések és a magyar környezeti nevelés. Megtekintés: 2016.02.10. Forrás: http://bit.ly/2k17E6s

Kövecsesné Gősi Viktória (2009): Az erdei iskola a környezeti nevelés szolgálatában. Iskolakultúra, 19 (5-6), 3-10.

Kuknyó János (2006): A környezeti nevelés. Szabolcs-Szatmár-Bereg Megyei Önkörmányzat Megyei Pedagógiai, Közművelődési és Képzési Intézete, Nyíregyháza.

Kuo, S-Y., Jackson, N. L. (2014): Influence of an Environmental Studies Course on Attitudes of Undergraduates at an Engineering University. The Journal of Environmental Education, 45 (2), 91-104. 
Kurucz Lászlóné (szerk.) (2012): Zöld könyv. Hahasznos tanácsok, jó gyakorlatok a környezeti neveléshez. Erdei Iskola Egyesület, Budapest.

Láng István (1980): A környezetvédelem nemzetközi körképe. Mezőgazdasági Kiadó, Budapest.

Láng István (2002): Környezet- és Természetvédelmi Lexikon. Akadémiai Kiadó, Budapest.

Láng István (2008): A Brundtland Bizottság és a fenntartható fejlődés. Egyenlitő, 6 (11), 23.

Lányi András (2007): A globalizáció folyamata. L'Harmattan Kiadó, Budapest.

Lasso de la Vega, E. (2006): A Preliminary Evaluation of Awareness, Knowledge, and Attitude in Environmental Education Specialist, Instructors, Students, and Parents in Southwest Florida. Florida Scientist, 69 (2), 166-178.

Lauder, A., Sari, R.F., Suwartha, Ny., Tjahjono, G. (2015): Critical review of a global campus sustainability ranking: GreenMetric. Journal of Cleaner Production, (108), 852-863.

Leeming, F. C., Dwyer, W. O., Bracken, B. A. (1995): Children's Environmental Attitude and Knowledge Scale: Consturtion and Validation. The Journal of Environmental Education, 26 (3), 22-32.

Lehoczky János (1998): Iskola a természetben - avagy A környezeti nevelés gyakorlata. RAABE, Budapest.

Lehoczky János (1999): Iskola a természetben avagy a környezeti nevelés gyakorlata. Raabe Klett, Budapest.

Lehtonen, M. (2004): The environmental-social interface of sustainable development: capabilities, social capital, institutions. Ecological Economics, 49 (2), 199-214.

Lichtveld, M. (2010): Education for Environmental Protection: Successes, Challenges, and Opportunities for USEPAl's Environmental Education Program. Human and Ecological Risk Assessment, 16 (6), 1242-1248.

Lončar, J. (2011): Obrazovanje za održivi razvoj na fakultetima društveno-humanističkih nauka. In: Pavlović, V.: Univerzitet i održivi razvoj. Fakultet političkih nauka, Centar za ekološku politiku i održivi razvoj, Beograd, 241-263. http://bit.ly/2aa8Iue

López-Ridaura, S., Masera, O., Astier, M. (2002): Evaluating the sustainability of complex socio-environmental systems. The MESMIS framework. Ecological Indicators, 2 (1-2), $135-148$.

Lovelock, J. E. (1989): Gaia. A földi élet egy új nézőpontból. Göncöl Kiadó, Budapest. In: Fűzné Kószó Mária (2002): A környezeti nevelés koncepciói. Iskolakultúra, 12 (1), $40-50$.

Lozano, R., Lukman, R., Lozano, F. J., Huisingh, D., Lambrechts, W. (2013): Declarations for sustainability in higher education: becoming better leaders, through addressing the university system. Journal of Cleaner Production, (48), 10-19.

Lucy J. Hawcroft, Taciano L. Milfont (2010): The Use (and Abuse) of the New Environmental Paradigm Scale Over the Last 30 Years: A Meta-Analysis. Journal of Environmental Psychology, 30 (2), 143-158.

Lükő István (1996): Bevezetés a környezeti nevelés pedagógiai és társadalmi kérdéseibe. Edutech Kiadó, Sopron.

Lükő István (2003): Környezetpedagógia. Nemzeti Tankönyvkiadó, Budapest.

Mácsai Anetta (szerk.) (2010): Múzeum? - Természetesen! Magyar Földrajzi Múzeum, 2010. 
Major L., Horák Rita (2015): A környezeti nevelés helye a tantárgyak rendszerében. 9. Nemzetközi Tudományos Konferencia. Újvidéki Egyetem Magyar Tannyelvü Tanítóképző Kar, Szabadka.

Major L., Namestovski, Ž., Horák, R., Bagány, Á., Pintér Krekić, V. (2017): Teach it to sustain it! Environmental attitudes of Hungarian teacher training students in Serbia. Journal of Cleaner Production, (154), 255-268.

Major Lenke (2011): A környezeti nevelési tartalmak beillesztésének lehetőségei a környezetünk, illetve a természet és társadalom tantárgy tanmenetébe. Új Kép, 14 (3-4), $56-63$.

Major Lenke (2012): A környezeti nevelés pedagógiai pszichológiai alapjai. Új Kép, 15 (1-2), $22-26$.

Major Lenke (2012a): A fenntartható fejlődés elméleti alapjai. Évkönyv, Újvidéki Egyetem Magyar Tannyelvü Tanitóképzö Kar, Szabadka, 6 (1), 42-51.

Major Lenke (2014): A környezeti nevelés módszertana. III. Nemzetközi Módszertani Konferencia. Újvidéki Egyetem Magyar Tannyelvű Tanítóképző Kar, Szabadka.

Major Lenke, Czékus Géza (2011): A környezeti nevelés mint a fenntarthatóság pedagógiájának alapvető eleme. III. Nemzetközi Tudományos Konferencia. Selye János Egyetem, Komárno.

Marlowe, M., Woodrow, T. (1996): The Adventures of Lead Commander: An Environmental Education Program to Prevent Lead Poisoning in Young Children. The Journal of Environmental Education, 28 (1), 19-23.

McGuire, W. J. (1979): Az attitüdök természete és az attitüdváltozás. In: Halász László, Hunyadi György, Marton L. Magda (szerk.) (1979): Az attitüd pszichológiai kutatásának kérdései. Akadémiai Kiadó, Budapest

Meadows, D. H. (1989): Harvesting One Hundredfold - Key Concepts and case Studies in Environmental Education. United Nations Environment Programme. Megtekintés: 2016.03.07. Forrás: http://bit.ly/24LkAWb

Meadows, D. H., Meadows D. L., Randers J., Behrens W. W. III, (1972): Limits to Growth. Universe Books, New York.

Medvés Dóra (2012): A környezettudatosság pszichológiai meghatározói. Disszertáció. Debreceni Egyetem, Debrecen.

Mérő Ágnes (2007): A projektmódszer lehetőségei a környezeti tanulásban. Új pedagógiai szemle, 57 (7-8), 138-145.

Mező Ferenc (2008): Az attitűdváltoztatást, -konzerválását célzó lélektani műveletek (PSYOPS). Hadtudomány, 18 (3-4), 71-82.

Mikházi Zsuzsanna (2006): A környezetvédelem és a környezeti tudatformálás összefüggései. XII. Nemzetközi Környezetvédelmi és Vidékfejlesztési Diákkonferencia, Mezőtúr.

Milutinović, S., Nikolić, V. (2014): Rethinking higher education for sustainable development in Serbia: an assessment of Copernicus charter principles in current higher education practices. Journal of Cleaner Production, (62), 107-113.

Molnár Gyöngyvér (2011): Az információs-kommunikációs technológiák hatása a tanulásra és oktatásra. Magyar tudomány, 172 (9), 1038-1047.

Molnár Katalin (2009): Erdővel kapcsolatos ismeretek gyermeket nevelő családok körében. Doktori $(\mathrm{PhD})$ értekezés. Nyugat-magyarországi Egyetem, Sopron. 
Monroe, M. C. (2010): Challenges for environmental education evaluation. Evaluation and Program Planning, 33 (2), 194-196.

Morrone, M., Mancl, K., Carr, K. (2001): Development of a Metric to Test Group Differences in Ecological Knowledge as One Component of Environmental Literacy. The Journal of Environmental Education, 32 (4), 33-42.

Moseley, C., Reinke, K., Bookout, V. (2002): The Effect of Teaching Outdoor Environmental Education on Preservice Teachers' Attitudes toward Self-Efficacy and Outcome Expectancy. Journal of Environmental Education, 34 (1), 9-15.

Musters, C. J. M., Graaf, H. J., Keurs, W.J. (1998): Defining socio-environmental systems for sustainable development. Ecological Economics, 26 (3), 243-258.

Mutisya, S. M., Barker, M. (2011): Pupils' environmental awareness and knowledge: A springboard for action in primary schools in Kenya's Rift valley. Science Education International, 22 (1), 55-71.

Nacionalna strategija održivog razvoja (2008). Vlada Republike Srbije, Beograd. Megtekintés: 2016.03.11. Forrás: http://bit.ly/2abhg0N

Nádai Magda (2005): Erdei ünnepek és hétköznapok gyerekekkel. Flaccus Kiadó, Budapest.

Nádasi M. Mária (2010): A projektoktatás elmélete és gyakorlata. Magyar Tehetségsegítő Szervezetek Szövetsége. Megtekintés: 2016.03.11. Forrás: http://bit.ly/1LYd3gA

Nagy C. Edit (2008): A környezeti nevelésben alkalmazott oktatási színterek, korszerü módszerek hatása a környezettudatos magatartás kialakítására. Szakdolgozat. BabesBolyai Tudományegyetem, Kolozsvár.

Nagy Eszter, Nagy Lászlóné (2014): A fenntarthatóság pedagógiájának elemei és megjelenésük a központi tantervekben a bevezetõ, kezdő és alapozó iskolaszakaszokban. A biológia tanítása, (1), 3-17.

Nahalka István (1997): Tanítható-e a környezetvédelem? Új Pedagógiai Szemle, 47 (4), $125-132$.

Nahalka István (1997a): Konstruktív pedagógia - egy új paradigma a láthatáron (I.). Iskolakultúra, 7 (2), 21-33.

Nahalka István (1997b): Konstruktív pedagógia - egy új paradigma a láthatáron (III.). Iskolakultúra, 7 (4), 3-20.

Nahalka István (2002): A tanulás folyamatának újraértelmezése. In: Nemzeti Környezeti Nevelési Stratégia, MKNE, Budapest.

Nahalka István (2002a): Pedagógiai háttér: környezeti nevelés - a fenntarthatóság pedagógiája. In: Nemzeti Környezeti Nevelési Stratégia, MKNE, Budapest.

Nahalka István (2002b): Hogyan alakul ki a tudás a gyerekekben? Nemzeti Tankönyvkiadó, Budapest.

Náray-Szabó Gábor (1999): Fenntartható fejlődés - fenntartható fogyasztás. Természet világa: természettudományi közlöny 130 (12), 531-534.

Néder Katalin, Saly Erika, Szentpétery Lászlóné (2013): Hazai és nemzetközi környezeti nevelési programok, projektek a közelmúltban. Megtekintés: 2016.03.07. Forrás: http://bit.ly/1QZh93M

Nemcsicsné Zsóka Ágnes (2005): Következetesség és rések a környezettudatos szervezeti magatartásban. Disszertáció. Budapesti Corvinus Egyetem, Budapest. 
Németh Gáborné Doktor Andrea (2008): A fenntartható fejlődés koncepciója. Új Pedagógiai Szemle, 58 (10), 3-16.

Niklanović, M., Miljanović, T. (2008): Doprinos nastave biologije edukaciji u oblasti ekologije i zaštite životne sredine. Pedagoška stvarnost, 54 (5-6), 498-508.

Okur-Berberoglu, E. (2015): The Effect of Ecopodagogy-Based Environmental Education on Environmental Attitude of In-service Teachers. International Electronic Journal of Environmental Education, 5 (2), 86-110.

Orgoványi Anikó (1999): Természetpedagógia. Új pedagógiai szemle, 49 (9), 84-92.

Ostertagová, E., Ostertag, O. (2013): Methodology and Application of Oneway ANOVA. American Journal of Mechanical Engineering, 1 (7), 256-261.

Ostrom, T. M. (1969): The relationship between the affective, behavioural, and cognitive components of attitude. Journal of Experimental Social Psychology, 5 (1), 12-30.

Pace, P. (2003): Environmental education: providing a context for a meaningful science education. Journal of Baltic Science Education, 3 (1), 28-35.

Palmberg, I. E., Kuru, J. (2000): Outdoor activities as a basis for environmental responsibility. Journal of Environmental Education, 31 (4), 32-37.

Palmer, J., Neal, P. (1998): A környezeti nevelés kézikönyve. Körlánc Környezeti Nevelési Program, Budapest.

Pavlović, V. (2011): Univerzitet $i$ održivi razvoj. Fakultet političkih nauka, Centar za ekološku politiku i održivi razvoj, Beograd. http://bit.ly/2aa8Iue

Pearce, D. W., Markandya, A., Barbier, E. (1989): Blueprint for a Green Economy. Earthscan Publication, London.

Pedretti, E., Nazir, J., Tan, M., Bellomo, K., Ayyavoo, G. (2012): A Baseline Study of Ontario Teachers' Views of Environmental and Outdoor Education. The Ontario Journal of Outdoor Education, 24 (2), 4-12.

Péntekné Szabó Ágota (1999): Környezeti nevelés. Egészségvirág Egyesület, Budapest.

Pintér Róbert (szerk.) (2007): Az információs társadalom: az elmélettől a politikai gyakorlatig. Gondolat, Budapest.

Pintér Tibor (2003): Zoopedagógia és fenntarthatóságra nevelés. Fővárosi Állat- és Növénykert, Budapest.

Poljaković Király Gyöngyi, Süli Szilvia, Gresák Lídia, Gál Angéla, Túrús Biacsi Renáta (2012): Globális tanári munkaterv a Természet és társadalom tantárgy tanításához 3. osztályban. Széchenyi István Általános Iskola, Szabadka.

Pruneau, D., Doyon, A., Langis, J., Martin, G., Ouellet, E., Boudreau, G. (2006): The process of change experimented by teachers and students when voluntarily trying environmental behaviours. Applied Environmental Education and Communication, 5 (1), 33-40.

Republika Srbija - Zavod za unapredjivanje obrazovanja i vaspitanja: Nastavni planovi $i$ programi za osnovne $i$ srednje škole. Megtekintés: 2016.03.06. Forrás: http://bit.ly/1QA2QXI

Republika Srbija (2010): Službeni glasnik RS - Prosvetni glasnik. 2010. március 15. 2 (7).

Rókusfalvy Pál (2002): A környezetpszichológia alapkérdései. Nemzeti Tankönyvkiadó, Budapest.

Rosenberg, M. J., Hovland, C. I. (1960): Attitude Organisation and Change: An Analysis of Consistency Among Attitude Components. Yale University Press, New Haven. 
Rosta István (2008): A tudomány történetéből - Világproblémák, globalizáció : A Római Klub három jubileuma 2008-ban. Magyar Tudomány, 169 (12), 1516-1521.

Ryan-Fogarty, Y., O’Regan, B., Moles, R. (2016): Greening Healthcare: Systematic Implementation of Environmental Programmes in a University Teaching Hospital. Journal of Cleaner Production, (126), 248-259.

Saraçli, S., Yilmaz, V., Arslan, T. (2014): The Effects of Mothers' Educational Levels on University Students' Environmental Protection Commitments and Environmental Behaviors. Eurasian Journal of Educational Research, (55), 177-200.

Schróth Ágnes (2004): Környezeti nevelés a középiskolában. Trefort Kiadó, Budapest.

Schróth Ágnes (szerk.) (2015): Környezettan szakmódszertan környezettan szakos tanárjelöltek részére. ELTE, Budapest.

Scott, W. (2015): Public Understanding of Sustainable Development: Some Implications for Education. International Journal of Environmental \& Science Education, 10 (2), 235-246.

Setyowati, L., Widiati, U. (2014): Integrating Environmental Education into a Genre-Based EFL Writing Class. English Teaching Forum, 52 (4), 20-27.

Shephard, K., Furnari, M. (2013): Exploring what university teachers think about education for sustainability. Studies in Higher Education, 38 (10), 1577-1590.

Simon, S. (2009): Environmental education for sustainability. Practice and Theory in Systems of Education, 4 (1), 10-14.

Smit, H. (2009): Shaping the Environmental Attitude of Military Geography Students at the South African Military Academy. Journal of Geography in Higher Education, 33 (2), 225-240.

Smith, E. R., Mackie, D. M. (2004): Attitüdök és attitűdváltozás. Attitüdök és viselkedés. In: Hunyadi György (szerk.): Szociálpszichológia. Osiris Kiadó, Budapest.

Smith-Sebasto, N. J., Cavern, L. (2006): Effects of pre and post trip activities associated with a residential environmental education experience on students' attitudes towards the environment. The Journal of Environmental Education, 37 (4), 3-17.

Sobel, D. (1999): Beyond Ecophobia: Reclaiming the Heart in Nature Education. Nature Study, 49 (3-4). Megtekintés: 2016.03.11. Forrás: http://bit.ly/2sbOib0

Song, G., Zhou, L., Zhang, L. (2011): Institutional Design for Strategic Environmental Assessment on Urban Economic and Social Development Planning in China. Environmental Impact Assessment Review, 31 (6), 582-586.

Sow, T. M. (2014): Using ANOVA to Examine the Relationship between Safety \& Security and Human Development. Journal of International Business and Economics, 2 (4), 101-106.

Stanišić, J., Maksić, S. (2014): Environmental Education in Serbian Primary Schools: Challenges and Changes in Curriculum, Pedagogy, and Teacher Training. Journal of Environmental Education, 45 (2), 118-131.

Staniškis, J. K., Katiliūte, E. (2016): Complex evaluation of sustainability in engineering education: case \& analysis. Journal of Cleaner Production, (120), 13-20.

Stojanović, S., Žderić, M., Matanović, V., Gavrilović, D., Brun, G. (1997): Mogući pravci razvoja obrazovanja $i$ vaspitanja za zaštitu, obnovu i unapređenje životne sredine. PMF, Institut za biologiju, Novi Sad. 
Szállassy Noémi (2008): Project method, as one of the basic methods of environmental education. Acta Didactica Napocensia, 1 (2), 44-49.

Szász Tibor (2010): A fenntartható fejlődés. Debreceni müszaki közlemények: A Debreceni Egyetem Müszaki Kar lapja, 9 (1), 31-42.

Takáts Alexandra (2010): Környezettudatos fogyasztói magatartás alakítása és a fa- és Bútoripari termékek iránti attitüd feltárása. Disszertáció. Nyugat-Magyarországi Egyetem, Sopron.

Tápai Renáta (2012): Nagy ütemben fogyatkozunk. Magyar Szó, 2012. augusztus 5. Megtekintés: 2016.12.09. Forrás: http://bit.ly/2hcve4Z

Thiengkamol, N. (2011): Development of Model of Environmental Education and Inspiration of Public Consciousness Influencing to Global Warming Alleviation. European Journal of Social Sciences, 25 (4), 506-514.

Tilbury, D., Wortman, D. (2004): Engaging People in Sustainability. Commission on Education and Communication IUCN, Gland, Switzerland and Cambridge, UK. Megtekintés: 2016.03.12. Forrás: http://bit.ly/1XkWfAQ

Tung, C.-Y., Huang, C.-C., Kawata, C. (2002): The Effects of Different Environmental Education Programs on the Environmental Behaviors of Seventh-Grade Students and Related Factors. Journal of Environmental Health, 64 (7), 24-29.

Turchany, G., Beranek László, Füleky György, Magyari Beck István, Turcsányi Károly (2004): A fenntartható fejlődés: mítosz vagy valóság? Valóság, 47 (6), 1-18.

UI Green Metric: Overall Rankin, 2015. Megtekintés: 2016.05.18. Forrás: http://bit.ly/1PSLDEx

UNESCO (1976): The Belgrade Charter: A global framework for environmental education. Connect. UNESCO-UNEP Environmental Education Newsletter, 1 (1-2), 1-10.

UNESCO (1978): Final report: Intergovernmental conference on environmental education. Organized by UNESCO in cooperation with UNEP, Tbilisi, USSR, 14-26 October 1977. Megtekintés: 2016.02.10. Forrás: http://bit.ly/1RpqqqX

UNESCO (2005): United Nations Decade of Education for Sustainable Development 2005 2014 Megtekintés: 2016.03.03. Forrás: http://bit.ly/1TVqeQo

UNESCO-UNEP (1992): Promoting education, public awareness and training. Environment and Development, Agenda 21. United Nations Sustainable Development. Megtekintés: 2016.03.03. Forrás: http://bit.ly/1QnEQFX

United Nations (2015): Transforming our World: The 2030 Agenda for Sustainable Development. Megtekintés: 2016.03.12. Forrás: http://bit.ly/1Epf648

University of Szeged: Sustainable development strategy. Megtekintés: 2016.05.18. Forrás: http://bit.ly/1WDI9xD

Varga Attila (2003): Lehet-e hatása a felnőttoktatásnak az ökológiai lábnyomra? In: Mayer József (szerk.): Tanári kulcskompetenciák. Módszertani stratégiák az iskolarendszerü felnöttoktatásban 5. Országos Közoktatási Intézet, Budapest.

Varga Attila (2004): A környezeti nevelés pedagógiai, pszichológiai alapjai. Disszertáció. Eötvös Loránd Tudományegyetem, Budapest.

Varga Attila, Czippán Katalin, Benedict, Faye (2011): Az iskolák társadalmi szerepvállalása a fenntartható fejlödésért. Új pedagógiai szemle, 61 (1-5), 259-267. 
Varga Miklósné (1998): A pedagógusszerepek átalakulása napjainkban. Új pedagógiai szemle, 48 (7-8), 112-117.

Vásárhelyi Judit (szerk.) (2010): Nemzeti Környezeti Nevelési Stratégia. Magyar Környezeti Nevelési Egyesület, Budapest.

Vásárhelyi Szilvia, Torma Tünde, Zoraje Ildikó, Dunai Attila (2012): Globális tanári munkaterv a Környezetünk tantárgy tanításához 2. osztályban. Széchenyi István Általános Iskola, Szabadka.

Vicente-Molina, M. A., Fernández-Sáinz, A., Izagirre-Olaizola, J. (2013): Environmental knowledge and other variables affecting pro-environmental behaviour: comparison of university students from emerging and advanced countries. Journal of Cleaner Production, (61), 130-138.

Victor András (1998): A környezeti nevelés rendszere. In: Sallai R. Benedek (szerk.): Zöldszemmel - Ötlettár környezeti neveléshez. "Nimfea" Természetvédelmi Egyesület, Túrkeve.

Vőcsei Katalin, Varga Attila, Horváth Dániel, Graça Simoes de Carvalho (2008): A pedagógusok és pedagógusjelöltek környezeti attitüdjei. Új Pedagógiai Szemle, 58 (2), $61-75$.

Vukasović, M. (2007): Inkluzivnost i efikasnost visokog obrazovanja u Srbiji. Centar za obrazovne politike, Belgrade.

Wals, A. E. J. (2013): Sustainability in higher education in the context of the UN DESD: a review of learning and institutionalization processes. Journal of Cleaner Production, 62 (1), 8-15.

Weiland, I. S., Morrison, J. A. (2013): The Integration of Environmental Education into Two Elementary Preservice Science Methods Courses: A Content-Based and a Method-Based Approach. Journal of Science Teacher Education, 24 (6), 1023-1047.

Wheeler, K., Bijur, A. P. (szerk) (2001): A fenntarthatóság pedagógiája - A remény paradigmája a XXI. századra. Körlánc, Budapest.

World Commission on Environment and Development (1987): Our Common Future: The Bruntland Report. Oxford University Press, Oxford. Megtekintés: 2016.03.03. Forrás: http://bit.ly/1bZJgwk

Yang, C-P. (2015): Education for Appreciating Environment-An Example of Curriculum Design of Natural Aesthetic Education in Taiwan. International Education Studies, 8 (5), 88-100.

Zimmermann, L. K. (1996): Knowledge, Affect and the Environment: 15 Years of Research (1979-1993). The Journal of Environmental Education, 27 (3), 5-13.

Živković, Ž., Nikolić, D., Djordjević, P., Mihajlović, I., Savić, M. (2015): Analytical Network Process in the Framework of SWOT Analysis for Strategic Decision Making (Case Study: Technical Faculty in Bor, University of Belgrade, Serbia). Acta Polytechnica Hungarica, 12 (7), 199-216.

Zsóka Ágnes, Marjainé Szerényi Zsuzsanna, Széchy Anna, Kocsis Tamás (2013): Greening due to environmental education? Environmental knowledge, attitudes, consumer behavior and everyday pro-environmental activities of Hungarian high school and university students. Journal of Cleaner Production, (48), 126-138. 


\section{A DISSZERTÁCIÓ TÉMAKÖRÉHEZ KAPCSOLÓDÓ PUBLIKÁCIÓK}

Major Lenke (2012): A környezeti nevelés jelentősége - attitüdvizsgálat. In: Tudás és tanulás: Neveléstudományi Konferencia, Babeş - Bolyai Tudományegyetem, Kolozsvár. 2012. március 30. - április 1.

Major Lenke (2012): A környezeti nevelés szerepe a környezettudatos magatartás formálásában. Iskolakultúra, 22 (9), 67-79.

Major Lenke (2012): A környezeti nevelési program hatásainak attitűdvizsgálata alsó tagozatos tanulók körében. In: Vajdasági Magyar Tudóstalálkozó, Szabadka. 2012. április 21 .

Major Lenke (2012): Környezeti nevelés alsó tagozatos tanulók és tanítóképzős hallgatók körében. In: VIII. Kárpát-medencei Környezettudományi Konferencia, Pannon Egyetem, Veszprém. 2012. április 18-21.

Major Lenke (2013): Tanítóképzős hallgatók környezeti attitüdje. In: 11. Pedagógiai Értékelési Konferencia, Szeged. 2013. április 11-13.

Major Lenke, Horák Rita (2013): The eco-friendly habits of lower primary school pupils in Vojvodina. Évkönyv, Újvidéki Egyetem Magyar Tannyelvü Tanitóképzö Kar, Szabadka, 8 (1), 242-249.

Major Lenke (2013): The motivation of eco-friendly behavior of teacher training students in Subotica. In: Motiváció-Fegyelem-Figyelem: VII. Nemzetközi Tudmányos Konferencia, Újvidéki Egyetem Magyar Tannyelvü Tanitóképzö Kar, Szabadka. 2013. október 4-5.

Major Lenke (2013): Tanítóképzős hallgatók környezeti attitüdje. In: IX. Kárpát-medencei Környezettudományi Konferencia, Miskolc. 2013. június 13-15.

Major Lenke (2013): Élményt nyújtó környezeti nevelési program bemutatása. In: Tudományos diszkurzusok: Vajdasági Magyar Tudóstalálkozó, Szabadka. 2013. április 13.

Major Lenke (2014): Szabadkai alsó tagozatos tanulók környezeti attitüdje. In: 12. Pedagógiai Értékelési Konferencia, Szeged. 2014. május 1-3.

Major Lenke (2014): The analisys of the environmental attitudes among teacher training students. Évkönyv, Újvidéki Egyetem Magyar Tannyelvü Tanitóképzö Kar, Szabadka, 9 (1), 141-152.

Major Lenke (2014): Az intenzív környezeti nevelési program hatása a szabadkai alsó tagozatos tanulók környezeti attitüdjére. In: Tudástérkép: Konferenciakötet. Vajdasági Magyar Tudóstalálkozó 2014, Szabadka. 2014. április 12.

Major Lenke (2014): The theory of Environmental Education - E.E. program: case study. In: A Selye János Egyetem 2014-es Nemzetközi Tudományos Konferenciája. Oktatás és tudomány a XXI. század elején. Komarno, 2014. szeptember 16-17.

Major Lenke (2015): Alsó tagozatos tanulók környezeti attitüdjének vizsgálata. In: XI. Kárpát-medencei Környezettudományi Konferencia. Pécsi Tudományegyetem Természettudományi Kar, Pécs, 2015. május 6-9.

Major Lenke (2015): Intenzív környezeti nevelési program hatásainak attitüdvizsgálata. In: 13. Pedagógiai Értékelési Konferencia, Szeged. 2014. április 23-25, 52. 
Lenke Major, Žolt Namestovski, Rita Horák, Ágnes Bagány, Valéria Pintér Krekić (2017): Teach it to sustain it! Environmental attitudes of Hungarian teacher training students in Serbia. Journal of Cleaner Production, (154), 255-268. 


\section{ÁBRÁK JEGYZÉKE}

Szám

1. ábra:

2. ábra:

3. ábra:

4. ábra:

5. ábra:

6. ábra:

7. ábra:

8. ábra:

9. ábra:

10. ábra:

11. ábra:

12. ábra:

13. ábra:

14. ábra:

15. ábra: A RevNEP skálával mért értékek alakulása a két mérés között, a kísérleti csoportban

16. ábra: A RevNEP skálával mért értékek alakulása a második mérés során, a két csoport tekintetében

17. ábra: A CHEAKS skálával mért értékek alakulása a két mérés között, a kísérleti csoportban

18. ábra: A CHEAKS skálával mért értékek alakulása a második mérés során, a két csoport tekintetében

19. ábra: A nemek eloszlása az alsó tagozatos tanulók mintájában

20. ábra: Az életkor megoszlása az alsó tagozatos tanulók mintájában

21. ábra:

22. ábra:

23. ábra:

24. ábra:

25. ábra:

26. ábra:

27. ábra:

28. ábra:

29. ábra: A kísérleti és a kontrollcsoport környezeti attitüdje az első mérés során, az alskálák tekintetében

30. ábra: A kísérleti csoport környezeti attitüdjének változása az első és a
Oldal

14

14

15

16

18 
második mérés során, az egyes itemek tekintetében

31.ábra: A kísérleti csoport környezeti attitüdjének változása az első és a 126 második mérés során, az alskálák tekintetében

32. ábra: A kontrollcsoport környezeti attitüdjének változása az első és a második 128 mérés során, az egyes itemek tekintetében

33. ábra: A kontrollcsoport környezeti attitüdjének változása az első és a második mérés során, az alskálák tekintetében

34. ábra: A kísérleti és a kontrollcsoport környezeti attitüdjének változása a második mérés során, az egyes itemek tekintetében

35. ábra: A kísérleti és a kontrollcsoport környezeti attitüdjének változása a második mérés során, az alskálák tekintetében

36. ábra: A kísérleti és a kontrollcsoport véleménye a környezetet veszélyeztető tényezőket illetően, az első mérés során

37. ábra: A kísérleti csoport véleményének alakulása a környezetet veszélyeztető tényezőket illetően, a két mérés között

38. ábra: A kísérleti és a kontrollcsoport véleményének összehasonlítása a környezetet veszélyeztető tényezőket illetően, a második mérést követően

39. ábra: A kísérleti és a kontrollcsoport véleménye a környezetszennyezés okait illetően, az első mérés során

40.ábra: A kísérleti csoport véleményének alakulása a környezetszennyezés okait illetően, a két mérés között

41.ábra: A kísérleti és a kontrollcsoport véleményének alakulása a környezetszennyezés okait illetően, a második mérést követően

42. ábra: A tanulók saját lehetőségei a környezet megóvása érdekében a kísérleti és a kontrollcsoportban, az első mérés alkalmával

43. ábra: A saját lehetőségek említésének változása a kísérleti csoportban, a két mérés között 


\section{TÁBLÁZATOK JEGYZÉKE}

Szám

1. táblázat:

2. táblázat:

3. táblázat:

4. táblázat:

5. táblázat:

6. táblázat:

7. táblázat:

8. táblázat:

9. táblázat:

10. táblázat:

11. táblázat:

12. táblázat:

13. táblázat:

14. táblázat:

15. táblázat:

16. táblázat: A program hatékonyságának elemzése pedagógusok által, SWOT analízis segítségével

17. táblázat: A környezeti attitüdöt mérő tételek besorolása az ENV kérdőíven (Bogner and Wiseman, 1999)

18. táblázat: A környezeti attitűdöt mérő tételek besorolása a RevNep kérdőíven (Dunlap et al., 2000)

19. táblázat: A környezeti attitüdöt mérö tételek besorolása a CHEAKS kérdöíven (Leeming, Dwyer and Bracken, 1995 alapján idézi Varga, 2004)

20. táblázat: A kísérleti csoport háttérváltozóinak összefüggése az ENV skálán elért attitüdértékekkel

21. táblázat: A kísérleti csoport háttérváltozóinak összefüggése a RevNEP skálán elért attitüdértékekkel

22. táblázat: A kísérleti csoport háttérváltozóinak összefüggése a CHEAKS skálán elért attitüdértékekkel

23. táblázat: A kontrollcsoport háttérváltozóinak összefüggése az egyes skálákon elért attitüdértékekkel

24. táblázat: A kontrollcsoport háttérváltozóinak összefüggése a RevNEP skálán elért attitüdértékekkel

25. táblázat: A kontrollcsoport háttérváltozóinak összefüggése a CHEAKS skálán elért attitüdértékekkel

26. táblázat: Az ENV skálával mért értékek a kísérleti csoportban

27. táblázat: Az ENV skálával mért értékek a kontrollcsoportban

28. táblázat: A kísérleti és a kontrollcsoport ENV skálával mért értékeinek összehasonlítása
Oldal

45

48

50

52

54

60

65

66

68

69

69

71

72

73

74

77

84

85

86

88

90

90

91

92

93

94

95

95 
29. táblázat: A RevNEP skálával mért értékek a kísérleti csoportban 96

30. táblázat: A RevNEP skálával mért értékek a kontrollcsoportban 97

31. táblázat: A kísérleti és a kontrollcsoport RevNEP skálával mért értékeinek 98 összehasonlítása

32. táblázat: A CHEAKS skálával mért értékek a kísérleti csoportban 98

33. táblázat: A CHEAKS skálával mért értékek a kontrollcsoportban 99

34. táblázat: A kísérleti és a kontrollcsoport CHEAKS skálával mért értékeinek 99 összehasonlítása

35. táblázat: Az attitüdértékek alakulása a teljes skála átlagát tekintve 100

36. táblázat: A tanítóképzős hallgatók környezeti attitüdjének változása a három 101 vizsgált tanévben

37. táblázat: Első osztályba íratkozó tanulók száma Szabadkán

38. táblázat: A tételek besorolása a gyerekek környezeti attitüdjének mérésekor 111 alkalmazott CHEAKS kérdőíven

39. táblázat: A létrejött faktorok, és az egyes kérdésekhez tartozó faktorsúlyok értéke az első mérés során

40. táblázat: A létrejött faktorok, és az egyes kérdésekhez tartozó faktorsúlyok értéke a második mérés során

41. táblázat Az attitüdértékek alakulása az első mérés során, az alsó tagozatos tanulók körében

42. táblázat: $A z$ attitűdértékek alakulása az első és a második mérés során, a kísérleti csoportban

43. táblázat: $A z$ attitüdértékek alakulása az első és a második mérés során, a kontrollcsoportban

44. táblázat: Az attitűdértékek alakulása a második mérés során, az alsó tagozatos tanulók körében

45. táblázat: $\mathrm{Az}$ alsó tagozatos tanulók háttérváltozóinak összefüggése az attitüdértékekkel a kísérleti csoportban

46. táblázat: $\mathrm{Az}$ alsó tagozatos tanulók háttérváltozóinak összefüggése az attitüdértékekkel a kontrollcsoportban

47. táblázat: Az életkor változó általi eltérések a kísérleti csoportban

48. táblázat: A környezetet veszélyeztető tényezők megítélése az első mérés során, az alsó tagozatos tanulók körében

49. táblázat: A környezetet veszélyeztető tényezők megítélése az első és a második mérés során, a kísérleti csoportban

50. táblázat: A környezetet veszélyeztető tényezők megítélése az első és a második mérés során, a kontrollcsoportban

51. táblázat: A környezetet veszélyeztető tényezők megítélése a második mérés során, a kísérleti és a kontrollcsoportban

52. táblázat: A környezetszennyezés okainak megítélése az első mérés során

53. táblázat: A környezetszennyezés okainak megítélése a kísérleti csoportban, a két mérés között

54. táblázat: A környezetszennyezés okainak megítélése a kontrollcsoportban, a két mérés között

55. táblázat: A környezetszennyezés okainak megítélése a második mérés során, a kísérleti és a kontrollcsoportban

56. táblázat: A saját lehetőségek észlelése a kísérleti és a kontrollcsoportban, az első mérés során

57. táblázat: Az említett lehetőségek a kísérleti és a kontrollcsoportban, az első mérés során 
58. táblázat: Indoklás, miért nincs lehetősége a környezet védelmére a kísérleti és a kontrollcsoport tagjainak, az első mérés során

59. táblázat: A saját lehetőségek észlelése a kísérleti és a kontrollcsoportban, a 150 második mérés során

60. táblázat: A saját lehetőségek észlelése a kísérleti és a kontrollcsoportban, a második méréskor

61. táblázat: Az említett lehetőségek a kísérleti csoportban, a második méréskor

62. táblázat: Indoklás, miért nincs lehetősége a környezet védelmére a kísérleti csoport tagjainak, a második mérés során

63. táblázat: A vizsgálatsorozat hipotézisei és eredményei 


\section{MELLÉKLETEK JEGYZÉKE}

Szám

1. melléklet:

2. melléklet:

3. melléklet:

4. melléklet:

5. melléklet:

6. melléklet:

7. melléklet:

8. melléklet:

9. melléklet:

10. melléklet:

11. melléklet:

12. melléklet:

13. melléklet:

14. melléklet:

15. melléklet:

\section{6. melléklet:}

17. melléklet:

18. melléklet:

19. melléklet:

20. melléklet:

21. melléklet:

22. melléklet:

23. melléklet:

24. melléklet:

25. melléklet:

26. melléklet:

27. melléklet:
Melléklet elnevezése

Előadás (Globális környezeti problémák)

Elöadás (Fenntartható fejlödés a természetközeliségtöl az

információs társadalomig)

Előadás (A fenntartható fejlödés fogalma és pedagógiája)

Elöadás (A környezeti nevelés alapjai)

Előadás (A környezeti nevelés pedagógiája)

Elöadás (A környezeti nevelés a gyakorlatban)

Előadás (Zoopedagógia a környezeti nevelés szolgálatában)

Óravázlat (A víz tulajdonságai)

Óravázlat (A vizek élövilága)

Óravázlat (Plakát: vízszennyezés, vízvédelem)

Óravázlat (Hideg-meleg színek: jégsapkák olvadása)

Óravázlat (Daltanulás: Ess esö, ess)

A víz témakörében megrendezett kiállítás résztvevői

A víz témakörében elvégzett projekt tartalma

A Magyar Tannyelvü Tanítóképző Karon megrendezett kiállítás részlete

A „Megérkezett a tavasz, vigyázzunk környezetünkre!” elnevezésü rendezvényről a hallgatók által készített plakát

Óravázlat (Környezetvédelem a mindennapokban)

Óravázlat (Anyagok és felhasználásuk)

Óravázlat (A hulladék életre kel)

Óravázlat (Hulladékhangszerek)

Óravázlat (Energiaforrások)

Óravázlat (Energiatakarékos és energia pazarló háztartás)

Feladatlap (Oltsd le a lámpát, zárd el a csapot! - projekt)

Óravázlat (Szélkerék készítése)

A környezeti nevelési programról a Jó Pajtás c. diáklapban megjelent cikk

Tanítók

Alsó tagozatos tanulók környezeti attitüdjének mértékét vizsgáló kérdöív
Oldal

184

185

186

187

188

189

190

191

192

193

195

196

197

197

198

199

200

201

202

204

205

207

208

209

210

211

214 


\section{KÖSZÖNETNYILVÁNÍTÁS}

Köszönetemet szeretném kifejezni témavezetőmnek, Papp Katalinnak munkám szakmai vezetéséért és folyamatos támogatásáért, valamint a közös munkánkat jellemző derüs, pozitív légkörért.

Köszönet illeti az SZTE BTK Neveléstudományi Doktori Iskolájának vezetőjét, Csapó Benőt, aki munkásságával és kimagasló eredményeivel az intézmény minden hallgatójának méltó példaképe.

Köszönöm Barabás Katalinnak, Zsolnai Anikónak, Józsa Krisztiánnak, valamint a doktori iskola összes oktatójának támogató hozzáállásukat, és a színvonalas kurzusokon való részvétel lehetőségét.

Hálával tartozom Csomorné Benkovics Ágnes felbecsülhetetlen személyes és szakmai segítségéért.

Köszönöm opponenseim építő javaslatait és segítő kritikáit.

Ezúton köszönöm mentoraim, dr. Pintér Krekity Valéria, dr. Ivanović Josip és dr. Czékus Géza támogatását doktori tanulmányaim során.

Köszönet illeti a mérésekben közremüködő tanítók, tanulók és tanítóképzős hallgatók segítségét.

Végül, de nem utolsósorban köszönöm családomnak a támogatást és segítséget, amellyel hozzájárultak tanulmányaim elvégzéséhez. 


\section{MELLÉKLET: ELŐADÁS (Globális környezeti problémák)}

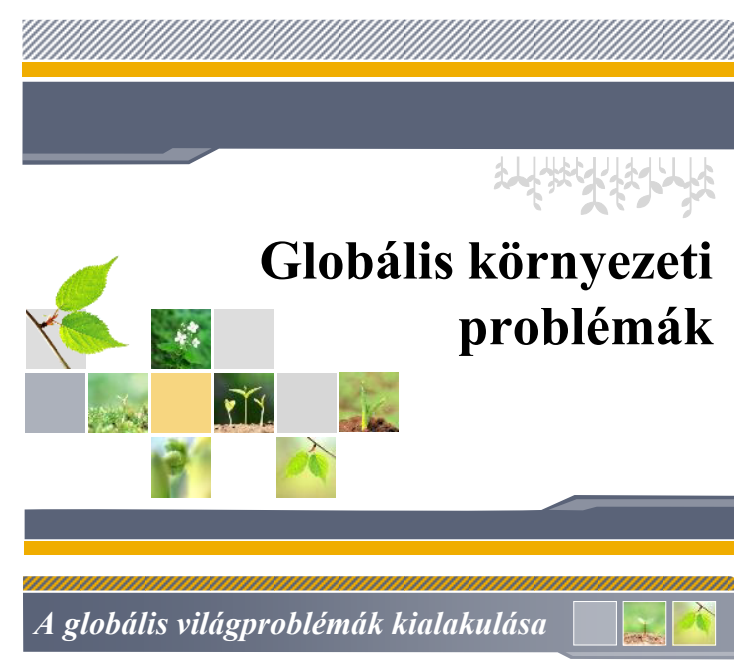

- A világproblémák kialakulása arra a tényre vezethető vissza, hogy helytelenül viszonyulunk a természethez, helytelenül használjuk a természet és emberi erőforrásokat.

\section{• Történelem elötti időszak:}

- A természet és ember viszonyára a harmónia jellemző.

- Az ember csak lét-és fajfenntartásának biztositására használja az erőforrásokat; nem végzett termelötevékenységet, és nem halmozott fel tartalékokat.

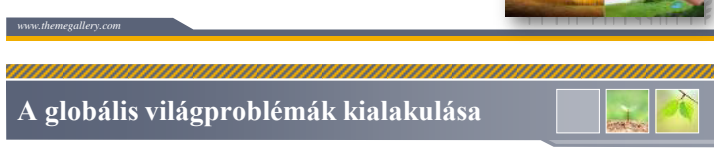

- A mezögazdasági forradalmától az ipari forradalomig tartó időszakban elsősorban a fizikai terjeszkedés volt a cél.

- Ebben az időszakban a lassú gazdasági növekedés és lassú népességnövekedés volt a jellemző.

- A környezeti és társadalmi problémák is lokálisak, esetleg regionálisak voltak.

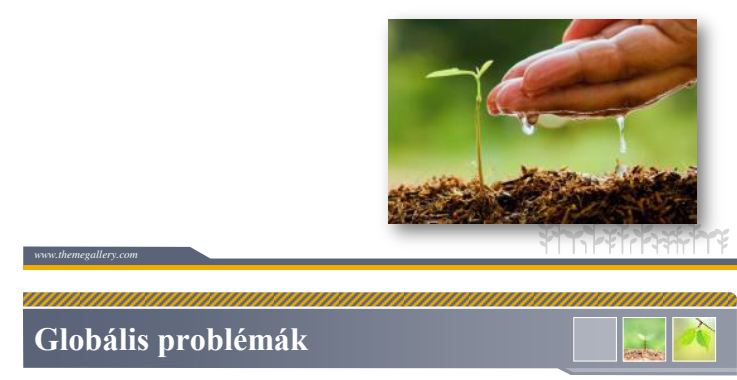

- Földünket érintő globális problémák, a teljesség igénye nélkül:

-Demográfiai robbanás
-Éhínség
-Vizhiány
- Éghajlatváltozás
- Túlfogyasztás
- Hulladék
-A biodiverzitás pusztulása

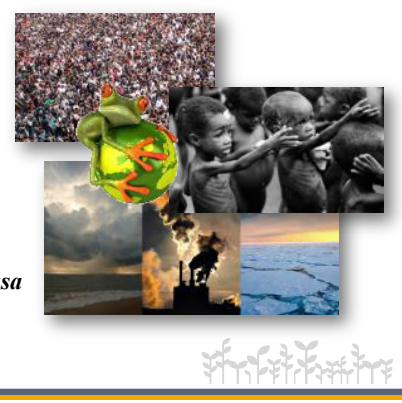

A globális világproblémák kialakulása

- A globális: az adott jelenség a földgolyó egészét érinti, annak egészére kiterjed.

-XX. század második fele: termelőerők fejlettsége, a munkamegosztás, kereskedelem globalizációja

- Globális információs rendszerek, és nemzetközi intézmények kialakulása

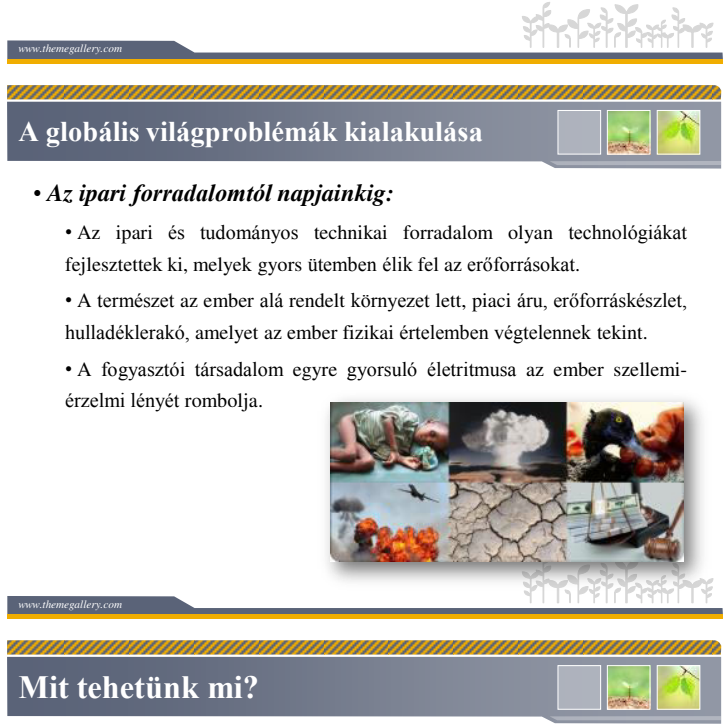

- A globális problémák megoldását sokan a jövő generációinak környezettudatos viselekedésében látják.

- Az oktatás területén a legfontosabb a tanítók, tanárok megfelelő szintü képzése, a problémákra való rádöbbentés, és a megoldási lehetőségek megismertetése.

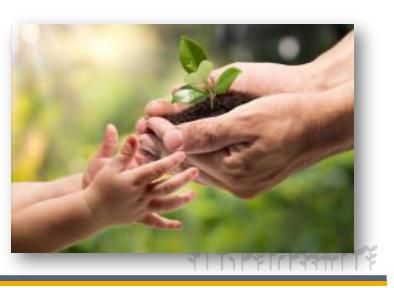




\section{MELLÉKLET: ELŐADÁS (Fenntartható fejlődés a természetközeliségtől az információs társadalomig)}

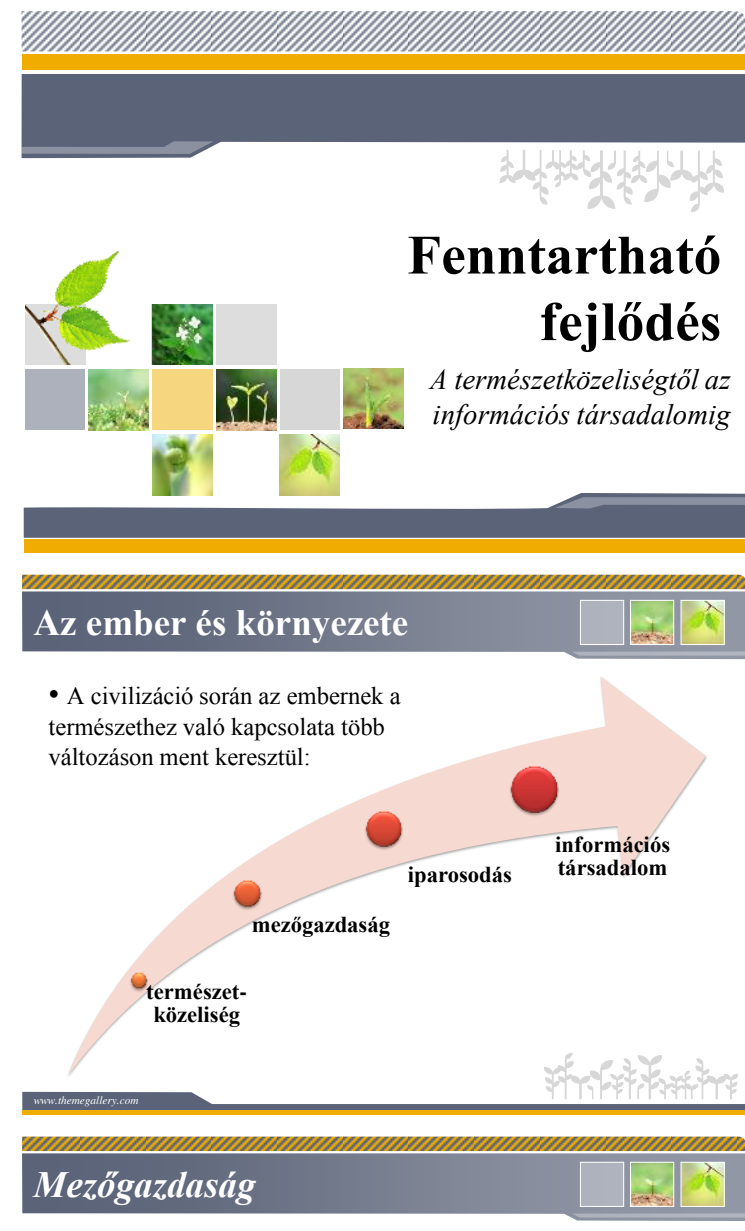

- A föld a gazda tulajdona lett, ahol az ö törvényei és akarata érvényesült.

- Minél nagyobb lett az ember szükséglete, minél bonyolultabb, hatásosabb módszerekkel tudta igényeit kielégíteni, annál nagyobb szeletet hasított ki a természetből.

- A gazdálkodó társadalmak természetfelfogásában a természet épp ezért kimeríthetetlennek tünik. A természetnek alárendelt emberből a természettel egyenrangú partner lesz.

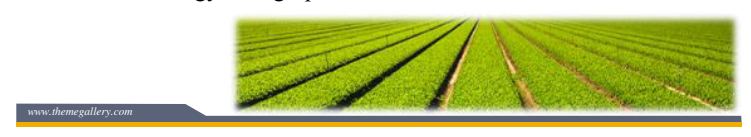

\section{Információs társadalom}

- A negyedik szint a napjaink civilizációjára jellemző felfogás: az elsődleges tőke maga az információ és az elméleti tudás lett, az új természetfelfogást pedig a fenntartható fejlődésre való törekvés jellemzi.

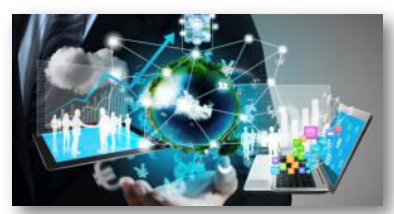

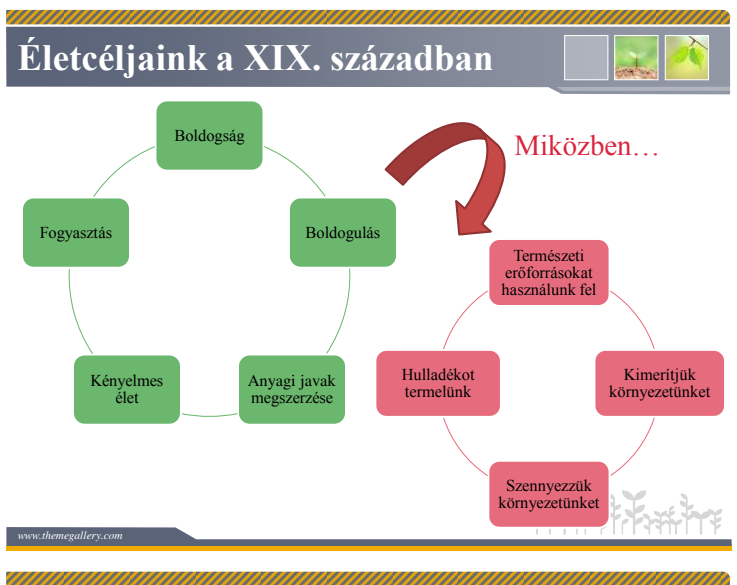

Természet-közeliség

- A első szakasz a kultúra hajnalán a vadászó, gyűjtögető életmóddal együtt járó természet-közeliség megtapasztalása.

- Ez az életforma a természettől való félelemmel jár együtt.

- Ez a természetfelfogás nem harmóniára törekedett a természettel, csak arra, hogy a természet megadja azt, ami az emberek számára szükséges.

- Környezetének ismeretére a puszta túlélés miatt volt szüksége az embernek.
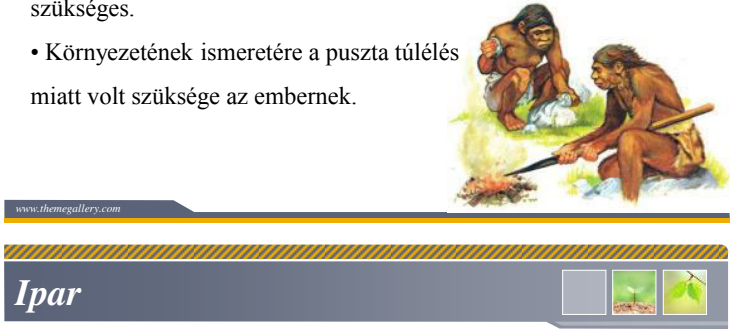

-A partnerségböl hamarosan fölöttiség lett, az ember a természetre csak kimeríthetetlen nyersanyagforrásként tekint.

- Az ember igénye, hogy újabb földterületeket hódítson meg és használjon ki, a természeti erőforrások drasztikus csökkenését, a szennyező anyagok olyan mértékű felhalmozódását eredményezte, ami bármikor ökológiai katasztrófához vezethet. -A fejlett civilizációkban a természet, az élőlények már nem partnerek, hanem a gazdasági haszonszerzés tényezői.
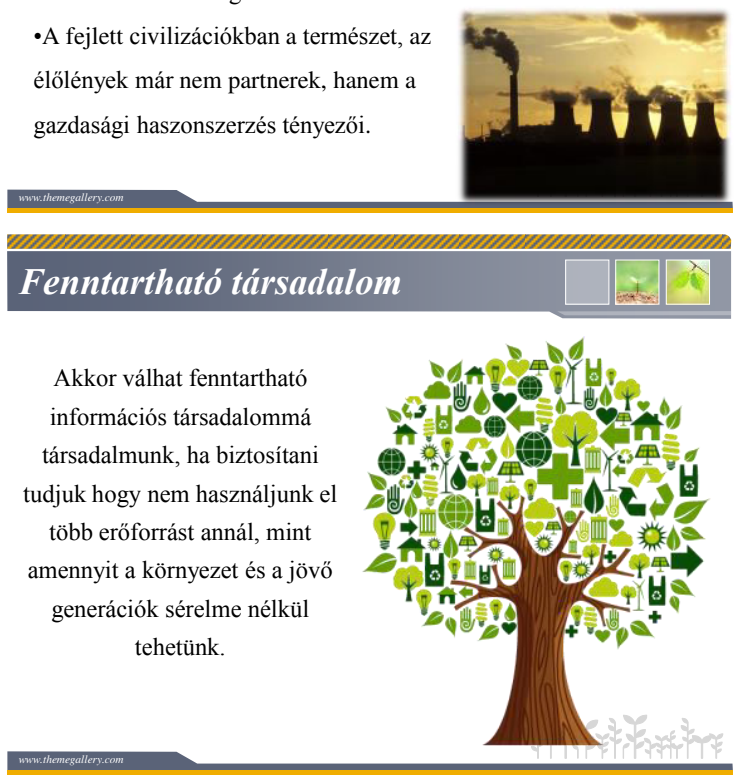


\section{MELLÉKLET: ELŐADÁS (A fenntartható fejlődés fogalma és pedagógiája)}

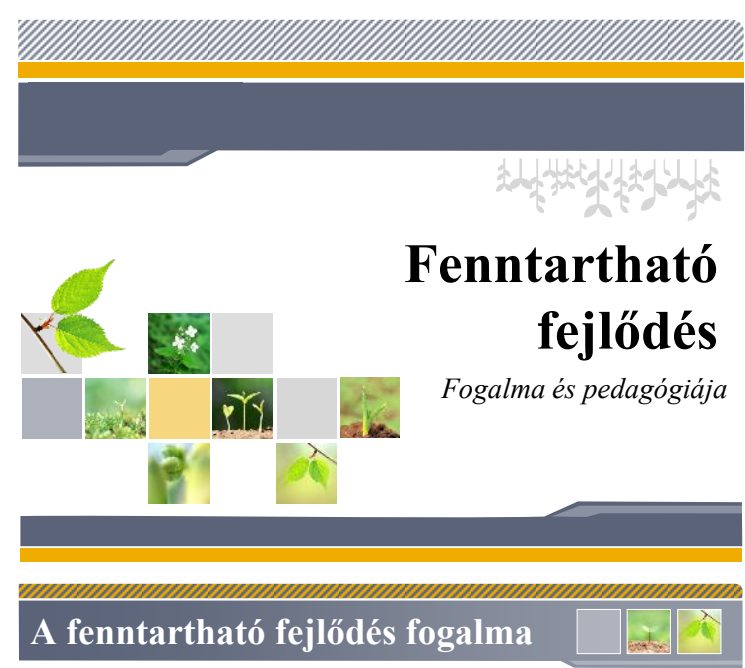

„A fenntartható fejlődés olyan fejlödés, amely kielégiti a jelen generációk szükségleteit anélkül, hogy veszélyeztetné a jövö generációk szükségleteinek kielégitését."

Az ENSZ Környezet és Fejlódés Konferenciája, 1992. Rio de Janeiró

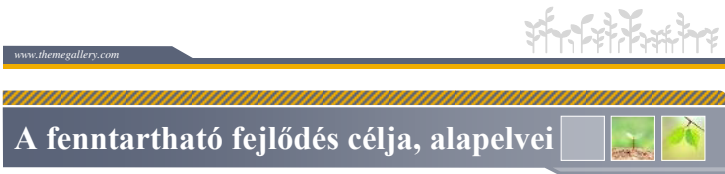

- Holisztikus gondolkodásmód kialakitása: rendszerszemléletű gondolkodás, a dolgok közötti összefüggések megértése, a beavatkozások rendszerre gyakorolt minden lehetséges hatásának figyelembe vétele.

A környezet elemekből

(levegő, víz, talaj, biológiai sokféleség) áll

ember által létrehozott környezetből!
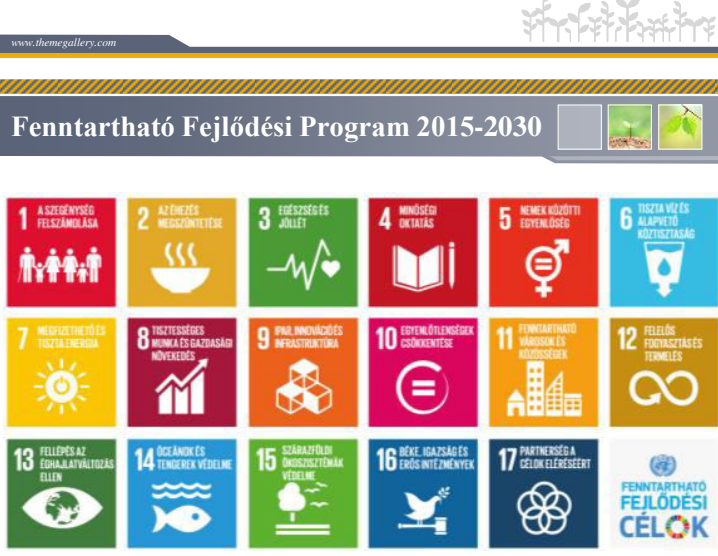

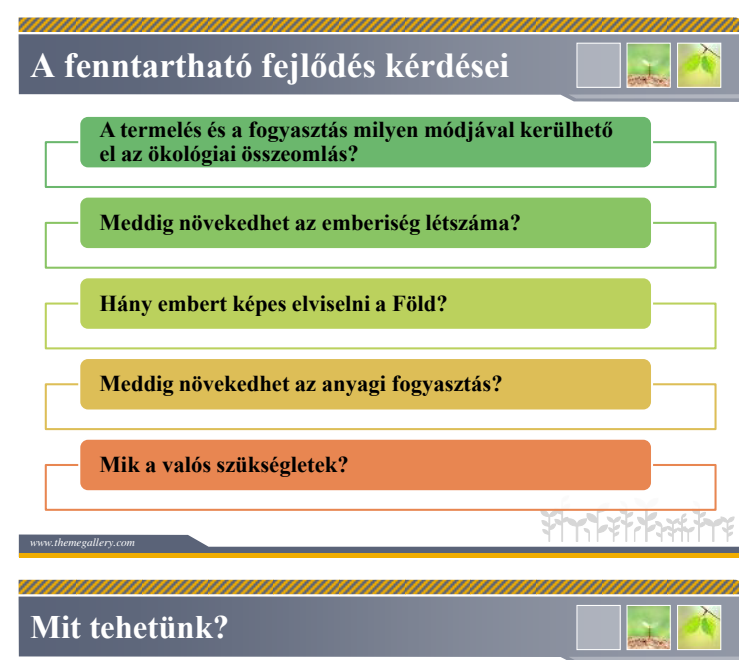

Takarékoskodjunk az energiával, vízzel

Csökkentsük a szeméthegyeket

Hasznosítsuk újra, amit csak lehet

Vásároljunk tudatosan
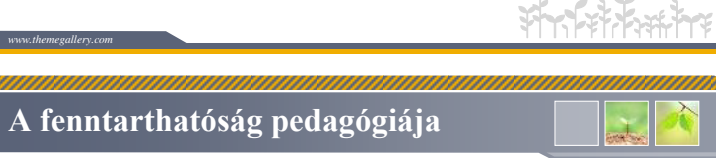

- Egész életen át tartó tanulási folyamat.

- Informált és tevékeny, állampolgárok nevelése a cél, akik felelős elkötelezettséget vállalnak környezetükért.

- Nagyon fontos szerepe lehet a jövőre nézve a gyerekek és a fiatalok ilyen irányú nevelésének

- A környezeti nevelés céljainak, feladatainak rendszerszintü, szervezett megvalósítását leghatékonyabban az általános iskolai gyakorlatba lehet beépíteni.

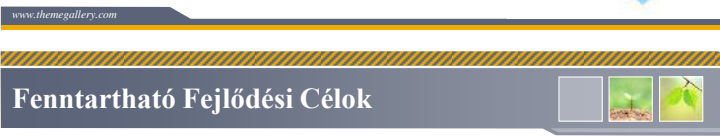

Minden oktatási intézmény célja és feladata, hogy hasznos tudást adjon tanulóinak, és felkészítse őket az előttük álló kihívásokra.

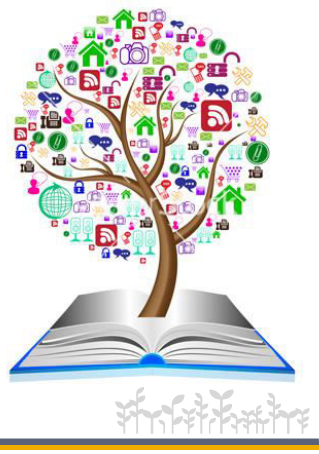




\section{MELLÉKLET: ELŐADÁS (A környezeti nevelés alapjai)}
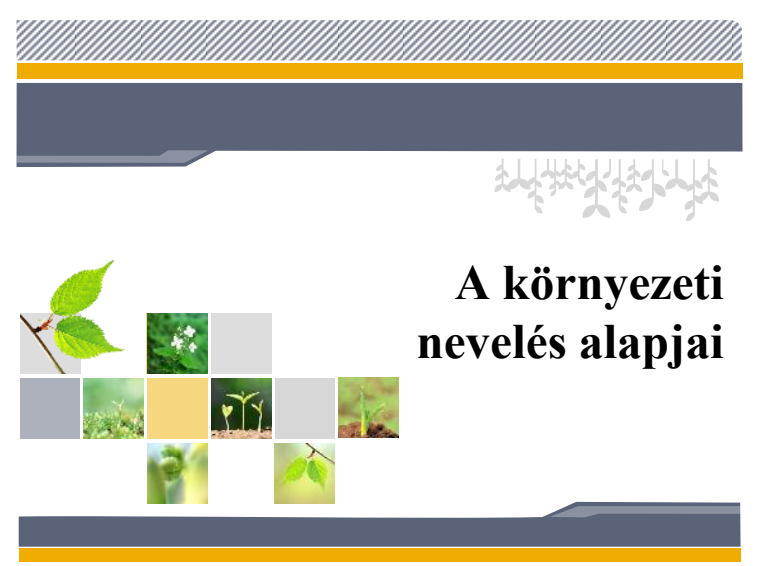

A környezeti nevelés kialakulása

-1977-ben került megrendezésre a Tbiliszi Konferencia. Az ott megfogalmazott definíció szerint:

\section{„A környezeti nevelés olyan folyamat, melynek célja, hogy a világ népessége környezettudatosan gondolkodjék, figyeljen oda a környezetre és minden azzal kapcsolatos problémára. Rendelkezzen az ehhez szükséges tudással, beállitódással, képességekkel, motivációval, valamint mind egyéni, mind közösségi téren eltökélten törekedjék a jelenlegi problémák megoldására és az újabbak megelözésére."}

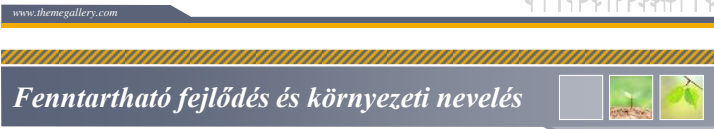

- A fenntarthatóság pedagógiája és a környezeti nevelés kapcsolata történeti eredetű. Világszerte a környezeti nevelés gyakorlata és fogalma alakult ki korábban, és csak fokozatosan válik a fenntarthatóság pedagógiai rendszerének részévé.

-A fenntarthatóság pedagógiája a környezeti nevelés kibővült tartalmára épül.
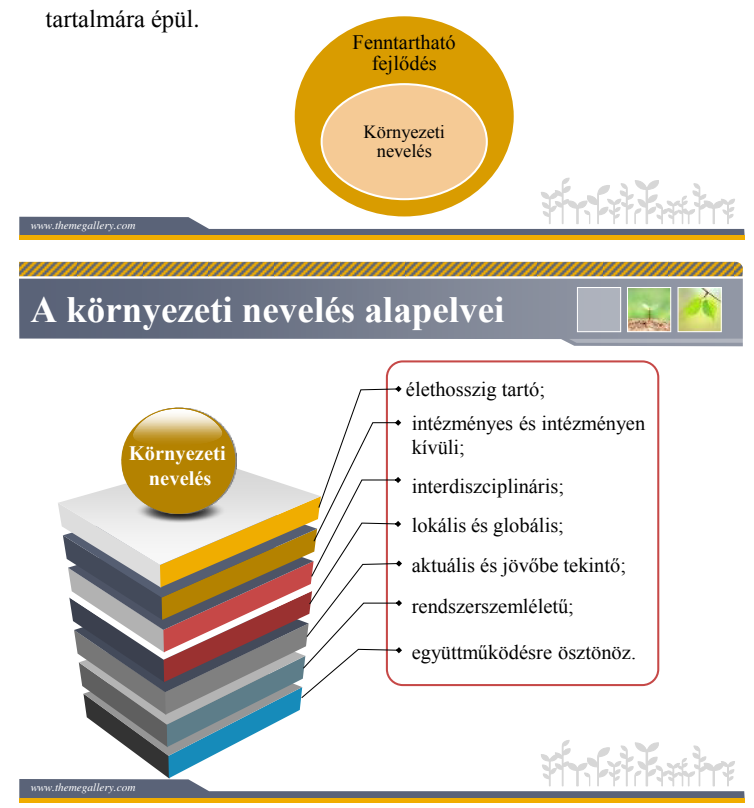

\section{A környezeti nevelés kialakulása}

- Az elmúlt század állami, civil és nemzetközi szervezetei, környezeti mozgalmai számos olyan eseményt indítottak el, amelyek nagymértékben hozzájárultak a környezeti nevelés koncepciójának pontos kidolgozásához.
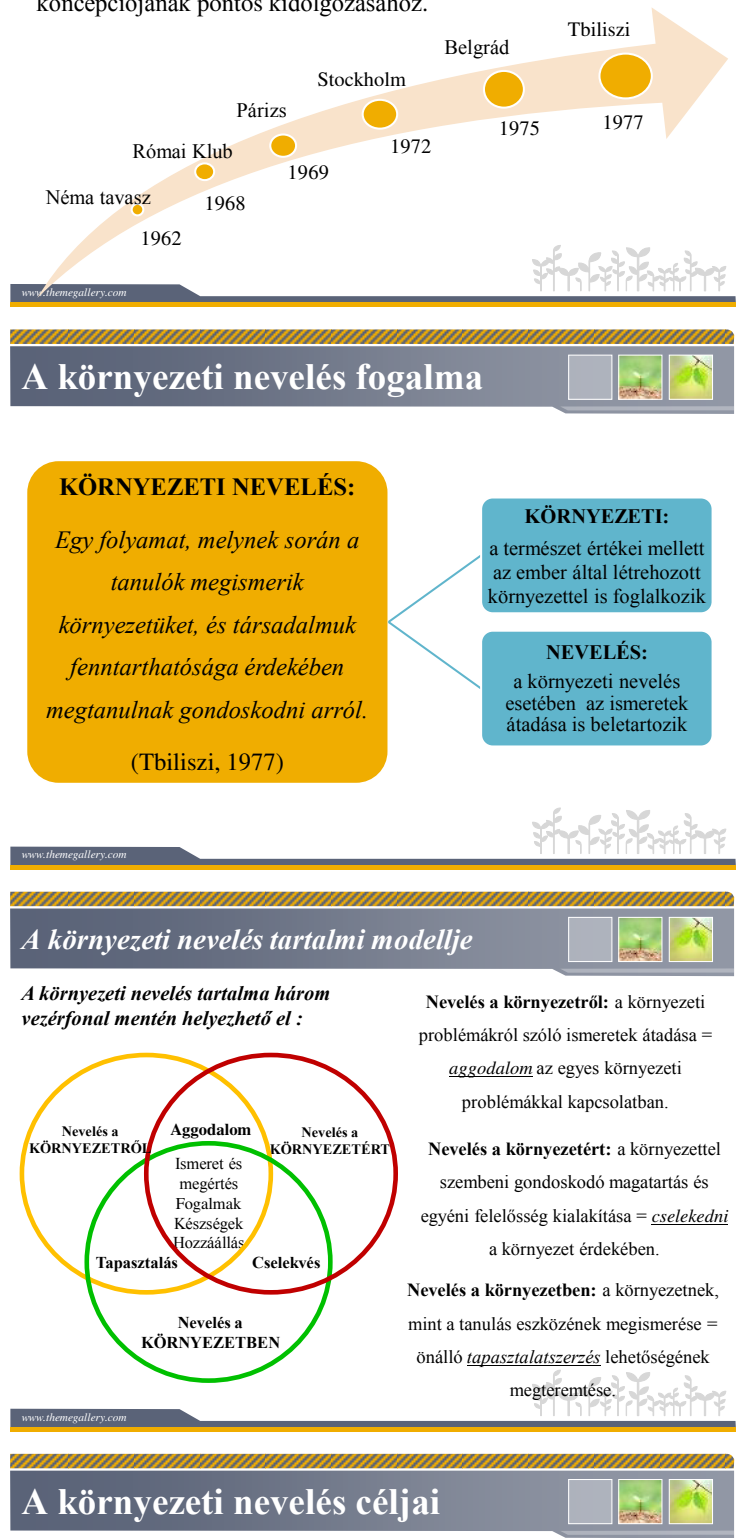

- Felelös állampolgárok nevelése, akik szembenéznek a környezeti problémákkal, és megoldják azokat.

- A társadalom tagjaiban kialakítani egy olyan viselkedésmintát a természettel kapcsolatban, amely nem a kihasználáson, hanem a harmonikus együttélésen alapul.

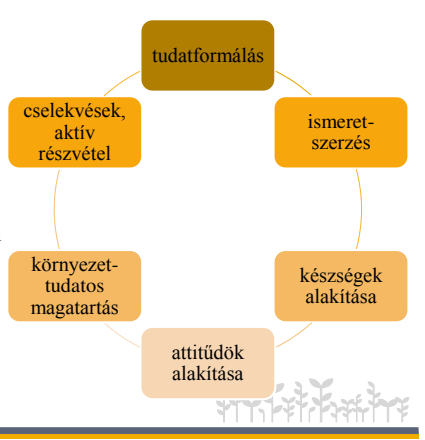




\section{MELLÉKLET: ELŐADÁS (A környezeti nevelés pedagógiája)}

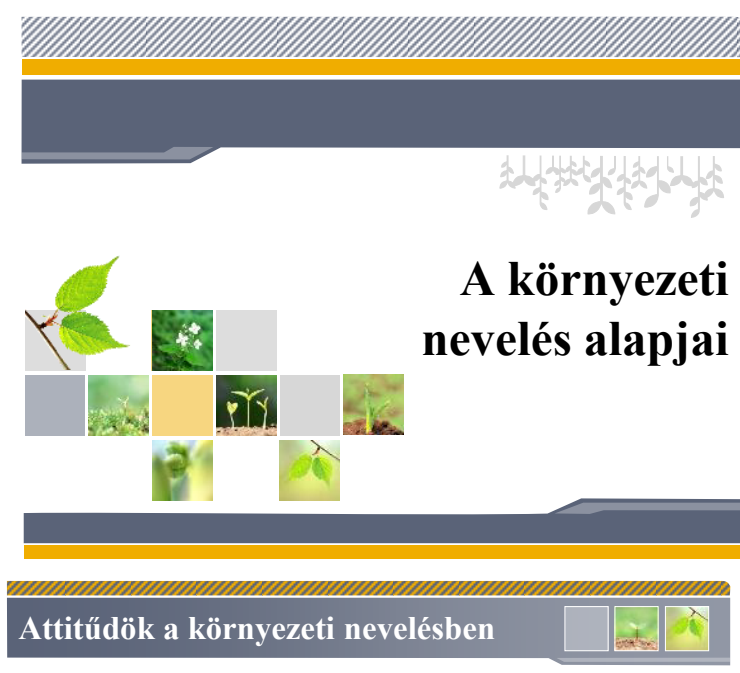

- A környezetre vonatkozó attitüdök fő szerkezeti elemei:
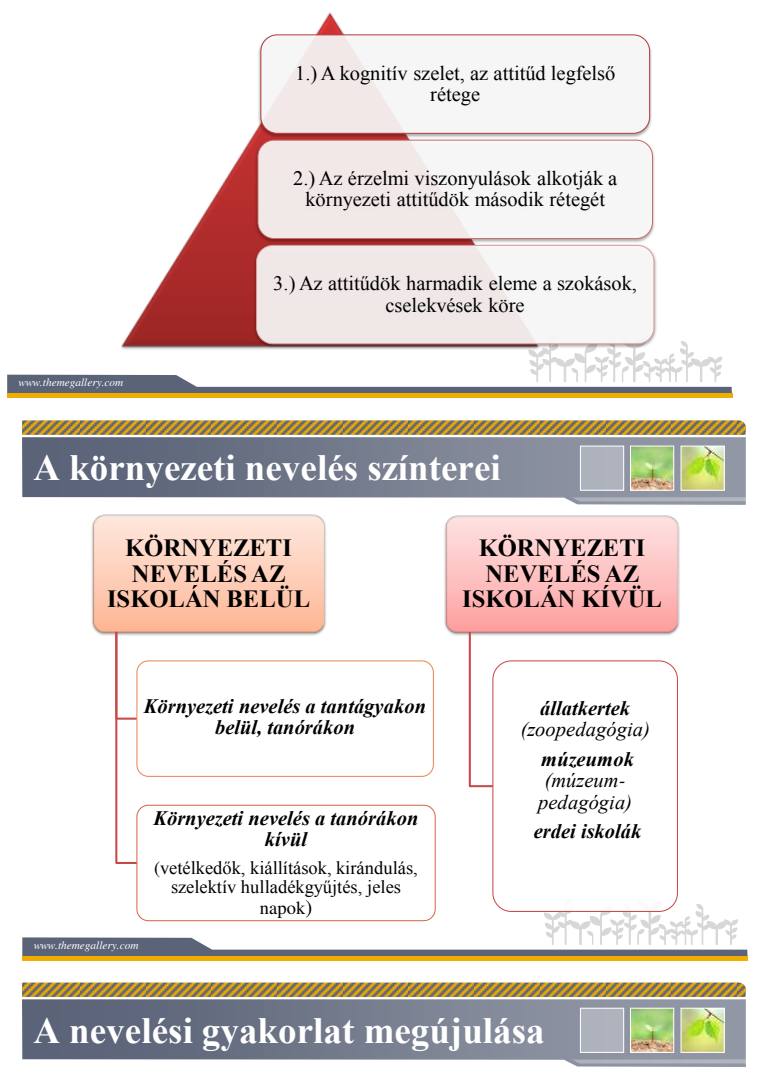

- A hagyományos nevelés gyakorlata: az összegyüjtött ismeretek, tapasztalatok és a létrejött értékek átadása a következő nemzedéknek:

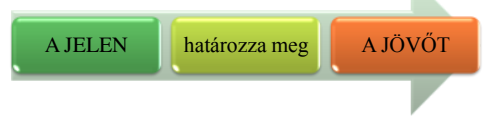

- A környezeti nevelés gyakorlata: a jövőt kell elörelátnia:

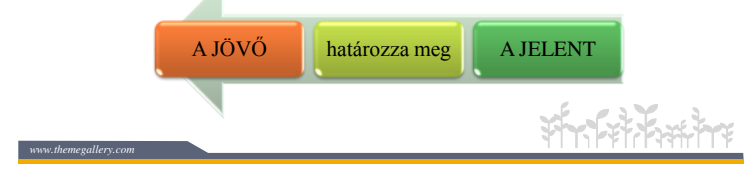

Attitüdök a környezeti nevelésben

- Az attitüdök szerepe: a környezeti nevelést úgy is értelmezhetjük, mint a viselkedés megváltozásával összefüggő készségek és értékek fejlesztését, amelyek szerves részét alkotják az ökológiai műveltségnek.

- A környezeti attitüd azt jelöli, ahogy az ember az öt körülvevő környezethez viszonyul.
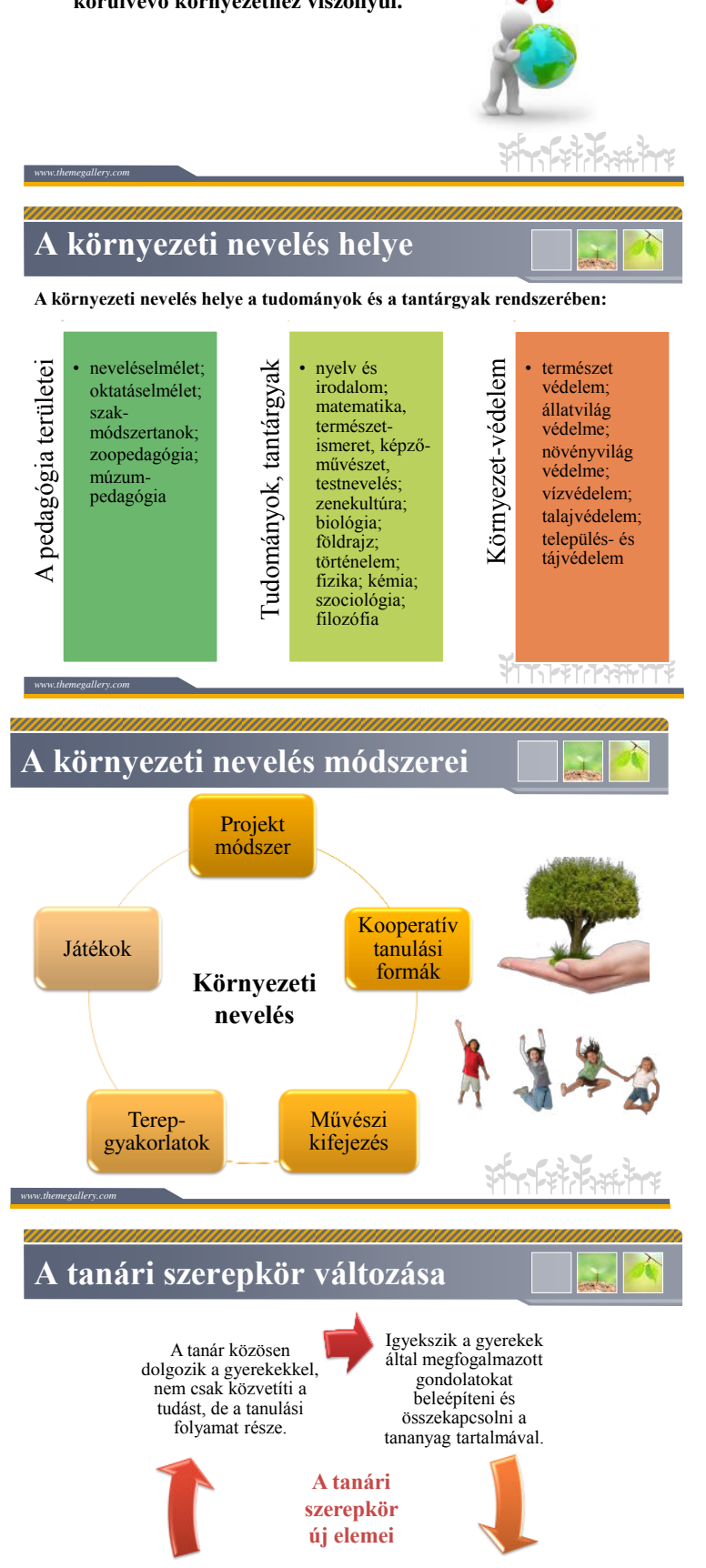

Sok szemléltetöeszközt használ, hogy a tanulókat segítse az önálló felfedezésben.

A tanítás során több teraktív megoldás alkalmaz. 


\section{MELLÉKLET: ELŐADÁS (A környezeti nevelés a gyakorlatban)}

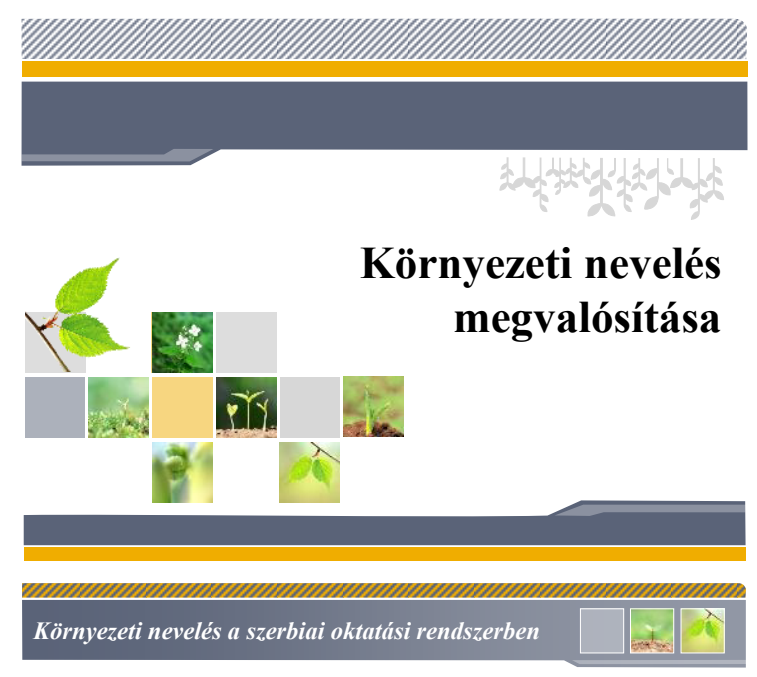

- Szerbiában a környezeti nevelés és a fenntarthatóság elvének szélesebb körű kibontakoztatására, és az ezzel kapcsolatos tanórai és tanórán kívüli tevékenységek megvalósítására alsó tagozaton a kötelezö Környezetünk (1. és 2. osztály), valamint a Természet és társadalom (3. és 4. osztály) tantárgyak mellett az Ifjú természetvédők és a Kéz a tésztában - a világ felfedezése elnevezésű választható tantárgyak adnak lehetőséget.

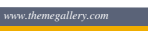

Környezeti nevelés az alsós tantárgyakban

- A második osztályos Környezetünk tantárgy globális tantervében meghatározott célok és feladatok:

- a tanulók tudásának bővítése a természeti és társadalmi jelenségekröl;

- az élő és élettelen természet közötti kölcsönhatásra való rámutatás;

- az ok-okozati összefüggések megértése (értsék meg az ember tevékenysége és a természetben végbemenő változások közötti kapcsolatot);

- természetvédelemre való nevelés;

az önálló tanulási tevékenységek serkentése: megfigyelés, kísérletezés, tapasztalatszerzés által.

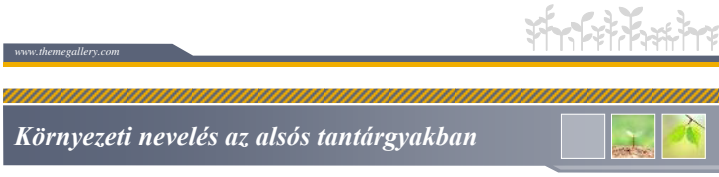

- A negyedik osztályos Természet és társadalom tantárgy globális tantervében meghatározott célok és feladatok:

- önismeret, a természeti és társadalmi környezet megismerése és a környezetben való felelősségteljes élethez szükséges képességek fejlesztése;

a természeti és társadalmi környezettel kapcsolatos alapfogalmak kialakítása és a fogalmak összekapcsolása;

fejleszteni a környezet létesítményei, jelenségei és folyamatai között fennálló alapvető összefüggések felismerésének képességét;

- az érdeklődés és a környezetre irányuló aktív megismerés képességének fejlesztése;

\section{Környezeti nevelés a szerbiai oktatási rendszerben}

- A környezeti nevelés alapjai a XX. század elején má megtalálhatóak Szerbiában. 1914-ben a Szerb Királyságban a diákok olyan fogadalmat tettek, amelynek ma is alapvető ökológiai üzenete van:

„Esküszöm, hogy nem pusztítom a fákat és virágokat, ... soha nem dobálom el a papírt, sem más szemetet az utcán; mindig udvarias leszek; védeni fogom a madarakat, megvédem más tulajdonát..."

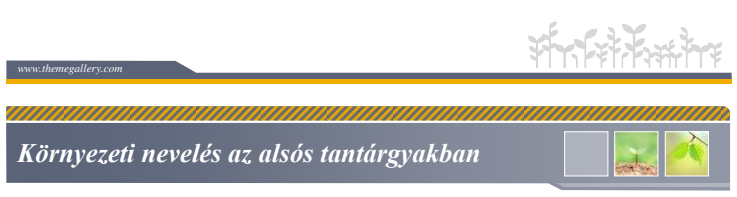

- Az első osztályos Környezetünk tantárgy globális tantervében meghatározott, környezeti neveléssel kapcsolatos célok és feladatok:

- a tanulók ismerjék meg önmagukat, környezetüket és tegyék magukévá a környezettudatos életmód elveit;

- alapvető természetismereti fogalmak kialakítása;

- az alapvető tudományos megismerési módszerek elsajátítása;

- az érdeklődés felkeltése a természeti jelenségekkel kapcsolatban;

- egyszerübb összefüggések levonása;

felelősségteljes viselkedés kialakitása másokkal és környezetünkkel szemben

\section{mows:hemegaller:com}

Környezeti nevelés az alsós tantárgyakban

- A harmadik osztályos Természet és társadalom tantárgy globális tantervében meghatározott célok és feladatok:

- mélyítse el a tanulók szerzett tapasztalatait, bővítse tudásukat vidékünk természeti adottságairól, és társadalmáról;

- az élő és az élettelen természet kölcsönhatásának ismertetése;

- ismertesse a tanulókkal az ember szerepét a természeti feltételek megváltoztatásában, a jobb életfeltételek biztositása érdekében, valamin az ökológiai egyensúly megőrzésében;

- ismertesse a tanulókkal az élöhelyek és életközösségek jellegzetességeit, a bennük uralkodó kölcsönhatásokat, valamint alkalmazkodásukat, táplálékláncukat, és világítson rá az ember rájuk gyakorolt hatására;

- a természet iránti csodálat fejlesztése, a környezetvédelem fontosságának belátása.

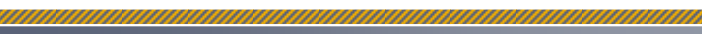

Környezeti nevelés az alsós tantárgyakban

- alkalmassá tenni a tanulókat az önálló tanulásra és az információk önálló megszerzésére;

- a tapasztalati és tudományos ismeretek integrálása a természet és társadalom fogalomkörébe;

- a civilizációs értékek befogadása és racionális használatuk, ezek továbbfejlesztésének lehetőségei;

- ökológiai öntudat fejlesztése.

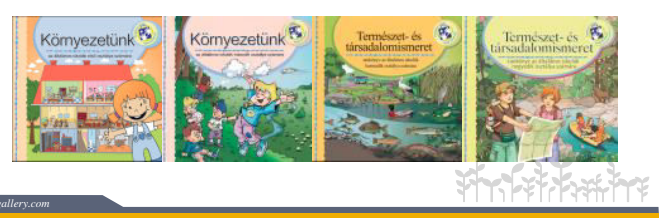




\section{MELLÉKLET: ELŐADÁS (Zoopedagógia a környezeti nevelés szolgálatában)}

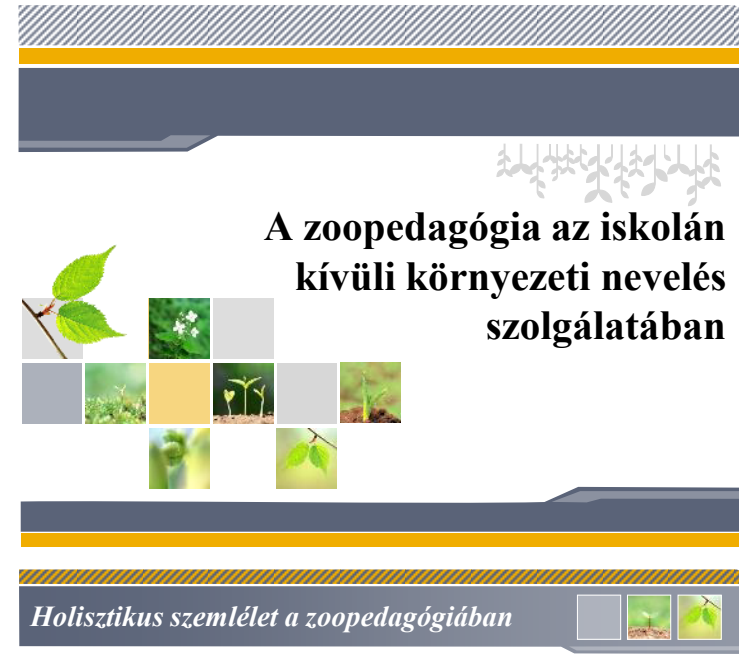

- A (kis)gyerekek létszükséglete az egyidejü, de szerteágazó tevékenység.

- A különbözö oktatási tartalmak összevonásával egyesítjük és megerősítjük a gyerekek motiválását és fokozzuk az oktatásban elért eredményeket is (racionalizáció, holisztikus hozzáállás, tartós tudás, a megszerzett ismeretek gyakorlati alkalmazása). Ezek a tények indokolják a különbözö területek integrálását.

- Amíg a tantermi munka folyamán az ismeretek tantárgyakhoz, tudományterületekhez kötötten jutnak el a tanulókhoz, addig az állatkertben komplexen találkoznak a jelenségekkel, az új ismeretekkel

- Az állatkerti foglalkozások magukba foglalják szinte az összes terület (tantárgy, foglalkozás) egy-egy szegmensét. Akár bevezetőként, akár a foglalkozás befejezéseként, de még a központi részt is képezheti egy anyanyelvi, matematikai, képzőmüvészeti feladat.
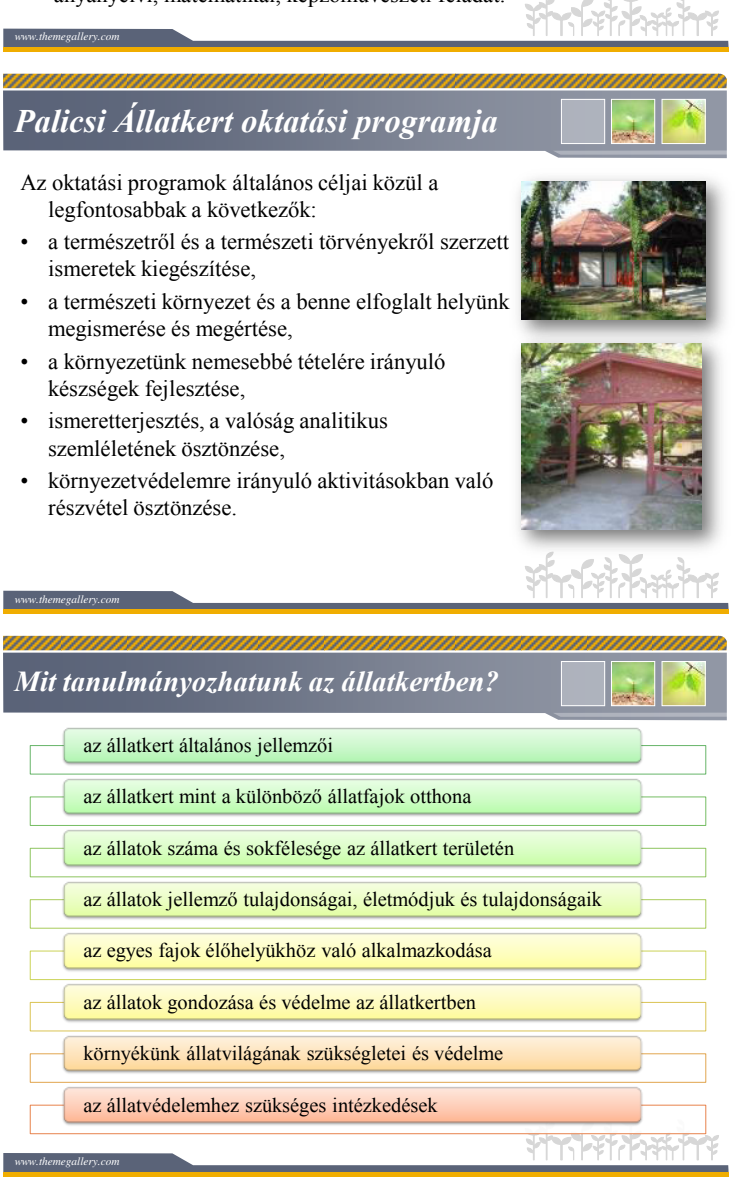

\section{Zoopedagógia}

- A környezeti nevelésnek egyik hatékony eszköze lehet a zoopedagógia, azaz az állatkerti nevelés, amely az állatok és az életközösségek közvetlen tanulmányozhatóságára épít.

- Az állatkertekben megvalósított foglalkozások nem csupán az állatok és növények gyüjteményekben való bemutatása szorítkoznak, hanem a látványosság mellett számos más feladatot is ellátnak.

- Ilyen tevékenységek például a nevelés, szemléletformálás, ismeretterjesztés, a kutatás, a fajok védelme, megőrzése, az állatkertben élő állatok eredeti élőhelyének védelme.

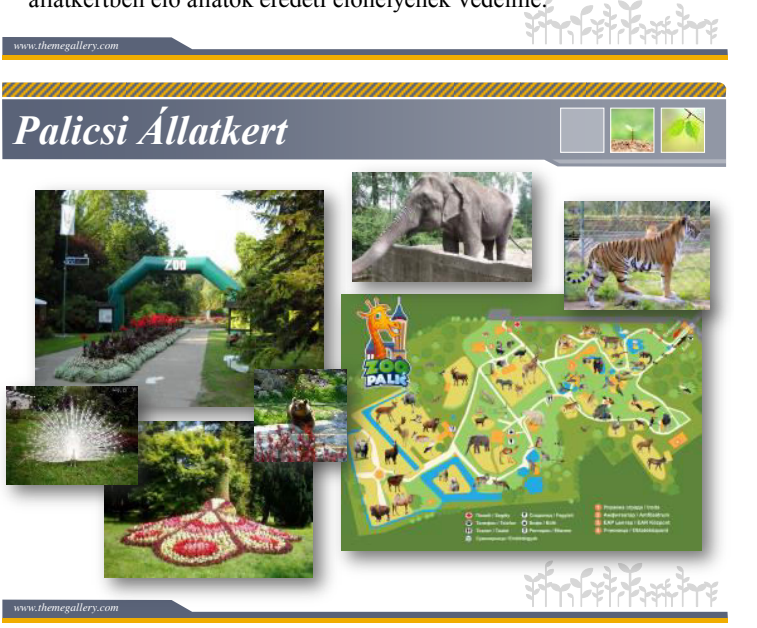

$$
\begin{aligned}
& \text { Mi teszi vonzóvá az állatkerti munkát? } \\
& \text { Az állatkertben folyó munka mindig serkenti a gyerekek (tanulók) } \\
& \text { aktivitását (különbözö ismeretforrások összehasonlitása, a gyerekek } \\
& \text { elötudásának kihasználása, szemléltetöeszközök aktív használata, } \\
& \text { megfigyelés, önálló kutatás, kísérletezés, felfedezés, következtetés stb.) } \\
& \text { Az állatkerti állatok és növények tanulmányozásával a tanulók logikai, } \\
& \text { alkotói és kritikai gondolkodásmenete fejlödik, amely az új ismeretek } \\
& \text { aktív elsajátitását segíti, } \\
& \text { A természettudományi jártasságuk különbözö területeken is fejleszthető } \\
& \text { (biológia, földrajz, fizika, kémia, történelem, matematika), } \\
& \text { Mind testileg, mind szellemileg aktívak a tanulók; megfigyelnek, leírnak, } \\
& \text { kérdéseket tesznek fel, megoldásokat keresnek, ismereteket szereznek, } \\
& \text { társaikkal vitatkoznak stb., } \\
& \text { Fokozatosan kialakul bennük a természet iránti pozitív magatartás. }
\end{aligned}
$$

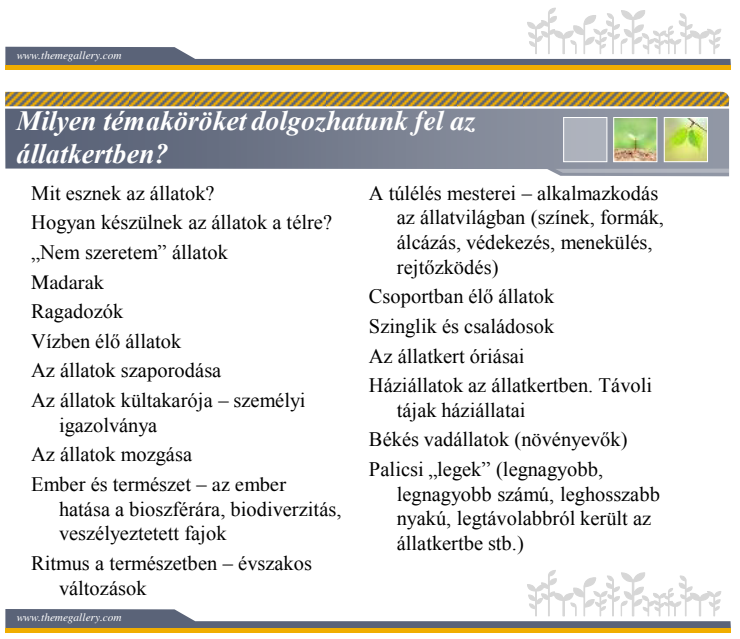




\section{MELLÉKLET: ÓRAVÁZLAT (A víz tulajdonságai)}

\begin{tabular}{|c|c|c|}
\hline \multicolumn{3}{|c|}{ ÓRAVÁZLAT } \\
\hline \multicolumn{3}{|c|}{ ÁLTALÁNOS MÓDSZERTANI ADATOK } \\
\hline MODUL & \multicolumn{2}{|l|}{ VÍZ, MÁSODIK OSZTÁLYOK } \\
\hline TANTÁRGY & \multicolumn{2}{|l|}{ KÖRNYEZETÜNK } \\
\hline TÉMA & \multicolumn{2}{|l|}{ ÉLETTELEN TERMÉSZET } \\
\hline TANÍTÁSI EGYSÉG & \multicolumn{2}{|l|}{ A VÍZ TULAJDONSÁGAI } \\
\hline $\begin{array}{l}\text { KÖRNYEZETI } \\
\text { NEVELÉSI } \\
\text { TARTALMAK, CÉLOK, } \\
\text { FELADATOK }\end{array}$ & \multicolumn{2}{|c|}{$\begin{array}{l}\text { VÍZZEL KAPCSOLATOS GLOBÁLIS PROBLÉMÁK } \\
\text { MEGISMERTETÉSE } \\
\text { A VÍZKÉSZLET SZENNYEZÉSÉNEK, KIMERÜLÉSÉNEK OKAI } \\
\text { VÍZVÉDELEM }\end{array}$} \\
\hline ÓRATÍPUS & \multicolumn{2}{|c|}{ ÚJ ANYAGOT FELDOLGOZÓ ÓRA } \\
\hline MUNKAFORMÁK & \multicolumn{2}{|l|}{ FRONTÁLIS, EGYÉNI, CSOPORTMUNKA } \\
\hline $\begin{array}{l}\text { TANÍTÁSI } \\
\text { MÓDSZEREK }\end{array}$ & \multicolumn{2}{|c|}{ ELŐADÁS, SZEMLÉLTETÉS, BESZÉLGETÉS, KÍSÉRLET, JÁTÉK } \\
\hline $\begin{array}{l}\text { SZEMLÉLETÖ-ÉS } \\
\text { SEGÉDESZKÖZÖK }\end{array}$ & \multicolumn{2}{|c|}{$\begin{array}{l}\text { tábla, tankönyv, füzet, boríték, szókártyák, kendö, víz, poharak, szivacs, } \\
\text { jégkocka, melegítö, lábos, fedö, szörp, olaj, só, homok, feketeföld }\end{array}$} \\
\hline HELYSZÍN & \multicolumn{2}{|l|}{ TANTEREM } \\
\hline \multicolumn{3}{|c|}{ AZ ÓRA SZERKEZETE } \\
\hline BEVEZETŐ RÉSZ & KÖZPONTI RÉSZ & BEFEJEZÖ RÉSZ \\
\hline $\begin{array}{l}\text { - bemutatkozás, } \\
\text { kapcsolatfelvétel } \\
\text { - házi feladat ellenőrzése } \\
\text { - a témakörhöz kapcsolódó } \\
\text { ismeretek felelevenítése } \\
\text { - figyelem felkeltése, } \\
\text { motiváció (borítékból húzott } \\
\text { képek az élő és élettelen } \\
\text { természet elemeivel, } \\
\text { amelyeket a táblán } \\
\text { csoportosítottak a megfelelő } \\
\text { címszavak alá) } \\
\text { - célkitüzés (találós } \\
\text { kérdések, válasz: A víz) }\end{array}$ & $\begin{array}{l}\text { - az élőlények vízszükséglete } \\
\text { - ki hány pohár vizet iszik meg naponta? } \\
\text { - ki hányszor ad inni otthon a } \\
\text { háziállatainak, illetve hányszor locsolják } \\
\text { meg a növényeket? } \\
\text { - csapadékfajták } \\
\text { - a víz előfordulási formái a } \\
\text { természetben (vízhiány kérdése, } \\
\text { vízszennyezés) } \\
\text { - a víz halmazállapotai } \\
\text { - kísérletek: a víz tulajdonságainak } \\
\text { vizsgálata különböző érzékszerveink } \\
\text { által; keverékek, oldatok; különböző } \\
\text { sűrüségü folyadékok } \\
\text { - a víz tulajdonságaival kapcsolatban } \\
\text { előforduló környezetvédelmi kérdések } \\
\text { (vízvédelem fontossága) }\end{array}$ & $\begin{array}{l}\text { - a tanultak összegzése, } \\
\text { rendszerezés (igaz-hamis } \\
\text { játék) } \\
\text { - házi feladat kijelölése, } \\
\text { megbeszélése } \\
\text { - elköszönés }\end{array}$ \\
\hline
\end{tabular}




\begin{tabular}{|c|c|c|}
\hline \multicolumn{3}{|c|}{ ÓRAVÁZLAT } \\
\hline MODUL & \multicolumn{2}{|l|}{ VÍZ, MÁSODIK OSZTÁLYOK } \\
\hline TANTÁRGY & \multicolumn{2}{|l|}{ KÖRNYEZETÜNK } \\
\hline TÉMA & \multicolumn{2}{|l|}{ ÉLETTELEN TERMÉSZET } \\
\hline TANÍTÁSI EGYSÉG & \multicolumn{2}{|l|}{ A VIZEK ÉLŐVILÁGA } \\
\hline $\begin{array}{l}\text { KÖRNYEZETI } \\
\text { NEVELÉSI } \\
\text { TARTALMAK, CÉLOK, } \\
\text { FELADATOK }\end{array}$ & \multicolumn{2}{|c|}{$\begin{array}{l}\text { A VÍZI ÉLETKÖZÖSSÉGEK TULAJDONSÁGAINAK } \\
\text { MEGISMERÉSE. KÖRNYEZETÜNK NÖVÉNY- ÉS } \\
\text { ÁLLATVILÁGÁNAK SOKSZÍNÜSÉGE. } \\
\text { AZ ÉLÖLÉNYEK MEGÖRZÉSÉNEK, VÉDELMÉNEK } \\
\text { FONTOSSÁGA. AZ ÉLÖLÉNYEK EGYMÁSRA HATÁSA, } \\
\text { SZEREPÜK EGYMÁS ÉLETÉBEN. KÖRNYEZETÜNK } \\
\text { MEGÓVÁSÁNAK FONTOSSÁGA. }\end{array}$} \\
\hline ÓRATÍPUS & \multicolumn{2}{|l|}{ ISMÉTLŐ, RENDSZEREZŐ ÓRA } \\
\hline MUNKAFORMÁK & \multicolumn{2}{|l|}{ FRONTÁLIS, EGYÉNI } \\
\hline $\begin{array}{l}\text { TANÍTÁSI } \\
\text { MÓDSZEREK }\end{array}$ & \multicolumn{2}{|c|}{ ELŐADÁS, BESZÉLGETÉS, SZEMLÉLTETÉS } \\
\hline $\begin{array}{l}\text { SZEMLÉLETÖ-ÉS } \\
\text { SEGÉDESZKÖZÖK }\end{array}$ & \multicolumn{2}{|l|}{ tábla, ceruza, feladatlap, írásvetítő, pohár, víz } \\
\hline HELYSZÍN & \multicolumn{2}{|l|}{ TANTEREM } \\
\hline \multicolumn{3}{|c|}{ AZ ÓRA SZERKEZETE } \\
\hline BEVEZETŐ RÉSZ & KÖZPONTI RÉSZ & BEFEJEZÖ RÉSZ \\
\hline $\begin{array}{l}\text { - bemutatkozás, } \\
\text { kapcsolatfelvétel } \\
\text { - házi feladat ellenőrzése } \\
\text { - visszacsatolás a Palicsi-tó } \\
\text { élővilága c. elóadáson } \\
\text { hallottakhoz } \\
\text { - figyelem felkeltése, } \\
\text { motiváció (beszélgetés a víz } \\
\text { fontosságáról az élőlények } \\
\text { számára ) } \\
\text { - célkitüzés (motivációs } \\
\text { vers: Fésűs Éva - Békanóta) }\end{array}$ & $\begin{array}{l}\text { - különféle édesvizi és tengeri állatok } \\
\text { bemutatása, életmódja (táplálkozás, } \\
\text { testfelépítés stb.) } \\
\text { - érdekességek a vízi élőlényekkel } \\
\text { kapcsolatban (az élőlények sokfélesége) } \\
\text { - feladatlap kitöltése a vízi állatokkal } \\
\text { kapcsolatban } \\
\text { - beszélgetés a vízi élőhelyekről (ki vagy } \\
\text { mi károsíthatja, szennyezheti ezeket az } \\
\text { élőhelyeket?) } \\
\text { - videó megtekintése a vízszennyezéssel } \\
\text { kapcsolatban (http://bit.ly/2uoivlp) } \\
\text { - beszélgetés a videóról: hogyan hat a } \\
\text { környezetszennyezés a vízi élőlényekre? } \\
\text { - hogyan tudunk takarékoskodni a } \\
\text { vízzel, illetve mit tehetünk a megóvása } \\
\text { érdekében? }\end{array}$ & $\begin{array}{l}\text { - a tanultak összegzése, } \\
\text { rendszerezés (kérdezz- } \\
\text { felelek módszer) } \\
\text { - elköszönés }\end{array}$ \\
\hline
\end{tabular}


10. MELLÉKLET: ÓRAVÁZLAT (Plakát: vízszennyezés, vízvédelem)

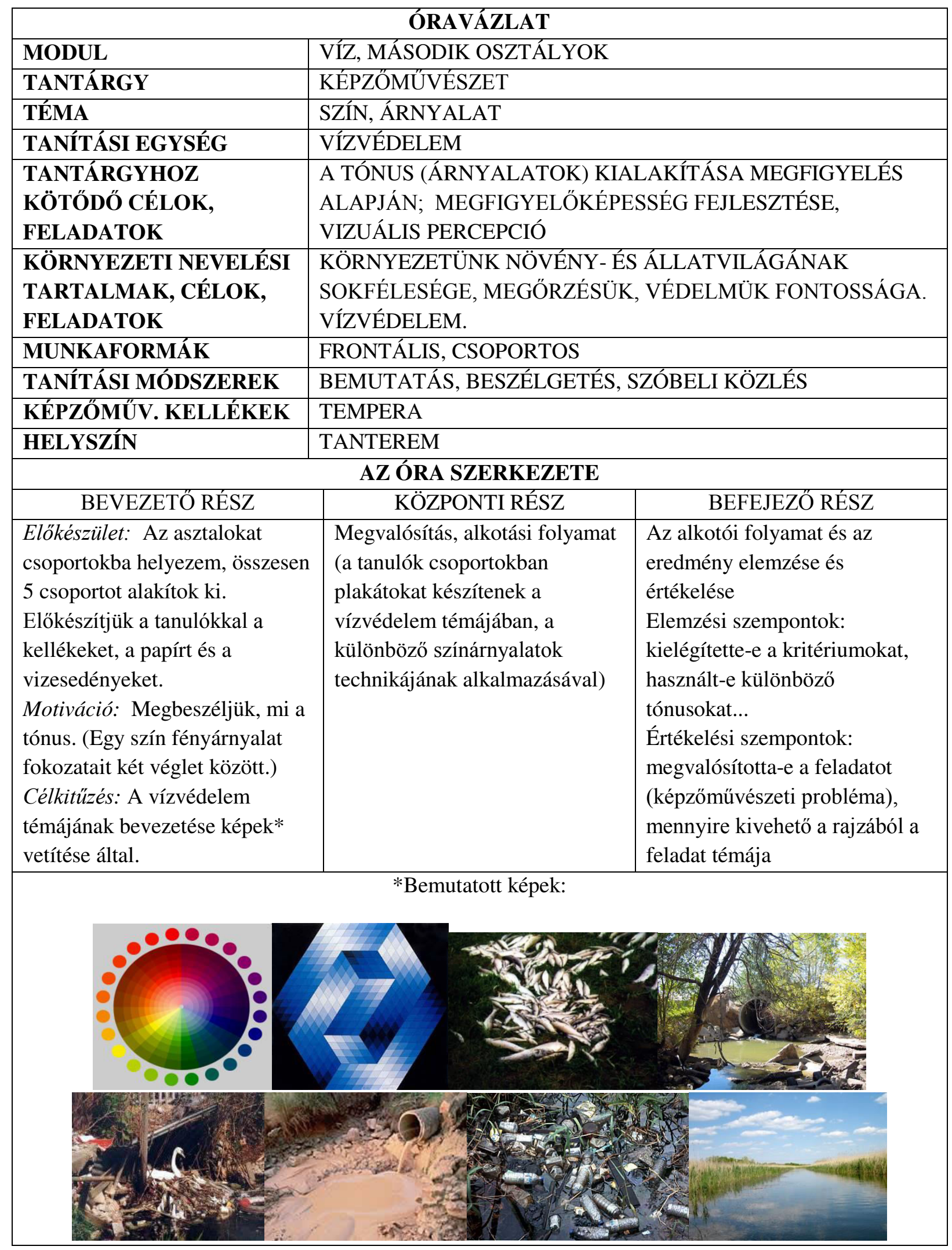


Néhány elkészült alkotás:
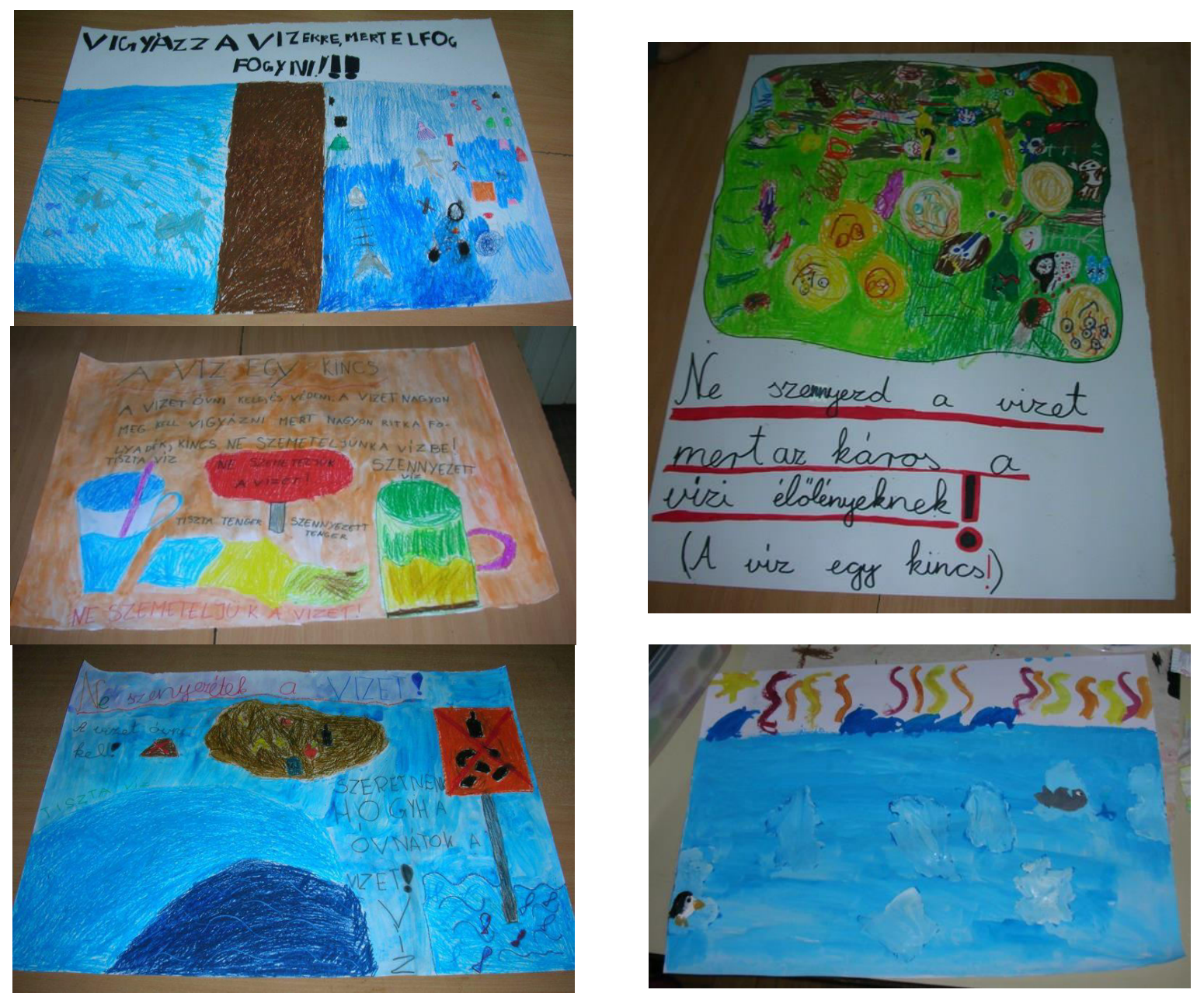
11. MELLÉKLET: ÓRAVÁZLAT (Hideg-meleg színek: jégsapkák olvadása)

\begin{tabular}{|c|c|c|}
\hline \multicolumn{3}{|c|}{ ÓRAVÁZLAT } \\
\hline MODUL & \multicolumn{2}{|l|}{ VÍZ, MÁSODIK OSZTÁLYOK } \\
\hline TANTÁRGY & \multicolumn{2}{|l|}{ KÉPZÖMÜVÉSZET } \\
\hline TÉMA & \multicolumn{2}{|l|}{ HIDEG ÉS MELEG SZÍNEK } \\
\hline TANÍTÁSI EGYSÉG & \multicolumn{2}{|l|}{ JÉGSAPKÁK OLVADÁSA } \\
\hline $\begin{array}{l}\text { TANTÁRGYHOZ } \\
\text { KÖTÖDÖ CÉLOK, } \\
\text { FELADATOK }\end{array}$ & \multicolumn{2}{|c|}{$\begin{array}{l}\text { HIDEG ÉS MELEG SZÍNEK KÖZÖTTI KÜLÖNBSÉGEK. } \\
\text { SZÍNÉRZÉKENYSÉG, FANTÁZIA, KÉPZELET FEJLESZTÉSE. }\end{array}$} \\
\hline $\begin{array}{l}\text { KÖRNYEZETI NEVELÉSI } \\
\text { TARTALMAK, CÉLOK, } \\
\text { FELADATOK }\end{array}$ & \multicolumn{2}{|c|}{$\begin{array}{l}\text { A VÍZ SZEREPE AZ EMBER ÉLETÉBEN. A GLOBÁLIS } \\
\text { FELMELEGEDÉS FOGALMA. A JÉGTAKARÓ } \\
\text { OLVADÁSÁNAK PROBLÉMÁJA ÉS VESZÉLYEI }\end{array}$} \\
\hline MUNKAFORMÁK & \multicolumn{2}{|l|}{ FRONTÁLIS, EGYÉNI } \\
\hline TANÍTÁSI MÓDSZEREK & \multicolumn{2}{|c|}{ SZÓBELI KÖZLÉS, BEMUTATÁS, MEGFIGYELÉS } \\
\hline KÉPZÖMÜV. KELLÉKEK & \multicolumn{2}{|l|}{ TEMPERA, AKVARELL } \\
\hline HELYSZÍN & \multicolumn{2}{|l|}{ TANTEREM } \\
\hline \multicolumn{3}{|c|}{ AZ ÓRA SZERKEZETE } \\
\hline BEVEZETŐ RÉSZ & KÖZPONTI RÉSZ & BEFEJEZÖ RÉSZ \\
\hline $\begin{array}{l}\text { Elökészület: Előkészítjük a } \\
\text { tanulókkal a kellékeket, a papírt } \\
\text { és a vizesedényeket. } \\
\text { Motiváció: Beszélgetés a víz és } \\
\text { a jég tulajdonságairól } \\
\text { Célkitüzés: A globális } \\
\text { felmelegedés fogalmának } \\
\text { magyarázata és érzékeltetése a } \\
\text { jegesmedvék életterének } \\
\text { csökkenése példájának } \\
\text { segítségével }\end{array}$ & $\begin{array}{l}\text { Megvalósítás, alkotási folyamat } \\
\text { (a tanulók egyéni munka során } \\
\text { alkotnak a kék, fehér, sárga, } \\
\text { piros, narancs szinek és } \\
\text { árnyalataik alkalmazásával) }\end{array}$ & $\begin{array}{l}\text { Az alkotói folyamat és az } \\
\text { eredmény elemzése és } \\
\text { értékelése } \\
\text { Értékelési szempontok: } \\
\text { megvalósította-e a feladatot } \\
\text { (képzőművészeti probléma), } \\
\text { mennyire kivehető a rajzából a } \\
\text { feladat témája }\end{array}$ \\
\hline
\end{tabular}


12. MELLÉKLET: ÓRAVÁZLAT (Daltanulás: Ess eső, ess)

\begin{tabular}{|c|c|c|}
\hline \multicolumn{3}{|c|}{ ÓRAVÁZLAT } \\
\hline MODUL & \multicolumn{2}{|l|}{ VÍZ, MÁSODIK OSZTÁLYOK } \\
\hline TANTÁRGY & \multicolumn{2}{|l|}{ ZENEI NEVELÉS } \\
\hline TÉMA & \multicolumn{2}{|l|}{ DALTANULÁS HALLÁS UTÁN } \\
\hline TANÍTÁSI EGYSÉG & \multicolumn{2}{|l|}{ ESS ESÖ, ESS } \\
\hline $\begin{array}{l}\text { KÖRNYEZETI } \\
\text { NEVELÉSI } \\
\text { TARTALMAK, CÉLOK, } \\
\text { FELADATOK }\end{array}$ & \multicolumn{2}{|c|}{$\begin{array}{l}\text { A VÍZ MEGJELENÉSI FORMÁI A TERMÉSZETBEN. } \\
\text { CSAPADÉKFAJTÁK. A VÍZ KÖRFORGÁSA. A VÍZKÉSZLET } \\
\text { KIMERÜLÉSÉNEK PROBLÉMÁJA. }\end{array}$} \\
\hline ÓRATÍPUS & \multicolumn{2}{|l|}{ ÚJ ANYAGOT FELDOLGOZÓ ÓRA } \\
\hline MUNKAFORMÁK & \multicolumn{2}{|l|}{ FRONTÁLIS, EGYÉNI } \\
\hline $\begin{array}{l}\text { TANÍTÁSI } \\
\text { MÓDSZEREK }\end{array}$ & \multicolumn{2}{|c|}{$\begin{array}{l}\text { SZÓBELI KÖZLÉS, MAGYARÁZAT, KÖZÖS ÉNEKLÉS, } \\
\text { GYAKORLÁS, ZENEHALLGATÁS }\end{array}$} \\
\hline $\begin{array}{l}\text { SZEMLÉLETÖ-ÉS } \\
\text { SEGÉDESZKÖZÖK }\end{array}$ & \multicolumn{2}{|c|}{ szintetizátor, ritmushangszerek (csörgők), számítógép, hanganyag } \\
\hline HELYSZÍN & \multicolumn{2}{|l|}{ TANTEREM } \\
\hline \multicolumn{3}{|c|}{ AZ ÓRA SZERKEZETE } \\
\hline BEVEZETŐ RÉSZ & KÖZPONTI RÉSZ & BEFEJEZÖ RÉSZ \\
\hline $\begin{array}{l}\text { - bemutatkozás, } \\
\text { kapcsolatfelvétel } \\
\text { - légzőgyakorlatok végzése } \\
\text { - bemelegítő } \\
\text { énekgyakorlatok } \\
\text { - előző órán tanult dal } \\
\text { éneklése: Süss fel nap } \\
\text { - motiváció: beszélgetés az } \\
\text { előző dal kapcsán az } \\
\text { időjárásról, napsütésről, } \\
\text { esőről } \\
\text { - célkitűzés (új dal tanulása: } \\
\text { Ess eső, ess) }\end{array}$ & $\begin{array}{l}\text { - beszélgetés az eső hangjáról, időjárási } \\
\text { jelenségek hangjának utánzása (,,s” hang } \\
\text { hangoztatása, kopogás, zörejek) } \\
\text { - beszélgetés az új dal szövegének } \\
\text { jelentéséről: esőért könyörgő dal; miért } \\
\text { fontos az eső, a víz az élőlények } \\
\text { számára? } \\
\text { - daltanulás: dallam, ritmus, szöveg }\end{array}$ & $\begin{array}{l}\text { - zenehallgatás (a dal } \\
\text { meghallgatása más } \\
\text { elöadásban) } \\
\text { - benyomások, érzések } \\
\text { megbeszélése } \\
\text { - az óra levezetése } \\
\text { - elköszönés }\end{array}$ \\
\hline
\end{tabular}




\section{MELLÉKLET: A víz témakörében megrendezett kiállítás résztvevői}

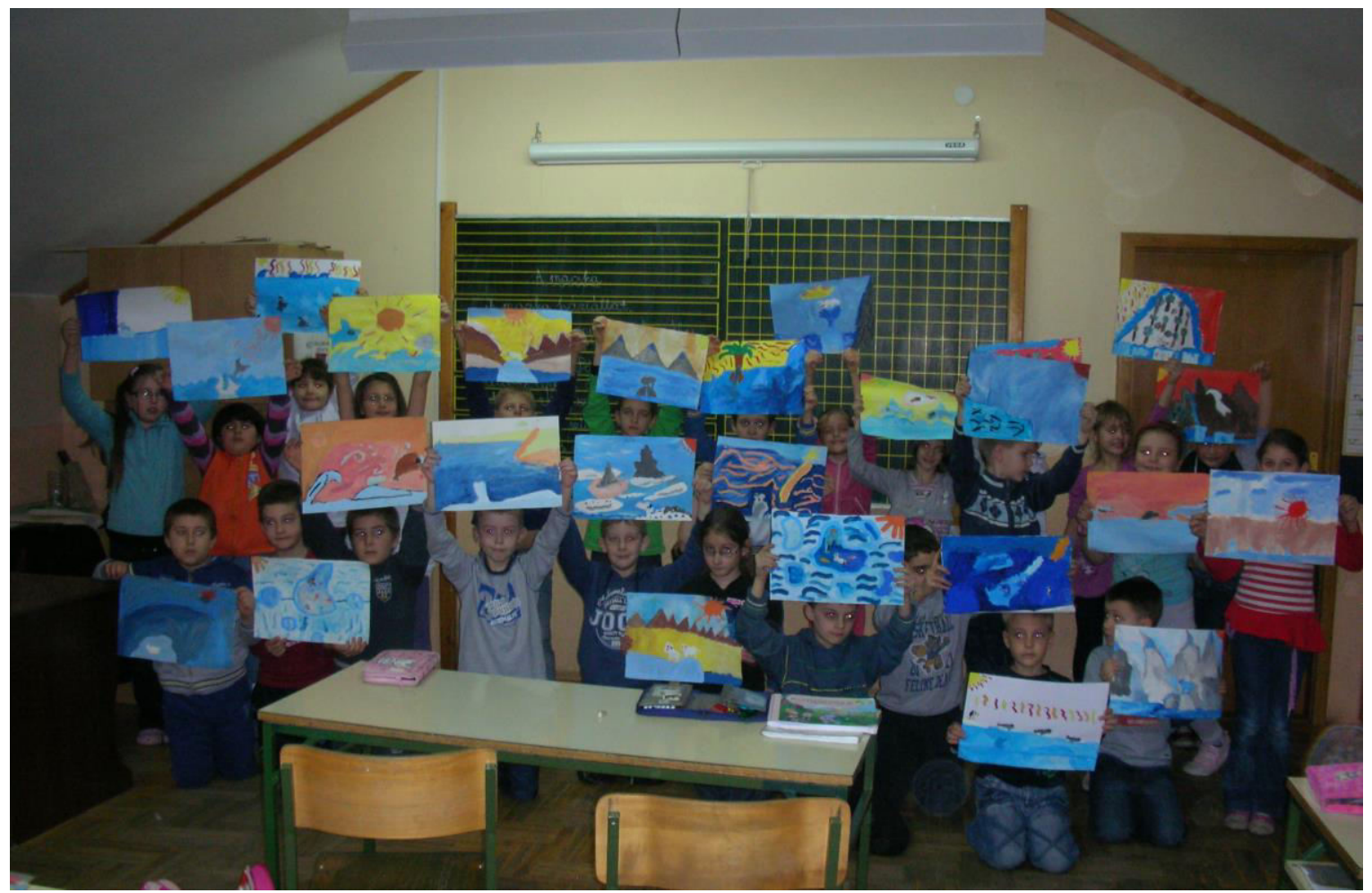

14. MELLÉKLET: A víz témakörében elvégzett projekt tartalma

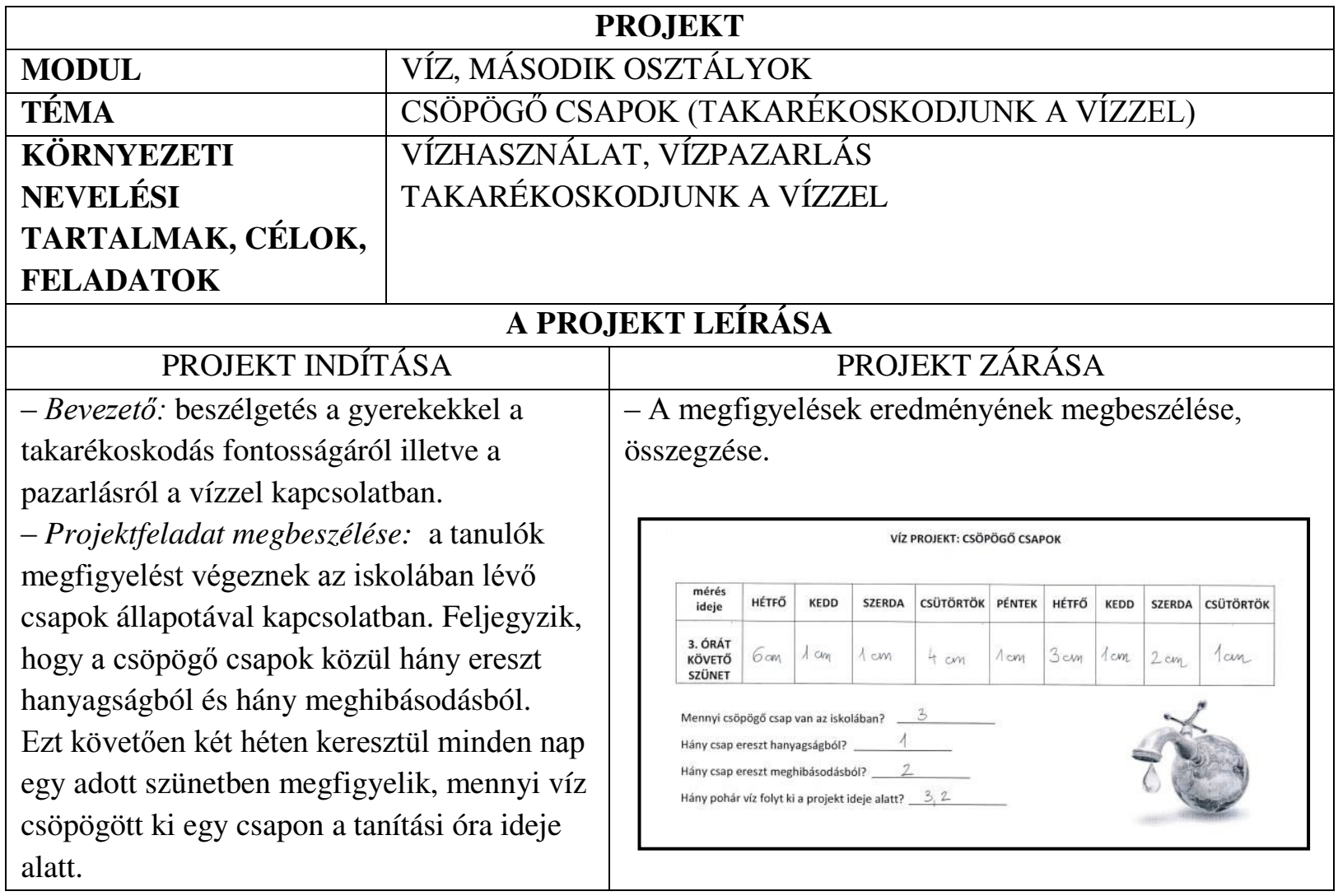


15. MELLÉKLET: A Magyar Tannyelvű Tanítóképző Karon megrendezett kiállítás részlete
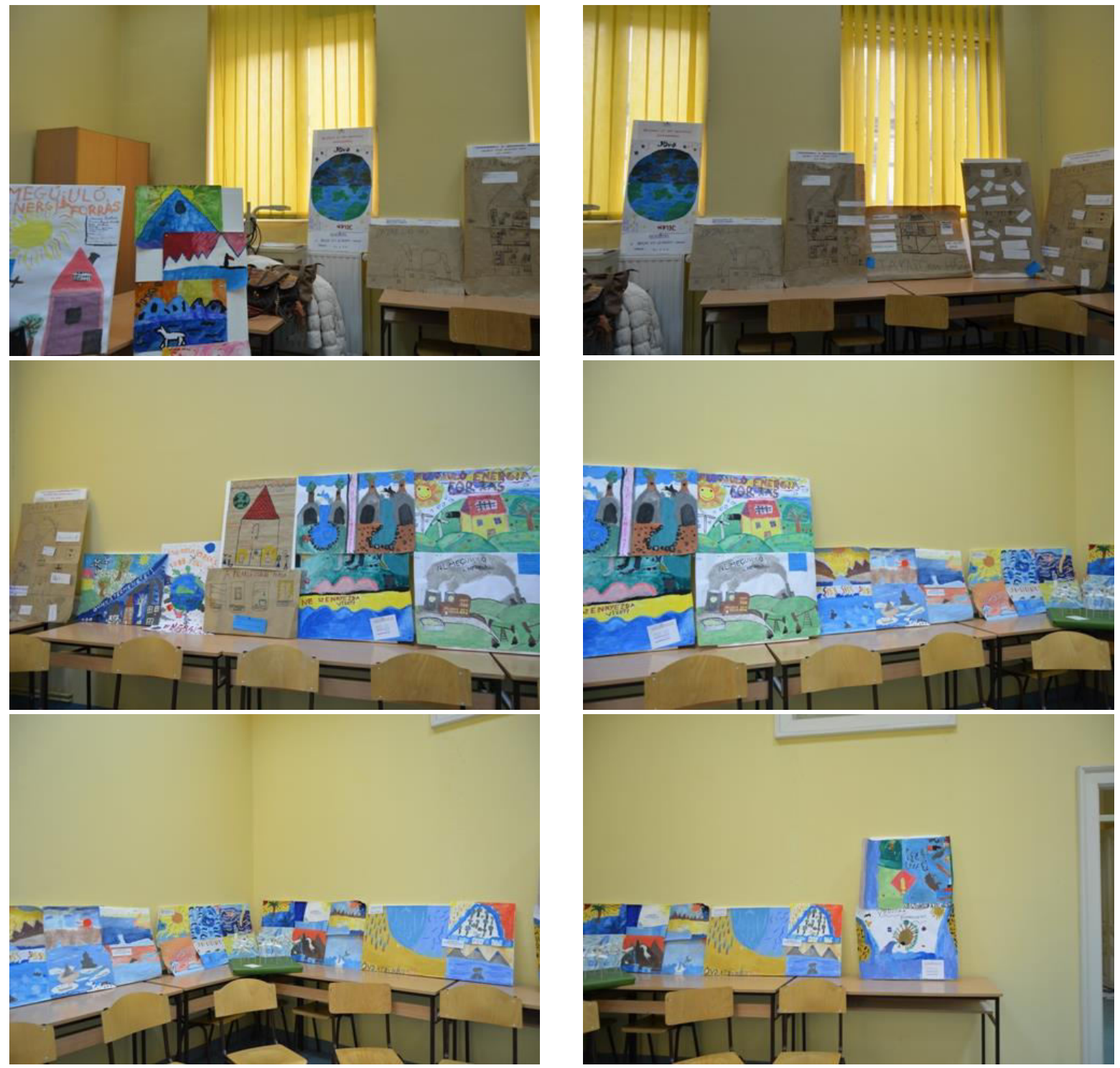
16. MELLÉKLET: A „Megérkezett a tavasz, vigyázzunk környezetünkre!’elnevezésü rendezvényről a hallgatók által készített plakát

\section{MEGÉRKEZETT A TAVASZ, VIGYÁZZUNK KÖRNYETÜNKRE!}

KÖRNYEZETVÉDELEM TÉMÁJÚ VETÉKEDŐK, JÁTÉKOK, PROGRAMOK

A MAGYAR TANNYELVŰ TANÍTÓKÉPZŐ KAR ÉPÜLETÉBEN

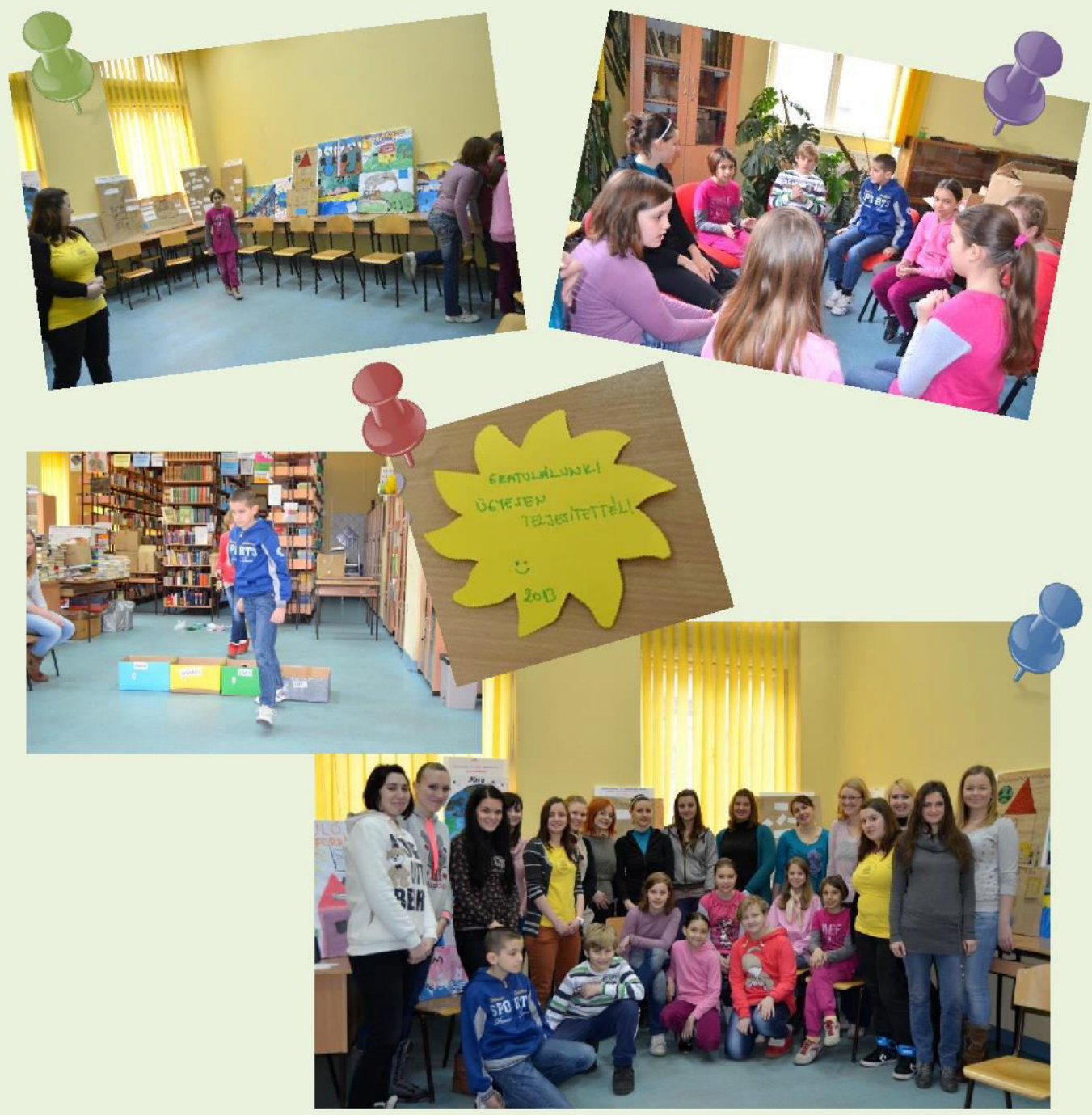


17. MELLÉKLET: ÓRAVÁZLAT (Környezetvédelem a mindennapokban)

\begin{tabular}{|c|c|c|c|}
\hline \multicolumn{4}{|c|}{ ÓRAVÁZLAT } \\
\hline \multicolumn{4}{|c|}{ ÁLTALÁNOS MÓDSZERTANI ADATOK } \\
\hline \multicolumn{2}{|l|}{ MODUL } & \multicolumn{2}{|l|}{ HULLADÉK, HARMADIK OSZTÁLYOK } \\
\hline \multicolumn{2}{|l|}{ TANTÁRGY } & \multicolumn{2}{|l|}{ TERMÉSZET ÉS TÁRSADALOM } \\
\hline \multicolumn{2}{|l|}{ TÉMA } & \multicolumn{2}{|c|}{ ÉLŐ ÉS ÉLETTELEN TERMÉSZET KÖZÖTTI KAPCSOLAT } \\
\hline \multicolumn{2}{|l|}{ TANÍTÁSI EGYSÉG } & \multicolumn{2}{|l|}{ KÖRNYEZETVÉDELEM A MINDENNAPOKBAN } \\
\hline \multicolumn{2}{|c|}{$\begin{array}{l}\text { KÖRNYEZETI NEVELÉSI } \\
\text { TARTALMAK, CÉLOK, } \\
\text { FELADATOK }\end{array}$} & \multicolumn{2}{|c|}{$\begin{array}{l}\text { KÖRNYEZETÜNK MEGÓVÁSÁNAK FONTOSSÁGA. A } \\
\text { KÖRNYEZET VÉDELMÉNEK LEHETŐSÉGE MINDENNAPI } \\
\text { TEVÉKENYSÉGEINK SORÁN. HULLADÉKKEZELÉS. } \\
\text { ÚJRAHASZNOSÍTÁS. SZELEKTÍV HULLADÉKGYÜJTÉS }\end{array}$} \\
\hline \multicolumn{2}{|l|}{ ÓRATÍPUS } & \multicolumn{2}{|l|}{ ÚJ ANYAGOT FELDOLGOZÓ ÓRA } \\
\hline \multicolumn{2}{|l|}{ MUNKAFORMÁK } & \multicolumn{2}{|l|}{ FRONTÁLIS, EGYÉNI } \\
\hline \multicolumn{2}{|c|}{ TANÍTÁSI MÓDSZEREK } & \multicolumn{2}{|l|}{ ELÖADÁS, BEMUTATÁS, BESZÉLGETÉS, JÁTÉK } \\
\hline \multicolumn{2}{|c|}{$\begin{array}{l}\text { SZEMLÉLETŐ-ÉS } \\
\text { SEGÉDESZKÖZÖK }\end{array}$} & \multicolumn{2}{|l|}{ digitális vetítő, számítógép, képek } \\
\hline \multicolumn{2}{|l|}{ HELYSZÍN } & \multicolumn{2}{|l|}{ TANTEREM } \\
\hline \multicolumn{4}{|c|}{ AZ ÓRA SZERKEZETE } \\
\hline & & KÖZPONTI RÉSZ & \\
\hline $\begin{array}{l}\text { - bemutatkozás, } \\
\text { kapcsolatfelvétel } \\
\text { - házi feladat } \\
\text { ellenőrzése } \\
\text { - a környezet- } \\
\text { védelemmel } \\
\text { kapcsolatos } \\
\text { ismeretek } \\
\text { felelevenítése } \\
\text { beszélgetés során } \\
\text { - beszélgetés a } \\
\text { környezeti } \\
\text { problémákról } \\
\text { - figyelem } \\
\text { felkeltése, motiváció } \\
\text { (videó megtekintése } \\
\text { az újrahasznosítással } \\
\text { kapcsolatban; forrás: } \\
\text { http://bit.ly/2t8JaTI) } \\
\text { - célkitüzés }\end{array}$ & \multicolumn{2}{|c|}{$\begin{array}{l}\text { - az újrahasznosítás fogalmának megbeszélése } \\
\text { - milyen anyagokat lehet újrahasznosítani, milyen új } \\
\text { dolgokat lehet elöállítani? } \\
\text { - a szelektív hulladékgyüjtés fogalmának, jelentöségének } \\
\text { megbeszélése } \\
\text { - a szemét és a hulladék fogalma közötti különbségek } \\
\text { megbeszélése } \\
\text { - otthoni hulladékgyüjtés, egyéb környezetvédő } \\
\text { tevékenységek, saját példák megbeszélése } \\
\text { - az eddig elhangzottak összefoglalása feladatlap } \\
\text { segítségével } \\
\text { - a komposztálás folyamatának megbeszélése } \\
\text { - otthoni komposztgyüijtó elkészítésének ötlete } \\
\text { Konyhai hulladek } \\
\text { Faforgacsizzalma } \\
\text { vázanyag } \\
\text { Level les } \\
\text { fanyese- } \\
\text { dek }\end{array}$} & $\begin{array}{l}\text { - a tanultak } \\
\text { összegzése, } \\
\text { rendszerezés } \\
\text { (kvízjáték) } \\
\text { - házi feladat } \\
\text { kijelölése, } \\
\text { megbeszélése } \\
\text { - elköszönés }\end{array}$ \\
\hline
\end{tabular}


18. MELLÉKLET: ÓRAVÁZLAT (Anyagok és felhasználásuk)

\begin{tabular}{|c|c|c|}
\hline \multicolumn{3}{|r|}{ ÓRAVÁZLAT } \\
\hline \multicolumn{3}{|c|}{ ÁLTALÁNOS MÓDSZERTANI ADATOK } \\
\hline MODUL & \multicolumn{2}{|c|}{ HULLADÉK, HARMADIK OSZTÁLYOK } \\
\hline TANTÁRGY & \multicolumn{2}{|c|}{ TERMÉSZET ÉS TÁRSADALOM } \\
\hline TÉMA & \multicolumn{2}{|c|}{ ANYAGOK ÉS FELHASZNÁLÁSUK } \\
\hline TANÍTÁSI EGYSÉG & \multicolumn{2}{|c|}{ AZ ANYAGOK ÚJRAHASZNOSÍTÁSA } \\
\hline $\begin{array}{l}\text { KÖRNYEZETI NEVELÉSI } \\
\text { TARTALMAK, CÉLOK, } \\
\text { FELADATOK }\end{array}$ & \multicolumn{2}{|c|}{$\begin{array}{l}\text { A KÖRNYEZETBEN ELÖFORDULÓ ANYAGOK } \\
\text { TULAJDONSÁGAINAK MEGFIGYELÉSE, VIZSGÁLATA. } \\
\text { AZ ÚJRAHASZNOSÍTÁS FOGALMÁNAK, JELENTÖSÉGÉNEK } \\
\text { MEGISMERTETÉSE. SZELEKTIIV HULLADÉKGYÜJTÉS }\end{array}$} \\
\hline ÓRATÍPUS & \multicolumn{2}{|c|}{ ISMÉTLŐ, RENDSZEREZŐ ÓRA } \\
\hline MUNKAFORMÁK & \multicolumn{2}{|c|}{ FRONTÁLIS, EGYÉNI, CSOPORTOS } \\
\hline TANÍTÁSI MÓDSZEREK & \multicolumn{2}{|c|}{ ELÖADÁS, BEMUTATÁS, BESZÉLGETÉS, SZEMLÉLTETÉS } \\
\hline $\begin{array}{l}\text { SZEMLÉLETŐ-ÉS } \\
\text { SEGÉDESZKÖZÖK }\end{array}$ & \multicolumn{2}{|c|}{ digitális vetítő, számítógép, képek } \\
\hline HELYSZÍN & \multicolumn{2}{|c|}{ TANTEREM } \\
\hline \multicolumn{3}{|r|}{ AZ ÓRA SZERKEZETE } \\
\hline \multicolumn{2}{|l|}{$\begin{array}{l}\text { BEVEZETÖ RÉSZ } \\
\text { - bemutatkozás, kapcsolatfelvétel } \\
\text { - házi feladat ellenőrzése } \\
\text { - elözetes ismeretek felelevenítése } \\
\text { a szelektív hulladékgyüjtésröl } \\
\text { - motiváció (különböző tárgyak } \\
\text { kihúzása a csodakalapból, azok } \\
\text { anyagának, tulajdonságainak } \\
\text { megbeszélése) } \\
\text { - célkitüzés }\end{array}$} & 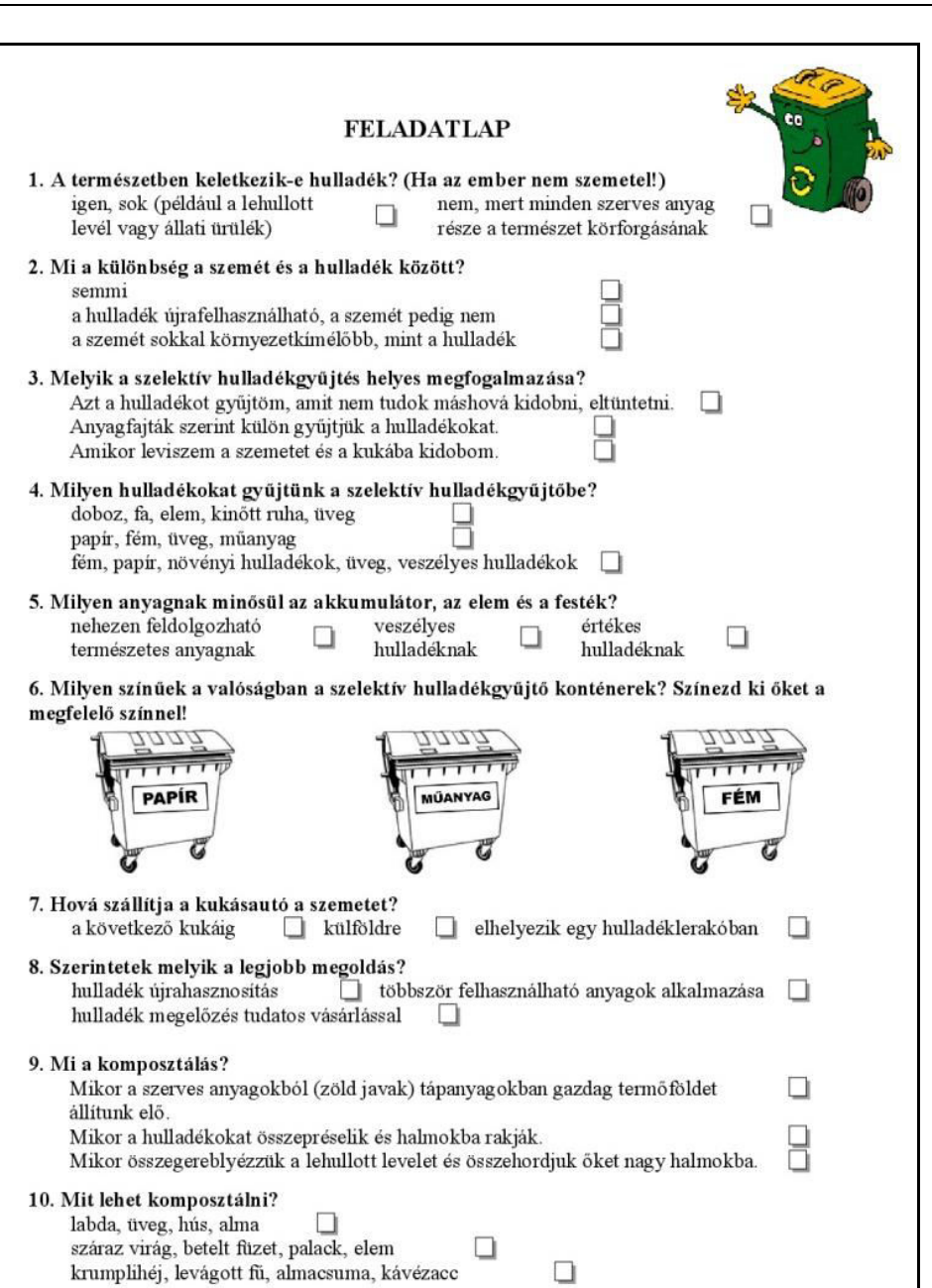 \\
\hline
\end{tabular}




\section{MELLÉKLET: ÓRAVÁZLAT (A hulladék életre kel)}

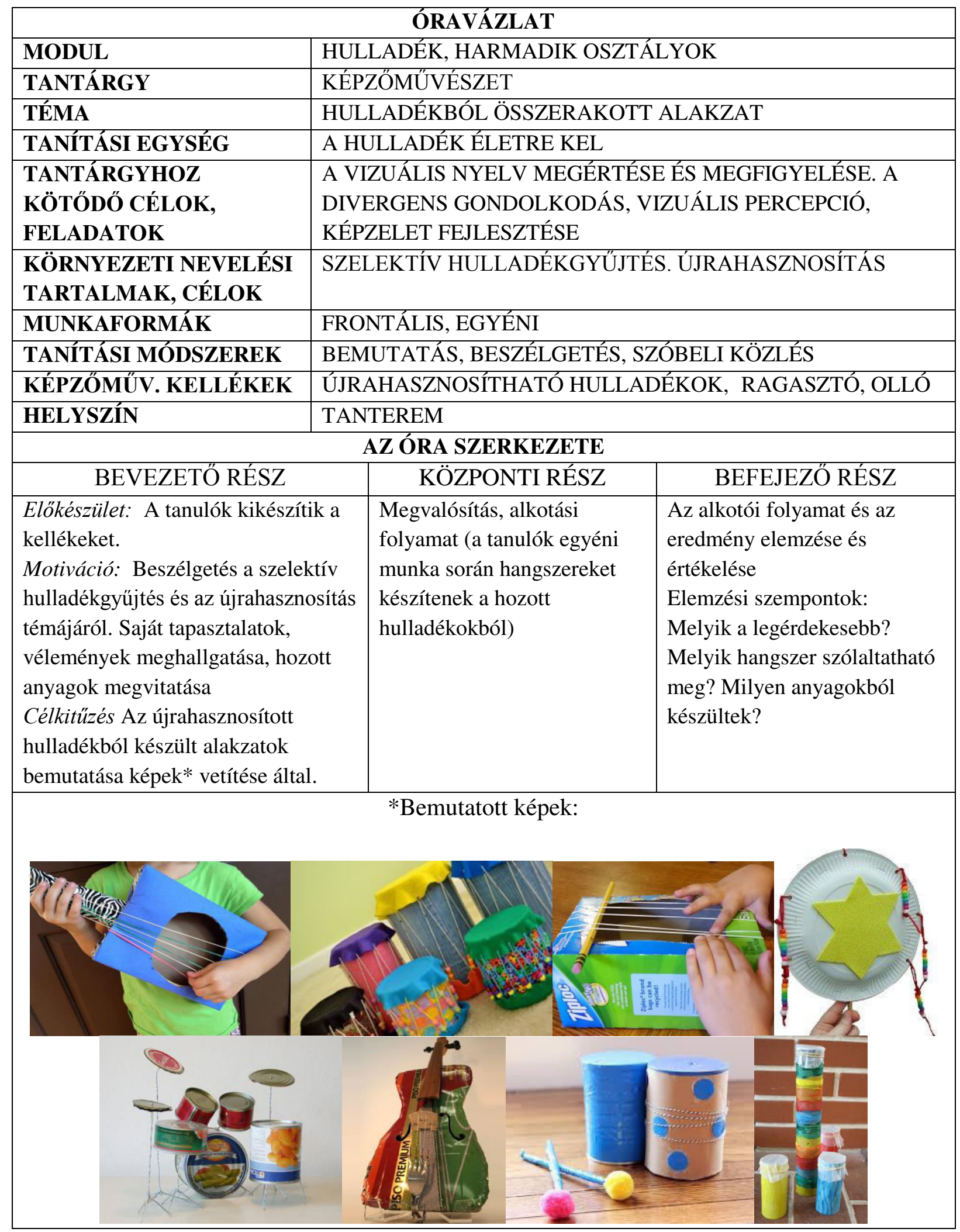


Néhány elkészült alkotás:
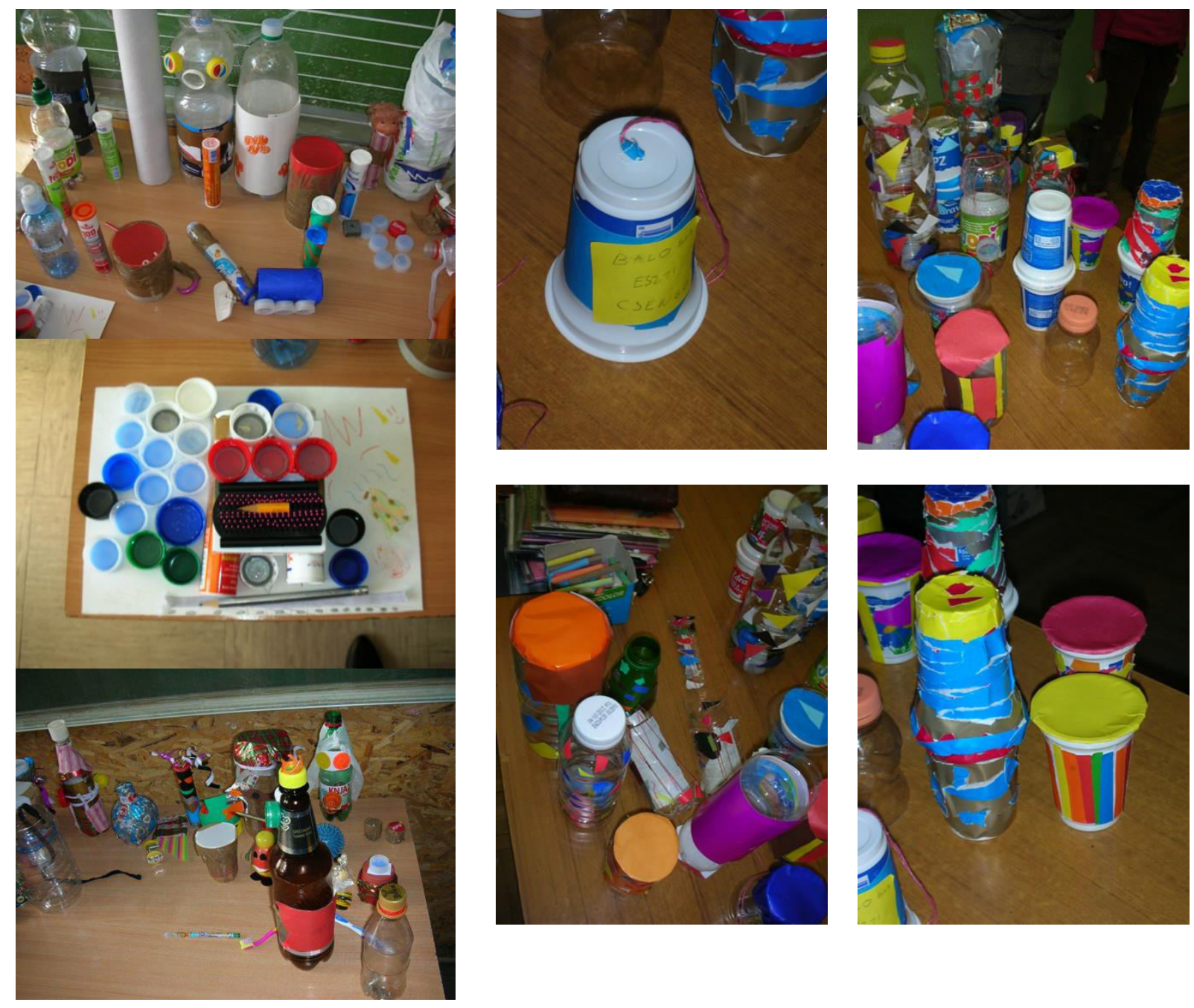
20. MELLÉKLET: ÓRAVÁZLAT (Hulladékhangszerek)

\begin{tabular}{|c|c|c|c|}
\hline \multicolumn{4}{|c|}{ ÓRAVÁZLAT } \\
\hline MODUL & \multicolumn{3}{|c|}{ HULLADÉK, HARMADIK OSZTÁLYOK } \\
\hline TANTÁRGY & \multicolumn{3}{|c|}{ ZENEI NEVELÉS } \\
\hline TÉMA & \multicolumn{3}{|c|}{ DALTANÍTÁS, HANGSZER } \\
\hline TANÍTÁSI EGYSÉG & \multicolumn{3}{|c|}{ HULLADÉKHANGSZEREK } \\
\hline $\begin{array}{l}\text { KÖRNYEZETI } \\
\text { NEVELÉSI } \\
\text { TARTALMAK, CÉLOK, } \\
\text { FELADATOK }\end{array}$ & \multicolumn{3}{|c|}{$\begin{array}{l}\text { SZELEKTÍV HULLADÉKGYÜJTÉS. ÚJRAHASZNOSÍTÁS. } \\
\text { MINDENNAPI TÁRGYAK FELHASZNÁLÁSA MÁS SZEREPBEN. }\end{array}$} \\
\hline ÓRATÍPUS & \multicolumn{3}{|c|}{ ÚJ ANYAGOT FELDOLGOZÓ ÓRA } \\
\hline MUNKAFORMÁK & \multicolumn{3}{|c|}{ FRONTÁLIS, EGYÉNI } \\
\hline $\begin{array}{l}\text { TANÍTÁSI } \\
\text { MÓDSZEREK }\end{array}$ & \multicolumn{3}{|c|}{$\begin{array}{l}\text { SZÓBELI KÖZLÉS, MAGYARÁZAT, HANGSZERHASZNÁLAT, } \\
\text { GYAKORLÁS, ZENEHALLGATÁS }\end{array}$} \\
\hline $\begin{array}{l}\text { SZEMLÉLETÖ-ÉS } \\
\text { SEGÉDESZKÖZÖK }\end{array}$ & \multicolumn{3}{|c|}{ hulladékhangszerek, számítógép, hanganyag } \\
\hline HELYSZÍN & \multicolumn{3}{|c|}{ TANTEREM } \\
\hline \multicolumn{4}{|c|}{ AZ ÓRA SZERKEZETE } \\
\hline BEVEZETŐ RÉSZ & & KÖZPONTI RÉSZ & BEFEJEZÖ RÉSZ \\
\hline $\begin{array}{l}\text { - bemutatkozás, } \\
\text { kapcsolatfelvétel } \\
\text { - légzőgyakorlatok végzése } \\
\text { - bemelegítő énekgyakorlatok } \\
\text { - motiváció: beszélgetés, } \\
\text { képzőmúvészet órán készített } \\
\text { hulladékhangszerek bemutatá } \\
\text { - célkitüzés (dal eljátszása } \\
\text { hulladékhangszereken: Nád a } \\
\text { házam teteje) }\end{array}$ & & $\begin{array}{l}\text { - dal bemutatása } \\
\text { - dal szövegének eljátszása, } \\
\text { elmutogatása } \\
\text { - daltanulás: dallam, ritmus, } \\
\text { szöveg } \\
\text { - daltanulás: hangszerek } \\
\text { használata } \\
\text { - új szöveg (vers) költése } \\
\text { közösen a már meglévő } \\
\text { dallamhoz }\end{array}$ & $\begin{array}{l}\text { - zenehallgatás (a dal } \\
\text { meghallgatása más előadásban) } \\
\text { - benyomások, érzések } \\
\text { megbeszélése } \\
\text { - az óra levezetése } \\
\text { - elköszönés }\end{array}$ \\
\hline
\end{tabular}




\begin{tabular}{|c|c|c|c|}
\hline \multicolumn{4}{|c|}{ ÓRAVÁZLAT } \\
\hline \multicolumn{4}{|c|}{ ÁLTALÁNOS MÓDSZERTANI ADATOK } \\
\hline \multicolumn{2}{|l|}{ MODUL } & \multicolumn{2}{|c|}{ ENERGIA, NEGYEDIK OSZTÁLYOK } \\
\hline \multicolumn{2}{|l|}{ TANTÁRGY } & \multicolumn{2}{|c|}{ TERMÉSZET ÉS TÁRSADALOM } \\
\hline \multicolumn{2}{|l|}{ TÉMA } & \multicolumn{2}{|c|}{$\begin{array}{l}\text { MUNKA, ENERGIA, TERMELÉS ÉS } \\
\text { FOGYASZTÁS }\end{array}$} \\
\hline \multicolumn{2}{|l|}{ TANÍTÁSI EGYSÉG } & \multicolumn{2}{|c|}{ ENERGIAFORRÁSOK } \\
\hline \multicolumn{2}{|c|}{$\begin{array}{l}\text { KÖRNYEZETI NEVELÉSI } \\
\text { TARTALMAK, CÉLOK, FELADATOK }\end{array}$} & \multicolumn{2}{|c|}{$\begin{array}{l}\text { A TERMÉSZETI KINCSEK KIAKNÁZÁSA. } \\
\text { TÚLZOTT KIHASZNÁLÁSUK, AMI } \\
\text { KÖRNYEZETI PROBLÉMÁKHOZ VEZET. } \\
\text { A KÜLÖNBÖZÖ NYERSANYAGFORRÁSOK } \\
\text { (VÍZ, ÜZEMANYAG, ÉLÖ TERMÉSZET } \\
\text { PRODUKTUMAI, ENERGIA STB.) ÉS A VELÜK } \\
\text { VALÓ TAKARÉKOSSÁG FONTOSSÁGA. } \\
\text { MEGÚJULÓ NYERSANYAGFORRÁSOK. }\end{array}$} \\
\hline \multicolumn{2}{|l|}{ ÓRATÍPUS } & \multicolumn{2}{|c|}{ ÚJ ANYAGOT FELDOLGOZÓ ÓRA } \\
\hline \multicolumn{2}{|l|}{ MUNKAFORMÁK } & \multicolumn{2}{|c|}{ FRONTÁLIS, EGYÉNI, CSOPORTOS } \\
\hline \multicolumn{2}{|l|}{ TANÍTÁSI MÓDSZEREK } & \multicolumn{2}{|c|}{$\begin{array}{l}\text { ELŐADÁS, BEMUTATÁS, TANULÓK ÖNÁLLÓ } \\
\text { ILLETVE CSOPORTOS MUNKÁJA }\end{array}$} \\
\hline \multicolumn{2}{|c|}{ SZEMLÉLETÖ-ÉS SEGÉDESZKÖZÖK } & \multicolumn{2}{|c|}{ digitális vetítő, számítógép } \\
\hline \multicolumn{2}{|l|}{ HELYSZÍN } & \multicolumn{2}{|l|}{ TANTEREM } \\
\hline \multicolumn{4}{|c|}{ AZ ÓRA SZERKEZETE } \\
\hline BEVEZETŐ RÉSZ & & KÖZPONTI RÉSZ & BEFEJEZÖ RÉSZ \\
\hline $\begin{array}{l}\text { - bemutatkozás, kapcsolatfelvétel } \\
\text { - házi feladat ellenőrzése } \\
\text { - energiával, élő és élettelen természet } \\
\text { elemeinek kapcsolatával foglalkozó } \\
\text { ismeretek felelevenítése beszélgetés } \\
\text { során, prezentáció segítségével } \\
\text { - a héten az energiával kapcsolatban } \\
\text { szerezett ismeretek elhelyezése az } \\
\text { eddig tanult ismeretek rendszerében } \\
\text { - motiváció: a szélgenerátor, a } \\
\text { napkollektor és a vízerőművek } \\
\text { működésének bemutatása } \\
\text { - videó a szélturbina müködéséről: } \\
\text { http://bit.ly/2teeBvV } \\
\text { - videó a vízenergia hasznosításáról: } \\
\text { http://bit.ly/2ud1Qlz } \\
\text { - beszélgetés a napenergia } \\
\text { hasznosításáról } \\
\text { - célkitűzés }\end{array}$ & $\begin{array}{l}-\mathrm{a} \\
\text { meg } \\
\text { ism } \\
-\mathrm{m} \\
\text { enè } \\
\text { otth } \\
\text { tapa } \\
-\mathrm{cs} \\
\text { kifo } \\
\text { bem } \\
\text { víze } \\
\text { ism } \\
\text { fela } \\
-\mathrm{a} \\
\text { egy }\end{array}$ & $\begin{array}{l}\text { lem megújuló és a } \\
\text { újuló energiaforrások } \\
\text { rtetése } \\
\text { ly nem megújuló } \\
\text { giaforrásokat használjuk } \\
\text { onunkban: gyerekek saját } \\
\text { sztalatának meghallgatása } \\
\text { pportmunka: a } \\
\text { gyhatatlan energiaforrások } \\
\text { utatása: napenergia, } \\
\text { nergia, szélenergia (az } \\
\text { retek összefoglalása } \\
\text { latlap segítségével)* } \\
\text { soportok beszámolója, az } \\
\text { s tartalmak ismertetése }\end{array}$ & $\begin{array}{l}\text { - a tanultak összegzése, } \\
\text { rendszerezés (videórészlet } \\
\text { megtekintése az „,Egyszer } \\
\text { volt a Föld: Az energia” és } \\
\text { az „Egyszer volt a Föld: } \\
\text { Megújuló energia” címü } \\
\text { rajzfilmekböl, beszélgetés } \\
\text { a látottak kapcsán); } \\
\text { Források: } \\
\text { http://bit.ly/2suE5rU; } \\
\text { http://bit.ly/2tzvi7o } \\
\text { - elköszönés }\end{array}$ \\
\hline
\end{tabular}




\section{* A csoportmunka során használt feladatlapok}

\section{Kedves NAPENERGLA csoport!}

Kérlek olvassátok el figyelmesen a napenergiával kapcsolatos tudnivalókat. Az alább felsorolt kérdések segitségével foglaljátok össze, hogy mit tudtatok meg a napenergiáról!

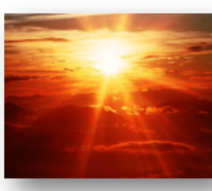

\section{NAPENERGIA}

Földünk számára a napenergia a legfontosabb energiaforrás. Az élổ szervezetek müködéséhez nélkülözhetetlen a napenergia. Az utóbbi idôben az ember is azon igyekszik, hogy kömyezetszennyezés nélkül különféle módon hasznositsa a napenergiát. A napenergiát a háztartásokban szükséges víz melegitésére is használhatjuk. A tetôre szerelt szoláris lemezek és a megfelelô szerkezetek a fényenergiát villamos energiává alakítják. Vannak országok, amelyek nagymértékben hasznositják a napenergiát

1. Mit tudtál meg, miért kutatunk új energiaforrások után?

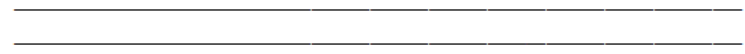

2. Fogalmazzátok meg egy mondatban, hogy miért fontos a napenergia?

3. Mire használjuk a napenergiát a háztartásokban?

\section{Kedves SZELENERGLA csoport:}

Kérlek olvassátok el figvelmesen a szélenergiával kapcsolatos tudnivalókat. Az alább felsorolt kérdések segitségével foglaljátok össze, hogy mit tudtatok meg a szélenergiáról

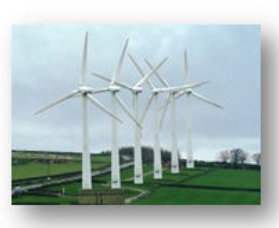

SZÉLENERGIA

A szél erejét hajtóeröként használja fel több madárfaj is, például az albatrosz. A szélerôt az ember is különbözö módon igyekszik kihasznälni. A szél régen szélmalmokat müködtetett és vitorláshajókat hajtott meg. Ma a szélenergia felhasználásával villamos energia is elöállitható. E célra különleges, egyenként vagy csoportosan elhelyezett szélturbinákat állitanak fel, vagyis ûn. szélerömüparkot létesitenek. Mivel a szélenergia kimerithetetlen, felhasználása megoldhatná az áramhiánybỏl eredô gondokat.

Miért kutatunk új energiaforrások utản?

Régen mire hasznâlta az ember a szél erejét és mire használja manapság?

Mit kell létesiteni ahhoz, hogy a szélenergiát fel tudjuk használni?

\section{Kedves VIZENERGLA csoport!}

Kérlek olvassátok el figyelmesen a vizenergiával kapcsolatos tudnivalókat. Az alább felsorolt kérdések segitségével foglaljátok össze, hogy mit tudtatok meg a vizenergiáról!

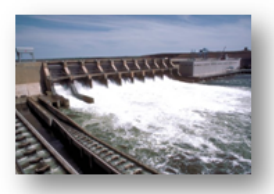

víZENERGIA

Az ember ösidök óta használja pl. közlekedésre és vízimalmok meghaitására A vizenergít ma villamos energia elôállitására használjuk. Ezzel a környezetet ugyan nem szennyezzük, a természetben mégis jelentös változást idézünk elô. A vízerơmunvek leginkább a folyókat eltorlaszoló gátakon épülnek, s ezzel megváltoztatják a vízinövények és állatok élöhelyének jelleget. A gátak korlátozhatják a vizben élö állatok mozgását is. Emellett a vízerömüvekbôl nagy mennyiségü meleg víz kerül a folyókba, ami veszélyezteti a kömyék szervezeteinek megmaradását.

Miért kutatunk új energiaforrások után?

Mióta hasznositják a vizenergiát az emberek?

Milyen változásokat idéznek elổ a természetben a vízerổmũvek? 
MODUL

TANTÁRGY

TÉMA

TANÍTÁSI EGYSÉG

TANTÁRGYHOZ

KÖTŐDŐ CÉLOK,

FELADATOK

KÖRNYEZETI NEVELÉSI

TARTALMAK, CÉLOK

\section{MUNKAFORMÁK \\ TANÍTÁSI MÓDSZEREK}

KÉPZŐMÜV. KELLÉKEK HELYSZÍN

\section{BEVEZETŐ RÉSZ}

Előkészület: A tanulók kikészítik a

kellékeket.

Motiváció: Beszélgetés az

energiatakarékosságról és a pazarlásról.

Saját tapasztalatok, vélemények

meghallgatása a mindennapi jó/rossz

szokásokkal kapcsolatban az

energiapazarlást/ spórolást illetően.

Táblakép* kialakítása a pazarlás és a

spórolás fő szempontjairól, a gyerekek

véleménye alapján

Célkitüzés Plakátok készítése az

energiapazarló és az energiaspóroló

háztartások közötti különbségekről

\section{ÓRAVÁZLAT}

ENERGIA, NEGYEDIK OSZTÁLYOK

KÉPZŐMÜVÉSZET

PLAKÁTKÉSZÍTÉS

ENERGIATAKARÉKOS ÉS ENERGIA PAZARLÓ HÁZTARTÁS ÁBRÁZOLÁS MEGFIGYELÉS ALAPJÁN, EMLÉKEZETBÖL, KÉPZELET ÉS EMLÉKEZET FEJLESZTÉSE

PAZARLÓ SZOKÁSOK. A MÉRTÉKTELEN FOGYASZTÁS

PROBLÉMÁJA, AMI TÁRSADALMI

EGYENLŐTLENSÉGEKHEZ VEZET. A SZÜKSÉGLETEK, IGÉNYEK, VÁGYAK MEGKÜLÖNBÖZTETÉSE.

ENERGIATAKARÉKOSSÁG A MINDENNAPOKBAN

FRONTÁLIS, CSOPORTOS

BEMUTATÁS, BESZÉLGETÉS, SZÓBELI KÖZLÉS, A TANULÓK CSOPORTOS MUNKÁJA

csomagolópapír, faszínesek, filctollak, olló, ragasztó

TANTEREM

\section{AZ ÓRA SZERKEZETE}

KÖZPONTI RÉSZ

Megvalósítás, alkotási

folyamat (a tanulók négy

csoportot alkotva

elkészítik a plakátokat)
BEFEJEZÖ RÉSZ Az alkotói folyamat és az eredmény elemzése és értékelése: minden csoport bemutatja a saját plakátját, és véleményt cserélnek egymás munkájával kapcsolatban

*Táblakép:

\section{PAZARLÓ HÁZ}

- szigetelés hiánya

- csöpögó csapok

- hagyományos izzók

- fútés nem megújuló energiával

\section{TAKARÉKOS HÁZ}

- megfelelő szigetelés

- energiatakarékos izzók

- megújuló energiaforrások

használata

- szelektív hulladékgyưjtés 
Az alkotás folyamata:
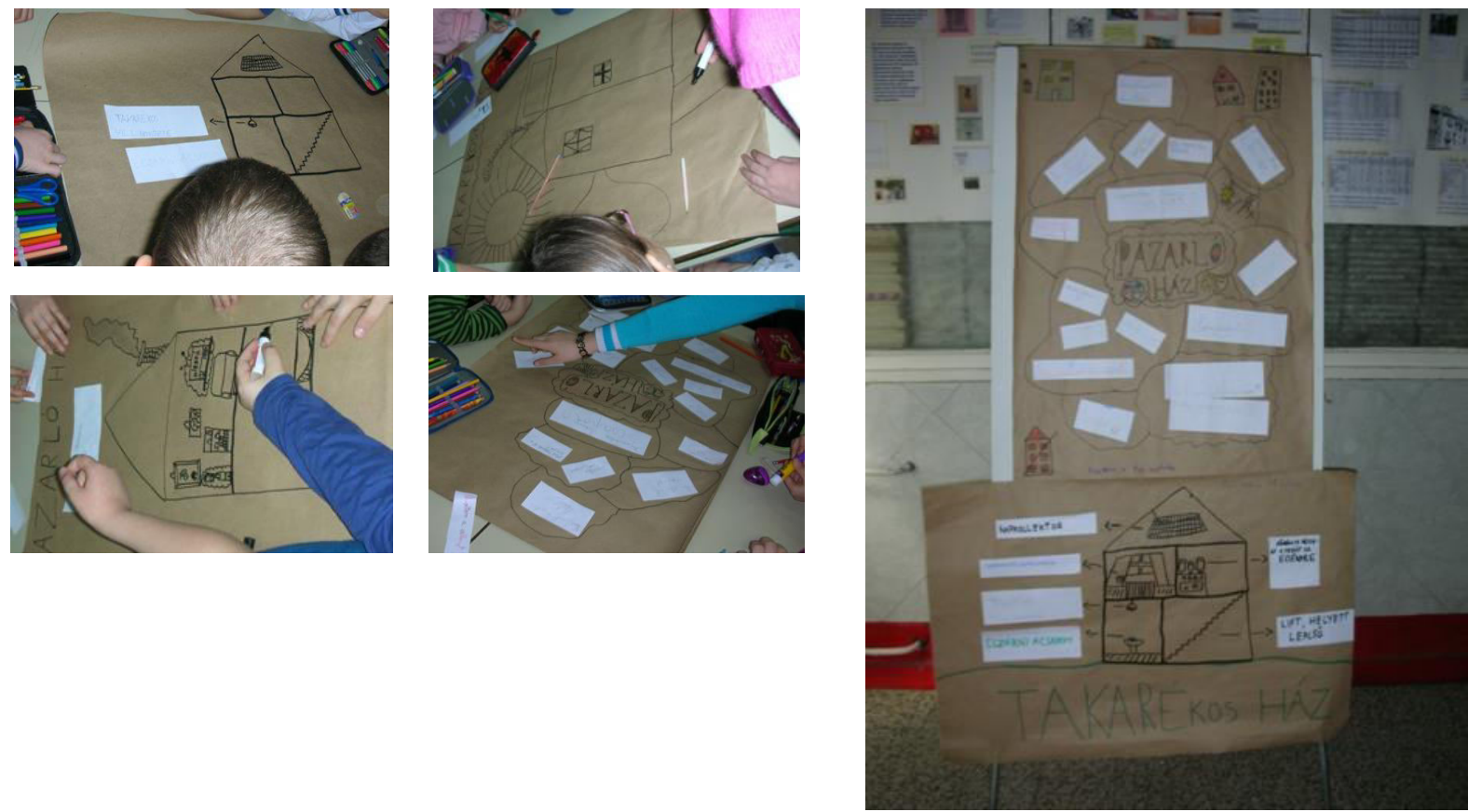

\section{MELLÉKLET: FELADATLAP (Oltsd le a lámpát, zárd el a csapot! - projekt)}

\section{KÖRNYEZETI NEVELÉSI PROGRAM 2013}

\section{FELADAT}

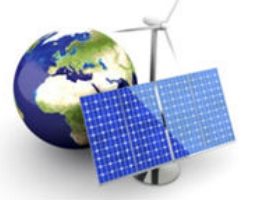

Kedves Kisdiák, kérlek, számold meg, hogy hány villanykörte, konnektor és vízcsap van az otthonotokban!

\begin{tabular}{|l|l|l|l|}
\hline & $\begin{array}{c}\text { villanykörte } \\
\text { (lámpában, csillárban...) }\end{array}$ & \multirow{2}{*}{ konnektor } & \\
\hline konyha: & & & \\
\hline fürdőszobap & & & \\
\hline nappali: & & & \\
\hline gyerekszoba: & & & \\
\hline elöszoba: & & & \\
\hline egyéb helyiségek: & & & \\
\hline
\end{tabular}

adf Figyeld meg, hogy családod tagjai, és te magad is elzárod-e a csapot fogmosás közben? Lekapcsoljátok-e a villanyt, ha nem tartózkodtok a szobában? Kikapcsoljátok-e a számítógépet, vagy kihúzzátok-e a konnektorból az elektromos készülékeket, amikor nem használjátok őket? 


\section{MELLÉKLET: ÓRAVÁZLAT (Szélkerék készítése)}

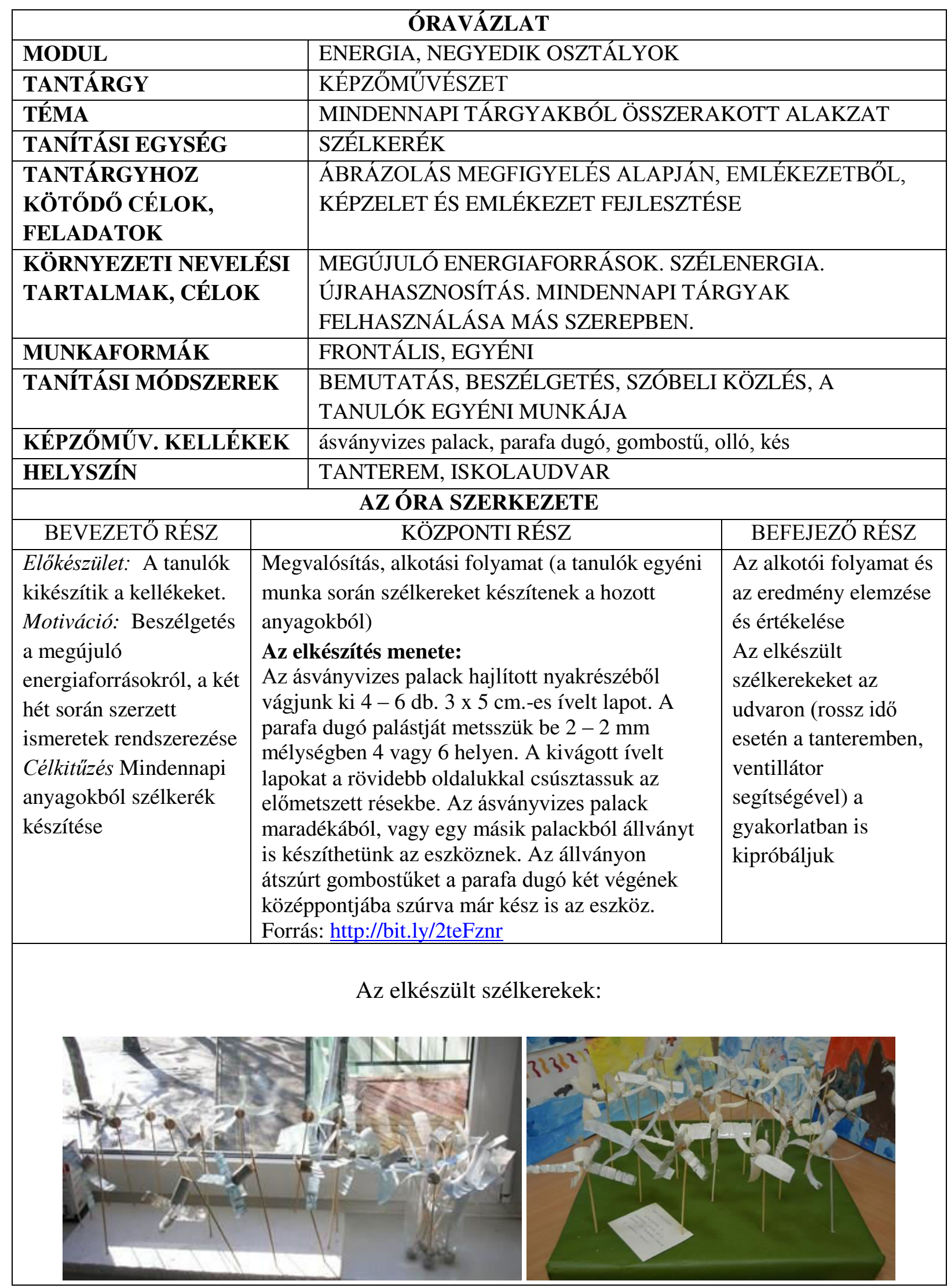




\section{MELLÉKLET: A környezeti nevelési programról a Jó Pajtás c. diáklapban}

megjelent cikk

Jó Pajtás, 67. évfolyam, 2013. V. 9.
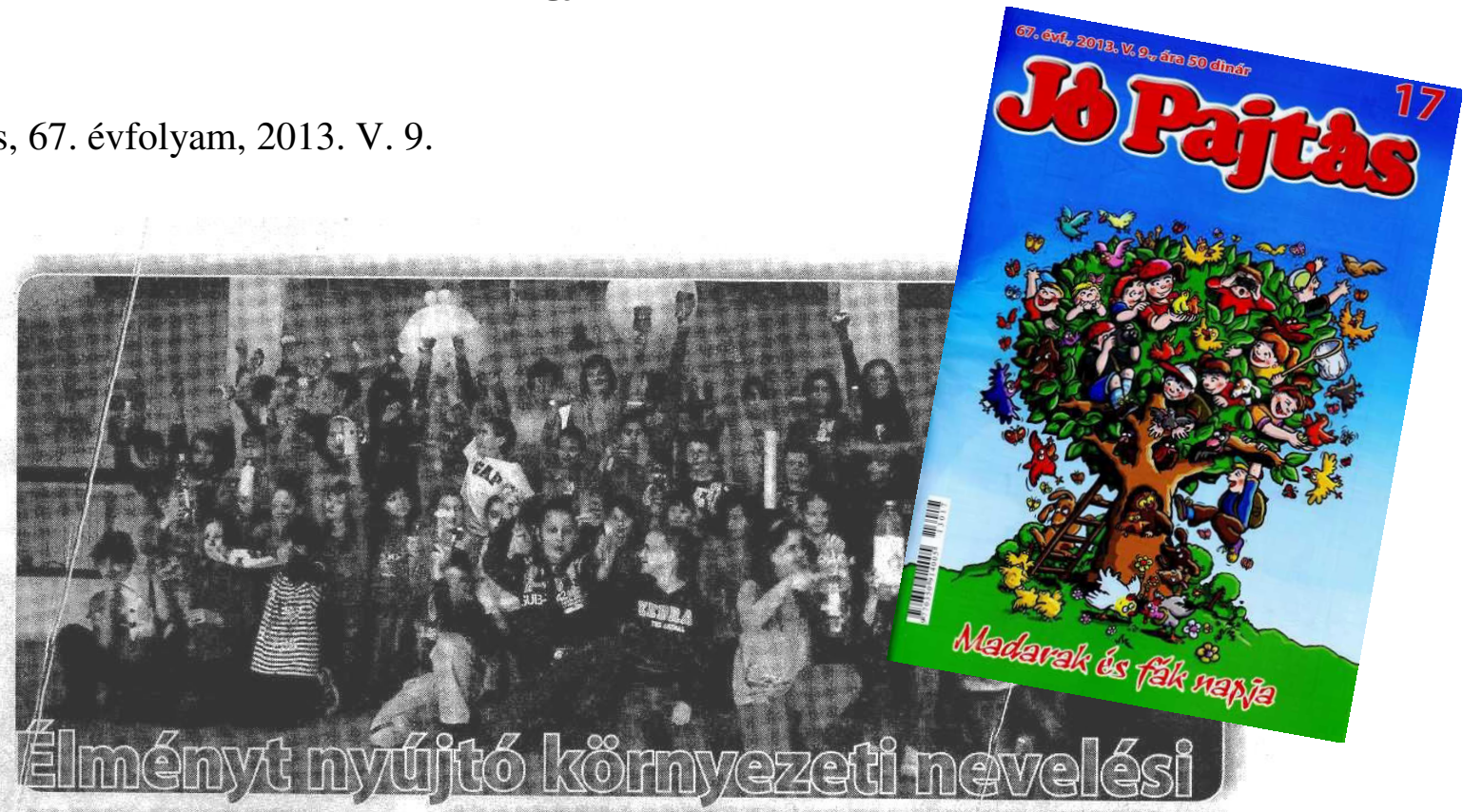

\section{program}

1 Magyar Tannyelvũ Tanitóképző Kar $\triangle$ hallgatói 2013. március 11. és 23 . $\square$ között kéthetes, Élményt nyújtó környezeti nevelési program kidolgozásában és végrehajtásában vettek részt.

A kéthetes program egy doktori disszertáció kutatási alapját képezi, és célja a tanítóképzős hallgatók és alsó tagozatos tanulók környezettudatos magatartásának fejlesztése volt. A hallgatók tanitási órák (környezetünk illetve természet és társadalom, képzőmüvészet, zenei nevelés), tanórán kivüli tevékenységek (elöadások, projektmunka, kiállitás) és iskolán kivüli tevékenységek szervezésében (állatkerti látogatás, környezetvédelmi nap) és végrehajtásában vettek részt két héten keresztül. A program a MTTK két gyakorlóiskolájában került megrendezésre, a Széchenyi István és a Majsai Úti Általános Iskolában. A program lebonyolitásában nagy segitséget nyújtott a kísérleti csoport, vagyis a Széchenyi István iskola 2. a, 3. a, 3. b, 4. a és 4 . b osztálya, valamint a Majsai Úti iskola 2. c, 2. d, 3. c., 3.d, 4. c és 4. d osztálya. A felsorolt osztályok mellett a Jovan Jovanović Zmaj és a Jovan Mikić iskolák alsó tagozatos hallgatói képezték a kontrollcsoportot, ök a kérdőivek kitöltésével

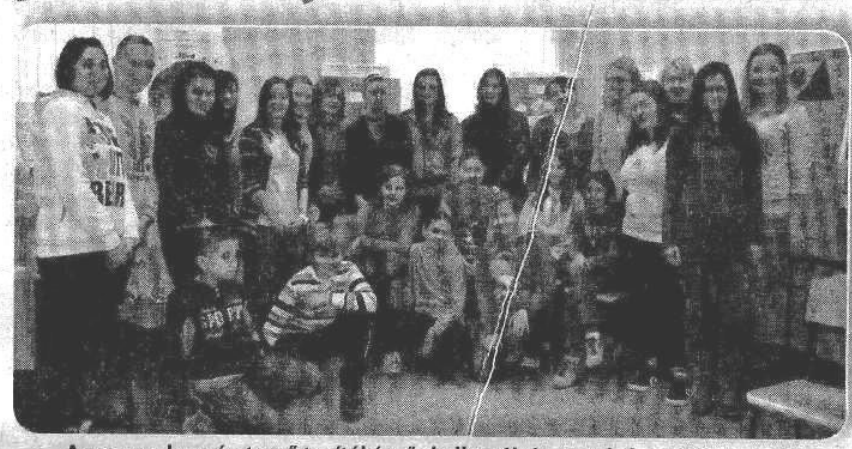

A programban résztvevő tanítóképzős haligatók és gyerekek egy kis csapata A második osztályokban a vizvédelem, a harmadik osztályokban a hulladék kérdése, a negyedik osztályokban pedig az energiafelhasználás témája került feldolgozásra.

A program lezárására március 23-án került sor, egy környezetvédelmi nap keretein belül melyet a Tanitóképző Kar épületében rendeztek meg a hallgatók. A nap jelszava a következö volt:,Megérkezett a tavasz, óvjuk környezetünket." Az esemény szervezésében húsz tanitóképzös hallgató vett részt, és a MTTK gyakorló iskoláinak tanulóit várták a köınyezetvédelem, viz, hulladék, energia témaköréhez kapcsolódó játékokkal, vetélkedökikel.
A programban résztvevő osztályok

Széchenyi István iskola, 2. a osztály (tanitónổ: Vásárhelyi Szilvia); Majsai Úti iskola, 2. c osztály (tanitónö: Tóth Márta); Majsai Úti iskola, 2. d osztály (tanitónõ: Bognár Beáta); Széchenyi lstván iskola, 3. a osztály (tanítónő: Borsos Éva); Széchenyi István iskola, 3. b osztály (tanítónö: Kovács Elvíra); Majsai Úti iskola, 3.c és 3. d osztály (tanítónők: Tilinkó Renáta és Pá Turzai Éva); Széchenyi István iskola, 4. a és 4. b osztály (tanitónők: Polyákovity Király Gyöngyi, Süli Szilvia); Majsai Úti iskola, 4. c és 4. d osztály (tanítók: Gálfi Csaba és Kokotovity Rita).
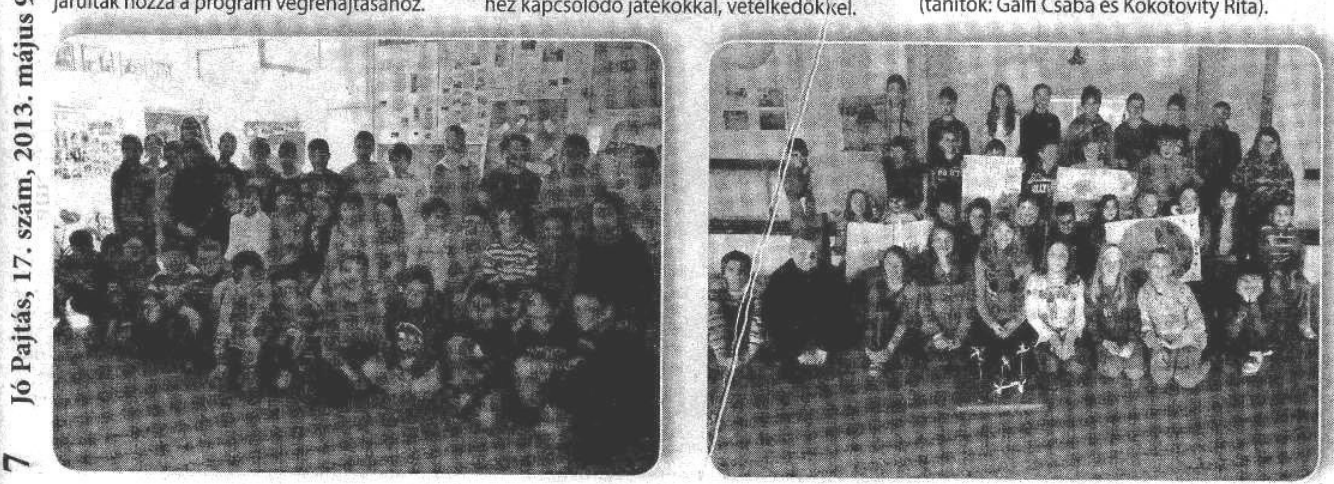


\section{MELLÉKLET: KÖRNYEZETI ATTITÜD VIZSGÁLATA}

Tanítóképzős hallgatók kérdőíve

\section{Kedves Hallgató!}

A Szegedi Tudományegyetem Neveléstudományi Doktori Iskolájának tanulójaként egy vizsgálatot végzek. Ehhez szeretném a segítségedet kérni.

Arra kérnélek, hogy válaszolj a következő kérdésekre. A kapott adatokat bizalmasan kezelem majd. Neved feltüntetésére csak a pontos azonosíthatóság kedvéért van szükség. Rajtam kívül senki sem fogja megismerni személyes véleményedet, válaszaidat.

Ha bármilyen kérdésed, kérésed van a vizsgálattal kapcsolatban, vagy ha kíváncsi vagy az eredményekre, hívj a 063/666-790-es telefonszámon, vagy írj a lenkemttk@gmail.com címre.

Köszönöm az együttmúködést!

Major Lenke

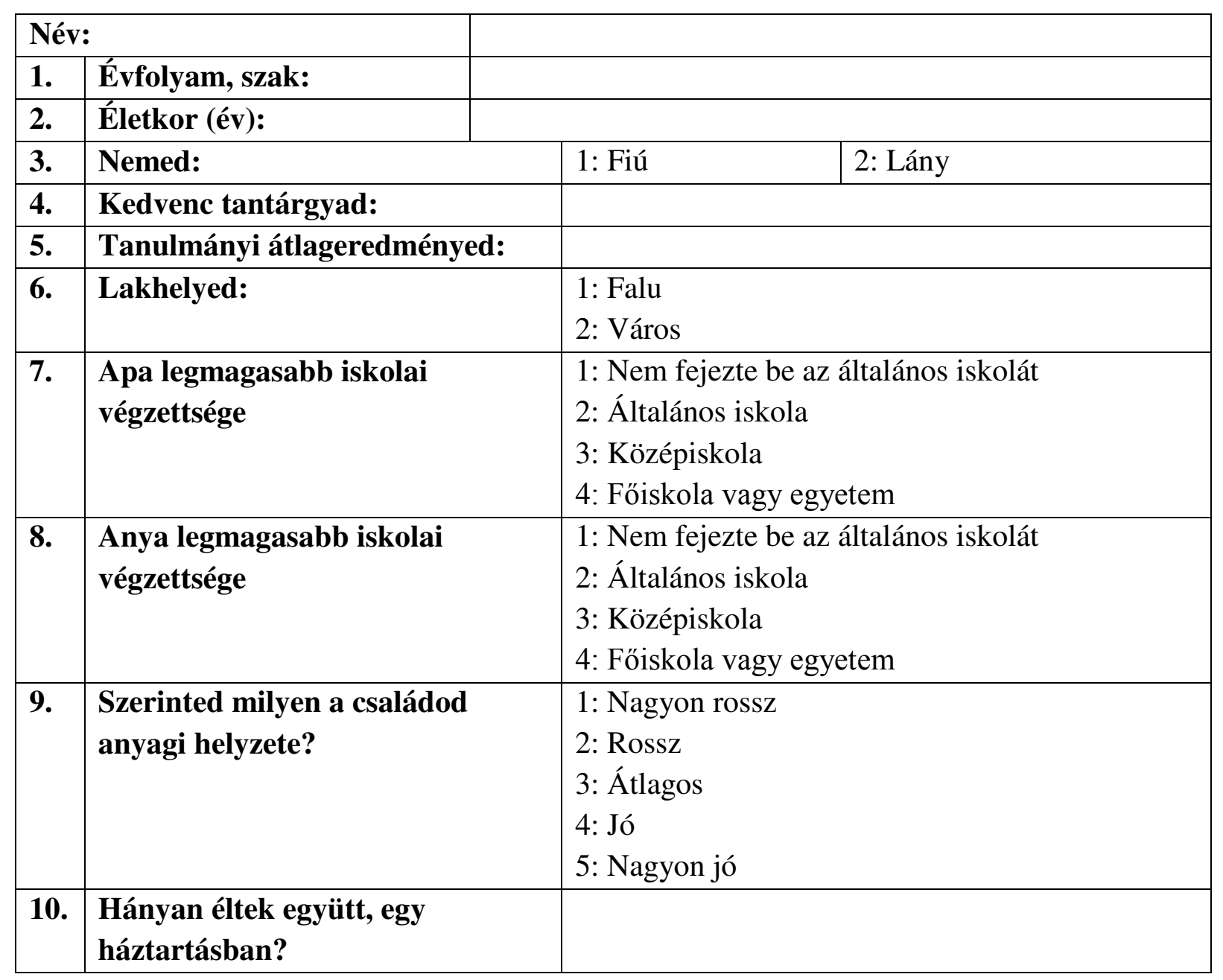




\section{A következőkben állításokat olvashatsz. Azt kell eldöntened, hogy mennyire igazak az állítások. Döntésed eredményét úgy jelölheted, hogy bekarikázol egy számot az állítás mellett. A számok a következőket jelentik:}

\section{1: Teljes mértékben hamis}

2: Többnyire hamis

3: Nem tudom

4: Többnyire igaz

\section{5: Teljes mértékben igaz}

\begin{tabular}{|c|c|c|c|c|c|c|}
\hline 1. & $\begin{array}{l}\text { Ha több pénzem lenne, valamennyit egy környezetvédelmi szervezetnek } \\
\text { adományoznék belöle. }\end{array}$ & 1 & 2 & 3 & 4 & 5 \\
\hline 2. & Mindig lekapcsolom a lámpát, amikor már nincs szükségem rá. & 1 & 2 & 3 & 4 & 5 \\
\hline 3. & A természet csendjében jól érzem magam. & 1 & 2 & 3 & 4 & 5 \\
\hline 4. & $\begin{array}{l}\text { Olyan fontos, hogy autópályákat és kerülőutakat építsünk, hogy ezért megéri } \\
\text { eltávolítani az erdőket és mezőket. }\end{array}$ & 1 & 2 & 3 & 4 & 5 \\
\hline 5. & Igazán gondozatlannak néz ki, ha fü és gaz nő a járda kövei közt. & 1 & 2 & 3 & 4 & 5 \\
\hline 6. & $\begin{array}{l}\text { A környezet védelme sok pénzbe kerül. Kész vagyok rá, hogy segítsek egy erre a } \\
\text { célra szervezett pénzgyüjtési akcióban. }\end{array}$ & 1 & 2 & 3 & 4 & 5 \\
\hline 7. & Amikor csak lehetséges, fürdés helyett zuhanyzom, hogy takarékoskodjak a vízzel. & 1 & 2 & 3 & 4 & 5 \\
\hline 8. & gyon & 1 & 2 & 3 & 4 & 5 \\
\hline 9. & $\begin{array}{l}\text { Hogy az embereknek legyen mit enniük, a természetet háttérbe kell szorítani, hogy } \\
\text { például gabonát termeszthessünk. }\end{array}$ & 1 & 2 & 3 & 4 & 5 \\
\hline 10. & $\begin{array}{l}\text { A gyomokat ki kell irtani, mert akadályozzák a haszon- és dísznövények } \\
\text { növekedését. }\end{array}$ & 1 & 2 & 3 & 4 & 5 \\
\hline 11. & $\begin{array}{l}\text { Ha idösebb leszek, csatlakozom és aktívan részt veszek egy környezetvédelmi } \\
\text { csoportban, ha még eddig nem lennék tagja. }\end{array}$ & 1 & 2 & 3 & 4 & 5 \\
\hline 12. & Megbizonyosodom róla, hogy télen & 1 & 2 & 3 & 4 & 5 \\
\hline 13. & gását, ahogy a szél átfúj a fák felett. & 1 & 2 & 3 & 4 & 5 \\
\hline 14. & $\begin{array}{l}\text { Mivel a szúnyogok tavacskákban fejlődnek ki, jobb lenne lecsapolni ezeket és } \\
\text { mezögazdasági termelésre alkalmassá tenni területüket. }\end{array}$ & 1 & 2 & 3 & 4 & 5 \\
\hline 15. & $\begin{array}{l}\text { Az emberiség létszáma közeledik ahhoz a határhoz, amennyi embert a föld el tud } \\
\text { tartani. }\end{array}$ & 1 & 2 & 3 & 4 & 5 \\
\hline 16. & $\begin{array}{l}\text { Az embereknek joga van olyanná változtatni a természetes környezetet, ahogy az az } \\
\text { igényeiknek megfelel. }\end{array}$ & 1 & 2 & 3 & 4 & 5 \\
\hline 17. & $\begin{array}{l}\text { Ha az emberek beleavatkoznak a természet rendjébe, az gyakran katasztrofális } \\
\text { következményekkel jár. }\end{array}$ & 1 & 2 & 3 & 4 & 5 \\
\hline 18. & $\begin{array}{l}\text { Az emberi leleményesség majd gondoskodik róla, hogy NE tegyük lakhat } \\
\text { földet. }\end{array}$ & 1 & 2 & 3 & 4 & 5 \\
\hline 19. & Az emberek súlyosan kihasználják a természeti környezetet. & 1 & 2 & 3 & 4 & 5 \\
\hline 20. & $\begin{array}{l}\text { A föld bővelkedik természeti erőforrásokban, csak meg kell tanulnunk hasznosítani } \\
\text { ezeket. }\end{array}$ & 1 & 2 & 3 & 4 & 5 \\
\hline 21. & A növényeknek és az állatoknak ugyanolyan joguk van élni, mint az embereknek. & 1 & 2 & 3 & 4 & 5 \\
\hline 22. & $\begin{array}{l}\text { A természet egyensúlya elég erős ahhoz, hogy megbirkózzon a modern ipari } \\
\text { társadalmak hatásaival. }\end{array}$ & 1 & 2 & 3 & 4 & 5 \\
\hline 23. & $\begin{array}{l}\text { Különleges képességeink ellenére még mindig ki vagyunk szolgáltatva a természet } \\
\text { törvényeinek. }\end{array}$ & 1 & 2 & 3 & 4 & 5 \\
\hline 24. & $\begin{array}{l}\text { Az emberiségre leselkedő úgynevezett „ökológiai válság”-elképzelés hatalmas } \\
\text { túlzás. }\end{array}$ & 1 & 2 & 3 & 4 & 5 \\
\hline
\end{tabular}




\begin{tabular}{|c|c|c|c|c|c|c|}
\hline 25. & A föld olyan, mint egy ürhajó, korlátozott mennyiségü területtel és erőforrással. & 1 & 2 & 3 & 4 & 5 \\
\hline 26. & Az embert arra teremtették, hogy uralkodjon a természet többi része felett. & 1 & 2 & 3 & 4 & 5 \\
\hline 27. & A természet egyensúlya nagyon törékeny és könnyen felborítható. & $\mathbf{1}$ & 2 & 3 & 4 & 5 \\
\hline 28. & $\begin{array}{l}\text { Az emberek végső soron eleget fognak megtudni arról, hogy hogyan müködik a } \\
\text { természet, hogy képesek legyenek azt irányítani. }\end{array}$ & $\mathbf{1}$ & 2 & 3 & 4 & 5 \\
\hline 29. & $\begin{array}{l}\text { Ha a dolgok így mennek tovább, hamarosan egy még nagyobb ökológiai } \\
\text { katasztrófát fogunk megélni. }\end{array}$ & 1 & 2 & 3 & 4 & 5 \\
\hline 30. & $\begin{array}{l}\text { Egy igazi természetjáró gyönyörü és ritka növényeket hoz magával haza } \\
\text { kirándulásról. }\end{array}$ & $\mathbf{1}$ & 2 & 3 & 4 & 5 \\
\hline 31. & Gyakran próbálok meggyőzni másokat arról, hogy a környezet ügye fontos. & $\mathbf{1}$ & 2 & 3 & 4 & 5 \\
\hline 32. & $\begin{array}{l}\text { Hogy ne szennyezzem a levegöt, inkább gyalog teszek meg rövid távokat, minthogy } \\
\text { megkérném, hogy vigyenek el. }\end{array}$ & $\mathbf{1}$ & 2 & 3 & 4 & 5 \\
\hline 33. & Szívesen üldögélnék egy tó partján és nézném, ahogy repkednek a szitakötők. & 1 & 2 & 3 & 4 & 5 \\
\hline 34. & A szabadstrandokat meg kellene tisztítani a hínártól. & 1 & 2 & 3 & 4 & 5 \\
\hline 35. & $\begin{array}{l}\text { Jobban tetszik egy jól ápolt pázsit, mint egy buja mező, ahol össze-vissza nőnek a } \\
\text { virágok. }\end{array}$ & 1 & 2 & 3 & 4 & 5 \\
\hline 36. & Szerintem gyönyörúek a falevelek színei összel. & 1 & 2 & 3 & 4 & 5 \\
\hline 37. & Ellenzem az állati szőrböl készült bunda használatát. & 1 & 2 & 3 & 4 & 5 \\
\hline 38. & Elszomorít, hogy a sok építkezés az állatokat megfosztja természetes lakóhelyüktöl. & 1 & 2 & 3 & 4 & 5 \\
\hline 39. & Becsülöm azokat, akik saját pénzüket áldozzák a környezet védelmére. & 1 & 2 & 3 & 4 & 5 \\
\hline 40. & $\begin{array}{l}\text { Jónak tartom, hogy ha egy kozmetikai készítményt élő állatokon próbálnak ki, } \\
\text { mielött emberek használnák. }\end{array}$ & $\mathbf{1}$ & 2 & 3 & 4 & 5 \\
\hline 41. & $\begin{array}{l}\text { Örülök, amikor azt látom, hogy az emberek újrahasznosítják a használt papírt, } \\
\text { üvegeket, konzervdobozokat. }\end{array}$ & $\mathbf{1}$ & 2 & 3 & 4 & 5 \\
\hline 42. & $\begin{array}{l}\text { Bosszant, hogy az emberek kidobnak a szemétbe dolgokat, amiket újra lehetne } \\
\text { hasznosítani. }\end{array}$ & $\mathbf{1}$ & 2 & 3 & 4 & 5 \\
\hline 43. & tek erdőben sétálni. & 1 & 2 & 3 & 4 & 5 \\
\hline 44. & Nyitva hagyom a hütőszekrény ajtaját, & 1 & 2 & 3 & 4 & 5 \\
\hline 45. & Otthon leoltom a lámpákat, ha kevesebb fény is elég, hogy energiát spóroljak. & 1 & 2 & 3 & 4 & 5 \\
\hline 46. & Amikor egy erdőben járok, figyelem az ott élő növényeket. & 1 & 2 & 3 & 4 & 5 \\
\hline 47. & Feldob, ha azt látom, hogy az emberek energiát próbálnak megtakarítani. & $\mathbf{1}$ & 2 & 3 & 4 & 5 \\
\hline 48. & Figyelem a környezetvédelemmel kapcsolatos híreket. & 1 & 2 & 3 & 4 & 5 \\
\hline 49. & ás közben általában elzáror & 1 & 2 & 3 & 4 & 5 \\
\hline 50. & $\mathrm{Nem}$ & 1 & 2 & 3 & 4 & 5 \\
\hline 51. & Megke & 1 & 2 & 3 & 4 & 5 \\
\hline 52. & $\begin{array}{l}\text { A háziszemét valamely részét elkülönítve gyüjtöm (pl.: elemeket, vagy a szerves } \\
\text { hulladékot, komposztot). }\end{array}$ & 1 & 2 & 3 & 4 & 5 \\
\hline 53. & Zavar, hogy mennyi energiát pocsékolnak el feleslegesen. & 1 & 2 & 3 & 4 & 5 \\
\hline 54. & Aggódom amiatt, hogy az emberek nem vigyáznak eléggé a környezetükre. & 1 & 2 & 3 & 4 & 5 \\
\hline 55. & Idegesít, ha azt látom, hogy az emberek pazarolják a vizet. & 1 & 2 & 3 & 4 & 5 \\
\hline 56. & Nem szoktam környezetvédelmi tanácsokat kérni másoktól. & 1 & 2 & 3 & 4 & 5 \\
\hline 57. & Szoktam télen etetni a madarakat. & 1 & 2 & 3 & 4 & 5 \\
\hline 58. & Ha feleslegesen folyik a víz, elzárom a vízcsapot. & 1 & 2 & 3 & 4 & 5 \\
\hline 59. & Bárhol kirándulok, gyakran viszek haza virágot. & $\mathbf{1}$ & 2 & 3 & 4 & 5 \\
\hline
\end{tabular}




\section{MELLÉKLET: KÖRNYEZETI ATTITÜD VIZSGÁLATA}

Alsó tagozatos tanulók kérdőíve

\section{KÉRDöÍV}

Kedves Tanuló,

kérlek válaszolj a következő kérdésekre.

Neved:

Hány éves vagy?

Nemed?

Fiú $\square \quad$ Lány

\begin{tabular}{|c|c|c|c|c|}
\hline \multicolumn{5}{|c|}{ Karikázd be a megfeleló válasz sorszámát: } \\
\hline \multirow[t]{2}{*}{$\begin{array}{l}1 . \\
2 .\end{array}$} & \multirow[t]{2}{*}{$\begin{array}{l}\text { Iskola: } \\
\text { Osztály: }\end{array}$} & \multicolumn{3}{|c|}{$\begin{array}{l}\text { 1. Jovan Jovanović Zmaj Általános Iskola } \\
\text { 2. Jovan Mikić Általános Iskola } \\
\text { 3. Majsai Úti Általános Iskola } \\
\text { 4. Széchenyi István Általános Iskola }\end{array}$} \\
\hline & & 1. második & 2. harmadik & 3. negyedik \\
\hline 3. & $\begin{array}{l}\text { Apa legmagasabb iskolai } \\
\text { végzettsége }\end{array}$ & \multicolumn{3}{|c|}{$\begin{array}{l}\text { 1. Nem fejezte be az általános iskolát } \\
\text { 2. Általános iskola } \\
\text { 3. Középiskola } \\
\text { 4. Főiskola vagy egyetem }\end{array}$} \\
\hline 4. & $\begin{array}{l}\text { Anya legmagasabb iskolai } \\
\text { végzettsége }\end{array}$ & \multicolumn{3}{|c|}{$\begin{array}{l}\text { 1. Nem fejezte be az általános iskolát } \\
\text { 2. Általános iskola } \\
\text { 3. Középiskola } \\
\text { 4. Föiskola vagy egyetem }\end{array}$} \\
\hline 5. & Kivel élsz együtt? & \multicolumn{2}{|c|}{$\begin{array}{l}\text { 1. Apa } \\
\text { 2. Anya } \\
\text { 3. Testvérek: ........... darab } \\
\text { 4. Nagyszülő } \\
\text { 5. egyéb családtag: ................ }\end{array}$} & $\begin{array}{l}\text { Összesen veled } \\
\text { együtt ......... fö }\end{array}$ \\
\hline 6. & $\begin{array}{l}\text { Szerinted milyen a családod } \\
\text { anyagi (pénzügyi) helyzete? }\end{array}$ & \multicolumn{2}{|c|}{$\begin{array}{l}\text { 1. Nagyon rossz } \\
\text { 2. Rossz } \\
\text { 3. Átlagos } \\
\text { 4. Jó } \\
\text { 5. Nagyon jó }\end{array}$} & \\
\hline 7. & Kedvenc tantárgyad: & & & \\
\hline 8. & Tanulmányi eredményed: & & & \\
\hline
\end{tabular}


A továbbiakban el kell döntened, mennyire igazak szerinted a felsorolt állítások.

1: Egyáltalán nem igaz : :

2: Talán nem igaz :)

3: Nem tudom $:$

4: Talán igaz :-)

5: Teljesen igaz $\odot)$

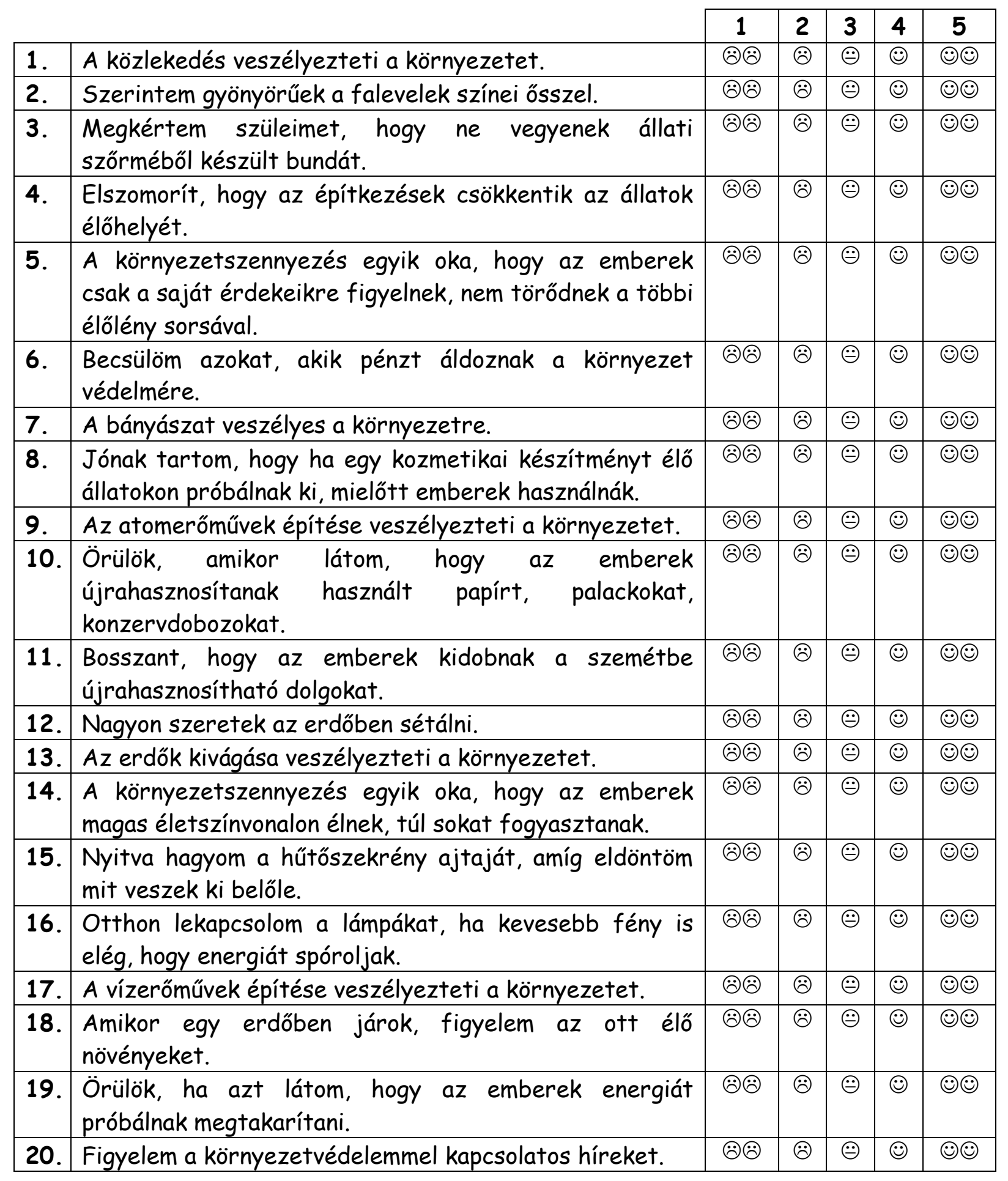




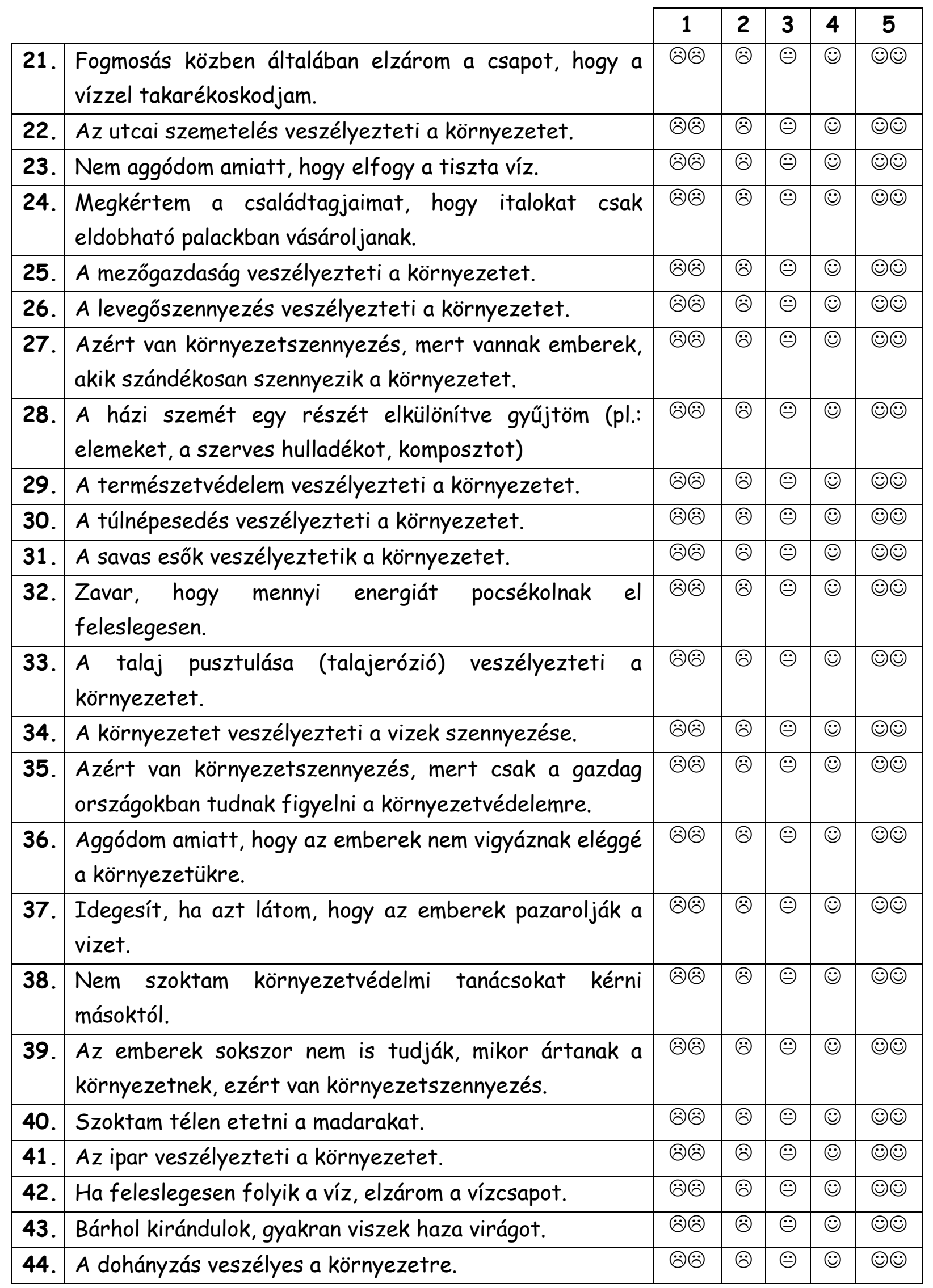


A következő mondatoknál karikázd be a megfelelö válasz sorszámát, és válaszolj a kérdésekre!

45. Szerinted neked vannak-e lehetöségeid a környezetszennyezés csökkentésére?

1. Nincsenek, mert:

2. Vannak.

Sorold fel, milyen lehetőségekre gondoltál!

A:

B:

C:

D:

E:

Köszönjük szépen a segítségedet! (;) 